VNIVERSIDAD B SALAMANCA CAMPUS DE EXCELENCIA INTERNACIONAL

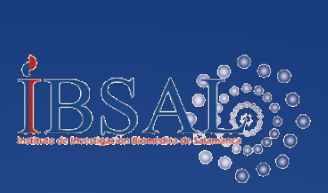

P

INSTITUTO DE NEUROCIENCIAS CASTILLA Y LEÓN

\title{
ALTERACIONES INDUCIDAS POR LA NICOTINA EN EL DESARROLLO DEL SISTEMA VISUAL DEL PEZ CEBRA
}

\author{
- TESIS DOCTORAL INTERNACIONAL -
}

\section{MIGUEL MOYANO TÉLLEZ}

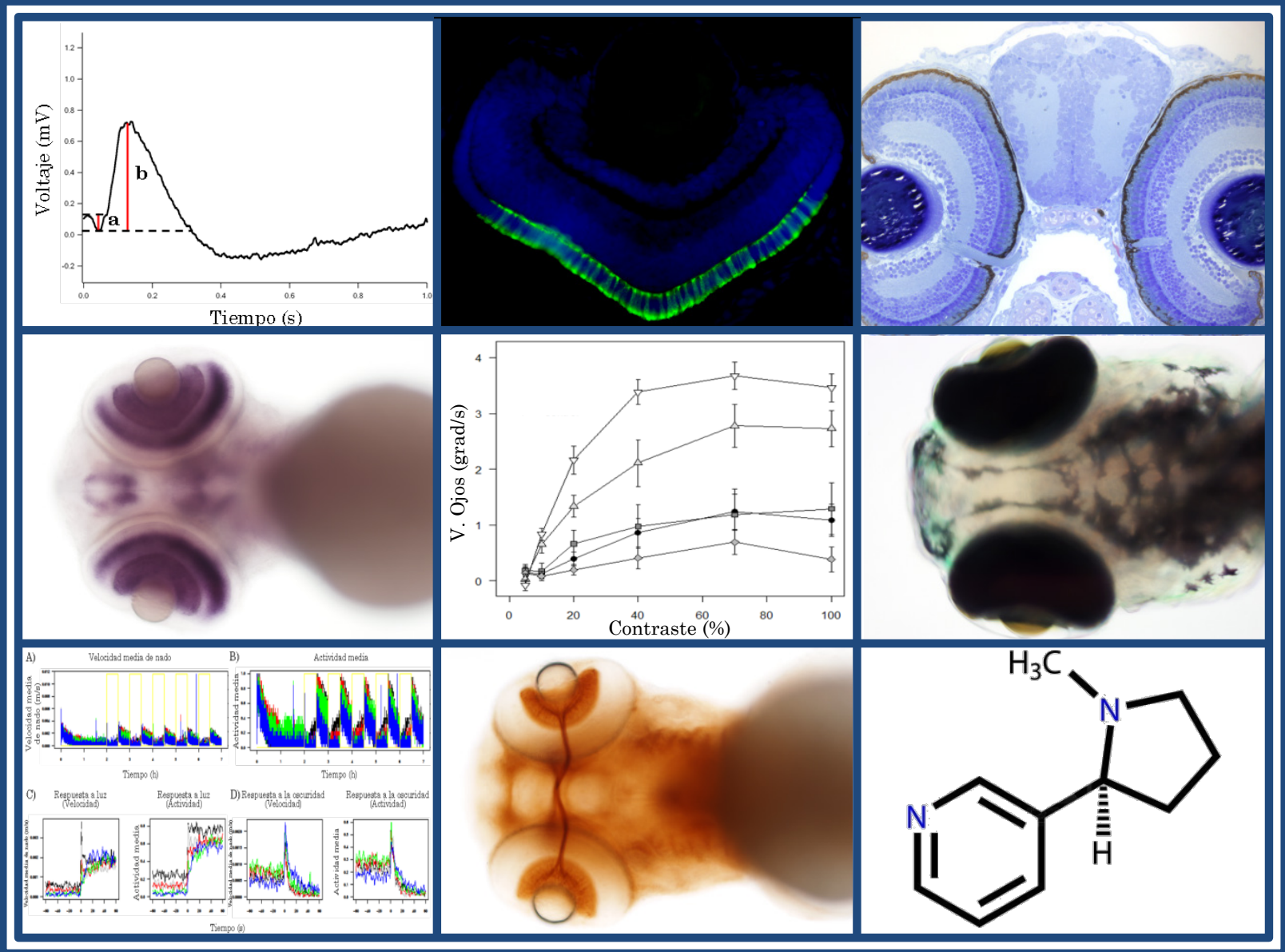

SALAMANCA, 2013 



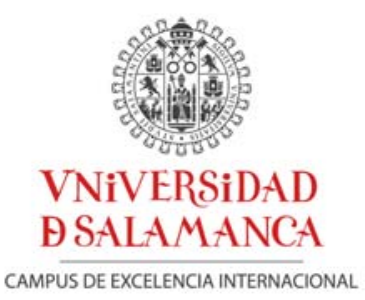

DPTO. BIOLOGÍA CELULAR Y PATOLOGÍA

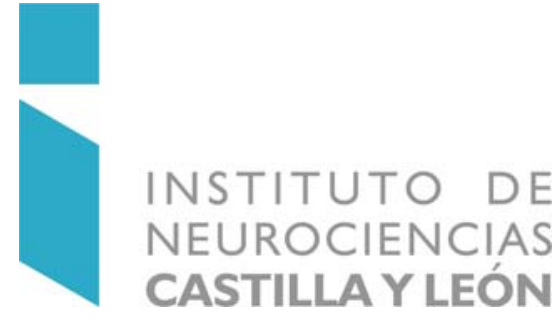

LAB. NEUROBIOLOGÍA COMPARADA

TESIS DOCTORAL

Alteraciones inducidas por la nicotina

en el desarrollo del sistema visual del pez cebra

Miguel Moyano Téllez

2013
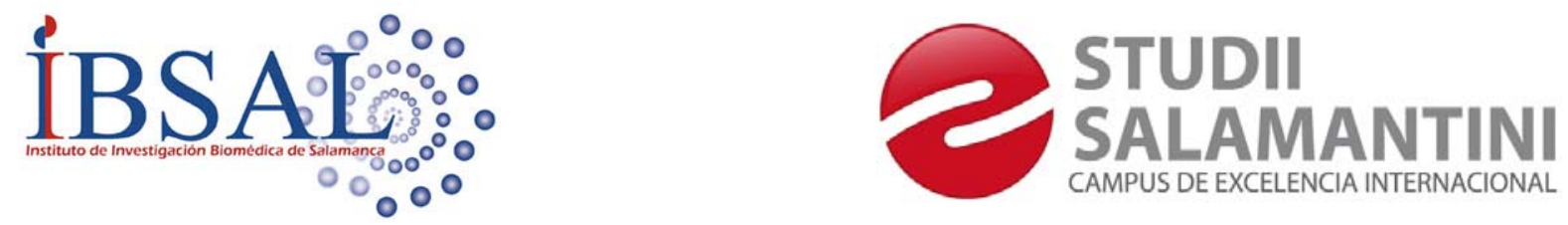



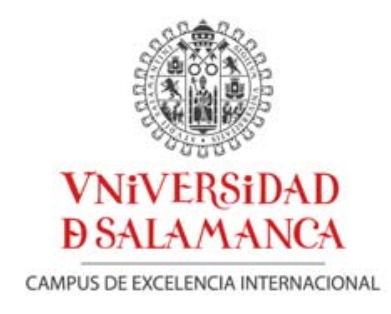

DPTO. BIOLOGÍA CELULAR Y PATOLOGÍA
INSTITUTO DE NEUROCIENCIAS CASTILLA Y LEÓN

LAB. NEUROBIOLOGÍA COMPARADA

\section{Alteraciones inducidas por la nicotina}

\section{en el desarrollo del sistema visual del pez cebra}

Memoria presentada por Miguel Moyano Téllez para optar al Título de Doctor Internacional

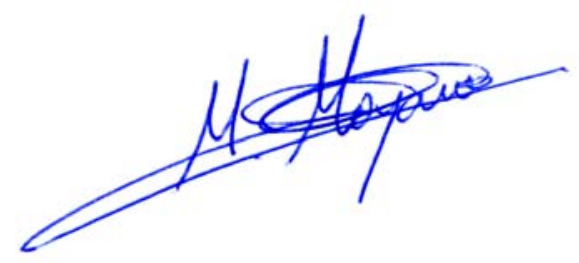

Fdo. Miguel Moyano Téllez Salamanca, 2013 

Juan M. Lara Pradas, Catedrático de Biología Celular y Ángel F. Porteros Herrero, Profesor Titular de Biología Celular de la Universidad de Salamanca.

\section{HACEN CONSTAR:}

Que el presente trabajo titulado "Alteraciones inducidas por la nicotina en el desarrollo del sistema visual del pez cebra", ha sido realizado por el licenciado en Biología D. Miguel Moyano Téllez en el Departamento de Biología Celular y Patología de la Universidad de Salamanca y en el Instituto de Neurociencias de Castilla y León.

Que ha sido desarrollado bajo nuestra dirección y dentro del programa de doctorado de Neurociencias de la Universidad de Salamanca.

Que, en nuestra opinión, reúne todos los requisitos científicos y formales para ser defendido como Tesis Doctoral y optar al grado de Doctor Internacional por la Universidad de Salamanca.

Para que así conste, expedimos el presente certificado.

\section{El Director}

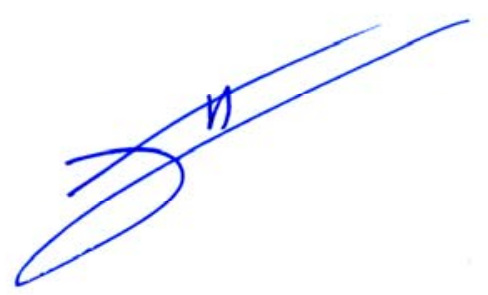

Fdo. J. M. Lara Pradas
El Director

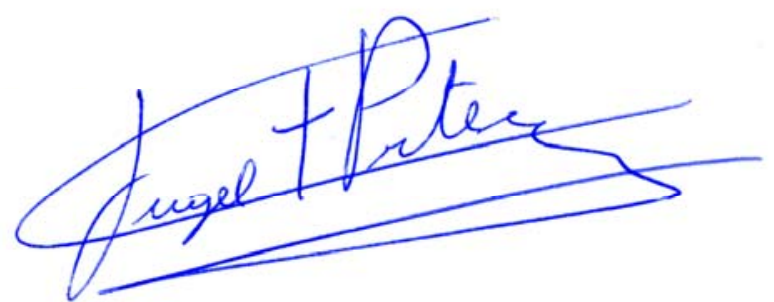

Fdo. A. F. Porteros Herrero 

"Sólo aquellos que se arriesgan a ir muy lejos, pueden llegar a saber lo lejos que pueden ir"

(T.S. Elliot)

\section{A mis padres, A mis hermanas}



Agradecimientos 

Son muchas las personas que de un modo $\mathrm{u}$ otro han participado en el desarrollo de este proyecto y a todas ellas debo estarles agradecidas.

En primer lugar agradecer a mis directores, la confianza depositada en todo momento tanto en mí, como en este proyecto. Al Prof. Juan M. Lara por dirigirme en este trabajo y por su sabiduría en cuestiones de biología celular. También al Prof. Ángel F. Porteros por su dirección y consejos durante el desarrollo de este trabajo de Tesis Doctoral.

Al Prof. Aijón Noguera por haberme dado la oportunidad de trabajar en el Departamento de Biología Celular y Patología y en el mundo de la neurobiología comparada.

A las Profas. $\mathrm{M}^{\mathrm{a}}$ Rosario Arévalo y Almudena Velasco, y a los Profs. Eduardo Weruaga y Jesús G. Briñón, por sus conocimientos y su tiempo dedicado en muchas ocasiones, porque siempre me han ayudado cuando lo he necesitado.

A la Profa. María Concepción Lillo, por su ayuda con los semifinos y al Dr. David Jimeno por todos sus consejos y porque siempre sacaba un ratito para solventar mis dudas.

A Dña. Maite Sánchez, nuestra técnico, por su sonrisa y bromas cuando me ayudaba en el procesamiento de embriones de pez cebra.

A la Profa. Raquel Rodríguez por permitirme usar sus instalaciones e interesarse siempre por mi formación. A la Dra. Verónica Núñez por tener tanta paciencia, ayudarme y resolverme diferentes cuestiones sobre genética molecular.

A todo el equipo del Prof. Neuhauss, por acogerme en su laboratorio y permitirme trabajar en su línea de investigación que despertó en mí gran 
interés. En especial, quiero agradecer al actual Dr. Kaspar Müller todo el tiempo dedicado en introducirme en el mundo del comportamiento animal.

A todo el equipo del Prof. Dowling, por recibirme en su laboratorio con los brazos abiertos e instruirme en las técnicas de electrorretinografía que allí se desarrollaban. Agradecer también al Dr. Adolph y al Dr. Saul el tiempo que dedicaron a enseñarme las técnicas electrofisiológicas.

A todas la personas que forman parte del INCyL con las que he compartido mi tiempo y me han ayudado en el uso de técnicas especializadas o solo con un “¿qué tal estas Miguel?”.

A todos mis compañeros y amigos de laboratorio. $\mathrm{Al}$ actual Dr. Adrián que me inició en el mundo de los peces cebra cuando llegué al laboratorio, por ayudarme con los experimentos y sobre todo por la paciencia que tuvo siempre conmigo. A todos los compañeros de laboratorio que me ayudasteis y me ayudáis. A los futuros doctores Maite y Saúl por su compañerismo y amistad, tanto dentro como fuera del laboratorio, por haber sido compañeros de penurias y alegrías (más de esto último) durante todos estos años. A la actual Dra. Marta por sus incontables horas de paciencia y risas en el laboratorio. A Fernando por haberme ayudado tanto en los últimos años de la Tesis. A todos los demás compañeros con los que he coincidido a lo largo de todo mi periodo en la investigación: Héctor, Antonio, Elena, Marchena, Azucena, Gloria, María, Carmencita, Javisan, David y Rodrigo. A Rubén Portugués sin él las estancias en Boston hubieran sido totalmente diferentes.

A mi familia, por todo su apoyo y ánimos. A mis abuelos, tíos, primos por enviarme siempre un soplo de energía; por apoyarme aunque todavía concretamente no saben a qué me dedico; por su paciencia en los largos periodos de tiempo entre visitas y su brevedad. A mis abuelos Flora y Victoriano porque aunque no estén presentes, sin sus mimos y ayuda no hubiera sido la persona que soy. 
A mis hermanas, Sara y Vanesa, por haberme soportado tantas peleas y no haber ejercido de continuo de un buen hermano mayor, os quiero mucho. A mis padres, por haberme querido tanto y a los que tanto quiero, por haberme enseñado los verdaderos valores en la vida y porque siempre puedo contar con ellos en los mejores y peores momentos. Tanto este proyecto, como los que tenga que realizar en el futuro serán siempre gracias a vosotros.

A mi querida Alicia por estar siempre en los momentos buenos y sobre todo por ayudarme tanto en los malos, por quererme, por aguantarme. Gracias por estar siempre ahí.

Muchas gracias a los que han creído en mí...

Este trabajo ha sido financiado por la ayuda al personal investigador de reciente titulación de la Junta de Castilla y León (ORDEN EDU/1486/2008), por el Ministerio de Ciencia e Innovación (BFU2009-11179), por la Consejería de Sanidad de la Junta de Castilla y León, y por la Fundación Samuel Solórzano. 

Îndice 



\section{Abreviaturas...............................................................7 \\ Introducción.................................................11}

1. Desarrollo del sistema visual en el pez cebra..................13

1.1 Ontogenia del sistema nervioso central de vertebrados............13

1.2 Morfogénesis del sistema visual en el pez cebra....................17

Retinogénesis................................................23

1.3 Marcadores implicados en la morfogénesis visual..................24

Histona H3-fosforilada........................................25

Calretinina...................................................25

Zn-8.......................................................26

Tirosina-hidroxilasa............................................27

Islet-1..................................................... 28

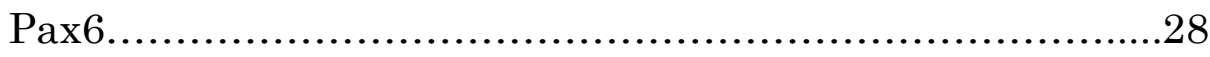

Zpr1 y Zpr3................................................. 29

2. Organización morfofuncional del sistema visual................30

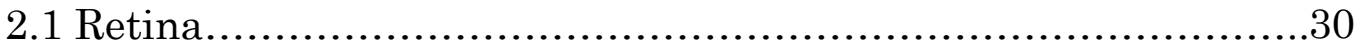

2.2 Fisiología de la retina.............................................32

Adaptación a la oscuridad...................................... 32

Adaptación a la luz...............................................32

$2.3 \mathrm{El}$ electrorretinograma como herramienta para evaluar la actividad retiniana....................................................33

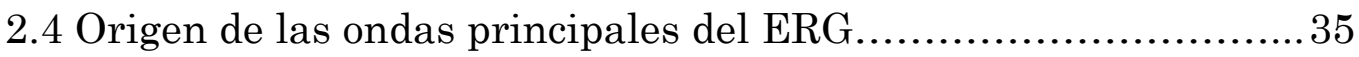

Generación de la onda-a........................................35

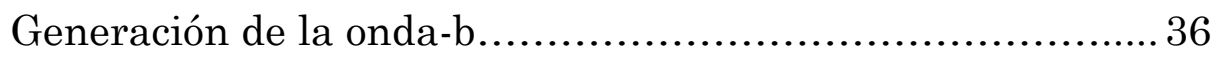

Generación de la onda-c..........................................38

Generación de la onda-d......................................... 38

2.5 Regiones visuales encefálicas.....................................39

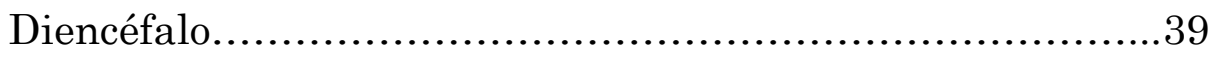

Mesencéfalo.....................................................41

3. Estudios de comportamiento en el análisis de la función visual...........................................................43

3.1 Respuestas tras entrenamiento con estímulos visuales............43

3.2 Respuesta innatas a los estímulos visuales.........................44

Respuesta optomotora......................................45

Respuesta optocinética......................................45

Respuesta visual motora.......................................46 
4. Efectos de la nicotina sobre el desarrollo del sistema nervioso central.....................................................48

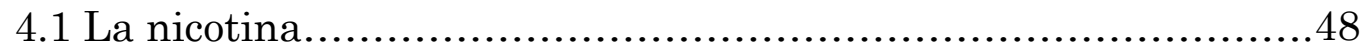

4.2 Mecanismo de acción de los nAChRs.................................... 49

4.3 Distribución en el organismo de los nAChRs..........................51

4.4 Distribución de los nAChRs durante el desarrollo.....................52

4.5 Repercusiones de la administración de nicotina durante el embarazo.......................................................................55

4.6 Efectos de la nicotina en el sistema visual...........................55

Hipótesis y objetivos........................................57

Material y Métodos..........................................63

1. Animal de experimentación...................................65

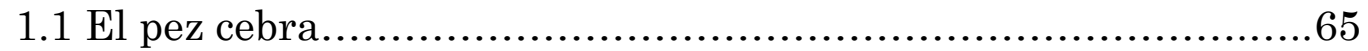

1.2 Mantenimiento y cría del pez cebra.................................65

2. Tratamiento con nicotina......................................67

3. Técnicas de experimentación..................................69

3.1 Cuantificación de nicotina por HPLC................................69

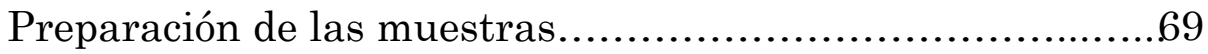

Cuantificación de la concentración efectiva de nicotina........70

3.2 Procesamiento histológico...............................................71

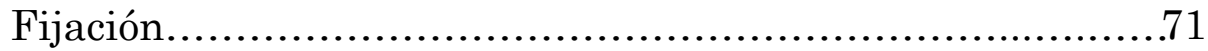

Seccionamiento en criostato.................................... 72

Obtención y tinción de cortes semifinos............................72

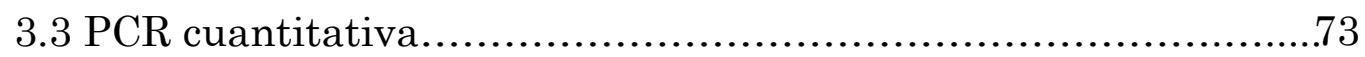

Homogeneización de embriones y extracción de RNA............73

Obtención de DNAc: retrotranscripción............................74

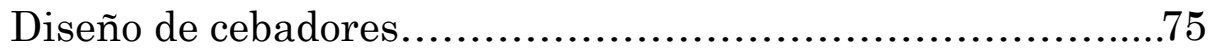

Diseño de la recta de calibrado......................................76

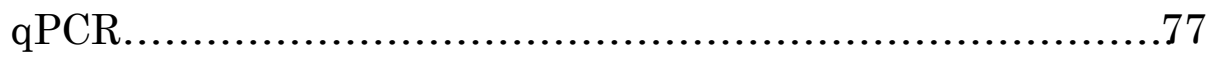

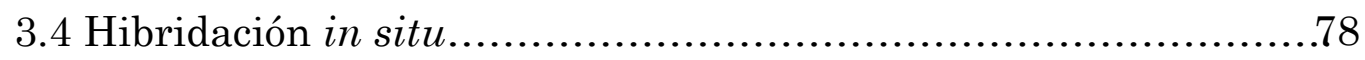

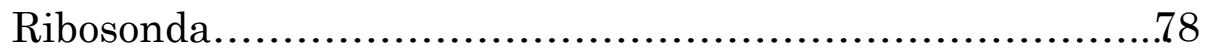

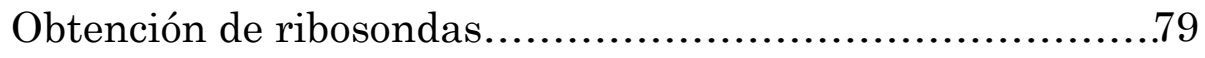

Protocolo de hibridación in situ.....................................81

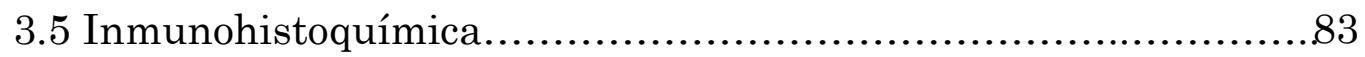

Inmunohistoquímica fluorescente en secciones..................83

Inmunohistoquímica in toto........................................84 


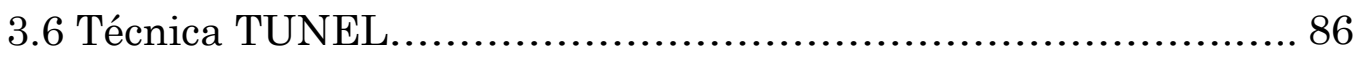

Protocolo de técnica TUNEL..................................... 86

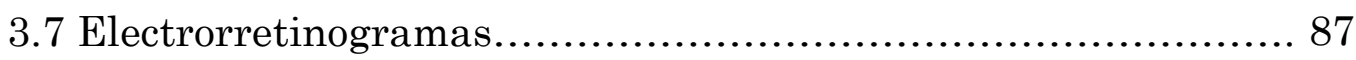

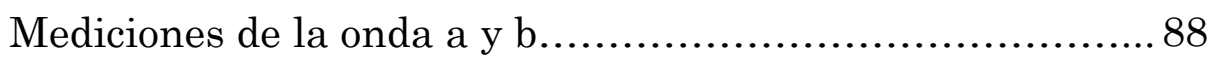

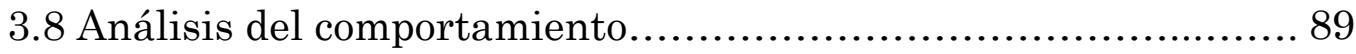

Valoración de la respuesta optomotora...........................89

Valoración de la respuesta optocinética..........................90

Valoración de la respuesta visual motora..........................93

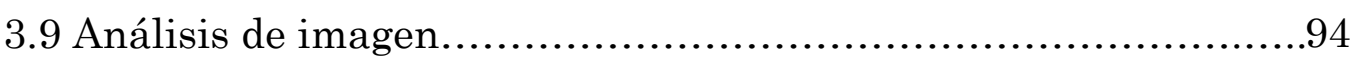

Obtención y procesamiento de imágenes...........................994

3.10 Toma de medidas y conteos.......................................... 94

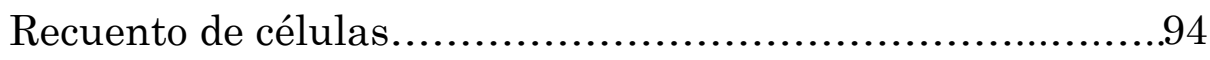

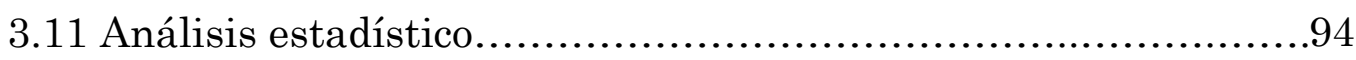

\section{Resultados...............................................................97}

1. Análisis morfológico................................................999

1.1 Efectos de la nicotina en el tamaño del ojo...........................99

1.2 Citoarquitectura de la retina y el techo óptico.......................104

1.3 Efectos de la nicotina en la retina.....................................109

2. Análisis neuroquímico....................................... 111

2.1 Alteraciones neuroquímicas tras el tratamiento de

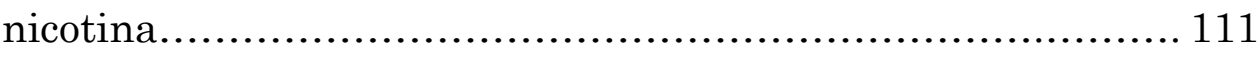

Proliferación celular ...............................................111

Apoptosis........................................................ 114

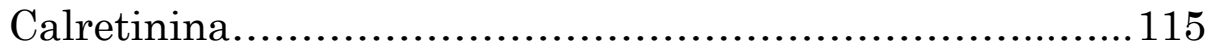

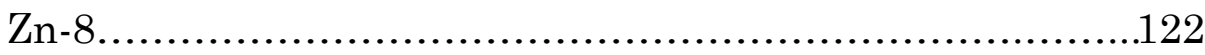

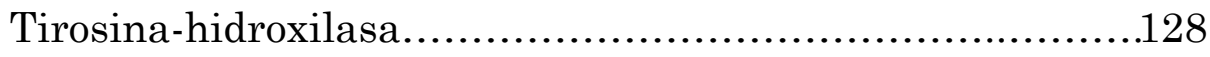

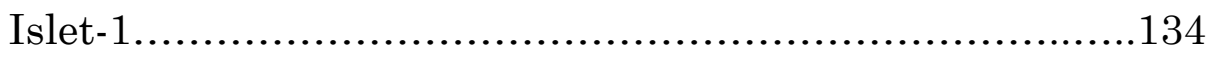

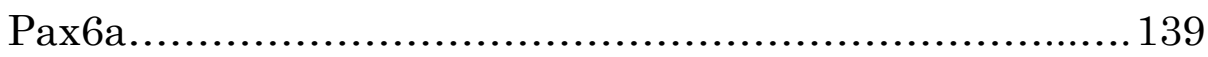

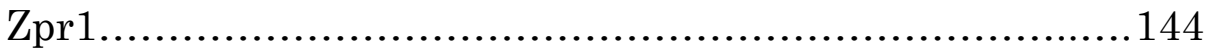

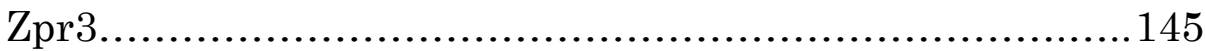

3. Análisis de los nAChRs en la vía visual........................148

3.1 Estudio con qPCR de la expresión de los nAChRs..................148

3.2 Estudio con hibridación in situ de la expresión de los nAChRs..150

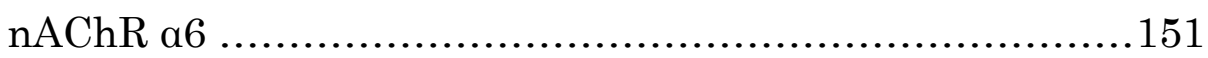

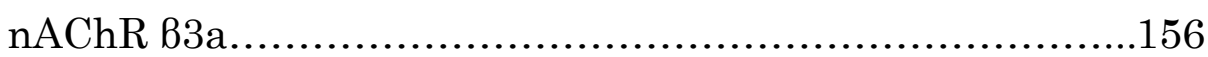

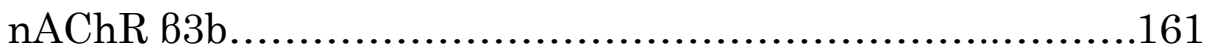


4. Análisis electrofisiológico de la retina...........................164

4.1 Efecto de la nicotina en los ERG con pulso de luz blanca......... 164

4.2 Análisis comparativo del ERG en los mutantes nof.................168

5. Análisis de comportamiento.....................................170

5.1 Efectos de la nicotina en el comportamiento inducido por

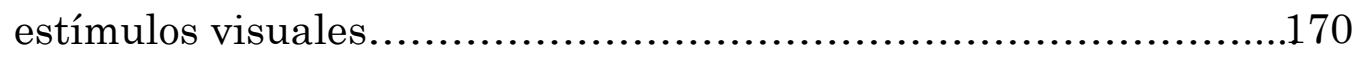

Respuesta optomotora..............................................

Respuesta optocinética...........................................174

Respuesta visual motora.........................................180

Discusión............................................................183

1. Efectos de la nicotina en el desarrollo del pez cebra..........185

2. Efectos de la nicotina sobre el sistema visual.................189

2.1 Efecto de la nicotina en la morfométría y citoarquitectura

del sistema visual........................................................190

2.2 Efecto de la nicotina en la proliferación y muerte celular..........194

2.3 Efecto de la nicotina en la neuroquímica del sistema visual.....195

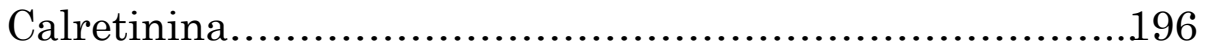

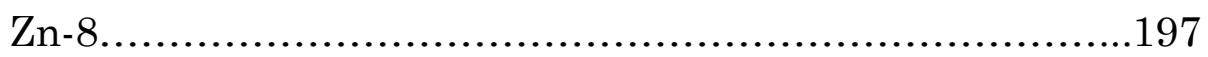

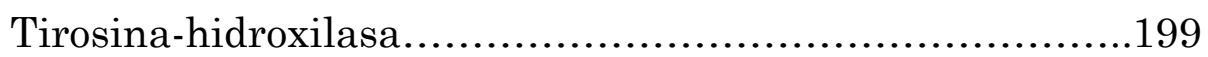

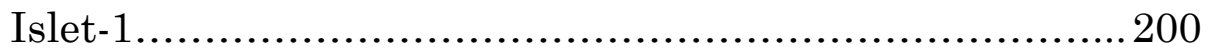

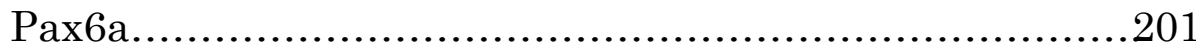

Zpr1 y Zpr3......................................................... 202

3. Efectos de la nicotina sobre los receptores nicotínicos

de la vía visual......................................................2204

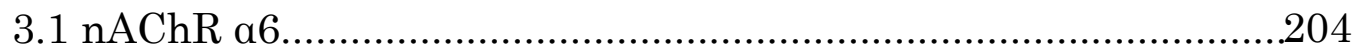

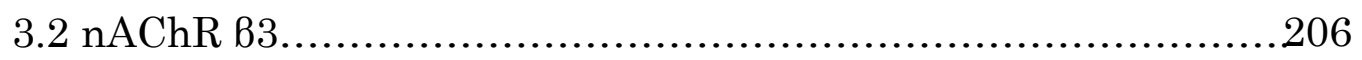

3.3 La relación entre receptores..........................................207

4. Efectos de la nicotina en la electrofisiología de la retina....210

5. Efectos de la nicotina en el comportamiento inducido por

la función visual......................................................213

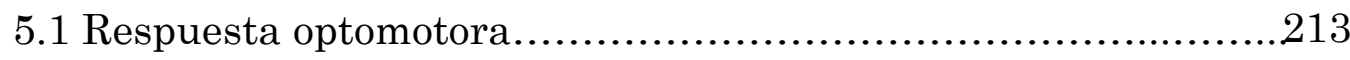

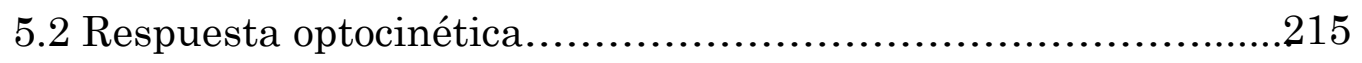

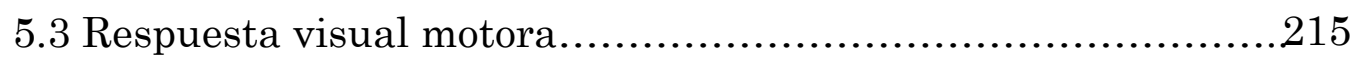

Conclusiones.........................................................217

Summary......................................................221

Bibliografía........................................................257 
Abreviaturas 



$\begin{array}{ll}\text { A: } & \text { Anterior } \\ \text { Ap: } & \text { Área preóptica } \\ \text { AMPA: } & \text { a-amino-3-hydroxy-5-methyl- } \\ & \begin{array}{l}\text { 4-isoxazolepropionic acid } \\ \text { receptor }\end{array}\end{array}$

BMP: Bone morphogenetic protein

E: $\quad$ Escleral

EAAT: Excitatory amino-acid transporter (receptor transportadores de aminoácidos excitadores)

EM: Estrato Marginal (Proteina morfogenética del EP: $\quad$ Epitelio Pigmentario hueso)

C: Caudal

CCG: Capa de las Células Ganglionares

CF: $\quad$ Capa de los Fotorreceptores

CFNO: Capa de las Fibras del Nervio Óptico

CNE: Capa Nuclear Externa

CNI: Capa Nuclear Interna

CPE: Capa Plexiforme Externa

CPI: Capa Plexiforme Interna

CR: Calretinina

Cr: $\quad$ Cristalino

D: Dorsal

DAB: $\quad 3,3$ '-diaminobencidina

DAPI: Dihidrocloreto de 4',6diamidino-2-fenilindole (Diclorhidrato de 4',6diamidino-2-fenilindol)

Di: Diencéfalo

DMSO: Dimetilsulfóxido

DNA: Ácido desoxirribonucleico

DNAc: DNA copia

DOPA: Dihidroxifenilalanina

dpf: Días postfecundación

ERG: Electrorretinograma

FGF: Fibroblast grow factor (Factor de crecimiento fibroblástico)

Fig: $\quad$ Figura

Frec: Frecuencia

GP: Glándula pineal

grad: Grado

GT: $\quad$ Ganglio trigémino

H: Hipotálamo

h: Hora

H3-F Histona H3-fosforilada

HIS: Hibridación in situ

hpf: Horas postfecundación

HPLC: High-performance liquid chromatography

(Cromatografía líquida de alta resolución)

IHQ: Inmunohistoquímica

qPCR: Quantitative polymerase chain reaction (Reacción en cadena de la polimerasa cuantitativa)

QO: Quiasma óptico

L: $\quad$ Lateral

M: Mesencéfalo

MC: Margen ciliar 
mGluR: metabotropic glutamate receptor (Receptor metabotrópico de glutamato)

min: Minuto

mV: Milivoltio

ms: Milisegundo

nAChR: Nicotinic acetylcholine receptor (Receptor nicotínico de acetilcolina)

NMDA: $\quad N$-Methyl-D-aspartate (Receptor inonotrópico de glutamato)

NO: $\quad$ Nervio Óptico

nof: $\quad$ mutantes nof de pez cebra

otx: $\quad$ Orthodenticle Homolog

Pax: $\quad$ Paired Box

pb: $\quad$ Pares de base

PBS: Tampón fosfato salino libre de RNasas

PBST: Tampón fosfato salino libre de RNasas con Triton X-100

PCR: Polymerase chain reaction (Reacción en cadena de la polimerasa)

PFH: Paraformaldehído

PK: $\quad$ Proteinasa K

Pr: $\quad$ Pretectum

Prox: Prospero-related Homeobox

PTU: Feniltiurea

R: $\quad$ Rostral

RNA: Ácido ribonucleico

RNAm: Ácido ribonucleico mensajero

RNAr: Ácido ribonucleico ribosómico

Ro: Rombencéfalo
ROC: Respuesta optocinética

ROM: Respuesta optomotora

rpm: Revoluciones por minuto

RVM: Respuesta visual motora

rx: $\quad$ Retinal Homebox

s: $\quad$ Segundo

six: $\quad$ Sineoculis Homeobox

shh: $\quad$ Sonic hedgehog

SNC: Sistema Nervioso Central

SNP: Sistema Nervioso Periférico

T: Tálamo

TA: Temperatura ambiente

TC: Tampón cacodilato

Tca: Trasducina alfa

Tg: $\quad$ Tegmentum

TGF-ß: Transforming grow factor beta (Factor de crecimiento transformante beta)

TH: Tirosina-hidroxilasa

Tm: $\quad$ Temperatura de melting (fusión)

TO: $\quad$ Techo Óptico

TUNEL: Terminal Transferase dUTPbiotin Nick End-Labeling

V: $\quad$ Velocidad

wnt: Wingless

ZBS: Zona Blanca Superficial

ZGPV: Zona Gris Periventricular

zic: $\quad$ Zic family member

ZLI: Zona limitante interna

Zpr: $\quad$ Zebrafish photoreceptor 


\section{Introducción}





\section{DESARROLLO DEL SISTEMA VISUAL EN EL PEZ}

\section{CEBRA}

\subsection{Ontogenia del sistema nervioso central de vertebrados}

El desarrollo del sistema nervioso consiste en un conjunto de procesos complejos y dinámicos que concurren en diversas etapas durante la formación del individuo. El cambio en su estructura se produce de manera continua como resultado de su dinámica interna y es desencadenado entre otros factores, por la interacción con las células circundantes. Este proceso esta orquestado por la actividad de diversas señales.

Tras el proceso de fecundación se genera el zigoto, la primera célula del individuo, a partir de cuya segmentación por una serie de mitosis, se originan los blastómeros progenitores, células aún indiferenciadas que organizarán posteriormente, entre otros, todos los derivados neurales (Hirose y Jacobson, 1979; Kimmel et al., 1991). En el desarrollo embrionario temprano tiene lugar la organización de campos morfogenéticos que, tras la gastrulación, originarán las tres hojas embrionarias: endodermo, mesodermo y ectodermo.

A continuación tiene lugar la inducción neural del ectodermo por el mesodermo, que dará lugar al tubo neural. Este proceso está dirigido por señales inductoras procedentes de la notocorda subyacente (Spemann, 1938; Sanes et al., 2000). Las células ectodérmicas expresan, entre otros, el factor de transcripción BMP-4 que provoca la expresión de un grupo de genes que inducen la formación de células epidérmicas (De Robertis y Sasai, 1996). La notocorda produce factores inductores neurales como Cordina, Noggina y Folistatina, que bloquean la señalización producida por el factor BMP-4 en el ectodermo (Wessely y De Robertis, 2002; Moreau y Leclerc, 2004). Así, un grupo de células ectodérmicas no forman tejido epidérmico, sino que se diferencian a tejido neural (Piccolo et al., 1996). El resultado de esta inducción es la formación de la placa 
neural, primer esbozo embrionario del Sistema Nervioso Central (SNC). A cada lado de la placa neural una banda de células se diferencian y constituyen las crestas neurales, estructuras precursoras, entre otras, del Sistema Nervioso Periférico (SNP) (Sanes et al., 2000).

La neurulación es el proceso morfogenético que desemboca en la formación del tubo neural a partir de la placa neural. Se han descrito dos tipos de neurulación: primaria y secundaria. En la neurulación primaria (Fig. 1A), la notocorda subyacente será la responsable de inducir la proliferación del ectodermo suprayacente y su posterior invaginación formando así un tubo hueco, que recibe el nombre de tubo neural (Schoenwolf, 1991; Lowery y Sive, 2004). En la neurulación secundaria (Fig. 1B) un grupo de células del ectodermo proliferan dando lugar a una masa de células, que a continuación se cavitará, originándose de este modo el tubo neural (Hisaoka y Battle, 1958; Schmitz et al., 1993; Kimmel et al., 1995). El mecanismo de neurulación varía en los diferentes grupos de vertebrados (Schoenwolf y Smith, 1990). En los peces teleósteos la neurulación se ha considerado tradicionalmente de tipo secundario (Ishii, 1967; Miyayama y Fujimoto, 1977; Nakao y Ishizawa, 1984). No obstante, el tubo neural correspondiente a la zona medular de los peces teleósteos deriva de una lámina epitelial curvada, lo que sugiere que en dicha región la neurulación

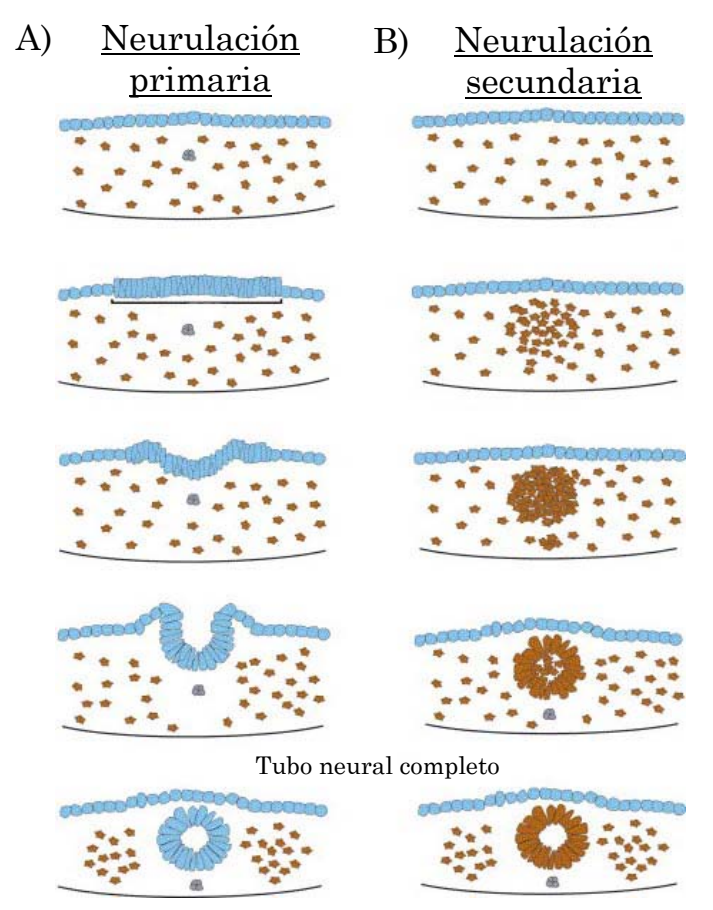

podría ser primaria.

Fig 1: El tubo neural se forma por dos
mecanismos diferentes a lo largo del eje
anteroposterior. En esta figura se preten-
de comparar la neurulación primaria y la
neurulación secundaria. (A) la neurula-
ción primaria implica columnización de
un epitelio existente, que luego se pliega y
se enrolla este epitelio (azul). (B) la neu-
rulación secundaria se caracteriza por la
condensación del mesénquima (marrón)
para formar un tubo, que experimenta
después una transición epitelial para for-
mar el tubo neural. (Modificado de Lo-
wery y Sive, 2004).

Fig 1: El tubo neural se forma por dos mecanismos diferentes a lo largo del eje anteroposterior. En esta figura se pretende comparar la neurulación primaria y la ción primaria implica columnización de un epitelio existente, que luego se pliega y se enrolla este epitelio (azul). (B) la neurulación secundaria se caracteriza por la condensación del mesénquima (marrón) para formar un tubo, que experimenta después una transición epitelial para forwery y Sive, 2004). 
El proceso de neurulación no ocurre simultáneamente a lo largo de todo el eje longitudinal del embrión, sino que sigue un gradiente rostrocaudal. Este gradiente se produce por la expresión diferencial de genes homeóticos, u homeogenes, todos ellos regulados por el ácido retinoico (Wilkinson, 1989). Por otra parte, en el establecimiento del eje dorsoventral intervienen diversos factores. El primero es la proteína Sonic hedgehog (Shh), secretada a partir de las células de la notocorda. Otro grupo de factores (que participan en el establecimiento de dicho eje) proceden del ectodermo dorsal y pertenecen a la familia de los factores de crecimiento transformante $B$ (TGF-B). Todos ellos inducirán la regionalización dorsoventral del tubo neural (Fig. 2), estableciendo una serie de parcelaciones que se denominan, de la porción más dorsal a la más ventral: placa superior o del techo, placa lateral alar, placa lateral basal (estas dos últimas separadas una de la otra por el surco limitante) y placa inferior o del suelo (Kuhlenbeck, 1973). Durante el desarrollo posterior, cada una de estas porciones, dará lugar a diferentes regiones y núcleos a lo largo del eje dorsoventral del tubo neural.

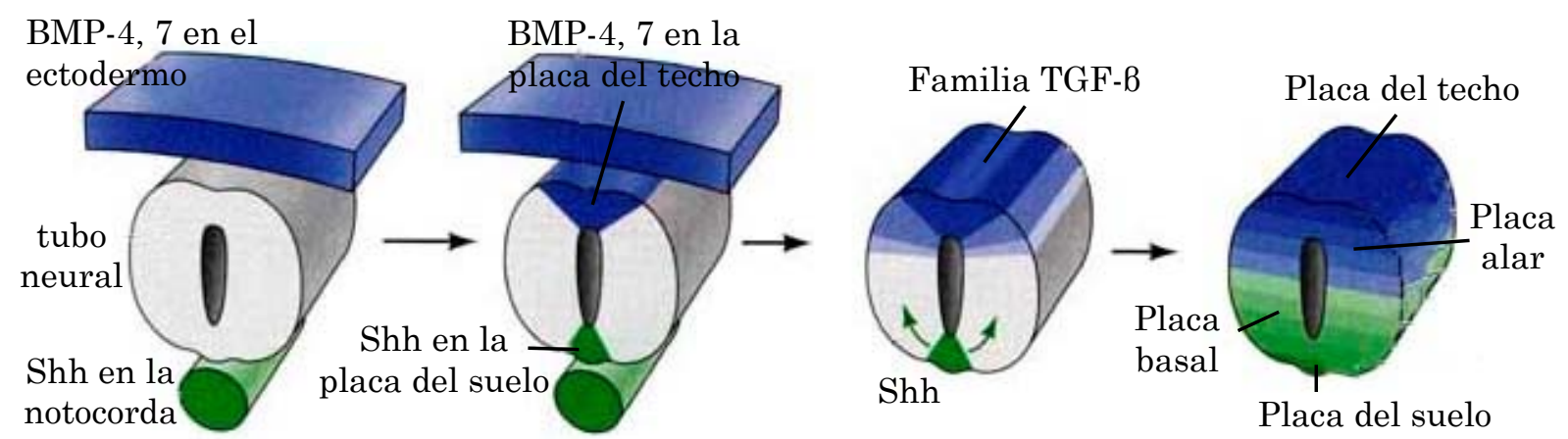

Fig. 2: Esquema de una sección transversal del ectodermo, tubo neural y notocorda donde se aprecian las diferentes regiones según el eje dorso-ventral y la actuación de determinados morfógenos. (Modificado de Gilbert, 2010).

A lo largo de su desarrollo, el tubo neural sufre una serie de cambios en su estructura y morfología más temprana para dar así todas las estructuras del SNC. Estas modificaciones se deben a procesos de histogénesis.

Una vez formado, el tubo neural no presenta el mismo calibre en toda su longitud. Se constituye de esta manera en segmentos neurales o neurómeros 
(Orr, 1887; Sane et al., 2000). Según el modelo neuromérico (Puelles y Rubenstein, 1993), los segmentos neurales se constituyen como subdivisiones transversales al eje mayor del tubo neural con características citogenéticas y morfogenéticas específicas. Dicho modelo describe que el tubo neural al inicio de su desarrollo es una estructura homogénea. A continuación, durante su desarrollo, y debido a la expresión diferencial de genes, se originan unas divisiones transversales (neurómeros) y longitudinales (placa del techo, placa del suelo, placa alar y placa basal) al eje rostrocaudal del tubo neural (Fig. 2). Una serie de señales intervienen en el proceso de segmentación del tubo neural, determinando el destino de cada neuroblasto, alcanzando éste una identidad única (Urbach y Technau, 2003). En vertebrados, según el modelo neuromérico, el encéfalo se divide en tres grandes regiones: prosencéfalo, mesencéfalo y rombencéfalo. La médula espinal se sitúa caudalmente a las vesículas encefálicas (Fig. 3).
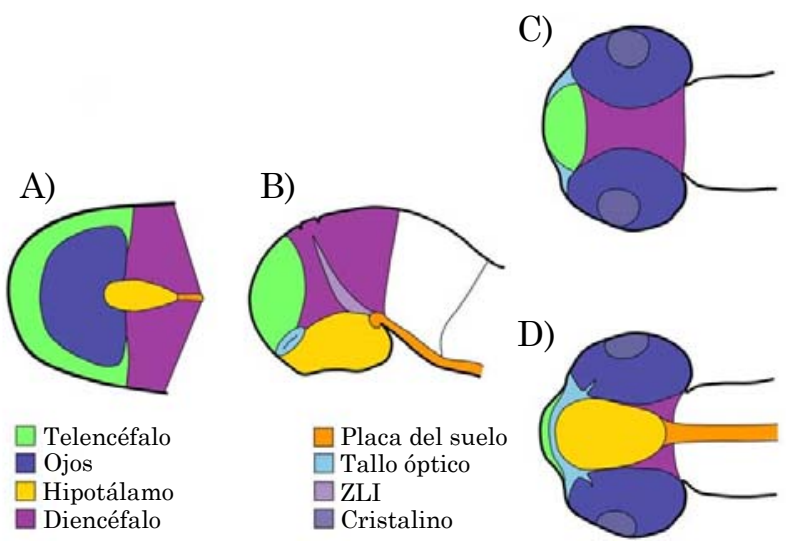

Fig. 3: (A) Organización de los zonas cerebrales en la etapa de la placa neural. Los grupos de células que dan lugar a cada zona se muestran en colores diferentes. (B-D) El mismo código de color se utiliza para mostrar las posiciones relativas de los diferentes zonas en los cerebros de embriones en una etapa posterior de desarrollo. Vista lateral (B), dorsal (C) y ventral (D). (Modificado de Cavodeassi et al., 2009).

Prosencéfalo: Es la vesícula más rostral y durante el desarrollo en ella se forman seis prosómeros. Los tres prosómeros más rostrales nombrados p6, p5, p4, establecen el prosencéfalo secundario, formado dorsalmente por el telencéfalo (p4p6) (Kuhlenbeck, 1973) y ventralmente por el hipotálamo (p4 -p6) (Wullimann y Puelles, 1999) y el área preóptica (p6). Los prosómeros más caudales (p3, p2 y p1) forman el diencéfalo (Wullimann et al., 1996). La región más rostral del diencéfalo (p3) dará lugar al tálamo ventral; la intermedia (p2) al tálamo dorsal y la glándula pineal; y la más caudal (p1) al pretectum.

Mesencéfalo: esta región no sufre ninguna división durante el desarrollo. 
$\mathrm{Su}$ único neurómero (mesómero) forma dorsalmente el techo óptico y ventralmente el tegmentum .

Rombencéfalo: es la región más caudal del encéfalo y limita con la médula espinal. Se subdivide en siete u ocho rombómeros, según la especie. En el caso del pez cebra (Danio rerio), el rombómero más rostral, que limita con el mesencéfalo, se denomina r0 y dará lugar al istmo. El rombómero r1 dará lugar al cerebelo (Moens y Prince, 2002). La parte más caudal dará lugar a la médula oblongata, compuesta por núcleos que derivan de los diferentes rombómeros.

Médula espinal: es la porción más caudal del tubo neural. En teleósteos presenta una porción de sustancia gris central en forma de Y invertida. En ella, las astas ventrales derivan de la placa basal, mientras que las astas dorsales proceden de la placa alar, y ambas zonas están separadas entre sí por el surco limitante (Kuhlenbeck, 1973). Por otro lado, en teleósteos hay tipos neuronales particulares (Nieuwenhuys, 1964) y conexiones sinápticas distintas a las existentes en otros vertebrados, como las células de Mauthner y sus contactos (Celio et al., 1979).

\subsection{Morfogénesis del sistema visual en el pez cebra}

La información visual es captada por la retina, que transforma la energía lumínica en impulso eléctrico que se transmite hasta las células ganglionares y por los axones de éstas hasta diferentes regiones encefálicas, dianas de la información visual; en el caso de los teleósteos la diana principal es el techo óptico mesencefálico.

Después del estadio de blástula tardía, 4-5 horas postfecundación (hpf), y justo antes de que comience la gastrulación, el destino de las células ya está parcialmente fijado. Con esta información se han trazado mapas en los que se recoge el destino celular (Kimmel et al., 1990). La gastrulación es el proceso por el cual las células situadas en el polo animal de la blástula, denominadas en 
conjunto blastodermo, originan las tres hojas embrionarias y se establecen los ejes del nuevo organismo. En el caso del pez cebra (y en la mayoría de los peces), este proceso comienza con la epibolia (4 2/3 -9 hpf), que consiste en la migración descendente de las células alrededor del vitelo (Betchaku y Trinkaus, 1978).

Al llegar aproximadamente al estadio de $50 \%$ epibolia (5 $1 / 4 \mathrm{hpf})$ tiene lugar un engrosamiento a lo largo del margen de la capa de la envoltura, que se denomina anillo germinal (5 2/3 hpf). En la región dorsal de este anillo se produce un proceso de involución celular, dando origen al escudo embrionario (6 hpf). Esta región es funcionalmente equivalente al labio dorsal del organizador de Spemman de anfibios o al nódulo de Hensen de aves y mamíferos (Gilbert, 2010). En la región del escudo embrionario, algunas células involucionan individualmente hacia el interior del embrión y constituyen el hipoblasto (8 hpf) y las células que no lo hacen constituyen el epiblasto (Blanco et al., 2007). Las células del hipoblasto convergen hacia la línea media intercalándose unas con otras y, a la vez, se extienden anteriormente, siempre por debajo del epiblasto. Las primeras células del hipoblasto en involucionar forman el mesodermo precordal, que es el precursor de la placa precordal; las siguientes en involucionar formarán el cordamesodermo, precursor de la notocorda. Las células adyacentes al cordamesodermo constituyen el mesodermo paraxial, responsable de la liberación de ácido retinoico que es el inductor de la polaridad antero-posterior del SNC.

El campo visual se encuentra situado en la placa neural anterior (6 hpf) que también dará lugar al telencéfalo, el diencéfalo y el hipotálamo. La placa neural anterior se origina cuando al progresar la epibolia, el anillo germinal, fuente de factores caudalizantes (como Wnts y ácido retinoico), va quedando alejado de la región dorsal (Wilson y Houart, 2004). Además, al migrar anteriormente, la placa precordal libera antagonistas de los factores caudalizantes, como Shh (Marlow et al., 1998). Hay que tener en cuenta que inicialmente todas las células de la placa neural anterior están mezcladas y se 
necesita una reordenación de las mismas. Esta reordenación, al menos en Xenopus, parece estar mediada por la interacción de las proteínas de factor de crecimiento fibroblástico (FGF) y las Efrinas (Moore et al., 2004).

Durante la especificación temprana del campo visual también es importante el antagonismo entre las rutas canónica y no canónica de Wnt (Logan y Nusse, 2004). Además, en pez cebra se han descrito otros genes muy importantes para la formación del campo visual, como six3 y la familia $r x$. Defectos en la expresión de estos genes conducen a alteraciones en la formación de los ojos o incluso a la ausencia de los mismos (Tucker et al., 2001; Lagutin et al., 2003). Para la adquisición de cierta identidad por parte de las células del campo visual, y que se diferencien del resto del telencéfalo, en teleósteos es necesaria la expresión diferencial de una serie de factores de transcripción como Pax6, Otx2 y la familia Rx (Kenyon et al., 2001). Estos factores están presentes durante mucho tiempo en el campo visual y también intervienen en la evaginación de las vesículas ópticas y en la diferenciación de las células retinianas.

La evaginación de las vesículas ópticas es el proceso por el cual un único campo morfogenético da lugar a dos dominios simétricos; es decir, el fenómeno por el cual este campo origina los dos primordios ópticos. El proceso se ha estudiado extensamente en diversas especies, pero todavía no se conoce en profundidad. De hecho, hasta los años 90 no se pudo demostrar con claridad que durante el desarrollo un único campo visual se divide en dos, ya que se consideraba que cada vesícula se formaba de un campo independiente (Li et al., 1997).

La evaginación de las vesículas ópticas comienza, aproximadamente, en el estadio de 3 somitos (11 hpf), cuando el dominio del campo visual adquiere forma bilobulada. El campo visual se encuentra limitado posteriormente por el primordio del hipotálamo y el pedúnculo óptico y anteriormente por el telencéfalo y por células del pedúnculo óptico y además de por células del 
diencéfalo en la periferia (England et al., 2006) (Fig. 3). Esta disposición es muy importante ya que, en etapas posteriores se invertirá parcialmente y el hipotálamo acabará situado entre las vesículas ópticas y un poco anterior a ellas. Anteriormente se consideró que el desplazamiento anterior del hipotálamo dividía el campo visual en dos (Varga et al., 1999). Sin embargo, esto no parece plausible, ya que justo antes de la neurulación, se produce una contracción de la parte posterior de la placa neural anterior, justo en el límite anterior del primordio del hipotálamo, que va a dar lugar a la formación de una quilla (England et al., 2006). Por tanto, el hipotálamo no divide el campo visual en dos, sino que se desplaza por debajo del mismo para, finalmente, emerger en posición anterior al telencéfalo. Durante este proceso, se arrastra a las células más posteriores del campo visual que comienza a plegarse. Simultáneamente, el telencéfalo, que arrastran a las células más anteriores del campo visual, se pliega hacia la línea media, lo que hace que se sitúen dorsalmente a las células más posteriores del campo visual (Cavodeassi et al., 2009).

Todos estos procesos generan las fuerzas necesarias para que comience la evaginación. Según England et al. (2006), la evaginación se produce por dos movimientos: 1. El diencéfalo dorsal se introduce hacia adelante empujando el campo visual y el pedúnculo óptico. 2. Las células del telencéfalo se dirigen al neuroporo anterior para sellarlo y las células de la línea media del campo visual se dirigen hacia las regiones laterales para ocupar el espacio libre.

Según estos mismos autores, la evaginación se debe a fuerzas generadas por otros dominios, que acaban arrastrando a las células del campo visual a sus posiciones laterales finales. No todos los autores apoyan esta teoría y así Rembold et al. (2006) postulan que la evaginación de las vesículas ópticas es consecuencia directa de la migración activa de los progenitores retinianos. Según estos autores los progenitores ventro-mediales permanecen inmóviles al principio del proceso, mientras que los progenitores situados en la región central convergen hacia la línea media. Este proceso lo realizan en dos movimientos, primero se hunden ventralmente y luego se dirigen hacia las regiones laterales 
de las vesículas ópticas. Durante este movimiento los progenitores retinianos extienden filopodios y lamelipodios, elongándose y retrayéndose, lo que demuestra la migración activa de estas células, tanto durante la convergencia hacia la línea media como durante la evaginación y separación final de las vesículas ópticas.

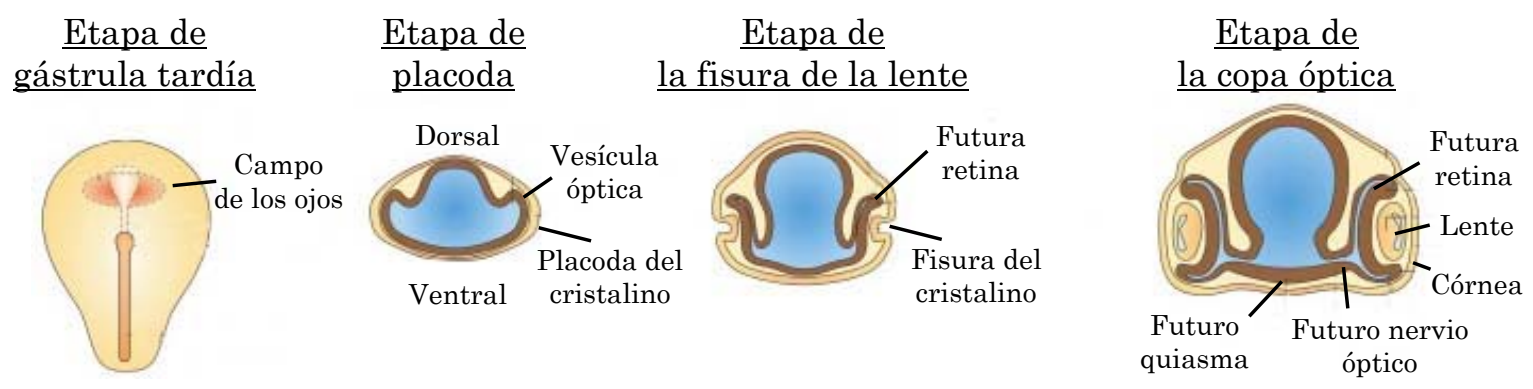

Fig. 4: Vista esquemática del desarrollo de los ojos en los vertebrados: desde la etapa de gástrula tardía hasta la formación de la copa óptica. (Modificado de Graw, 2010).

Una vez que se ha producido la división del campo visual, se forman los primordios ópticos (10 1/3 hpf), que quedan en contacto con el ectodermo superficial. Dicho contacto va a transformar los primordios en copas ópticas biestratificadas (epitelio pigmentario y retina neural) (Fig. 4). Durante la formación de las copas es necesario que el tejido retiniano se doble según el eje antero-posterior y también según el eje dorso-ventral (Schmitt y Dowling, 1994). El mecanismo por el cual sucede esto no se conoce en detalle, pero estudios en medaka han demostrado que es necesaria una constricción de la lámina basal donde se apoyan los progenitores retinianos, proceso regulado por la formación de adhesiones focales (Martínez-Morales et al., 2009). Simultáneamente se formará la lente (en el estadio de 21 somitos; 19,5 hpf) y se establecerá los patrones dorso-ventral y latero-medial de la retina (Graw, 2010). Las enzimas retinoaldehído deshidrogenasas, enzimas encargadas de la síntesis de ácido retinoico y de regular gran parte del desarrollo del sistema visual (Lupo et al., 2005) son muy importantes para la correcta formación de las vesículas ópticas (11 2/3 hpf). De esta manera, dichas enzimas presentan una distribución claramente diferencial, y se ha descrito que ésto podría regular los factores de transcripción implicados en el control del patrón dorso-ventral de la retina 
(Hyatt et al., 1996; Halilagic et al., 2007). Dichos factores de transcripción son Pax5, Bmp4 y Tbx5, que intervienen en la dorsalización de los primordios (Bäumer et al., 2002); y Shh, ácido retinoico y distintos FGFs, que regulan la ventralización (Lupo et al., 2005). La determinación del eje naso-temporal está controlada por Pax6 (Bäumer et al., 2002) y por diferentes miembros de la familia de las Efrinas (Connor et al., 1998).

Al mismo tiempo se está induciendo la formación de los pedúnculos ópticos gracias a una serie de moléculas, como por ejemplo Pax2 (MacDonald et al., 1995) y Shh (Dakubo et al., 2003). También se produce una rotación de todo el conjunto en el eje antero-posterior, de manera que la superficie superior se dirige hacia el exterior y la inferior hacia el encéfalo (Schmitt y Dowling, 1994). Es en este momento cuando se forma la copa óptica, y la conexión entre ésta y el resto del prosencéfalo se reduce a una estrecha abertura llamada fisura coroidea (19,5 hpf) que se dirige hacia el saco vitelino. A continuación, sucede otra rotación, por lo que la fisura coroidea queda orientada hacia el corazón (Schmitt y Dowling, 1994). Finalmente los pedúnculos ópticos darán lugar a los nervios ópticos.

En las primeras etapas de la morfogénesis de la retina, las células que componen las vesículas ópticas son morfológica y molecularmente equivalentes, pudiendo generar todos los componentes de la retina neural, pedúnculo óptico y epitelio pigmentario. La diferenciación de los distintos tipos celulares de la retina neural se inicia en la región más interna (o vitreal) de la parte central de la copa óptica y progresa concéntricamente hasta alcanzar las capas más periféricas (o esclerales) de la retina (Prada et al., 1991; Holt y Harris, 1993).

Hay abundantes datos sobre la diferenciación cronológica y secuencial de los distintos tipos celulares, así como de los factores que regulan la diferenciación a un tipo celular u otro. Sin embargo, no es bien conocido cómo una célula del margen ciliar deja de proliferar para diferenciarse. Algunos autores, basándose en modelos mutantes que presentan exceso o déficit de 
diferenciación, postulan que el ambiente generado por varios factores de transcripción en el margen ciliar induce proliferación, mientras que el ambiente existente en la zona central de la retina, alejado del margen ciliar, induce diferenciación (Cerveny et al., 2010).

En el estadio de pre-eclosión de 48 hpf, el ojo esta casi completamente formado, aunque la fisura coroidea no está totalmente cerrada hasta la eclosión, aproximadamente a los $3 \mathrm{dpf}$.

\section{Retinogénesis}

La potencialidad de las células de las vesículas ópticas es muy amplia y muchas de estas expresan marcadores de células altamente indiferenciadas (rx1, otx2, pax6 y six3) (Zuber et al., 2003). El proceso de neurogénesis en la retina del pez cebra comienza alrededor de las 20-24 hpf (Schmitt y Dowling, 1994). Las primeras células post-mitóticas, las células ganglionares, se diferencian entre las 28 y 32 hpf y expresan un factor de transcripción llamado Athonal5, que constituye el primer marcador de diferenciación de la retina. Aproximadamente a partir de las $48 \mathrm{hpf}$ se produce la diferenciación de las células amacrinas, bipolares y horizontales. Las células de Müller se diferenciarán a partir de las 60 hpf. Por último, algo más tarde, se diferencian los fotorreceptores. A los 3 días post-fecundación (dpf) se distinguen la mayoría de los tipos celulares y todas las capas de la retina, habiéndose organizado la zona proliferativa denominada margen ciliar. Además de esta secuencia temporal en la diferenciación de los tipos celulares de la retina también hay una secuencia espacial, ya que la primera zona en diferenciarse es la ventro-nasal y se extiende hacia la ventro-temporal (Morris y Fadool, 2005).

La teoría más aceptada actualmente propone que Shh es responsable de propagar la diferenciación en la retina, pero se desconoce qué inicia la diferenciación, aunque la señal podría proceder del pedúnculo óptico (Masai et $a l ., 2000)$. Shh se libera en oleadas desde distintos lugares para desencadenar la 
salida del ciclo celular de las células en división y su diferenciación a los distintos tipos celulares. Inicialmente Shh es generado por el epitelio pigmentario (Stenkamp et al., 2000), que dará lugar a una oleada posterior que es importante para el reclutamiento y diferenciación de fotorreceptores (Stenkamp et al., 2000). A continuación una segunda oleada de Shh se libera desde las células ganglionares, modulando la diferenciación de las regiones vitreales y organizando el margen ciliar; es decir, el remanente de células proliferativas que quedan en la retina adulta de teleósteos (Shkumatava et al., 2004). Esta segunda oleada de Shh es la más controvertida, ya que en ausencia de las células ganglionares se desarrollan todos los demás tipos celulares, aunque en exceso (Kay et al., 2001). Por último, una tercera oleada libera Shh desde las células amacrinas. En este caso, Shh es responsable de la laminación y si esta oleada no se produce, no se forma el patrón típico de alternancia de capas nucleares y plexiformes (Shkumatava et al., 2004).

Todos los procesos descritos anteriormente transforman la organización inicial del neuroepitelio simple pseudoestratificado de la retina neural en una estructura estratificada, con alternancia de capas con somas neuronales y neuropilo (Ramón y Cajal, 1889, 1892). Pero para que un sistema tan complejo como el visual sea funcional, (desde los $3 \mathrm{dpf}$ ) es necesario que los impulsos eléctricos resultantes de la transducción de la luz y moduladas por los circuitos de la retina sean transportados a diferentes regiones encefálicas donde serán integrados.

\subsection{Marcadores implicados en la morfogénesis visual}

Durante el desarrollo de las diferentes regiones del sistema visual se expresan distintos marcadores moleculares. Ello nos facilita el análisis de las diferentes zonas de la vía visual durante la ontogenia, así como el estudio de la proliferación, diferenciación y distribución final de poblaciones celulares concretas. 


\section{Histona H3-fosforilada}

Las histonas son proteínas esenciales de unión al DNA que regulan entre otras funciones el nivel de condensación del mismo. Además de constituir los nucleosomas, la unidad básica de la cromatina, las diversas modificaciones postraduccionales que pueden sufrir controlan los diferentes niveles de organización del DNA (Luger et al., 1997; Ridgway y Almouzni, 2001). En todos los eucariotas, durante la mitosis la histona H3 presenta una fosforilación en su extremo N-terminal, en el residuo de serina 10 (Ser10) (Prigent y Dimitrov, 2003). Esta modificación está relacionada espacial y temporalmente con la condensación cromosómica: comienza en la fase G2 tardía, en la heterocromatina pericentromérica y se extiende por todo el núcleo durante la transición a la fase M; su desfosforilación se inicia en la anafase y se completa en la telofase (Hendzel et al., 1997).

Aunque hay controversia, varios estudios indican que esta fosforilación es necesaria para que se produzca la condensación cromosómica durante la mitosis y la meiosis (Prigent y Dimitrov, 2003). No interviene, en cambio, en la condensación asociada a la apoptosis (Yoshida et al., 1997). Recientemente, se ha observado que en la interfase del ciclo celular también se produce una fosforilación en Ser10 de la histona H3; en este caso, no afecta a todo el genoma sino a genes específicos y estaría relacionada con su activación transcripcional (Prigent y Dimitrov, 2003).

\section{Calretinina}

La Calretinina (CR) se expresa abundantemente en los tejidos neurales centrales y periféricos, especialmente en la retina, pero también en otras vías sensoriales (Bertschy et al., 1998). Se ha propuesto que la Calretinina podría jugar un papel importante en la supervivencia de las células nerviosas durante alteraciones de la homeóstasis del calcio, debido a su capacidad de tamponar calcio (Andressen et al., 1993; Guglielmone y Corvetti, 2000). 
La CR es un miembro de la superfamilia de proteínas de unión a calcio, a la que pertenecen también la Calbindina, la Parvalbúmina y la Calmodulina. Esta familia se caracteriza por tener una secuencia de aminoácidos que se pliega para formar una estructura de seis hélice-bucle-hélice que constituye el dominio de unión a calcio (sección del lado EF) (Lukas y Jones, 1994). Los anticuerpos contra proteínas ligantes de calcio se han utilizado en estudios de neuroanatomía porque dan un excelente marcaje citoarquitectónico, marcando las células de forma similar a la impregnación de Golgi (Blümcke et al., 1990; Résibois y Rogers, 1992).

En peces, la Calretinina está ampliamente distribuida en el sistema nervioso central (Castro et al., 2006 a, b) y también se encuentra en células quimiosensoras (Pombal et al., 2002; Díaz-Regueira et al., 2005; Germanà et al., 2007). En la vía visual de peces teleósteos adultos se ha estudiado su distribución para caracterizar poblaciones neuronales en la retina (Weruaga et al., 2000), región preóptica, pretectum y tálamo (Díaz-Regueira y Anadón, 2000), y en el techo óptico (Arévalo et al., 1995; Díaz-Regueira y Anadón, 2000). Durante el periodo embrionario también se ha analizado la expresión de CR en la retina (Doldan et al., 1999) y en el techo óptico (Porteros et al., 1997).

\section{$\underline{\mathrm{Zn}-8}$}

Una vez que cesa la actividad mitótica, la maduración morfológica y funcional, puede analizarse mediante la detección de diferentes marcadores moleculares. El anticuerpo monoclonal (IgG1) anti-Zn8 permite inmunodetectar las células ganglionares y sus axones en crecimiento (Westerfield, 1995). El antígeno reconocido por el anticuerpo anti-Zn8 es una molécula de superficie de la superfamilia de las inmunoglobulinas llamada Neurolina/ALCAM (Laessing et al., 1994; Paschke et al., 1992). En peces, durante el desarrollo embrionario, la Neurolina (también llamada ALCAM o zf DM-GRASP) (Kanki et al., 1994) está involucrada en el crecimiento y guía de los axones de las células ganglionares hasta el disco óptico (Ott et al., 1998; Leppert et al., 1999; Paschke et al., 1992; 
Stuermer y Bastmeyer, 2000); y de los axones de las motoneuronas secundarias (Fashena y Westerfield, 1999; Ott et al., 2001). En retina, tanto en procesos de crecimiento continuado como en regeneración tras lesión, la Neurolina participa en la guía axonal de la misma manera que lo hace durante el desarrollo (Paschke et al., 1992; Parrilla et al., 2009). Sin embargo, en neuronas maduras sólo se encuentra en los sitios de contacto y sinapsis (Paschke et al., 1992), pudiendo estar implicada en la comunicación célula-célula y en la transducción de las señales (Diekmann y Stuermer, 2009). En mamíferos, el complejo proteico DMGRASP/SC-1/BEN participa en la adhesión celular y promueve el crecimiento y fasciculación de axones (Pourquie et al., 1992), así como la formación de sinapsis (Chédotal et al., 1996). Recientemente se han encontrado dos genes para la Neurolina en pez cebra: Neurolina-a, necesaria para la diferenciación de las células ganglionares y precede al crecimiento axonal, y Neurolina-b implicada en la guía de los axones desde el quiasma óptico hacia el techo óptico (Diekmann y Stuermer, 2009). El anticuerpo Zn-8 posiblemente reconozca ambas proteínas, dado que son muy parecidas (Mann et al., 2006).

\section{Tirosina-hidroxilasa}

Uno de los sistemas más significativos en el SNC es el de modulación mediada por catecolaminas, a través de un sistema que se extiende por todas las estructuras del sistema visual. En la síntesis de las catecolaminas, la enzima limitante es la Tirosina-hidrosilasa (TH). Esta enzima se expresa en regiones visuales encefálicas de peces teleósteos durante el desarrollo (Becerra et al., 1994; Holzschuh et al., 2001; Arenzana et al., 2006).

La Tirosina-hidroxilasa, o Tirosín 3-monooxigenasa, es la enzima responsable de catalizar la conversión del aminoácido L-tirosina a dihidroxifenilalanina (DOPA). La DOPA es el precursor de la dopamina, que a su vez es el precursor de la noradrenalina y de la adrenalina; todos ellos funcionan como neurotransmisores en el SNC (Bear et al., 1996). Se ha estudiado su distribución en peces teleósteos durante el desarrollo del SNC, 
encontrando expresión de la misma en la retina, área preóptica, pretectum, tálamo y techo óptico (Arenzana et al., 2006; Schweitzer y Driever, 2009).

\section{$\underline{\text { Islet-1 }}$}

El factor de transcripción Islet-1 pertenece a la familia de proteínas que poseen el homeodominio LIM. El término LIM hace referencia a las iniciales de los tres grupos prototipos: Lin-11, Isl-1 y Mec-3 (Freyd et al., 1990; Karlsson et al., 1990). La función de los dominios LIM es todavía desconocida, aunque este tipo de moléculas están implicadas en la determinación celular en algunos sistemas tisulares (Thor et al., 1991; Ericson et al., 1992). Este grupo de proteínas se caracteriza por presentar, además de dicho homeodominio, dos motivos Cys-His repetidos en tandem (Pfaff et al., 1996). En mamíferos adultos, Islet-1 ha sido detectado tanto en el SNC como en el SNP (Thor et al., 1991). En la retina de pollo, el gen islet-1 es considerado un marcador específico de las células ganglionares (Austin et al., 1995), comenzando su expresión en dichas células una vez que éstas han finalizado su migración hasta la superficie vitreal y comienzan su diferenciación (Sakagami et al., 2003). En estadios posteriores, el gen islet-1 se expresa en células amacrinas colinérgicas (Galli-Resta et al., 1997; Fischer et al., 2002) y en células bipolares (Fischer et al., 2002).

\section{$\underline{\operatorname{Pax} 6}$}

Los factores de transcripción que se encargan de regular la expresión génica, controlando así la síntesis de proteínas, se emplean como marcadores moleculares. Entre ellos se encuentra Pax6, implicado en la regulación de diferentes aspectos del desarrollo temprano (Stuart et al., 1994), como por ejemplo la formación del ojo (MacDonald et al., 1995; MacDonald y Wilson, 1996).

Pax es una familia de factores de transcripción altamente conservados en la evolución (Chalepakis et al., 1991; Czerny et al., 1993). Los genes pax 
codifican proteínas que constituyen una familia de factores de transcripción; se caracterizan por la presencia de una caja paired-box de $384 \mathrm{pb}$, con un dominio de unión al DNA de 128 aminoácidos muy conservado (Callaerts et al., 1997).

Los genes pax6 se expresan durante la morfogénesis del sistema visual, tanto en vertebrados como en invertebrados y están implicados en la regionalización de los diferentes tejidos presuntivos del ojo de vertebrados, siendo su expresión excluyente (Schwarz et al., 2000). El gen pax6, necesario para mantener la multipotencialidad de las células progenitoras de la retina (Marquardt et al., 2001), se expresa inicialmente en el primordio óptico, y posteriormente en todas las células de la futura retina, del epitelio pigmentario y del epitelio del cristalino, participando en la formación de la copa óptica (Grindley et al., 1995).

\section{Zpr1 y Zpr3}

En el caso del pez cebra hay marcadores específicos para los fotorreceptores. Así, Zpr1 (zebrafish photorreceptor 1) marca los conos y reconoce la arrestina 3 de proteína en los conos dobles de color rojo y verde (Larison y Bremiller, 1990; Ile et al., 2010). Zpr3 (zebrafish photorreceptor 3) marca los bastones. Tanto Zpr1 como Zpr3 se localizan no sólo en el soma sino también en los segmentos externos de los fotorreceptores. 


\section{ORGANIZACIÓN MORFOFUNCIONAL DEL SISTEMA}

\section{VISUAL}

\section{$\underline{2.1 \text { Retina }}$}

La estructura de la retina es muy similar en todos los vertebrados (Ramón y Cajal, 1892), si bien presenta algunas peculiaridades en teleósteos, como su forma más alargada y la localización desplazada de la papila óptica, la organización y número de sus fotorreceptores (Ali y Anctil, 1976), así como la aportación continua de nuevas células en su periferia y la subsiguiente reorganización de la capa de las fibras del nervio óptico (Johns, 1977).

La retina es un órgano estratificado que presenta alternancia de capas de células y neuropilo, con citoarquitectura muy conservada en todos los vertebrados. La luz entra por la cara vitreal y, tras atravesar todas las capas, incide sobre los fotorreceptores, que transforman dicha señal en impulsos eléctricos que se transmiten hasta las células ganglionares. El axón de estas neuronas constituye el nervio óptico, que sale de la retina y proyecta al techo óptico. La retina está formada por las siguientes capas y tipos celulares (Ramón y Cajal, 1889; 1892) (Fig. 5):

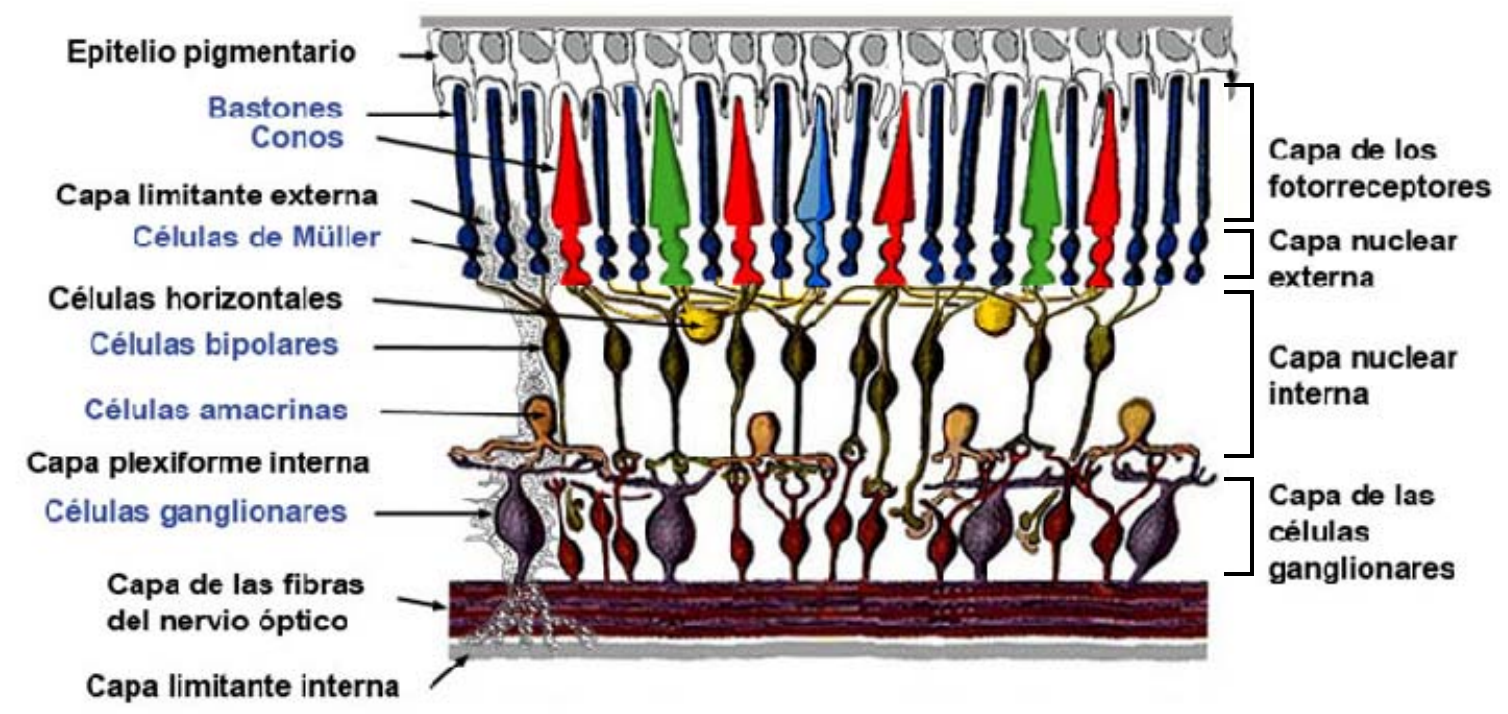

Fig. 5: Esquema de los estratos de una retina de vertebrados. Modificado de la página web: http://webvision.med.utah.edu/sretina.html 
Capa del epitelio pigmentario (EP): Es la capa más externa y está constituida por células epiteliales estrechamente unidas y con gran cantidad de pigmento en su interior. En su cara apical presentan interdigitaciones que se entremezclan con los segmentos externos de los fotorreceptores. Estas células intervienen en el transporte de sustancias hacia el resto de la retina y en la protección de los fotorreceptores frente a radicales libres y el exceso de luz (Dayhaw-Barker, 2002).

Capa nuclear externa (CNE): En esta capa se encuentran los somas de los fotorreceptores: los conos que se encargan de la visión fotópica y los bastones que se encargan de la visión escotópica. En su límite vitreal se encuentra la membrana limitante externa, constituida por los extremos de las prolongaciones de las células de Müller que se unen entre sí o con los fotorreceptores.

Capa plexiforme externa (CPE): En esta capa se producen las sinapsis entre las células fotosensibles y las interneuronas (células bipolares, horizontales e interplexiformes).

Capa nuclear interna (CNI): Aquí encontramos los somas de las células horizontales, bipolares, amacrinas, interplexiformes y de Müller.

Capa plexiforme interna (CPI): Contiene los axones de las células bipolares y las dendritas de las células amacrinas, interplexiformes y ganglionares. En esta capa se produce un nuevo relevo en la transmisión de la información visual.

Capa de las células ganglionares (CCG): Compuesta por los somas de las células ganglionares y de las células amacrinas desplazadas.

Capa de las fibras del nervio óptico (CFNO): constituida por los axones de las células ganglionares, que se disponen en fascículos paralelos a la superficie de la retina y convergen hacia la papila óptica, donde se pierde la laminación ya que las fibras atraviesan todo el espesor de la retina para formar el nervio 
óptico.

Los axones de las células ganglionares constituyen el nervio óptico, que sale de la retina a través de una región llamada cabeza del nervio óptico. Las células positivas para Pax2 de esta región en teleósteos, astrocitos, son importantes en el empaquetamiento de los axones durante el desarrollo (MacDonald et al., 1995), y en procesos regenerativos (Parrilla et al., 2013).

\subsection{Fisiología de la retina}

La retina presenta diferencias en la respuesta fisiológica respecto a la adaptación lumínica:

\section{Adaptación a la oscuridad}

Una vez expuestos a la luz, los conos y bastones se adaptan a un ritmo diferente. Por ejemplo, si se pasa de una zona de alta luminosidad (un día soleado) a una situación de oscuridad (una zona interior), es difícil ver en esta zona más oscura hasta que no han transcurrido unos minutos. Este fenómeno se conoce como adaptación a la oscuridad, y establece la base de la teoría de la duplicidad enunciada por Max Schütze (1866): por encima de un cierto nivel de luminancia, la respuesta de los conos está implicada en la mediación fotópica (luz) de la visión. Por debajo de este nivel, entra en juego la respuesta de los bastones, proporcionando la función escotópica (oscuridad) de la visión. El punto en el cual los bastones se vuelven más sensibles se denomina ruptura de bastóncono.

\section{Adaptación a la luz}

Los receptores para la luz de los conos en los segmentos externos, que contienen fotopigmentos (existen cuatro tipos de opsinas de cono en animales como la ardilla, el pollo, la musaraña y los peces; mientras que solo tres tipos de conos en humano). Los fotopigmentos en los conos se blanquean cuando se 
exponen a la luz. Por ejemplo, se pasa de un ambiente oscuro (en una zona interior) a una luminosa (un día soleado). Este fenómeno se conoce como adaptación a la luz. Nuestros ojos tienen que adaptarse rápidamente a la iluminación de fondo para poder discriminar los objetos en él. Una de las principales diferencias entre adaptación a la oscuridad y a la luz es su evolución en el tiempo. Mientras que para completar una adaptación total a la oscuridad en humanos son necesarios unos 30 minutos, la adaptación a la luz ocurre muy rápidamente, por lo general en menos de un minuto.

\subsection{El electrorretinograma como herramienta para evaluar la} actividad retiniana

Mediante técnicas de registro electrofisiológico podemos conocer la respuesta funcional de la retina tras una estimulación lumínica. Consiste en la suma de distintos potenciales de acción simultáneos, en diferentes estructuras de la retina. Dicha respuesta esta separada en diferentes ondas. En el pez cebra la primera respuesta electrofisiológica se produce a los 3 dpf (Fadool y Dowling, 2008), pero para tener una respuesta más robusta se realizan registros electrorretinográficos a partir de los 5 dpf.

Los métodos electrorretinográficos registran un potencial de campo sumatorio de la retina en respuesta a la luz. Holmgren fue el primero, en 1865, que descubrió que un estímulo de luz podía evocar un cambio en el potencial eléctrico del ojo en anfibios. Se demostró que la iluminación causa un ligero movimiento en un galvanómetro que sugiere un cambio eléctrico positivo en la córnea con respecto a la parte posterior del ojo (Armington, 1974).

Ragnar Granit (1933) publicó un estudio detallado de los componentes del electrorretinograma (ERG) en los gatos (Fig. 6). Realizó los registros con animales anestesiados y supervisó la eliminación gradual de los componentes del ERG en los diferentes niveles de anestesia. Granit nombra tres componentes diferentes en los registros electrorretinográficos: PI, P-II y P-III. El componente 
P-I es un una onda lenta, con voltaje positivo en la córnea. P-II es también una onda con voltaje positivo en la córnea que se eleva relativamente rápido a una amplitud máxima y luego se recupera a un potencial intermedio, mientras que el

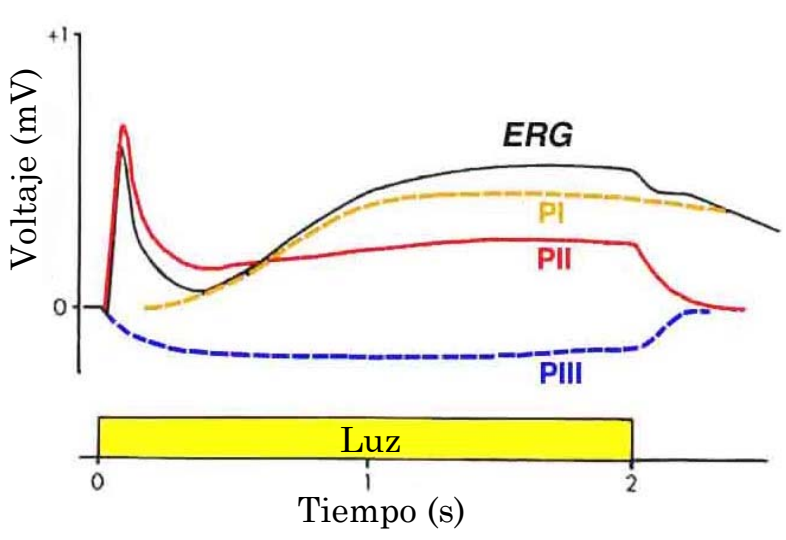

Fig. 6: El ERG de un gato en respuesta a un estímulo de luz de 2 segundos. Los componentes, PI, P-II y P-III, se han aislado mediante la profundización del estado de anestesia (Modificado de Granit, 1933). estímulo de luz se mantiene. Y el componente P-III, el más resistente al nivel de la anestesia, es una onda con voltaje negativo en la córnea que se desarrolla más rápidamente que las otras dos y se mantiene como un potencial negativo durante el tiempo que el estímulo de luz perdura. El análisis de estos componentes sigue siendo la base del ERG hasta nuestros días.

Hay dos vías de conducción eléctrica a través de la retina de vertebrados: radial y lateral. Los fotorreceptores están dispuestos en la retina en paralelo y, por lo tanto, sus corrientes están en paralelo y se suman, dando lugar a una fuerte corriente extracelular radial que fluye fuera de la capa nuclear interna hacia el epitelio pigmentario. Las corrientes extracelulares procedentes de todos los tipos de células retinianas se suman cuando se dirigen radialmente. En cambio, las corrientes laterales se inhiben entre sí dado que la disposición lateral de la retina es completamente simétrica. Por lo tanto, cuando un estímulo de luz homogéneo se dirige a toda la retina, sólo se forman las corrientes extracelulares radiales. Estas corrientes fluyen a través de diferentes vías (Fig. 7): (A) una local

y (B) una remota.

La corriente en la vía A permanece en la retina, mientras que la corriente en la vía B está fluyendo

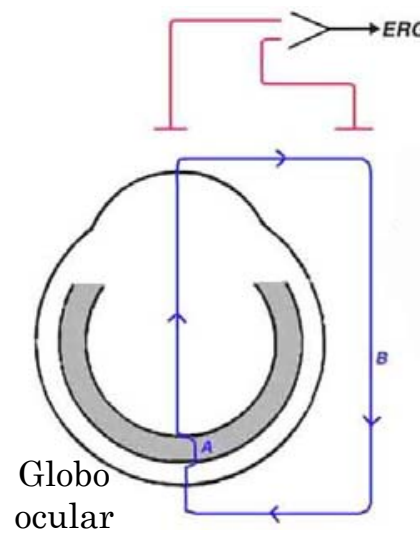

Fig. 7: Una representación esquemática de las corrientes extracelulares que se forman después de la estimulación con luz. Vía A representa las corrientes locales dentro de la retina, mientras que la vía $\mathrm{B}$ muestra las corrientes que salen de la retina a través del vítreo y la córnea y regresan a la retina a través de la coroides y el epitelio pigmentario. El registro de ERG en humanos se realiza a lo largo de la ruta B. Modificado de la página web: http://webvision.med.utah.edu/book/ electrophysiology/the-electroretinogram-erg/ 
fuera de la retina. El ERG es la medición de la corriente a lo largo de la vía B. Necesitamos un sistema de dos electrodos para registrar un ERG. La mayor intensidad de luz posible induce el cambio, observándolo cuando un experimentador registra un ERG. Cuando se realizan estudios de ERG en animales de laboratorio in vivo, los electrodos no se pueden insertar en la retina. Por lo tanto, la alternativa es registrar el ERG en localizaciones extraoculares mediante la colocación de dos electrodos.

\subsection{Origen de las ondas principales del ERG}

Como se ha mencionado anteriormente, el ERG se compone de al menos tres componentes principales. De estos análisis, se sabe que el negativo es la onda-a, que es el borde de ataque del componente negativo P-III; el positivo en la onda-b que refleja la suma de P-II y P-III, mientras que la onda-c es una onda lenta, que es la suma de los componentes P-I y P-III. Hay dos tipos de enfoques, fisiológicos y farmacológicos, que han sido intensamente utilizados para obtener información sobre el origen de la ERG.

\section{Generación de la onda-a}

Los fotorreceptores contribuyen en el ERG mediante la generación de la onda-a. Es un potencial negativo corneal, que es el más temprano cuando se aplica un estímulo luminoso (Brown, 1968; Brown y Wiesel, 1961). La onda-a en un ERG es la parte principal del componente P-III. Witkovsky sugirió dividir el componente P-III en potenciales lento y rápido (Witkovsky et al., 1975). La ondaa puede ser aislada por la aplicación exógena de L-glutamato (ácido 2aminofosfonobutírico, APB) (Slaughter y Miller, 1981). Se ha demostrado que APB (actualmente llamado L-AP4) (Schoepp y Johnson, 1988) es un agonista selectivo para todos los receptores mGluR del grupo III (mGluR 4, 6, 7 y 8) que bloquean la transmisión sináptica del primer nivel sináptico en la retina (Slaughter y Miller, 1981). En retinas aisladas del epitelio pigmentario se ha demostrado que el componente P-I puede ser eliminado y el componente P-III 
puede ser aislado (Witkovsky et al., 1975).

\section{Generación de la onda-b}

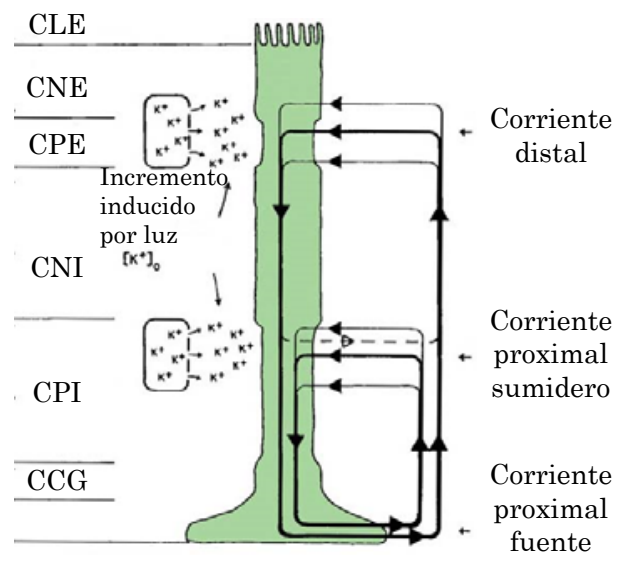

Fig. 8: Los caminos de las corrientes extracelulares que se han sugerido como la base de la generación de la onda b del ERG. Los dos sumideros (CPE y PCI) reflejan el aumento de los iones de potasio extracelular debido a la luz inducida por la actividad eléctrica. El vítreo sirve como una gran fuente de corriente debido a la conductancia de potasio de los pies de las células de Müller (Modificado de Newman, 1984).

La onda-b es el componente principal de los ERG. La mayoría de los investigadores han sugerido que el generador de la onda-b se encuentra en la capa nuclear interna (CNI). La idea fue sugerida por primera vez por Granit (1947) que concluye que, basándose en la sensibilidad de la onda-b al $\mathrm{KCl}$ y la asociación general de la excitación de la ondab, ésta inicia la despolarización de la membrana (Granit, 1962). Miller y Dowling (1970) fueron los primeros en sugerir que las células de Müller desempeñan un papel en la generación de la onda-b del ERG. Newman (Newman, 1979; 1980; Newman y Odette,1984) propuso su hipótesis de la "fuente de corriente" tras analizar la onda-b (Fig. 8).

Al elevarse la concentración de potasio extracelular se genera una corriente que fluye tanto en sentido proximal como distal en las células de Müller. Estas corrientes de entrada deben ser equilibradas por la corriente hacia fuera de otras regiones en las células de Müller. Estas fuentes de corriente se dirigen hacia el exterior saliendo por la región del extremo del pie (membrana limitante interna, MLI) de las células de Müller. Las corrientes de flujo hacia el interior parten a través de espacios extracelulares en los niveles de la capa plexiforme externa (CPE) y la membrana limitante externa (MLE). Estas corrientes establecen el voltaje positivo de la onda-b. Además de las células de Müller, en la onda-b también participan las células bipolares ON. Hay dos tipos de células bipolares con las que conectan los fotorreceptores; son las llamadas 
células bipolares ON y OFF (Fig. 9). En respuesta a una estimulación por luz, las células bipolares ON se despolarizan, mientras que las células bipolares OFF se hiperpolarizan. Las células bipolares ON usan mGluR de tipo 6 (Nakajima et

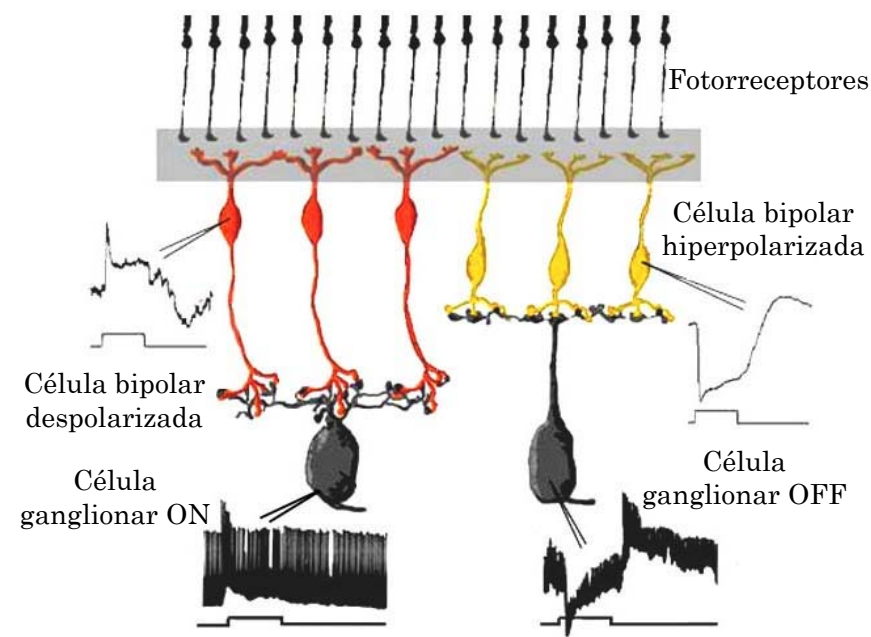

Fig. 9: Un esquema de células bipolares $\mathrm{ON}$ y OFF en la retina. En respuesta a una estimulación en condiciones lumínicas a la izquierda y una respuesta a una estimulación en oscuridad a la derecha. Modificado de la página web: http:// webvision.med.utah.edu/book/electrophysiology/the -electroretinogram-erg/ al., 1993) que detectan el glutamato en la sinapsis. Las células bipolares OFF usan los receptores amino-3-hidroxi-5metil-4-isoxazolepropionato

(AMPA/Kainato) (Sasaki y Kaneko, 1996; DeVries y Schwartz, 1999). La onda-b del ERG refleja principalmente la estimulación inducida por la luz en la actividad de las células bipolares ON y células de Müller.

Se ha postulado que las neuronas de tercer orden de la retina (células ganglionares y amacrinas) pueden contribuir a la onda-b. Por ejemplo, la aplicación exógena de GABA, glicina o dopamina afecta a la onda-b (Starr, 1975, Gottlob et al., 1988;. Naarendorp y Sieving, 1991). Otras neuronas de zonas distales de la retina parecen modular la respuesta de la onda-b en determinadas condiciones. Hay pruebas de que la actividad de la hiperpolarización de neuronas de segundo orden (células bipolares OFF) afectan tanto a la amplitud como a la cinética de la onda-b fotópica (Sieving et al., 1994).

Recientemente se ha demostrado (Wong et al., 2005a; Wong et al., 2005b; Wong y Dowling, 2005) que los tipos de receptores que median en la transmisión sináptica de conos y bastones en células bipolares ON y OFF en adultos de pez cebra utilizan receptores de glutamato para mediar : 1) señales de conos a través de células bipolares $\mathrm{ON}$ que implican al principal transportador de aminoácidos excitadores (EAATs), aunque también mGluRs (presumiblemente mGluR6) en menor medida; 2) las señales de bastones mediadas por células bipolares ON, en 
las que son principalmente mGluR6; 3) señales procedentes de fotorreceptores mediadas por células bipolares OFF que utilizan receptores AMPA/Kainato. Estos resultados son coherentes con la hipótesis de que, tanto los EAATs como los receptores AMPA/Kainato, están implicados en la generación de respuestas evocadas por la luz en células bipolares dirigidas por conos, que confieren a estas células propiedades de bipolares $\mathrm{ON}$ y $\mathrm{OFF}$, respectivamente. Estas células bipolares en la que la señal procede de conos pueden generar respuestas dobles, procedentes de las aportaciones de algunos conos a través de ciertos EAATs y de otros conos a través de receptores de AMPA/Kainato (Wong y Dowling, 2005).

\section{Generación de la onda-c}

El origen de la onda-c en los ERG procede del componente P-I de los ERG de Granit. Fue descrito por primera vez por Noell (1954). Se considera que la fuente de la onda-c está en el epitelio pigmentario (EP) (Noell, 1954; Steinberg et al., 1970; Pepperberg et al., 1978;. Pepperberg y Masland, 1978). Cuando el EP es destruido, la onda-c es eliminada; pero ,por otro lado, las descargas de las vías ópticas y las ondas a y b del ERG no se ven afectadas. Hay varios mecanismos posibles por los que la retina puede promover la interacción con el EP. Sólo una hipótesis fue aceptada, la del potasio (Oakley y Green, 1976): debe haber una disminución inducida por la luz en el potasio extracelular con tiempos similares a los de la onda-c.

\section{Generación de la onda-d}

Un ERG típico (sin adaptación a la oscuridad) presenta las ondas a, b, y d cuando los estímulos de luz aplicados son prolongados (más de $500 \mathrm{~ms}$ ). Como hemos mencionado anteriormente hay dos tipos de células bipolares en la retina, de acuerdo con sus patrones de respuesta. Las células bipolares ON (que corresponden a la onda-b del ERG) y las células bipolares OFF (que corresponden con la onda-d del ERG) fueron identificadas por criterios electrofisiológicos y anatómicos: los dos tipos de células bipolares producen 
corrientes postsinápticas de polaridad opuesta y los terminales de sus axones hacen sinapsis en diferentes partes de la capa plexiforme interna. Las células bipolares OFF se hiperpolarizan en respuesta a la luz (Fig. 9). Los receptores de AMPA/Kainato se encuentran en las zonas postsinápticas de estas células en todas las especies estudiadas hasta ahora (Hensley et al., 1993: Euler et al., 1996; Sasaki y Kaneko, 1996). El glutamato activa un canal catiónico no selectivo en estos receptores, lo que conlleva a un flujo hacia dentro de cationes y, consecuentemente, a la despolarización de la célula (Ozawa et al., 1998). DeVries y Schwartz (1999) mostraron, por registros de conos y células bipolares OFF simultáneamente, que la transmisión está mediada por el subtipo de receptores ionotrópicos kainato de receptores de glutamato y no por los subtipos AMPA.

\subsection{Regiones visuales encefálicas}

\section{Diencéfalo}

Durante el desarrollo, la región diencefálica se subdivide en tres vesículas. La más rostral da lugar al área preóptica y al tálamo ventral (prosómero 3), la intermedia forma las regiones del tálamo dorsal y la glándula pineal (prosómero 2) y la región más caudal organiza el pretectum (prosómero 1). Las regiones diencefálicas que reciben aferencias retinianas en peces teleósteos son el área preóptica, el tálamo y el pretectum (Wulliman et al., 1996) (Fig. 10).

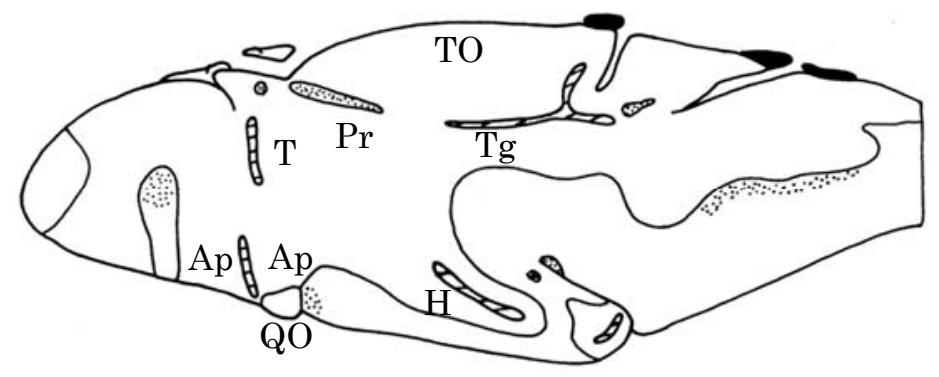

Fig. 10: Esquema de una sección parasagital de un encéfalo de pez cebra a los 5 dpf. Las áreas negras representan pigmento en las meninges. Las comisuras se indican con punteado. Los ventrículos son indicados por el sombreado. Las letras corresponden a áreas visuales. Ap: área preóptica, H: hipotálamo, QO: quiasma óptico, Pr: pretectum, T: tálamo, Tg: Tegmentum, TO: techo óptico, (Modificado de Wulliman y Knipp, 2000).

$\mathrm{Al}$ área preóptica llegan axones retinianos, en concreto a las regiones 
dorsal y caudal del núcleo supraquiasmático (Northcutt y Butler, 1993), el cual podría estar implicado en la generación y regulación de los ritmos circadianos, por homología con otros vertebrados (Northcutt y Wulliman, 1988).

Los núcleos talámicos anterior, intermedio $\mathrm{y}$ ventrolateral reciben aferencias retinianas directas (Schellart, 1990). El núcleo talámico anterior, junto con el dorsoposterior (que recibe aferencias tectales), constituyen la principal vía de entrada de la información visual hacia el telencéfalo (Echteler y Saidel, 1981). Estas vías ascendentes recuerdan a los sistemas visuales geniculado y extrageniculado de mamíferos y sus homólogos en otros tetrápodos.

El pretectum recibe aferencias retinianas y tectales, estando implicado funcionalmente en la modulación de la información visual (Butler y Hodos, 1996). Dentro del pretectum, los núcleos relacionados con el procesamiento de la información visual son el pretectal central y el pretectal periventricular dorsal (Wullimann et al., 1996). Con clara participación en la vía visual se encuentra el núcleo pretectal superficial parvocelular (Wulliman et al., 1991), donde la información visual hace relevo en su camino hacia el hipotálamo.

El hipotálamo se origina como un derivado prosencefálico procedente de la placa alar, en concreto de su zona más ventral. En mamíferos, la región hipotalámica donde se forma el quiasma óptico se caracteriza por presentar tanto glía radial a ambos lados de la línea media (Reese et al., 1994; Marcus et al., 1995) como neuronas (Easter et al., 1993; Sretavan et al., 1994) antes de que lleguen los axones maduros retinianos. No obstante, el entorno celular en el futuro hipotálamo es diferente en pez cebra. Así, en el pez cebra, en el estadio en el que llegan los axones de las células ganglionares, no se detectan neuronas, sino que aparecen las fibras de la comisura postóptica. Otra diferencia importante en el desarrollo de la vía visual la constituye el hecho de que los axones ópticos en el pez cebra se encuentran recubiertos por glía, a diferencia de lo que ocurre en mamíferos, de forma que las interacciones entre axones procedentes de copas ópticas distintas son casi inexistentes (MacDonald et al., 
1994; Guillery et al., 1995; Marcus et al., 1995).

\section{Mesencéfalo}

Durante el desarrollo, el mesencéfalo procede de un único mesómero que no se subdivide en nuevos neurómeros tras la morfogénesis temprana. Las estructuras mesencefálicas relacionadas con la vía visual son el techo óptico y el tegmentum, que están separados por el ventrículo. El tegmentum se desarrolla a partir de la placa basal del mesómero (Ross et al., 1992; Sanders et al., 2002).

La diana principal de la información visual en el techo óptico, que se diferencia a partir de la placa alar del mesencéfalo y es el encargado de analizar la información perteneciente a movimiento, forma y color (Guthrie y Banks, 1990). Además, formando parte del mesencéfalo encontramos ventralmente al tegmentum, que también está involucrado en el procesamiento de la información visual, ya que envía proyecciones al techo óptico (Grover y Sharma, 1981).

El techo óptico (TO) es una estructura mesencefálica bilobulada que actúa de centro integrador de toda la información visual, y a él llegan los axones de las células ganglionares. En los animales adultos está compuesto por 6 capas de somas y neuropilo (Vanegas et al., 1984; Meek y Nieuwenhuys, 1998), pero a las edades utilizadas en esta Tesis Doctoral, 5 dpf como máximo, sólo se diferencian tres: la zona gris periventricular (ZGPV), donde se encuentran la mayor parte de los somas, la zona blanca superficial (ZBS), que incluye las prolongaciones de los somas de la ZGPV y de otras regiones del encéfalo; y el estrato marginal (EM), que consiste en una monocapa celular en la región más exterior del TO.

En el pez cebra, cada lóbulo recibe la mayoría de aferencias de la retina contralateral y muy pocas de la ipsilateral (Springer y Gaffney, 1981). Dentro del TO y organizadas en los diversos estratos se encuentran diferentes tipos de interneuronas, algunas de las cuales son positivas para Pax6, CR y Prox1. La retina proyecta, principalmente, a los estratos superficiales (Laufer y Vanegas, 
1974). Sin embargo, el EM sólo recibe aferencias de la región del tegmentum (Lara et al., 1995). Se ha descrito que algunas proyecciones que se encuentran dentro del TO, tanto aferencias como eferencias, son positivas para marcadores como CR y la glía es positiva a GS (Arenzana, 2006).

El TO, al igual que la retina y otras regiones del cerebro de teleósteos, mantiene una población de células proliferativas hasta la edad adulta (Zupanc et al., 2005; Ito et al., 2010). Hasta las $24 \mathrm{hpf}$, el TO permanece indiferenciado y con una elevada actividad proliferativa. A partir de ese momento comienza la diferenciación y las células proliferativas con características de células troncales van quedando restringidas a los márgenes medial, lateral y caudal de la ZGPV (Zupanc et al., 2005).

En teleósteos, las proyecciones retinotectales están ordenadas topográficamente, la ubicación final de cada axón retiniano en el TO refleja la posición de su cuerpo celular en la retina (Culverwell y Karlstrom, 2002). Estas relaciones topográficas se mantienen después de procesos de degeneración y regeneración, aunque debido al continuo aporte de nuevas células tanto en la retina como el TO, sufren un continuo reordenamiento (Easter y Stuermer, 1984). El refinamiento del mapa retinotópico depende de la actividad retiniana (Thompson y Holt, 1989). Sin embargo, la diferenciación inicial del TO es independiente de la llegada del nervio óptico ya que en mutantes que carecen de ojos (mutantes $c h k$ ), ésta es prácticamente normal, al menos durante el desarrollo temprano. 


\section{ESTUDIOS DE COMPORTAMIENTO EN EL ANÁLISIS DE LA} FUNCIÓN VISUAL

Desde los primeros estudios sobre la función visual, los ensayos de comportamiento han sido una herramienta importante para complementar las investigaciones anatómicas y electrofisiológicas. Ya en 1866, Schültze estableció la diferencia funcional entre los fotorreceptores, bastones y conos, con una inteligente combinación de observaciones anatómicas y de comportamiento, estableciendo la piedra angular de lo que hoy se conoce como la teoría dúplex de la visión. Los experimentos de comportamiento con animales son más complejos de realizar que en humanos. Los investigadores Hecht y Wolf (1929b) afirmaron que: "Estudiar la visión de animales distintos del hombre se hace difícil por la imposibilidad de la comunicación verbal entre el animal y el experimentador".

\section{$\underline{3.1}$ Respuestas tras entrenamiento con estímulos visuales}

La forma más obvia, aunque no la más fácil experimentalmente, para investigar el sistema visual de un animal es entrenarlo para discriminar entre diferentes estímulos visuales. Esta técnica se ha aplicado durante décadas para investigar diferentes aspectos del sistema visual en animales, por ejemplo para probar la visión del color en las abejas (von Frisch, 1914), o para determinar la agudeza visual de ratones y ratas (Prusky et al., 2000). Este tipo de experimentos de formación también se ha empleado en especies de peces, en particular para el carpín dorado (Carassius auratus) (Neumeyer, 1984; Ingle, 1985; Neumeyer y Arnold, 1989; Fratzer et al., 1994; Dörr y Neumeyer, 1997, 2000; Neumeyer et al., 2002; Neumeyer, 2003). El pez de agallas azules (Lepomis macrochirus) también resulta muy cooperativo en los experimentos de formación y se utiliza en estudios psicofísicos: por ejemplo, para la investigación de la discriminación del color y la textura (Hurst, 1953; Bando, 1993) o para la determinación de la agudeza visual, el contraste y la sensibilidad durante la regeneración del nervio óptico (Northmore et al., 2007). Otras especies de teleósteos pueden entrenarse, con éxito, en respuesta a estímulos visuales, como 
ya demostró von Frisch (1913), que utilizó la cabezona (Phoxinus laevis) para mostrar por primera vez la visión de color en un vertebrado, incluso antes de la publicación de sus clásicos experimentos con abejas (von Frisch, 1914). Brunner (1935) también la utilizó para evaluar la discriminación de agudeza visual bajo diferentes intensidades de iluminación.

\subsection{Respuestas innatas a los estímulos visuales}

En contraste, el estudio de la respuesta innata frente a estímulos visuales no requiere entrenamiento. El uso de tales conductas reflejas en la investigación de la visión fue iniciado a principio del siglo XX y con ellas se han estudiado muchas propiedades del sistema visual en diversos animales. Así, Hecht y Wolf (1929b) estudiaron la agudeza visual de abejas utilizando un comportamiento reflejo: las abejas que se arrastran en una superficie inclinada responderán a un movimiento repentino en su campo visual por un lateral, ocasionando el movimiento de la cabeza y el tórax. Se observaron las reacciones obtenidas al mover los patrones de rejillas con diferentes frecuencias espaciales en diferentes iluminaciones por debajo de una abeja que se arrastra en una placa de vidrio, para establecer la relación entre la agudeza visual y la iluminación (Hecht y Wolf, 1929a, b). En los peces, esta reacción, conocida hoy como respuesta optomotora, fue estudiada por primera vez por Lyon (1904); y utilizada más adelante por Grundfest (1931) para estudiar la sensibilidad espectral del pez de agallas azules y por Wolf y Wolf-Zerrahn (1936) para determinar la frecuencia de fusión de destellos en la misma especie.

Una prueba ideal de comportamiento para la valoración de una respuesta innata (es decir, los animales no tienen que ser entrenados) debe ser lo más sólida posible (es decir, todos los animales examinados deberán mostrar la misma conducta) y debe ser cuantificable y automatizable. Se han desarrollado ensayos de comportamiento para larvas de pez cebra, que han sido utilizados para la detección de mutaciones del sistema visual y para caracterizar la visión de larvas silvestres y/o mutantes. Los ensayos más utilizados son: 


\section{Respuesta optomotora:}

La respuesta optomotora (ROM) es el comportamiento locomotor de un animal, inducido por un patrón de estímulos visuales repetitivos en movimiento. En la mayoría de los estudios este patrón consiste en franjas verticales, que pueden ser blancas y negras (Clark, 1981), de diferentes contrastes de grises (Lindsey et al., 2002), o de colores diferentes (Schaerer y Neumeyer, 1996). La ROM ha sido descrita en diferentes especies animales tan distantes como la mosca de la fruta (David, 1979), la salamandra tigre (Lindsey et al., 2002), el pez cebra (Clark, 1981) y el humano (Klein et al., 2000). La hipotética función de la ROM sería actuar sobre el control de la velocidad y dirección del movimiento del cuerpo (Srinivasan et al., 1999); o más en general, estimularía el mecanismo neuronal implicado en el procesamiento del flujo óptico, que es necesario para la guía visual propio del movimiento (Kern et al., 2001). La ROM es una natación refleja en la dirección de movimiento percibido. Los peces presentan esta respuesta para mantener una posición estable en un río que fluye, o para responder al movimiento aparente de las señales visuales presentes en el lecho del río (Roeser y Beier, 2003).

Esta respuesta se valora en grupos de larvas de peces que se disponen en canales longitudinales y a las que se les presenta un patrón de rayas en todo el campo visual en movimiento desde abajo (Fig. 11A). Ya que tienden a seguir las rayas, las larvas atenderán al estimulo y nadarán en la dirección de movimiento percibido, dirigiéndose hacia el extremo del canal. El índice optomotor puede ser calculado como la relación entre las larvas en una parte definida (por ejemplo, en el último cuarto del canal) y el número total de larvas en un canal. Se postula que la ROM está mediada por los conos rojos y verdes (Orger y Baier, 2005).

\section{Respuesta optocinética:}

Este ensayo cumple con los requisitos anteriormente citados y, por lo tanto, en una herramienta válida para la detección de mutaciones que afectan al 
sistema visual de larvas de pez cebra (Brockerhoff et al., 1995, 1997; Neuhauss et al., 1999, Gross et al., 2005; Muto et al., 2005). La respuesta optocinética consiste en que las larvas de peces están incluidas en metilcelulosa para evitar los movimientos del cuerpo y se les presenta un patrón de rayas verticales que gira alrededor de ellas. Si son capaces de ver este patrón, muestran un movimiento estereotipado de sus ojos, que se compone de dos fases: una fase lenta en la dirección de la percepción del movimiento, con lentos movimientos de seguimiento en la dirección del movimiento percibido y rápidos movimientos de reposición (sacádicos) en la dirección opuesta, que se produce cuando los ojos han alcanzado su ángulo de desviación máxima.

Para evocar un ROC en condiciones de laboratorio, por lo general se presenta al sujeto un patrón de rayas verticales en blanco y negro con movimiento horizontal. El patrón, por lo tanto, tiene que ocupar la totalidad o al menos una gran parte del campo visual, lo que se consigue colocando el objeto en el centro de un tambor giratorio equipado con rayas verticales en blanco y negro (Fig. 11B). El pez cebra es especialmente adecuado para este estudio debido a su desarrollo rápido (Fadool y Dowling, 2008). En el pez cebra, un ROC se puede observar ya a los 3 dpf, aunque es más fiable a los 5 dpf (Easter y Nicola, 1997; Rinner et al., 2005).

\section{Respuesta visual motora:}

La respuesta visual motora (RVM) registra la actividad locomotora de las larvas en respuesta a los cambios en la iluminación ambiental. Después de un cambio repentino en la intensidad de la luz, las larvas muestran una típica respuesta de sobresalto, seguida por un período de actividad mejorada o deprimida. Mediante la colocación de larvas de peces en pocillos individuales de una placa de múltiples pocillos, la actividad de muchas larvas se pueden grabar en paralelo (Fig. 11C).

Un estímulo de luz de alta intensidad provoca una serie de conductas 
estereotípicas motoras en larvas de pez cebra. El conjunto del ensayo se puede dividir en cuatro grandes fases: una fase de fondo pre-estímulo, otra de latencia, una fase de excitación y otra refractaria (Kokel et al., 2010). Se ha estudiado también el efecto de la manipulación del periodo de duración de la luz y la oscuridad (McPhail et al., 2009).

A)

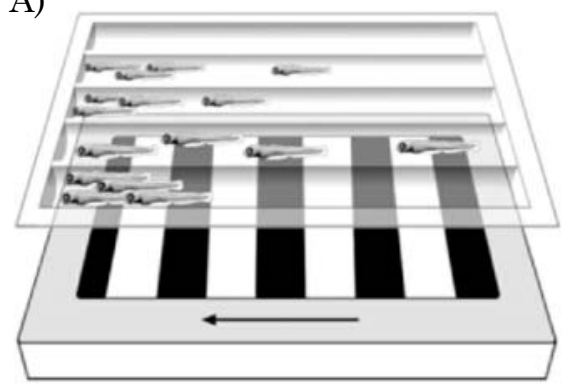

B)

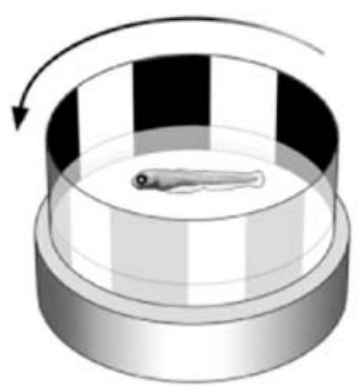

C)

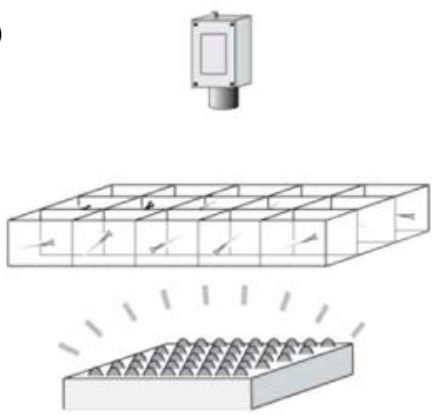

Fig. 11: Ensayos de comportamiento visual en larvas de pez cebra. A) Respuesta optomotora (ROM). B) Respuesta optocinética (ROC). C) Respuesta visual motora (RVM). (Modificado de Neuhauss et al., 2010). 


\section{EFECTOS DE LA NICOTINA SOBRE EL DESARROLLO DEL SISTEMA NERVIOSO CENTRAL}

La adicción al tabaco es uno de los problemas socio-económicos y sanitarios más importantes de los países civilizados y la prevalencia de esta enfermedad está aumentando de manera significativa en los países en vía de desarrollo. Según la Organización Mundial de la Salud (OMS), más de 1000 millones de personas fuman tabaco en todo el mundo y su consumo produce más de 5 millones de muertes cada año. Además, el consumo de tabaco constituye un factor de riesgo para 6 de las 8 principales causas de mortalidad en el mundo (OMS, 2012). La nicotina es el principal componente psicoactivo del tabaco y la responsable de la adicción al mismo.

\subsection{La nicotina}

La nicotina es un alcaloide que se encuentra en la planta Nicotiana tabacum (Fig. 12A) en cantidades que varían entre el 0,3\% y el 5\% siendo en las hojas donde se localiza la mayor concentración de dicha sustancia. La nicotina toma su nombre de Jean Nicot, (embajador francés en Portugal, 1559), que usaba el tabaco para curar las migrañas de la reina Catalina de Médicis. Se denominaba entonces "hierba santa" o "hierba para todos los males" por su empleo casi indiscriminado: se recetaba, entre otros, para el dolor, la cefalea o la flatulencia. La nicotina se aisló por primera vez de la planta del tabaco en 1828 por los químicos alemanes Posselt y Reimann (Koob y Le Moal, 2006).

La nicotina es una amina terciaria que existe en sus dos formas isoméricas, pero el tabaco contiene sólo la forma más activa desde el punto de vista farmacológico, el isómero L-nicotina (Fig. 12B). Ésta es una base débil cuya absorción va a depender del $\mathrm{pH}$. Así, la nicotina presente en los cigarrillos con un $\mathrm{pH}$ de 5,5 se absorbe en el pulmón, de un $79 \%$ a un $90 \%$, y en menor medida a través de la mucosa bucal, plexos sublinguales y piel, mientras que la nicotina 


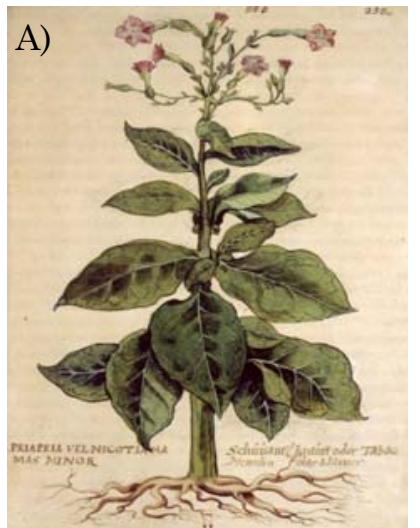

B)

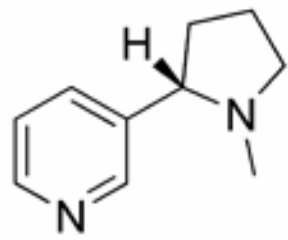

Fig. 12: A) Planta de tabaco. B) Estructura química de la nicotina (C10H14N2, 3-(1Metilpirrolidin-2-il) piridina). PM: 162 presente en pipas, puros, tabaco de mascar y rapé con un pH de 8,5 se absorbe de manera más importante en las mucosas nasal y oral (Koob y Le Moal, 2006). Una vez absorbida en el organismo, la nicotina se distribuye rápidamente por los

tejidos del cuerpo y tarda entre 10-19 segundos en llegar al cerebro (Benowitz, 1996) donde ejerce su acción psicoactiva a través de su unión a los receptores nicotínicos de acetilcolina $(\mathrm{nAChRs})$. La vida media de la nicotina es de 2-3 horas. El 80\% de la droga se metaboliza en el hígado, convirtiéndose en cotinina, su principal metabolito. El 90\% de la metabolización de la droga se realiza a través del citocromo CYP2A6, aunque otros enzimas, como el CYP2B6, el UGT (UDPglucoronosiltransferasa) o el FMO (monooxigenasa contenedora de flavina) pueden también metabolizarla. Un porcentaje bajo de la nicotina es eliminado sin metabolizar por vía urinaria. Es importante resaltar que variaciones en la metabolización de la nicotina afectan al patrón del consumo del tabaco (Wall et al., 2007).

\subsection{Mecanismo de acción de los $\mathrm{nAChRs}$}

Las acciones farmacológicas de la nicotina son debidas a la activación de unos receptores pertenecientes al sistema colinérgico, los nAChRs, que pertenecen a la superfamilia de los receptores ionotrópicos activados por ligando, siendo la acetilcolina su ligando endógeno. La acetilcolina también activa otro tipo de receptores, los muscarínicos, perteneciente a la superfamilia de receptores acoplados a proteínas G. Los nAChRs son pentámeros de combinaciones homo o heteroméricas de diferentes subunidades $(\alpha, b, y, \delta)$ cada una con cuatro dominios transmembrana (Le Novere y Changeux, 1995). Se conoce 10 subunidades a (a1-a10), 3 subunidades $B$ (B2-B4), una y y otra $\delta$. Estas subunidades se agrupan alrededor de un poro central permeable a cationes $\left(\mathrm{Na}^{+}\right.$, $\left.\mathrm{K}^{+}, \mathrm{Ca}^{++}\right)$. Las posibles combinaciones de estas subunidades y su extensa 
localización en el organismo hacen que el receptor tenga multitud de funciones fisiológicas (Gotti y Clementi, 2004).

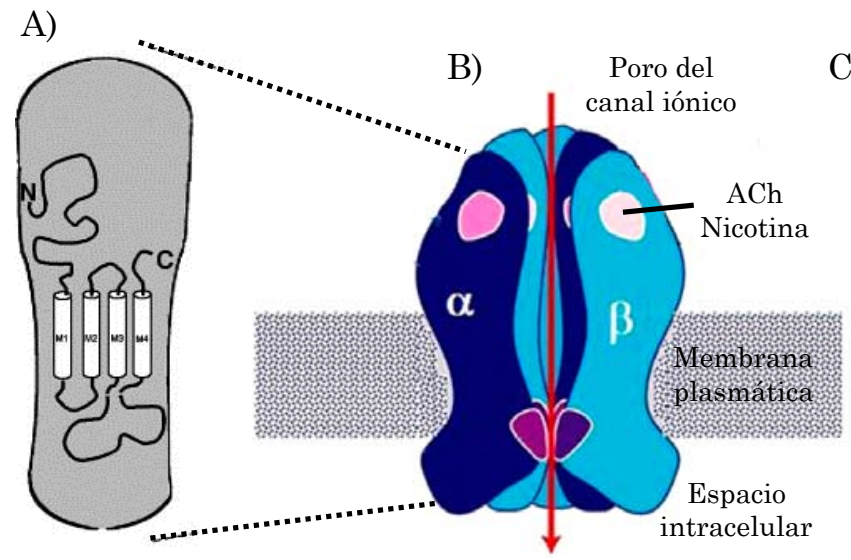

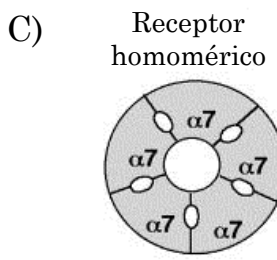

Receptor heteromérico

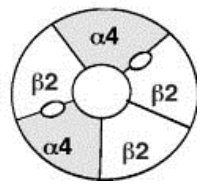

Fig. 13: A) Organización y estructura de las subunidades de los nAChRs. B) Representacion esquematica del nAChR ensamblado en la membrana celular. (C) Receptor homo y heteropentamerico y el sitio de union de sus ligandos (modificado de Gotti y Clementi, 2004).

Como se puede observar en la Figura 13, estos receptores contienen una porción extracelular amino-terminal hidrofílica, que constituye el sitio de unión de los ligandos a dicho receptor. A continuación le siguen 3 dominios transmembrana hidrofóbicos (M1-M3), una larga cadena intracelular y un cuarto dominio transmembrana también hidrofóbico (M4). La región transmembrana M2 es la que se cree responsable de la formación del poro. Esta subunidad está compuesta por aminoácidos cargados negativamente, que facilitan el paso de cationes a través del poro. Los diferentes sitios posibles de fosforilación y la secuencia aminoacídica divergente de la cadena intracelular que une a M3 y M4, son los que determinan las diferencias funcionales del nAChR (Freedman et al., 1997; Picciotto et al., 2001).

Desde el punto de vista funcional hay 4 formas en el estado conformacional del receptor: reposo, abierto, desensibilizado e inactivo. Los nAChRs se encuentran principalmente en estado de reposo antes de la llegada del agonista. Una vez que el agonista se une al receptor cambia al estado abierto. En este estado el canal está conduciendo cationes durante sólo unos milisegundos. Estos dos estados son los que poseen menor afinidad por el ligando. Inmediatamente después el receptor cambia a un estado desensibilizado o inactivo, dependiendo del tiempo que se mantiene cerrado el canal. Estos dos estados son refractarios y vuelven al estado de reposo en cuestión de milisegundos o minutos. Bajas concentraciones de agonistas en el medio pueden 
inducir estados desensibilizados del receptor sin pasar por el estado abierto, debido a la gran afinidad del receptor por el agonista en el estado desensibilizado (Dani y Heinemann, 1996). La transición entre los distintos estados conformacionales puede ser regulado por la fosforilación del receptor (Changeux y Edelstein, 1998). El porcentaje de tiempo que los nAChRs pasan en cada uno de estos estados depende, entre otras cosas, del tipo de subunidades que lo formen y de la concentración de agonista que haya en el medio (Dani y Heinemann, 1996). Se han identificado dos subfamilias principales de receptores: los sensibles a la a-bungarotoxina (a-Bgt), menos afines a la nicotina, y los a-Bgt-insensibles, que poseen mayor afinidad por la nicotina. Los receptores a-Bgt-sensibles pueden ser homopentaméricos (a7, a8, a9) o heteropentaméricos ( $\alpha 7 \alpha 8, \alpha 9 \alpha 10$ ó $\alpha 1 Y$, a1816), mientras que los receptores $\alpha$ Bgt-insensibles son heteropentaméros formados por subunidades a ( $\alpha 2$ - $\alpha 6)$ y $B$ (62-84) (Gotti et al., 2006). Los receptores homopentaméricos tienen 5 sitios de unión al ligando idénticos (uno en cada subunidad) (Fig. 13c), mientras que los heteropentaméricos solamente disponen de dos sitios de unión al ligando y se localizan en la interfase entre las subunidades a y 8 (Fig. 13C) (Gotti et al., 2006). Cada interfase de estos receptores heteropentaméricos tiene diferente afinidad para los agonistas o antagonistas, mientras que en los homopentaméricos la afinidad por las moléculas es idéntica (Sine et al., 1995; Sine, 1997).

\subsection{Distribución en el organismo de los nAChRs}

Los nAChRs se encuentran en el sistema nervioso central, sistema nervioso periférico, músculo esquelético, tejido linfoide, macrófagos, piel, células del pulmón, tejido vascular, células cromafines de la médula adrenal y órganos sensoriales (Gotti y Clementi, 2004). En el sistema nervioso periférico se localizan en los ganglios autónomos, tanto simpáticos como parasimpáticos, y en la placa neuromuscular. El músculo esquelético es el único tejido donde se expresa el receptor formado por la combinación de las cuatros subunidades (2a, B, Y, 8). En el SNC, los nAChRs están compuestos únicamente por las 
subunidades heteropentaméricas a (a2-a10) y B (B2- B4) o por la combinación de las 5 subunidades a7 formando un receptor homopentamérico. Los nAChRs presentan una amplia distribución de acuerdo con la extensa localización de las vías colinérgicas (Gotti y Clementi, 2004). Estos receptores están localizados de manera preferente a nivel presináptico tanto en médula como en cerebro, donde modulan la liberación de diversos neurotransmisores. Con menor frecuencia se encuentran en cuerpos celulares o dendritas, en disposición postsináptica (Gotti y Clementi, 2006). Los nAChRs formados por las subunidades a 462 constituyen el principal subtipo localizado en el SNC. Se expresan en áreas tales como el tálamo, la corteza, el estriado, el hipotálamo y el hipocampo (Sher et al., 2004). Así, en el estriado forman el 70\% de los nAChRs, mientras que la combinación a662 sólo constituye el 20\% (Gotti y Clementi, 2006).

Los receptores que contienen las 5 subunidades a 7 se localizan en corteza, hipocampo y regiones límbicas subcorticales, expresándose en menor medida en tálamo y ganglios basales (Gotti et al., 2006). Los receptores formados por las combinaciones de las subunidades a3, a6, B3 ó $B 4$ tienen una menor distribución en el cerebro (Gotti et al., 2006).

Como se ha comentado anteriormente, los nAChRs se encuentran localizados principalmente a nivel presináptico. La activación de los mismos facilita la liberación de diferentes neurotransmisores. Receptores formados fundamentalmente por las subunidades a7, a482 y a384 se encuentran también a nivel postsináptico en varias regiones del SNC (Gotti y Clementi, 2004).

\subsection{Distribución de los nAChRs durante el desarrollo del SNC}

A partir de estudios con animales se ha determinado que el receptor nicotínico de acetilcolina (nAChR) es funcional desde el desarrollo fetal temprano, cuando se está formando el tubo neural (Atluri et al., 2001). Desde el punto de vista del desarrollo del sistema nervioso, la característica fisiológica más importante de la nicotina es su capacidad para estimular nAChRs y es el 
desencadenante de eventos del desarrollo neural que normalmente se atribuyen a la acción de acetilcolina (Navarro et al., 1989; Eriksson et al., 2000). En modelos animales se ha demostrado que la acetilcolina tiene un papel muy activo en el desarrollo del cerebro y es responsable de la proliferación, la maduración y diferenciación de múltiples tipos de células cerebrales (Kolb, 1989; Pugh y Margiota, 2000). Ciertos estudios han demostrado que los niveles de RNAm de las subunidades nAChR están presentes en el cerebro, en estadios tempranos, en el desarrollo del sistema nervioso de la rata y del pollo (Gotti et al., 1994; Broide et al., 1995; Cimino et al., 1995; Moser et al., 1996, Morley et al., 1997; Conroy y Berg, 1998). La presencia de nAChRs durante la embriogénesis temprana también sugiere que el sistema colinérgico puede estar implicado en el desarrollo (Zoli et al., 1995; Role y Berg, 1996). Se ha demostrado que las alteraciones en el sistema colinérgico durante el desarrollo causan daños estructurales, con efectos sobre el comportamiento (Hohman et al., 1988, 1991; Bachman et al., 1994; Slotkin, 1999).

La familia de nAChR, y especialmente la subunidad a7 de nAChRs, ha demostrado una alta permeabilidad a iones $\mathrm{Ca}^{++}$(Decker y Dani, 1990; Vernino et al., 1992; Seguela et al., 1993, Vernino et al., 1994; Castro y Albuquerque, 1995; Dani y Mayer, 1995). Esto sugiere un papel en la expresión temprana de genes (Greenberg et al., 1986; Quik et al., 1994), como la participación en la supervivencia de las neuronas espinales motoras (Messi et al., 1997). También se le ha asociado a la degeneración y pérdida de neuronas a lo largo del desarrollo. La mutación de la subunidad a $7 \mathrm{nAChR}$ en Caenorhabditis elegans causa períodos prolongados de exposición a una alta concentración de $\mathrm{Ca}^{++}$, dando como resultado degeneración neuronal (Treinin y Chalfie, 1995). Un exceso en la estimulación de los nAChRs durante el desarrollo de las neuronas del hipocampo da lugar a apoptosis (Berger et al., 1998). Del mismo modo, el tratamiento con nicotina en cultivos de embriones de rata produce profundos efectos en el desarrollo neuronal (Roy et al., 1998), lo que sugiere que la exposición a agonistas colinérgicos puede provocar muerte celular. La exposición a nicotina en embriones de pez cebra provoca un retraso en el desarrollo de 
neuronas motoras secundarias, y la ruta de sus axones se altera (Svoboda et al., 2002). Estos resultados demuestran la participación de los nAChRs en el desarrollo.

\subsection{Repercusiones de la administración de nicotina durante el} desarrollo

En humanos, el consumo de tabaco durante el embarazo expone al feto a posibles efectos deletéreos de la nicotina, que pueden afectar a la salud perinatal y futura del niño. Los datos epidemiológicos muestran una gran variación en la prevalencia del consumo de tabaco durante el embarazo; y en países como España, esta tasa se mantiene alta: un 40 \% (Ministerio de Sanidad, Servicios Sociales e Igualdad). La exposición prenatal al tabaco puede afectar el desarrollo neurológico normal del feto al principio de la vida. Además, se ha observado que la exposición del feto, dentro del útero, al consumo de tabaco por parte de la madre podría inducir un síndrome de abstinencia neonatal a la nicotina (Pichini y García-Algar, 2006).

La exposición al humo del tabaco es una de las principales causas de morbilidad y mortalidad, tanto para la madre como para el feto. Los daños causados por el tabaquismo materno tiene un efecto negativo directo sobre el desarrollo de la placenta, lo que disminuye la transferencia de nutrientes y oxígeno al feto y puede provocar un parto prematuro, restricción del crecimiento fetal, y/o un tamaño más pequeño de la cabeza (Castles et al., 1999). La exposición al humo del tabaco durante la gestación también se ha asociado con problemas más allá del período perinatal, que pueden perdurar hasta la adolescencia (Linnet et al., 2003; DiFranza et al., 2004). En el desarrollo del feto, la nicotina atraviesa tanto la placenta, como la barrera hematoencefálica del feto, encontrándose en los compartimientos fetales en una concentración del 15\% o en concentraciones más altas en los tejidos de la madre (Lambers y Clark, 1996). Fumar durante el embarazo además puede provocar muerte súbita del lactante (Anderson et al., 2005). 


\section{$\underline{4.6 \text { Efectos de la nicotina en el sistema visual }}$}

En estudios histopatológicos se han demostrado daños en la retina de ratas recién nacidas causados por consumo materno de nicotina. En los animales tratados con dosis altas de nicotina, la capa de las células ganglionares retinianas y el espesor global de la retina se reducen en comparación con retinas control. Se observaron cambios degenerativos selectivos en la capa plexiforme interna, que es una característica de atrofia isquémica retiniana (Evereklioglu et al., 2003).

Los receptores nicotínicos son también importantes para el sistema visual en su organización y funcionamiento normal. La administración de nicotina puede dar lugar a cambios en la organización de este sistema, refinando un mapa topográfico del espacio visual, de manera que requiere y aumenta la actividad de los receptores NMDA. La nicotina afecta a la organización y actividad de los terminales de células ganglionares de la retina. Esto puede provocar consecuencias a largo plazo en el funcionamiento del sistema visual en personas expuestas a nicotina, en particular en individuos que están expuestos durante el desarrollo (Yan et al., 2006). 

Hipótesis y Objetivos 

Los efectos de la nicotina son fundamentalmente resultado de su acción sobre el receptor nicotínico de acetilcolina (nAChR), cuya función principal es modular la transmisión sináptica. Además, hallazgos recientes indican que la nicotina puede jugar un papel importante en el desarrollo del sistema nervioso.

Datos preliminares documentan algunas de las alteraciones producidas por la exposición a nicotina en el pez cebra durante el desarrollo. Los primeros estudios de los efectos de la nicotina sobre el desarrollo neural han demostrado que la exposición temprana produce fallos en el crecimiento axonal (Svoboda et al., 2002). También se ha demostrado que la nicotina retrasa la diferenciación de las motoneuronas espinales (Higashijima et al., 2000). Por otra parte, se ha demostrado la implicación de receptores específicos de nicotina en la alteración y recuperación fenotípica (Higashijima et al., 2000). Todo lo anterior apoya la utilidad del pez cebra como modelo general para analizar los efectos de la nicotina durante el desarrollo embrionario.

En el pez cebra, se han analizado los efectos crónicos de la exposición a nicotina desde el periodo embrionario. Así, se han analizado las variaciones en la respuesta de sobresalto en animales adultos expuestos a nicotina durante su desarrollo embrionario (Eddins et al., 2009). También se ha valorado la persistencia en adultos de las alteraciones en la diferenciación neuronal y en el crecimiento axonal (Menelaou et al., 2008), descritos previamente en los embriones (Svoboda et al., 2002). Estos hallazgos de efectos crónicos en el pez cebra complementan lo descrito en roedores tras exposición prenatal a nicotina (Shacka et al., 1997; Slotkin et al., 2006). Además, en modelos de mamíferos la exposición a nicotina durante el desarrollo fetal, provoca anomalías en las tasas de crecimiento (Wang et al., 2009) y alteraciones en el desarrollo del sistema nervioso (Mao et al., 2008).

No obstante lo anterior, la bibliografía solo documenta un estudio que describe alteraciones en estructuras visuales del pez cebra tras la exposición embrionaria a nicotina: una disminución en el diámetro del ojo directamente 
proporcional a la concentración de nicotina administrada (Parker y Connaughton, 2007).

El estudio de los efectos adversos después de una exposición breve a la nicotina durante el desarrollo embrionario del pez cebra, y de las alteraciones que pudieran mantenerse en la edad adulta, puede ser de utilidad para la salud humana, al proporcionar nuevos datos sobre los mecanismos de dichos efectos en el feto como consecuencia del tabaquismo materno.

Como hipótesis de trabajo nos planteamos que la nicotina altera el patrón de expresión neuroquímica durante el desarrollo en diferentes poblaciones celulares del sistema visual, alterando propiedades electrofisiológicas visuales, lo que se traducirá en efectos comportamentales visualmente dirigidos.

En el presente trabajo de Tesis Doctoral nos proponemos comparar la morfogénesis del sistema visual del pez cebra en condiciones normales y tras la exposición a nicotina en un momento concreto del desarrollo del sistema visual, en concreto en el estadio de 21 somitos (19,5 hpf en el desarrollo del pez cebra), en el que se inician los procesos de diferenciación celular (Blader et al., 2003; Quillien et al., 2011) y en el que el ojo posee el esbozo embrionario de todas las estructuras que lo conformarán en la etapa adulta. El análisis se realizará bajo diferentes enfoques: anatómico, neuroquímico, electrofisiológico y comportamental. 
Como objetivos concretos proponemos:

I. Analizar las posibles alteraciones en la citoarquitectura de los principales componentes de la vía visual, tras la exposición a diferentes concentraciones de nicotina y en diferentes estadios de desarrollo.

II. Estudiar las posibles alteraciones en el desarrollo neuroquímico de la vía visual tras la exposición a nicotina, mediante el análisis de las variaciones en los patrones de expresión de diferentes marcadores.

III. Determinar las posibles variaciones de los nAChR propios de la vía visual, tras la exposición a nicotina en diferentes estadios de desarrollo.

IV. Analizar las posibles alteraciones de la respuesta electrofisiológica de la retina en los animales expuestos a nicotina.

V. Estudiar las posibles repercusiones en el comportamiento visual que provoca el tratamiento con diferentes concentraciones de nicotina. 

Material y Métodos 



\section{ANIMAL DE EXPERIMENTACIÓN}

\subsection{El pez cebra}

El animal de experimentación utilizado para la realización de la presente Tesis Doctoral es el pez cebra Danio rerio (Hamilton -Buchanan, 1822) (Fig. 14). Los ejemplares adultos utilizados como reproductores pertenecían a la estirpe $\mathrm{AB}$ y procedían de la Universidad de Oregon (Oregon, EE.UU.).

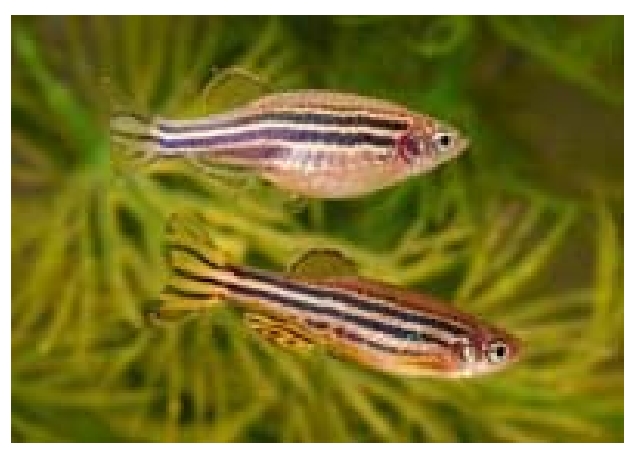

Fig. 14: Fotografía de un pez cebra hembra (arriba) y macho (abajo).

Adicionalmente se utilizaron mutantes nof de pez cebra, suministrados por el Prof. John E. Dowling, de la Universidad de Harvard (Cambridge, EE.UU.). Los mutantes nof presentan un mutación puntual por transición en el gen de la transducina a (Tca) de los conos, haciéndola no funcional. Esta Tca se expresa en los cuatro tipos de conos en condiciones normales, y es la encargada de la fototransducción de la señal luminosa. Como cabe esperar, los conos de estos mutantes no responden a la luz, y los mutantes no presentan respuesta optocinética (Brockerhoff et al., 2003).

Los animales fueron manipulados bajo la supervisión del Servicio de Experimentación Animal de la Universidad de Salamanca, siguiendo las directrices de la Comunidad Europea (86/609/EEC, 2003/65/EC y 2010/63/EU) y la legislación española (RD 1201/2005, BOE 252/34367-91, 2005) para el uso y cuidado de animales de experimentación.

\subsection{Mantenimiento y cría del pez cebra}

Los animales adultos reproductores de la estirpe $\mathrm{AB}$ fueron mantenidos en agua desionizada, suplementada con sales Instant Ocean ${ }^{\circledR}$ (Aquarium Systems, Mentor, Ohio; EE.UU.) a una concentración de 0,3 g/l. Los ejemplares 
adultos se encontraban a $28,5^{\circ} \mathrm{C}$, con un ciclo de 14 horas de luz y 10 de oscuridad (Westerfield, 1995).

Los ejemplares en desarrollo se mantuvieron en una estufa a $28,5^{\circ} \mathrm{C}$ en medio $\mathrm{E} 3\left(5 \mathrm{mM}\right.$ de $\mathrm{NaCl}, 0,17 \mathrm{mM}$ de $\mathrm{KCl}, 0,33 \mathrm{mM}$ de $\mathrm{CaCl}_{2}$ y $0,33 \mathrm{mM}$ de $\mathrm{MgSO}_{4}$ ), al que se añadían un par de gotas de azul de metileno para evitar el crecimiento de hongos.

El día previo a la puesta, dos machos y una hembra reproductores fueron dispuestos en parideras externas. El primer estímulo luminoso tras un periodo de oscuridad desencadena la liberación de los gametos. El uso de parideras externas facilita la recolección de los embriones al quedar estos depositados en una cámara separada. Tras la fecundación, los huevos eran analizados bajo una lupa con el fin de eliminar todos aquellos no fecundados o con anomalías morfológicas. Todos los embriones fueron datados bajo una lupa, según las características morfológicas descritas por Kimmel et al., (1995).

Los ejemplares utilizados en la presente Tesis Doctoral se dividen en dos grupos:

1) Embriones: animales en estadios que comprenden desde la fecundación del óvulo hasta la eclosión. Hemos analizado el estadio de 21 somitos (19,5 hpf) periodo en el cual empiezan los procesos de diferenciación y están presentes todas las estructuras del ojo, así como el estadio de pre-eclosión de 48 hpf.

2) Larvas: animales en estadios que comprenden desde la eclosión del huevo hasta la reabsorción del saco vitelino. Hemos empleado ejemplares de estadios post-eclosión de 3, 4, 5 y 6 dpf. 


\section{TRATAMIENTO CON NICOTINA}

En cada ensayo se dispusieron 50 embriones como máximo en una placa Petri, que contenía medio E3 con las concentraciones de nicotina deseadas $5 \mu \mathrm{M}$, $10 \mu \mathrm{M}, 20 \mu \mathrm{M}$ y $40 \mu \mathrm{M}$. En todos los estadios analizados la nicotina era renovada cada 12 horas, cambiando las 2/3 partes del contenido de la placa Petri. Como ejemplares control se utilizaron animales de las mismas edades y de la misma puesta no expuestos a nicotina.

Hemos realizado un tratamiento con distintas concentraciones de nicotina, y analizado tres edades distintas: 48 hpf, 3 y 5 dpf.

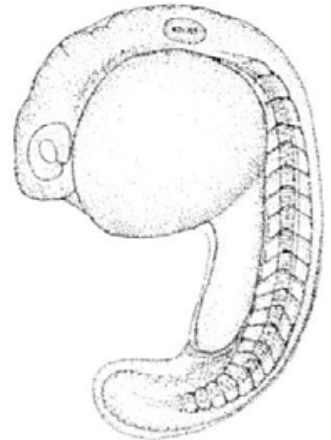

Fig. 15: Embrión de 21 somitos de pez cebra (Modificado de Kimmel et al., 1995).

El tratamiento consistía en tratar a los ejemplares en el estadio de 21 somitos (19,5 hpf) (Fig. 15). En este estadio comienza los procesos de diferenciación celular generalizada en el animal (Blader et al., 2003; Quillien et al., 2011). Además, es el primer estadio en el que están presentes todos los componentes del ojo. Después del tratamiento con nicotina los animales continuaron su desarrollo hasta la edad de sacrificio programada.

En la Tabla 1 se muestran los diferentes estadios de desarrollo utilizados en la presente Tesis Doctoral y una relación de las hpf y el proceso embrionario de interés que tiene lugar en ese estadio. 


\begin{tabular}{|c|c|c|}
\hline Horas postfecundación & Nombre del estadio & Proceso \\
\hline 19,5 & Prímula 5 (Embrión) & $\begin{array}{l}\text { Inicio de la diferenciación del animal. For- } \\
\text { mación del ojo con todas sus partes }\end{array}$ \\
\hline 48 & Embrión & $\begin{array}{c}\text { Diferenciación extendida por toda la retina } \\
\text { y salida de axones hacia el techo óptico. }\end{array}$ \\
\hline 72 & Larva & $\begin{array}{l}\text { Todos los tipos celulares en la retina. Iner- } \\
\text { vación del techo óptico. Laminación de am- } \\
\text { bas estructuras. }\end{array}$ \\
\hline 96 & Larva & $\begin{array}{l}\text { Primeros reflejos de la respuesta } \\
\text { optomotora }\end{array}$ \\
\hline 120 & Larva & $\begin{array}{l}\text { Organización de la retina similar al adulto. } \\
\text { Aparición del estrato marginal en el techo } \\
\text { óptico. } \\
\text { Respuesta electrorretinográfica correcta }\end{array}$ \\
\hline 144 & Larva & $\begin{array}{c}\text { Maduración de las respuestas de comporta- } \\
\text { miento visual }\end{array}$ \\
\hline
\end{tabular}

Tabla 1: Ejemplares utilizados en la presente Tesis Doctoral. 


\section{TÉCNICAS DE EXPERIMENTACIÓN}

\subsection{Cuantificación de nicotina por HPLC}

\section{Preparación de las muestras}

Para este tipo de ensayos se establecieron grupos de 200 animales por cada grupo experimental, así como en distintos estadios de desarrollo: 48 hpf, 3 y 5 dpf. Se dieron a los animales varios lavados rápidos, para eliminar el medio al que estuvieron expuestos durante el tratamiento con nicotina, y evitar así posibles errores en la cuantificación. Los animales fueron colocados en microtubos de centrifuga $(2 \mathrm{ml})$, retirando el máximo del medio al que estaban expuestos. Las muestras se pesaron en una balanza de precisión (Electronic Balance BP $61 \mathrm{~S}$, Sartorius AG, Alemania) y se congelaron a $-80^{\circ} \mathrm{C}$ hasta tener un número de muestras adecuado para procesarlas simultáneamente.

Una vez obtenidas todas las muestras, se descongelaron, primero a $4^{\circ} \mathrm{C}$ durante una hora y luego a temperatura ambiente (TA) durante $30 \mathrm{~min}$. A continuación se añadieron $3 \mathrm{ml}$ de tampón $10 \mathrm{mM}$ de carbonato amónico a $\mathrm{pH}$ 9,3. Cada muestra fue disgregada y homogeneizada con un Politron ${ }^{\circledR}$ (modelo PT 2100, Kinematic AG, Lucerna, Suiza), proceso que fue realizado siempre en hielo. El homogeneizado se centrifugó durante $30 \mathrm{~min}$ a $4.000 \mathrm{~g}$ y $4^{\circ} \mathrm{C}$ en una centrifuga (modelo 5417R Eppendorf AG, Hamburgo, Alemania).

Posteriormente se recogió el sobrenadante para lavarlo a través de columnas SPE C18 de 3ml (Chromabond® C18 3ml, Macherey-Nagel, Alemania), este paso se realizó para purificar la muestra manteniendo solamente las sustancias a determinar: nicotina y cotinina. Además en este paso se añadió un estándar interno (LiChro Test Standard-Samples for HPLCSystem Qualification Caffeine solution for gradient test, MERCK, Darmstadt, Alemania), necesario como referencia, para evitar los errores de pipeteo. Seguidamente se hicieron varios lavados de las columnas con tampón de 
carbonato amónico $10 \mathrm{mM}$ a pH 9,3.

Posteriormente, las columnas se eluyeron añadiendo 2 veces de una solución 1:1 $\mathrm{HCl} /$ Metanol. El líquido resultante tras el paso por la columna contendrá nuestros alcaloides de estudio. Esta solución se evaporó en un Speed Vac Concentrator (modelo SVC100H, Savant Instrument, Inc. Farmingdale, Nueva York, EE.UU.). Por último, el pellet se reconstituyó con $100 \mu \mathrm{l}$ de HCl. A partir de este punto la muestra fue procesada en el Servicio General de Espectrometría de Masas de la Universidad de Salamanca.

\section{Cuantificación de la concentración efectiva de nicotina}

Para medir las concentraciones de nicotina y cotininina (metabolito mayoritario de la nicotina) presentes en el cuerpo de los ejemplares, se utilizó un sistema de cromatografía líquida de alta resolución (HPLC). El sistema que se utilizó fue un Waters Alliance 2795 (MSVision, Goch, Alemania) y el espectrómetro de masas fue un Waters ZQ4000 (Waters Co., Milford, MA, EE. UU.).

Los estándares o patrones internos utilizados para la identificación y cuantificación de picos de nicotina y cotininina se obtuvieron a partir de soluciones de $5000 \mathrm{nM}, 1000 \mathrm{nM}, 500 \mathrm{nM}, 100 \mathrm{nM}, 50 \mathrm{nM}, 10 \mathrm{nM}, 5 \mathrm{nM}, 1 \mathrm{nM}$ 0,5 nM, 0,1 nM, 0,05 nM, 0,01 nM, 0,005 nM, 0,001 nM. Las sustancias analizadas se expresó en $\mathrm{mg} / \mathrm{l}$, que son las unidades del standard interno.

En la Tabla 2 se muestran los estadios utilizados para cuantificar la concentración de nicotina; los datos se expresan en $\mu \mathrm{M}$. La cotinina no fue posible cuantificarla al encontrarse en unas concentraciones inferiores al límite del equipo. 


\begin{tabular}{|c|c|}
$\begin{array}{c}\text { Grupos analizados } \\
\text { a las } 48 \text { hpf }\end{array}$ & $\begin{array}{c}\text { Cantidad } \\
\text { cuantificada en } \\
\boldsymbol{\mu M}\end{array}$ \\
\hline Control & 0 \\
\hline Nicotina $5 \mu \mathrm{M}$ & 4,37321 \\
\hline Nicotina $10 \mu \mathrm{M}$ & 8,68761 \\
\hline Nicotina $20 \mu \mathrm{M}$ & 18,43780 \\
\hline Nicotina $40 \mu \mathrm{M}$ & 33,35559 \\
\hline
\end{tabular}

\begin{tabular}{|c|c|}
$\begin{array}{c}\text { Grupos analizados } \\
\text { a las 5 dpf }\end{array}$ & $\begin{array}{c}\text { Cantidad } \\
\text { cuantificada en } \\
\mathbf{p M}\end{array}$ \\
\hline Control & 0 \\
\hline Nicotina $5 \mu \mathrm{M}$ & 5,02174 \\
\hline Nicotina $10 \mu \mathrm{M}$ & 11,80571 \\
\hline Nicotina $20 \mu \mathrm{M}$ & 22,87314 \\
\hline Nicotina $40 \mu \mathrm{M}$ & 47,20846 \\
\hline
\end{tabular}

\begin{tabular}{|c|c|}
$\begin{array}{c}\text { Grupos analizados } \\
\text { a las } 3 \text { dpf }\end{array}$ & $\begin{array}{c}\text { Cantidad } \\
\text { cuantificada en } \\
\mathbf{\mu M}\end{array}$ \\
\hline Control & 0 \\
\hline Nicotina $5 \mu \mathrm{M}$ & 4,72084 \\
\hline Nicotina $10 \mu \mathrm{M}$ & 9,73422 \\
\hline Nicotina $20 \mu \mathrm{M}$ & 20,1536 \\
\hline Nicotina $40 \mu \mathrm{M}$ & 37,37303 \\
\hline
\end{tabular}

Tabla 2: Datos obtenidos de la cuantificación de nicotina por HPLC.

\section{$\underline{3.2}$ Procesamiento histológico}

\section{Fijación}

Una vez datados los embriones se procedió a su fijación. En el caso de los embriones mayores de $24 \mathrm{hpf}$, previamente fueron anestesiados con etil 3aminobenzoato metanosulfonato (Sigma Co., St. Louis, MO, EE.UU) al 0,03\% en medio E3.

El tipo de fijación utilizado varió según la técnica a desarrollar posteriormente. Los ejemplares destinados a la detección de RNAm mediante hibridación in situ (HIS) o de proteínas mediante inmunohistoquímica fueron fijados en paraformaldehído (PFH) al 4\% durante una noche a $4^{\circ} \mathrm{C}$. Tras ello, se retiró el PFH lavando con tampón fosfato salino (PBS) libre de RNAsas. Tras un paso intermedio en 50\% PBS $/ 50 \%$ metanol, los embriones se mantuvieron en metanol a $-20^{\circ} \mathrm{C}$ hasta su uso.

Para la obtención de cortes semifinos, los embriones fueron fijados en una 
solución de $\mathrm{PFH}$ al $2 \%$ y glutaraldehído al $2 \%$ en tampón cacodilato (TC) durante una noche a $4^{\circ} \mathrm{C}$. Tras retirar el fijador mediante tres lavados de diez minutos en TC, se procedió a su procesamiento tal y como se detalla en el apartado "Obtención y tinción de cortes semifinos".

Los animales de $48 \mathrm{hpf}$ fueron descorionados con la ayuda de unas pinzas, mientras que la mayoría de los ejemplares mayores de $3 \mathrm{dpf}$ se descorionaron de manera natural, encontrándolos ya nadando libremente. En todos los casos los ejemplares fueron fijados sin corion.

Los embriones de $48 \mathrm{hpf}, 3$ y 5 dpf empleados para realizar técnicas in toto fueron tratados con una solución de $3 \mathrm{mg} / \mathrm{ml}$ de fenil-tiurea (PTU, Sigma) a partir de las 24 hpf, disuelta en el medio E3 con el fin de inhibir su pigmentación.

\section{$\underline{\text { Seccionamiento en criostato }}$}

Con el fin de obtener secciones en el criostato, los embriones de pez cebra fueron encastrados en una solución de agar al 1,5\% y sacarosa al 10\% en PBS. Los ejemplares que se encontraban en metanol fueron previamente rehidratados con PBS. Los ejemplares de $48 \mathrm{hpf}$, 3 y $5 \mathrm{dpf}$, se orientaron para obtener secciones coronales, sagitales y horizontalmente. Los bloques se crioprotegieron en una solución de $30 \%$ de sacarosa en PBS, durante una noche a TA y en agitación. Tras congelar el bloque se obtuvieron secciones de $10 \mu \mathrm{m}$ de grosor en un criostato Leica Jung CM3000 (Nussloch, Alemania), que se recogieron en portaobjetos tratados con Poli-L-Lisina (Thermo Scientific). Las secciones se mantuvieron a $-20^{\circ} \mathrm{C}$ hasta su uso.

\section{Obtención y tinción de cortes semifinos}

Las secciones semifinas se realizaron a partir de animales de 48 hpf, 3 y 5 dpf, con el fin de observar la morfología de la retina, nervio óptico y el techo óptico (TO). Los especímenes fueron decorionados con unas pinzas, antes de la 
fijación. Tras tres lavados de 20 min en TC a TA, las muestras se postfijaron en una solución acuosa de tetróxido de osmio con ferricianuro potásico al $1 \%$ a $4^{\circ} \mathrm{C}$ durante $45 \mathrm{~min}$. A continuación se lavaron las muestras varias veces durante dos horas en TC.

Una vez finalizada la postfijación, se procedió a la deshidratación de las muestras con baños de $5 \min$ a $4^{\circ} \mathrm{C}$ en soluciones crecientes de etanol de $50^{\circ}, 70^{\circ}$, $80^{\circ}, 90^{\circ}, 96^{\circ}$ y $100^{\circ}$. A continuación las muestras se lavaron tres veces durante 10 min en óxido de propileno antes de proceder a la inclusión en resina EMbed-812 (Electron Microscopy Sciences, Fort Washington, PA, EE.UU.). Para este proceso las muestras se incubaron en mezclas de EMbed-812:óxido de propileno (1:3; $1: 1 ; 3: 1), 60$ min en cada una de ellas a TA. Finalmente, se dispusieron las muestras en EMbed-812 durante toda la noche a TA. La inclusión definitiva se realizó con la misma resina, en moldes que permiten una correcta orientación de las muestras bajo la lupa, que polimerizaron en una estufa a $60^{\circ} \mathrm{C}$ durante 24 horas.

Posteriormente se realizaron cortes semifinos de $1 \mu \mathrm{m}$ de grosor en un ultramicrotomo Reichert-Jung Ultracut E (Nussloch, Alemania). Se realizaron secciones coronales que fueron recogidas de forma seriada en portaobjetos tratados con Poli-L-Lisina (Thermo Scientific) y posteriormente teñidas con azul de toluidina. A continuación las secciones se montaron con Entellan ${ }^{\circledR}$ y cubreobjetos para el posterior análisis a microscopía óptica.

\subsection{PCR cuantitativa}

\section{Homogeneización de embriones y extracción de RNA}

La homogeneización de los embriones de pez cebra del estadio y tratamiento correspondiente se realizó mecánicamente mediante pipeteo. Tras obtener una solución homogénea procedimos a la extracción del RNA total con Trizol Reagent (Sigma), siguiendo el protocolo recomendado por el fabricante. 
Por cada 100 embriones se utilizó $1 \mathrm{ml}$ de Trizol al que se añadieron 0,2 $\mathrm{ml}$ de cloroformo, que solubiliza los componentes orgánicos separándolos de esta manera del RNA. Tras agitar la mezcla 15 segundos se dejó incubar 3 minutos a TA. A continuación se centrifugó la solución a 12.000 revoluciones por minuto (rpm) durante 15 minutos, se centrifugó la solución a 12.000 rpm durante 15 minutos a $4^{\circ} \mathrm{C}$ y se precipitó el RNA total mediante la adición de $0,5 \mathrm{ml}$ de isopropanol. Para ello se dejó incubar durante 10 minutos a TA y se volvió a centrifugar de la misma manera para obtener un pellet. El RNA precipitado se lavó en $1 \mathrm{ml}$ de etanol al 70\% y después se centrifugó a $7.000 \mathrm{rpm}$ durante 5 minutos. Tras retirar el exceso de etanol el pellet se eluyó en $20 \mu \mathrm{l}$ de agua libre de RNAsas, incubando durante 10 minutos a $60^{\circ} \mathrm{C}$. La concentración de RNA total fue cuantificada utilizando un NanoPhotometerTM Clase Pearl (Implen).

\section{Obtención de DNAc: retrotranscripción}

Una vez extraído el RNA total se obtuvo del DNA copia (DNAc) de todas las formas de RNA presentes en las células, incluyendo el RNA ribosómico (RNAr) y el RNA mensajero (RNAm).

Para ello utilizamos el kit de Applied Biosystems "High-capacity cDNA Archive Kit", que utiliza cebadores aleatorios que permiten la retrotranscripción de todo el RNA. El procedimiento se llevó a cabo siguiendo las instrucciones del fabricante: para un volumen final de $20 \mu \mathrm{l}$ se utilizaron $2 \mu \mathrm{l}$ de tampón 10x, $2 \mu \mathrm{l}$ de cebadores 10x, 0,8 $\mu \mathrm{l}$ de mezcla de nucleótidos $25 \mathrm{x}, 4,2 \mu \mathrm{l}$ de agua, $1 \mu \mathrm{l}$ de retro-transcriptasa y $10 \mu \mathrm{l}$ de una solución de $0,2 \mu \mathrm{g} / \mu \mathrm{l}$ de RNA.

El programa de retrotranscripción consta de tres pasos: incubación a $25^{\circ} \mathrm{C}$ durante 10 minutos, incubación a $37^{\circ} \mathrm{C}$ durante 2 horas e incubación a $85^{\circ} \mathrm{C}$ durante 5 minutos (para inhibir la enzima), para lo cual se utilizó un termociclador Veriti (modelo 9902, Applied Byosistems).

El producto obtenido fue el material de partida para realizar la PCR 
cuantitativa (qPCR).

\section{Diseño de cebadores}

Los cebadores para la realización de la qPCR se detallan en la Tabla 3.

\begin{tabular}{|c|c|c|c|c|}
\hline Gen & Cebador Forward & Cebador Reverse & Amplicón (nt) & $\begin{array}{c}\text { Referencia } \\
\text { ENSEMBL }\end{array}$ \\
\hline Ef1alfa & $\begin{array}{c}\text { GTACTTCTCA- } \\
\text { GGCTGACTGTG }\end{array}$ & $\begin{array}{c}\text { ACGATCGCTGTTT- } \\
\text { CACTCC }\end{array}$ & 136 & $\begin{array}{c}\text { ENS- } \\
\text { DARG00000020850 }\end{array}$ \\
\hline $\begin{array}{c}\text { nAchR } \\
\text { alfa6 }\end{array}$ & $\begin{array}{c}\text { CCGCAACAAA- } \\
\text { GCTAAAGAGG }\end{array}$ & $\begin{array}{c}\text { AGGAAGATGC- } \\
\text { GGTCAATCAC }\end{array}$ & 49 & $\begin{array}{c}\text { ENS- } \\
\text { DARG00000031546 }\end{array}$ \\
\hline $\begin{array}{c}\text { nAchR } \\
\text { beta } 3 \mathrm{a}\end{array}$ & $\begin{array}{c}\text { GGCTGCCAGA- } \\
\text { TATTGTCCTTT }\end{array}$ & $\begin{array}{c}\text { CAATGGCTTTAGT- } \\
\text { CATTAGAGATCC }\end{array}$ & 47 & $\begin{array}{c}\text { ENS- } \\
\text { DARG00000074678 }\end{array}$ \\
\hline $\begin{array}{c}\text { nAchR } \\
\text { beta } 3 b\end{array}$ & $\begin{array}{c}\text { TGACGCTGA- } \\
\text { CAGTCATTGGT }\end{array}$ & $\begin{array}{c}\text { GGTTTGCGTG- } \\
\text { CAGAATGG }\end{array}$ & 224 & $\begin{array}{c}\text { ENS- } \\
\text { DARG00000050037 }\end{array}$ \\
\hline
\end{tabular}

Tabla 3: Genes analizados por qPCR, con su cebador Forward y Reverse, el tamaño del amplicón en nucleótidos y la referencia de la base de datos genéticos ENSEMBL.

Todos los cebadores se diseñaron a partir de las secuencias de RNAm específicas de pez cebra (Danio rerio, estirpe AB), cumpliendo las siguientes normas:

- Tamaño entre 15 y 25 nucleótidos.

- Índice GC entre $50 \%$ y $60 \%$.

- Temperatura de fusión $(\mathrm{Tm})$ entre $56^{\circ} \mathrm{C}$ y $60^{\circ} \mathrm{C}$.

Se prestó especial atención a que las características antes descritas fueran lo más parecidas entre ambos cebadores.

Estas características fueron comprobadas mediante el programa Sequence Manipulation Suite: Version 2, disponible en internet (http://www.protocolonline.org/tools/sms2/). Con este programa también comprobamos que los cebadores no formaran horquillas, ni que hibridaran consigo mismo ni con el otro cebador. En ninguna de las parejas se detectaron estos fenómenos. 
Por último, con la aplicación informática BLAST (http://www.ensembl.org/ Multi/blastview) se comprobó que los cebadores sólo hibridaran con una secuencia del genoma del pez cebra. Todos los cebadores hibridaron con una única secuencia.

\section{Diseño de la recta de calibrado}

En la recta de calibrado se expresa la concentración de DNAc utilizado y el ciclo en el cual el termociclador empieza a detectar fluorescencia. El paquete informático empleado para analizar los resultados establece una línea umbral, a partir de la cual la cantidad de producto amplificado es suficientemente alta como para que el termociclador detecte la fluorescencia producida por el SYBRGreen al unirse al DNA de doble cadena. El ciclo en el cual la reacción cruza este umbral se denomina valor $\mathrm{Ct}$. El valor $\mathrm{Ct}$ de las diluciones 1:10 a partir de las cuales se diseña la recta patrón para cada gen debe diferenciarse en 3,3 ciclos, y por ello se considera este número como pendiente perfecta de la recta de calibrado.

Para poner a punto la recta de calibrado de cada uno de los genes estudiados, realizamos una PCR básica con un termociclador GeneAmp PCR System 9700 de Applied Biosystems, sometiendo $5 \mathrm{\mu l}$ del producto final de la reacción a electroforesis en un gel con $1,5 \%$ de agarosa (BIORAD) y $0,5 \mathrm{mg} / \mathrm{ml} \mathrm{de}$ bromuro de etidio, un agente intercalante que permite visualizar el producto de reacción. Una vez identificada la banda resultante por luz UV, el resto de la reacción se purificó con el kit QIAquick PCR purification Kit (Qiagen). Después se midió la concentración del producto mediante un NanoPhotometer ${ }^{\mathrm{TM}}$ clase Pearl (Implen) y se realizaron 4 diluciones seriadas 1:10, con el fin de cubrir un amplio espectro de concentraciones y que los datos obtenidos a partir de la recta de calibrado fueran de mayor fiabilidad.

Finalmente se realizaron qPCRs tal y como se indica en el siguiente apartado, utilizando como muestras las distintas concentraciones: $10^{-5}, 10^{-6}$, 
$10^{-7}$ y $10^{-8} \mathrm{ng}$. Según los resultados obtenidos se diseñó una recta de calibrado óptima para cada marcador, utilizando las 3 diluciones consecutivas que mejor pendiente proporcionaban.

\section{$\underline{\text { qPCR }}$}

Para la realización de la PCR cuantitativa (Fig. 15) se utilizó el kit SYBRGreen Power Mix (Applied Biosystems), que incluye Taq Polimerasa, nucleótidos, Tampón, $\mathrm{MgCl}_{2}$ y agua, todo en una concentración 2x. Así, a cada reacción se añaden $10 \mu \mathrm{l}$ de Sybr-Green Power Mix, $5 \mu \mathrm{l}$ de DNAc, $1 \mu \mathrm{l}$ de oligonucleótido Forward, $1 \mu \mathrm{l}$ de oligonucléotido Reverse y 7,4 $\mu \mathrm{l}$ de agua libre de nucleasas. El programa de amplificación que se utilizó, tanto con las muestras de embriones como con las rectas patrón en el termociclador ABI7300 (Applied Biosystems), fue el siguiente: 2 minutos a $50^{\circ} \mathrm{C}, 10$ minutos a $95^{\circ} \mathrm{C}, 40$ ciclos de 15 segundos a $95^{\circ} \mathrm{C}$ y 1 minuto a $60^{\circ} \mathrm{C}$. Las qPCRs se realizaron por triplicado en cada experimento y el número de grupos para cada tratamiento fue mayor o igual a 3 .

El programa informático incorporado de Applied Biosystems nos proporciona el valor $\mathrm{Ct}$, que será utilizado por el programa informático REST 2009; con este programa se efectúa el análisis de la expresión génica de todos los genes utilizados, en donde la expresión de un gen o genes de interés es normalizada por un gen de referencia. REST 2009 es un programa informático que aplica un modelo matemático que tiene en cuenta las diferentes eficiencias del producto PCR de los genes de interés, nAchR a6, B3a y B3b, y el gen de referencia Ef1a. 

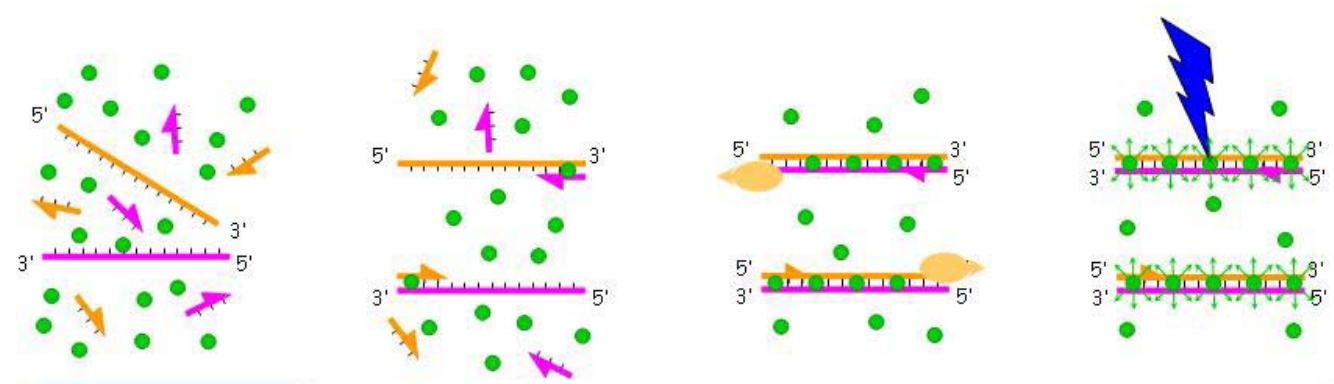

Fig. 15: Resumen de la PCR cuantitativa. Tras la unión de los cebadores se produce la síntesis de las cadenas de DNA. El Sybr-Green se une a la doble hebra y, solo entonces, emite fluorescencia.

\subsection{Hibridación in situ}

Para la realización de la técnica de hibridación in situ (HIS) todo el material utilizado, tanto líquido como sólido, se autoclavó previamente para eliminar las RNAsas presentes en los materiales y que podrían degradar el RNAm.

\section{Ribosondas}

Para la realización de HIS se utilizaron ribosondas sintetizadas a partir de plásmidos amablemente cedidos por diversos laboratorios (Tabla 4). Por otro lado otras ribosondas fueron de diseño propio (Tabla 5).

\begin{tabular}{|c|c|c|c|}
\hline Ribosonda & Procedencia & $\begin{array}{c}\text { Enzimas de } \\
\text { restricción }\end{array}$ & Polimerasa \\
\hline Islet-1 & $\begin{array}{c}\text { S. Wilson } \\
\text { (UCL) }\end{array}$ & XbaI & $\mathrm{T} 7$ \\
\hline Pax6a & $\begin{array}{c}\text { S. Wilson } \\
\text { (UCL) }\end{array}$ & SmaI & $\mathrm{T} 7$ \\
\hline
\end{tabular}

Tabla 4: Características de las ribosondas cedidas

Todos los cebadores se diseñaron a partir de las secuencias de RNAm específicas de pez cebra (Danio rerio, estirpe $\mathrm{AB}$ ). La ribosonda debe tener un tamaño entre 600 y 1000 pares de base. Una vez realizada la PCR con los cebadores correspondientes, se obtuvo un gran número de copias de nuestro DNA de nuestro fragmento de estudio. El DNA purificado en el paso anterior se 
subclona en el vector pCR®2.1-TOPO® (TOPO TA Cloning ${ }^{\circledR}$ Kit) de Invitrogen, vector linearizado que presenta una timidina terminal en ambos extremos y una topoisomerasa unida a cada extremo. El empleo de este plásmido supone una mejora en la eficiencia de inserción de los productos de PCR con adenosinas terminales, que son añadidas por polimerasas termoestables, así como también se evita la recircularización del plásmido sin inserto. La Tabla 5 muestra la ribosondas diseñadas en nuestro laboratorio.

\begin{tabular}{|c|c|c|c|c|c|}
\hline Ribosonda & $\begin{array}{c}\text { Cebador } \\
\text { Forward }\end{array}$ & $\begin{array}{c}\text { Cebador } \\
\text { Reverse }\end{array}$ & $\begin{array}{c}\text { Amplicón } \\
\text { (nt) }\end{array}$ & $\begin{array}{c}\text { Enzima de } \\
\text { restricción }\end{array}$ & Polimerasa \\
\hline $\begin{array}{c}\text { nAchR } \\
\text { alfa } 6\end{array}$ & $\begin{array}{c}\text { TGAAGTGGTC- } \\
\text { ACCAGCAGAG }\end{array}$ & $\begin{array}{c}\text { GCTTTCCCCT } \\
\text { CTCCAAATTC }\end{array}$ & 943 & $\begin{array}{c}\text { Hind } \\
\text { III }\end{array}$ & $\mathrm{T} 7$ \\
\hline $\begin{array}{c}\text { nAchR } \\
\text { beta } 3 \mathrm{a}\end{array}$ & $\begin{array}{c}\text { CTCACAGTTG } \\
\text { GTGGATGTGG }\end{array}$ & $\begin{array}{c}\text { ATGGTCCCAA } \\
\text { GCACAGAAAC }\end{array}$ & 1164 & $\begin{array}{c}\text { Hind } \\
\text { III }\end{array}$ & $\mathrm{T} 7$ \\
\hline $\begin{array}{c}\text { nAchR } \\
\text { beta } 3 \mathrm{~b}\end{array}$ & $\begin{array}{c}\text { AGTCAACCT } \\
\text { CCGCTTTTCCT }\end{array}$ & $\begin{array}{l}\text { GTACGAACCC } \\
\text { ACGGAGACAT }\end{array}$ & 1160 & $\mathrm{XbaI}$ & $\mathrm{Sp} 6$ \\
\hline
\end{tabular}

Tabla 5: Características de las ribosondas de síntesis propia.

\section{Obtención de ribosondas}

El primer paso consistió en la amplificación del plásmido circular en bacterias, con el fin de obtener una mayor cantidad del mismo para la síntesis de la ribosonda. Para este fin se utilizaron bacterias super-competentes One shot ${ }^{\circledR}$ Top10F' (Invitrogen) y se siguió el protocolo indicado por el fabricante. Brevemente: el vial con las bacterias se descongeló en hielo durante media hora y se añadieron $5 \mu \mathrm{l}$ de plásmido circular disuelto en agua. A continuación el vial se introdujo 30 segundos en un baño a $42^{\circ} \mathrm{C}$ e, inmediatamente después, se puso otra vez en hielo. Se añadieron al vial $250 \mu \mathrm{l}$ de medio $\mathrm{SOC}$ precalentado a $37^{\circ} \mathrm{C}$ (este medio es suministrado por el fabricante). El vial se mantuvo en agitación rotacional a $37^{\circ} \mathrm{C}$ y $225 \mathrm{rpm}$ durante una hora. A continuación distintas cantidades del medio con las bacterias se pipetearon en placas Petri con medio LB Agar (Sigma) suplementado con ampicilina. Todos los plásmidos portaban el gen de resistencia a ampicilina, de manera que solo aquellas bacterias transformadas eran capaces de sobrevivir. Además, las colonias fueron 
seleccionadas por color ya que, cuando se introduce el inserto en el vector, se inactiva el gen de la B-galactosidasa y las bacterias pierden la capacidad de degradar el 5-bromo-4-cloro-3-indolil-B-D-galactopiranósido (X-Gal) previamente añadido al cultivo. De esta manera, las colonias con inserto son blancas, mientras que las que no lo tienen son azules. Las bacterias crecieron en una estufa a $37^{\circ} \mathrm{C}$ durante una noche. A continuación se seleccionaron colonias individuales que crecieron a $37^{\circ} \mathrm{C}$ en medio LB Broth líquido (Sigma), durante una noche en un agitador a $225 \mathrm{rpm}$. De esta manera se obtuvo una gran cantidad de bacterias que portan el plásmido que nos interesa. El plásmido de estudio se envió a secuenciar al Servicio de secuenciación de la Universidad de Salamanca para confirmar la presencia de nuestro inserto, así como su orientación.

Para extraer el plásmido de las bacterias se procedió al lisado y purificación del plásmido utilizando el kit “QIAprepr® Spin Miniprep” (Qiagen), siguiendo las instrucciones del fabricante. Se midió la concentración del producto final y se realizaron las diluciones pertinentes para obtener soluciones de trabajo a una concentración de $0,5 \mathrm{mg} / \mathrm{ml}$.

A partir del plásmido circular se sintetizaron las ribosondas mediante dos pasos. El primero consiste en la linealización del plásmido mediante el uso de una enzima de restricción situada en el extremo 3' de la secuencia a sintetizar. Para ello se incubaron $10 \mu \mathrm{l}$ de plásmido, $2 \mu \mathrm{l}$ del tampón correspondiente a la enzima de restricción, $2 \mu \mathrm{l}$ de enzima de restricción (Tabla 5) y $4 \mu \mathrm{l}$ de agua ultrapura, durante dos horas en un baño a $37^{\circ} \mathrm{C}$. El resultado de la reacción se purificó con el kit “QIAquick® PCR purification Kit” (Qiagen), utilizando las instrucciones del fabricante. Una pequeña cantidad del producto obtenido se corrió en un gel de agarosa al 1\% para comprobar la correcta linealización.

Tras la linealización se sintetizaron las ribosondas mediante una incubación de $5 \mu \mathrm{l}$ del plásmido lineal, $2 \mu \mathrm{l}$ de nucleótidos marcados con digoxigenina (Roche), $1 \mu \mathrm{l}$ de inhibidor de RNAsas (Promega), $5 \mu \mathrm{l}$ de tampón 
(Promega), $1 \mu \mathrm{l}$ de DTT (Promega), $1 \mu \mathrm{l}$ de RNA polimerasa (Promega) (Tabla 5) y $5 \mu \mathrm{l}$ de agua ultrapura, durante dos horas en un baño a $37^{\circ} \mathrm{C}$. Para eliminar el DNA lineal empleado como molde, el producto resultante de la utilización del kit fue tratado con DNAasa [20 $\mu \mathrm{l}$ de mezcla; $1 \mu \mathrm{l}$ de DNAasa I (Roche); $3 \mu \mathrm{l}$ de tampón] durante 15 minutos a $37^{\circ} \mathrm{C}$. La reacción se detuvo añadiendo $1 \mu \mathrm{l}$ de EDTA 0,5 M y calentando la solución 10 minutos a $75^{\circ} \mathrm{C}$.

Por último, para purificar la ribosonda se utilizó el kit "RNeasy® Mini Kit” (Qiagen), siguiendo las instrucciones del fabricante. Se obtuvo un volumen final de $30 \mu \mathrm{l}$ de ribosonda en agua ultapura, al que se le añadieron $30 \mu \mathrm{l}$ de formamida (Sigma) y se mantuvo a $-80^{\circ} \mathrm{C}$ hasta su uso.

Las ribosondas para HIS se utilizan diluídas 1/100 en medio Hyb+. Además, las diluciones se reciclan y se utilizan varias veces.

\section{Protocolo de hibridación in situ}

Para la realización de la HIS, los embriones mantenidos en metanol se rehidrataron en PBS con Triton X-100 al 0,1\% (PBST 0,1), con un paso intermedio en 50\% metanol y 50\% PBST 0,1. Tras la rehidratación, los

\begin{tabular}{|c|c|c|}
\hline Edad & $\begin{array}{c}\text { Concentración } \\
\text { de PK }\end{array}$ & $\begin{array}{c}\text { Duración del } \\
\text { tratamiento } \\
\text { (min.) }\end{array}$ \\
\hline $48 \mathrm{hpf}$ & $10 \mu \mathrm{g} / \mathrm{ml}$ & 30 \\
\hline $3 \mathrm{dpf}$ & $20 \mu \mathrm{g} / \mathrm{ml}$ & 30 \\
\hline $5 \mathrm{dpf}$ & $40 \mu \mathrm{g} / \mathrm{ml}$ & 30 \\
\hline
\end{tabular}

Tabla 6: Duración y concentración del tratamiento con Proteinasa K (PK) embriones fueron tratados con una solución de proteinasa K (PK, Sigma) para permeabilizarlos y así permitir la entrada de la ribosonda. La concentración de PK utilizada dependió de la edad del embrión tal y como se detalla en la Tabla 6.

A continuación los ejemplares se postfijaron en $\mathrm{PFH}$ al 4\% durante veinte minutos a TA y se lavaron varias veces durante una hora en PBST 0,1. Tras ello, se procedió a la prehibridación durante dos horas en un termobloque a $68^{\circ} \mathrm{C}$ en la solución de hibridación (Hyb+) sin la ribosonda [50\% de formamida (Sigma); $25 \%$ de $\mathrm{SSC} 20 \mathrm{x}(\mathrm{NaCl} 3 \mathrm{M}$; citrato tri-sódico 0,34M); 0,5 mg/ml de RNA de 
levadura (Sigma); 0,05 mg/ml de heparina (Sigma); ácido cítrico 1mM; 0,1\% de Tween20 (Sigma)] y posteriormente se añadió la ribosonda diluida en solución Hyb+. Los embriones se mantuvieron en dicha solución a $68^{\circ} \mathrm{C}$ durante una noche. Tras la hibridación los embriones se sometieron a cuatro lavados de media hora de duración cada uno, en solución Hyb- (50\% de formamida; $25 \%$ de SSC20x; 0,1\% Tween20), seguida de un aclarado en SSC 2x y dos lavados de media hora en solución SSC 0,2x. A continuación los embriones se lavaron varias veces durante una hora en PBST 0,1 , y se preincubaron 2 horas en solución MAB [Ácido málico 0,1M; $\mathrm{NaCl}$ 0,15M; 2\% de Bloking Reagent (Roche) $\mathrm{pH}$ 8]. Tras ello se procedió a la incubación en medio MAB con suero antidigoxigenina conjugado con fosfatasa alcalina (Roche Applied Science), durante una noche a $4^{\circ} \mathrm{C}$ (Fig. 16). El exceso de anticuerpo se retiró mediante varios lavados en PBST 0,1 durante 2 horas. A continuación se incubaron los embriones en medio Xpho (Tris HCL pH 9,5 0,1M; $\mathrm{MgCl} 250 \mathrm{mM}$; $\mathrm{NaCl} 0,1 \mathrm{M}$; Triton X-100 0,1\%) durante media hora. Por último se revelaron las secciones en dicha solución a la que se añadieron $1 \mu \mathrm{l}$ de NBT (Roche) y $3.5 \mu \mathrm{l}$ de BCIP (Roche) por ml de Xpho (Fig. 16).

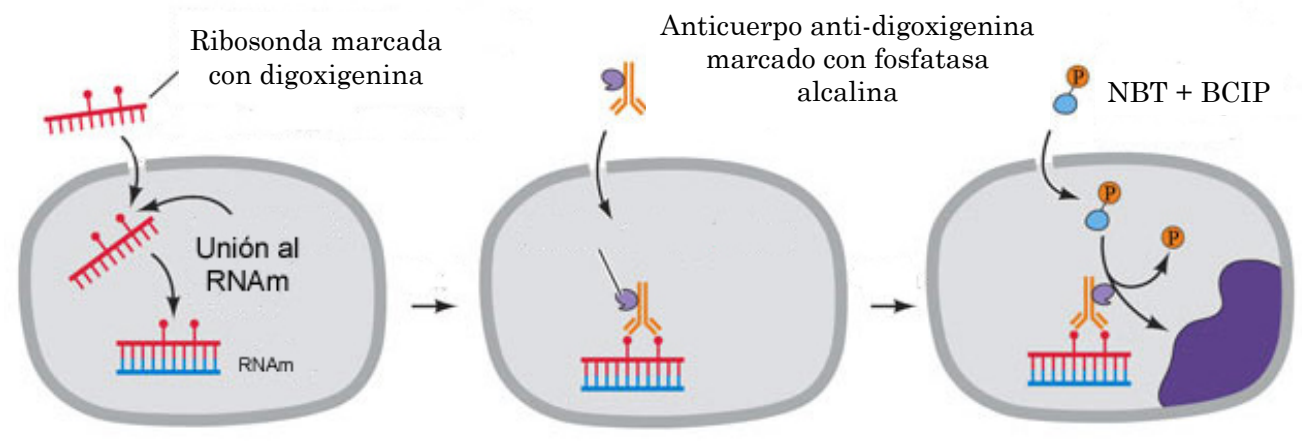

Fig. 16: Esquema de la técnica de HIS revelada mediante fosfatasa alcalina.

El desarrollo de la reacción se siguió bajo la lupa y se detuvo mediante varios lavados en PBST 0,1 y postfijación en $\mathrm{PFH} 4 \%$ durante una noche a $4{ }^{\circ} \mathrm{C}$. Los embriones se deshidrataron en una batería creciente de glicerol (30\%, 50\%, $70 \%$ y $100 \%)$ donde se mantuvieron hasta su fotografiado.

Se realizaron los siguientes controles para comprobar la especificidad del marcaje: 
1) Realización del protocolo descrito sin la correspondiente ribosonda antisentido.

2) Hibridación con la correspondiente ribosonda sentido.

3) Hibridación previo tratamiento con RNAsa A.

4) Incubación de las secciones sin el anticuerpo anti-digoxigeninafosfatasa alcalina.

En ningún caso se obtuvo marcaje.

\subsection{Inmunohistoquímica}

\section{$\underline{\text { Inmunohistoquímica fluorescente en secciones }}$}

Para realizar la técnica inmunohistoquímica indirecta fluorescente (Fig. 17) se dejaron secar las secciones obtenidas en el criostato a TA durante al menos dos horas. Se rehidrataron mediante tres lavados de cinco minutos en PBS. A continuación se preincubaron con una solución compuesta por 5\% de suero de cabra y $0,2 \%$ de Triton X-100 en PBS durante dos horas a TA. Las secciones se incubaron en la solución anterior más el anticuerpo primario (Tabla 7) durante 1 noche a TA. Tras la incubación con el anticuerpo se lavaron tres veces durante cinco minutos, en agitación, en PBS con gelatina de pez (Sigma) para eliminar la autofluorescencia y el exceso de anticuerpo. A continuación, las secciones se incubaron con una solución compuesta por 5\% de suero de cabra,

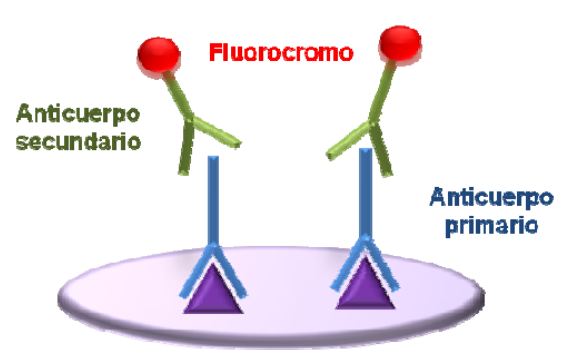

Fig. 17: Esquema de la IHQ indirecta fluoresescente.
0,2\% de Triton X-100 y una dilución 1:250 del anticuerpo secundario (Tabla 8) en PBS durante una hora a TA. Los núcleos se contrastaron con DAPI (Diclorhidrato de 4',6diamidino-2-fenilindol) y tras varios lavados en PBS se montaron con la solución "ProLong® Gold Antifade Reagent" (Invitrogen). 


\begin{tabular}{|c|c|c|c|c|}
\hline Antígeno & \multicolumn{1}{|c|}{ Anticuerpo } & $\begin{array}{c}\text { Dilución } \\
\text { de uso }\end{array}$ & $\begin{array}{c}\text { Casa } \\
\text { comercial }\end{array}$ & Testado en \\
\hline $\begin{array}{c}\text { Histona H3- } \\
\text { fosforilada(H3P) }\end{array}$ & IgG de ratón, monoclonal & $1: 500$ & Abcam & Cid et al., 2010 \\
\hline Calretinina (CR) & IgG de conejo, policlonal & $1: 10000$ & Swant & Castro et al., 2006 \\
\hline Digoxigenina & IgG de ratón, monoclonal & $1: 500$ & Jackson & Hibridoma \\
\hline Neurolina (Zn-8) & IgG de ratón, monoclonal & $1: 250$ & Parrilla et al., 2012 \\
\hline $\begin{array}{c}\text { Tirosina hidroxi- } \\
\text { lasa (TH) }\end{array}$ & IgG de ratón, monoclonal & $1: 800$ & Chemicon & $\begin{array}{c}\text { Arenzana et al., } \\
2006\end{array}$ \\
\hline Zpr1 & IgG de rata, monoclonal & $1: 200$ & ZIRC & $\begin{array}{c}\text { Específico de pez } \\
\text { cebra }\end{array}$ \\
\hline Zpr3 & IgG de rata, monoclonal & $1: 200$ & ZIRC & $\begin{array}{c}\text { Específico de pez } \\
\text { cebra }\end{array}$ \\
\hline
\end{tabular}

Tabla 7: Anticuerpos primarios utilizados en la técnica inmunohistoquímica.

\begin{tabular}{|c|c|c|c|c|}
\hline Método & Antígeno & Anticuerpo & $\begin{array}{c}\text { Casa } \\
\text { Conjugado }\end{array}$ & $\begin{array}{c}\text { comercial } \\
\text { con }\end{array}$ \\
\hline ABC & IgG de conejo & IgG de cabra & Biotina & Vector \\
\hline ABC & IgG de ratón & IgG de caballo & Vector \\
\hline Fluorescencia & IgG de rata & IgG de cabra & Cy2 & Jackson \\
\hline Fluorescencia & IgG de ratón & IgG de cabra & Cy2 & Jackson \\
\hline
\end{tabular}

Tabla 8: Anticuerpos secundarios utilizados en la técnica inmunohistoquímica.

\section{Inmunohistoquímica in toto}

Para realizar la inmunohistoquímica indirecta revelada con ABC (Fig. 18), los embriones se rehidrataron mediante varios lavados en PBS con Triton $X$ -100 al 0,5\% (PBST 0,5) y, con el fin de permeabilizarlos, se trataron con PK a una concentración y durante un tiempo que dependía de la edad (Tabla 6).

Tras los lavados en PBST 0,5, los embriones se postfijaron en PFH al $4 \%$ durante 20 min a TA, para eliminar cualquier resto de PK. A continuación se dieron varios lavados durante una hora con PBST 0,5. Antes de incubar en el 
anticuerpo, los embriones se preincubaron en una solución compuesta por $10 \%$ de suero y $1 \%$ de DMSO en PBST 0,5. Posteriormente, los embriones se incubaron durante una noche a TA en una solución como la anterior, a la que se añadió el anticuerpo primario (Tabla 7). Los embriones se lavaron en PBST 0,5 varias veces durante dos horas y se incubaron, durante una noche a $4^{\circ} \mathrm{C}$, en una solución compuesta por $10 \%$ de suero, $1 \%$ de DMSO y anticuerpo secundario biotinilado (Tabla 8) en PBST 0,5.

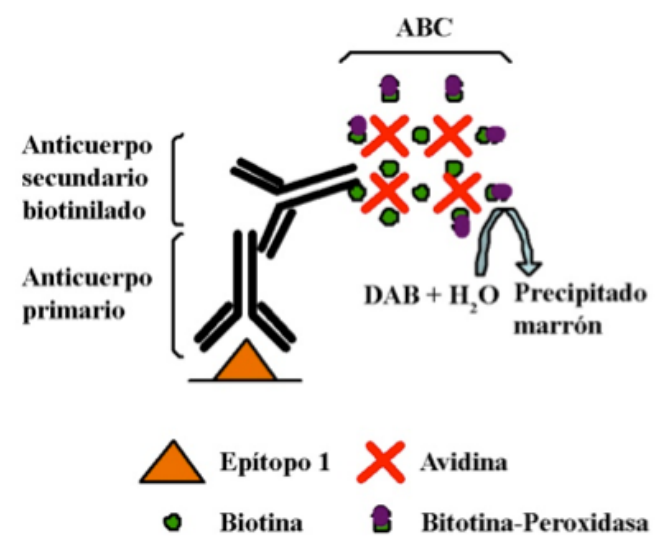

Fig. 18: Esquema de la IHQ indirecta por el método ABC.
Tras la incubación con el anticuerpo secundario, los ejemplares se lavaron tres veces con PBST 0,5. Después se añadió el complejo avidina-biotina peroxidasa (ABC) (\#PK-61000 "Kit Elite ABC", Vetastain" Vector Laboratories Inc., Burlingame, CA, EE.UU.), incubándose los animales en este medio durante una noche a $4^{\circ} \mathrm{C}$. El medio de incubación, que debe prepararse media hora antes de su uso y mantenerse siempre en oscuridad, estaba formado por avidina y biotina peroxidasa a una concentración de 1:250 disueltos en PBST 0,5.

Posteriormente los animales se lavaron tres veces. Los dos primeros lavados se efectuaron en PBST 0,5, mientras que el último se realiza en tampón Tris-HCl 0,1 M, pH 7,6 (Sigma). El revelado de las secciones se realizó con una solución que contenía 3-3'diaminobencidina (DAB, Sigma) al 0,02\% y $\mathrm{H}_{2} \mathrm{O}_{2}$ al 0,0003\% en tampón Tris- $\mathrm{HCl}$ 0,1 M, pH 7,6. La reacción se controló bajo la lupa y se detuvo mediante el lavado de las secciones en el mismo tampón y postfijación en $\mathrm{PFH} 4 \%$ durante una noche a $4{ }^{\circ} \mathrm{C}$. Los embriones se deshidrataron en una batería creciente de glicerol (30\%, 50\%, 70\% y 100\%) donde se mantuvieron hasta su fotografiado. 


\subsection{Técnica TUNEL}

La detección de cuerpos apoptóticos se llevó a cabo usando la técnica de TUNEL (marcaje con dUTP de extremos cortados del DNA mediado por la desoxinucleotidil transferasa). En la muerte celular apoptótica, el primer evento bioquímico es la rotura del DNA de cadena sencilla, seguido por la abertura del DNA de doble cadena en las regiones entre nucleosomas (Peitch et al., 1993; Oba y Koji, 2000). El marcaje TUNEL es una técnica molecular usada para detectar estas roturas en el DNA. Se basa en la adición repetida de dUTP-digoxigenina a los extremos 3'-OH generados en el DNA tisular durante la apoptosis. Esta adición la lleva a cabo el enzima desoxinucleotidil-transferasa. Posteriormente, el dUTP se puede localizar gracias a la molécula de digoxigenina que tiene conjugada.

\section{Protocolo de la técnica TUNEL}

Los embriones se rehidrataron mediante varios lavados en PBST 0,1 con el fin de permeabilizarlos, y se trataron con PK a una concentración y durante un tiempo que dependió de la edad (Tabla 6).

Tras dos lavados en PBST 0,1, los embriones se postfijaron en PFH al 4\% durante 20 minutos a TA, para eliminar cualquier resto de PK. A continuación se dieron varios lavados durante una hora con PBST 0,1.

Posteriormente, hicimos una postfijación con etanol 100\% y ácido acético (2:1), preenfriado a $-20^{\circ} \mathrm{C}$. Siguieron varios lavados con PBST 0,1. A partir de aquí utilizamos el kit “ApopTag® Peroxidase In Situ Apoptosis Detection Kit” (Chemicon International), siguiendo las instrucciones del fabricante. Para el revelado, en vez de usar el método $\mathrm{ABC}$ que facilita el kit, decidimos visualizar los resultados con fluorescencia, por lo que utilizamos un anticuerpo primario asociado con una molécula fluorescente (Tabla 7) que reconoce los residuos de digoxigenina situados por la enzima. Finalizada la técnica TUNEL 
convencional, procesamos los ejemplares para cortarlos en el criostato y montar las secciones en portaobjetos.

\section{$\underline{3.7 \text { Electrorretinogramas }}$}

Todos los registros de ERG se realizaron siguiendo la directrices de los estudios de Wong et al. (2005a,b) y Emra et al., (2008, 2010). Todo el equipo de registro, tanto la parte óptica como la eléctrica, se colocaron dentro de una caja de Faraday, para evitar interferencias eléctricas.

Las larvas fueron colocadas en un papel de filtro sobre una base de agarosa al $4 \%$, regada continuamente con una solución Ringer $(\mathrm{NaCl} 130 \mathrm{mM}$, $\mathrm{KCl} 2,5 \mathrm{mM}, \mathrm{NaHCO}_{3} 20 \mathrm{mM}, \mathrm{CaCl}_{2} * 2 \mathrm{H}_{2} \mathrm{O} 0,7 \mathrm{mM}, \mathrm{MgCl}_{2} * 2 \mathrm{H}_{2} \mathrm{O} 1 \mathrm{mM}$, Dextrosa $20 \mathrm{mM}$ ) a pH 7,8, con un aporte gaseoso aproximado de $97 \%$ de $\mathrm{O}_{2} \mathrm{y}$ $3 \%$ de $\mathrm{CO}_{2}$. Bajo control estereomicroscópico se enucleó el ojo de la larva con un bucle de alambre de tungsteno y se colocó bajo la fuente de luz. El ojo aislado se colocó con la córnea orientada hacia arriba en el centro del estímulo luminoso (diámetro $5 \mathrm{~mm}$ ) (Fig. 19).

Para las medidas del ERG durante la adaptación a la oscuridad, la cirugía ocular se realizó bajo una fuente de luz que emitía un rojo tenue lejano (670 $\mathrm{nm}$ ). Todas las grabaciones se realizaron utilizando una intensidad de flash de $5,3 \times 103 \mu \mathrm{W} / \mathrm{cm}^{2}$ a $500 \mathrm{~nm}(\log \mathrm{I}=-1)$, a través de un filtro de UV. La fuente de luz era una lámpara de mercurio (Newport). Mediante el uso de lentes focales y espejos, el haz de luz fue orientado hacia el ojo. El haz de luz atravesaba una caja con diferentes filtros de densidad neutra $(3 ; 2 ; 1 ; 0,6 ; 0,3 ; 0,15)$.

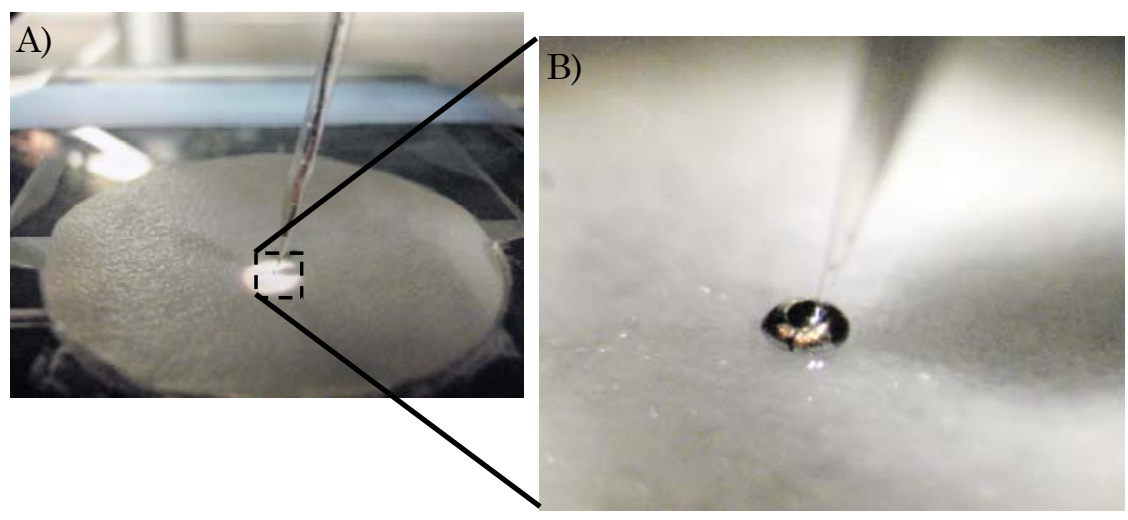

Fig. 19: A) Medición de un registro electrorretinográfico de un ojo enucleado de una larva de 5 dpf, mediante la colocación de un electrodo en un capilar de vidrio. B) Ampliación de la imagen. 
Las respuestas se registraron mediante un electrodo incluido dentro de un capilar de vidrio, con una punta de 15-30 micras de diámetro debajo del cristalino del ojo, sin llegar a tocar la superficie de la retina (Fig. 19). El electrodo de referencia se colocó dentro de la agarosa, en la cámara de registro.

Mediante un ordenador se controlaron el estímulo y el registro. Un programa creado con "LabView 8.0", controló los pulsos del estimulo luminoso y el registro electrofisiológico. Los pulsos de los estímulos se controlan mediante un "Shutter Control Power Supply" (modelo 325B, Uniblizt). Los destellos de luz, presentados a intervalos de $8 \mathrm{~s}$, se promediaron típicamente en respuesta a $1000 \mathrm{~ms}$. Los ERG se ampliaron a 1.000 de ganancia total y filtrado de paso a $300 \mathrm{~Hz}$.

Posteriormente, la señal electrofisiológica registrada fue amplificada y filtrada con un amplificador (modelo 5115, Textronic Inc.) y digitalizada a 10 $\mathrm{KHz}$ con una tarjeta de adquisición de datos de "National Instruments" (modelo BNC-2090). La señal fue finalmente representada en la pantalla de un ordenador. Tanto para la representación gráfica de los registros como para el control del estimulador luminoso se empleó el programa "Labview 8.0".

\section{Medición de las ondas a y b}

Los datos registrados por el programa Labview 8.0 fueron representados gráficamente mediante el programa IGOR Pro (Wave Matrics). Los registros electrorretinográficos produjeron ondas como la representada en la figura 20. Para hacer las mediciones de la amplitud de la onda-a se midió desde la línea de base antes del estímulo de luz, a la depresión de la onda negativa (Fig. 20). Puesto que la onda-b refleja la suma del componente negativo P-III y el componente positivo P-II, su amplitud se mide desde el seno de la onda-a al máximo de pico de la onda-b (Fig. 20). 


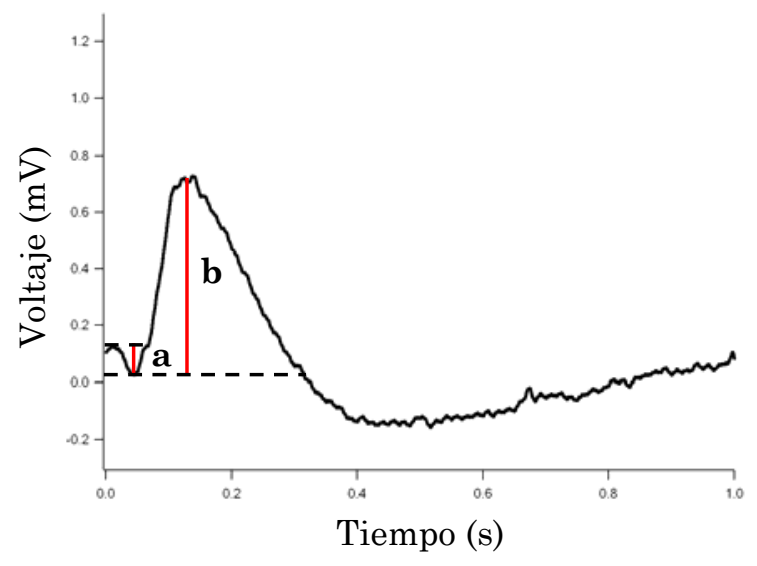

Fig. 20: Electrorretinograma de $5 \mathrm{dpf}$ de un animal control en condiciones escotópicas. (a) pequeña onda inicial que se origina a partir de la actividad de los fotorreceptores, (b) onda grande que refleja principalmente la despolarización de la células bipolares ON. La amplitud de la onda-b se mide desde el seno de la onda al pico de la onda-b . El estímulo fue de luz atenuada en la unidad logarítmica 0 .

\subsection{Análisis del comportamiento}

Todos los experimentos descritos a continuación se llevaron a cabo desde las 10 a.m. hasta las 4 p.m., con un periodo de habituación en una sala oscura durante aproximadamente 15 minutos, exceptuando la respuesta visual motora, en la que el periodo de habituación fue de dos horas.

\section{Valoración de la respuesta optomotora}

Para valorar esta repuesta se empleó un recipiente de plexiglás transparente de $200 \times 14 \times 30 \mathrm{~mm}$, con una serie de carriles horadados de 28x10x280 mm (Fig. 21). Este recipiente estaba dividido en cuatro zonas, siendo

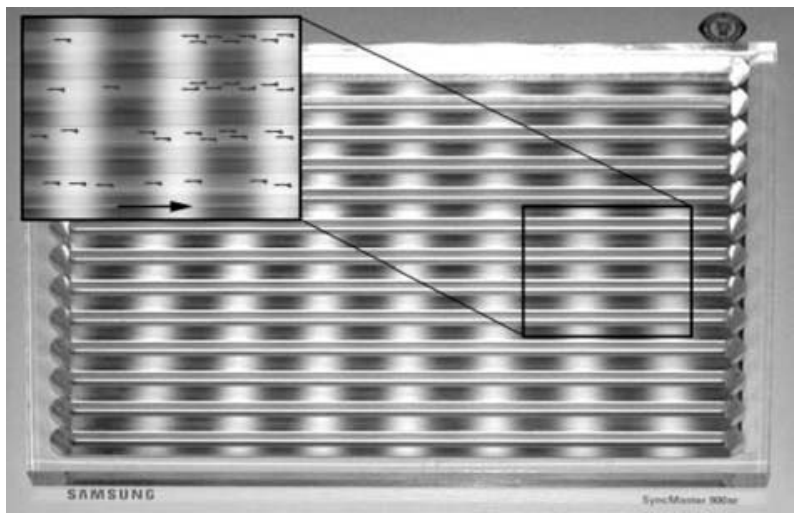

Fig. 21: Respuesta optomotora en larvas. El recipiente de natación de plexiglás se coloca encima de un monitor de ordenador. Las larvas siguen la dirección del movimiento de las bandas en la pantalla, de modo que las larvas se concentran en un lado de los carriles (recuadro). (Modificado de Fleisch y Neuhauss, 2006). la "zona final" la situada en los extremos de los carriles. El recipiente fue colocado de manera horizontal sobre una pantalla de ordenador plana de 800x600 píxeles en la que se emitía el estímulo. La pantalla estaba unida a un ordenador que controlaba el programa generador de estímulos, que, como en el caso de la respuesta optocinética, fue el "Phynton 2.5". 
Para realizar el procedimiento, las larvas se depositan en la zona media del canal, lo que la permite nadar en solo dos direcciones. El estímulo estaba constituido por franjas blancas y negras; la duración era de 45 segundos de estímulo, 20 segundos de pausa y otros 45 segundos de estímulo. Tras ello se cuenta el número de larvas que han llegado a la "zona final", dependiendo del numero total de larvas que se dispusieron en el canal, a esta relación se le llama índice optomotor (el número fue de 25 larvas como máximo por carril). Cada estímulo y dirección se repite cinco veces. Las larvas con visión normal se movían en la dirección del desplazamiento de las franjas blancas y negras.

\section{Valoración de la respuesta optocinética}

La larva fue inmovilizada colocándola en una placa Petri de $35 \mathrm{~mm}$ con un medio de metilcelulosa al $3 \%$. De esta manera se evita que se mueva la cabeza, pero el movimiento de los ojos es libre. La larva se bañó suavemente con el medio viscoso, evitando la aparición de burbujas, y usando una aguja, se alineó de manera horizontal en el centro de la placa, con la parte dorsal para arriba. La placa Petri con la larva se colocó bajo la lupa en el centro del tambor blanco (Fig. 22). Debajo de la larva se situó una lámpara infrarroja, para poder orientar la larva bajo la lupa, pues todo el ensayo se realizó en oscuridad.

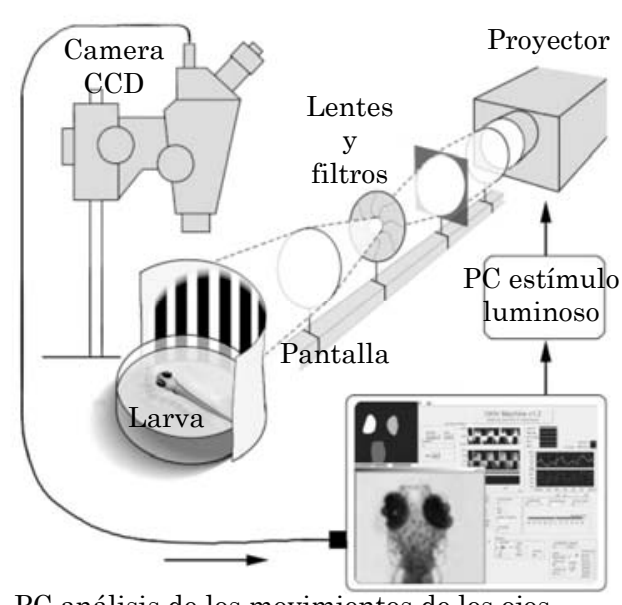

PC análisis de los movimientos de los ojos

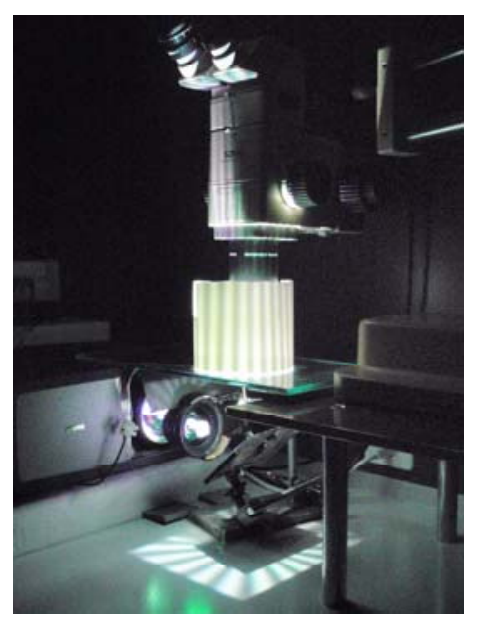

Fig. 22: Esquema para estimular y registrar la respuesta optocinética. Larvas de pez cebra se estimulan con bandas proyectadas sobre una pantalla cilíndrica. La proyección se enfoca y se ajusta mediante lentes y filtros. Los movimientos oculares se graban y son evaluados en tiempo real. (Modificado de Rinner et $a l ., 2005)$.

Las partes del sistema que facilitó la captura de la respuesta optocinética se muestran en la figura 22. Consta de un proyector (modelo PLV-Z3000, Sanyo) que envía el estímulo requerido hacía un espejo, este a su vez proyecta el 
estímulo bajo el tambor blanco que esta situado alrededor de la larva. En este tambor se proyecta el estímulo de franjas blancas y negras que servirá para el estudio de esta respuesta en larva del pez cebra. Gracias a una lupa (modelo S710, Olympus), pudimos capturar la imagen de la larva. Esta lupa tenía acoplada una cámara CCD (modelo GF-038B-NIR, Allied Vision Technologies), a su vez conectada a un equipo informático; la cámara estaba equipada con un filtro de paso IR (SI-093-SN1-49; Schneider Kreuznach). De esta manera fue posible grabar y analizar la respuesta optocinética de la larva.

El sistema informático para este experimento requirió dos equipos para realizar el estudio. Uno es el que generó el diseño del estímulo de franjas verticales en blanco y negro en el tambor (Fig. 23B). Para ello, proyectó un patrón de estímulo molino rotatorio (Fig. 22). Para crear este estímulo se empleó el programa "Python 2.5" archivo "VisionEgg" (Straw, 2008). El control de la estimulación, la sincronización de las grabaciones del ojo y de los parámetros de estímulo fueron implementados, desde el "VisionEgg", que incorpora un controlador TCP. Entre los límites entre las franjas blancas y negras del patrón se empleó un degradado, de tal manera que se generó un patrón de rejilla sinusoidal en el tambor. Para reducir al mínimo la frecuencia de los movimientos sacádicos, el patrón no gira en una sola dirección sino que cambia la dirección del movimiento cada 3 segundos.

El otro equipo informático requerido se empleó en el análisis de los movimientos oculares (Fig. 23A). Para ello se identificó la pigmentación de los ojos de las larvas, que contrasta claramente contra el cuerpo transparente,

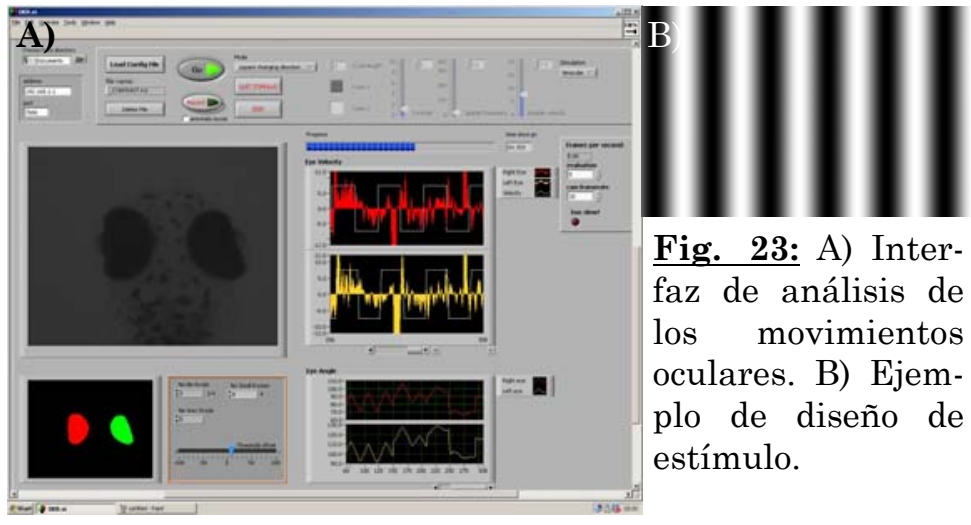

mediante el programa "LabView 7.1" y "NI-IMAQ 3.7 "

(National

Instruments). El programa reconoce de manera automática los ojos sobre la base de la intensidad de 
píxeles, utilizando el procesamiento de imagen estándar de algoritmos implementados en el Módulo de Desarrollo NI Vision. Identifica también en los ojos su forma elíptica, la intersección máxima y su orientación (ángulo). Las velocidades de los ojos pueden ser calculadas como la primera derivada del ángulo con respecto al tiempo. Las larvas fueron grabadas a 5 fotogramas por segundo (fps). A esta velocidad, todos los cálculos se pudieron hacer en tiempo real utilizando una pantalla estándar de ordenador (para obtener información más detallada, especialmente sobre las velocidades de los movimientos sacádicos). También es posible el reconocimiento de los ojos y el análisis de las velocidades de los ojos en películas grabadas anteriormente. Idealmente, las propiedades del estímulo pueden ser definidas desde el control del programa y se envían al equipo informático que controla el estímulo lumínico, a través de una conexión TCP/IP. Es muy recomendable vincular directamente los dos equipos (el que controla el estímulo lumínico y el que analiza el movimiento de los ojos) con un cable de red para asegurar alta fiabilidad y velocidad. Además, los controladores de TCP de "VisionEgg" no contienen características de seguridad y fácilmente podrían permitir la ejecución de códigos arbitrarios en el equipo. Todos los datos fueron representados con el programa "R", versión 2.9.2 (http://www.r-project.org).

En un experimento estándar, por lo general, varía más de un parámetro de la estimulación a la vez; por ejemplo, contraste, frecuencia espacial o frecuencia temporal. El patrón cambió su dirección de movimiento con una frecuencia de $1 / 3 \mathrm{~Hz}$ después de 9 segundos de la estimulación inicial con un estímulo estándar (contraste $=99 \%$, frecuencia espacial $=0,05$ ciclos $/$ grado, la velocidad angular $=7,5$ grados $/ \mathrm{s}$ ), se comenzó con la medición real. Cada 9 segundos (es decir, después de 3 ciclos), el parámetro de interés se incrementó o disminuyó paso a paso. Después de alcanzar su valor final, el parámetro se cambió de nuevo paso a paso para alcanzar su valor inicial. 


\section{Valoración de la respuesta visual motora}

Para el análisis, las larvas se dispusieron en los pocillos individuales de una placa de 96 pocillos (modelo 7701-1651; Whatman) (Fig. 24) con medio E3 o los distintos tratamientos. Los animales tratados y los controles fueron dispuestos a manera de tablero de ajedrez para evitar efectos posicionales. La placa se iluminó desde abajo con luz infrarroja. Encima de los pocillos se situó una fuente de luz LED con posibilidad de emitir en distintos colores. Las larvas fueron controladas desde arriba con una cámara CCD (Pike F-032B, Allied Vision Technologies) equipada con una lente de zoom (C6Z1218-FA; Pentax) y con un filtro de paso IR (SI-093-SN1-49; Schneider Kreuznach).

A)

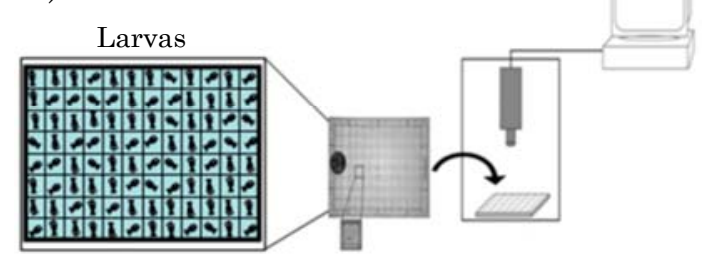

B)

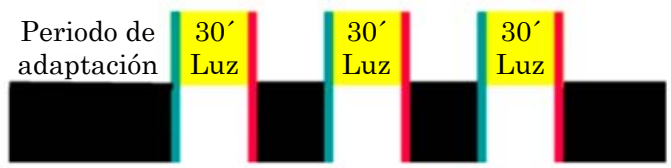

Fig. 24: Diseño experimental de la respuesta visual motora. A) Las larvas individuales se colocan en una placa de 96 pocillos en una cámara de registro. La actividad de cada larva se mide en tiempo real. B) Las larvas tienen un período de adaptación a la oscuridad, después existen una alternacia de períodos de 30 minutos con luz y de oscuridad consecutivamente. (Modificado de Emran et al., 2008.
Mediante un ordenador se controlaron los estímulos y la detección de cada larva de forma individual mediante los programas "LabView 7.1" y "NI-IMAQ 3.7” (National Instruments). El programa monitoriza la velocidad de natación de cada larva, que se calcula en tiempo real a 20 fotogramas por segundo, promediada sobre un periodo de 1 segundo y guardada en la memoria del ordenador cada segundo. Los movimientos de las larvas fueron rastreados durante un periodo de 7 horas al cambiar la iluminación. Se aplicó un primer período de 2 horas de oscuridad (iluminación IR) para adaptar y sincronizar las larvas (Fig. 24). Posteriormente, una luz se encendió y se apagó en intervalos de 30 minutos. Después del experimento, se empleó un umbral derivado empíricamente para recodificar velocidad de nado de cada larva en una medida de la actividad binaria. Se utilizó el programa "R", versión 2.9.2 (http:// www.r-project.org), para trazar la actividad promedio de las larvas. 


\subsection{Análisis de imagen}

\section{Obtención y procesamiento de imágenes}

Las imágenes de las secciones se obtuvieron con un fotomicroscopio Olympus Provis AX70 equipado con campo claro y epifluorescencia, conectado a una cámara digital Olympus DP70. Por último, las propiedades de luz y brillo de todas las imágenes fueron ajustadas con el programa Adobe Photoshop CS5, para que reflejara fielmente lo observado en el microscopio.

\section{$\underline{3.10}$ Toma de medidas y recuentos}

\section{$\underline{\text { Recuento de células }}$}

Con el fin de analizar las alteraciones en la diferenciación de las áreas visuales de los animales tratados con las distintas concentraciones, se contaron las células positivas para diferentes marcadores de estudio en la retina, con la ayuda del programa "ImageJ". Debido a que los ejemplares tratados presentan una retina más pequeña que los controles, se relativizó el recuento al área correspondiente. Así, el resultado está expresado en número de células/área. En los casos en los que un marcador se expresó en una única población celular muy localizada se contó el número total de células.

Se contaron las células y se midió el área en un mínimo de tres secciones por embrión, obteniendo una media de células/área observadas en el embrión, empleando un mínimo de tres embriones por cada marcador y grupo experimental.

\subsection{Análisis estadístico}

El análisis estadístico de todos los resultados se realizó mediante el programa "Prism 4.0" (GrapPad), salvo en los referidos en el comportamiento optocinético y visual motor que se utilizó el programa "R", versión 2.9.2 (http:// 
www.r-project.org). En todos los casos se realizó una comparación mediante una t de Student con una corrección de Welch entre el grupo tratado y su respectivo control. Un valor $\mathrm{p}<0,05$ fue considerado significativo. Se utilizó el mismo programa para realizar las distintas representaciones gráficas, aunque éstas fueron posteriormente modificadas con el programa Adobe PhotoShop CS5. 

Resultados 



\section{ANÁLISIS MORFOLÓGICO}

\subsection{Efectos de la nicotina en el tamaño del ojo}

Tras los tratamientos con las diferentes concentraciones de nicotina, los ojos de los animales muestran una marcada, y macroscópicamente evidente, reducción del tamaño de los ojos, que a su vez, va acompañada de la reducción del cuerpo del animal en comparación con los animales control. Esta disminución estructural esta asociada a la concentración de nicotina y al tiempo de exposición con los tratamientos. Para realizar los distintos análisis del presente estudio, se ha tenido en cuenta la disminución del tamaño ocular y de las demás estructuras visuales. Cuando se pesaron los embriones y larvas destinados al análisis de HPLC (ver en Material y Métodos "Protocolo de cuantificación de las muestras") la reducción del peso (Tabla 9), se acompaña de una reducción del tamaño del animal.

\begin{tabular}{|c|c|c|c|c|}
\hline \multicolumn{5}{|c|}{ Edad 48 hpf } \\
\hline Control & Nicotina $5 \mu \mathrm{M}$ & Nicotina $10 \mu \mathrm{M}$ & Nicotina $20 \mu \mathrm{M}$ & Nicotina $40 \mu \mathrm{M}$ \\
\hline $0,069 \mathrm{~g}$ & $0,067 \mathrm{~g}$ & $0,066 \mathrm{~g}$ & $0,060 \mathrm{~g}$ & $0,060 \mathrm{~g}$ \\
\hline \multicolumn{5}{|c|}{ Edad 3 dpf } \\
\hline Control & Nicotina $5 \mu \mathrm{M}$ & Nicotina $10 \mu \mathrm{M}$ & Nicotina $20 \mu \mathrm{M}$ & Nicotina $40 \mu \mathrm{M}$ \\
\hline $0,077 \mathrm{~g}$ & $0,066 \mathrm{~g}$ & $0,065 \mathrm{~g}$ & $0,066 \mathrm{~g}$ & $0,054 \mathrm{~g}$ \\
\hline & & Edad 5 dpf & \\
\hline Control & Nicotina $5 \mu \mathrm{M}$ & Nicotina $10 \mu \mathrm{M}$ & Nicotina $20 \mu \mathrm{M}$ & Nicotina $40 \mu \mathrm{M}$ \\
\hline $0,081 \mathrm{~g}$ & $0,078 \mathrm{~g}$ & $0,057 \mathrm{~g}$ & $0,059 \mathrm{~g}$ & $0,055 \mathrm{~g}$ \\
\hline
\end{tabular}

Tabla 9: Peso de 200 animales por grupo de estudio para cada edad. Se detecta una reducción del peso de los animales en los estadios de mayor edad y esa reducción esta relacionada con la concentración de nicotina usada.

Las mediciones del área de la proyección del ojo (tanto lateral, como ventral en el animal) de los animales tratados con las diferentes concentraciones de nicotina, se han comparado con la medición desde el centro del ojo hasta la formación del otolito (una estructura fija situada en la cabeza y cercana al ojo) en una vista lateral del animal. También medimos la distancia de un ojo a otro, 
desde una vista ventral, para saber si existe una reducción del área del ojo. Estas mediciones morfométricas han sido realizadas a los 48 hpf, 3 dpf y 5 dpf.

En embriones de 48 hpf (Fig. 25), hemos observado una escasa reducción del área ocular lateral y tampoco hay diferencias con la distancia óculo-otolito en ninguna de las concentraciones. Tampoco se han encontrado diferencias significativas del área ocular ventral, ni tampoco en la distancia entre ojos, en los diferentes tratamientos de exposición a nicotina.

A los 3 dpf la exposición a nicotina es más prolongada, y produce diferencias significativas entre los animales tratados y los controles (Fig. 26). La reducción del área ocular tanto lateral como ventral, es muy significativa en todos los casos. La relación entre la concentración de nicotina y la reducción ocular afecta significativamente tanto a las áreas de proyección latera y ventral, como a las mediciones morfométricas de distancia entre el ojo y otolito y entre ojos.

A los 5 dpf (Fig. 27) la reducción del área ocular sigue siendo evidente, pero las diferencias son significativas sólo en los animales expuestos a las mayores concentraciones de nicotina, las de $20 \mu \mathrm{M}$ y $40 \mu \mathrm{M}$ (Fig. 27); igual ocurre con los parámetros morfométricos del ojo al otolito y entre ojos. 


\section{Embriones de $48 \mathrm{hpf}$}

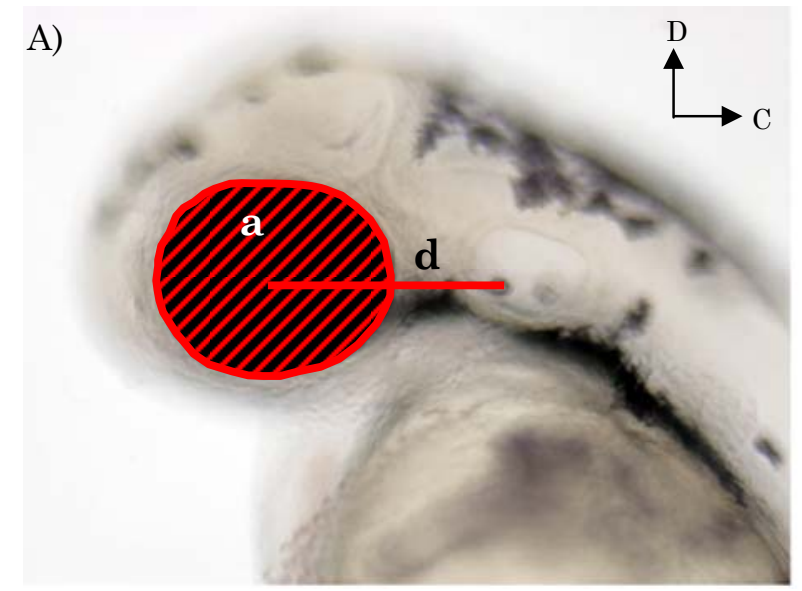

C)

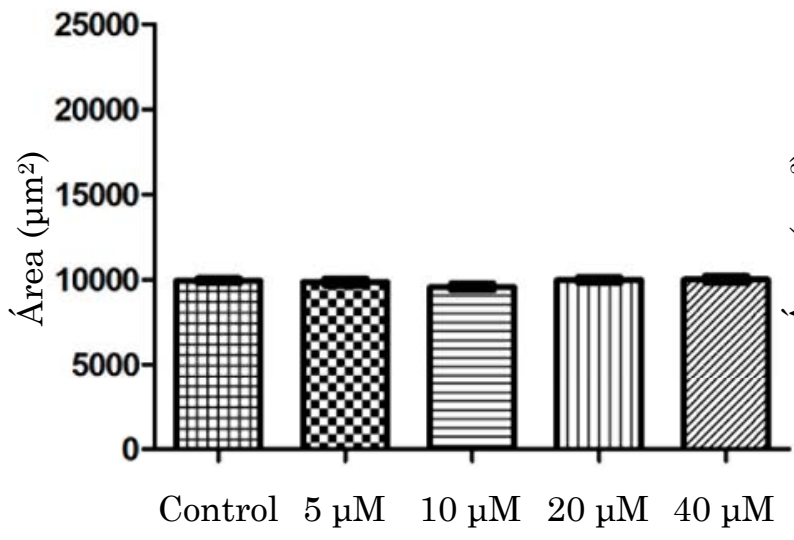

E)

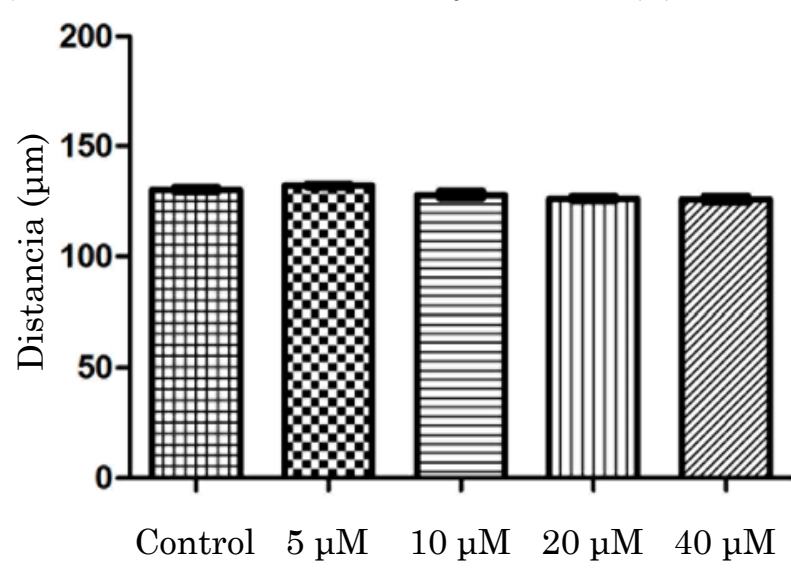

B)

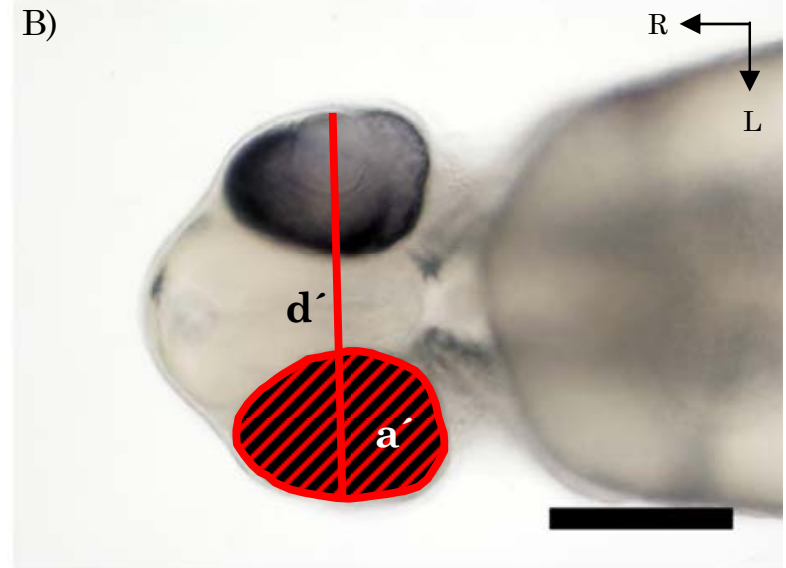

D)

Área ocular ventral (a')

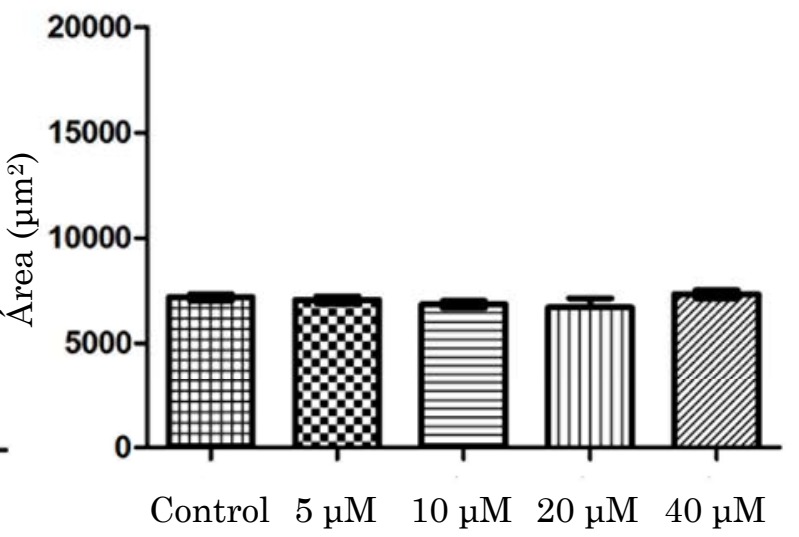

F)

Distancia entre ojos (d')

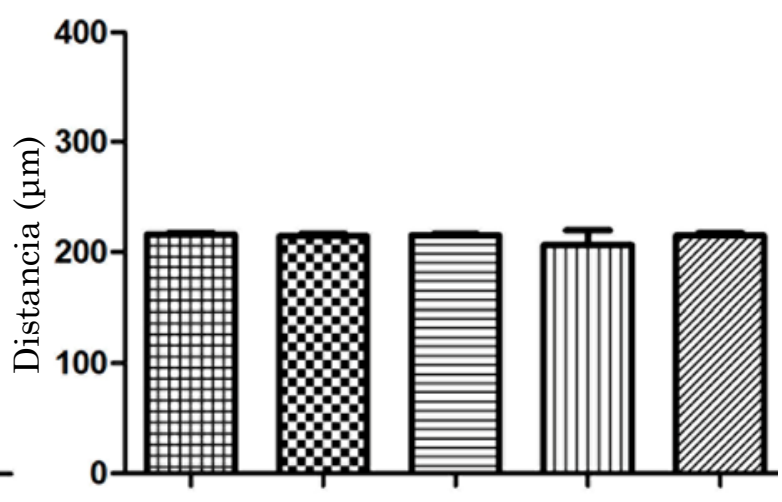

Control $5 \mu \mathrm{M} \quad 10 \mu \mathrm{M} \quad 20 \mu \mathrm{M} \quad 40 \mu \mathrm{M}$

Fig. 25: A) Vista lateral de un embrión de pez cebra de 48 hpf. a: área de la proyección de un ojo. d: distancia entre ojo y otolito. B) Vista ventral de un embrión de pez cebra de 48 hpf. a': área de la proyección de un ojo. d': distancia entre ojos. C), D), E) y F) Histograma del área ocular y distancias morfométricas en la cabeza de embriones en los diferentes grupos de estudio. C) Área ocular lateral. D) Área ocular ventral. E) Distancia entre el punto central del ojo hasta el otolito. F) Distancia desde el extremo central de un ojo hasta el otro ojo. C: Caudal. D: Dorsal. L: Lateral. R: Rostral. Barra de escala: $100 \mu \mathrm{m}$. 
Larvas de 3 dpf

A)
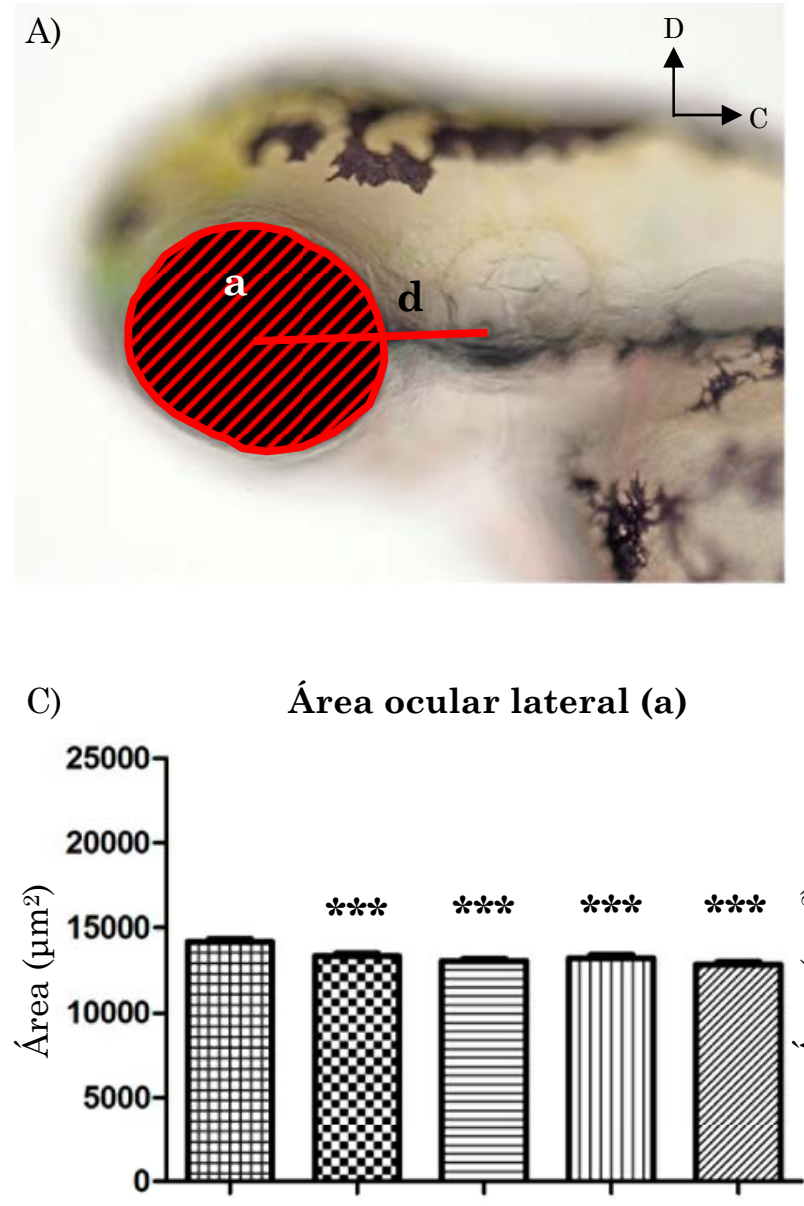

Control $5 \mu \mathrm{M} \quad 10 \mu \mathrm{M} \quad 20 \mu \mathrm{M} \quad 40 \mu \mathrm{M}$

E)

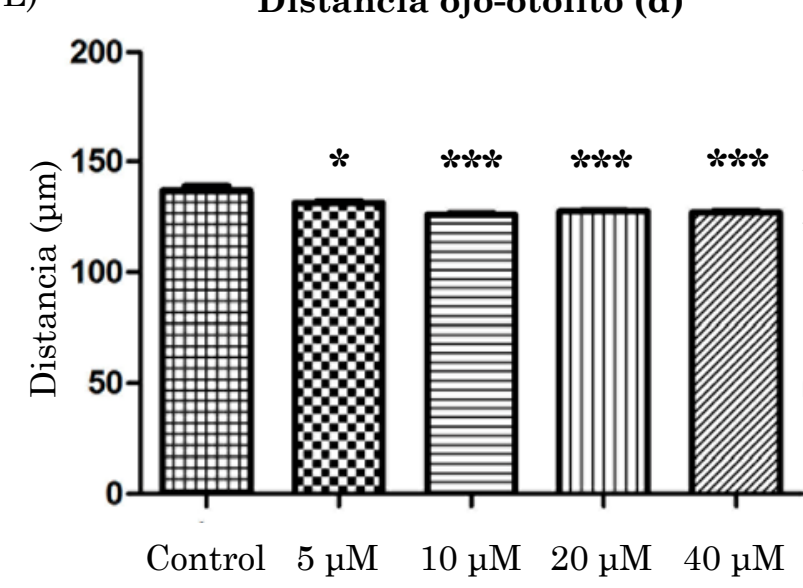

B)

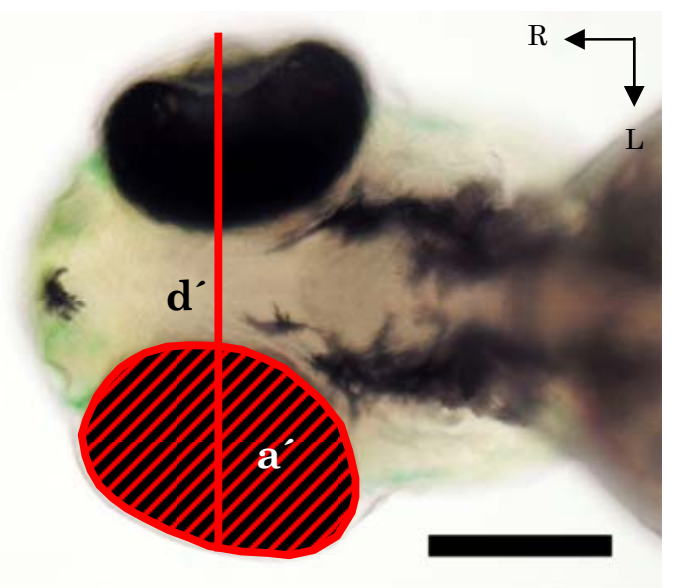

D)

Área ocular ventral (a')

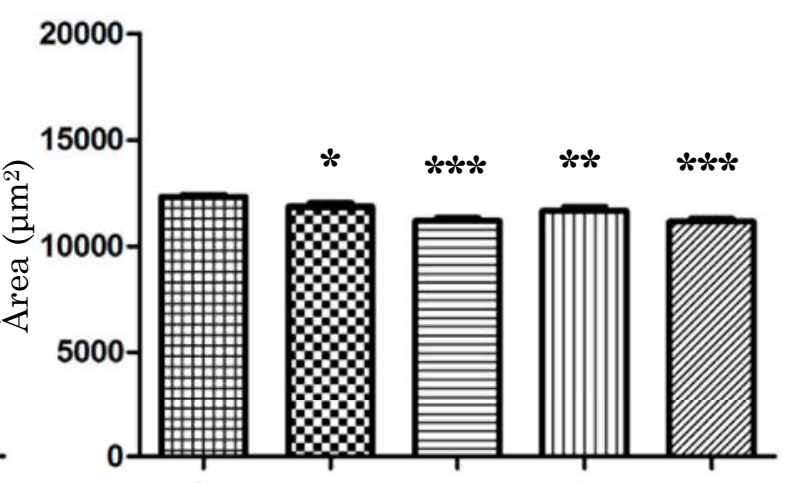

Control $5 \mu \mathrm{M} \quad 10 \mu \mathrm{M} \quad 20 \mu \mathrm{M} \quad 40 \mu \mathrm{M}$

Fig. 26: A) Vista lateral de un embrión de pez cebra de 3 dpf. a: área de la proyección de un ojo. d: distancia entre ojo y otolito. B) Vista ventral desde abajo de un embrión de pez cebra de 3 dpf. a': área de la proyección de un ojo. d': distancia entre ojos. C), D), E) y F) Histograma del área ocular y distancias morfométricas en la cabeza de embriones en los diferentes grupos de estudio. C) Área ocular lateral. D) Área ocular ventral. E) Distancia entre el punto central del ojo hasta el otolito. F) Distancia desde el extremo central de un ojo hasta el otro ojo. C: Caudal. D: Dorsal. L: Lateral. R: Rostral. ${ }^{*}=p<0,05 .{ }^{* *}=0,05>p>0,001 .{ }^{* * *}=p<0,001$. Barra de escala: $100 \mu \mathrm{m}$. 
Larvas de 5 dpf
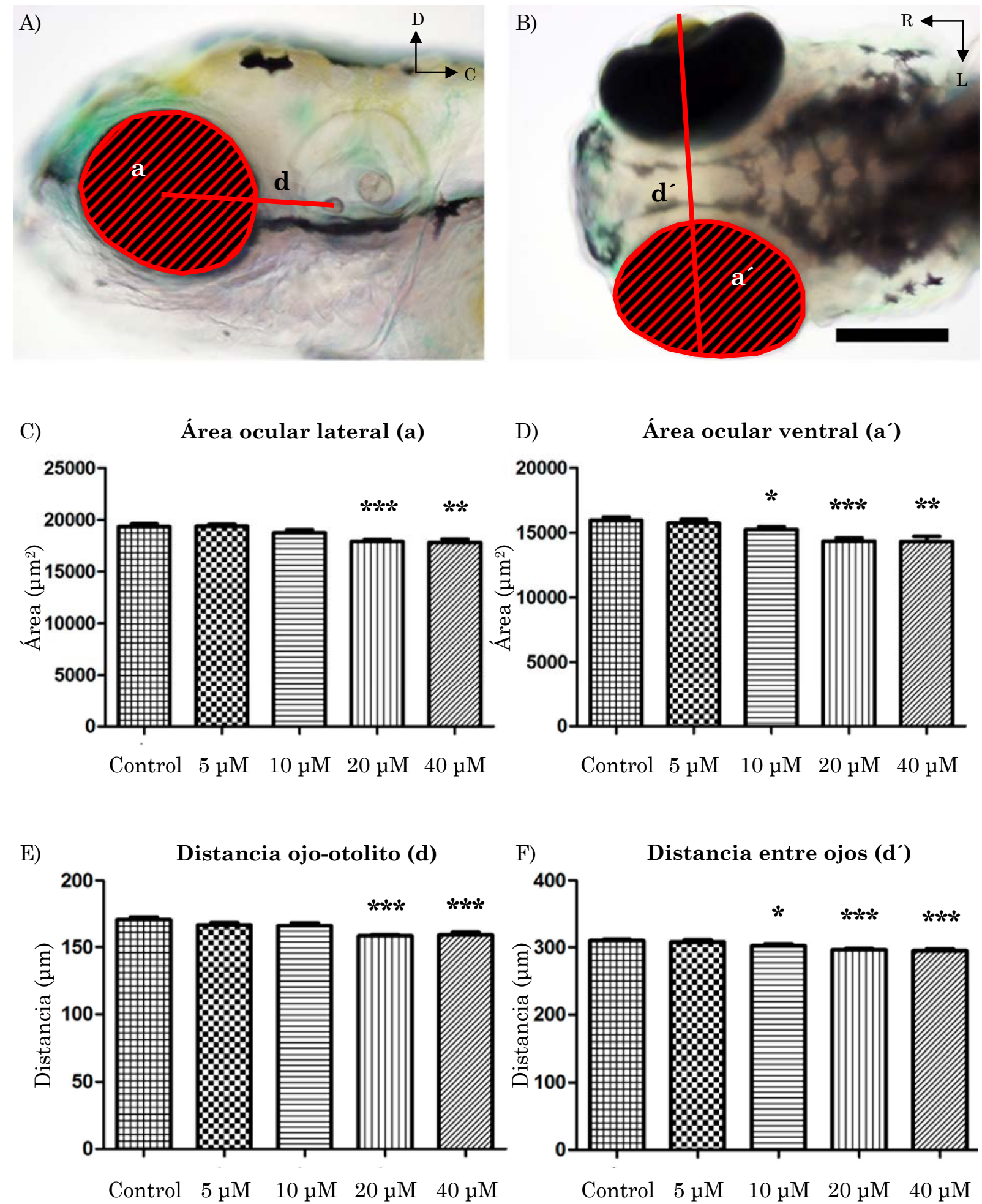

Fig. 27: A) Vista lateral de un embrión de pez cebra de 5 dpf. a: área de la proyección de un ojo. d: distancia entre ojo y otolito. B) Vista ventral desde abajo de un embrión de pez cebra de 5 dpf. a': área de la proyección de un ojo. d’: distancia entre ojos. C), D), E) y F) Análisis del área ocular y distancias morfométricas en la cabeza de embriones en los diferentes grupos de estudio. C) Área ocular lateral. D) Área ocular ventral. E) Distancia entre el punto central del ojo hasta el otolito. F) Distancia desde el extremo central de un ojo hasta el otro ojo. C: Caudal. D: Dorsal. L: Lateral. R: Rostral. ${ }^{*}=p<0,05 .{ }^{* *}=0,05>p>0,001 .{ }^{* * *}=p<0,001$. Barra de escala: $100 \mu \mathrm{m}$. 


\subsection{Citoarquitectura de la retina y techo óptico}

Las mediciones morfométricas muestran que el tamaño del ojo sufre una consistente reducción de tamaño. La vía visual en su conjunto también parece sufrir alteraciones tras el tratamiento con la nicotina. Las secciones semifinas teñidas con azul de toluidina, permiten analizar potenciales alteraciones en la vía visual como consecuencia del tratamiento con diferentes concentraciones de nicotina.

A las 48 hpf (Fig. 28), en los ejemplares control, se observa la segregación morfológica de los dos estratos que componen las copas ópticas: el neuroepitelio pseudoestratificado columnar y el epitelio pigmentario cúbico. Además se aprecia la salida de los axones de las células ganglionares que formarán el nervio óptico. En este estadio están formadas la mayoría de las estructuras relacionadas con la vía visual, pero no están totalmente maduras. También es visible la zona prospectiva que dará lugar al TO. El TO y la retina todavía no se han terminado de desarrollar estratigráficamente.

En los animales de 48 hpf tratados con nicotina (Fig. 28), no se aprecian grandes cambios o alteraciones en la estratificación de la retina ni en la formación de las estructuras visuales. Están presentes los dos estratos de la retina, la salida del nervio óptico de la retina y la zona correspondiente al primordio del TO. En ninguna de las concentraciones de nicotina estudiada se han observado grandes diferencias morfológicas.

En el estadio de 3 dpf (Fig. 29), en los animales control, la laminación de la retina se ha completado y muestra los seis estratos característicos en vertebrados. Las células presentes en las capas nucleares son predominantemente de morfologías esféricas y fusiformes, mientras que el neuropilo de las capas plexiformes es una matriz homogénea. El epitelio pigmentario también está formado en este estadio del desarrollo. Tras la eclosión, el TO del pez cebra se caracteriza por la presencia de dos zonas 
germinativas: la ZBS y la ZGPV. La ZGPV es una banda que limita con el ventrículo tectal ventralmente y con la ZBS como límite dorsal. Tras la tinción con azul de toluidina se diferencian en esta zona gran cantidad de cuerpos celulares caracterizados, en la mayoría de los casos, por su soma de morfología esférica. La ZBS se caracteriza por su aspecto neuropilor que, con esta tinción, aparece como una matriz uniforme. Disperso en el neuropilo se encuentran algunos cuerpos celulares de morfología esférica.

$\mathrm{Al}$ igual que ocurre en el estadio anterior, los ejemplares de $3 \mathrm{dpf}$ (Fig. 29), no se aprecian diferencias morfológicas con los controles. La retina presenta sus seis estratos característicos de esta edad. Sin anomalías en el tamaño de los estratos nucleares ni plexiformes. Por lo que respecta al epitelio pigmentario, está bien constituido. En el TO tampoco hemos encontrado diferencias significativas. Por tanto, en este estadio, la disminución del tamaño del ojo no se refleja en la disminución o ausencia de alguna de las capas de la retina, al igual que ocurre en el TO.

En los animales de 5 dpf (Fig. 30) la laminación de la retina muestra las seis capas características. Las células de las capas nucleares presentan una morfología fusiforme o esférica. La CCG, aunque no es tan gruesa como la CNI, tiene una elevada densidad de células, con morfología mayoritariamente fusiforme. Las capas plexiformes aparecen como una matriz homogénea, siendo la de mayor grosor la CPI. Además, el EP está totalmente constituido. El TO mantiene las dos capas germinativas del estadio larvario anterior.

En este estadio larvario los animales tratados con las diferentes concentraciones de nicotina (Fig. 30) tienen las seis capas de la retina, sin diferencias con los controles en el grosor de las capas nucleares o plexiformes. Tampoco hay diferencias en la morfología de los cuerpos celulares en las capas nucleares. En el TO persisten sus dos estratos y no se observan diferencias los animales control con respecto al volumen de cuerpos celulares ni su morfología. 

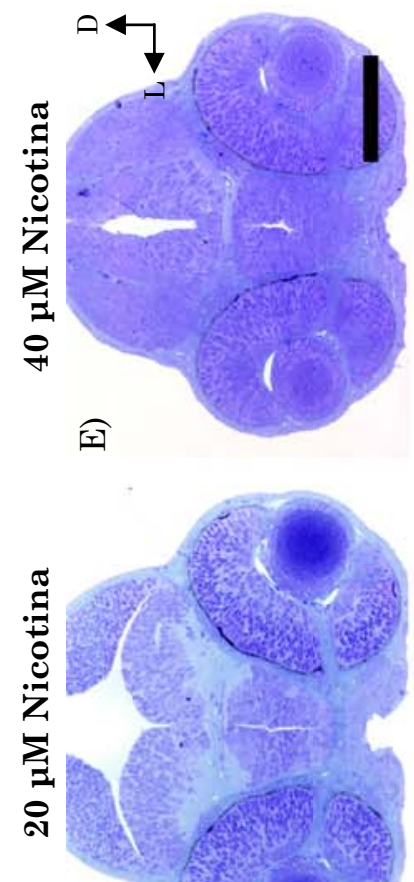

$\widehat{ค}$
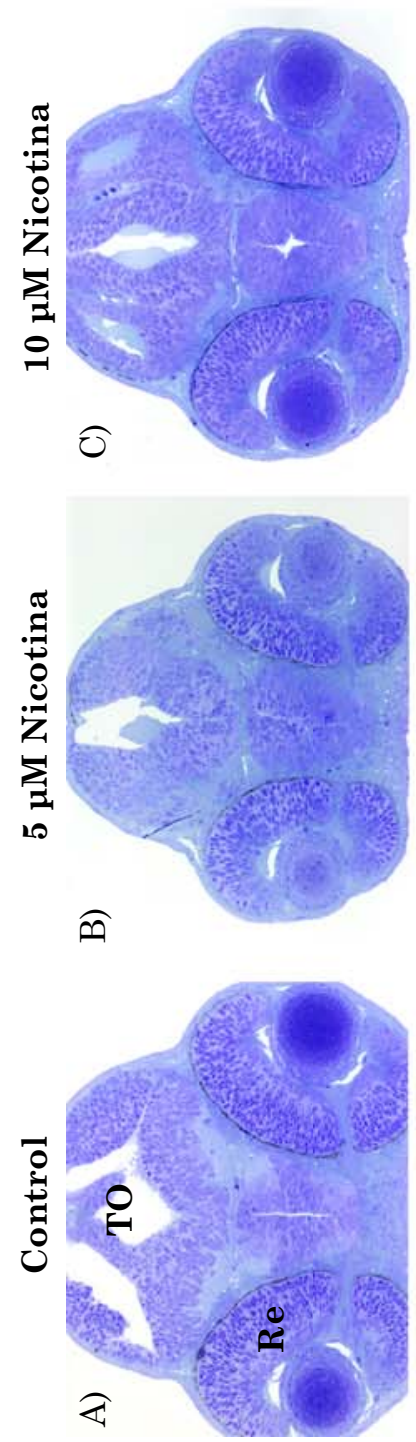
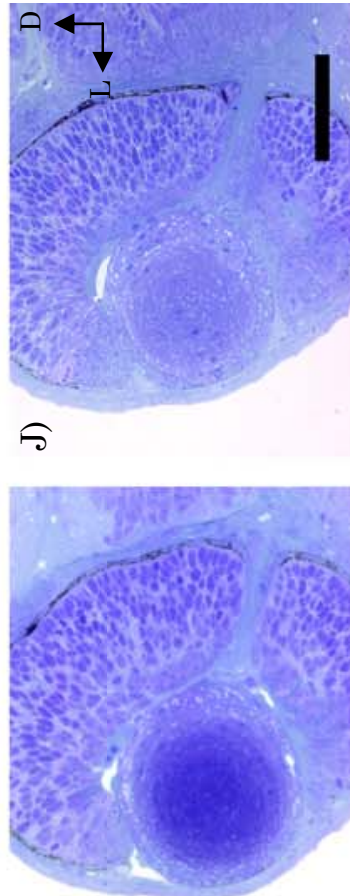

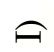
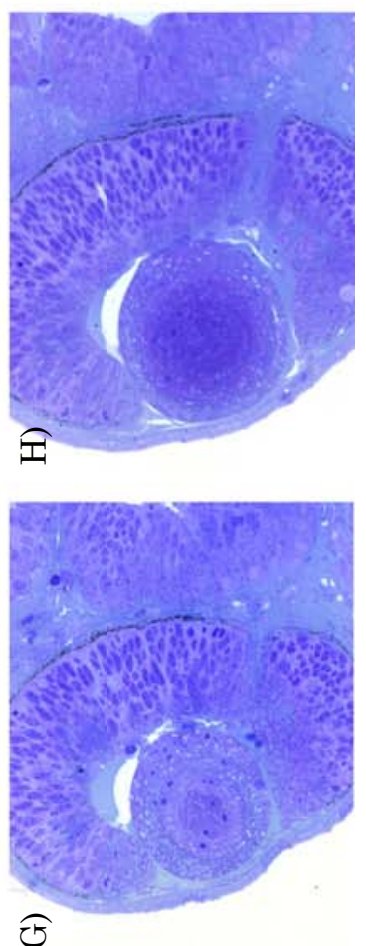

$\stackrel{8}{z}$

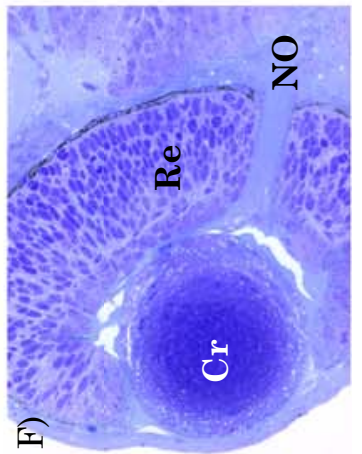

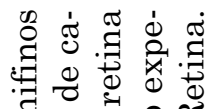

हुำ

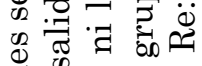

.

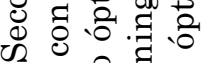

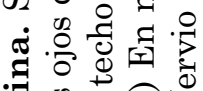

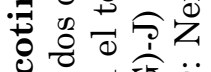

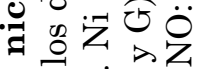
0

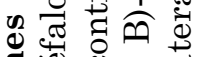
‡: 0 is

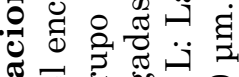
๘ ఫ ปี ส

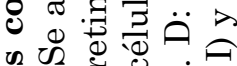

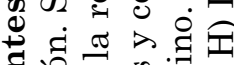

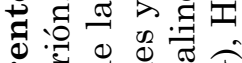
बै

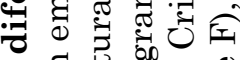

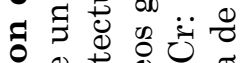

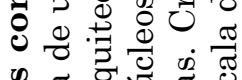
๒ ส

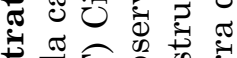
7 约。

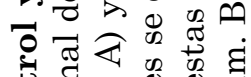

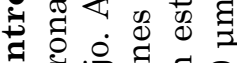
잉 잉융

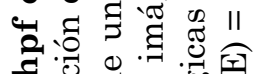

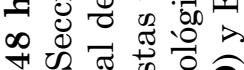
† 认ิ

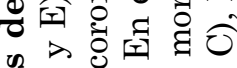
ฮิ่

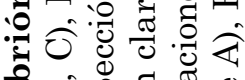

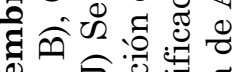

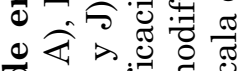
๙ $\hat{A}$

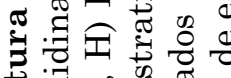

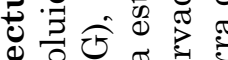

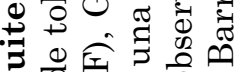
ริ드응

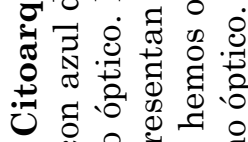

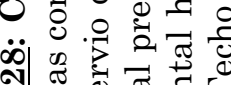
จ.

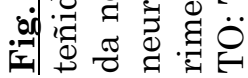




\section{Resultados}

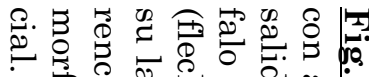

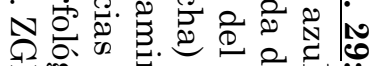

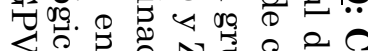

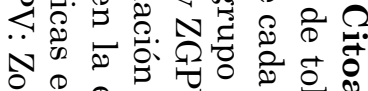
它 8 \& 8 \&

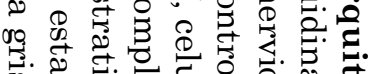

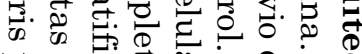

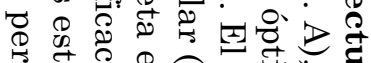

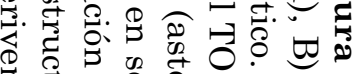

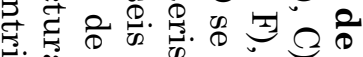

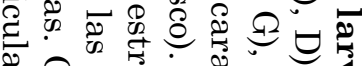
$\Omega$ फ० क्ष 40 ज.

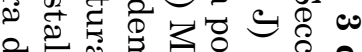

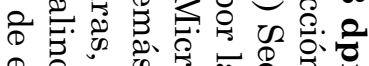
里

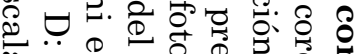
จ.

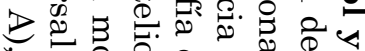
Ш

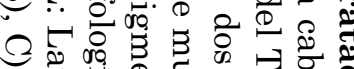
$\forall$ बै

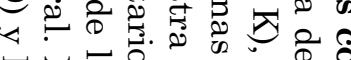

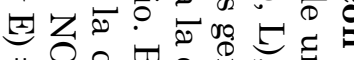

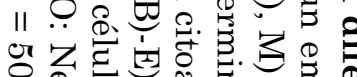
讨造

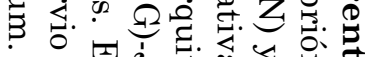

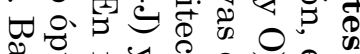

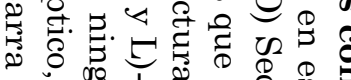
๙

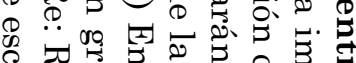

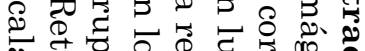

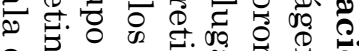

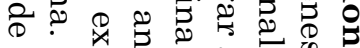
201

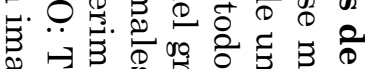
\%

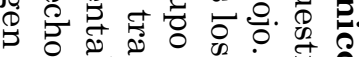

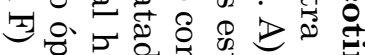

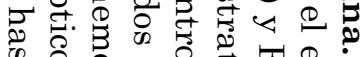
足. ڤ

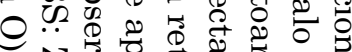
II 0 出:

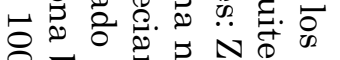
8 б

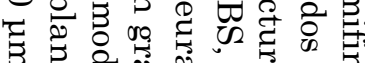
की प 焉
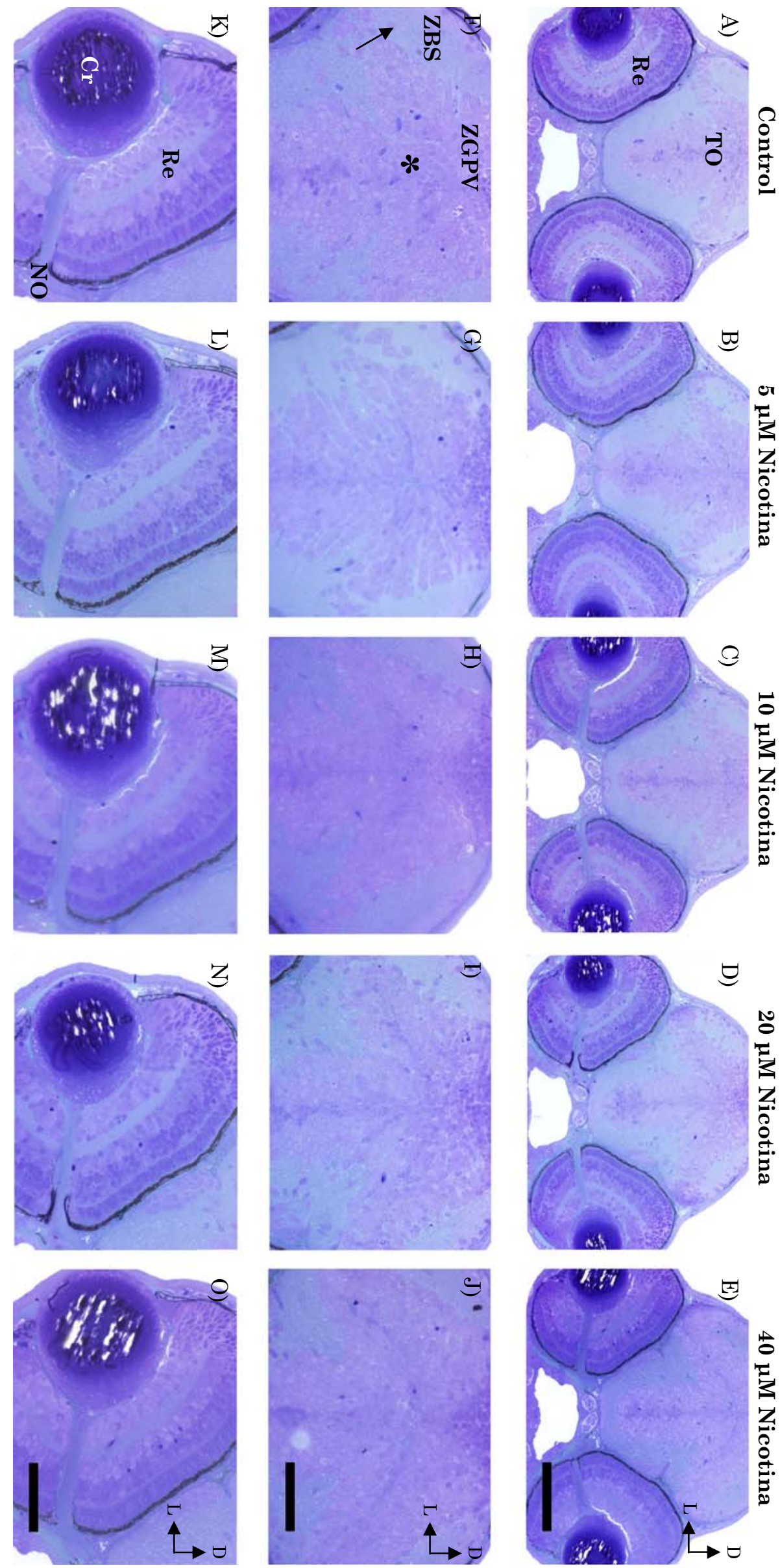


\section{Resultados}
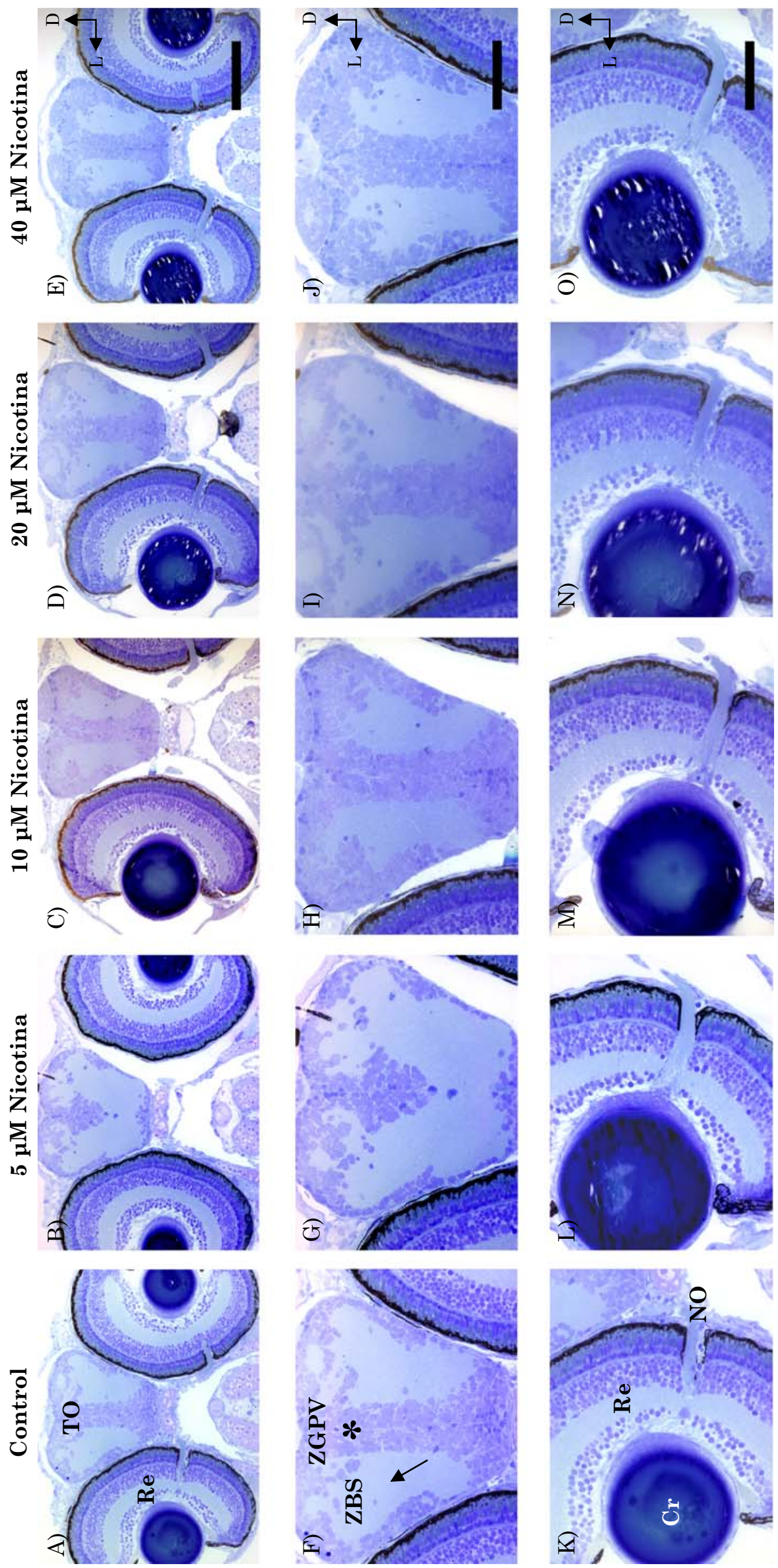

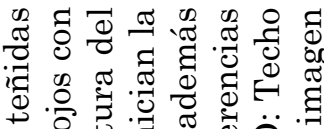

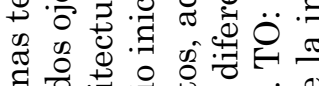

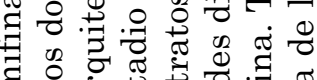

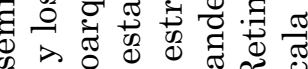

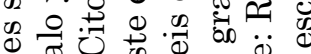

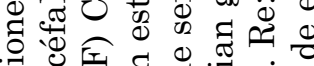

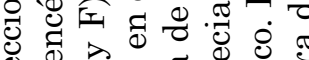

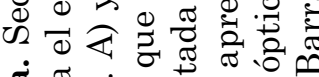

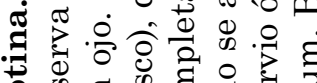

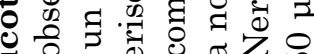

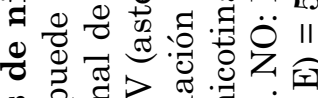
\&

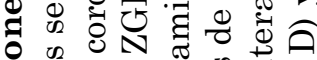
ల్ర 禹

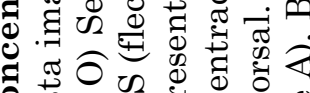

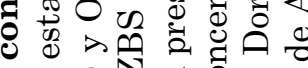

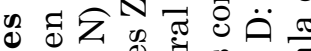

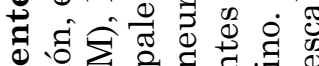

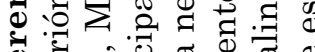
屯ैं

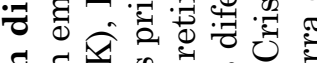
ஓ इ थ क

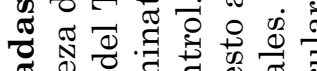

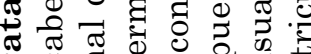
ఫ $\rightarrow$ ठ

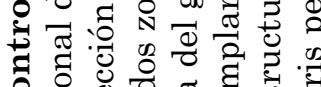
ల

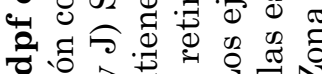
10:

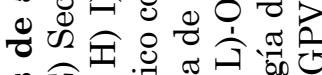

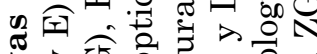

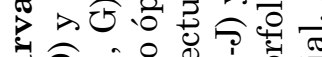

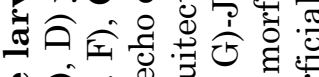

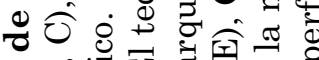

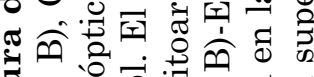

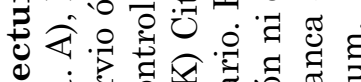

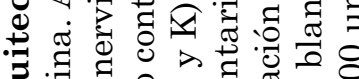
ㅂ.

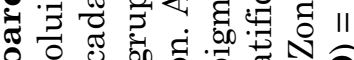

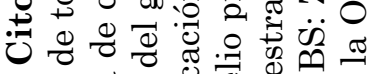

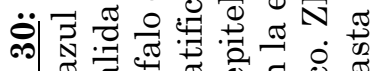
बं 祬 


\section{$\underline{1.3 \text { Efectos de la nicotina en la retina }}$}

Tras comprobar el efecto de la exposición a nicotina en la talla del ojo y del tamaño de los animales, además de analizar su citoarquitectura, nos proponemos cuantificar el tamaño medio de la retina de los ejemplares tratados con nicotina para la que, medimos el área de regiones coronales centrales de la retina de los ejemplares control y de los tratados con diferentes concentraciones de nicotina. En todos los casos seleccionamos regiones anatómicamente comparables (Fig. 31A) entre todos los grupos.

En el estadio de $48 \mathrm{hpf}$ en animales tratados con nicotina (Fig. 31B) apenas se aprecia disminución del área retiniana, y se conserva el tamaño en los tratados respecto a los controles. El tamaño medo del área retiniana es de $13.390 \pm 684,1 \mu \mathrm{m}^{2}$. En los estadios de $3 \mathrm{dpf}$ (Fig. 31C) el tamaño medio del área de la retina $\left(16.490 \pm 616,2{\mu \mathrm{m}^{2}}^{2}\right)$ fue significativamente inferior en los ejemplares tratados, siendo las mayores diferencias, con respecto al grupo control, en los animales tratados con la concentraciones más altas de nicotina. A los 5 dpf (Fig. 31D) la tendencia de la disminución del tamaño de la retina es mayor que en el estadio anterior, con la mayoría de las concentraciones de nicotina utilizadas inducen reducción del área retiniana, estos valores son altamente significativos con respecto al de los ejemplares control, con un área de la retina de $17.830 \pm 291,2 \mu^{2}$. 


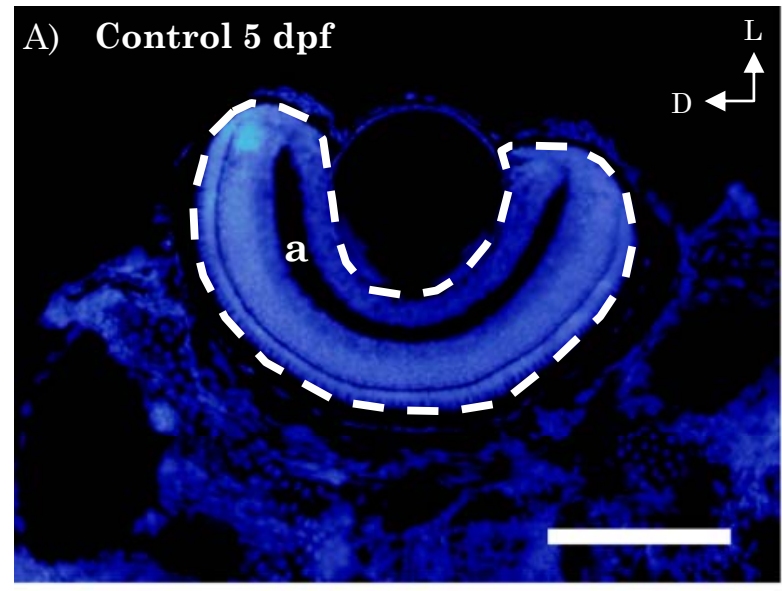

C)

Área retiniana a los $3 \mathrm{dpf}$

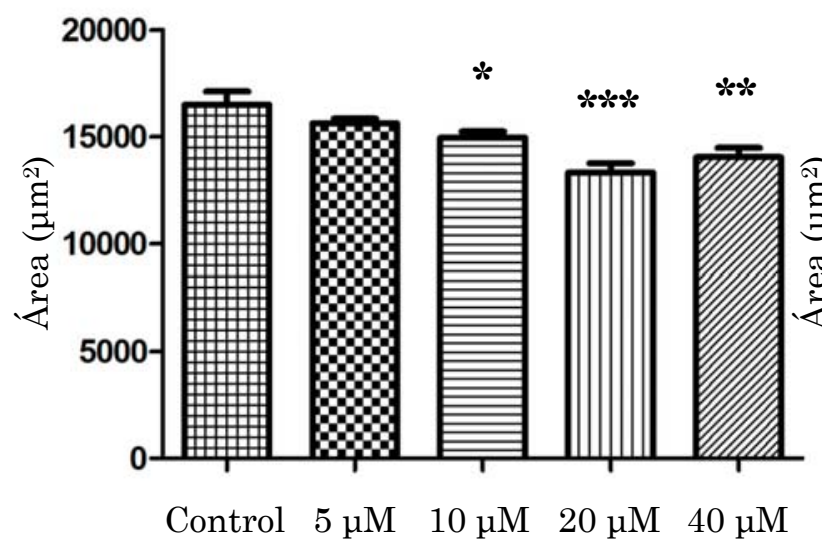

B)

Área retiniana a las 48 hpf

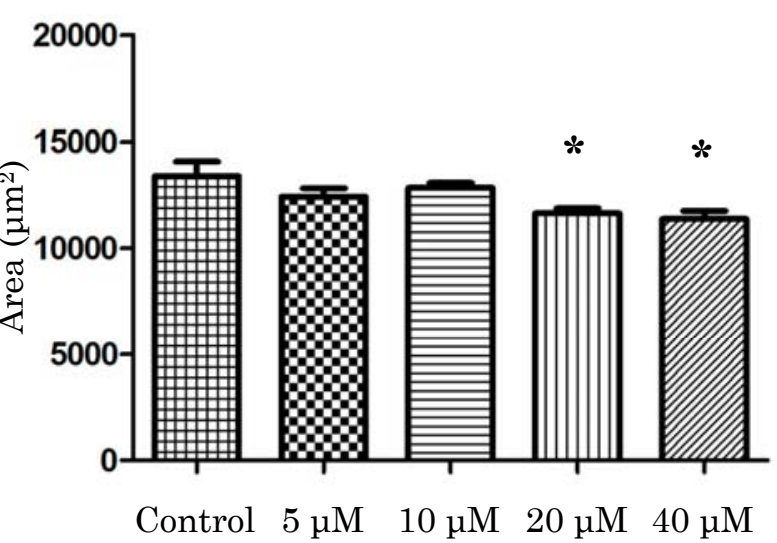

D)

Área retiniana a los $5 \mathrm{dpf}$

Fig. 31: A) Sección coronal de un ojo a los 5 dpf. B), C) y D) Histogramas del área de la retina en diferentes estadios y tratamientos. B) Área retiniana en embriones de $48 \mathrm{hpf}$. C) Área retiniana en larvas de 3 dpf. D) Área retiniana en larvas de 5 dpf. a: área de una sección coronal de una retina de 5 dpf. D: Dorsal. L: Lateral. ${ }^{*}=p<0,05 .{ }^{* *}=0,05>p>0,001 .{ }^{* * *}=p<0,001$. Barra de escala: $50 \mu \mathrm{m}$. 


\section{ANÁLISIS NEUROQUÍMICO}

\subsection{Alteraciones neuroquímicas tras el tratamiento con nicotina}

Hemos analizado el efecto de la nicotina sobre la proliferación, muerte y diferenciación celular en las áreas visuales. Utilizando marcadores específicos.

En todos los ensayos seleccionamos regiones anatómicamente comparables en los animales "in toto" de los distintos grupos experimentales, en vista lateral, dorsal y ventral. En el caso de las secciones, se utilizaron las mismas secciones sagitales de la parte central de la retina en las que posteriormente contaríamos el número de células positivas.

El estudio en un estadio embrionario (48 hpf) y en dos larvarios (3 y 5 dpf), permiten conocer la evolución de las áreas visuales primarias hasta la maduración del sistema visual. El análisis de la distribución de distintos marcadores moleculares permite la identificación de diferentes poblaciones y subpoblaciones celulares, cuantificar el número de células positivas en cada caso y evaluar la diferenciación global de la retina. Con este propósito analizamos la densidad relativa de células positivas para cada marcador (número de células por unidad de superficie).

\section{Proliferación celular}

- Animales control

Para analizar la proliferación celular utilizamos anticuerpos para el marcador mitótico Histona H3-fosforilada. A las 48 hpf, las células proliferativas de la retina de los ejemplares control están situadas en los márgenes laterales, aunque es frecuente ver células positivas en la región central (Fig. 32). Al cuantificar la densidad de las células en división en la retina obtuvimos como un valor medio superior a 3,223 $\pm 0,2041$ células $/ 1000 \mu^{2}$. 

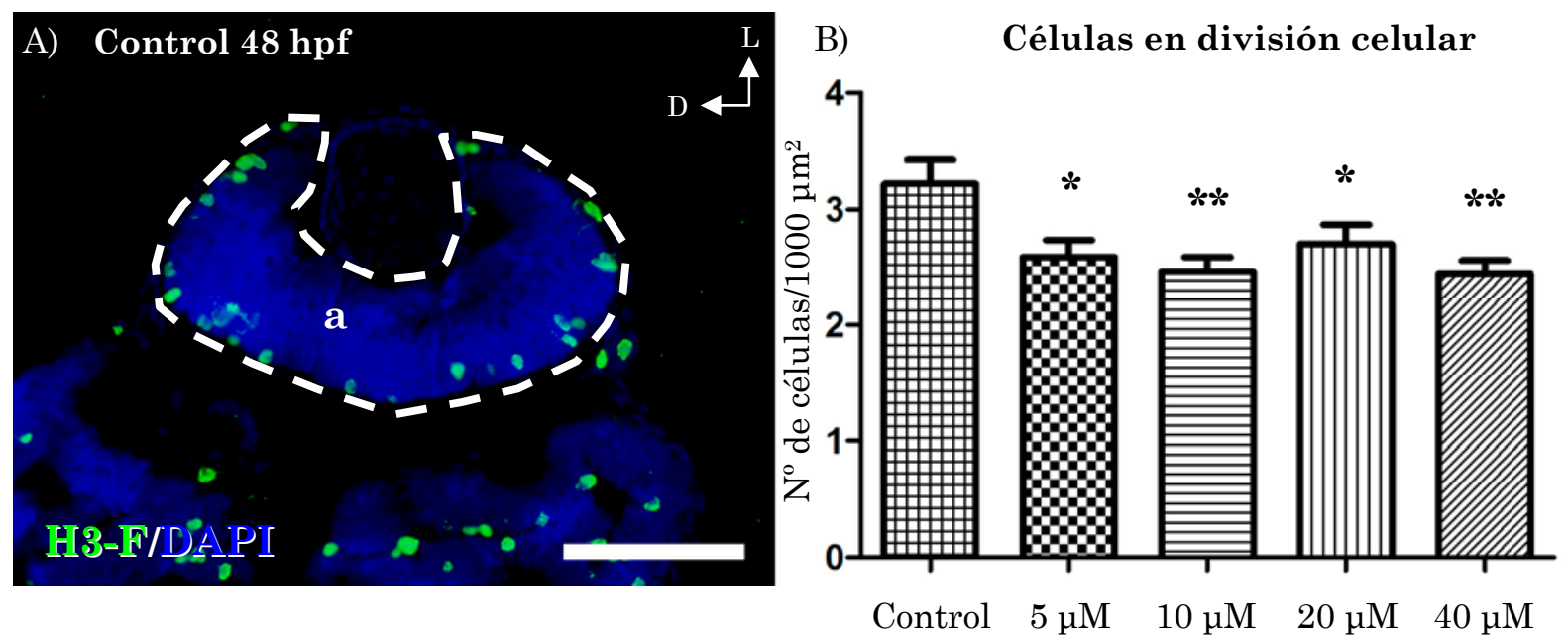

Fig. 32: A) Imagen de una sección coronal de un ojo a las 48 hpf. B) Histograma del recuento de células marcadas con Histona $\mathrm{H} 3$-fosforilada en retinas de embriones de $48 \mathrm{hpf}$. a: área de una sección coronal de una retina. D: Dorsal. L: lateral. ${ }^{*}=p<0,05 .{ }^{* *}=0,05>p>0,001 .{ }^{* * *}=p<0,001$. Barra de escala: $50 \mu \mathrm{m}$.

A los 3 dpf, el margen ciliar (MC) de los ejemplares control está organizado (Fig. 33). Aunque la mayoría de las células proliferativas están situadas en esta región lateral, también se observan algunas en la retina central, sobre todo en la CNI. Tras el recuento se parecía una reducción del número de células en división en este estadio, con un valor de 0,7303 $\pm 0,05450$ células $/ 1000 \mathrm{\mu m}^{2}$.
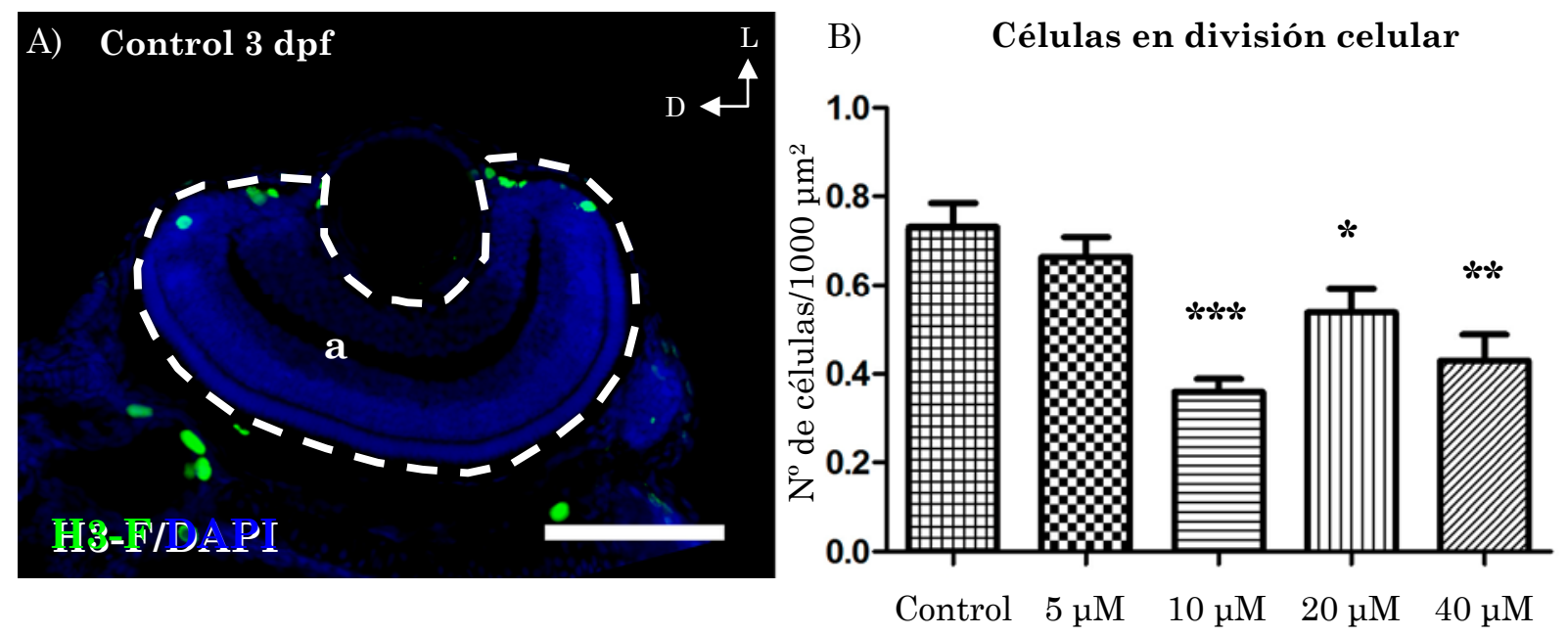

Fig. 33: A) Imagen de una sección coronal de un ojo a los 3 dpf. B) Histograma del recuento de células marcadas con Histona H3-fosforilada en retinas de embriones de 3 dpf. a: área de una sección coronal de una retina. D: Dorsal. L: lateral. ${ }^{*}=p<0,05 .{ }^{* *}=0,05>p>0,001 .{ }^{* * *}=p<0,001$. Barra de escala: $50 \mu \mathrm{m}$. 
A los 5 dpf, el MC está totalmente constituido en los ejemplares control (Fig. 34). La distribución de células proliferativas es similar a la de este grupo a los 3 dpf. La cuantificación de células en división mantiene los valores similares al estadio anterior, observamos un número medio de $0,3037 \pm 0,03118$ células $/ 1000 \mathrm{\mu m}^{2}$.
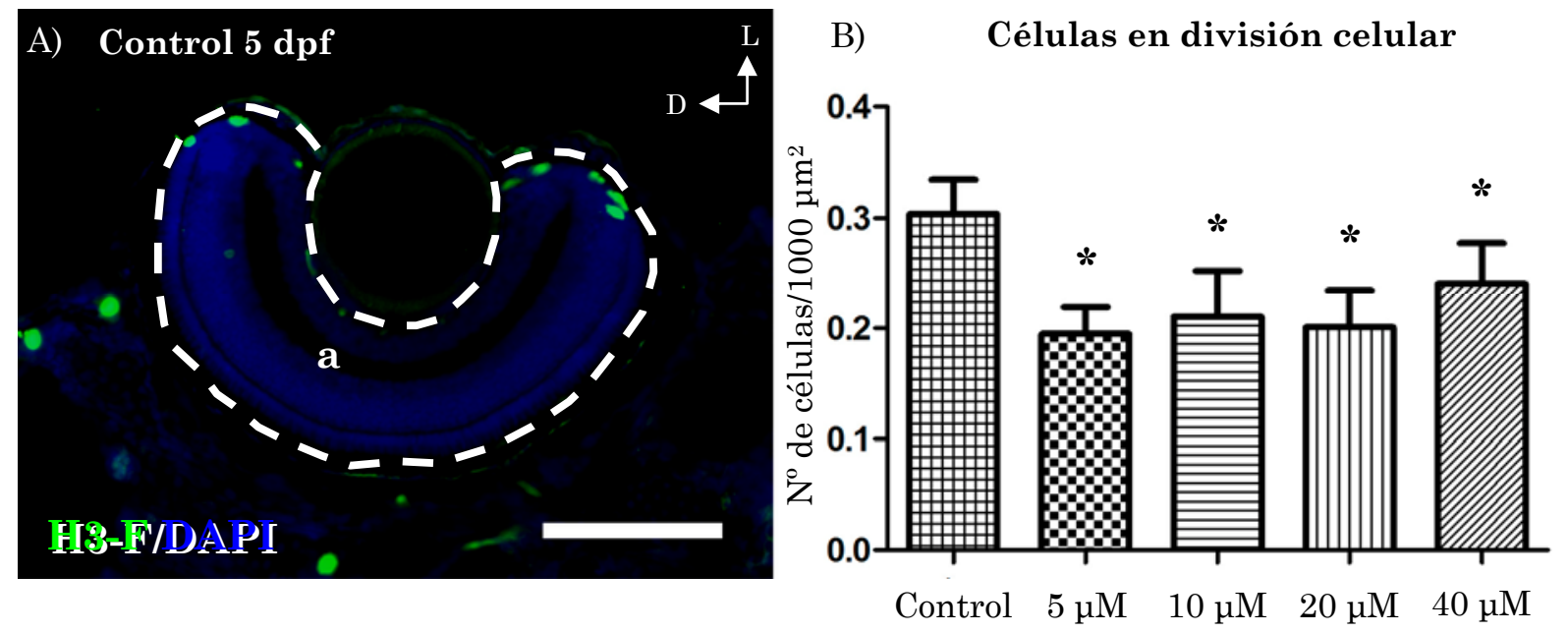

Fig. 34: A) Imagen de una sección coronal de un ojo a los 5 dpf. B) Histograma del recuento de células marcadas con Histona H3-fosforilada en retinas de embriones de $5 \mathrm{dpf}$. a: área de una sección coronal de una retina. D: Dorsal. L: lateral. ${ }^{*}=p<0,05 .{ }^{* *}=0,05>p>0,001 .{ }^{* * *}=p<0,001$. Barra de escala: $50 \mu \mathrm{m}$.

- Animales tratados con nicotina

La distribución de la histona H3-fosforilada en la retina no presenta diferencias aparentes en los animales y los controles. Por el contrario la cuantificación de la densidad de células proliferativas, demuestra una disminución significativa del número de células en división, aunque con una variabilidad dependiente del estadio y concentración analizada.

En el estadio de $48 \mathrm{hpf}$ en los animales tratados con nicotina observamos marcaje tanto en los márgenes laterales como en la zona central de la retina. Al cuantificar las células proliferativas se aprecia un descenso significativo (Fig. 32), menos significativo en la concentración de $5 \mu \mathrm{M}$, mientras que en las otras concentraciones utilizadas la reducción de células es mayor. 
En los ejemplares tratados, a los 3 dpf, hay células proliferativas en el MC $y$, en menor cantidad, en la zona central de la retina. El recuento evidencia que la reducción en el número de células proliferativas persiste (Fig. 33). El único valor estadísticamente no significativo se encuentra en la concentración de $5 \mu \mathrm{M}$. En las demás dosis utilizadas $(10,20$ y $40 \mu \mathrm{M})$ la disminución es significativa y el grado de ésta asociado a la concentración utilizada.

A los 5 dpf la distribución del marcaje de histona H3-fosforilada es parecida al del estadio anterior. Al cuantificar, persiste el mismo patrón de descenso de la actividad proliferativa, pero los valores son menos significativos (Fig. 34).

\section{$\underline{\text { Apoptosis }}$}

- Animales control

En la retina de todos los estadios analizados (Fig. 35) hay células apoptóticas en la retina sin un patrón concreto. A las 48 hpf él número medio de células apoptóticas es de 0,01750 $\pm 0,01159$ células/1000 $\mu^{2}$. Y aumenta en el estadio de post-eclosión a 0,1257 $\pm 0,03193$ células $/ 1000 \mu \mathrm{m}^{2}$. En el estadio larvario de 5 dpf, la cuantificación de células apoptóticas resulta en valores cercanos a $0,07447 \pm 0,01610$ células $/ 1000 \mathrm{\mu m}^{2}$.

- Animales tratados con nicotina

La presencia de apoptosis en la retina indica que es escasa, en los animales tratados con nicotina. En células apoptóticas de la retina los ejemplares tratados con nicotina tampoco tienen un patrón claro. En ninguno de los estadios analizados, ni en las concentraciones analizadas, hemos encontrado diferencias estadísticamente significativas (Fig. 35). Aunque apenas se aprecian diferencias en la apoptosis en el estadio de $48 \mathrm{hpf}$ (Fig. 35), con respecto a los controles, a los 3 dpf encontramos una reducción no significativa en los grupos con las concentraciones más altas de nicotina (Fig. 35). Por el contrario, en el 
estadio de 5 dpf, hay una aumento no significativo de apoptosis en la retina en las concentraciones de 20 y $40 \mu \mathrm{M}$ (Fig. 35).
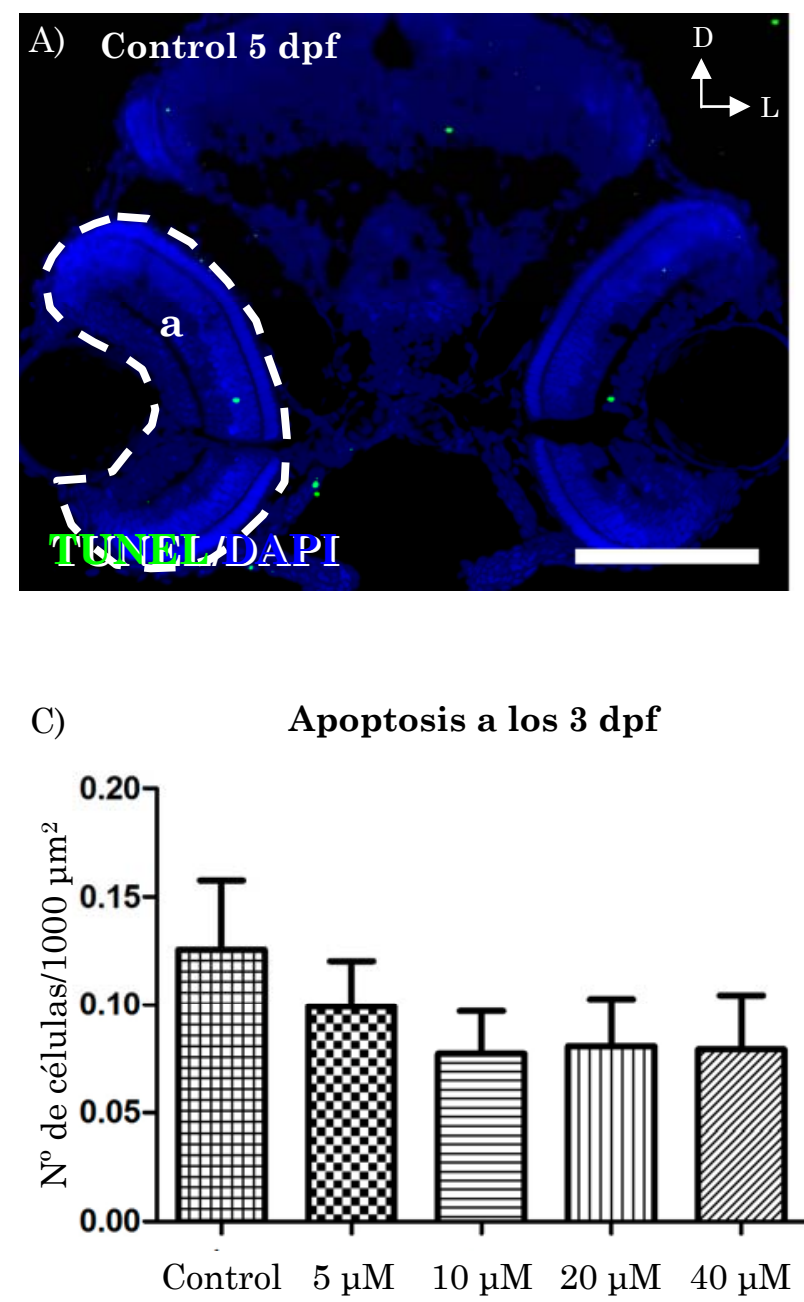

B) Apoptosis a las $48 \mathrm{hpf}$

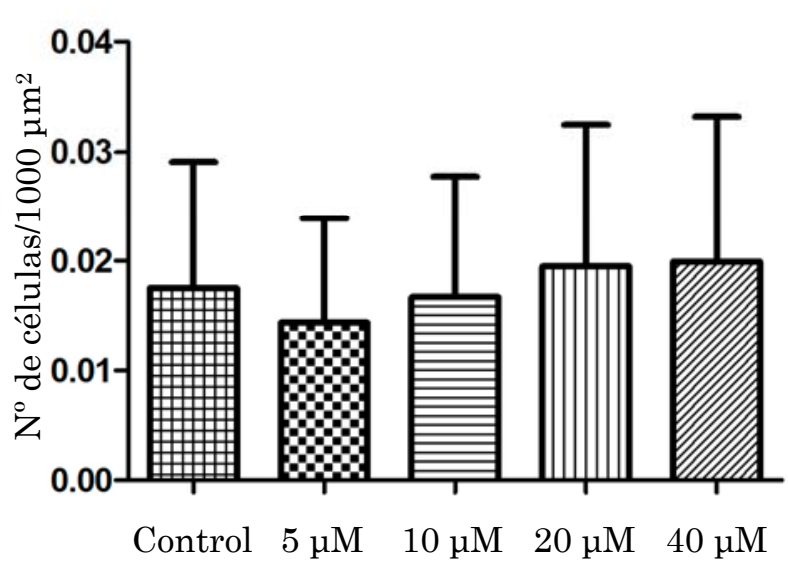

Apoptosis a los 5 dpf

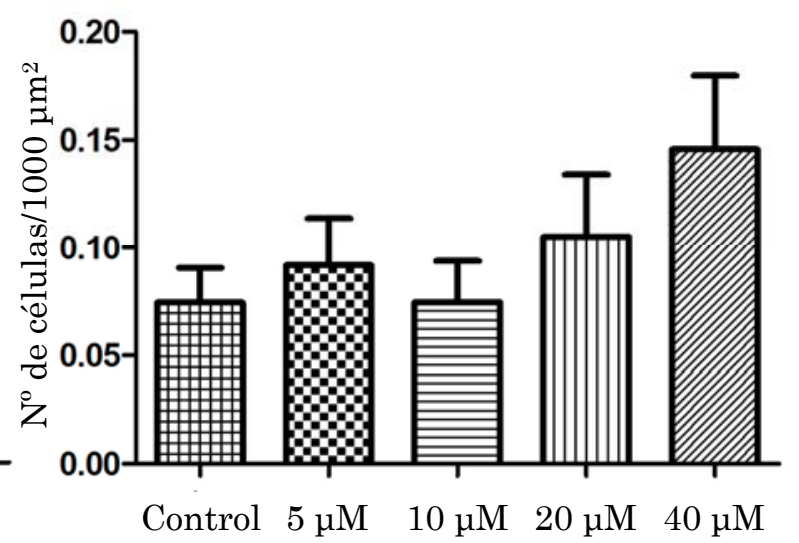

Fig. 35: A) Imagen de una sección coronal de una larva de 5 dpf. B), C) y D) Histogramas del recuento de células en apoptosis en diferentes estadios de estudios y tratamientos. B) en embriones de 48 hpf. C) en larvas de 3 dpf. D) en larvas de 5 dpf. D: Dorsal. L: lateral. Barra de escala: $100 \mu \mathrm{m}$.

\section{Calretinina}

- Animales control

El estadio de $48 \mathrm{hpf}$ es todavía muy inmaduro con respecto a la estratificación de estructuras, como la retina y el TO. Debido a esta falta de maduración algunas regiones aparecen a las 48 hpf como zonas prospectivas de estructuras maduras. 
En el estadio de 48 hpf (Fig. 36) no hemos encontrado células positivas para CR ni en la retina ni en el TO. Dentro del diencéfalo, a las 48 hpf, hay marcaje positivo para $\mathrm{CR}$ en algunas células de morfología esférica localizadas en el pretectum $(\mathrm{Pr})$ y en el tálamo $(\mathrm{T})$.

En el periodo larvario de 3 dpf (Fig. 37) hay más poblaciones de células positivas para CR repartidas por el encéfalo. A esta edad detectamos marcaje en la retina, tanto en somas como en prolongaciones de células de la capa de las células ganglionares (CCG) y de la capa nuclear interna (CNI). Tras la eclosión, aumenta el número de células inmunorreactivas a $\mathrm{CR}$ en la CCG, cuyos axones aparecen también marcados, disponiéndose en fascículos constituyendo los nervios, el quiasma y los tractos ópticos. El patrón de distribución de CR en el pretectum y el tálamo es similar al del estadio analizado anterior. Dentro del prosencéfalo secundario, aparece marcaje positivo para $\mathrm{CR}$ en el área preóptica (Ap). En el mesencéfalo encontramos numerosas células esféricas positivas para $\mathrm{CR}$, tanto en el techo óptico como en el tegmentum (Tg), pero en el mesencéfalo más caudal hay menos células positivas. La zona blanca superficial (ZBS) aumenta su espesor y en la zona gris periventricular (ZGPV), observamos solamente fibras teñidas para CR.

A los 5dpf (Fig. 38) el marcaje para CR está en las mismas zonas que en el estadio larvario anterior, pero más intenso y con distribución más amplia. En la retina, se mantiene el marcaje en los mismos tipos celulares de la CCG y de la CNI, descritos en los estadios anteriores. El patrón de distribución de CR en el área preóptica, el pretectum y el tálamo es similar al observado a las $48 \mathrm{hpf}$. El patrón de laminación del TO de ejemplares larvarios de 5 dpf es similar al observado a los $3 \mathrm{dpf}$, pero las prolongaciones de las células de la ZGPV son positivas a $\mathrm{CR}$. Por lo que respecta al tegmentum hay células positivas a $\mathrm{CR}$, al igual que a los $3 \mathrm{dpf}$. 
- Animales tratados con nicotina

La distribución de elementos positivos a CR en los animales tratados con nicotina se reduce al incrementar, la concentración, tanto a las 48 hpf como a los 3 dpf, y que se irá recuperando con respecto a los controles hasta el estadio de 5 dpf, cuando las diferencias son mínimas.

En el estadio de 48 hpf (Fig. 36) los patrones de distribución de inmunorreactividad para esta proteína ligante de calcio son parecidos a los encontrados en los animales control, con marcaje en las áreas visuales, como el pretectum y tálamo. Existe una disminución en la extensión del marcaje, diferente segun la concentración de nicotina suministrada. En las concentraciones más baja, de 5 y $10 \mu \mathrm{M}$, el marcaje para CR presenta una disminución en las zonas anteriormente citadas, menos acusado que en las concentraciones de 20 y $40 \mu \mathrm{M}$ (Fig. 36), que presentan una disminución de la extensión de marcaje más acusada.

En el estadio de 3 dpf (Fig. 37), el marcaje para CR se encuentra en toda la extensión de la retina y en los mismos tipos celulares que en el grupo control. Tras el tratamiento de la nicotina, el patrón de distribución de CR afecta a las mismas áreas visuales primarias, pero con un menor número de células marcadas con menor intensidad, en comparación con los controles. La distribución de este marcador es más reducida en estructuras como el TO y las proyecciones retinotectales. Al igual que ocurre en el estadio anterior, disminuye la intensidad y la extensión del marcaje según a la concentración de nicotina. Así, la disminución es más drástica en las mayores concentraciones de nicotina, siendo la concentración de $40 \mu \mathrm{M}$ (Fig. 37) la que presenta mayor reducción del marcador.

Al final del periodo larvario (5dpf) (Fig. 38), encontramos inmunorreactividad para $\mathrm{CR}$ en animales tratados con nicotina en la retina, en las mismas capas del grupo control, y en las mismas áreas visuales primarias. 
En este estadio, con las estructuras ya maduradas, la distribución de CR se recupera, con respecto a los controles, en extensión e intensidad. A las concentraciones más bajas (5 y $10 \mu \mathrm{M}$ ) la distribución de este marcador es muy parecida a las encontradas en el grupo control. Mientras que en los animales tratados con las concentraciones más altas $(20$ y $40 \quad \mu \mathrm{M})$, persiste una disminución de marcaje para CR (Fig. 38). 


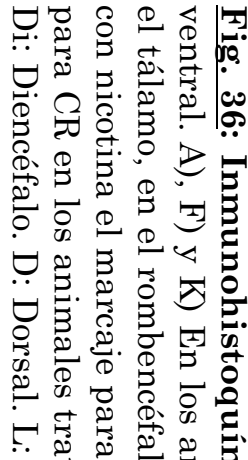

ㄴ.

बे

कृ

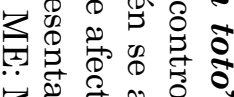

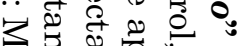

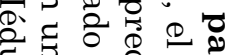

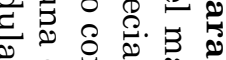

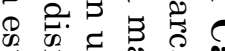

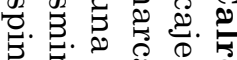

D :

?

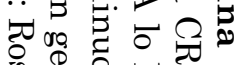

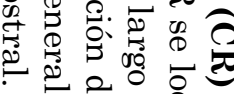

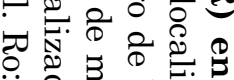

पृ

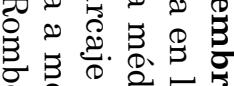

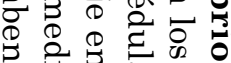

車事造

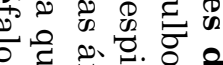

वे :

ખै

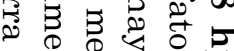

०

(1)

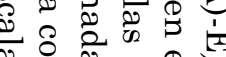

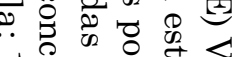

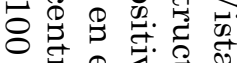

है.

s: .

के

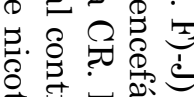

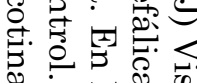

四四总语

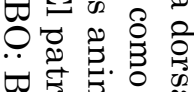

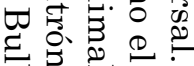

वृ क ष

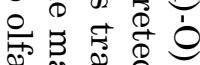

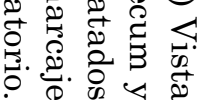

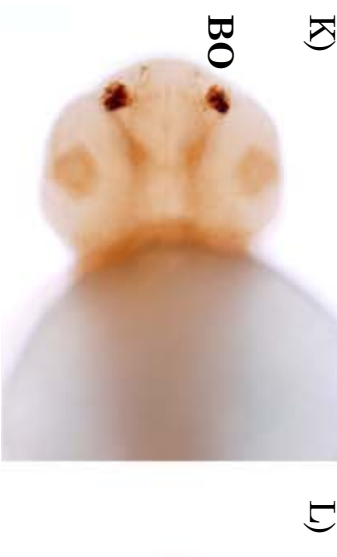

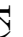

$\stackrel{\square}{0} \mathbb{2}$

3 i

$\exists$.

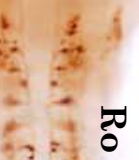

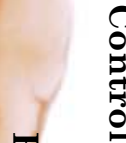

0

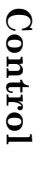

当

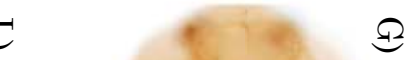

$\Omega$

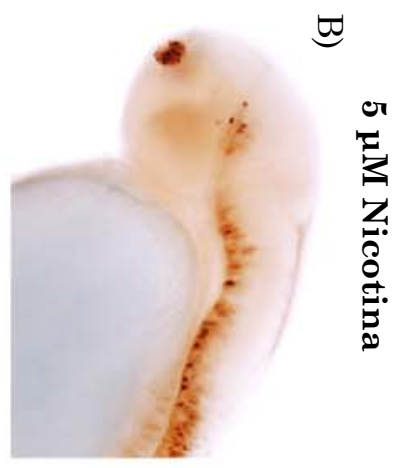

3

$\Xi$

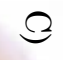

0
$\vdots$
$z$
$\vdots$
0
0
0
0
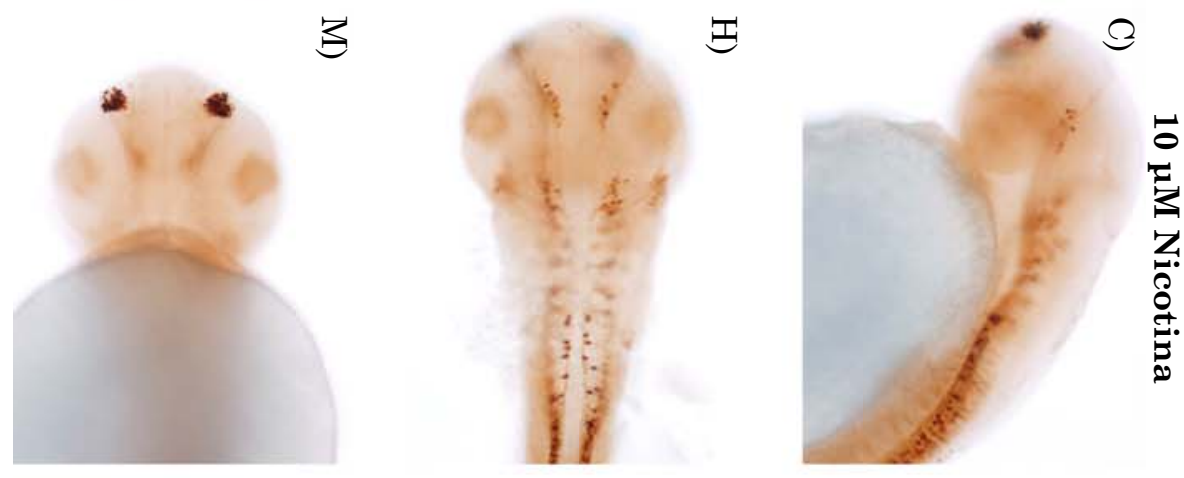

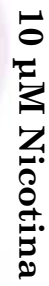

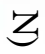

$\ominus$

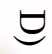
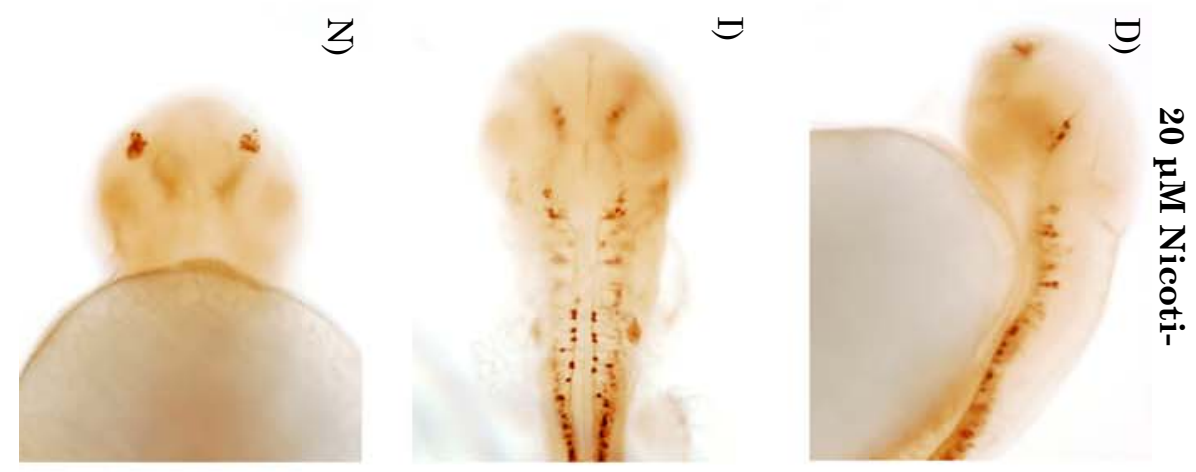

0

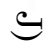

핌

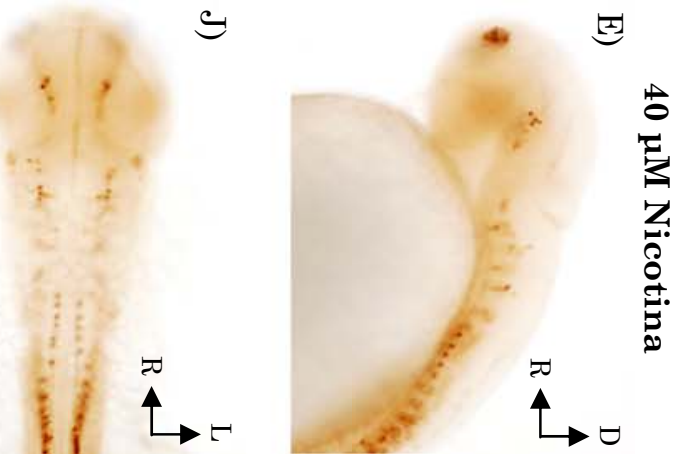




\section{Resultados}
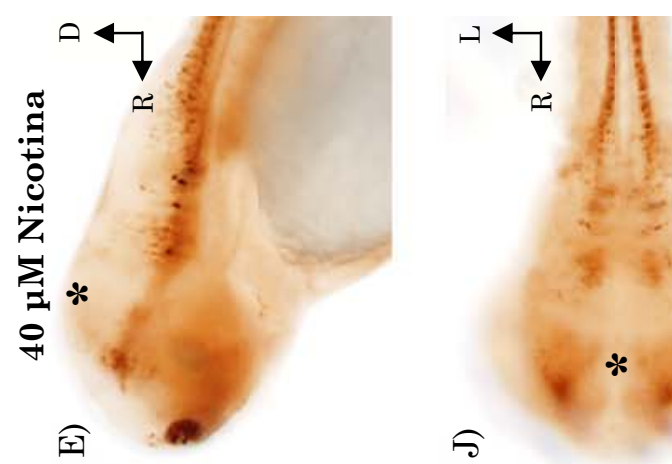

ค

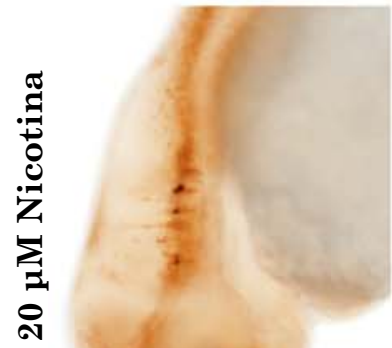

$\widehat{\oplus}$
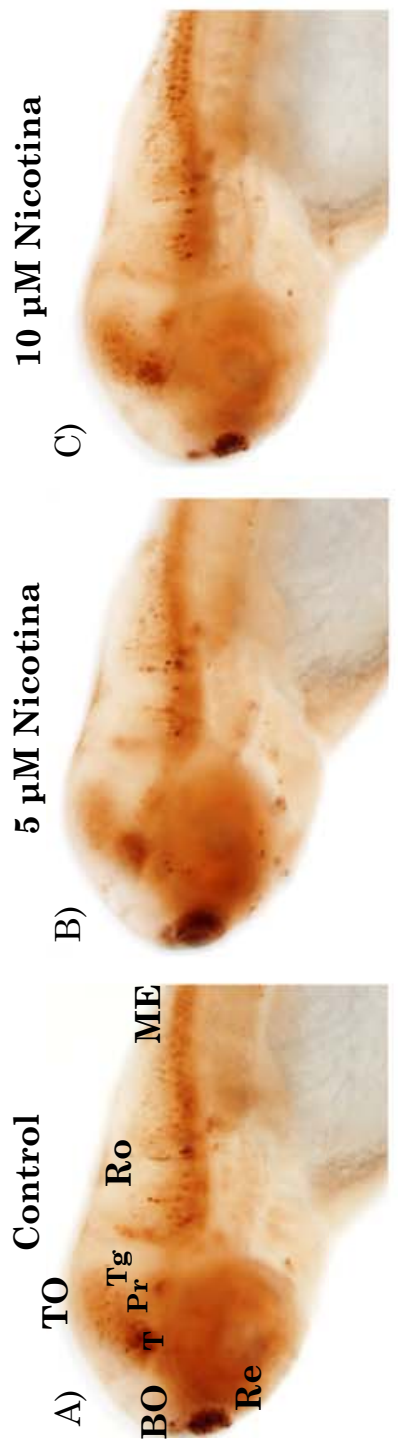

$\widehat{I}$

ำ

$\stackrel{0}{1}$

厌
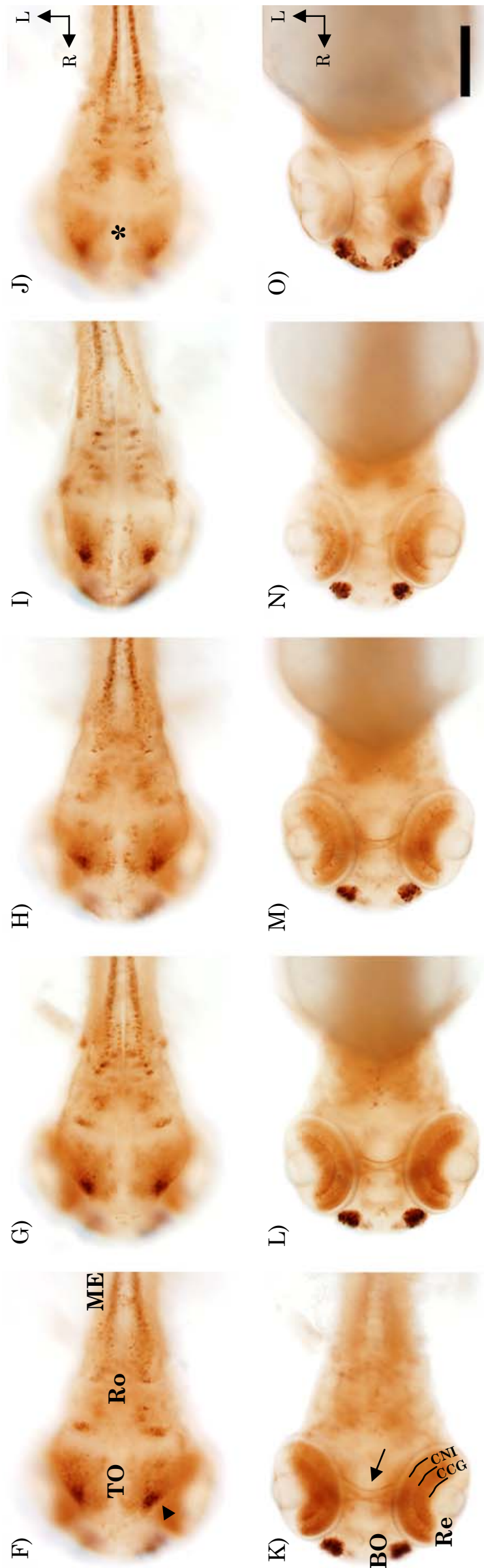

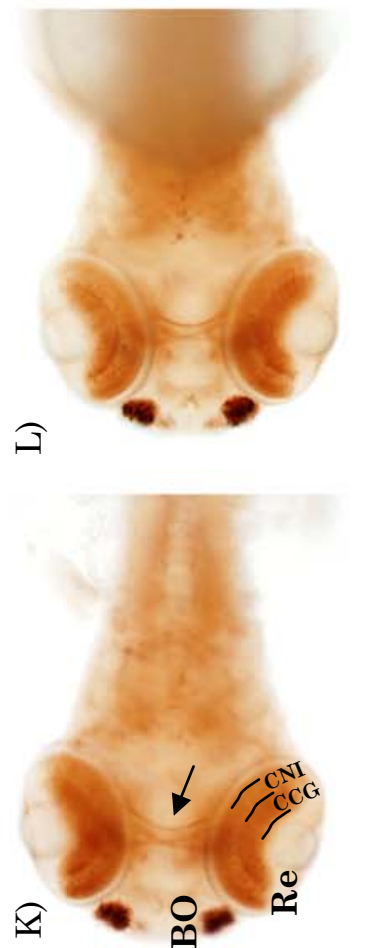

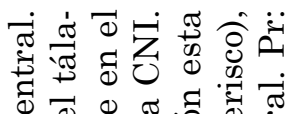

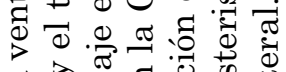
需

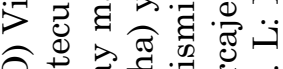

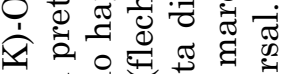
तं क्ष̃

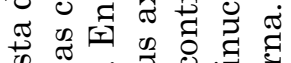

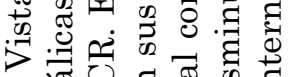
ค䨌

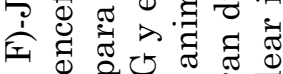
बं.

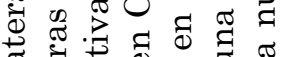

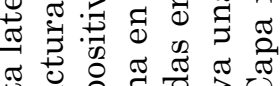

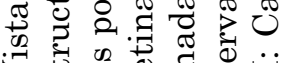

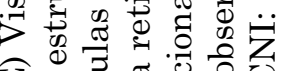
외 정

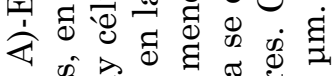

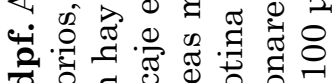
ช

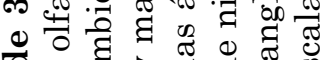
ช

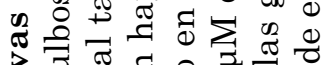

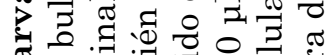
의 융 ฮี ชิ ๘ .

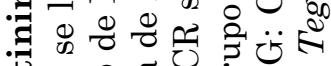

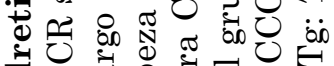
ส

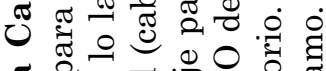
๙

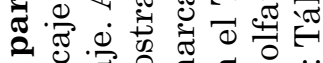
ڤ

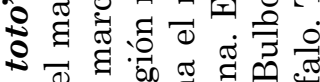

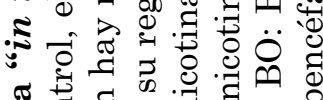

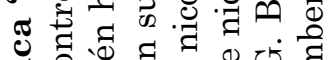
¿

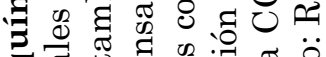

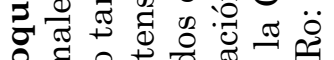

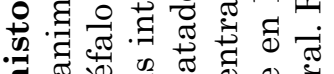

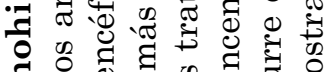
马 व

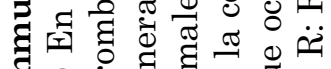

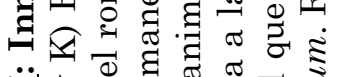

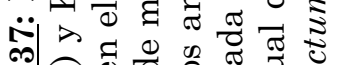
की

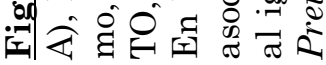




\section{Resultados}

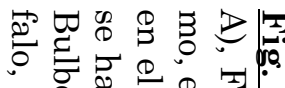

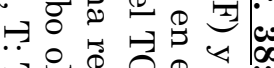

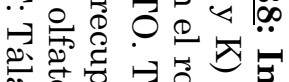

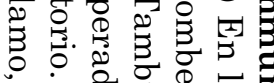

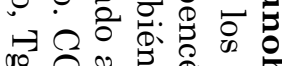
पद्र.

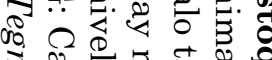
इ

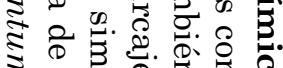

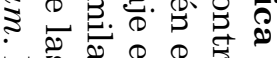

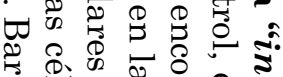

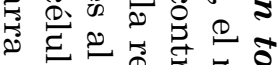
के (1) 2.

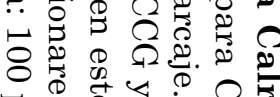
प्रते बै

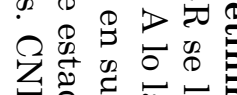

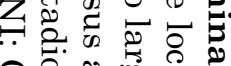

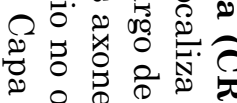
요요 0

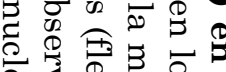

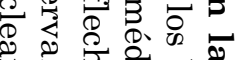

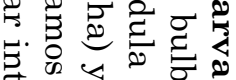
क क 4 \& 80

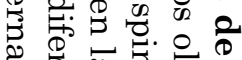
\%

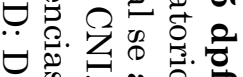

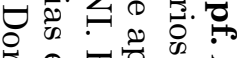
औ马

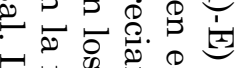

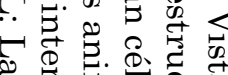
क के कृ की Tृ

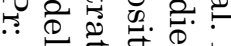
ج大 के

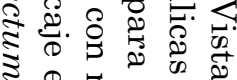

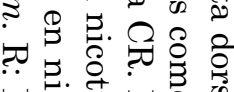

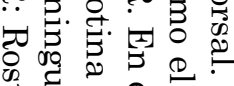
可

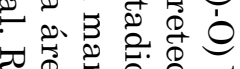
प्र 可

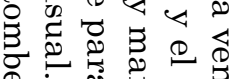

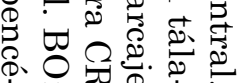
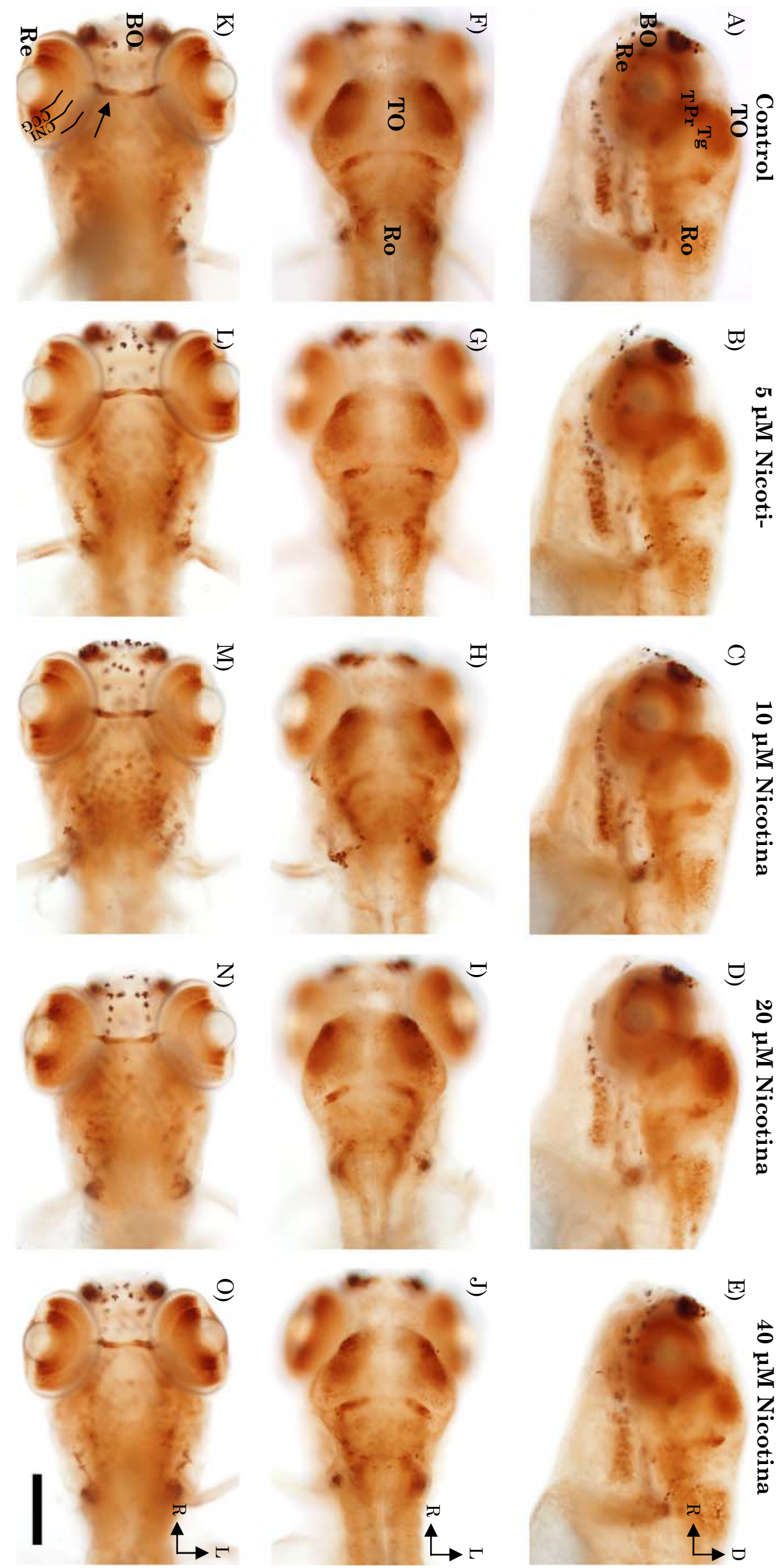


\section{$\underline{\mathrm{Zn}-8}$}

- Animales control

En el estadio de 48 hpf (Fig. 39) se encuentra marcaje para Zn-8 en la retina central y en el nervio óptico. Se encuentra Neurolina tanto en los somas como en los axones de las células ganglionares que constituyen el nervio óptico. El inmunoprecipitado se distribuye por toda la capa de las células ganglionares, que a esta edad ya están morfológicamente diferenciadas. Igualmente obtenemos marcaje en todos los axones del nervio óptico. Se evidencia cómo los axones decusan dando lugar al quiasma óptico, se adentran en el encéfalo y se dirigen hacia el techo óptico rostral.

En las larvas de 3 dpf (Fig. 40) el patrón de marcaje para Zn-8 es similar al del estadio anterior, tanto en la retina como en el nervio óptico. No obstante, apreciamos que, acompañando al incremento de tamaño que experimentan las retinas desde las $48 \mathrm{hpf}$, se ha producido un aumento del espesor de la capa de las células ganglionares. Así mismo, los axones procedentes de esta capa inervan densamente la totalidad del techo óptico. Por lo que respecta al mesencéfalo, hemos observado Zn-8 en células y en neuropilo localizado en la región más caudal del mesencéfalo. Aparece marcaje para Zn-8 tanto en células en el pretectum y en el tálamo, como en el hipotálamo (Fig. 40).

Sin embargo, al final del periodo larvario (5 dpf) (Fig. 41) el marcaje es menos intenso en la CCG y en el nervio óptico, mientras que se hace más amplio en las demás estructuras visuales, en la que apenas se aprecia antes de la eclosción. Además, se conserva el marcaje en el pretectum, tálamo e hipotálamo. En el TO al igual que el estadio anterior, también se aprecia marcaje. Por otra parte, al final del periodo larvario encontramos células marcadas en el tegmentum y en la totalidad del TO. 
- Animales tratados

Los elementos inmunorreactivos a $\mathrm{Zn}-8$ en los animales tratados con nicotina presenta a las 48 hpf una diminución de su patrón de distribución asociado inversamente a la concentración administrada. Tras la eclosión recuperarán, manteniéndose hasta el estadio de 5 dpf.

En el estado embrionario de 48 hpf (Fig. 39), el marcaje para Zn-8 se distribuye por las mismas estructuras visuales que en el grupo control. Se aprecia marcaje en la retina, en concreto en las CCG y sus prolongaciones que forman el nervio óptico. En este área, existe una diminución en el número de células inmunorreactivas a este marcador y una reducción de la extensión del marcaje en sus axones. Esta disminución en la distribución de este marcador esta asociada inversamente a las concentraciones de nicotina usada. Así, los animales tratados con la concentración más baja $(5 \mu \mathrm{M})$ presentan mayor reducción de marcaje, con una disminución de células ganglionares marcadas en la retina $y$, en consecuencia, disminuyen los axones inmunomarcados que forman el nervio óptico. A medida que la concentración de nicotina aumenta, los efectos son menos severos. Con la concentración de nicotina de $40 \mu \mathrm{M}$, el marcaje se asemeja al del grupo control.

En el estadio de 3 dpf (Fig. 40), el marcaje para Zn-8 en la retina se localiza en la CCG, y en sus axones, y en las mismas áreas visuales que en el grupo control. En cuanto el marcaje en las proyecciones retino-tectales, se aprecian una disminución en los animales tratados con nicotina. La disminución de estas proyecciones hacia el TO y es mucho mayor, en las concentraciones más bajas, 5 y $10 \mu \mathrm{M}$.

En el estadio de 5 dpf (Fig. 41), se aprecia para Zn-8 en la retina, en la misma capa del grupo control y en las mismas áreas visuales primarias. La vía visual, tanto las neuronas como sus dianas, son más maduras que en estadios previos, por lo que se establecen las conexiones, presentando los animales 
tratados con cualquier concentración de nicotina inmunorreactividad para Zn-8 un aspecto parecido al de los animales control. 


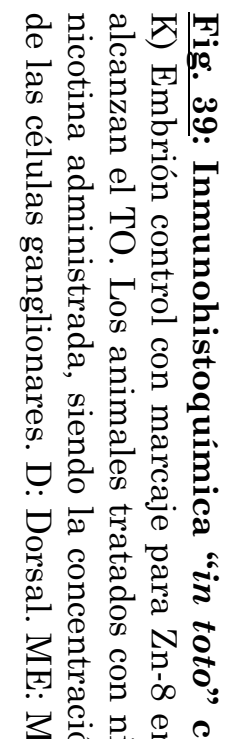

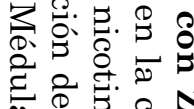
D o : ․

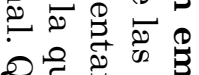
$80 \%$ 융

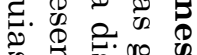
政 웅

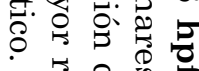
पب 겅유.

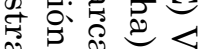
20. कृ 赵. 숭. ․ㅠㅇ.

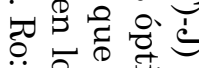

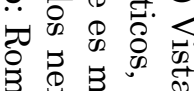
象害. 过.

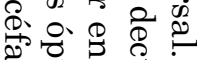
당. 해 낭 in

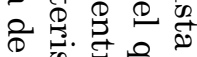
(1) है क्ष 웅

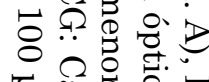

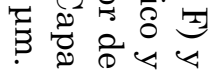

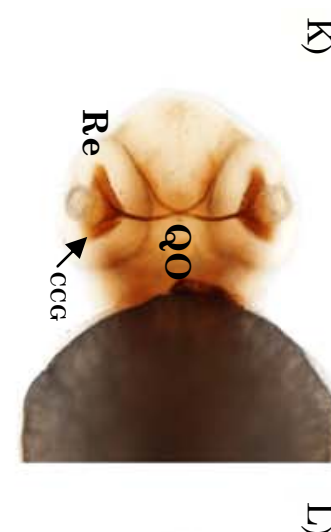

5

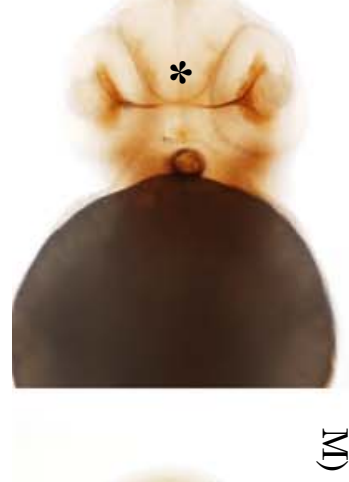

当
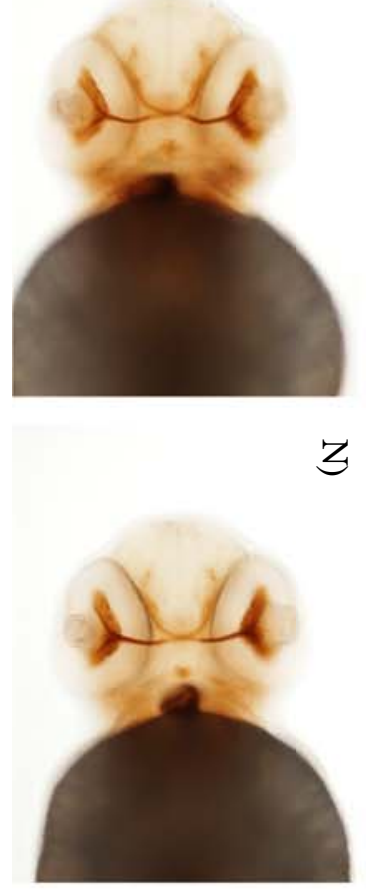

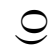

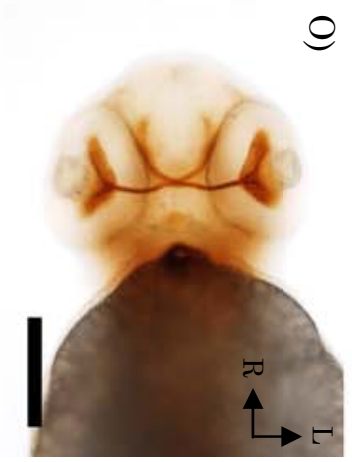

정

巴

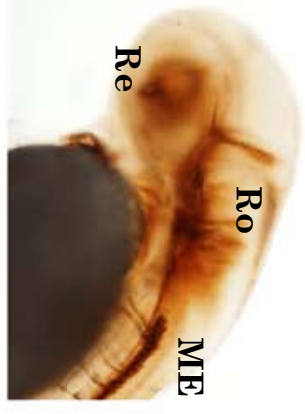

2
0
5
0
0
0

Q

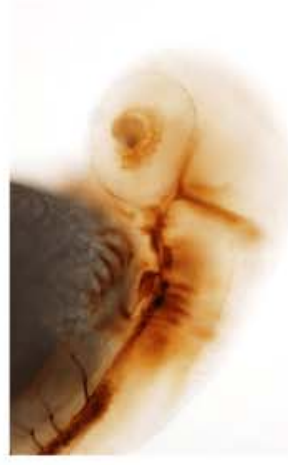

$\varpi$

ن

$\Xi$

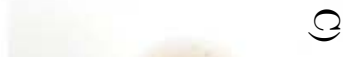

훌.

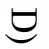

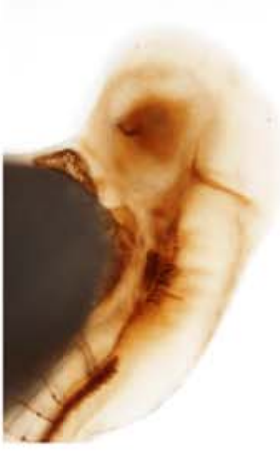

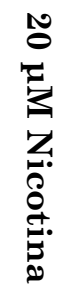

$s$

퍼

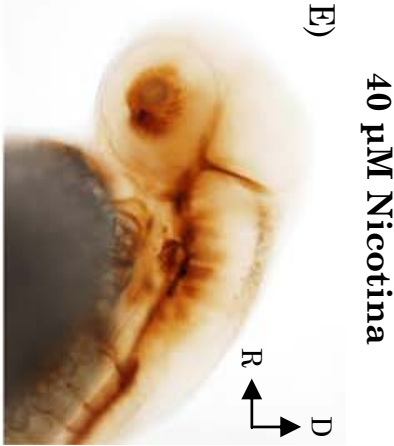




\section{Resultados}
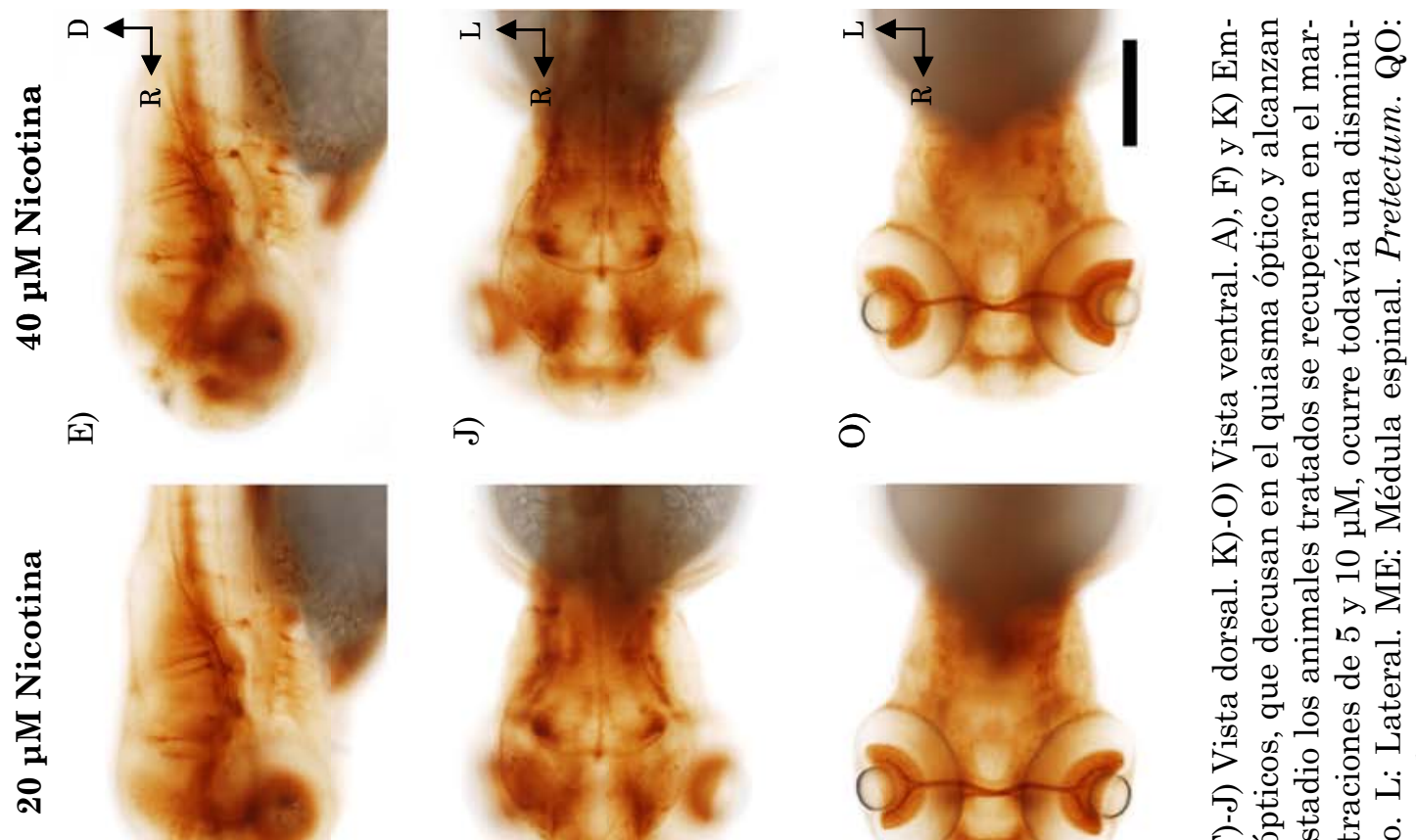

$\widehat{ด}$

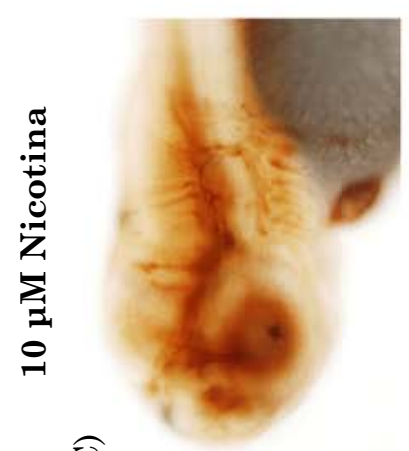

0

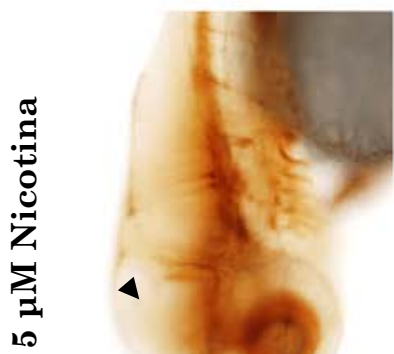

$\widehat{\oplus}$

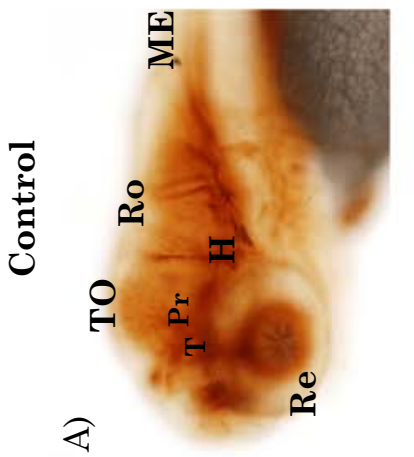

๑

$\widehat{o}$

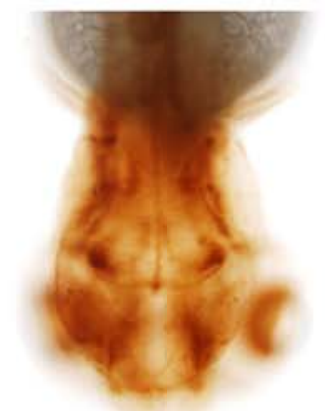

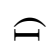

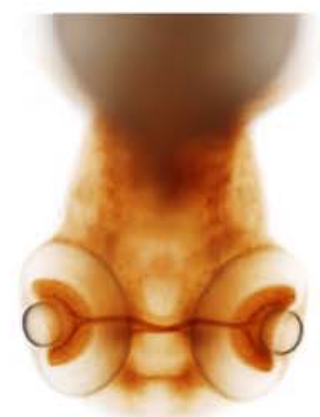

乙

玵
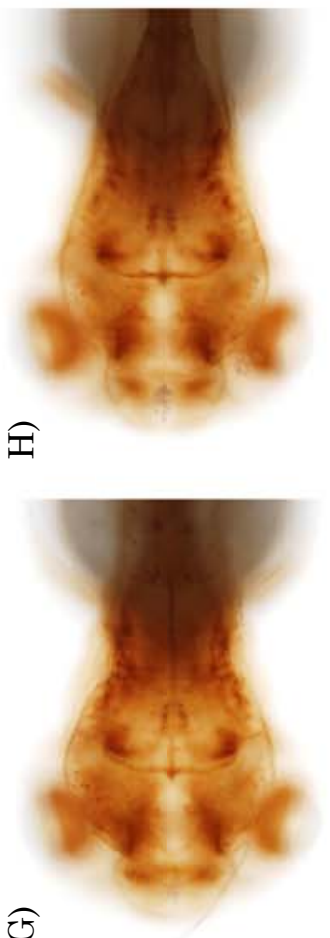

ส

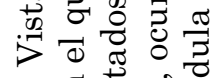

○ิ व

4

ॠं

ซ ๘

ॠ

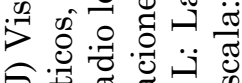

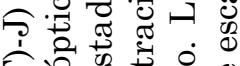

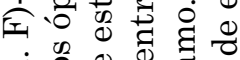

क्ष.

屯

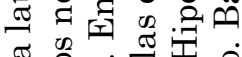

要

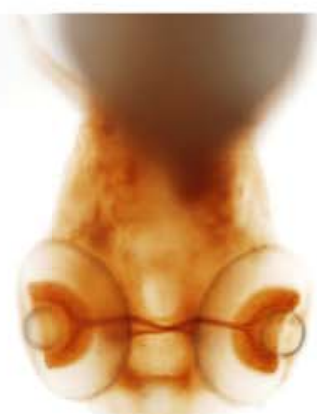

$\widehat{\Sigma}$

ชิ สิ

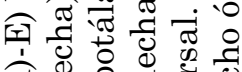

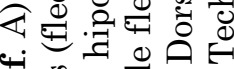

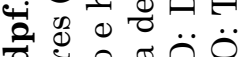

๓ ఫี \&

ช

w

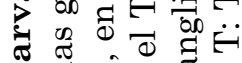

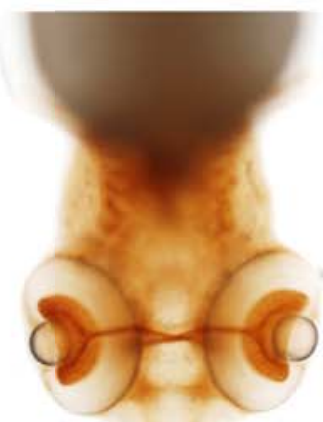

๑

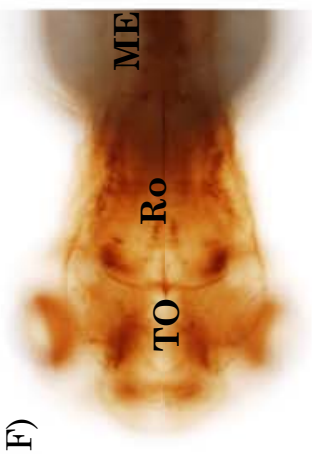

व $\infty$ of 0 .

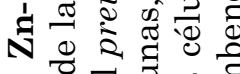
ฮี 웡 종

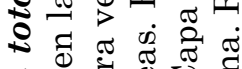
క $\infty$ \&

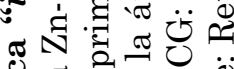
.0

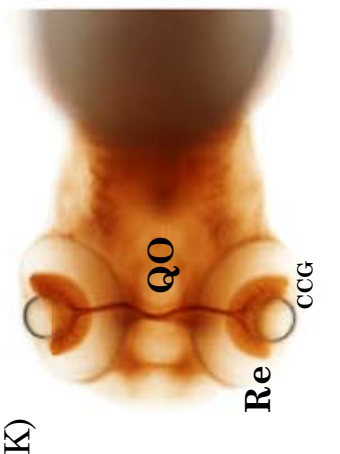
ส ప.

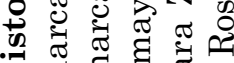

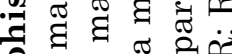
वृ

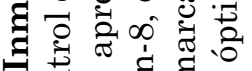

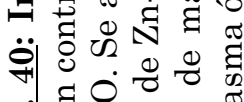

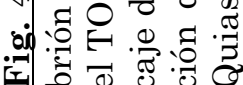


Resultados

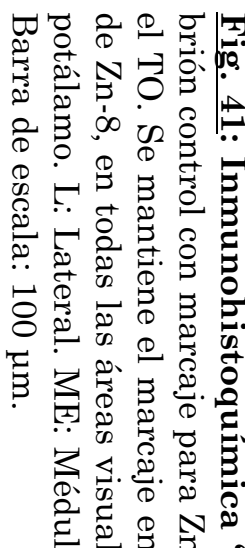

$\Delta$

퍽
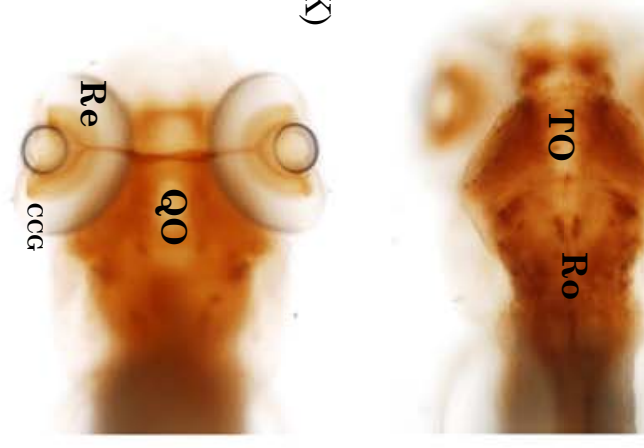

$\mathbb{E}$

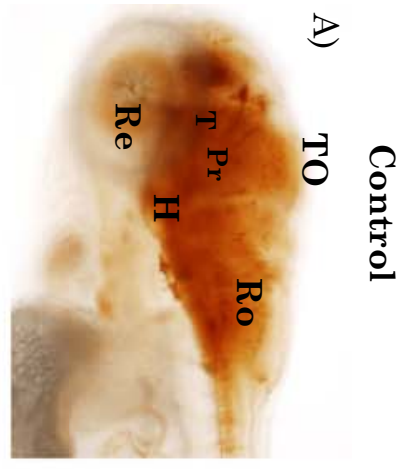

5
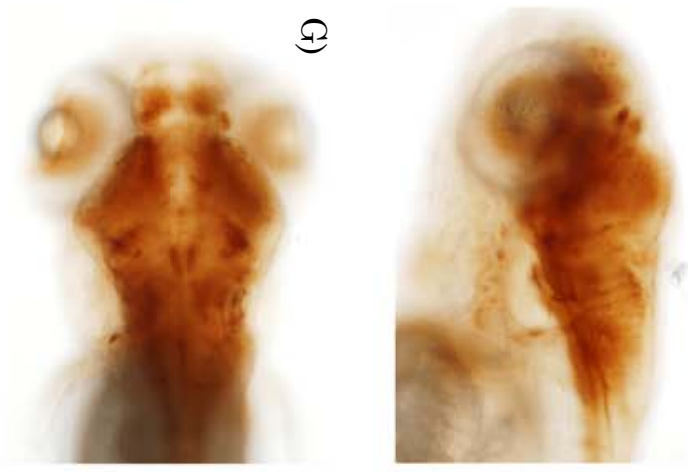

ש्]

20.

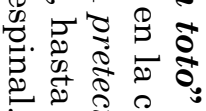
ช

용

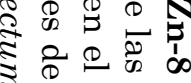

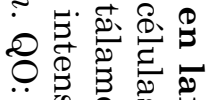

赑. $\begin{array}{ll}0 \\ 0 \\ 0\end{array}$

. है की

象 웅

ט

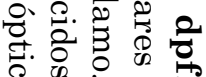

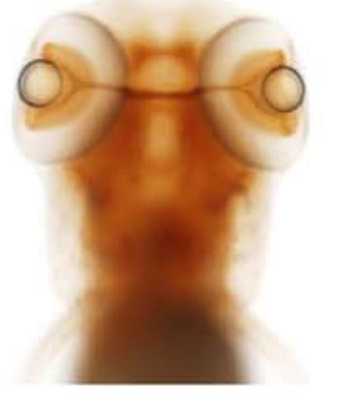

尚
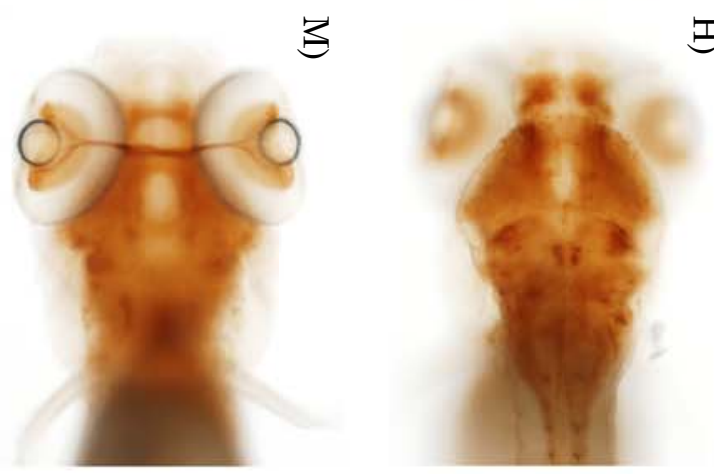

$\Xi$

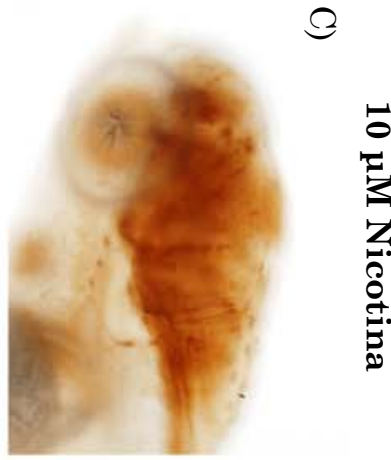

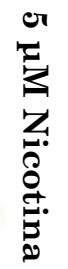

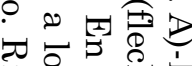

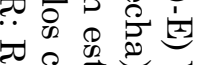

象 क

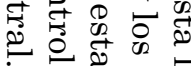

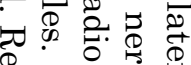

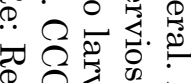

象.

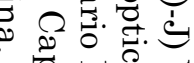

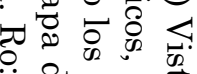

דृ
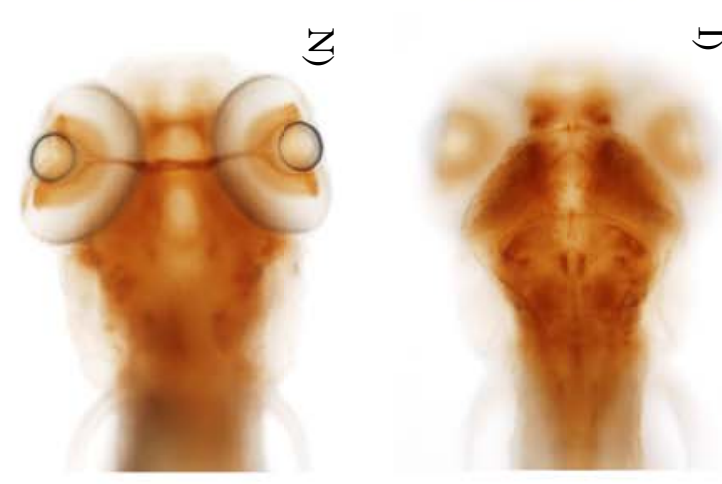

称
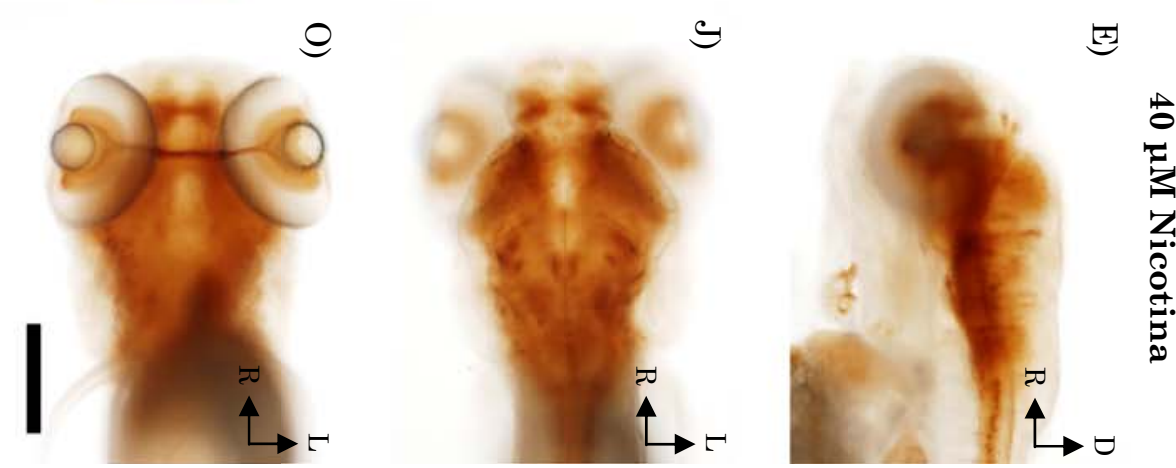


\section{Tirosina-hidroxilasa}

- Animales control

En el estadio de 48 hpf (Fig. 42) no encontramos marcaje para TH en la retina. En el prosencéfalo secundario, se aprecian dos grupos de células positivas a TH en el hipotálamo. Uno de ellos está constituido por células con somas grandes, en posición lateral respecto a la línea media. El otro grupo lo integran células con somas más pequeños, dispuestos más próximos a la línea media. En el área preóptica se marcan algunos somas. En el diencéfalo de embriones de 48 hpf, también hay marcaje para TH en neuronas en el tálamo. A medida que avanza el desarrollo se produce un aumento de la intensidad del marcaje y del número de células talámicas TH positivas. No hemos detectado inmunorreactividad para TH en el TO.

Tras la eclosión, a los 3 dpf (Fig. 43), se encuentran por primera vez células positivas a TH en la retina. Se trata de somas de morfología esférica, pequeño tamaño, situados en la CNI. El patrón de distribución de TH en el hipotálamo es similar al del estadio previo (Fig. 43). Por lo que respecta al área preóptica, se mantiene el marcaje para TH descrito a las 48 hpf. En el pretectum, el marcaje para TH se encuentra por primera vez en larvas de 3 dpf. En este estadio no se detecta inmunorreactividad para TH en el TO.

En animales juveniles de 5 dpf (Fig. 44), el patrón de distribución de TH en la retina sufre modificaciones con respecto al observado en el estadio anterior. Así, además de somas inmunorreactivos para TH en la CNI, observamos fibras marcadas tanto en la CPE como en la CPI. En la CNI, se encuentran de somas positivos a TH es mayor que en edades anteriores y éstas, son de mayor tamaño. Además, estas células emiten prolongaciones dirigidas hacía la CPI donde se ramifican a diferentes niveles. El hipotálamo y el área preóptica mantienen un marcaje similar a de los 3 dpf. Al final del periodo larvario también, el patrón de distribución de TH en el pretectum, es similar al descrito en el estadio de 3 dpf. A 
los $5 \mathrm{dpf}$ aparece inmunorreactividad para TH en fibras del tracto óptico. En este estadio se encuentran fibras inmunorreactivas para TH en las regiones rostrales del TO pero no en las regiones caudales.

- Animales tratados con nicotina

El patrón distribución de esta enzima de la ruta catecolaminérgica en animales tratados con nicotina, es menos extenso en las áreas visuales marcadas, disminuyen además las proyecciones hacia otros centros dianas. Estos cambios son drásticos en las dosis más altas y en los tratamientos más prolongados.

En el estadio embrionario de 48 hpf (Fig. 42), la distribución de elementos positivos a TH, reduce ligeramente la extensión del marcaje con respecto a los controles. Se detecta marcaje en el área preóptica, tálamo e hipotálamo, pero en estás zonas se reduce el marcaje, además se aprecia una disminución de las proyecciones hipotalámicas hacia otras zonas. Esta diminución parece independiente la concentración de nicotina.

A la edad de 3 dpf (Fig. 43), los elementos positivos a TH en la retina se localizan en toda la extensión de la CNI. Además, se marcan las mismas áreas visuales que en el grupo control, tales como el área preóptica, pretectum, tálamo e hipotálamo. Pero se detecta una disminución de la intensidad y extensión del marcaje de TH. Estas diferencias varían según la concentración de nicotina utilizada. Así, en las más altas (20 y $40 \mu \mathrm{M})$ ), la diminución de marcaje es más acusado con menos células TH positivas en la retina, disminuyen la extensión de las áreas inmunoreactivas y las proyecciones de estas células.

En el estadio de 5 dpf (Fig. 44), hay inmunorreactividad para TH en la retina, en las mismas capas del grupo control, y en las mismas áreas visuales primarias. En este estadio correspondiente al final del periodo larvario, en todas las concentraciones utilizadas el marcaje para TH es netamente menor en los 
elementos positivos. Se aprecia una drástica reducción de células marcadas en la retina. Así como, en las demás áreas visuales con marcaje para TH. Los animales que presentan una reducción más apreciable, son los tratados con las concentraciones de 20 y $40 \mu \mathrm{M}$ de nicotina. En ningún grupo de tratamiento hemos observado marcaje en el TO. 


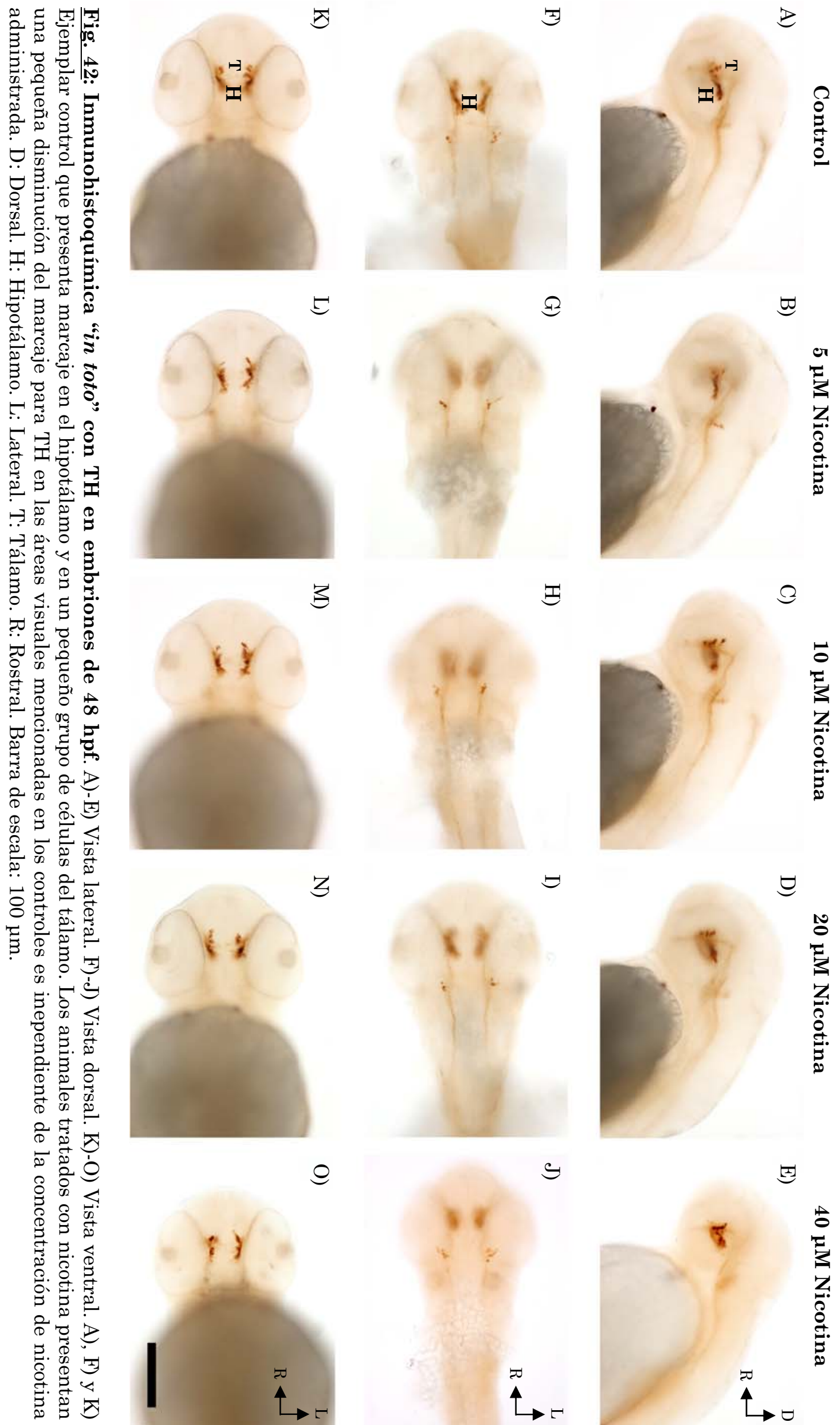




\section{Resultados}
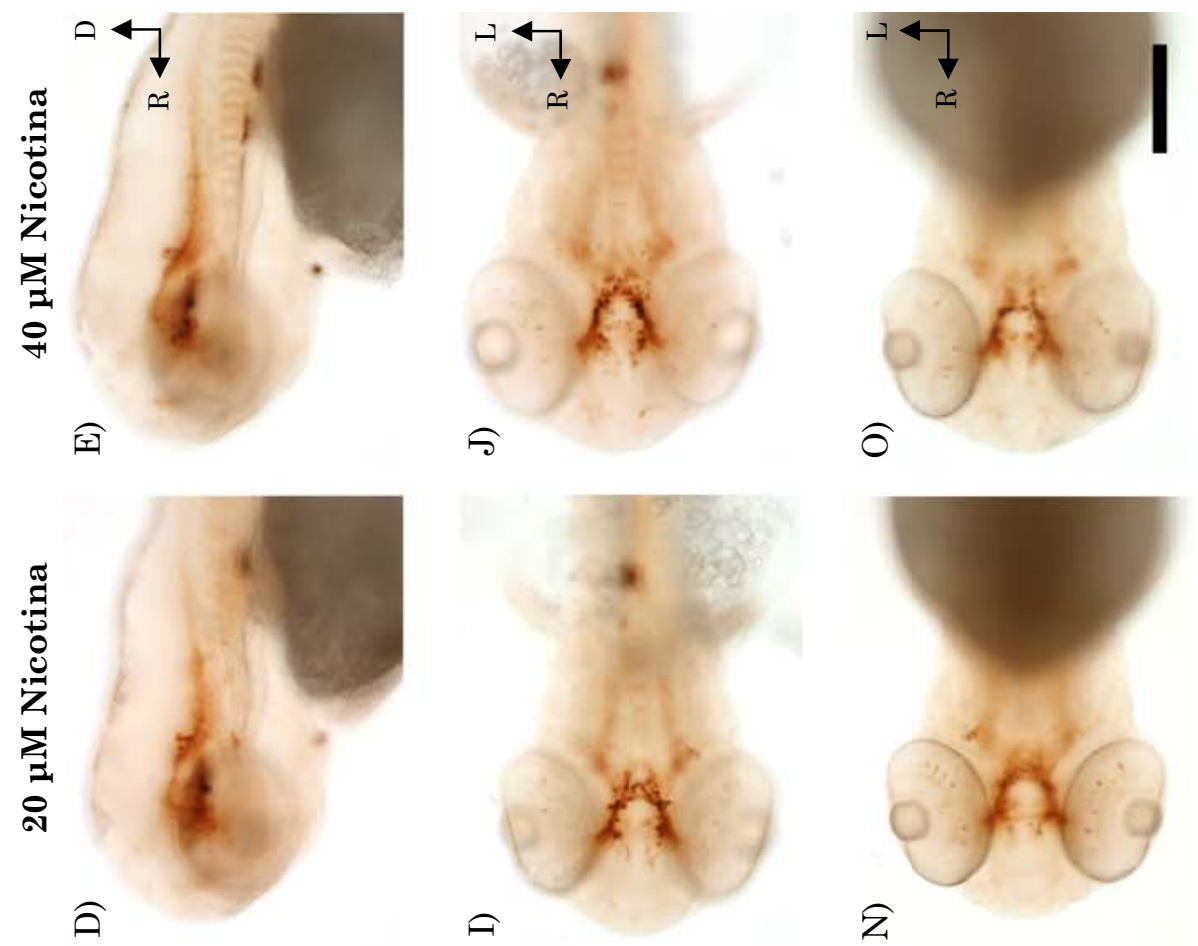

$\widehat{ิ}$

๑

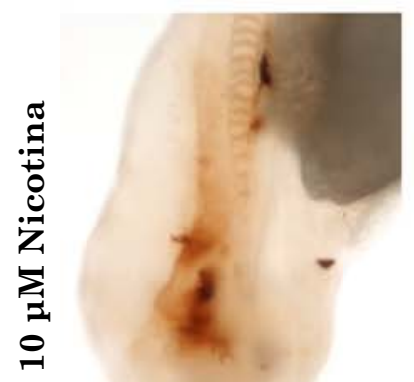

0

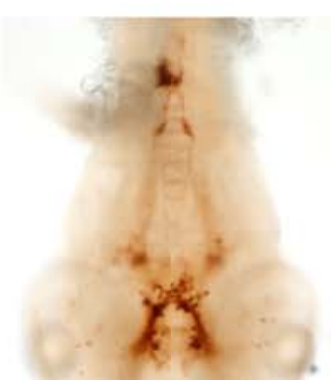

$\widehat{\underline{1}}$

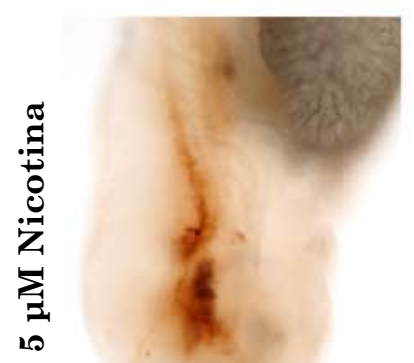

กิ
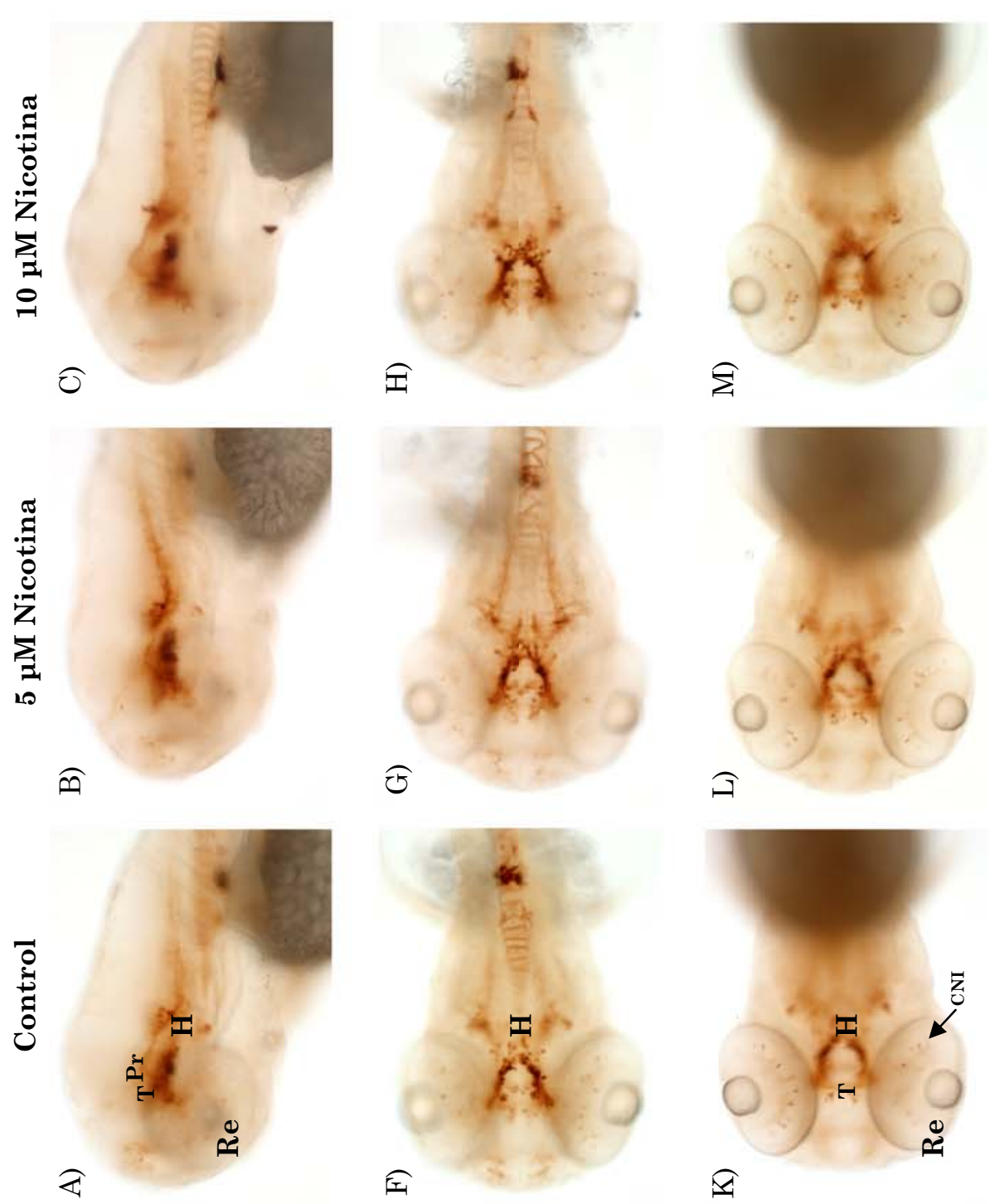

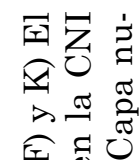

现 잉

㐫咢窎

तु

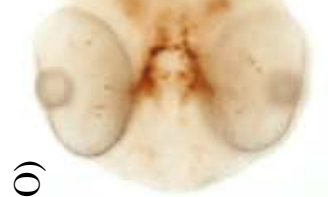

㐘

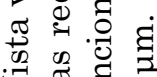

$>^{2} \frac{\pi}{2}$ ह

Oิ)

(4)

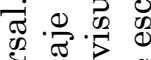

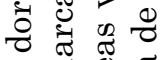

范

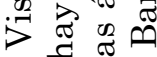

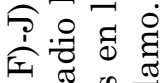

त

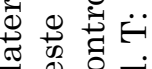

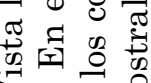

$>\dot{\varepsilon} \sigma$ भी

括亏

ये ज्ञ

हैं के क्जि

히봅

๑ वृ कृ

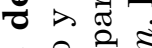

ข2

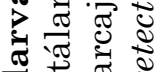

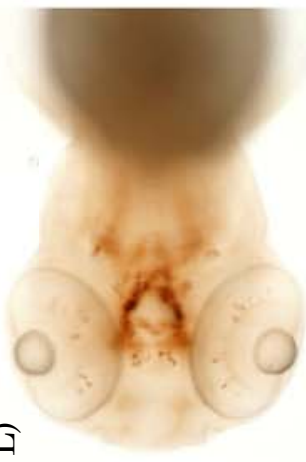

뎨

- ㄷำ

田

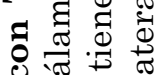

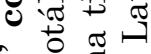

过.

하열

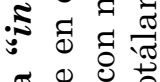

ช.

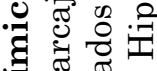

光票茜

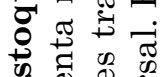

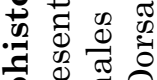

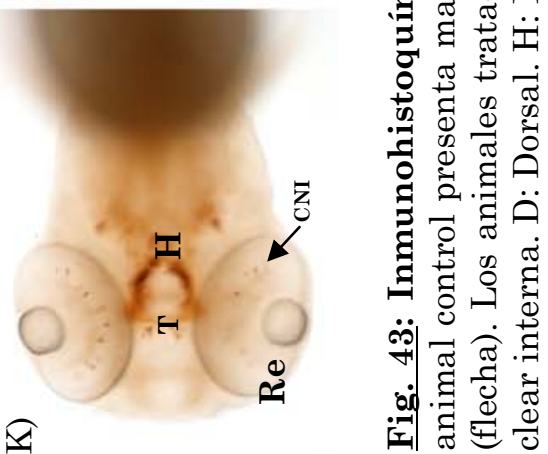



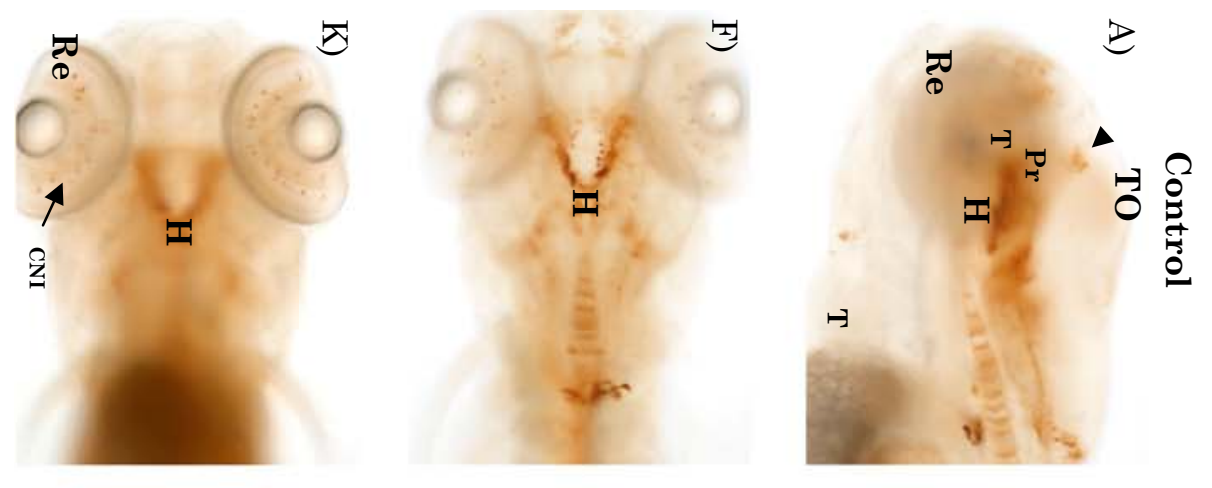

\%

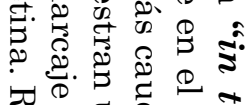

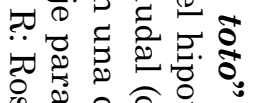

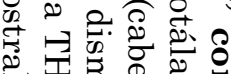
政. ․․ㅇ.

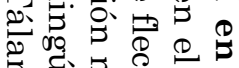

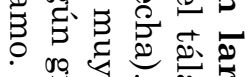

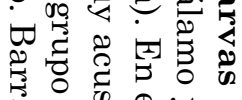
एक से 00 or

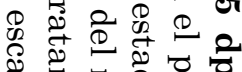

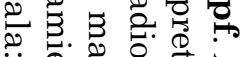

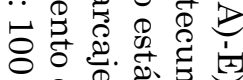
\& 5

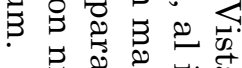
. D.

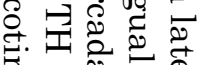
용 율

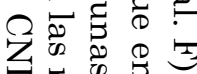

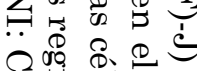

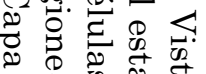
ही है 范 。 (8) 5.82 造蛋 5 क क 20

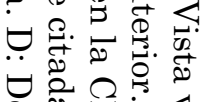

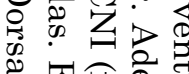

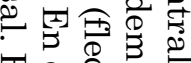
I 0 원? स है क्र

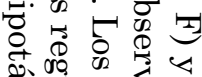

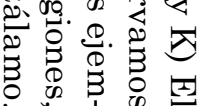
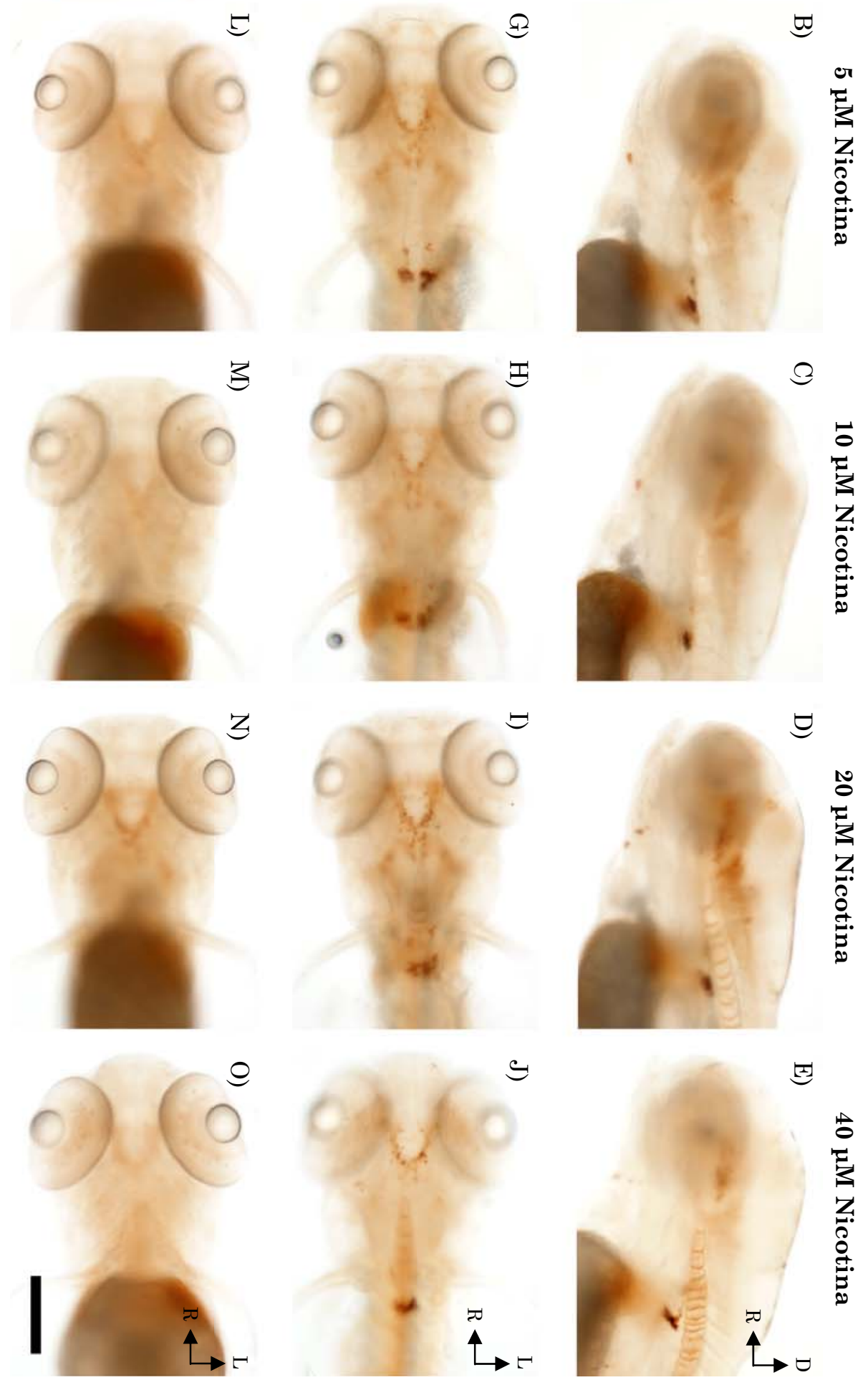


\section{$\underline{\text { Islet-1 }}$}

- Animales control

Este marcador nos permite identificar células en diferenciación en el sistema visual. En la retina de embriones de 48 hpf (Fig. 45),se localiza Islet-1 principalmente en células de la CCG y CNI, en la retina central. También dentro del prosencéfalo secundario en el hipotálamo hay células Islet-1.

Durante el periodo larvario de 3 dpf (Fig. 46) el factor de transcripción Islet-1 se mantiene en la CCG y en la CNI. En este periodo el marcaje se extiende por toda la retina. El marcaje para Islet-1 en el hipotálamo es similar al encontrado a las $48 \mathrm{hpf}$. Por lo que respecta al área preóptica hemos observado marcaje para Islet-1 y también en el pretectum y en el tálamo. Tras la eclosión, el marcaje de este marcador no se detecta en estructuras mesencefálicas, como el TO.

Al final del periodo larvario (5 dpf) (Fig. 47), el patrón de expresión de Islet1 no sufre modificaciones significativas ni en la retina, ni en el pretectum, ni en el tálamo, ni en el hipotálamo. No observamos elementos positivos a Islet-1 en el TO.

- Animales tratados con nicotina

El marcaje por HIS para el RNAm de Islet-1 en los animales tratados con nicotina, presenta una diminución del patrón de expresión, asociado inversamente a la concentración administrada, durante los tres estadios.

En el estado embrionario de 48 hpf (Fig. 45), observamos que la expresión de Islet-1, se localiza en las mismas estructuras visuales que en el grupo control: en la retina, en concreto en las CCG y CNI, y en el hipotálamo. En ambas se aprecia una diminución en la intensidad y extensión de este marcador. Además, esta reducción de expresión es inversa a las concentraciones de nicotina. Los 
animales tratados con la concentración más baja $(5 \mu \mathrm{M})$ presentan mayor reducción de marcaje. A medida que aumentamos la concentración de nicotina los efectos son menos severos, pero sin alcanzar niveles de expresión similaes a los controles.

A los 3 dpf (Fig. 46) Islet-1 mantiene la expresión en la retina (en la CCG y en la CNI) y en el hipotálamo. En este estadio, al igual que en el grupo control, aparece marcaje en el área preóptica, pretectum y tálamo. El marcaje no está en estructuras mesencefálicas, como el TO. Por lo tanto, la expresión de Islet-1 se localiza en las mismas estructuras visuales que en el animales control, el nivel de marcaje continua reducido de manera inversa a la concentración de nicotina. La mayor concentración de nicotina utilizada $(40 \mu \mathrm{M})$, se asocia en este estadio a niveles de marcaje parecidos a los del grupo control.

En el estadio larvario de 5 dpf (Fig. 47), el patrón de expresión del factor de transcripción Islet-1 en los animales tratados con nicotina sigue manteniéndose en las misma estructuras visuales que en el estadio larvario anterior. A los 5 dpf los animales siguen presentando una disminución de la expresión inversa a la concentración de nicotina administrada, pero en este estadio hay cierta recuperación del marcaje, con diferencias menos acusadas con el grupo control. 


\section{Resultados}
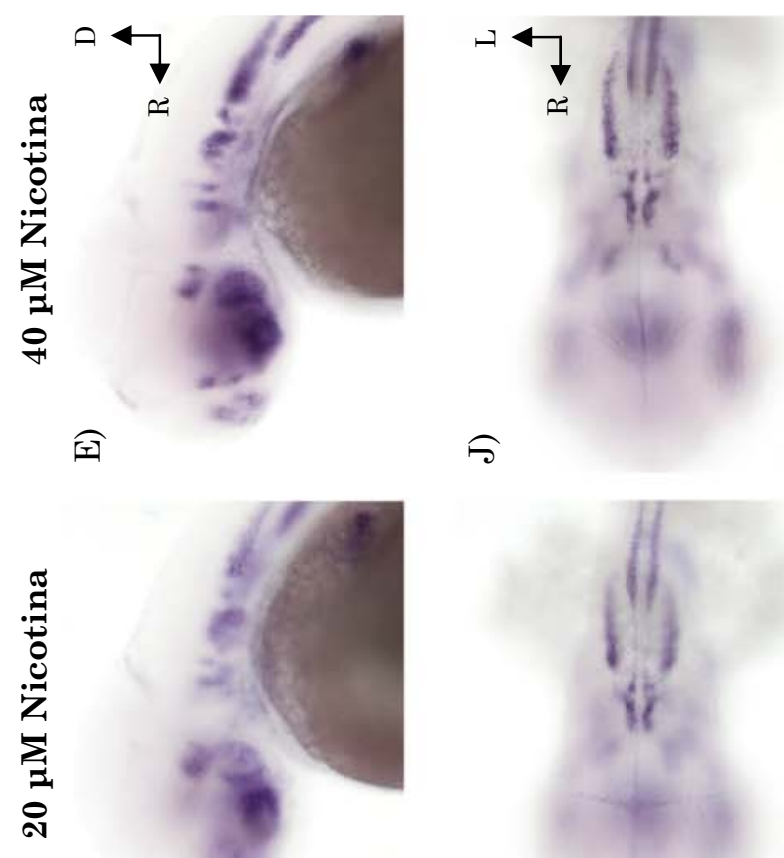

ค

$\widehat{\mathrm{A}}$
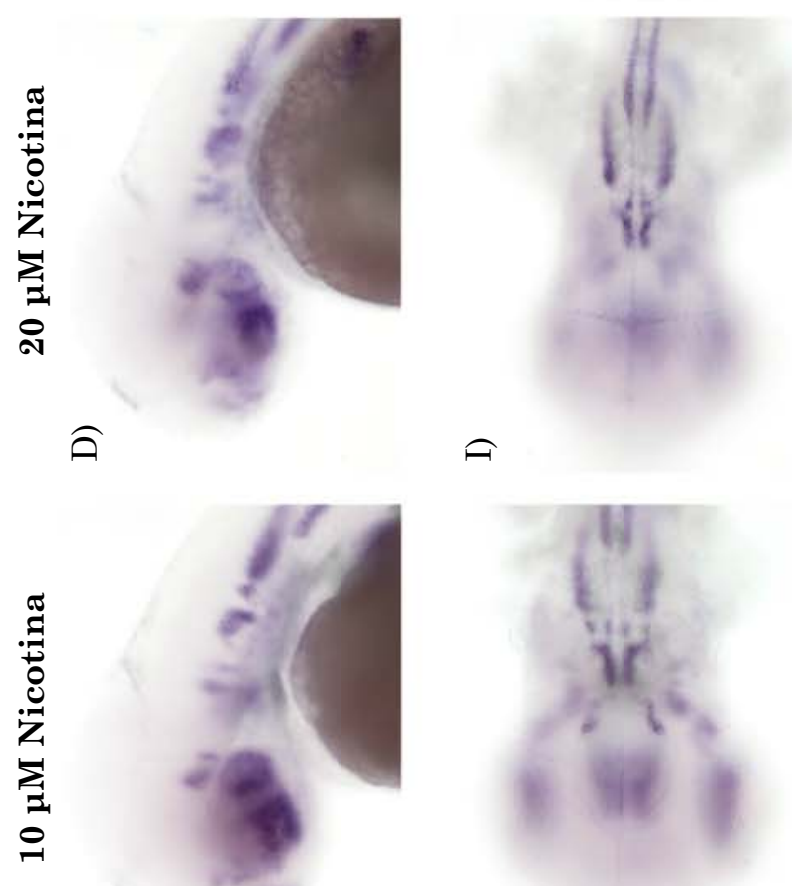

ช

ค
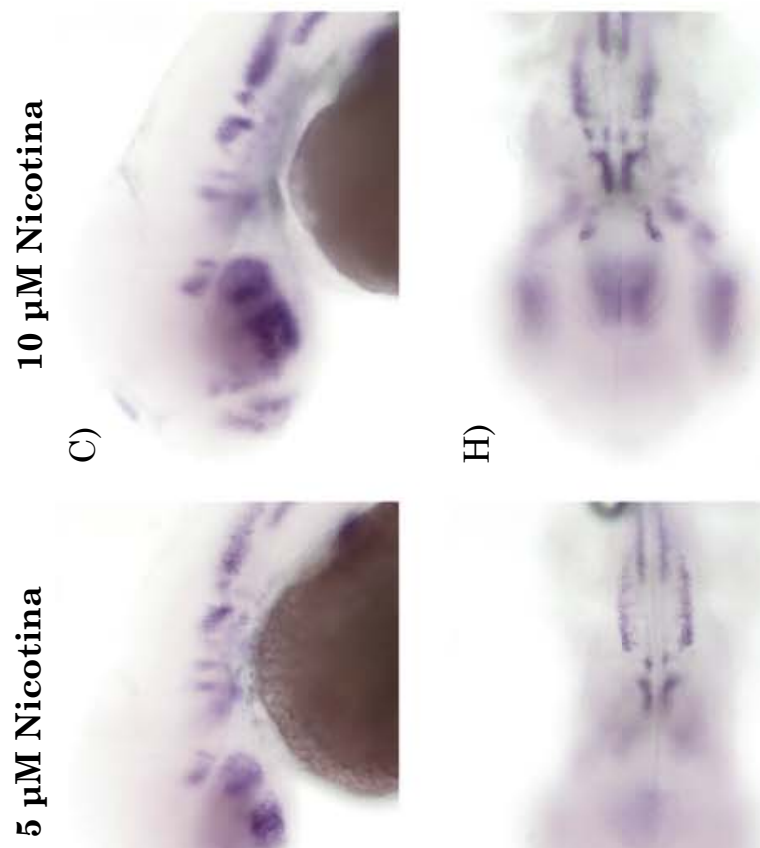

I

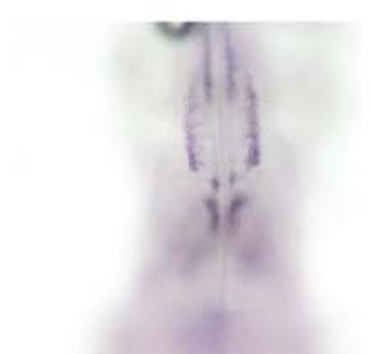

ิิ

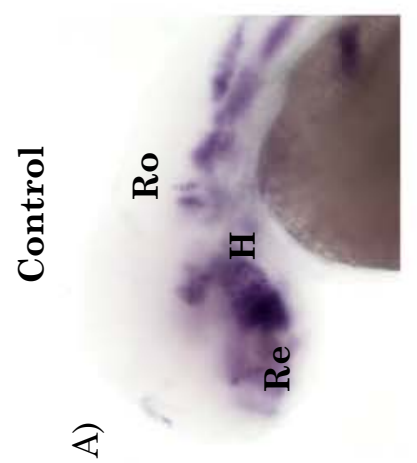

E

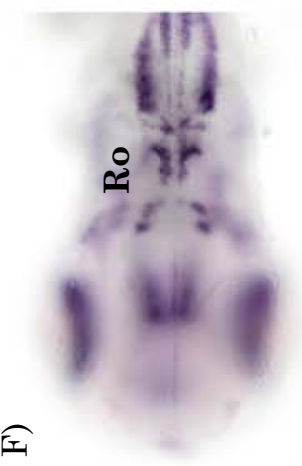

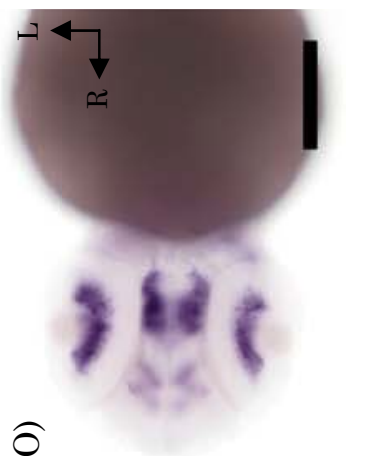

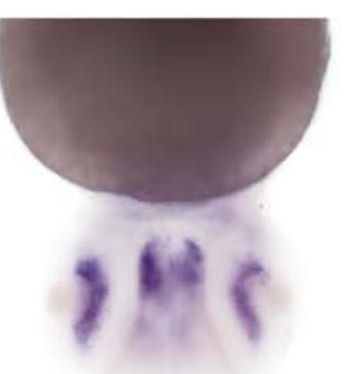

Z

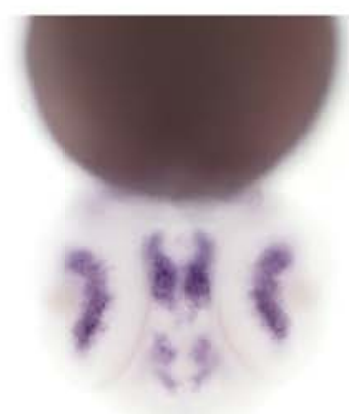

$\widehat{\Sigma}$

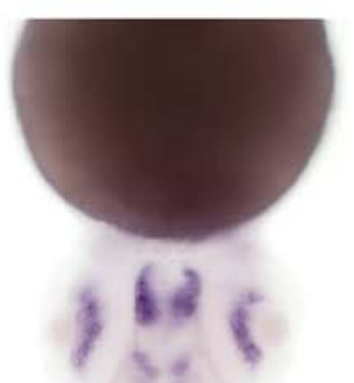

$\widehat{๑}$

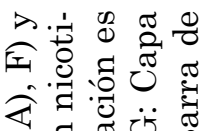
๘ 苟 吾 西 类

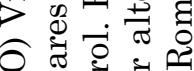
生范 . 0 \& क्षं कृँ है 范

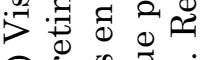

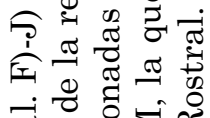
वृ ब 要 $>$ व 政船

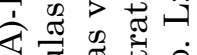
४.

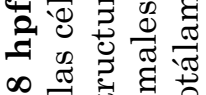

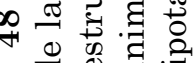
워 0 वี

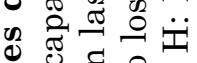

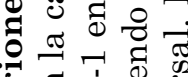

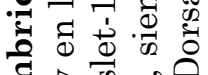
द्वे $\overrightarrow{0}$ ज्ञ द है ه

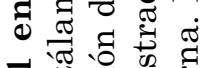

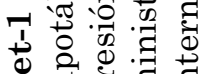
远猔 이

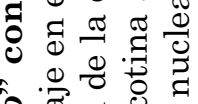

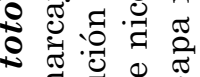

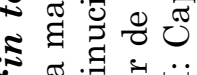

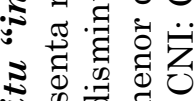
के .

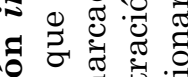

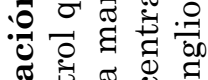
을 苛 : 茥 荝 茟

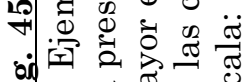
$\sqrt{1}$

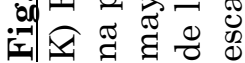




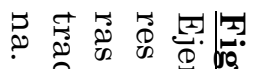

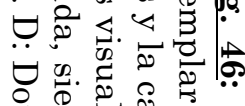

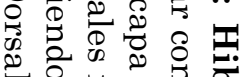

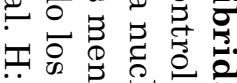

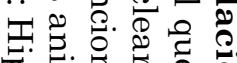
잉

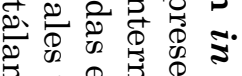

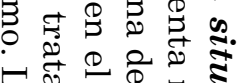

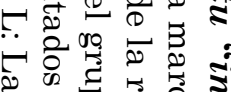
क \& 둥

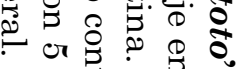

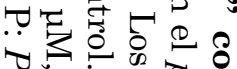

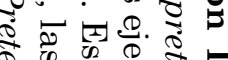

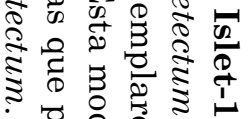

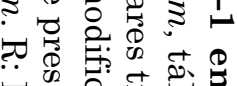

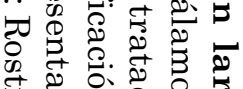

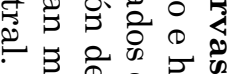

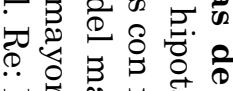

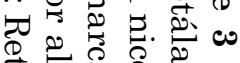

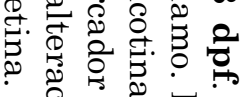

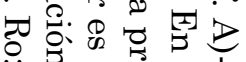

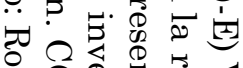

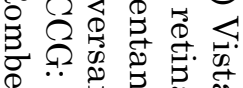
政

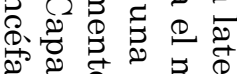

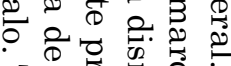

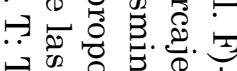

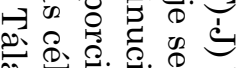

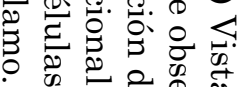

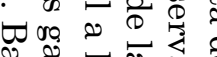

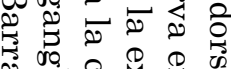

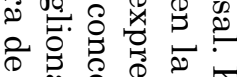

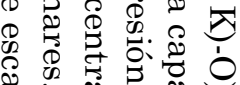
ํ.

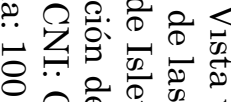
द्र 5 : 울.

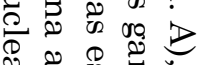
要 들. 달

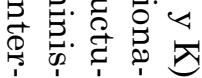

$\nabla$

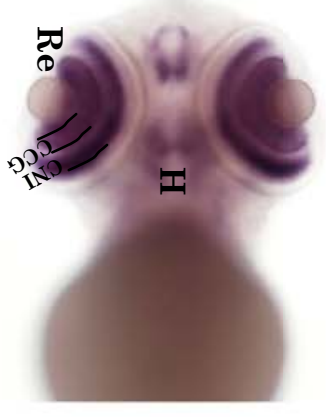

5

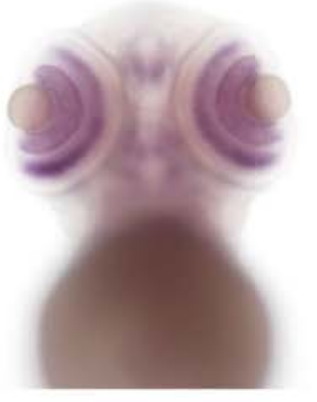

3

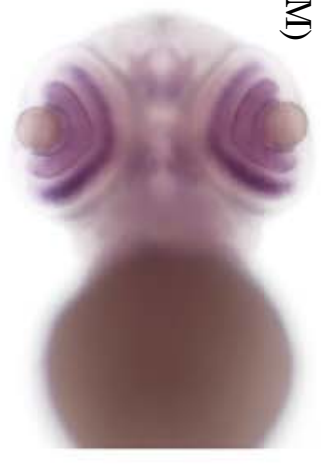

z

ไై

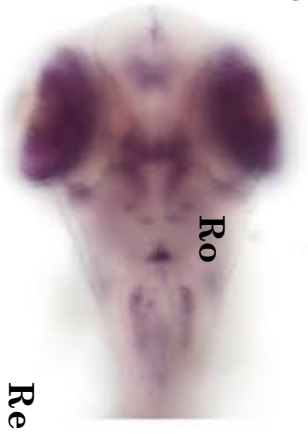

@

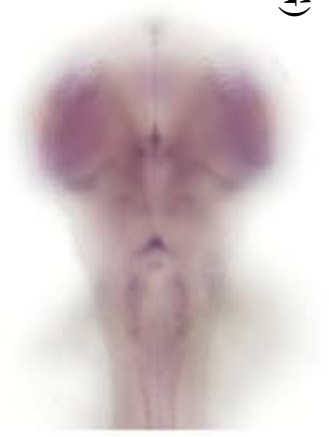

$\pm$

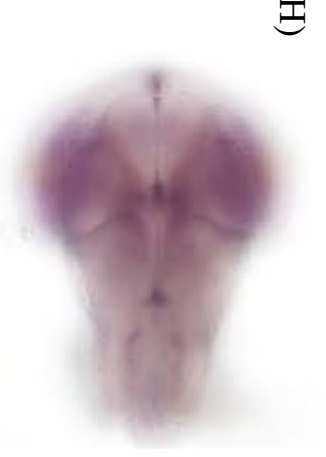

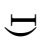
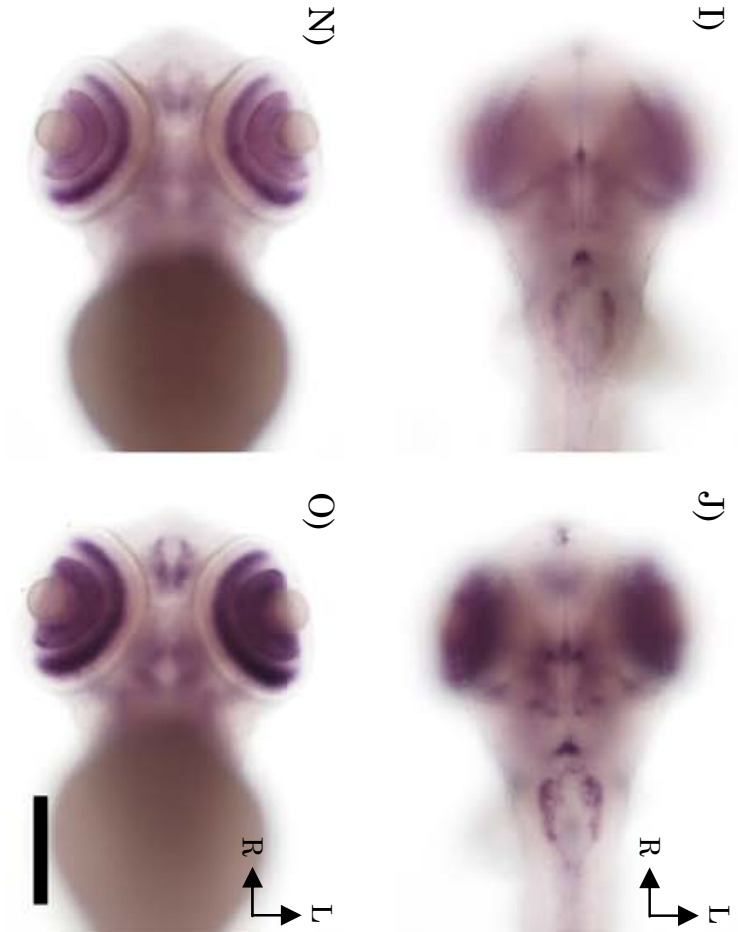

퍽
巴

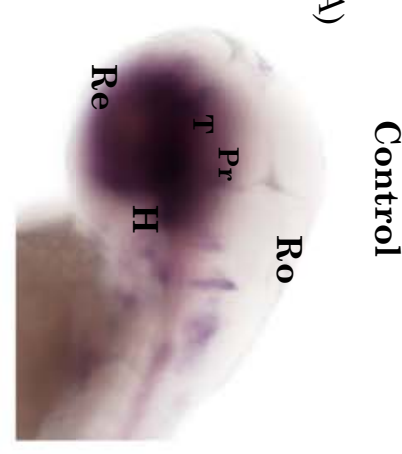

$\varpi$

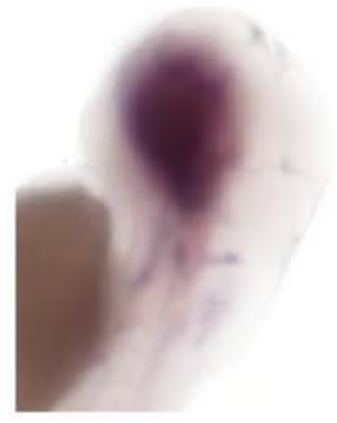

ن

$\Omega$

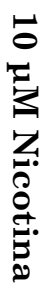

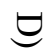

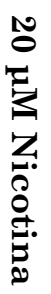

[ᄑ]

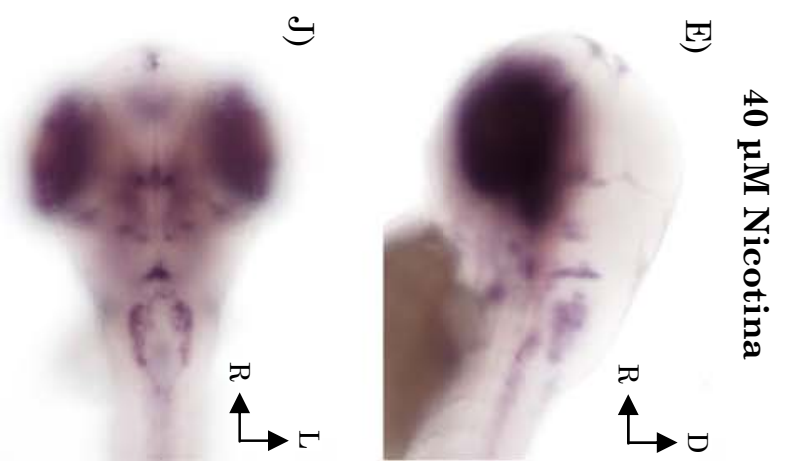




\section{Resultados}

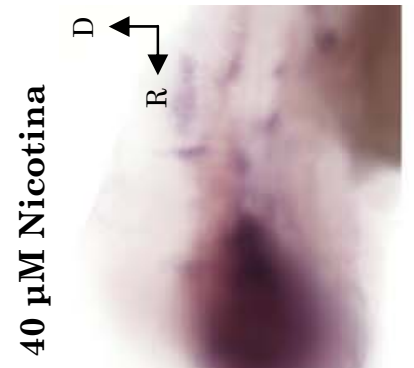

国
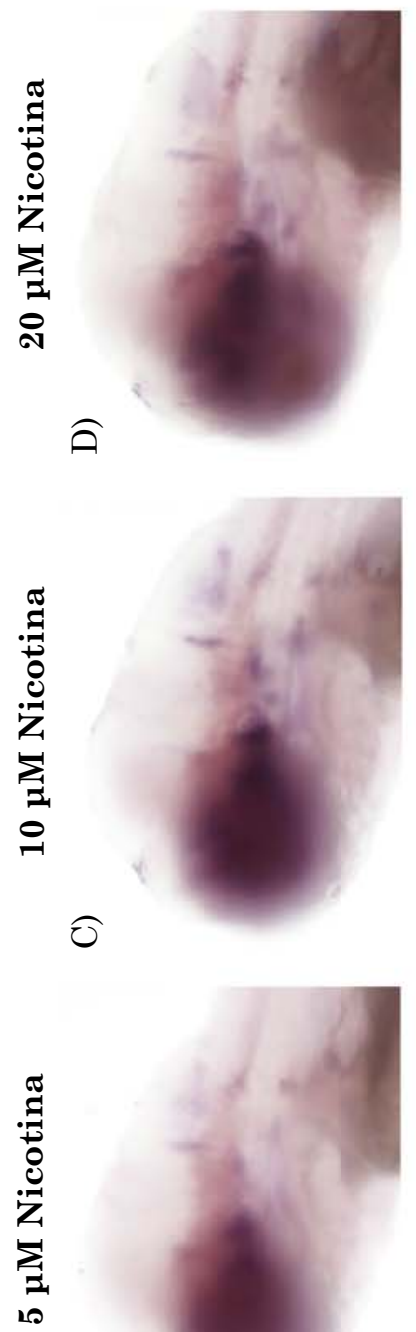

กิ

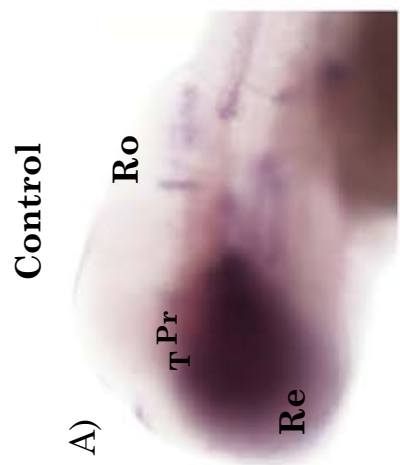

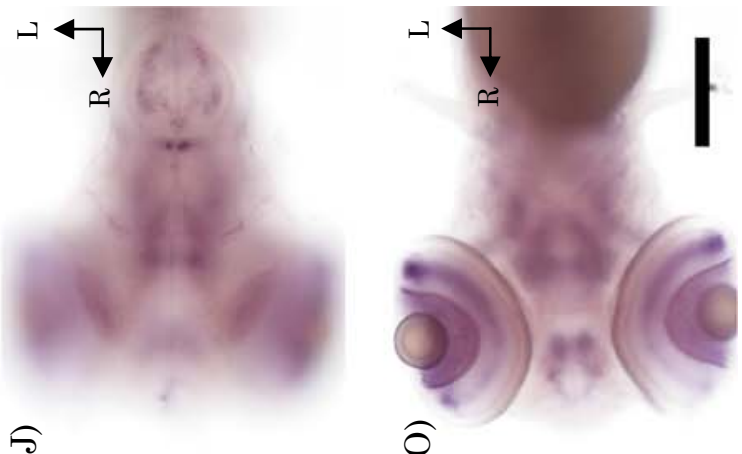

คิ

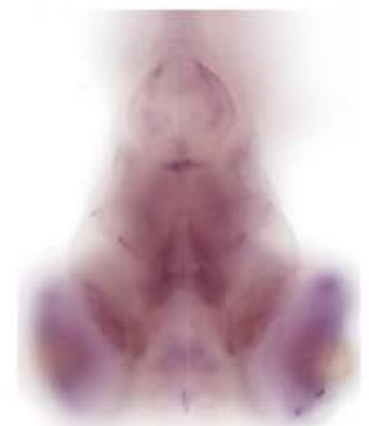

ค

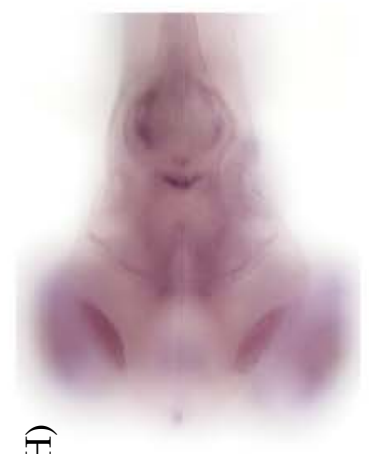

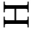
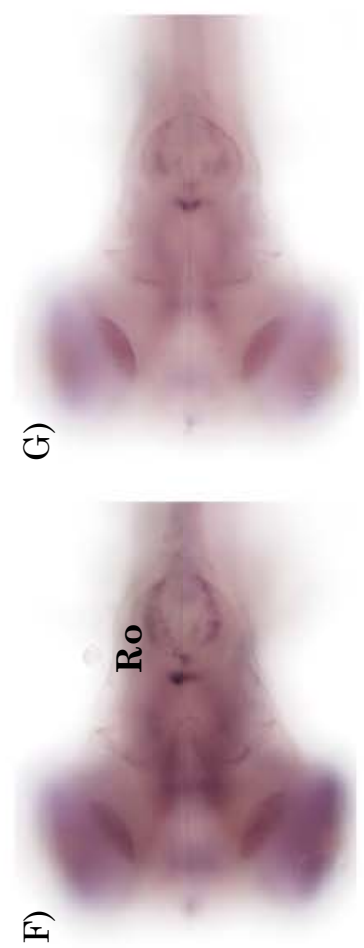

$\widehat{0}$

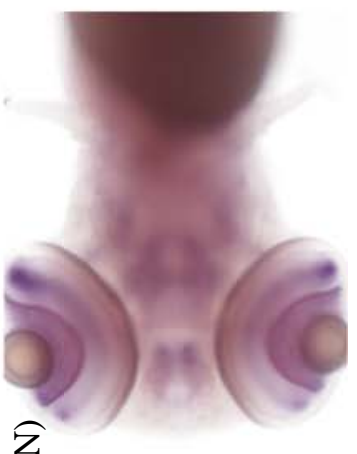

乏
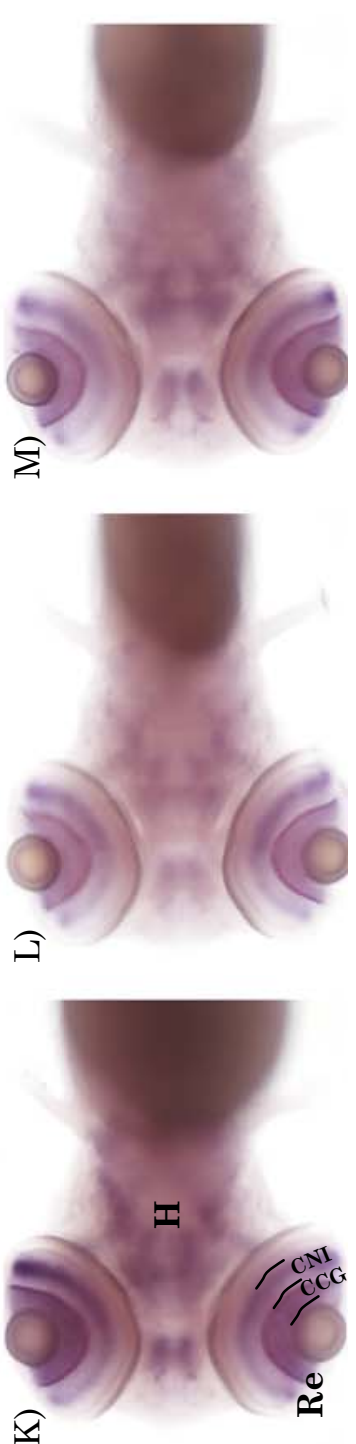

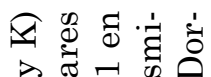

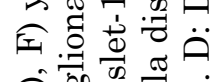
<ิ

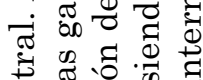
艺

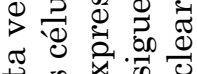
要 ỗ बิ எं

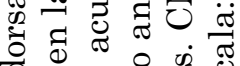

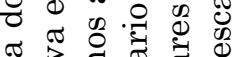

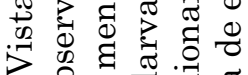
คิ

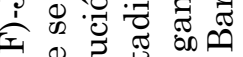
तं 屯

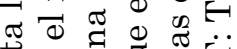

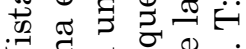
$>$. द्न

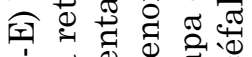

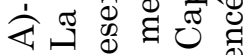

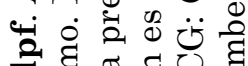

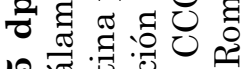
10 需

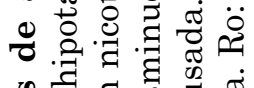

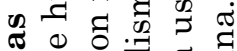

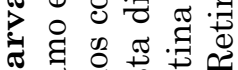

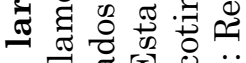

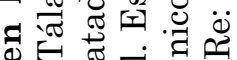
न हु

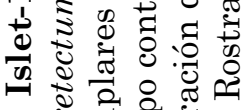

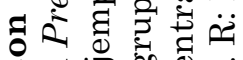

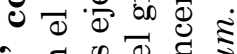
월 ช. $\frac{0}{\sigma}$ व

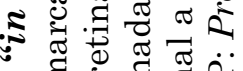
리 고 कि इ . :월. 苛 응 ส 5 ह

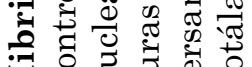
讯 范

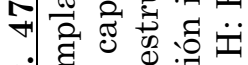

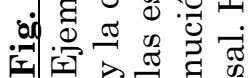




\section{$\underline{\text { Pax6a }}$}

- Animales control

El factor de transcripción Pax6a es imprescindible para la formación de diferentes estructuras visuales. En la retina, a las 48 hpf (Fig. 48), Pax6a se expresa en células situadas en toda la extensión de la CCG y de la CNI. En este estadio de desarrollo, hay expresión de Pax6a en el área preóptica. Durante el periodo embrionario detectamos marcaje para Pax6a tanto en el pretectum como en el tálamo. Por lo que respecta a las estructuras mesencéfalicas, no presentan elementos marcados para Pax6a en el estadio de 48 hpf.

A los 3 dpf (Fig. 49), la expresión de Pax6a se mantiene en la retina en la CCG y en la CNI, pero más intenso que a las 48 hpf. Tras la eclosión, seguimos sin observar marcaje para Pax6a en el hipotálamo. El patrón de expresión de dicho factor de transcripción en el área preóptica no sufre modificaciones tras la eclosión. No se aprecia modificaciones en el patrón de distribución de Pax6a en estas regiones del pretectum y tálamo. El marcaje para Pax6a en el TO se observa en células localizadas únicamente en la región más rostral.

Al final del periodo larvario (5 dpf) (Fig. 50) el patrón de expresión de Pax6a en el área preóptica, pretectum y tálamo no sufre modificaciones en este periodo larvario. En ninguno de los estadios de desarrollo analizados hemos observado marcaje para Pax6a en el hipotálamo. Por lo que respecta al TO, se sigue observando marcaje en su zona más rostral, sin variaciones en su patrón de expresión.

- Animales tratados con nicotina

El patrón de expresión de Pax6a en los animales tratados con diferentes concentraciones de nicotina presenta una disminución muy poco acusada que se mantiene en los tres edades analizadas. Esta disminución se acentúa cuanto mayor sea la concentración de nicotina que administrada. 
En el estadio de 48 hpf (Fig. 48) el tratamiento con nicotina no altera el patrón de expresión de Pax6a en las estructuras visuales. Hay expresión en las mismas capas de la retina (CCG y CNI). Observamos marcaje en el área preóptica, tálamo y pretectum. La intensidad y extensión del marcaje para Pax6a es muy similar en todos los grupos tratados con nicotina.

Tras la eclosión a los 3 dpf (Fig. 49), el patrón de expresión de Pax6a se mantiene en las mismas estructuras visuales que en el estadio anterior, además de en el TO en su región más rostral. Pero en este periodo si se aprecia una disminución moderada en la intensidad de expresión de Pax6a en estas estructuras visuales. Esta disminución se relaciona a la concentración de nicotina, así el grupo tratado con $40 \mu \mathrm{M}$, es el que presenta la mayor disminución de intensidad.

En el periodo larvario de 5 dpf (Fig. 50), se aprecia marcaje en las mismas regiones que en el periodo larvario anterior. En este estadio la disminución de marcaje para Pax6a con respecto al estadio anterior es aun mayor, produciendo las mayores concentraciones de nicotina (20 y $40 \mu \mathrm{M})$ la reducción más acusada de Pax6a. 


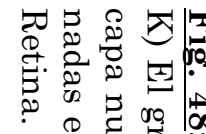

$\rightarrow$ 을

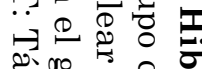

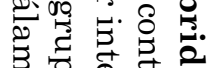

영 웡

엉 8

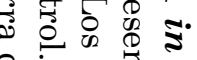

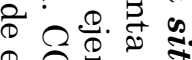

(1) 2 : 3

نج

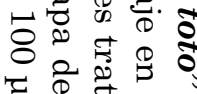

它

w

क.

알. 울

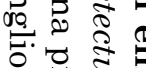

施

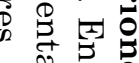

Z

퉁

哠:

鄉总

亭 ․․ㅇ.

.

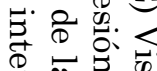

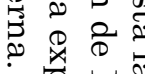

$\forall$ 突

웅:

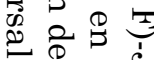

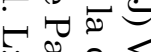

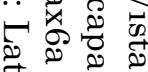

\& \& 8

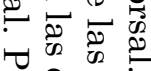

$\therefore$

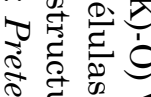

है है कू

? 4 .

물 可

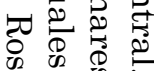

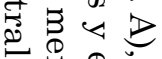

可题.

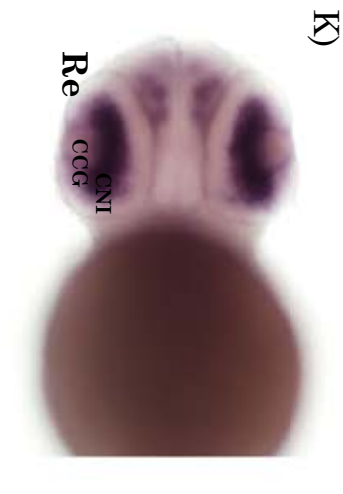

$\nabla$
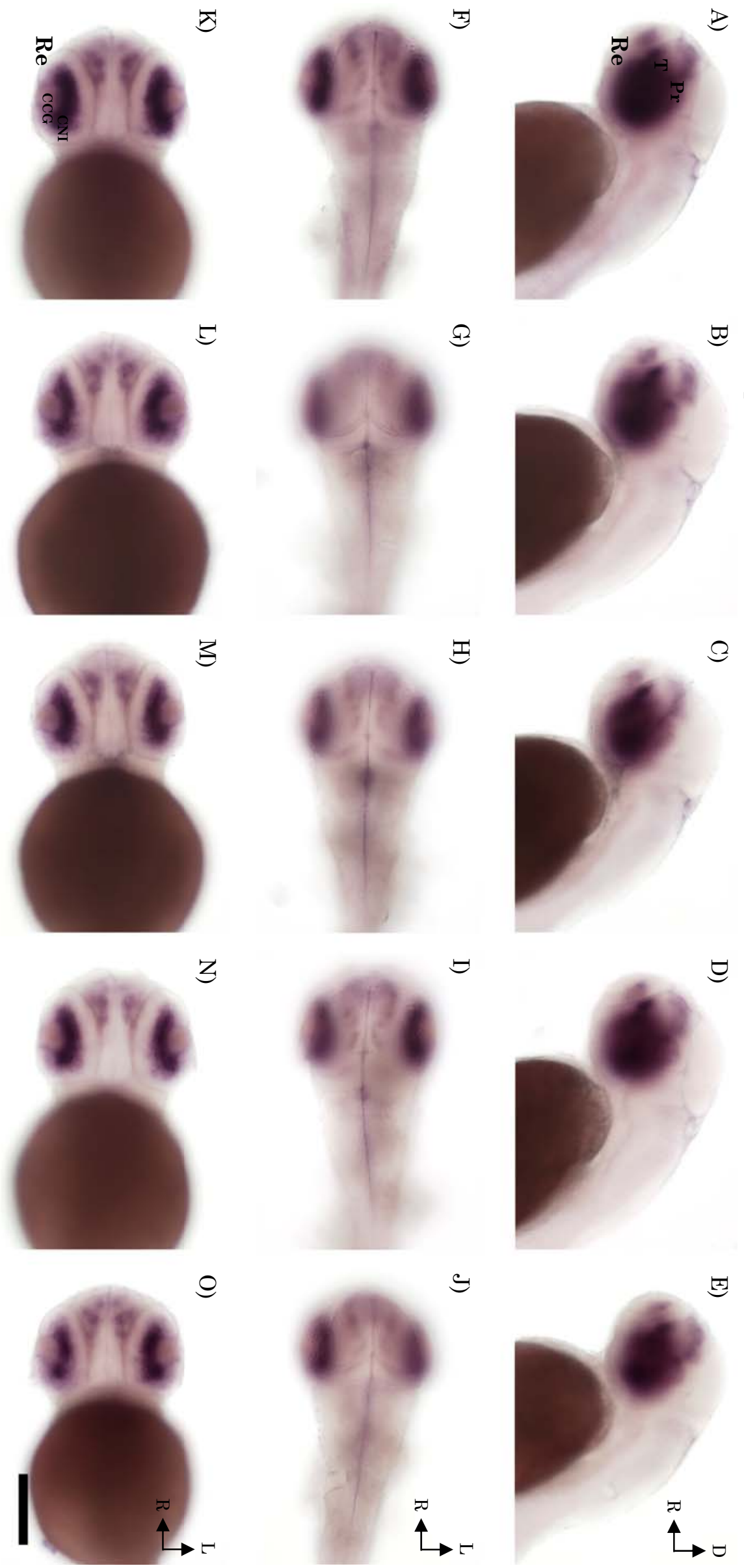

@

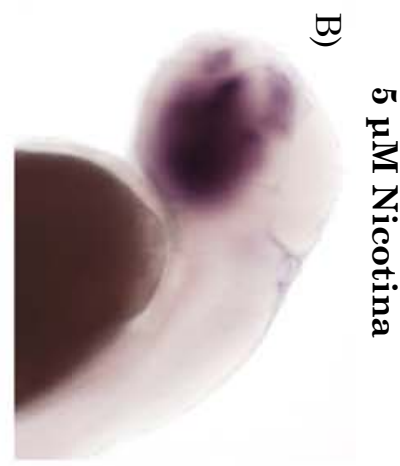

ت

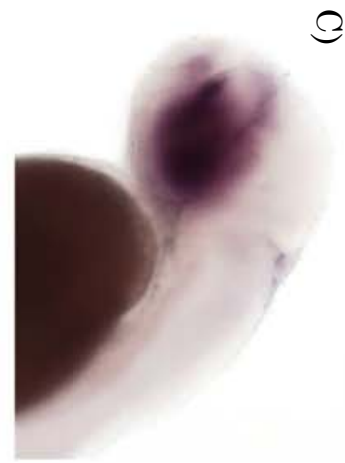

$\Omega$

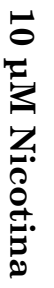

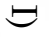

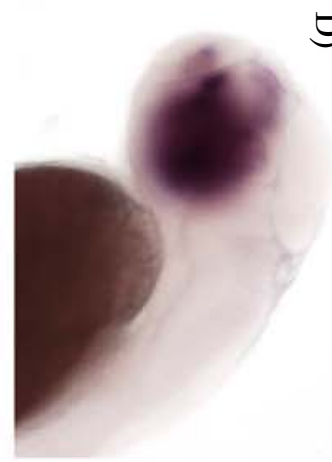

$\exists$

0
8
3
3
$\vdots$
0
0
0

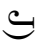

점

20

ت.

$\stackrel{+\infty}{\longrightarrow}$

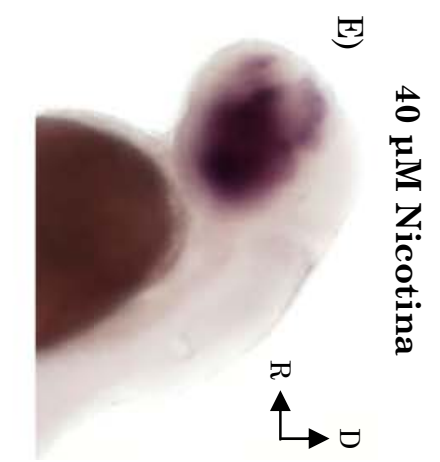




\section{Resultados}
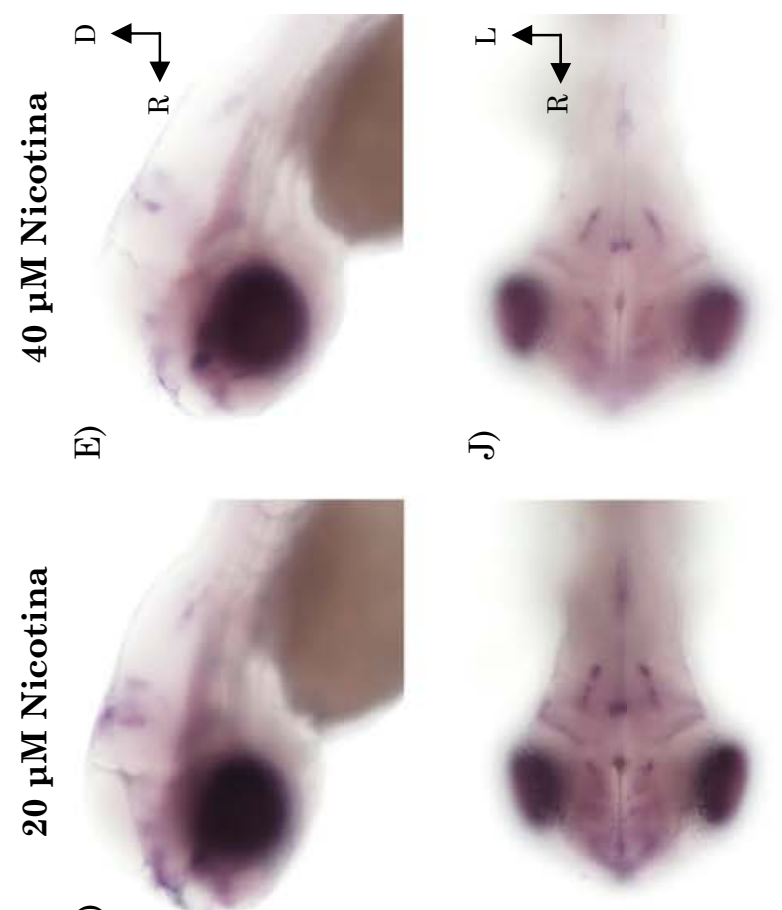

ค

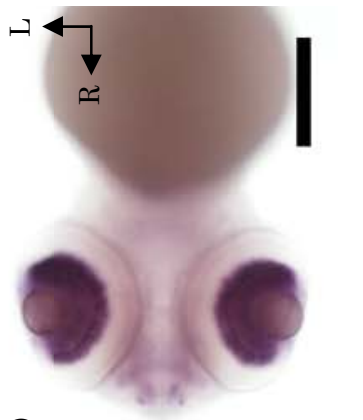

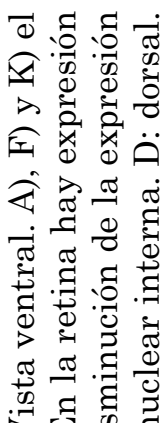

$\widehat{o}$

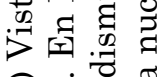

○ิ

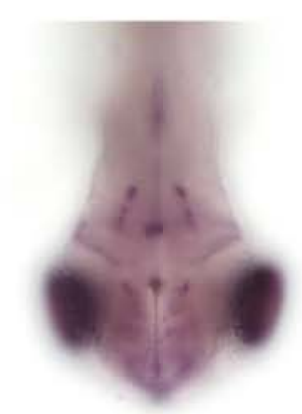

$\widehat{ค}$

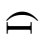
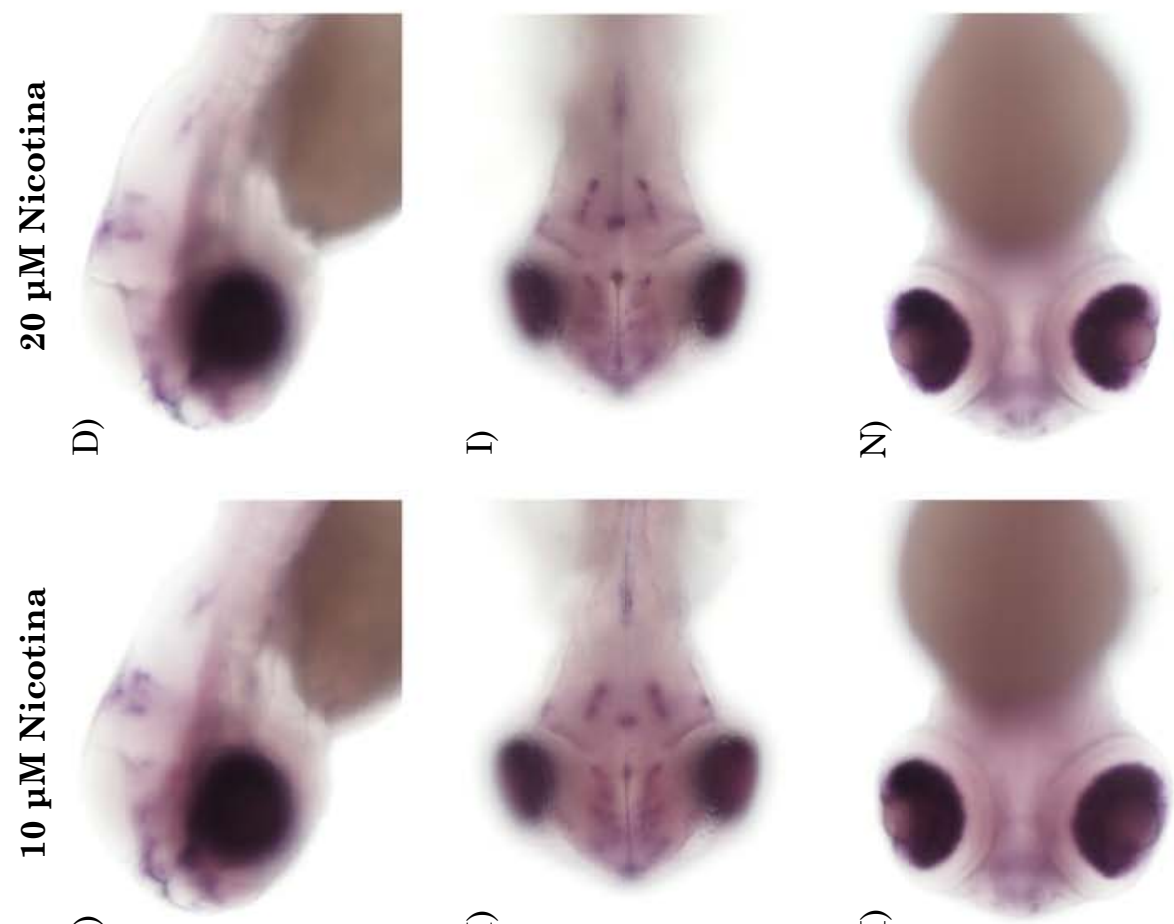

开
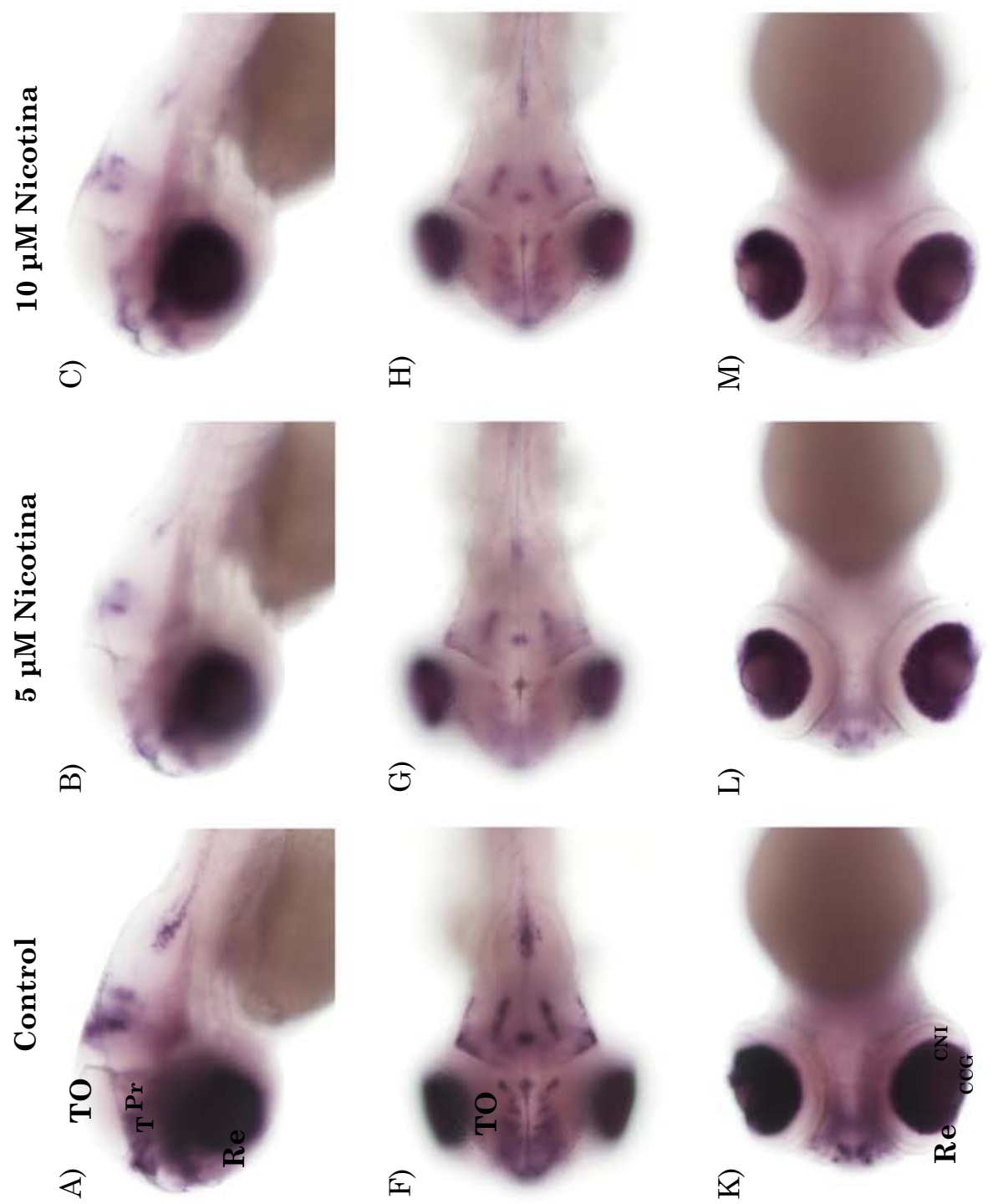

य

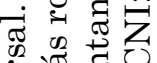

ठั

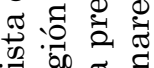

$>0$ ऽ

Pि 㐘

约

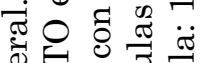

ब

雪

$>$ :

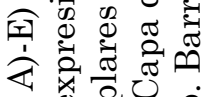

४ बे

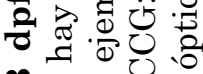

๓

थ ส

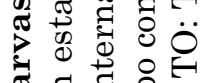
పี व

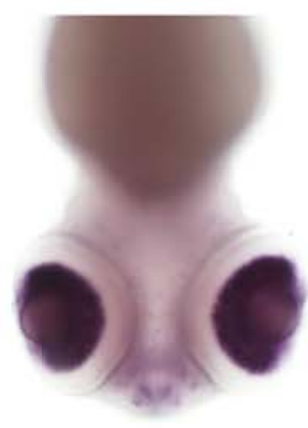

๑

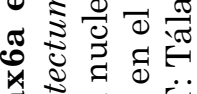

๘ $\approx$ o

ㄴ, శ్워

용 $\overrightarrow{0}$.

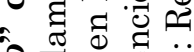

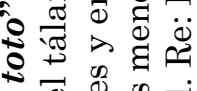

సै

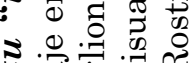

ㄴ.

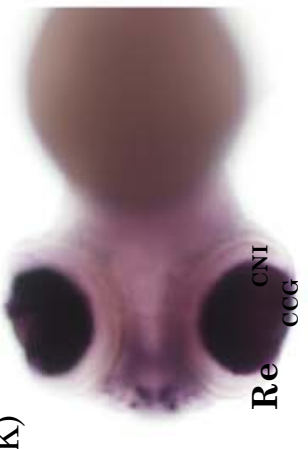

ऽ สై

व वै ह

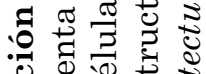

(I) क्ष

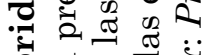

苟 월

范

จ

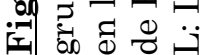




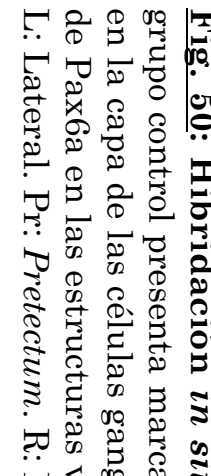

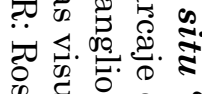

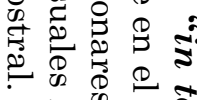

प्र

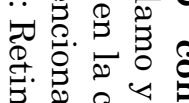

ใृ

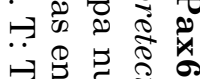

ข.

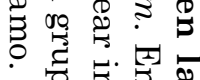

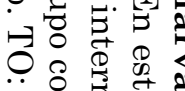

$\rightarrow$ 它

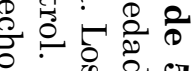

을

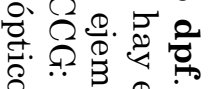

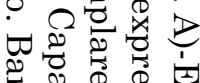
क क

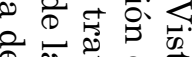
कृ in 8 . ํㅜㅇ

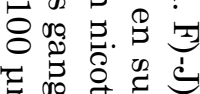

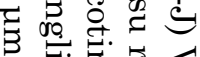
용 둥 की

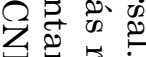
考 है \% ب

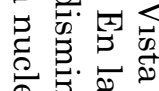
?

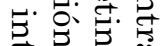
क वृ 붕

융 象客㽞
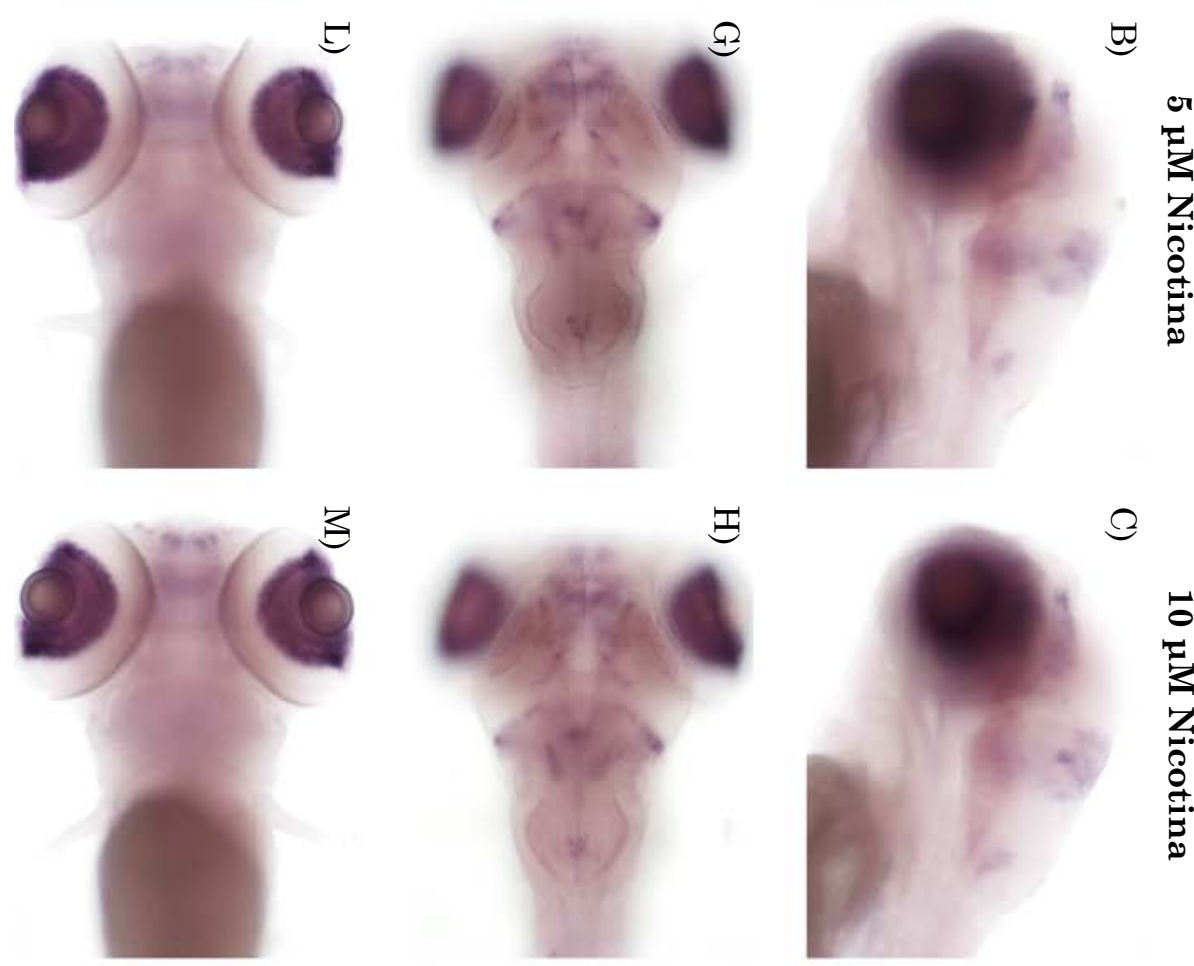

3
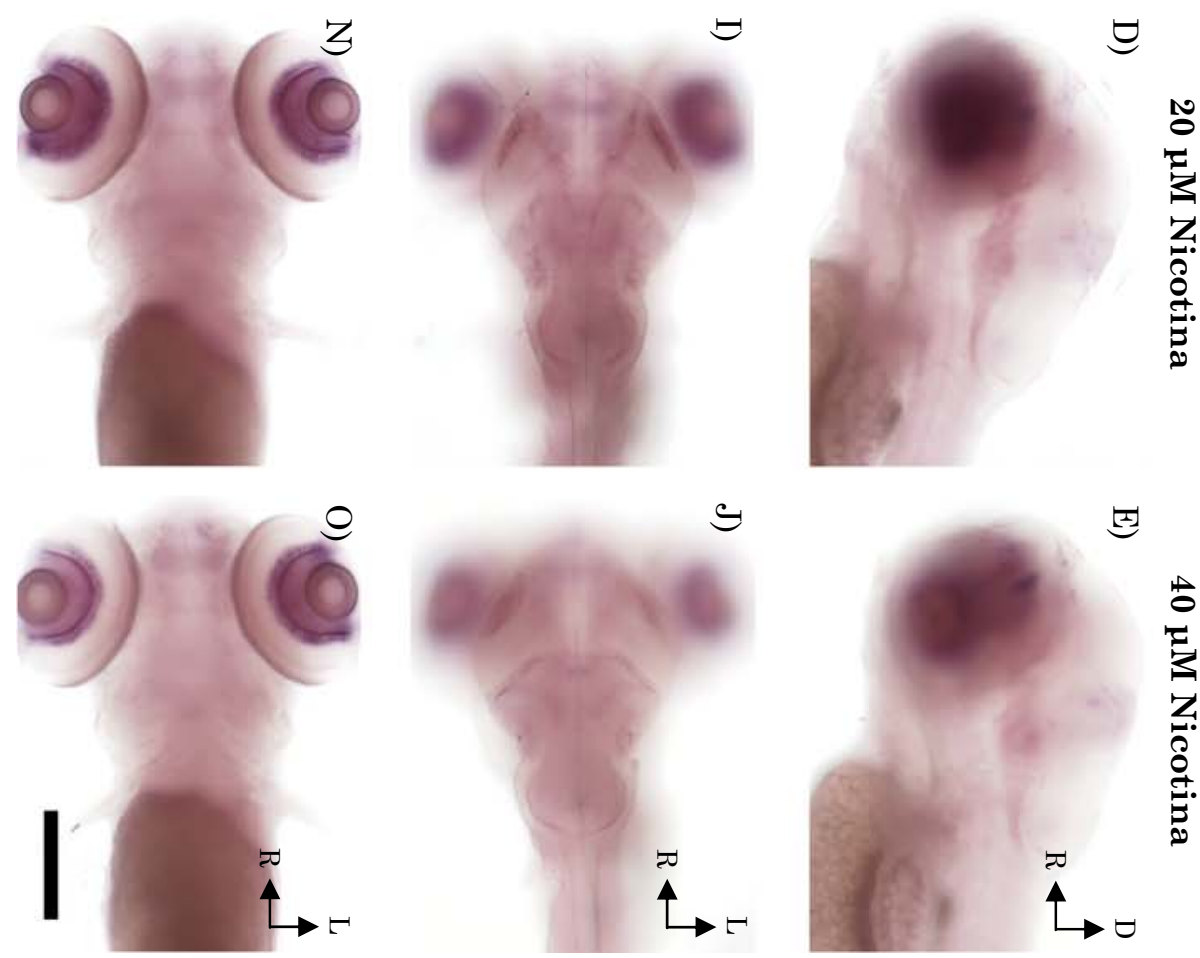


\section{$\underline{\text { Zpr1 }}$}

- Animales control

Zpr1 se utiliza como marcador de conos. En los ejemplares control, ya en el estadio de $3 \mathrm{dpf}$ se encuentra por primera vez células positivas para Zpr1, conos, distribuidos por toda la extensión de la retina (Fig. 51A).

$\mathrm{Al}$ cuantificar este marcador en el estadio de 3 dpf obtuvimos, en la retina central, la cantidad media de 3,907 $\pm 0,1385$ conos $/ 1000 \mu^{2}$ (Fig. 51C). Al final del periodo larvario (5dpf) también se observó una gran cantidad de elementos inmunorreactivos para este marcador en toda la extensión de la retina (Fig. 51B), se cuantificó salvo margen ciliar (MC). La densidad media de conos en este estadio es de 7,535 $\pm 0,2017$ conos/1000 $\mu^{2}{ }^{2}$ (Fig. 51D).

- Animales tratados con nicotina

Hemos observado marcaje para Zpr1 en los dos estadios larvarios analizados y en ellos no se aprecia ninguna diferencia significativa con respecto al número medio de conos en la retina de los grupos control.

A los 3 dpf, en los animales tratados observamos células positivas a Zpr1 en toda la extensión de la retina, al igual que ocurre en los ejemplares control. El número medio de conos en los ejemplares tratados con nicotina, independientemente de la concentración suministrada, presentan valores muy similares a los animales control (Fig. 51C). A los 5 dpf, también hay células marcadas con Zpr1 en la retina. En este estadio, al igual que ocurre en el estadio larvario anterior, no se parecían diferencias significativas en el número medio de conos por retina entre los animales tratados con nicotina (Fig. 51D) con respecto a los controles. 


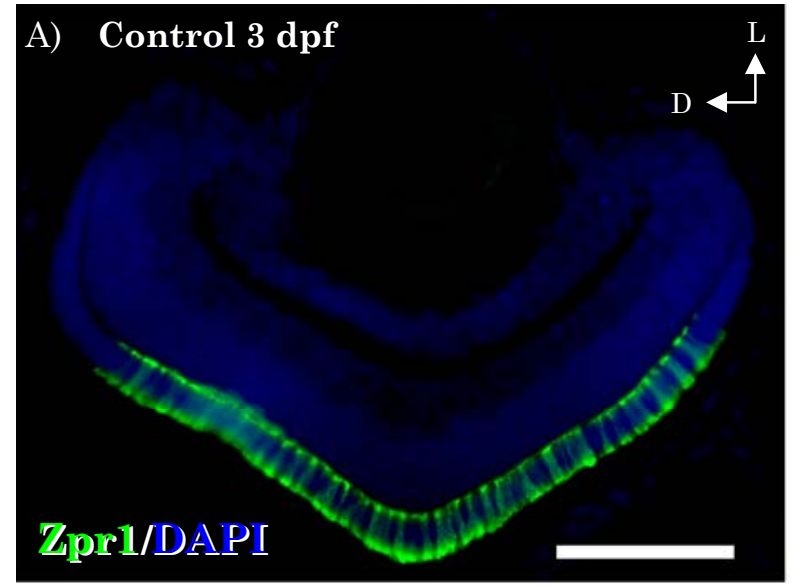

C)

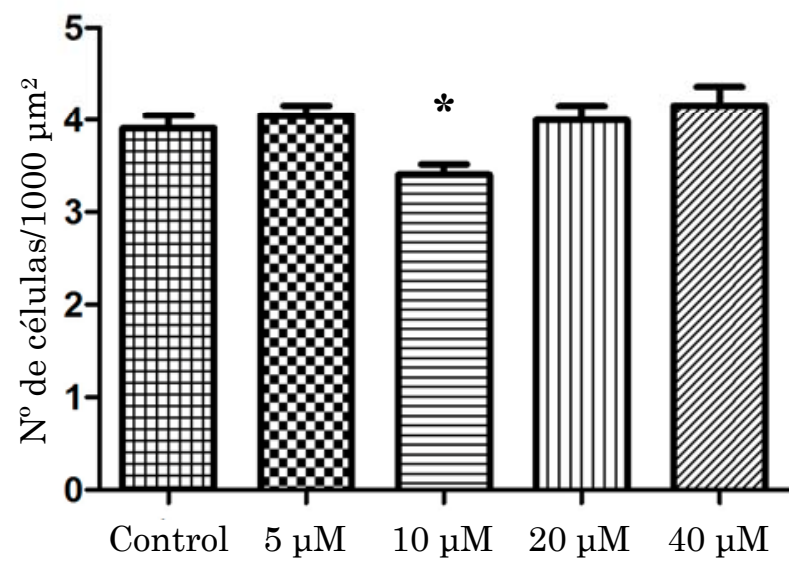

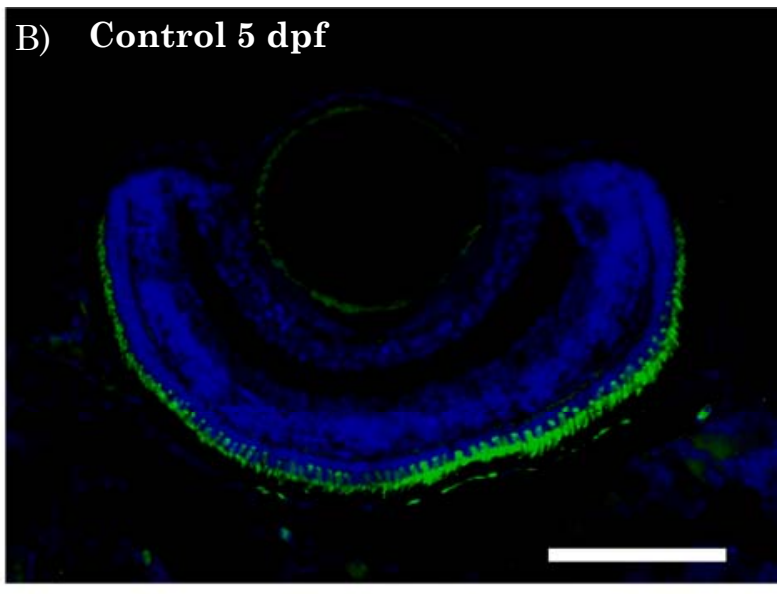

D) Células Zpr1+ a los 5 dpf

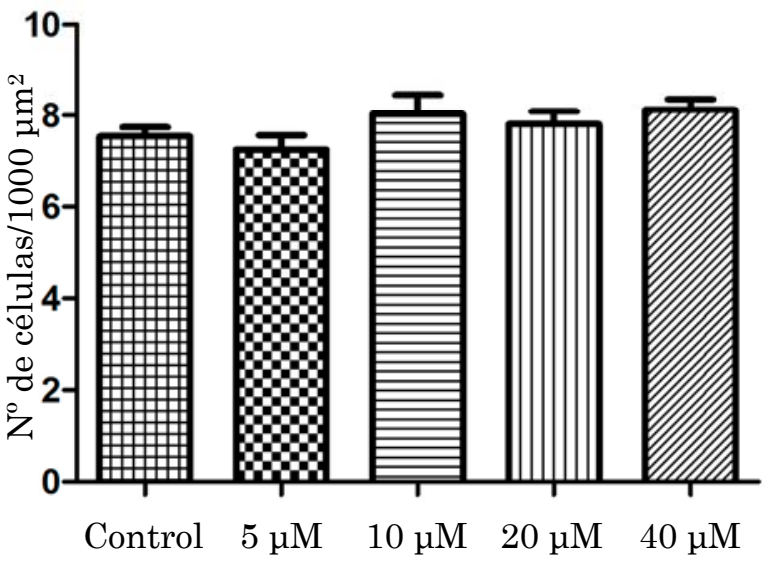

Fig. 51: A) Imagen de una sección coronal de un ojo a los 3 dpf. B) Imagen de una sección coronal de un ojo a los $5 \mathrm{dpf}$ C) y D) Histogramas del recuento de células marcadas con Zpr3 en retinas. C) en larvas de 3 dpf. D) en larvas de 5 dpf. D: Dorsal. L: lateral. ${ }^{*}=p<0,05$. $^{* *}=$ $0,05>p>0,001$. ${ }^{* * *}=p<0,001$. Barra de escala: A) $50 \mu \mathrm{m}$. B) $100 \mu \mathrm{m}$

\section{$\underline{\text { Zpr3 }}$}

- Animales control

El marcador Zpr3 es un marcador exclusivo de bastones. A los 3 dpf se ven células positivas para Zpr3 en las retinas de los animales control (Fig. 52A). En este estadio al cuantificar el número de bastones obtuvimos una densidad media de 2,139 \pm 0,09603 bastones $/ 1000 \mu^{2}$ (Fig. 52C). A los 5 dpf, los bastones están distribuidos a lo largo de toda la retina excepto en el MC (Fig. 52B). Al cuantificar la densidad de bastones encontramos que aumenta 
considerablemente en los ejemplares control alcanzando un valor aproximado de $6,855 \pm 0,2967$ bastones $/ 1000 \mu^{2}$ (Fig. 52D).

- Animales tratados con nicotina

Hemos analizado la densidad de bastones a los 3 y 5 dpf en los ejemplares tratados con las diferentes concentraciones de nicotina y encontramos un aumento significativo en el número medio de bastones por retina en ambos estadios larvarios, más acusado a los $3 \mathrm{dpf}$.

En el estadio de 3 dpf, hay un aumento significativo de la densidad de bastones en la retina, en los animales tratados con cualquiera de las concentraciones de nicotina (Fig. 52C). El incremento en el número de bastones es significativo en las concentraciones de 10, 20 y $40 \mu \mathrm{M}$. En el estadio de $5 \mathrm{dpf}$, se aprecia que existe una compensación parcial del número de bastones en la retina entre los animales tratados y los ejemplares control (Fig. 52D). Mientras que en los animales tratados con las dosis más bajas (5 y $10 \mu \mathrm{M})$, no hay diferencias significativas en el número de bastones con respecto a los controles, encontramos un aumento significativo en las concentraciones más altas (20 y 40 $\mu \mathrm{M})$, pero menos acusado que en el estadio larvario anterior. 

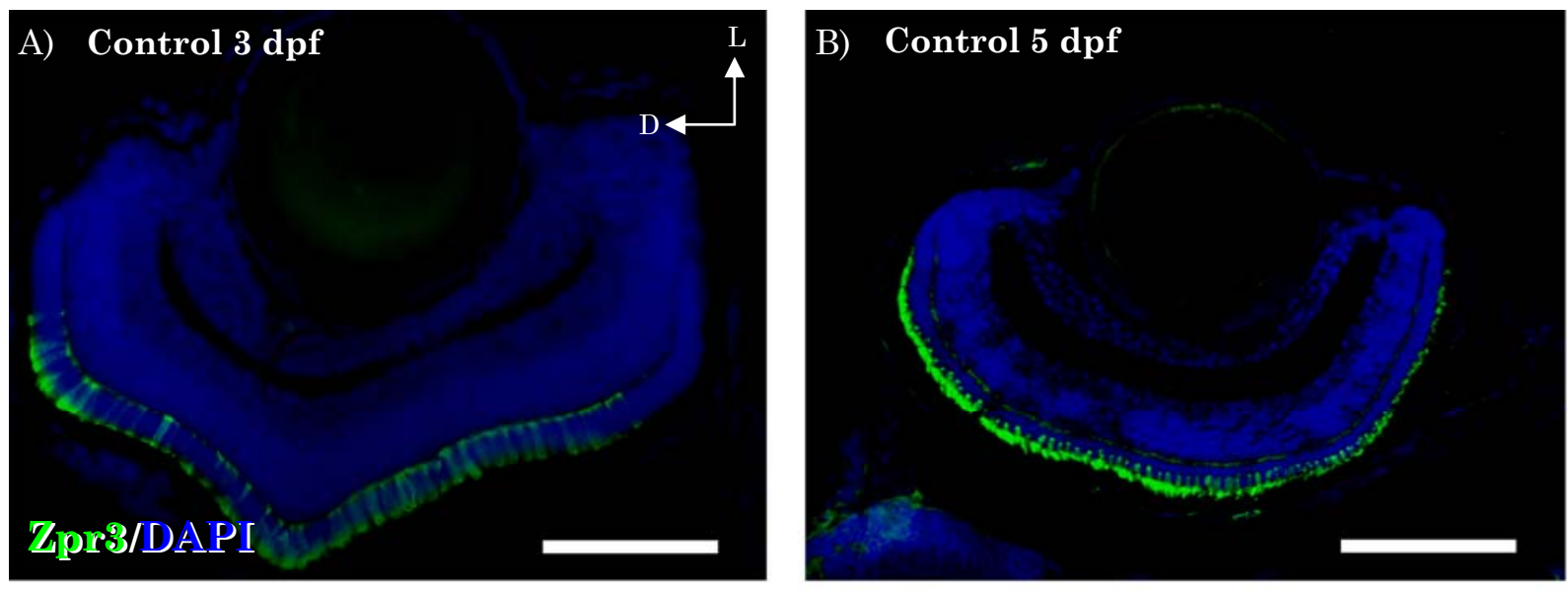

C)

Células Zpr3+ a los 3 dpf

D)

Células Zpr3+ a los 5 dpf

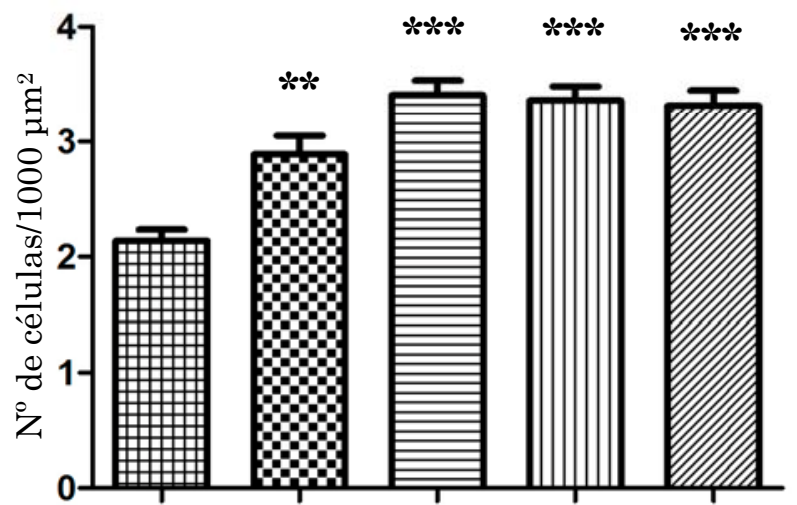

Control $\quad 5 \mu \mathrm{M} \quad 10 \mu \mathrm{M} \quad 20 \mu \mathrm{M} \quad 40 \mu \mathrm{M}$

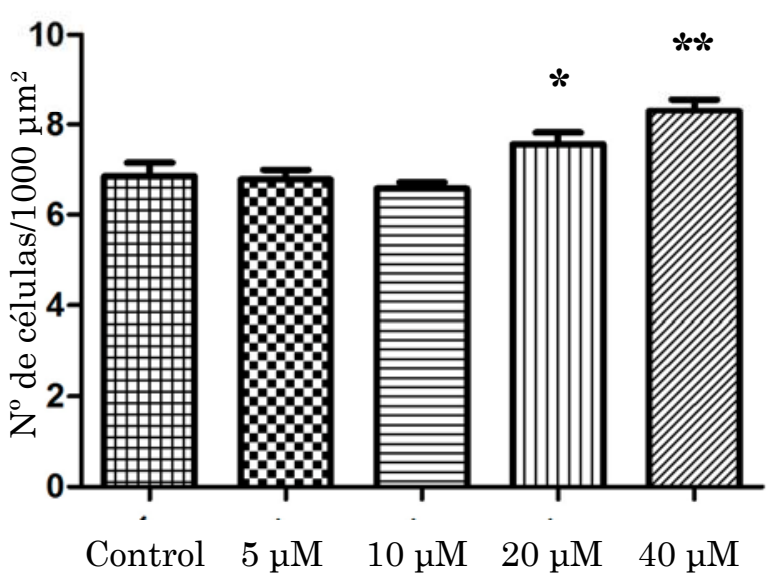

Fig. 52: A) Imagen de una sección coronal de un ojo a los 3 dpf. B) Imagen de una sección coronal de un ojo a los 5 dpf C) y D) Histogramas del recuento de células marcadas con Zpr3 en retinas. C) en larvas de 3 dpf. D) en larvas de 5 dpf. D: Dorsal. L: lateral. * ${ }^{*} p<0,05$. Barra de escala: A) $50 \mu \mathrm{m}$. B) $100 \mu \mathrm{m}$. 


\section{ANÁLISIS DE LOS nAChRs EN LA VÍA VISUAL}

\subsection{Estudio con qPCR de la expresión de los nAChRs}

Los efectos de la nicotina son el resultado de su acción sobre el receptor nicotínico de acetilcolina (nAChR). Los nAChRs se distribuyen ampliamente en la gran mayoría de los organismos y, cuando se activa el, nAChR se abre para permitir que fluyan cationes a través de la membrana plasmática de las células. Cada nAChR está compuesto por cinco subunidades que están ensambladas de manera que dejan un canal en el medio. La combinación de estas subunidades originan las diversas propiedades de los nAChRs. La función principal de los nAChRs es modular la transmisión sináptica. Sin embargo, hallazgos recientes indican que los nAChRs neuronales participan en el desarrollo del sistema nervioso.

Quisimos cuantificar la expresión de estos genes: $n A C h R$ a $6, n A C h R \beta 3 a$, $n A C h R \beta 3 b$, que se encuentran en la vía visual del pez cebra. Analizamos esto mediante PCR cuantitativa, tanto en embriones control, como tratados con las distintas concentraciones de nicotina en los distintos estadios, para conocer como cambia la expresión a lo largo del tiempo de exposición. No se observaron variaciones significativas en la expresión del gen de referencia usado, Ef1a, en ninguno de los grupos experimentales. En las gráficas, el valor 1 corresponde al grupo control.

Mediante qPCR comprobamos que se produce un aumento de expresión del gen $n A C h R$ a6 a lo largo del tiempo de exposición a nicotina, siendo más significativos en las concentraciones mayores. En las concentraciones de nicotina de 5 y $10 \mu \mathrm{M}$, en los diferentes estadios analizados la expresión de este gen se incrementa muy ligeramente. Los valores son muy cercanos a uno, por lo son parecidos a la expresión en el grupo control. Por otro lado, en los animales expuestos a las concentraciones más altas, 20 y $40 \mu \mathrm{M}$, a las 48 hpf no hay 
diferencias de expresión con al grupo control. Mientras que a los 3 y 5 dpf se demuestra un aumento significativo de la expresión de este gen.

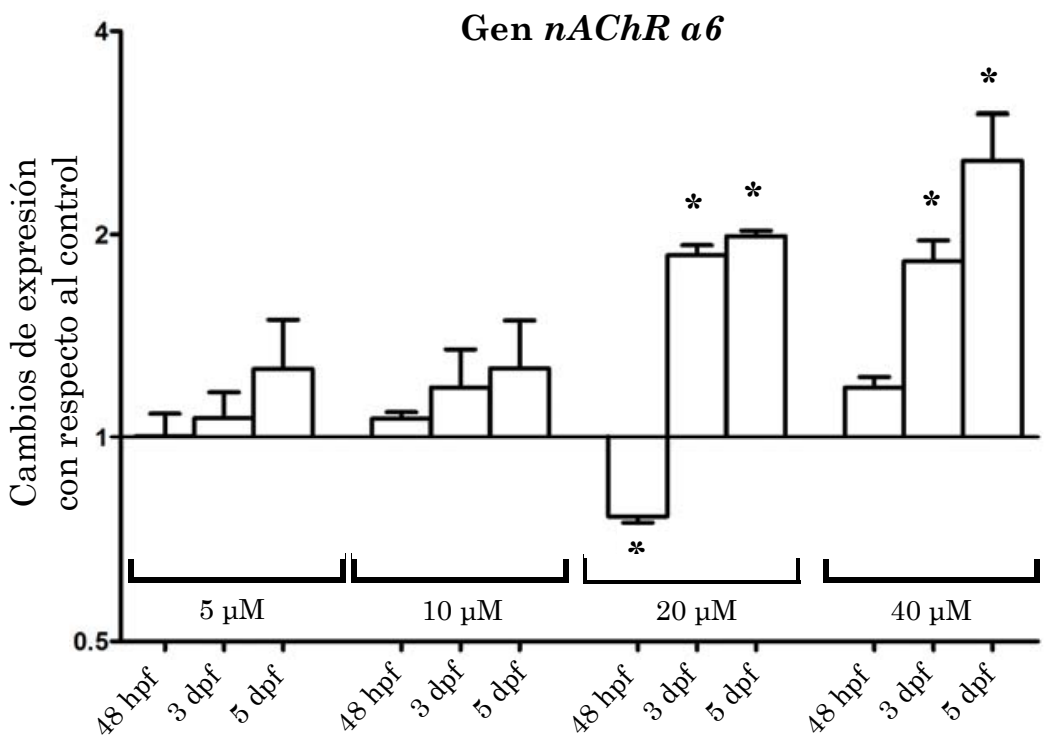

Fig. 53: Niveles de expresión del gen $n A C h R$ a 6 en diferentes grupos experimentales en los estadios de 48 hpf, 3 y 5 dpf por qPCR. Todos los valores están normalizados al gen de referencia Ef1a. La línea horizontal indica el valor del grupo control. A las $48 \mathrm{hpf} \mathrm{no}$ hay grande cambios, pero al seguir con el tratamiento en el tiempo, observamos un aumento de la expresión, sobre todo en la concentraciones de nicotina más altas. * = $\mathrm{p}<0,05$.

Al cuantificar la expresión del gen $n A C h R \quad \beta 3 a$ hay diferencias de expresión dependientes de la concentración de nicotina administrada (Fig. 54). En los animales tratados con $5 \mu \mathrm{M}$ no hay grandes cambios de expresión en los estadios analizados, teniendo valores cercanos a 1. En los ejemplares tratados con $10 \mu \mathrm{M}$ se aprecia un aumento de la expresión a lo largo del tiempo de exposición, pero sin diferencias significativas. En la concentración de $20 \mu \mathrm{M}$, de nicotina a los $3 \mathrm{dpf}$, hay un aumento significativo, de la expresión de $n A C h R$ $\beta 3 a$; esta expresión decrece a los 5 dpf. En los ejemplares tratados con la mayor concentración, $40 \mu \mathrm{M}$, se detecta un aumento significativo a lo largo del tiempo. Los estadios de 3 y 5 dpf, presentan mayor expresión el gen. 


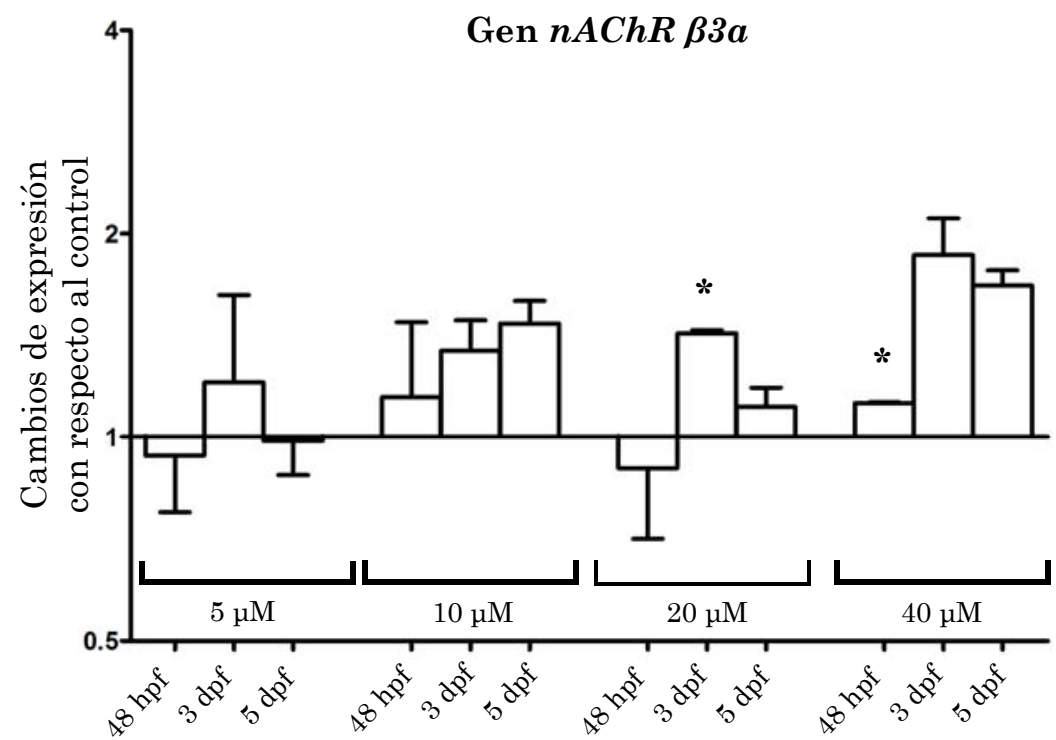

Fig. 54: Niveles de expresión del gen $n A C h R \beta 3 a$ en diferentes grupos experimentales en los estadios de $48 \mathrm{hpf}, 3 \mathrm{y}$ 5 dpf por qPCR. Todos los valores están normalizados al gen de referencia Ef1a. La línea horizontal indica el valor del grupo control. Hay variaciones significativas en las concentraciones mayores. ${ }^{*}=$ $\mathrm{p}<0,05$.

El análisis del gen $n A C h R \beta 3 b$ mediante la técnica qPCR ofrece unos valores de expresión que demuestra que en las distintas concentraciones (Fig. 55), hay una disminución en la expresión en el estadio de 48 hpf, que es significativa en la concentración de $5 \mu \mathrm{M}$. Mientras que a los 3 y 5 dpf existe un aumento no significativo en la expresión del gen.

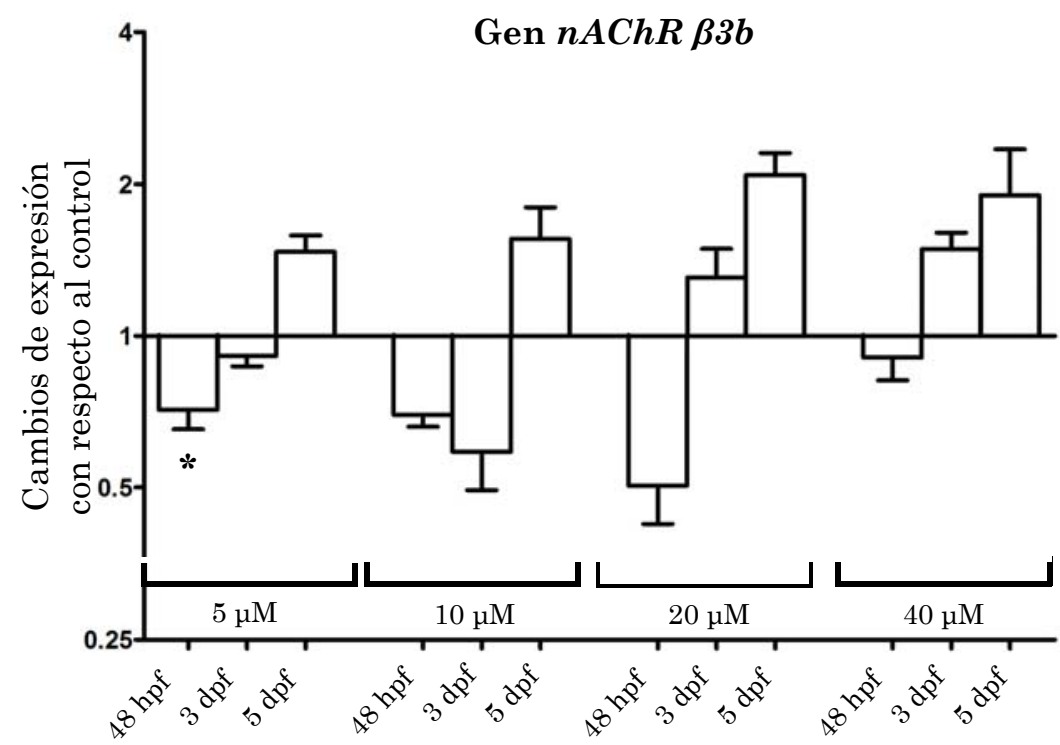

Fig. 55: Niveles de expresión del gen $n A C h R \beta 3 b$ en diferentes grupos experimentales en los estadios de $48 \mathrm{hpf}, 3 \mathrm{y}$ 5 dpf por qPCR. Todos los valores están normalizados al gen de referencia Ef1a. La línea horizontal indica el valor del grupo control. En todas las concentraciones, disminuye la expresión 48 hpf. $\mathrm{Al}$ aumentar el tiempo de administración de la nicotina, aumenta la expresión del gen. $*=p<0,05$.

\subsection{Estudio con hibridación in situ de la expresión de los nAChRs}

Para corroborar los resultados sobre los niveles de expresión de estos genes, utilizamos sondas de RNA para la detección de los correspondientes 
RNAm in situ. Hemos seleccionado aquellos receptores nicotínicos cuyas subunidades se expresan en estructuras visuales del pez cebra. Los receptores estudiados son el nAChR a6, nAChR B3a y nAChR B3b. Para revelar el patrón de expresión temporal y espacial de estos receptores durante el desarrollo, realizamos un estudio con HIS en diferentes estadios.

\section{$\underline{\operatorname{nAChR~a6}}$}

- Animales control

En embriones de 48 hpf (Fig. 56), se encuentra el nAChR a6 en la retina, concretamente en la CCG. También hay marcaje en un pequeño grupo de células en el TO, en su parte más caudal. En estructuras no visuales el nAChR a6 se expresa en la glándula pineal (GP) y en los ganglios trigéminos (GT).

En el estudio de 3 dpf (Fig. 57) el marcaje se mantiene en las mismas estructuras que a las 48 hpf, pero más extenso. Además el marcaje en la CCG de la retina, se aprecia un ligero marcaje en la CNI. Por otra parte, la extensión de la expresión de la subunidad a6 en el TO es mucho mayor que en el estadio anterior. Las estructuras no visuales, como la glándula pineal y los ganglios trigéminos se conserva la expresión de este gen. También encontramos pequeños grupos celulares repartidos por el encéfalo.

En el estadio de 5 dpf (Fig. 58), se marcan las mismas estructuras que en el estadio larvario de 3 dpf. En la retina se marca la CCG y la CNI. También hay expresión de nAChR a6 en el TO y en las estructuras no visuales antes mencionadas.

- Animales tratados con nicotina

El patrón de expresión nAChR a6 analizado en los diferentes grupos tratados con nicotina, presenta un aumento en relación con el grupo control, 
mayor a medida que aumentamos la concentración de nicotina. Además, esta expresión se acentúa a medida que aumenta el tiempo de exposición.

En el estadio de 48 hpf (Fig. 56), el marcaje de la subunidad a6 de los nAChR se localiza en la retina, en la CCG. También se expresa esta subunidad del receptor en el TO, en las estructuras no visuales: en glándula pineal y en ganglios trigéminos. No se aprecian diferencias de expresión entre los grupos tratados con diferentes concentraciones de nicotina.

En el estadio larvario de 3 dpf (Fig. 57) se detecta marcaje en la CCG en la retina y un sutil punteado en la CNI. El patrón de marcaje del RNAm de nAChR a6 se mantiene en el TO y de las estructuras no visuales (glándula pineal y ganglios trigéminos). También encontramos punteado de marcaje sin patrón preciso en el encéfalo de los ejemplares de estudio. La intensidad del marcaje en animales de 3 dpf tratados con nicotina aumenta al subir la dosis de tratamiento, por lo que los grupos de 20 y $40 \mu \mathrm{M}$ de nicotina muestran más marcaje en las zonas mencionadas anteriormente.

En el estadio larvario de 5 dpf (Fig. 58), el marcaje se mantiene en las mismas regiones que en el estadio larvario anterior, pero más extenso debido a la maduración de sus estructuras. En este estadio no se aprecia diferencias significativas del marcaje asociada a las concentraciones de nicotina utilizada. 
Resultados

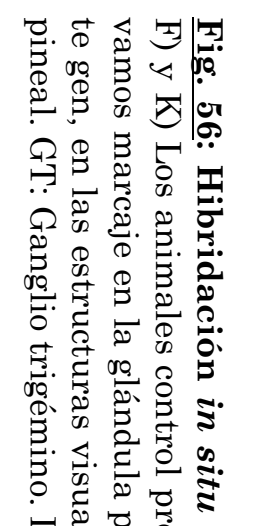

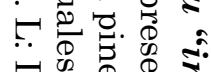
舟出造遇 要 可

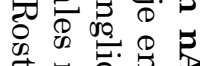

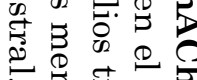

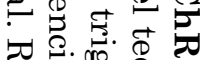

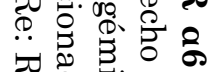
苦. 设 요유 电. $\subseteq$. की

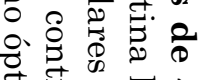
की पूڤ बी भ ०ै बी 里 0 .

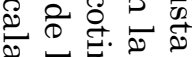

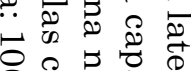
○

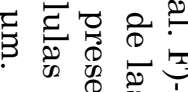

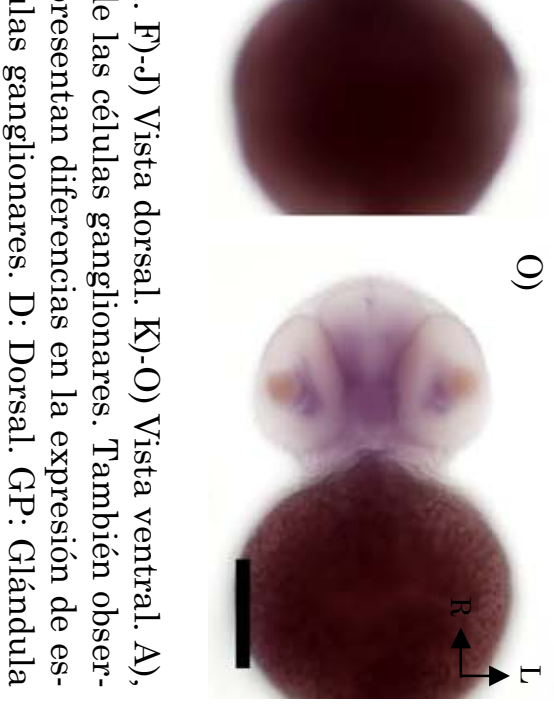

D

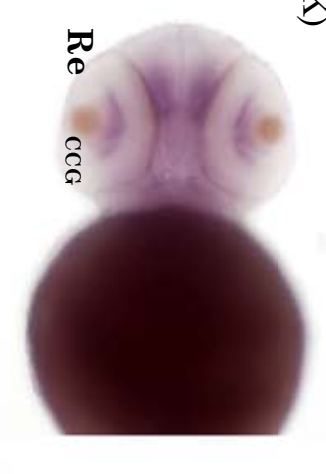

5

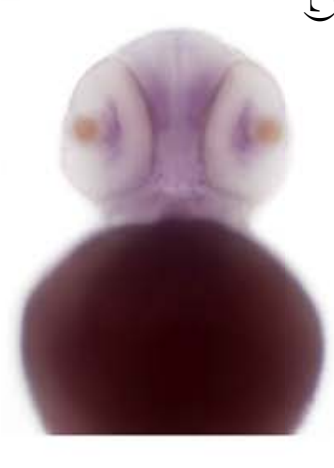

3
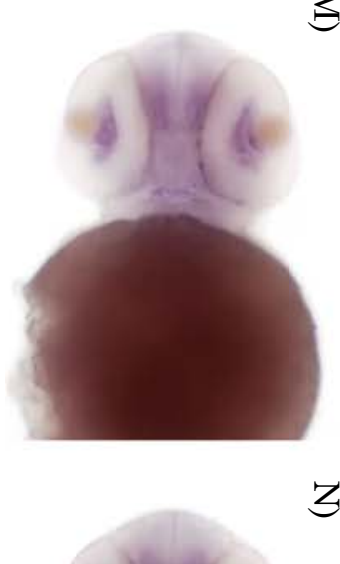

z

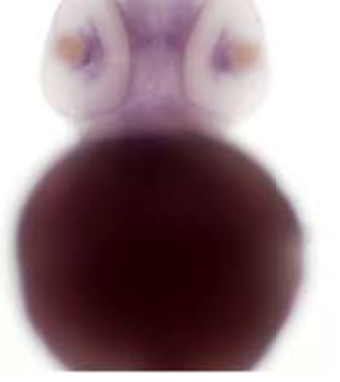

인

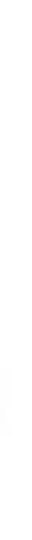

$\Omega$

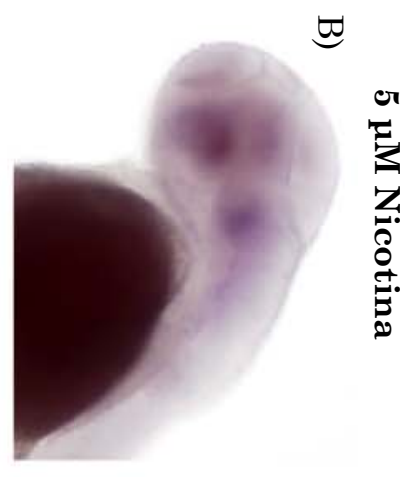

$\Xi$

$\Omega$

苍

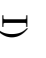

$\bigoplus$

ס.

$\sqrt{-1}$

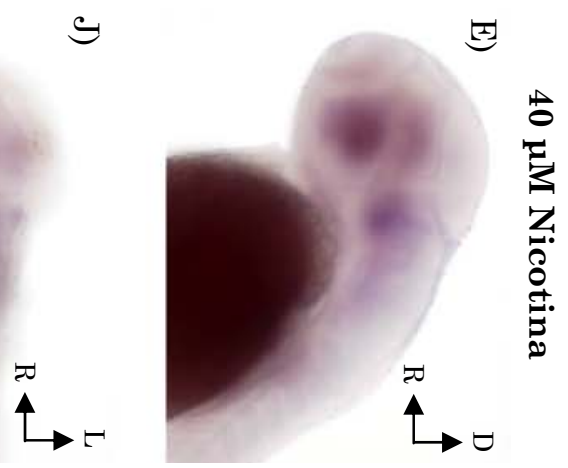




\section{Resultados}
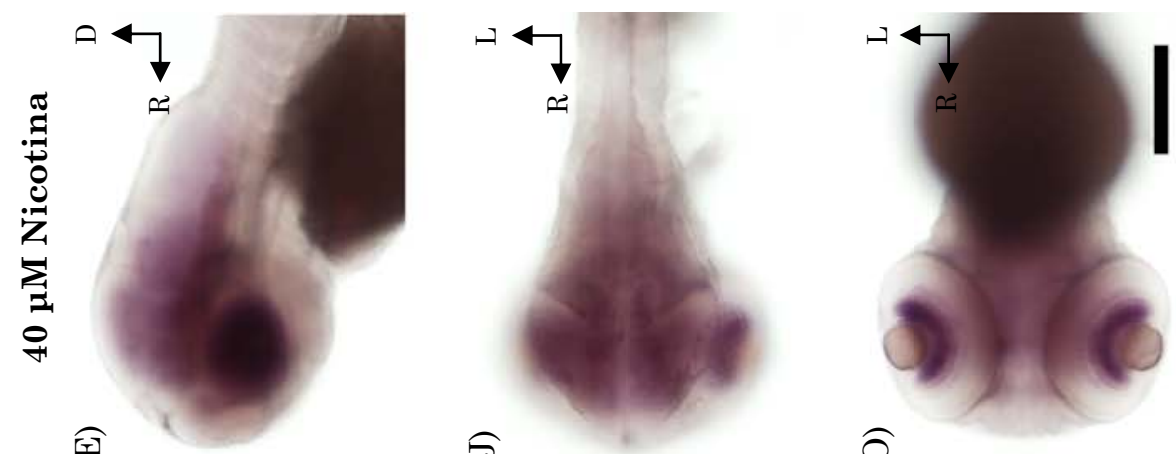

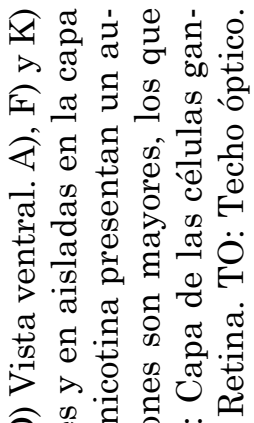

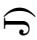

$\widehat{o}$
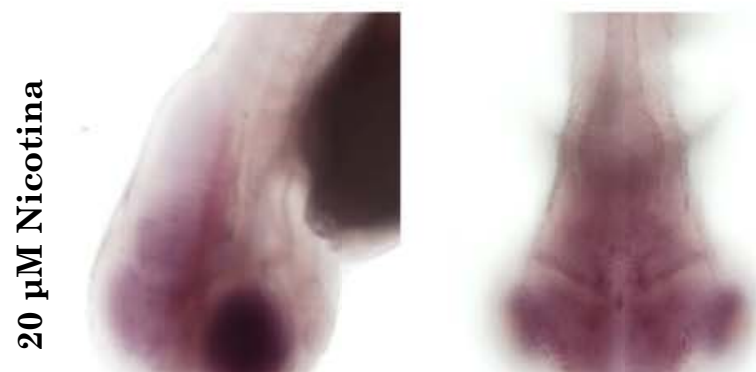

$\widehat{\cap}$

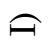
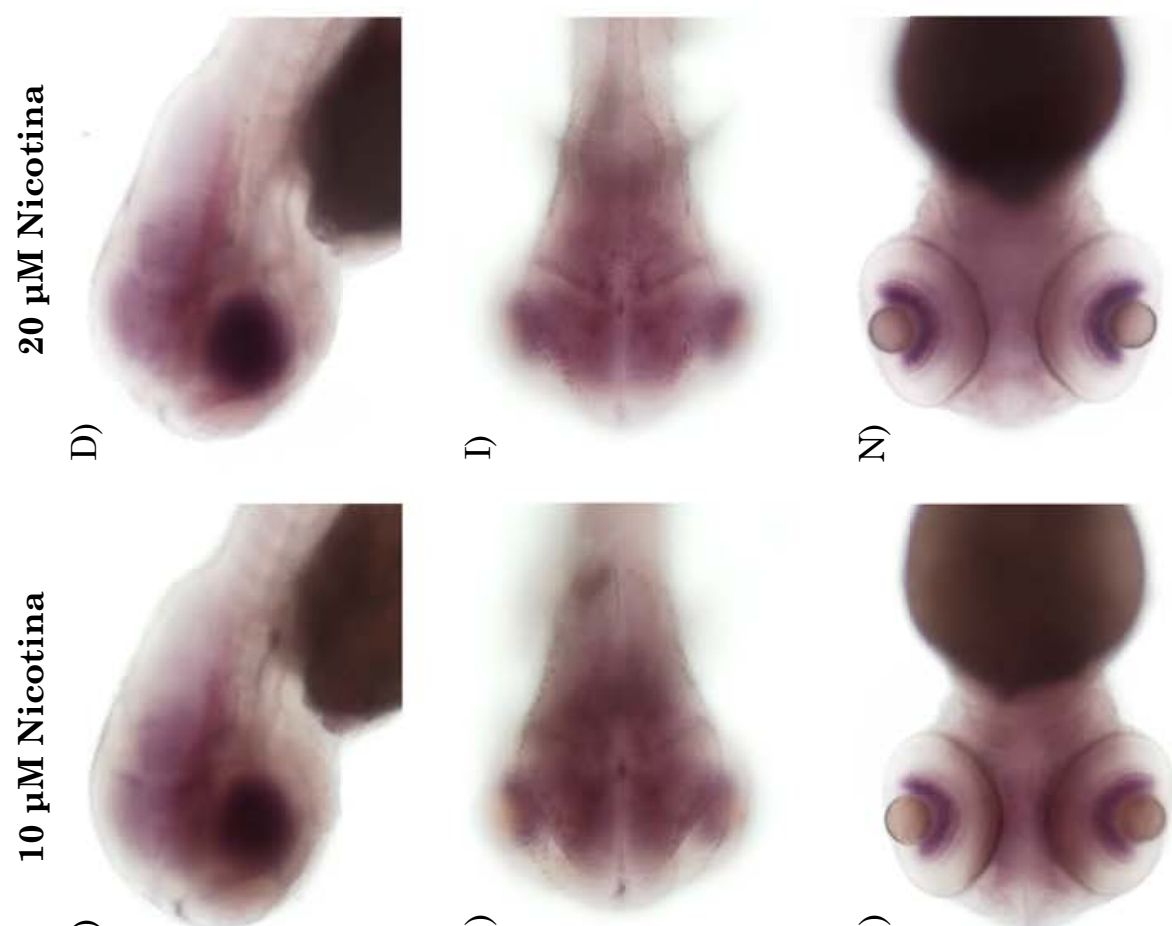

0

I

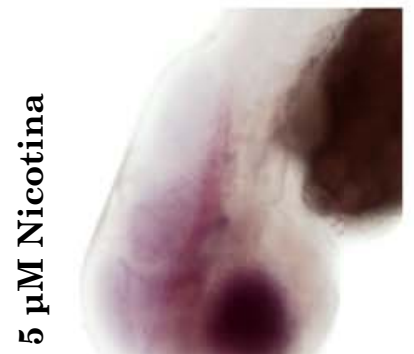

กิ

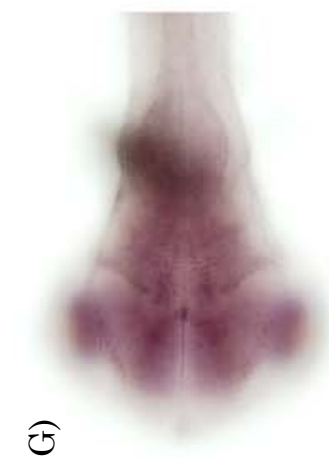

必
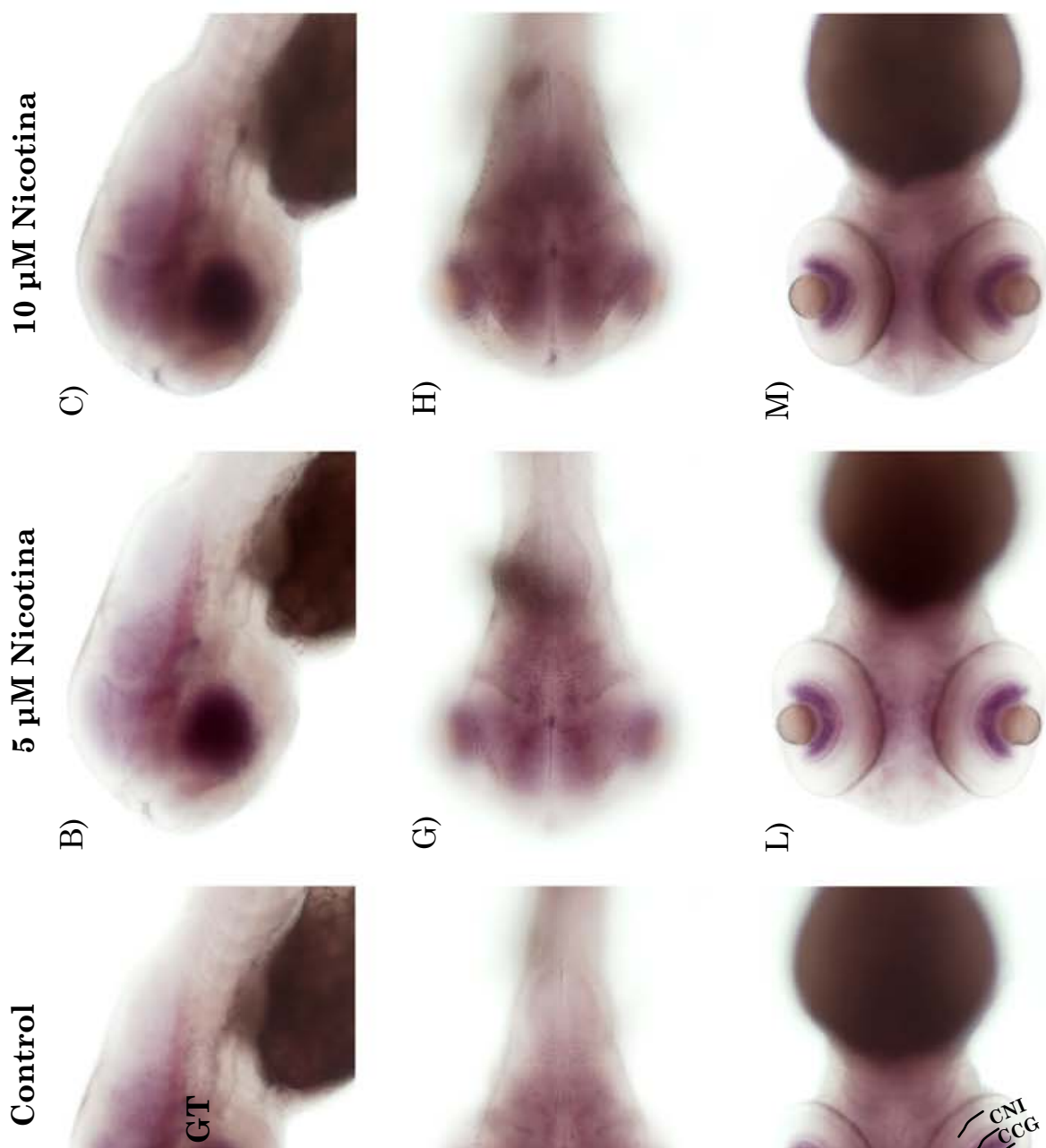

$\stackrel{\circ}{H}$

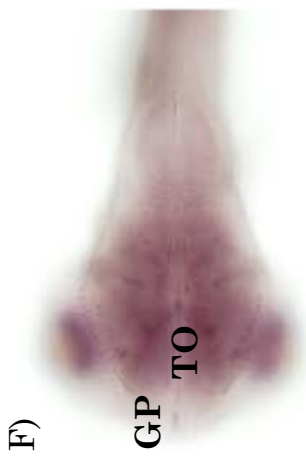

ব

क्ष

王

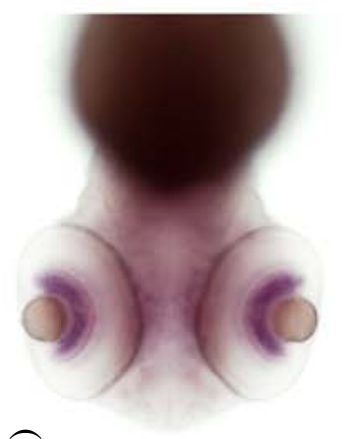

$\widehat{\Im}$

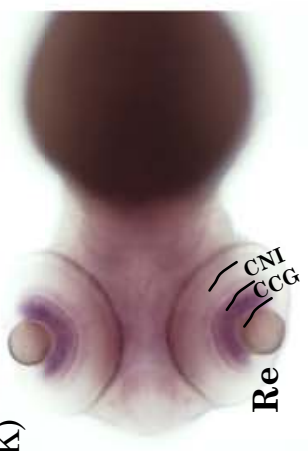

○ิ बृ.

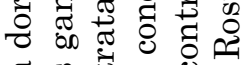

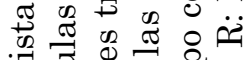
ᄀ宓范 个ิ ธ่ 密

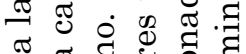

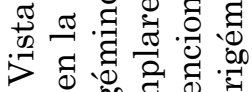
(0)

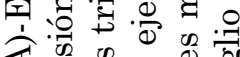

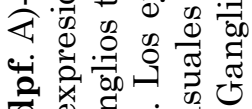

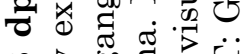

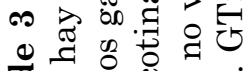
ช ปै.

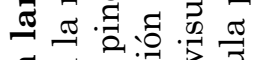

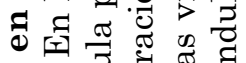
ช. 술

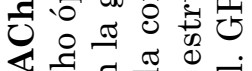

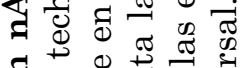
ฮี ¿0. 雨

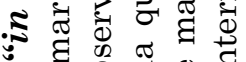

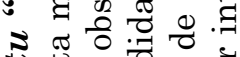

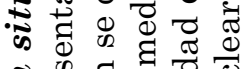

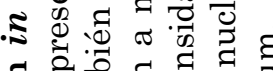

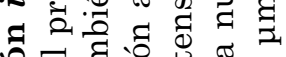
:0ี

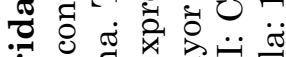

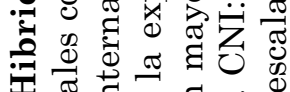
I เి.

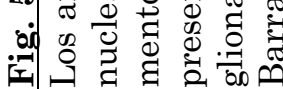


Resultados

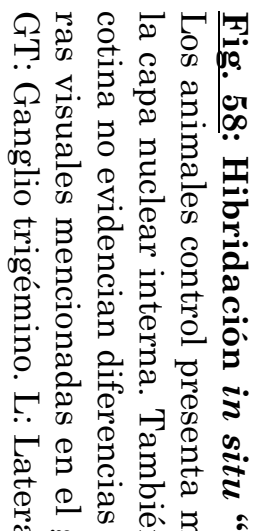

क 10.0

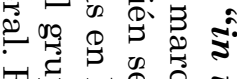

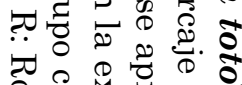

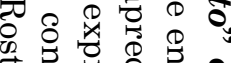

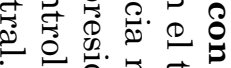

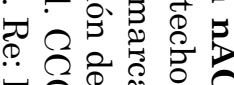

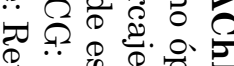

志

$\rightarrow$ 过

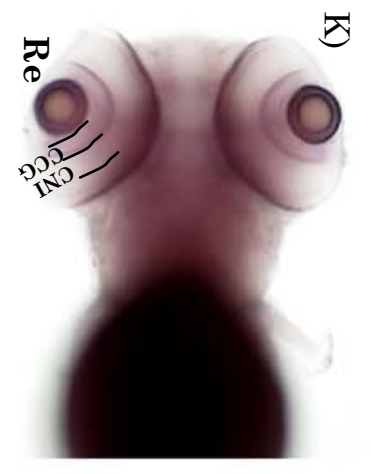

$\sqrt{1}$
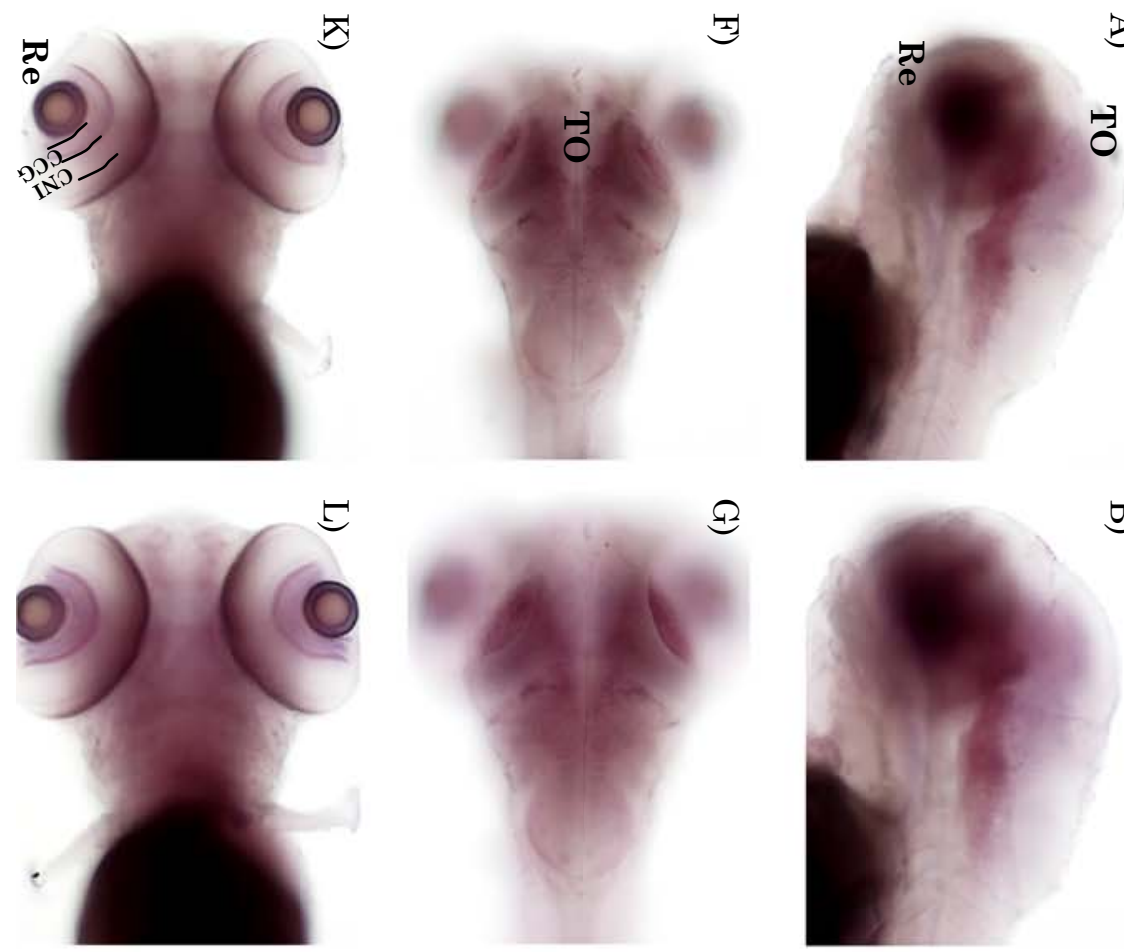

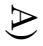

0

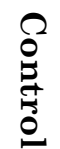

$\rightarrow$ कृ

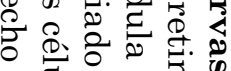

응 ఐ

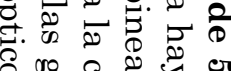

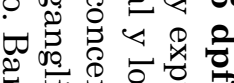

룽유

—.

( ) क 용.

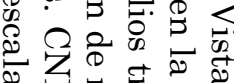
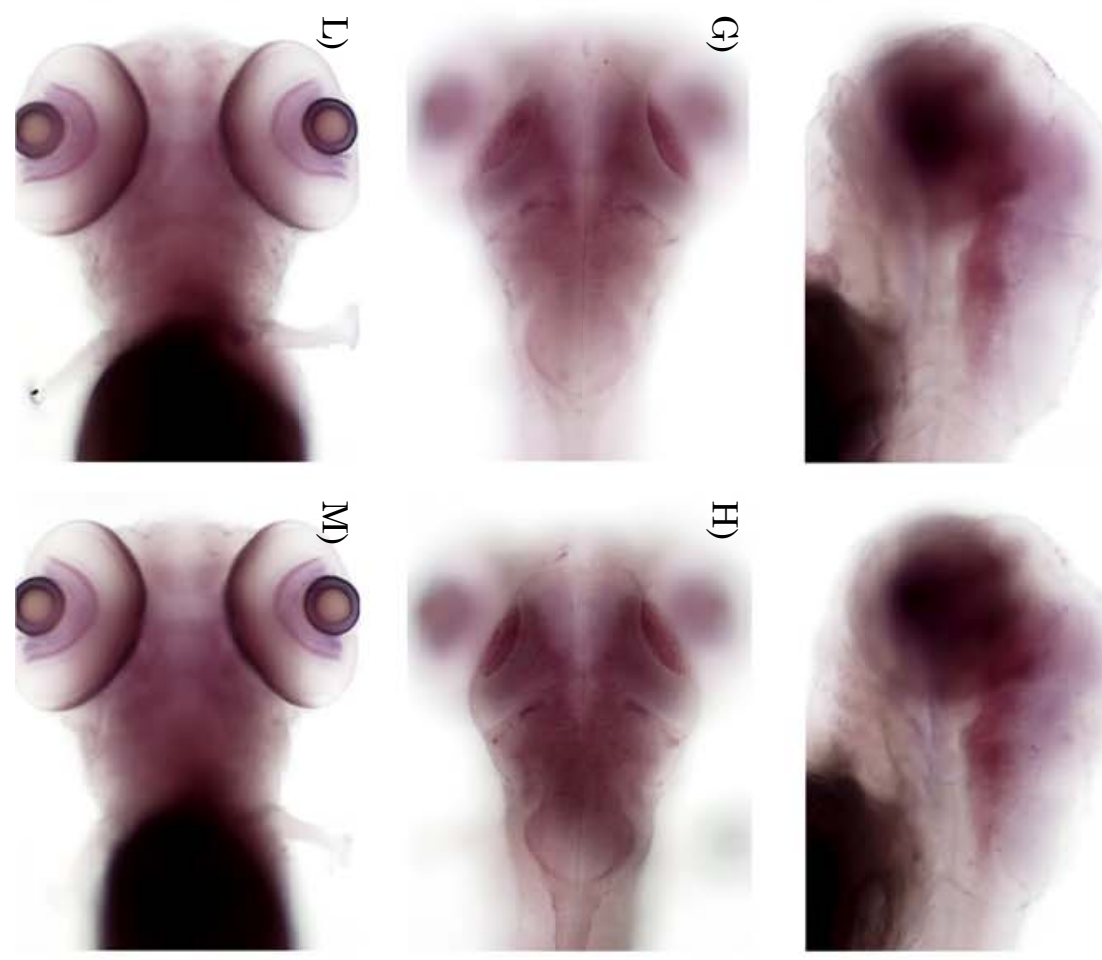

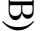

er

○)

ह

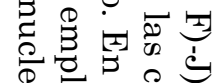

पर

E. शे की

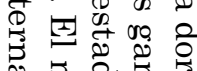

$\forall$ 車

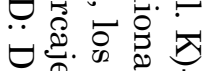
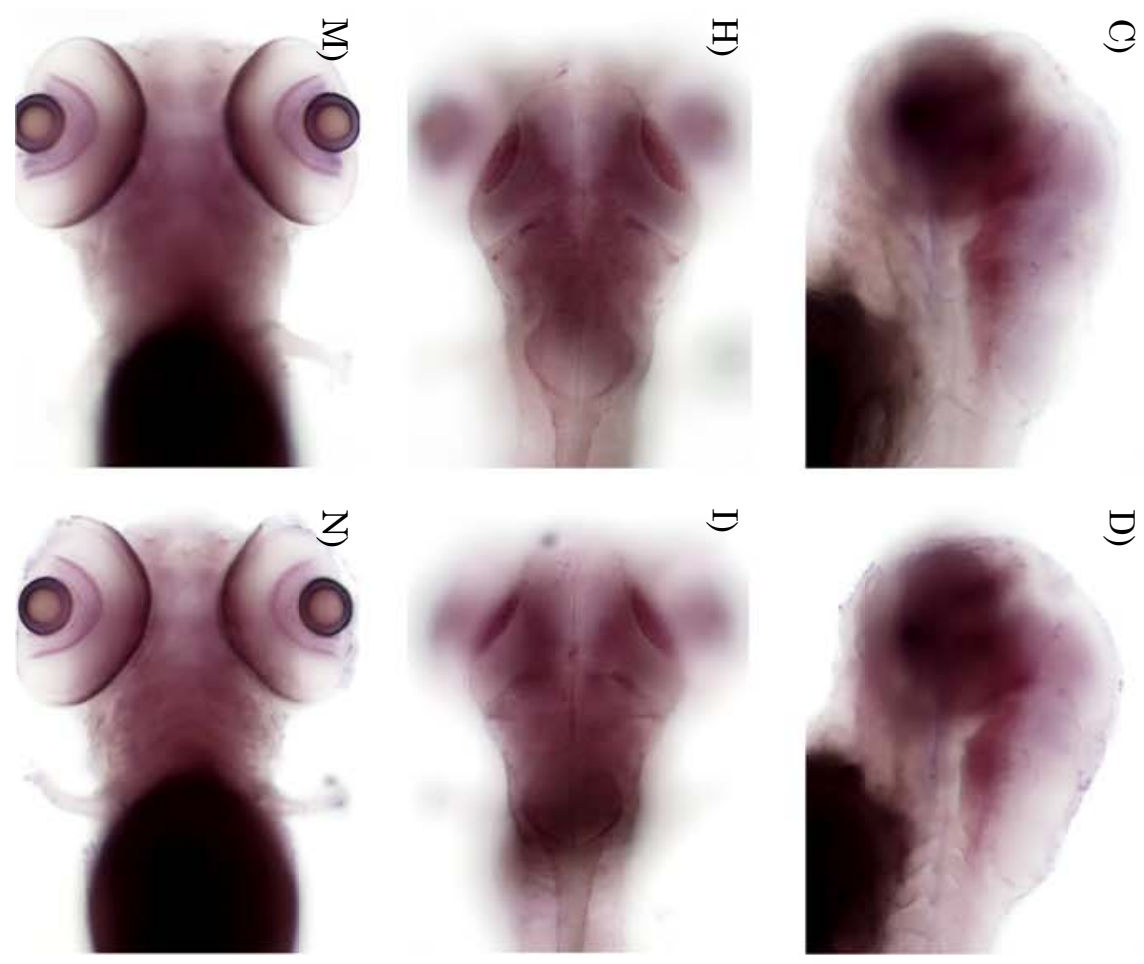

匀

Dी

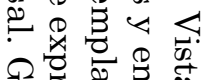

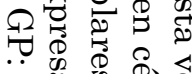

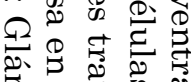

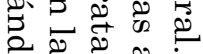

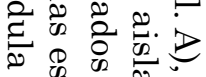

일.

?
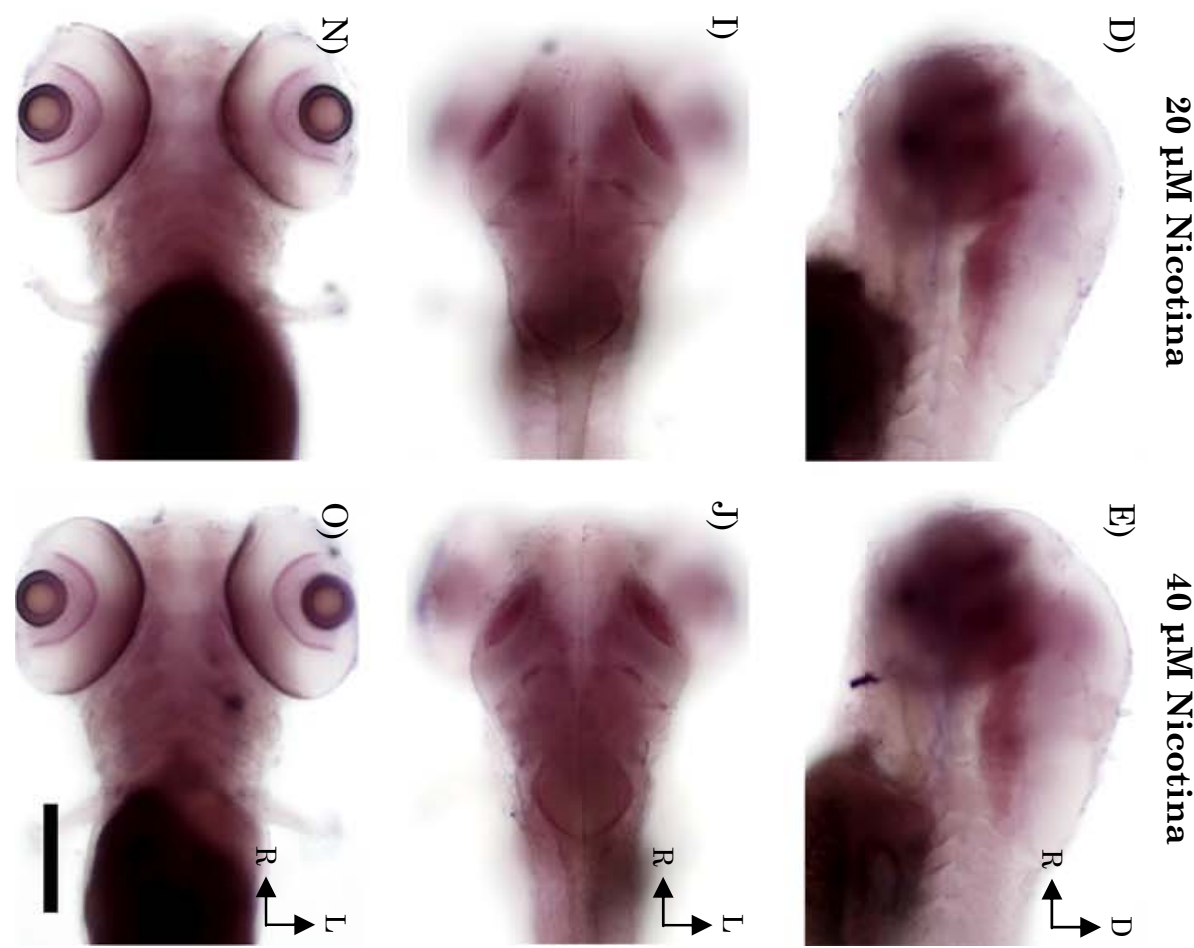

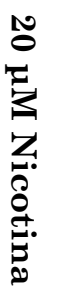
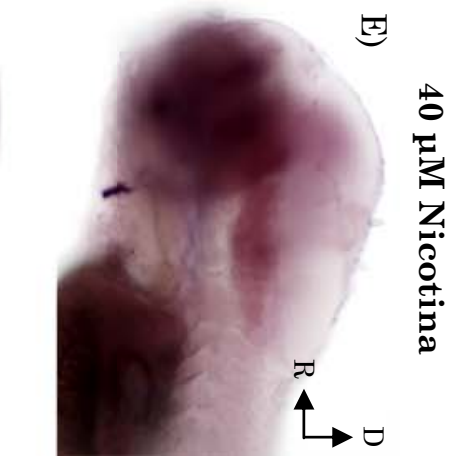


\section{$\underline{\text { nAChR ß3a }}$}

- Animales control

En el estadio de 48 hpf (Fig. 59) se expresa nAChR B3a en la CCG de la retina, de la zona mas central. También hay marcaje en la glándula pineal, en los ganglios trigéminos y pequeños grupos de células dispersas por el encéfalo.

En el estadio de 3 dpf (Fig. 60), se aprecia el marcaje en toda la extensión de la CCG. En este estadio observamos marcaje en estructuras mesencefálicas, como el TO. También se mantiene el marcaje glándula pineal, en los ganglios trigéminos y pequeños grupos de células dispersas por el encéfalo.

En el estadio larvario de 5 dpf (Fig. 61) el marcaje para el RNAm de nAChR 63a se mantienen en toda la extensión de la CCG de la retina, en el TO y en las estructuras no visuales como la glándula pineal y en los ganglios trigéminos. Además hay marcaje en pequeños grupos de células dispersas por el encéfalo.

- Animales tratados con nicotina

A las 48 hpf (Fig. 59), se expresa la subunidad B3a de los nAChR en la CCG de la retina, pero limitado a la retina central. Este marcaje también se encuentra en la glándula pineal, en los ganglios trigéminos y en un punteado disperso por el encéfalo de los animales. Los tratamientos con concentraciones de nicotina de 5, 10, $20 \mu \mathrm{M}$ ofrecen notables reducciones de expresión en comparación con los controles, pero poco entre ellas. El tratamiento con dosis de $40 \mu \mathrm{M}$ producen intensidades de marcaje próximos a los controles.

Tras la eclosión (3 dpf) la expresión de nAChR B3a (Fig. 60) se mantiene en las mismas estructuras que en el grupo control: CCG de la retina, glándula pineal y ganglios trigéminos. Pero el marcaje, en este estadio es más extenso, debido al desarrollo de las estructuras. A los 3 dpf se expresa este gen en el TO. 1 
Al contrario que el estadio larvario, los animales tratados con nicotina, presentan un leve aumento de la intensidad del marcaje al aumentar la dosis de nicotina, así este aumento es más destacable en las concentraciones mayores (20 y $40 \mu \mathrm{M})$.

En el estadio larvario de 5 dpf (Fig. 61) se mantiene el marcaje en las mismas estructuras que en el estadio anterior, continuando la extensión debido a la maduración de las estructuras. En este estadio el patrón de marcaje en los animales tratados con nicotina, evoluciona como en el estadio anterior: aumenta la intensidad de marcaje, al incrementar la dosis de nicotina. 


\section{Resultados}
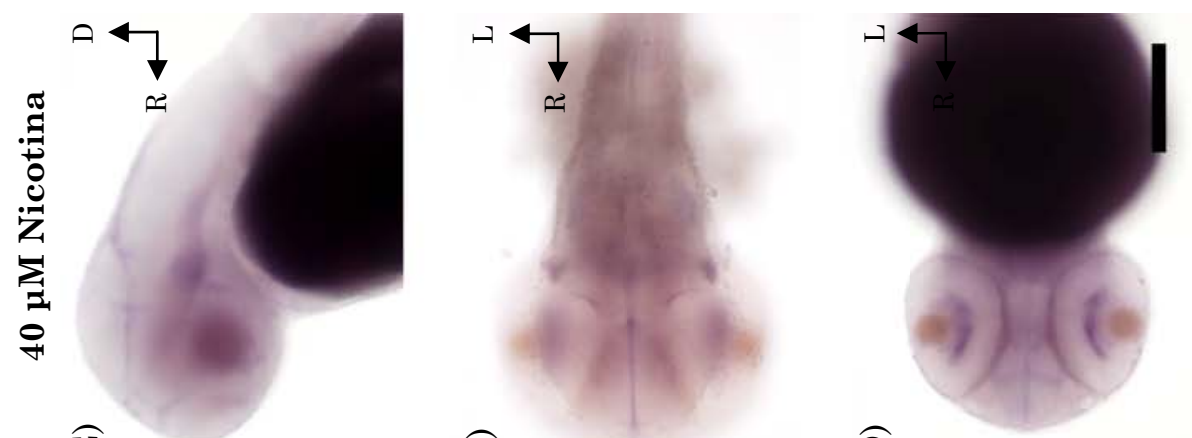

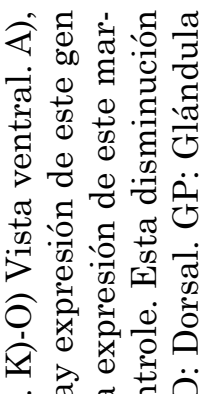

ร

$\widehat{o}$

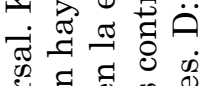
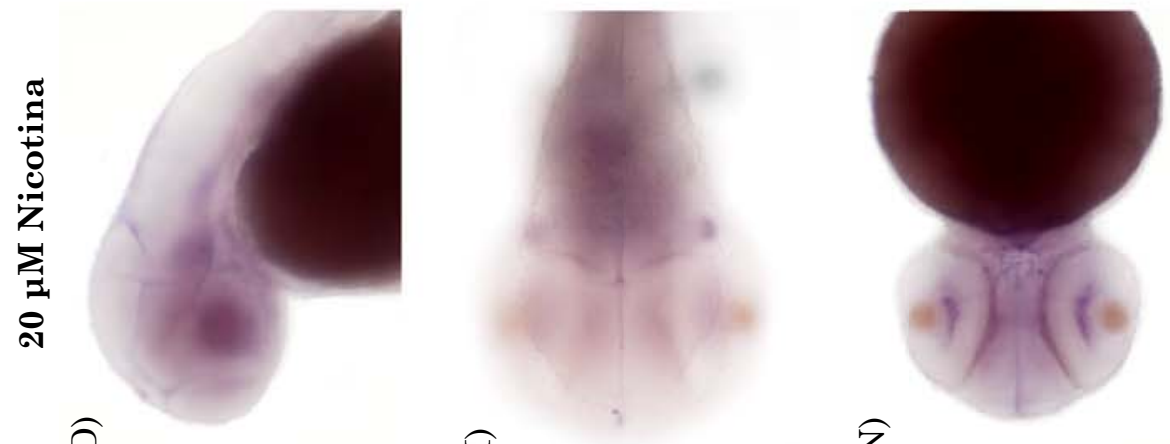

$\widehat{\cap}$

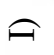

乙

它过

का द्वे ब

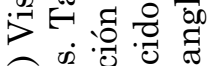

T)

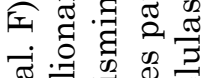

तై

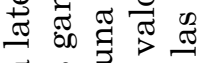

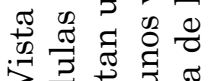

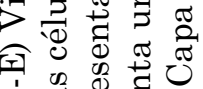

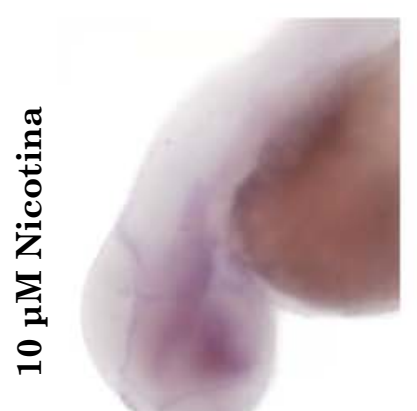

0

王
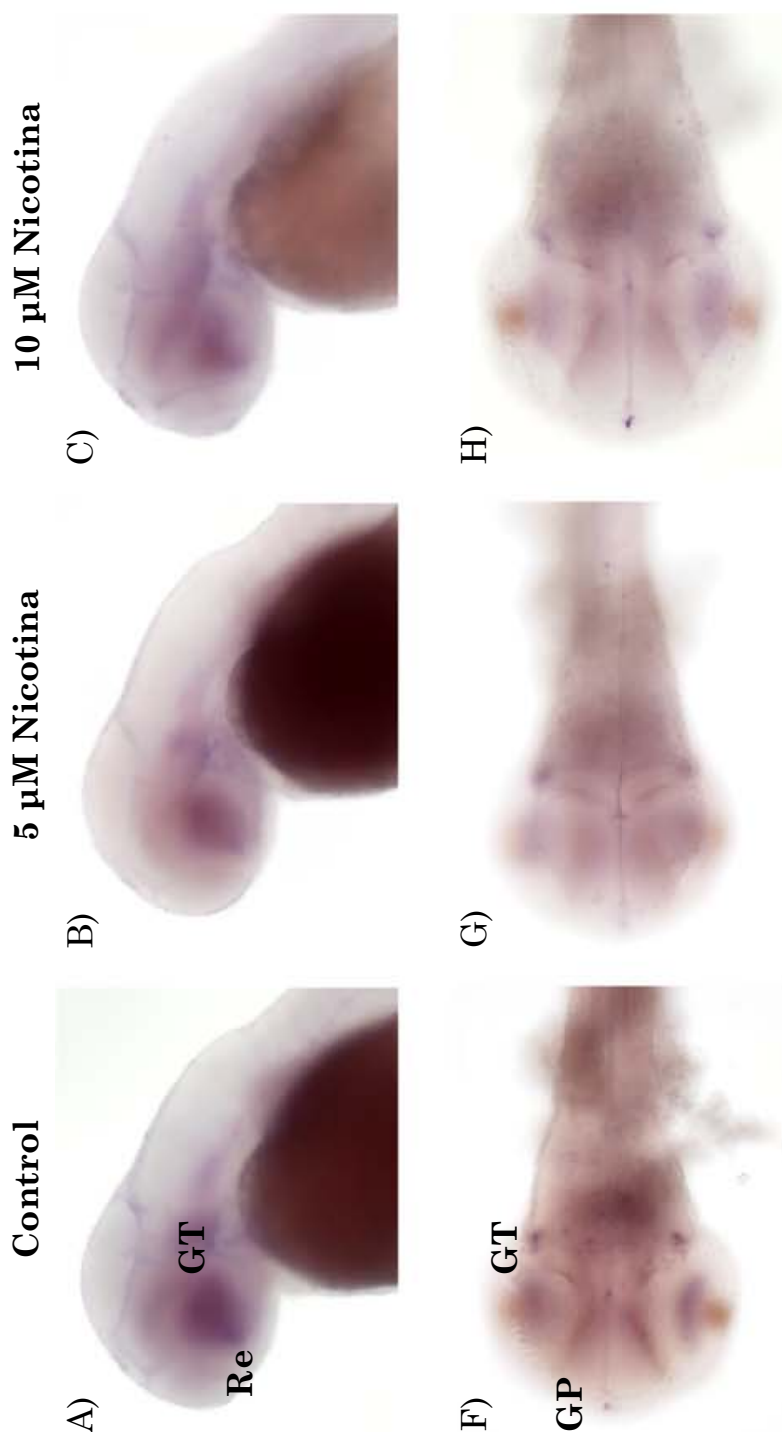

(f)

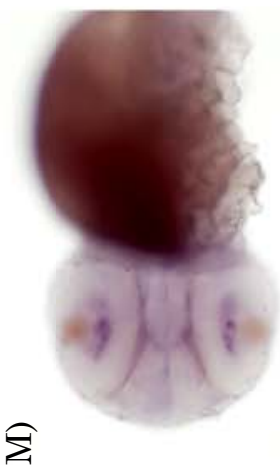

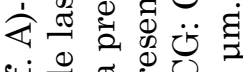

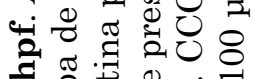

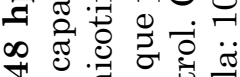
๙

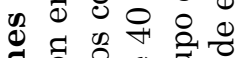

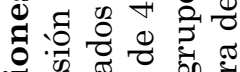

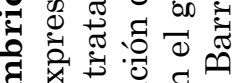
द्व

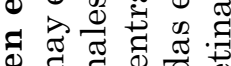

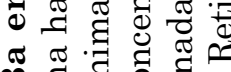
๙ึ. 2 ปี

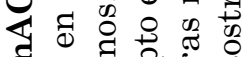

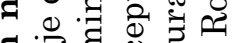

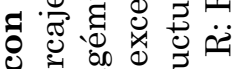

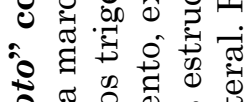

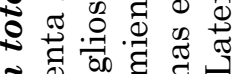
: 0 क

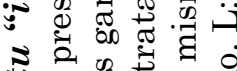

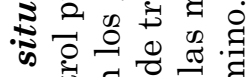

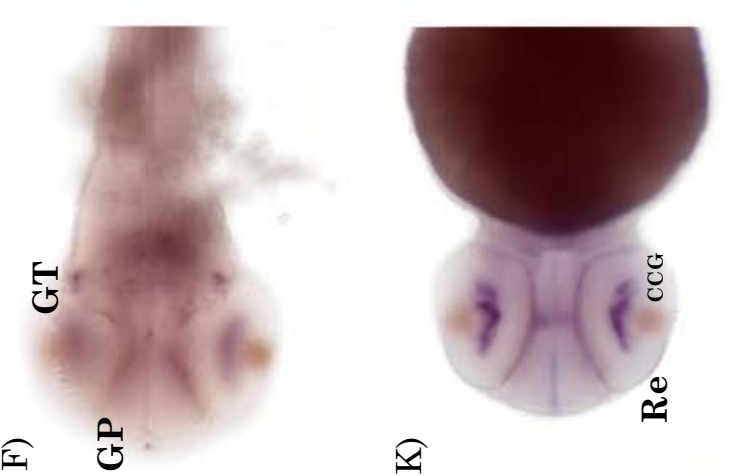

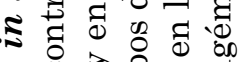

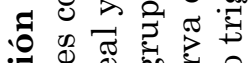
०ै क्षे क्षे

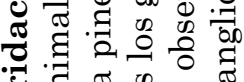
ㅎำ

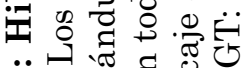
荫结

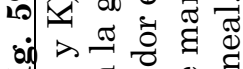

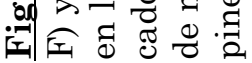



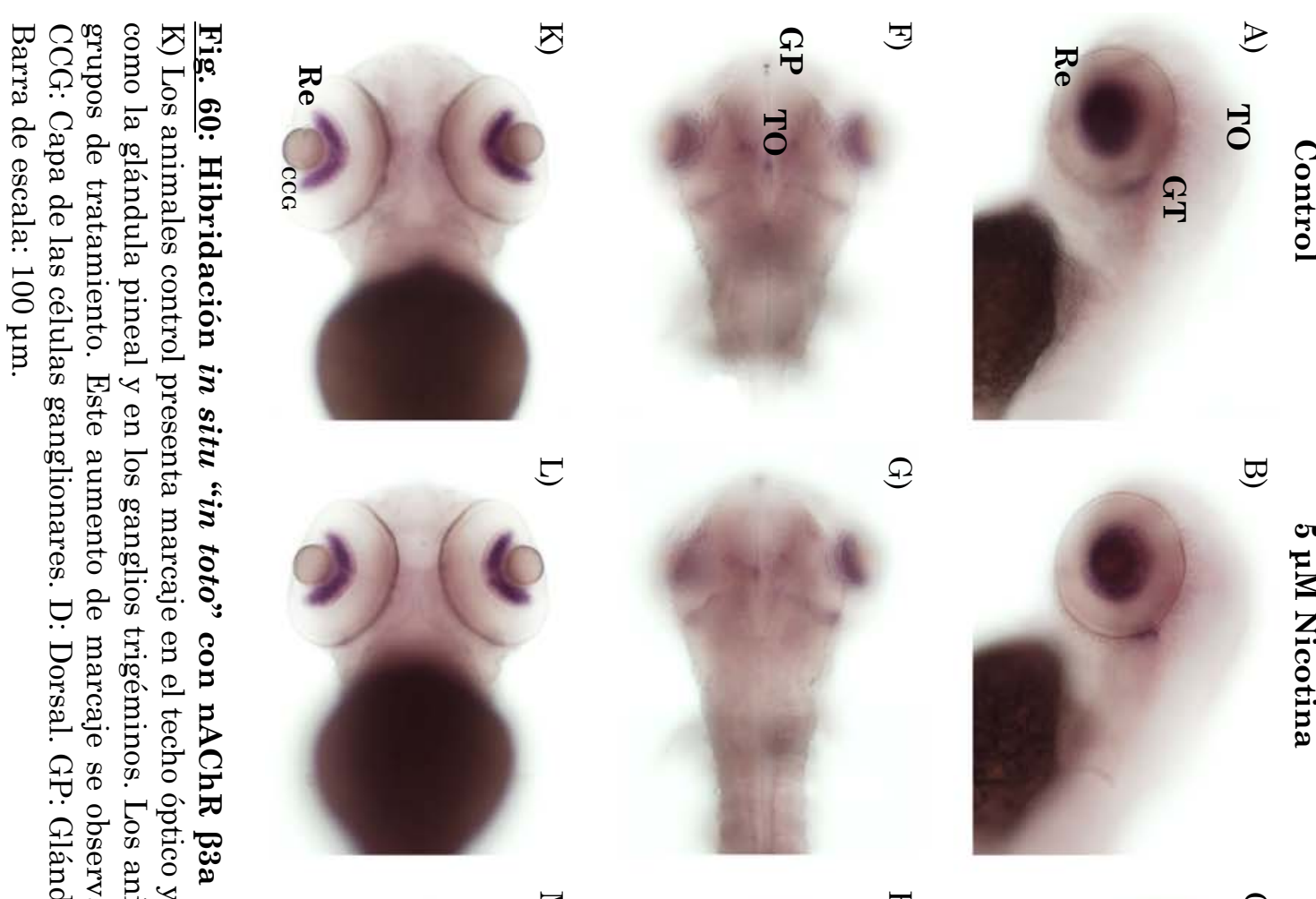

叉
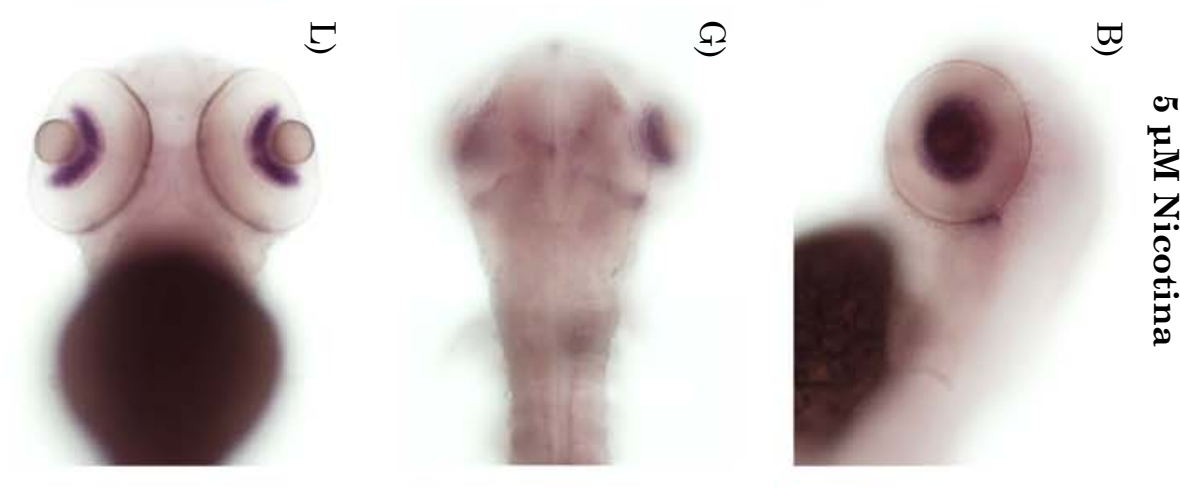

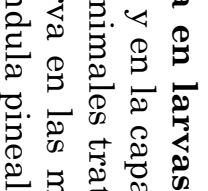

Q है.

零

वे 8 \&

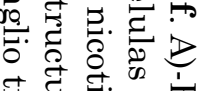

है. है.

约.

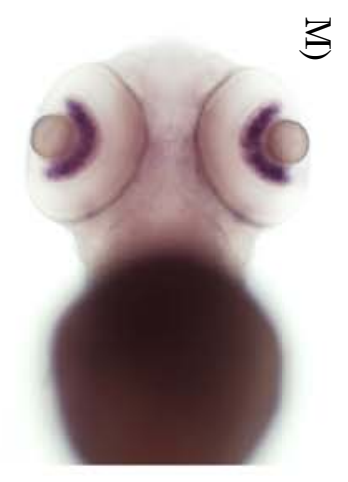

3

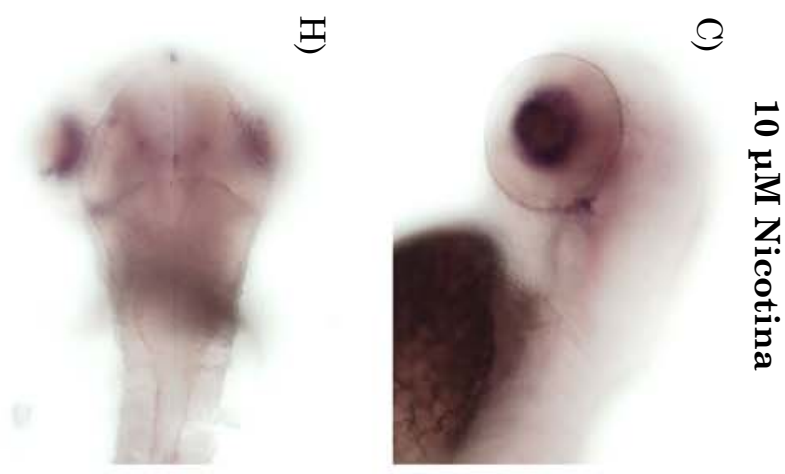

-

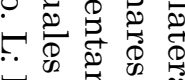

넌

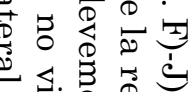

एٕ

एक क क क

के

- 苋完

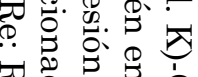

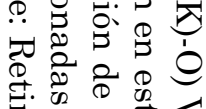

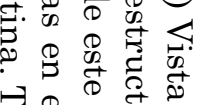

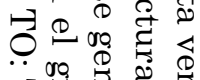

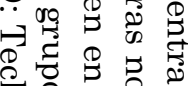

उ००

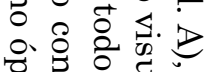

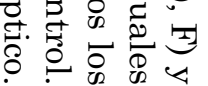

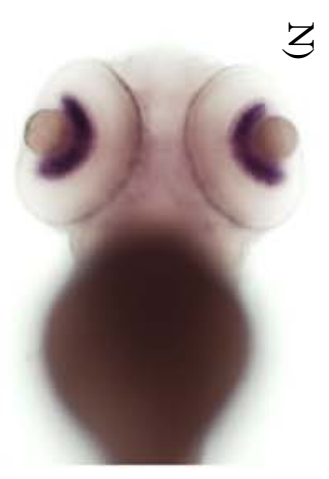

द
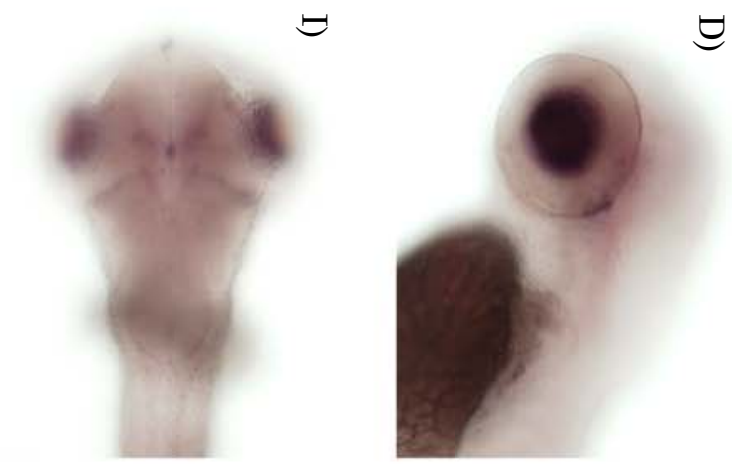

$\vartheta$

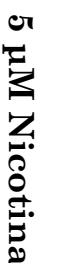

5
0
5
3
$z$
0
0
0
0

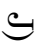

$\mathbb{E}$

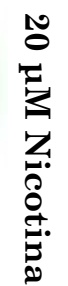
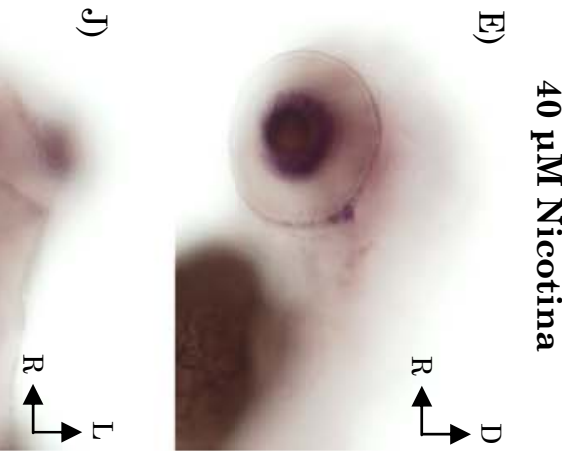


\section{Resultados}
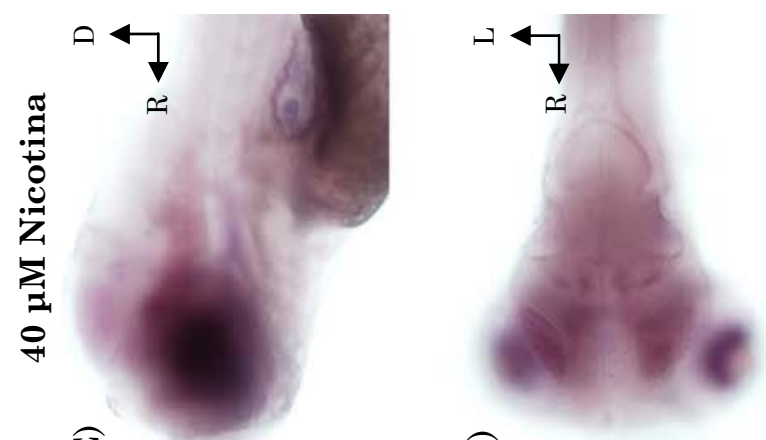

ค

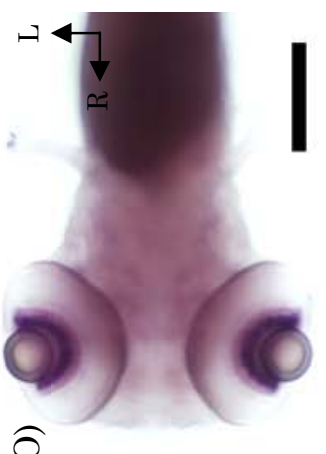

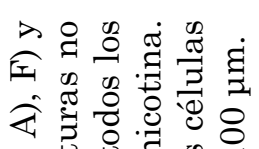

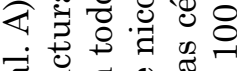

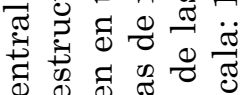

व

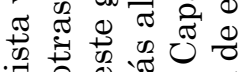

○े व

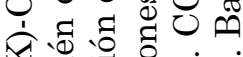

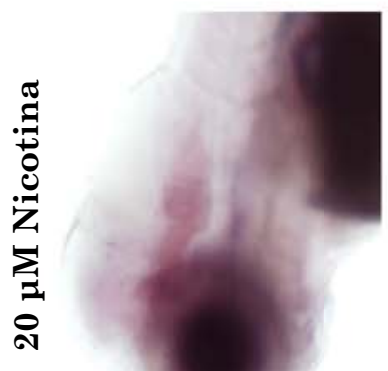

$\widehat{ค}$

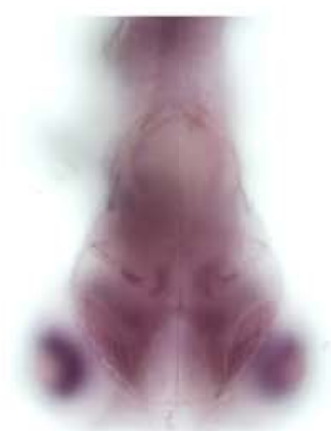

ค

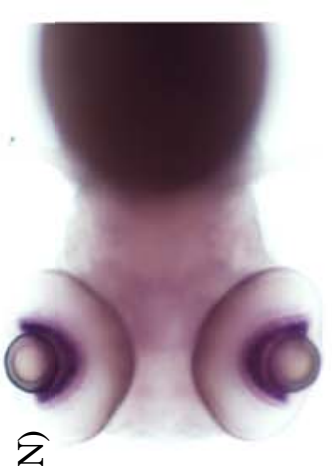

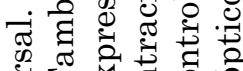

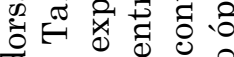

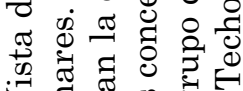

$>$ वี

คे

王芩

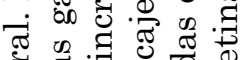

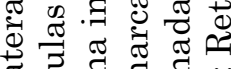

๙

䨔
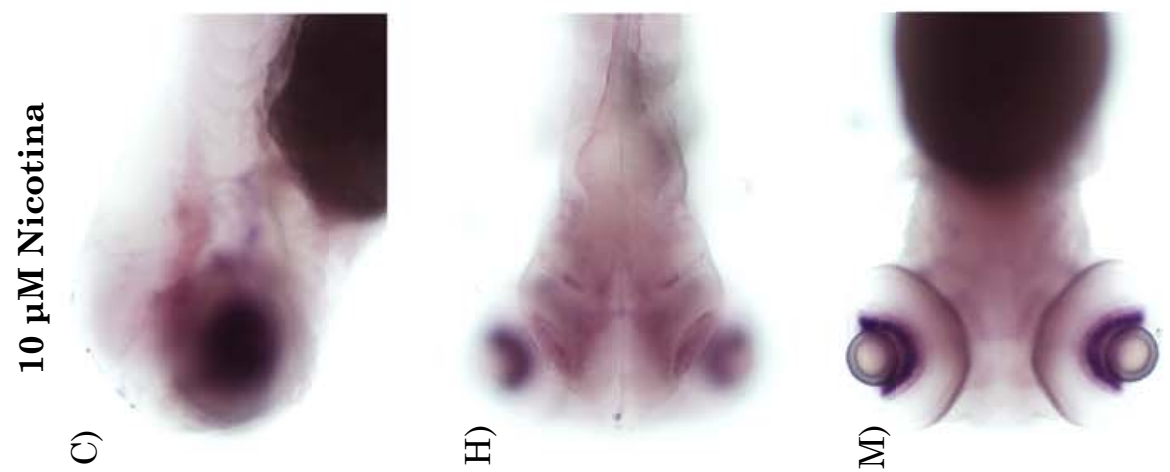

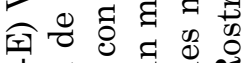

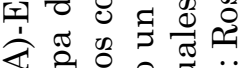

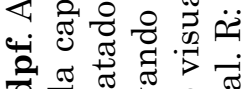

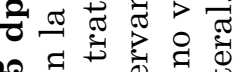

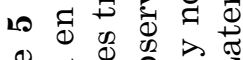
ช $\frac{0}{0}$ वे ขै

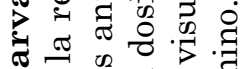

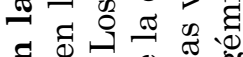
के क्ष

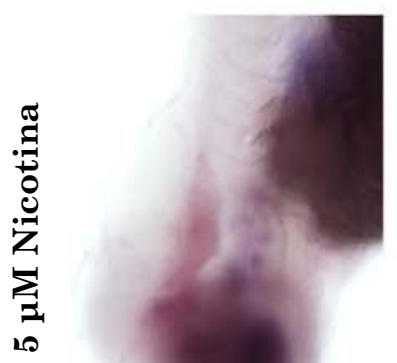

$\widehat{\oplus}$
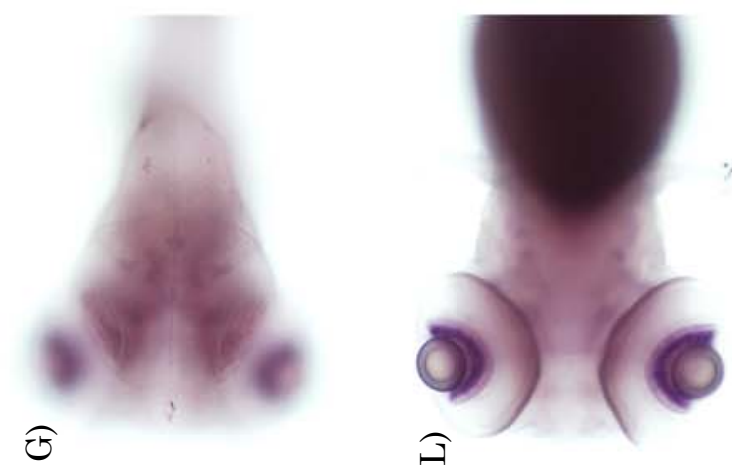

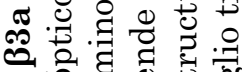

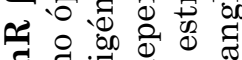

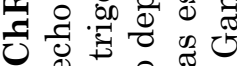

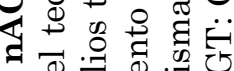

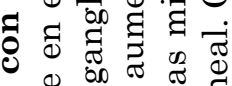
:

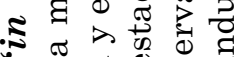
出

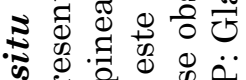
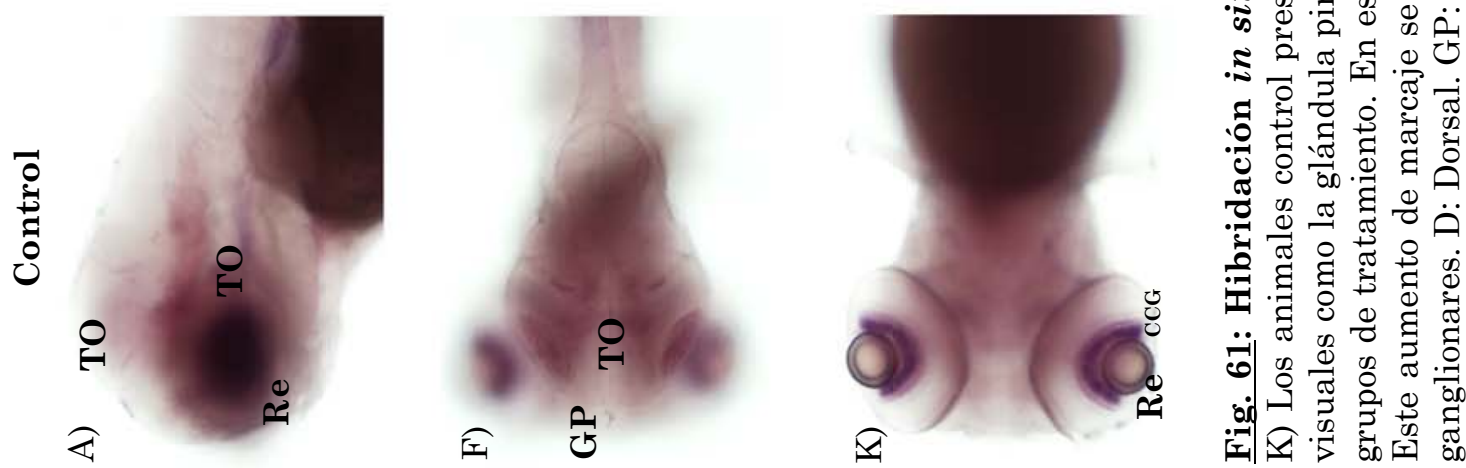


\section{$\underline{\text { nAChR } \beta 3 b}$}

\section{- Animales control}

En el estadio embrionario de 48 hpf no se detecta expresión de nAChR B3b con la técnica de HIS, en ninguna parte del embrión.

En el estadio de 3 dpf (Fig. 62), ya después de la eclosión, aparece marcaje de este transcrito en la retina, en concreto en CCG. Pero no en toda su extensión, sino solo en la retina central. También, al igual que los otros dos marcadores, encontramos marcaje en los ganglios trigéminos.

En el estadio de 5 dpf (Fig. 63) se mantiene la exposición del transcrito de nAChR B3b en la CCG, pero en este estadio el marcaje se observa en toda la extensión de la retina. También se conserva el marcaje en los ganglios trigéminos.

- Animales tratados con nicotina

Aparece marcaje por primera vez después de la eclosión, a los 3 dpf (Fig. 62). nAChR $33 \mathrm{~b}$ se expresa en las mismas regiones que en el grupo control: en la CCG de la retina central y en los ganglios trigéminos. En este estadio los animales tratados con nicotina, reducen la intensidad del marcaje. El grupo que presenta la mayor disminución es el grupo tratado con $5 \mu \mathrm{M}$ de nicotina, los demás grupos presentan reducciones de expresión muy similares entre si en cuanto a la intensidad del marcaje.

En animales tratados con nicotina de 5 dpf (Fig. 63), la expresión de la subunidad $83 b$ de $\mathrm{nAChR}$ se detecta en la CCG de la retina, en toda la extensión, y en los ganglios trigéminos. En este estadio se aprecia una leve disminución en la intensidad del marcaje, de gradación inversa a la concentración de nicotina utilizada: a medida que aumenta la dosis de nicotina, el marcaje es más intenso. 


\section{Resultados}

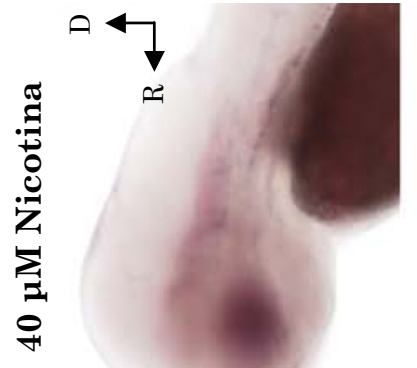

王

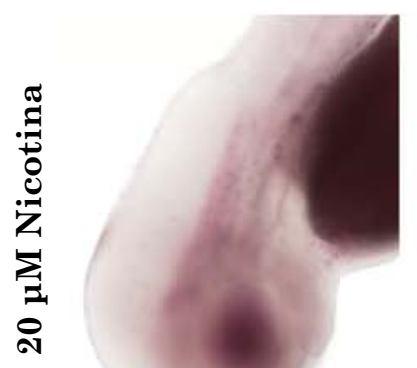

$\widehat{A}$

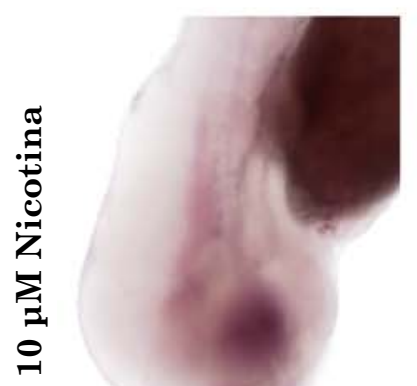

o

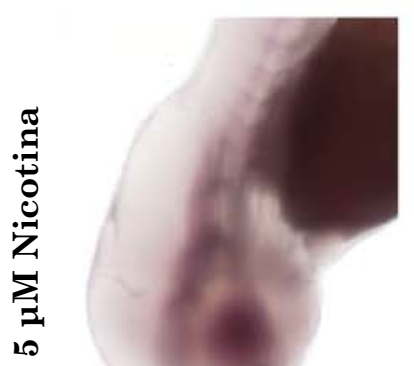

ิิ

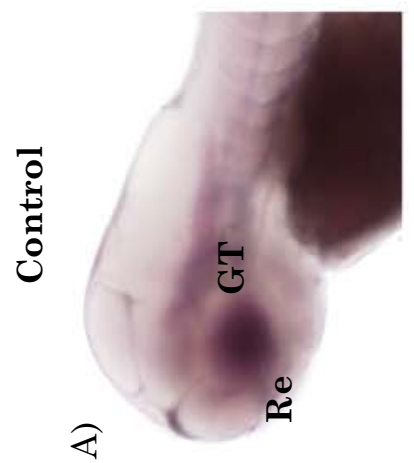

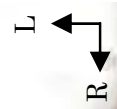

ร

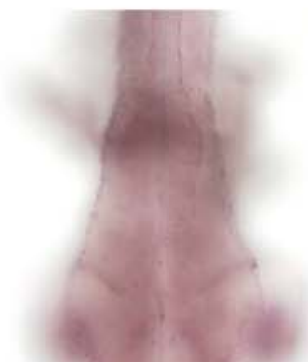

ค

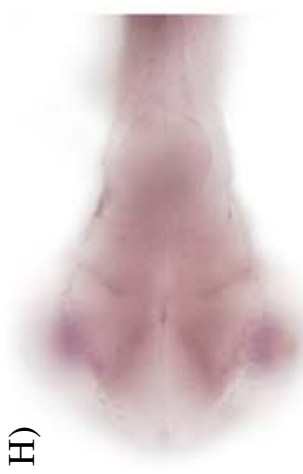

王

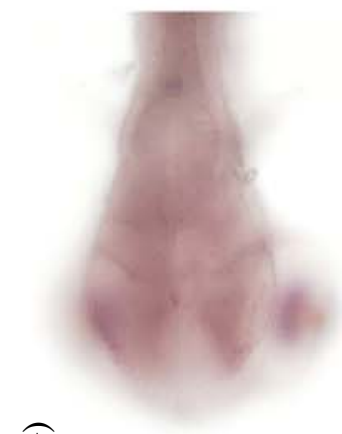

$\widehat{\mathcal{F}}$

王

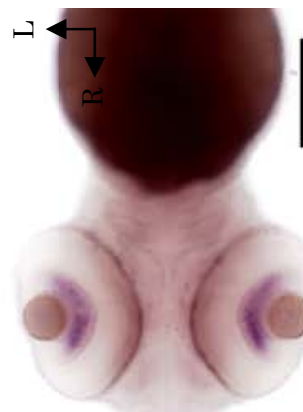

$\widehat{o}$

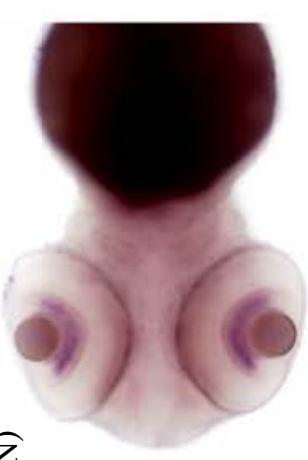

$\widehat{z}$

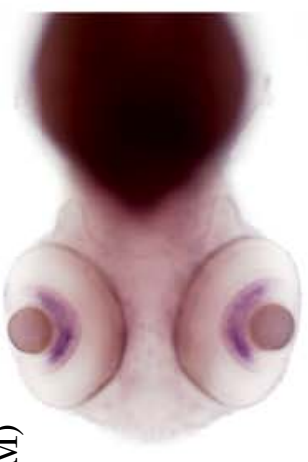

$\widehat{\Sigma}$

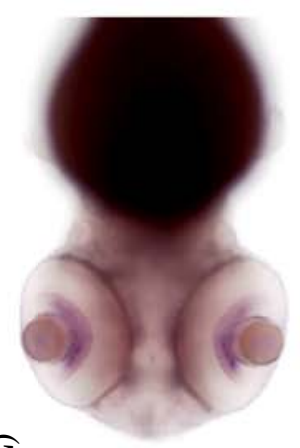

$\widehat{૭}$

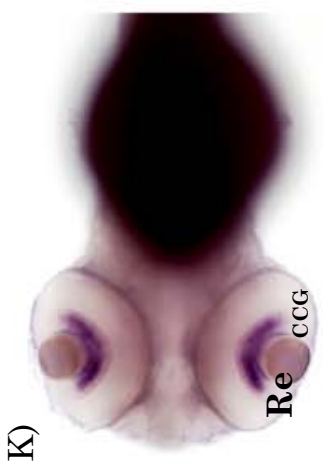

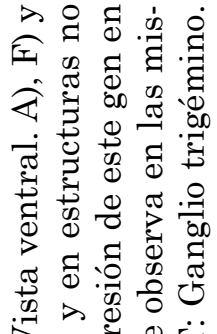

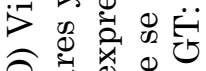
○ิ สี ه. Q बं के छี

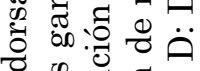
ส

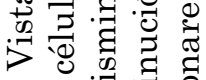
คิ

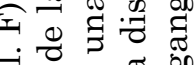
赵 离 ๘ 可 व 红 전

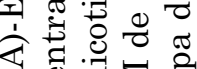
४ ซิ

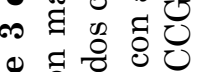

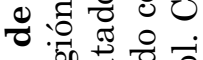

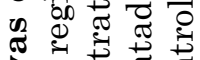

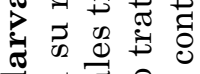

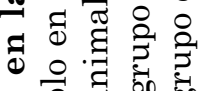

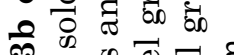
象 थ

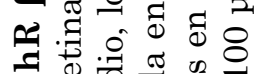

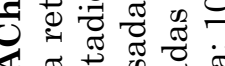

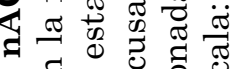
ฐ ฐี

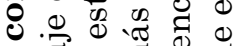
. Ж

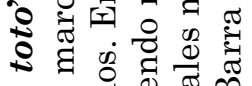

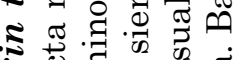
ऽ के

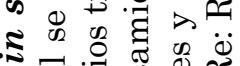
2

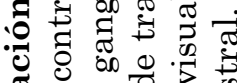
कृ की की की की

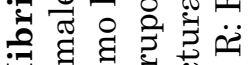

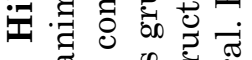
نิ

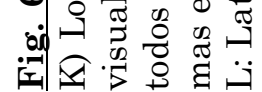




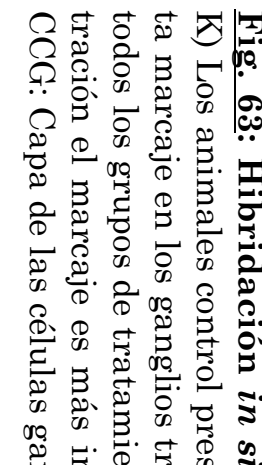

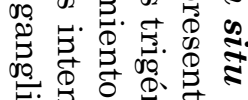

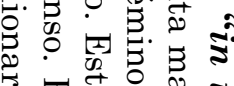

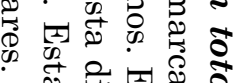

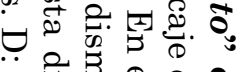

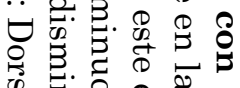
कृ

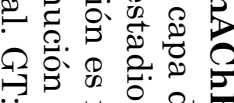

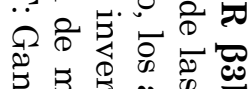
品

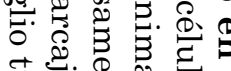
氜. . . of of o T.

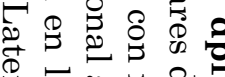

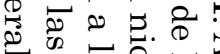

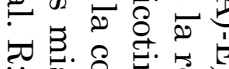
可 둥 象娄 कृ 궁 身 代

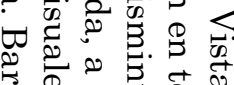
舟

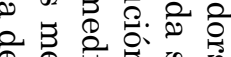

年 党

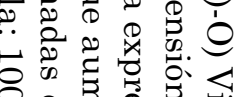
\& s 0

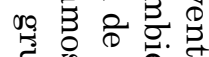

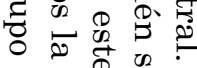

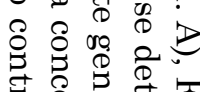

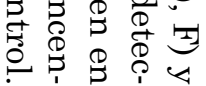

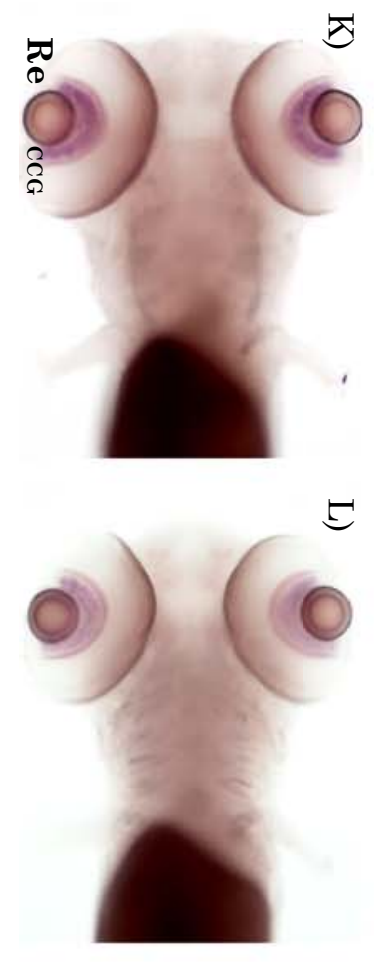

퍽

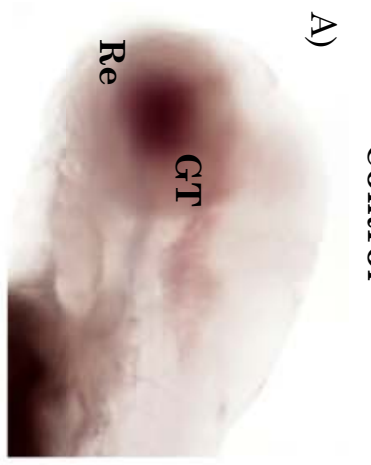

20

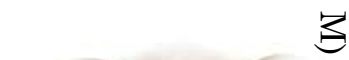

当
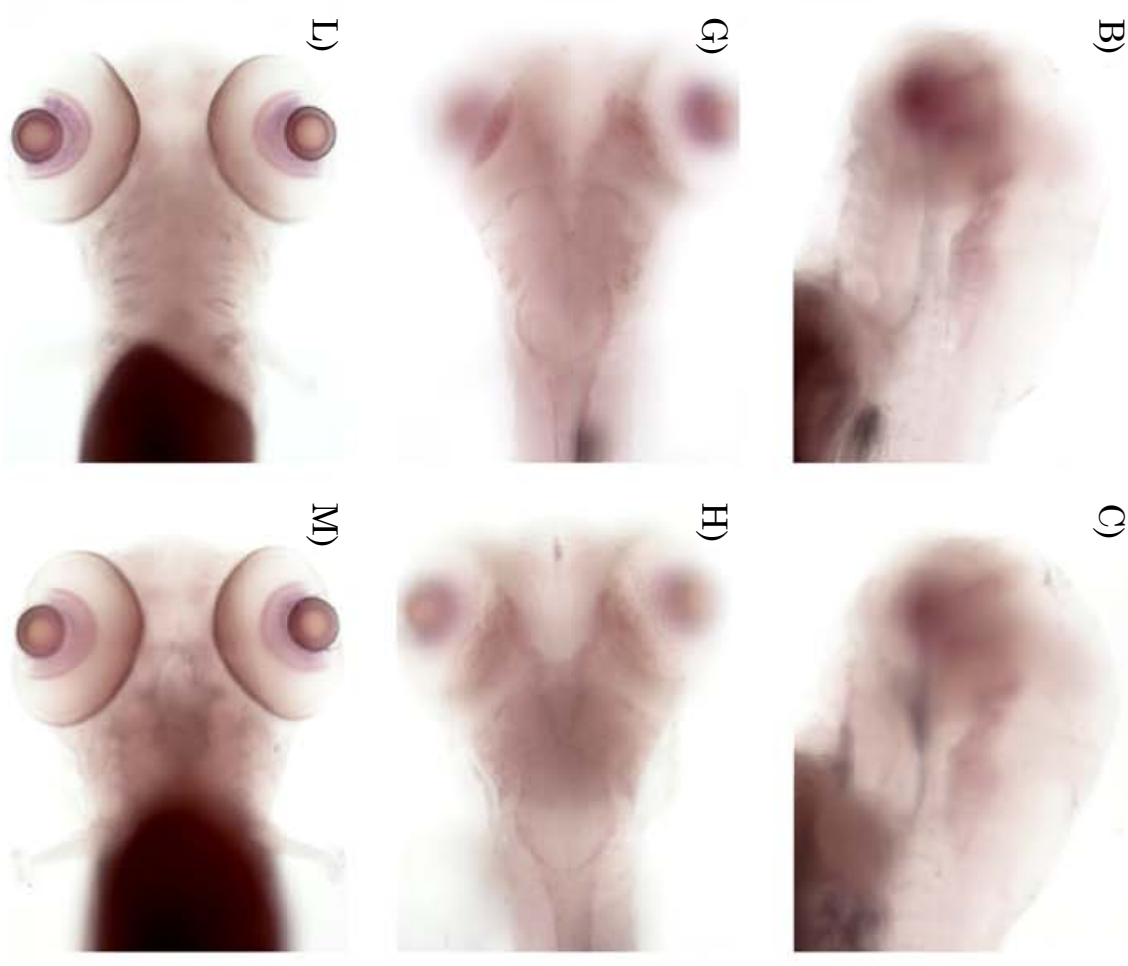

$\varpi$
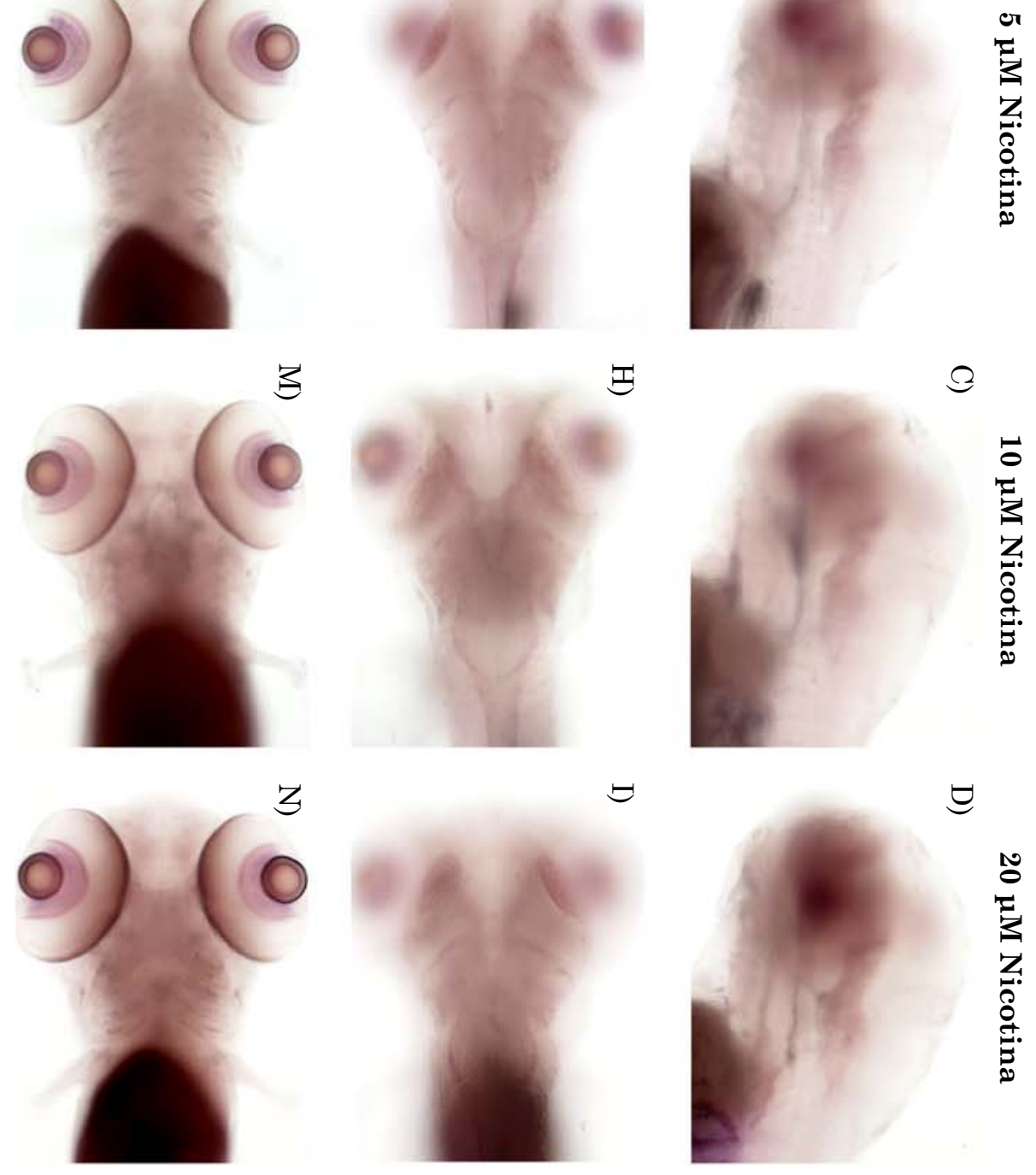

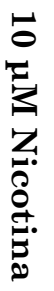
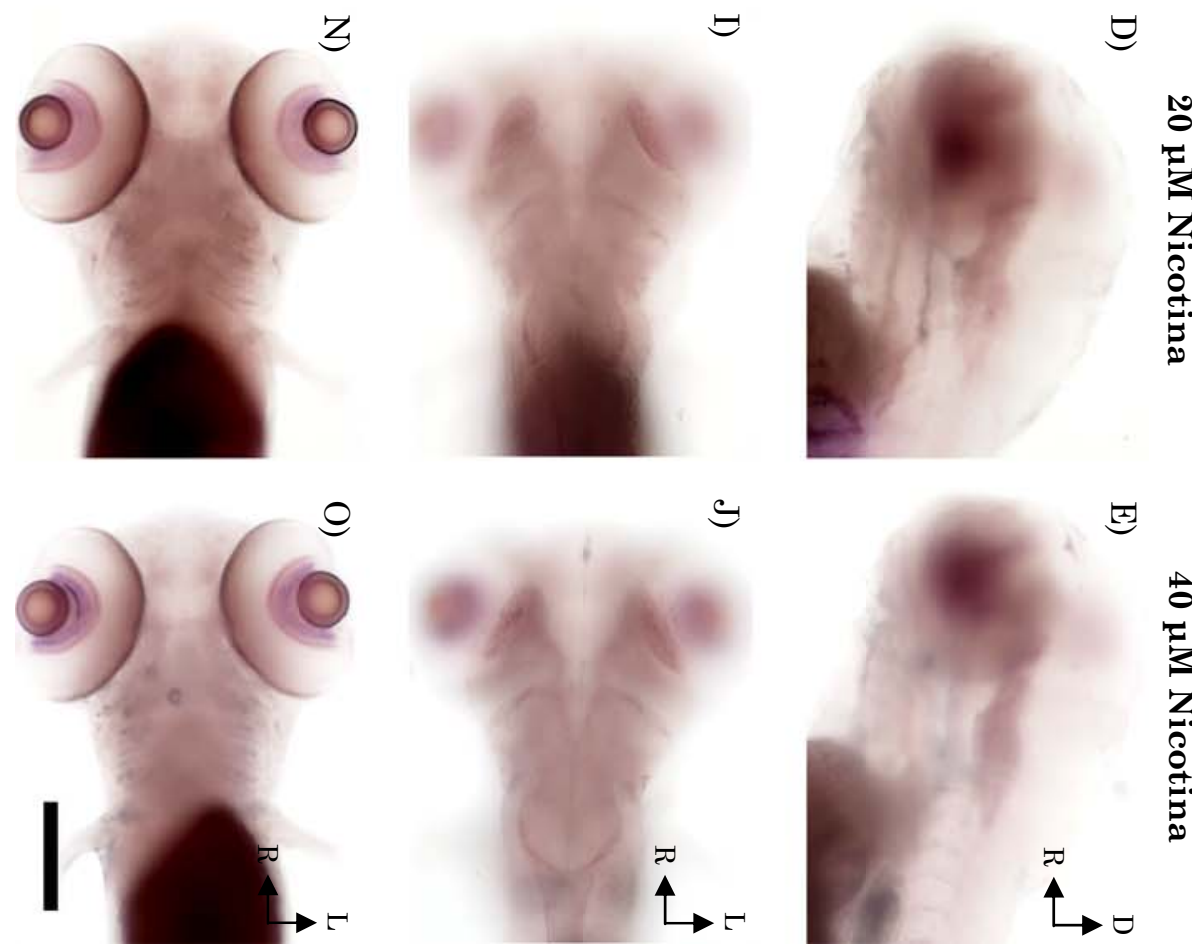

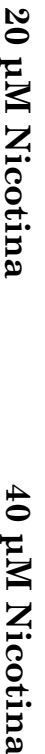




\section{ANÁLISIS ELECTROFISIOLÓGICO DE LA RETINA}

Tras el análisis de estudios morofológicos y de diferenciación celular durante la neurogénesis visual de los ejemplares tratados con las diferentes concentraciones de nicotina y en controles. Analizamos los cambios de potencial eléctrico de la retina mediante electrorretinogramas (ERG) en larvas de entre 56 dpf.

La técnica de electrorretinografía mide los cambios inducidos en la actividad eléctrica del ojo en respuesta a la luz. El método registra un potencial de campo en la retina en respuesta a la luz. Esta técnica se utiliza tanto en modelos experimentales como en la práctica clínica. El ERG es útil para evaluar la función de la retina en los animales con deficiencias visuales con el fin de localizar los defectos en la vía visual.

El ERG, en las larvas de 5-6 dpf del pez cebra, está dominado por una onda-b. que se debe principalmente a la respuesta de las células bipolares ON. La onda-b nos da información sobre la respuesta de los fotorreceptores. Por ello se utiliza como medida indirecta de la función de los fotorreceptores.

\subsection{Efecto de la nicotina en los ERG con pulso de luz blanca}

Los ojos de los animales fueron expuestos con pulsos de luz blanca. En los grupos de estudio se constató que durante la estimulación lumínica, se produce una onda eléctrica que generan: una onda-a y una onda-b (hiperpolarización).

En los animales control esta onda-b muestra un incremento en la amplitud con el aumento de la intensidad lumínica. Durante el registro las unidades logarítmicas (u log) más bajas (-5, -4, -3, -2), la amplitud la onda-b tiende a ser más baja (Fig. 64). Esto es debido que la cantidad de luz recibida provoca un actividad eléctrica baja, estas u log están en condiciones escotópicas, y corresponden a con las células bipolares ON asociadas a los bastones. Con 
registros en u log más altas la amplitud de la onda-b es mayor, corresponde a $u$ $\log -1,-0,6,-0,15,0$ (la cantidad de luz del estímulo es mayor). La amplitud de la onda-b que se detecta en $u \log 0$ en el grupo control es $699 \pm 111 \mu \mathrm{V}$. Estas amplitudes corresponden a células bipolares ON asociadas a conos, son condiciones fotópicas.

Cuando hacemos un registro de la intensidad con una u log -4 (rango escotópico) en los grupos de animales tratados con nicotina se detecta una disminución en la amplitud de la onda-b. La disminución es similar entre los animales tratados con las diferentes concentraciones de nicotina, sin diferencias. $\mathrm{Al}$ aumentar la intensidad de luz, se registra un incremento en la amplitud de la onda-b, que es mayor en intensidades lumínicas altas con grandes diferencias entre las amplitudes de las ondas en los diferentes grupos (Fig. 64, 65).

Con la concentración más baja de nicotina analizada $(5 \mu \mathrm{M})$, después del registro ERG disminuye la respuesta de la onda-b en la unidad de registro de log -4 comparada con el valor del grupo control. Pero al aumentar la intensidad de luz, se incrementa la amplitud, con valores similares a los del grupo control. La amplitud de la onda-b, en la unidad de registro log 0 es $720 \pm 115 \mu \mathrm{V}$ (Fig. $64,65)$.

Tras el tratamiento con $10 \mu \mathrm{M}$ de nicotina, la onda-b presenta una disminución en el tamaño en la unidad de registro log -4, en comparación con el grupo control. En las intensidades de luz en condiciones fotópicas la onda-b tiene valores más altos que los del grupo control, con una amplitud de la onda-b de $920 \pm 145 \mu \mathrm{V}$ (Fig. 64,65).

El grupo tratado con una concentración de nicotina de $20 \mu \mathrm{M}$ no presentó respuesta de la onda-b del ERG en la unidad de registro de log -4, mientras que el aumento de la intensidad de la luz incrementa la amplitud, con una onda-b mayor que en los animales control, con una intensidad de la unidad de registro $\log 0$ de $1.160 \pm 181 \mu \mathrm{V}$ (Fig. 64,65). A esta concentración, los valores de la onda- 


\section{Resultados}

b mostraron una gran diferencia en la amplitud en comparación con los valores control.

En la concentración más alta analizada, $40 \mu \mathrm{M}$, en la unidad logarítmica de -4 , no se observó ninguna onda-b, pero el aumento de la intensidad lumínica produce la aparición de un aumento de la amplitud de la onda-b con una intensidad en la unidad de registro $\mathrm{u} \log 0$ se observó un valor de $1.050 \pm 170 \mu \mathrm{V}$ (Fig. 64, 65), con, una gran diferencia en la amplitud en comparación con los valores control.

En la Tabla 10 se muestran en los distintos grupos analizados a los $5 \mathrm{dpf}$, el voltaje máximo alcanzado en la medición de la amplitud de la onda-b en la intensidad de luz u log 0 .

\begin{tabular}{|c|c|}
$\begin{array}{c}\text { Grupos } \\
\text { experimentales }\end{array}$ & $\begin{array}{c}\text { Voltaje máximo } \\
\text { en } \mathbf{u} \text { log } \mathbf{0}\end{array}$ \\
\hline Control & $699 \mu \mathrm{V} \pm 111 \mu \mathrm{V}$ \\
\hline Nicotina $5 \mu \mathrm{M}$ & $720 \mu \mathrm{V} \pm 115 \mu \mathrm{V}$ \\
\hline Nicotina $10 \mu \mathrm{M}$ & $920 \mu \mathrm{V} \pm 145 \mu \mathrm{V}$ \\
\hline Nicotina $20 \mu \mathrm{M}$ & $1.160 \mu \mathrm{V} \pm 181 \mu \mathrm{V}$ \\
\hline Nicotina $40 \mu \mathrm{M}$ & $1.050 \mu \mathrm{V} \pm 170 \mu \mathrm{V}$ \\
\hline
\end{tabular}

Tabla 10: Amplitudes máximas de la onda -b, registradas en la intensidad de luz u $\log 0$ en distintos grupos experimentales.

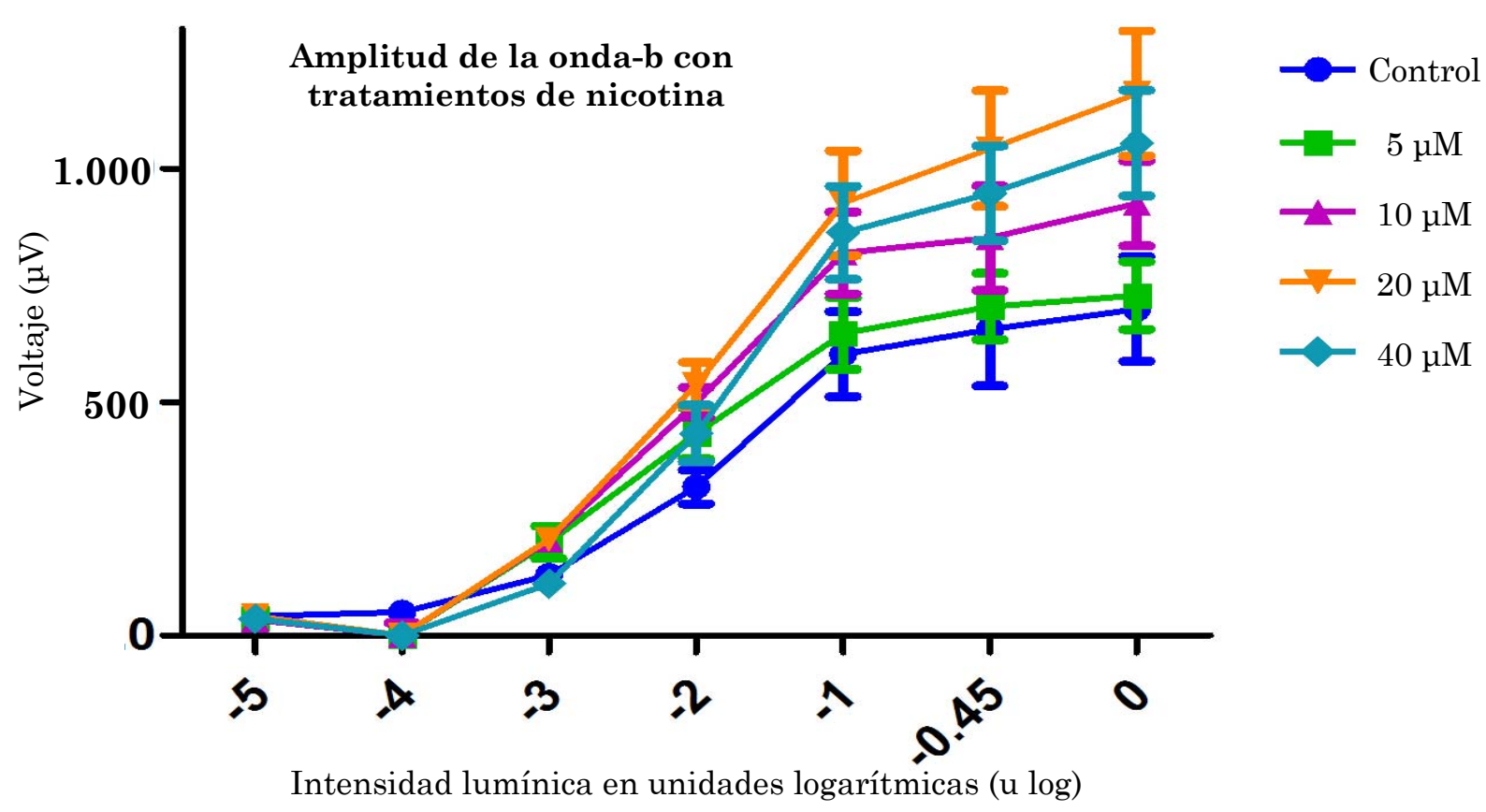

Fig. 64: Electrorretinograma (ERG) de larvas de 5 dpf en condiciones escotópicas. La gráfica indica los promedios de amplitud de la onda-b en los diferentes grupos tratados con diferentes concentraciones de nicotina. 


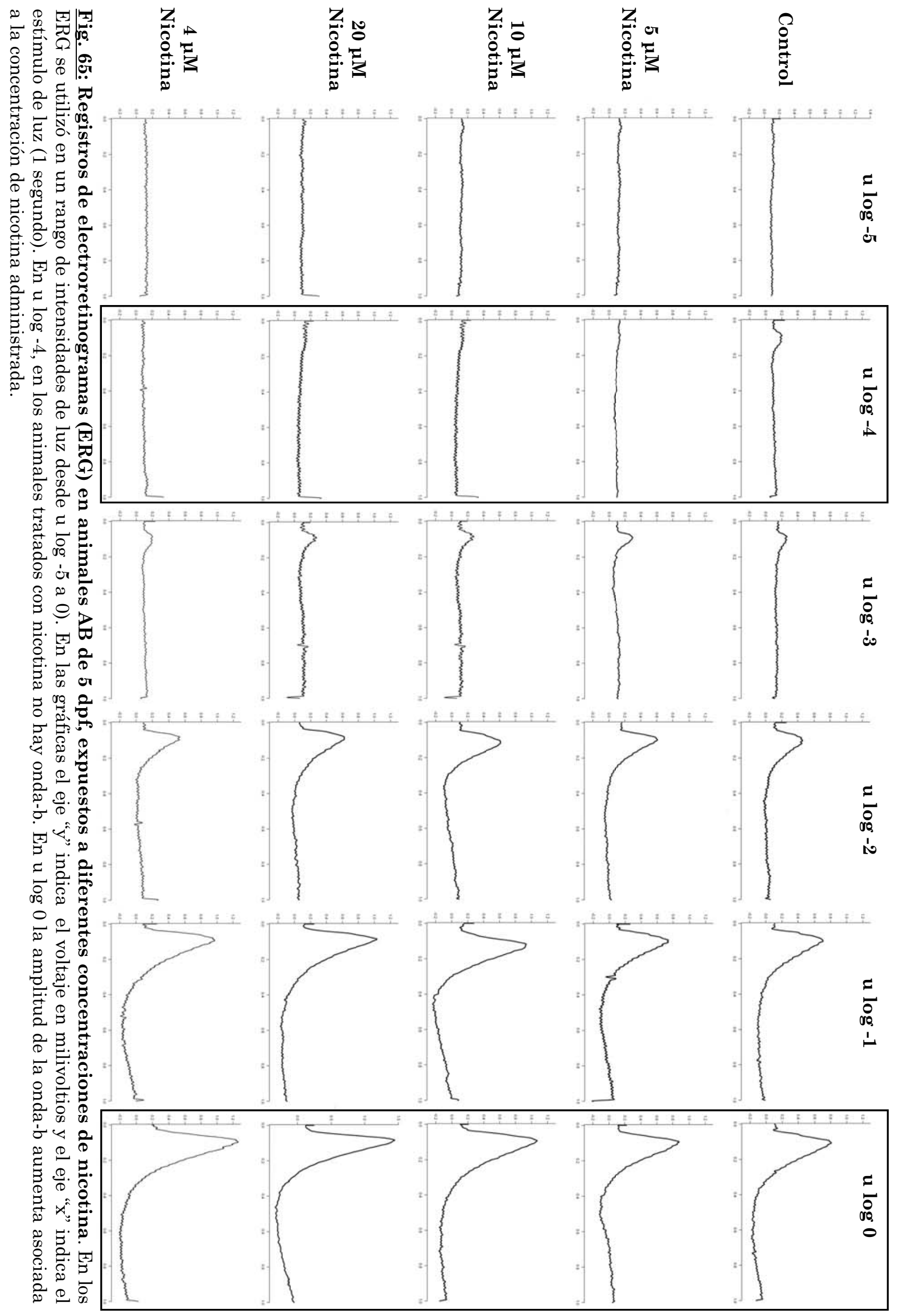




\subsection{Análisis comparativo del ERG en los mutantes nof}

Los mutantes nof se utilizan para analizar la respuesta específica de los bastones, sin interferencia de los conos, en condiciones de luz brillante. Los mutantes nof sufren una mutación puntual por la ninguno de sus cuatro tipos de conos son funcionales. Medimos el ERG de mutantes nof a las 5 dpf. Los mutantes exhiben un patrón de amplitud de la onda-b en el rango de la unidad de registro escotópico de $\mathrm{u} \log -5$ a -2 , donde sus bastones funcionan correctamente, el valor de la unidad de registro -4 de la onda b es el 42,5 $\pm 6,11$ $\mu \mathrm{V}$ (Fig. 65). Por el contrario, en el intervalo fotópico (desde la unidad de registro $\log$-1 a 0), no presentan ninguna respuesta ERG porque los conos no son funcionales (Fig. 65).

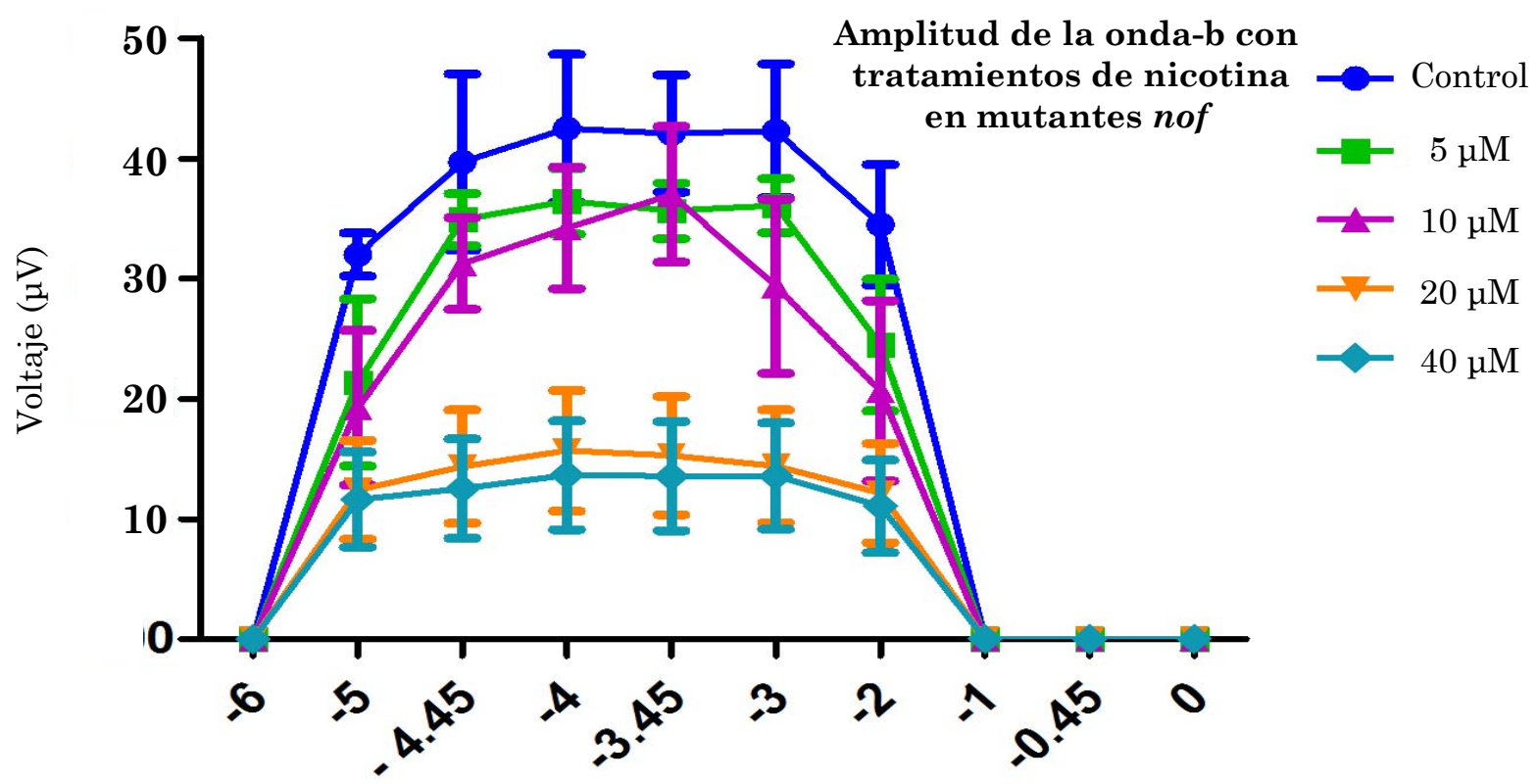

Intensidad lumínica en unidades logarítmicas (u log)

Fig. 66: Electrorretinograma (ERG) de larvas mutantes nof de 5 dpf en condiciones escotópicas. La gráfica indica los promedios de amplitud de la onda-b en los diferentes grupos tratados con diferentes concentraciones de nicotina.

Los mutantes nof tratados con las diferentes concentraciones de nicotina reducen la respuesta de la onda-b de manera más marcada a altas dosis de nicotina con respecto al control. 
En los mutantes nof tratados con una concentración de nicotina de $5 \mu \mathrm{M}$ disminuye la amplitud de la onda b en comparación con las mismas intensidades (u log) en el grupo control. En el intervalo de unidad de registro u log -4 aumenta los valores de la amplitud de la onda-b (36,4 $\pm 2,7 \mu \mathrm{V})$ (Fig. 65).

Con la concentración de nicotina de $10 \mu \mathrm{M}$, se produjo una disminución en la amplitud de la onda-b, con valores similares a los del grupo anterior. La intensidad lumínica de la unidad de registro log -4 se registran una amplitud de

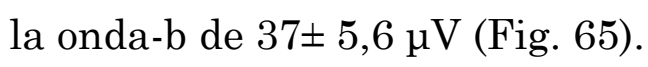

En el grupo tratado con una concentración de nicotina de $20 \mu \mathrm{M}$ la disminución de la amplitud de la onda-b es mayor. El valor de la onda-b en la unidad de registro es de log -4 15,6 $\pm 5 \mu \mathrm{V}$ (Fig. 65).

Esta concentración produjo una gran diferencia en los valores de la amplitud de la onda-b. A la mayor concentración analizada (40 $\mu \mathrm{M})$, la amplitud de la onda-b disminuyó de manera más acusada. En la intensidad de luz de la unidad de análisis log -4 se registro un valor de $13,6 \pm 4,5 \mu \mathrm{V}$.

En la Tabla 11 se muestran los mutantes nof en los distintos grupos analizados a los $5 \mathrm{dpf}$, el voltaje máximo alcanzado en la medición de la amplitud de la onda-b entre las intensidades de luz $\mathrm{u} \log -4$.

\begin{tabular}{|c|c|}
\hline $\begin{array}{c}\text { Grupos } \\
\text { experimentales }\end{array}$ & $\begin{array}{c}\text { Voltaje máximo } \\
\text { en u log } \mathbf{- 4}\end{array}$ \\
\hline Control & $42,5 \pm 6,11 \mu \mathrm{V}$ \\
\hline Nicotina $5 \mu \mathrm{M}$ & $36,4 \pm 2,7 \mu \mathrm{V}$ \\
\hline Nicotina $10 \mu \mathrm{M}$ & $37 \pm 5,6 \mu \mathrm{V}$ \\
\hline Nicotina $20 \mu \mathrm{M}$ & $15,6 \pm 5 \mu \mathrm{V}$ \\
\hline Nicotina $40 \mu \mathrm{M}$ & $13,6 \pm 4,5 \mu \mathrm{V}$ \\
\hline
\end{tabular}

Tabla 11: Amplitudes máximas de la onda -b en mutantes nof, registradas en la intensidad de luz u log -4 en distintos grupos experimentales. 


\section{ANÁLISIS DEL COMPORTAMIENTO}

\section{$\underline{5.1}$ Efectos de la nicotina en el comportamiento inducido por} estímulos visuales

Los experimentos comportamentales han sido ampliamente utilizados para evaluar las funciones visuales de las larvas de pez cebra. Las respuestas del comportamiento visual-motor incluyen movimientos dirigidos a la huida, de natación simple y movimientos guiados para la captura de alimento. Una respuesta visual clave en las larvas de pez cebra es la respuesta optomotora (ROM), en la que hay una coordinación motora para seguir el movimiento. También la respuesta optocinética (ROC), que estabiliza la imagen en la retina durante la natación libre. La respuesta visual motora (RVM) en las larvas del pez cebra es la respuesta de sobresalto a cambios en la intensidad de la luz.

Hemos estudiado estas diferentes respuestas de comportamiento en larvas de 4, 5 y 6 dpf, como modelo para estudiar las alteraciones neurales en el contexto visual, en comportamientos relativamente básicos. A los 4 dpf es el primer estadio en el que aparece esta respuesta, después evaluamos la repuesta en estadio posteriores para evaluar la evolución de la repuesta a lo largo de más tiempo.

\section{$\underline{\text { Respuesta optomotora }}$}

La respuesta optomotora $(\mathrm{ROM})$ es un reflejo innato en la mayoría de los vertebrados. Hemos analizado distintos parámetros visuales como el contraste, la frecuencia espacial y la frecuencia temporal en animales de 4, 5 y 6 dpf. En esta Tesis Doctoral evaluamos estar respuesta con el índice optomotor, que es el número de larvas que llegan al final de los carriles, divido por el número total de larvas analizadas.

En el análisis del contraste a los 4 dpf (Fig. 67A), los animales control 
presentan una respuesta correcta, pero inmadura, con un índice optomotor que mejora al aumentar el contraste, ya que todavía la respuesta y el movimiento coordinado de la larva no están completamente desarrollados.

Los animales tratados con diferentes concentraciones de nicotina, tienen una disminución significativa de la ROM. En la mayoría de los casos, a concentraciones mayores disminuye el índice optomotor. En los animales tratados con la concentración de nicotina de $40 \mu \mathrm{M}$, se reduce considerablemente el índice optomotor con respecto al control. Las larvas tratadas con nicotina recuperan los niveles de actividad a medida que aumenta el contraste, pero sin alcanzar niveles control.

La respuesta optomotora en larvas de $5 \mathrm{dpf}$ del grupo control es mayor que a los 4 dpf (Fig. 67B), llegando a responder el número máximo de larvas en los contrastes más altos. En los animales tratados con diferentes concentraciones de nicotina, disminuye significativamente la ROM, pero se recupera progresivamente con el aumento del contraste, sin alcanzar los niveles control.

En el estadio de 6 dpf, los animales control alcanzan su máxima respuesta al estímulo visual (Fig. 67C), incluso desde niveles de contraste muy bajos. A este edad, las diferencias de los animales tratados con respecto a los animales control son menores que en los estadios anteriores aunque se mantienen las diferencias, puesto que no alcanzan los valores de respuesta de los controles.

En los animales tratados con nicotina, el parámetro de contraste en la ROM, esta relacionado con la concentración de nicotina usada. 


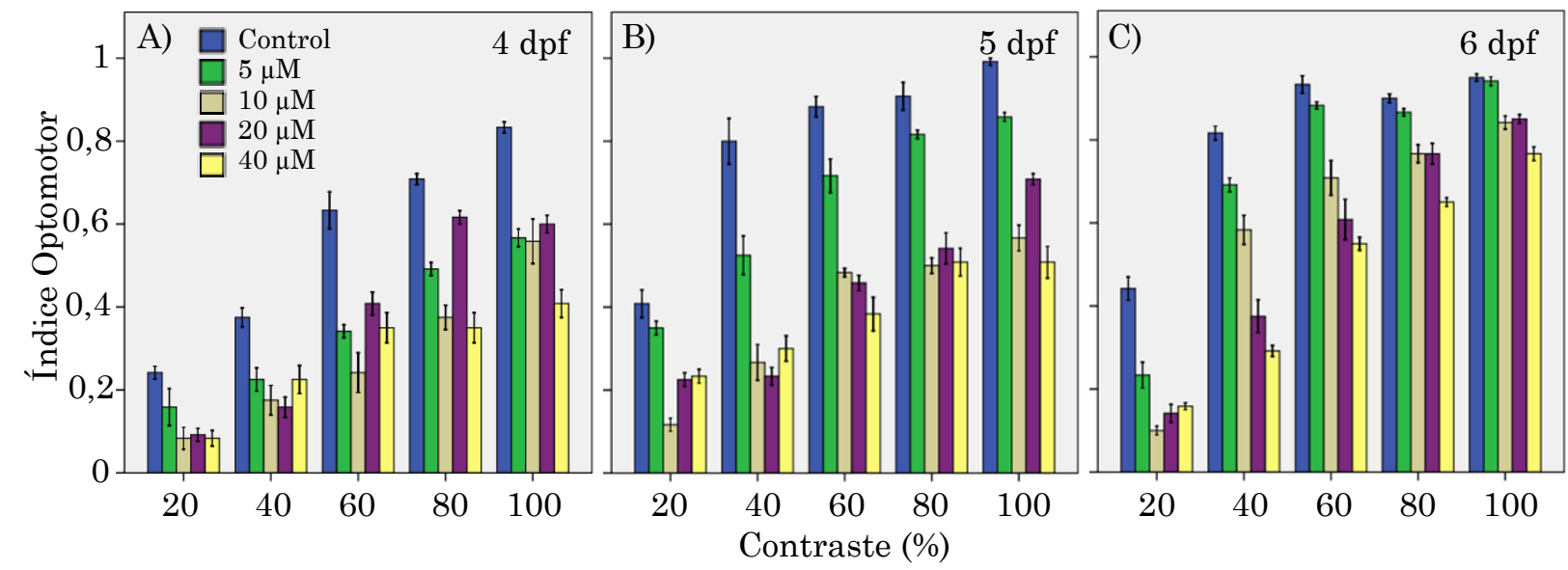

Fig. 67: Mediciones del comportamiento del contraste de la ROM a los 4, 5 y 6 dpf. Media del índice optomor, número de larvas que llegan al final del tanque, por valores de contraste. Barras de errores \pm 1 en el error estándar.

Con respecto a la medición del parámetro de frecuencia espacial de la ROM, a los 4 dpf (Fig. 68A) las variaciones son similares a lo descrito para el contraste. Los animales control no presentan todos una correcta ROM, ni tan siquiera en las frecuencias espaciales mayores. En las larvas expuestas a nicotina disminuye la respuesta con respecto al control, al incrementar las concentraciones de nicotina en cada una de las frecuencias espaciales.

En el estadio de 5 dpf (Fig. 68B), los niveles de respuesta son más altos, alcanzando máximos en las frecuencias más altas. La disminución de la ROM, en la frecuencia espacial es más acusada a medida que aumentan las concentraciones de nicotina. Estas larvas responden de manera más eficaz con el aumento del tamaño de la banda. Esta disminución de la ROM es máxima en concentraciones de nicotina de $20 \mu \mathrm{M}$ y $40 \mu \mathrm{M}$.

Las larvas control de 6 dpf (Fig. 68C) presentan un máximo en su respuesta optomotora, con alto índice optomotor en la mayoría de las frecuencias espaciales. Al igual que en los casos anteriores, también disminuye la respuesta en los animales tratados con nicotina con respecto a los estadios más inmaduros, pero se mantienen estas diferencias y están asociadas con la concentración de nicotina. 


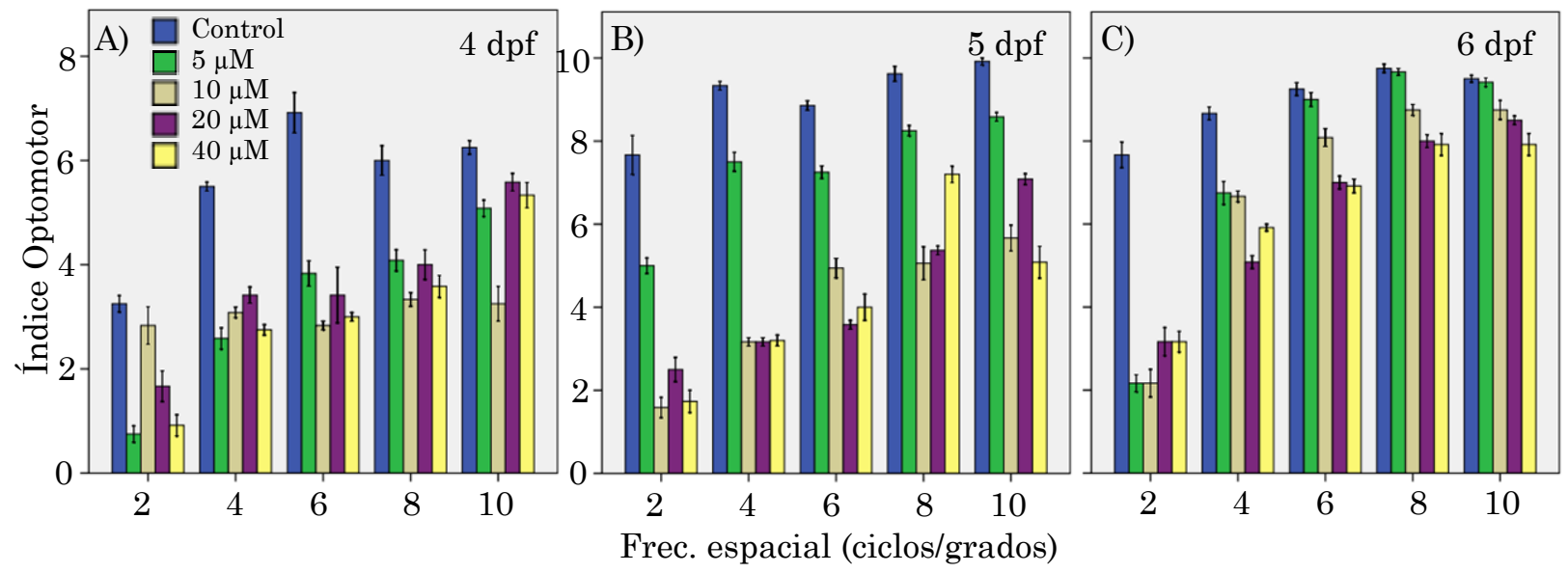

Fig. 68: Mediciones del comportamiento de la frecuencia espacial de la ROM a los 4,5 y 6 dpf. Media del índice optomor, número de larvas que llegan al final del tanque, por valores de contraste. Barras de errores \pm 1 en el error estándar.

Otro parámetro analizado es la frecuencia temporal en la ROM. A los 4 dpf (Fig. 69A) los animales control tienen una correcta función temporal en la ROM, pero todavía inmadura. Las larvas tratadas con las diferentes concentraciones de nicotina responden a las frecuencias espaciales altas sin diferir de manera significativa, pero con una disminución del índice optomotor asociado a la concentración de nicotina.

En el estadio de 5 dpf (Fig. 69B), los animales control responden como en el caso anterior, pero con el máximo índice optomotor en la mayoría de las frecuencias temporales. Los animales tratados con nicotina, presentan una acusada disminución del índice optomotor en la concentración de $40 \mu \mathrm{M}$, respondiendo solo la mitad de las larvas; mientras que los otros grupos de tratamiento con nicotina no presentan grandes diferencias.

A los 6 dpf (Fig. 69C), los animales control mantienen el máximo del índice optomotor en la mayoría de las frecuencias temporales. Las larvas tratadas con nicotina en bajas concentraciones presentan pocas diferencias con el grupo control en la frecuencia temporales altas, pero se mantienen las diferencias asociadas a la concentración de nicotina administrada. 


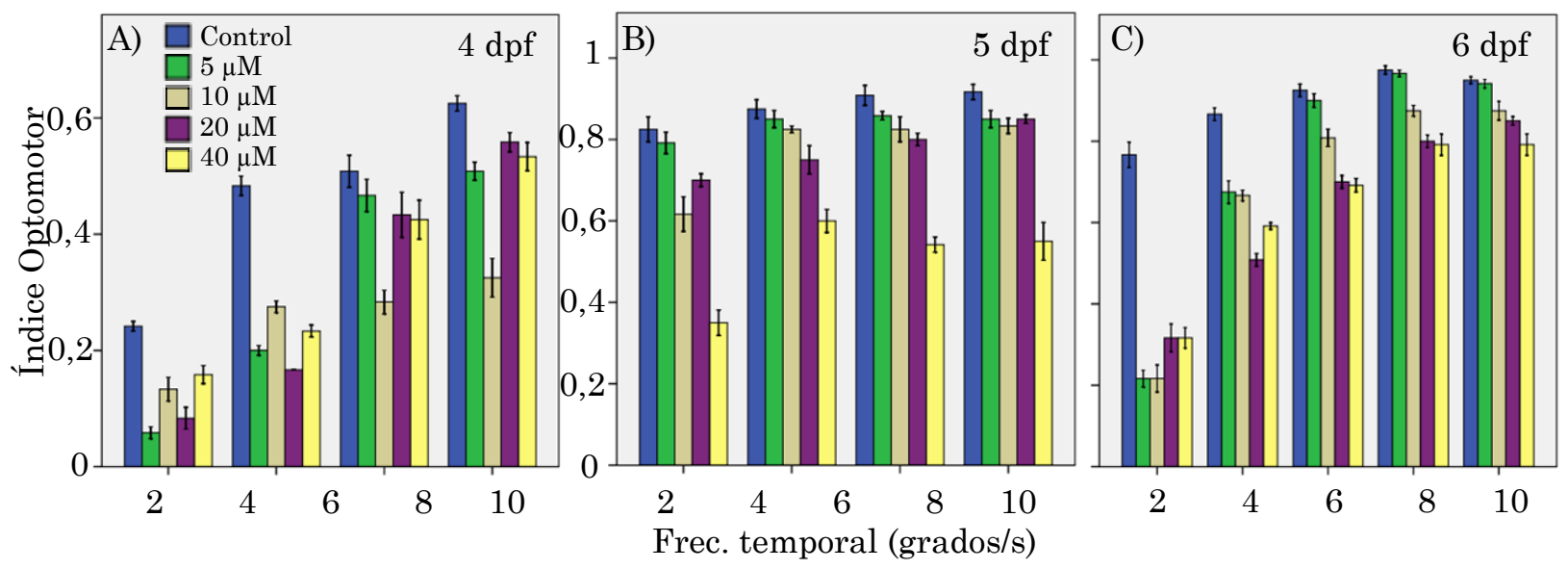

Fig. 69: Mediciones del comportamiento de la frecuencia temporal de la ROM a los 4, 5 y 6 dpf. Media del índice optomor, número de larvas que llegan al final del tanque, por valores de contraste. Barras de errores \pm 1 en el error estándar.

\section{Respuesta optocinética}

Este tipo de respuesta se produce como resultado de un reflejo oculomotor y se utiliza para detectar defectos de la ruta visual. Como en el caso anterior, en este reflejo hemos analizado, tres parámetros: el contraste, la frecuencia espacial y la frecuencia temporal en animales de 4, 5 y 6 dpf.

Este reflejo innato se produce por primera vez en la edad larvaria de $4 \mathrm{dpf}$ (Fig. 70A). En los animales control, a medida que aumenta el contraste los animales presentan una velocidad del ojo mayor. La velocidad de seguimiento de las bandas blancas y negras es máxima a 4 grados por segundo, en niveles de 90 $\%$ de contraste. Los animales tratados con nicotina reducen esa velocidad ocular. Esta diferencia de velocidad ocular no varía apreciablemente entre los distintos grupos de tratamientos con nicotina.

A la edad de 5 dpf (Fig. 70B) los animales control aumentan la velocidad del movimiento ocular a medida que aumenta el contraste. Entre los distintos grupos de larvas expuestas a diferentes concentraciones de nicotina, no existen grandes diferencias en la velocidad de los ojos. Mientras que se detecta una disminución de velocidad de los movimientos oculares si comparamos los ejemplares tratados con nicotina y los ejemplares control. 
En el estadio de 6 dpf (Fig. 70C), los animales control siguen respondiendo de manera correcta al contraste. Los animales tratados presentan una diferencia en la velocidad de movimiento ocular con el grupo control. Esta disminución en el movimiento ocular es diferente dependiendo de la concentración de nicotina suministrada. Los animales tratados con $5 \mu \mathrm{M}$ de nicotina son los que presentan menor disminución, con un valor máximo respecto a la velocidad de los ojos en valores de 2,75 grados por segundo en $75 \%$ de contraste. Los demás grupos de tratados presentan menores niveles de disminución, cercanos a 1 grado por segundo, en la mayoría de \% contraste. Esto indica que aunque suba el contraste de las bandas blancas y negras, persiste la disminución de la velocidad del movimiento ocular. Los animales tratados con la concentración de $40 \mu \mathrm{M}$ son los que presentan la menor velocidad de movimiento de los ojos.
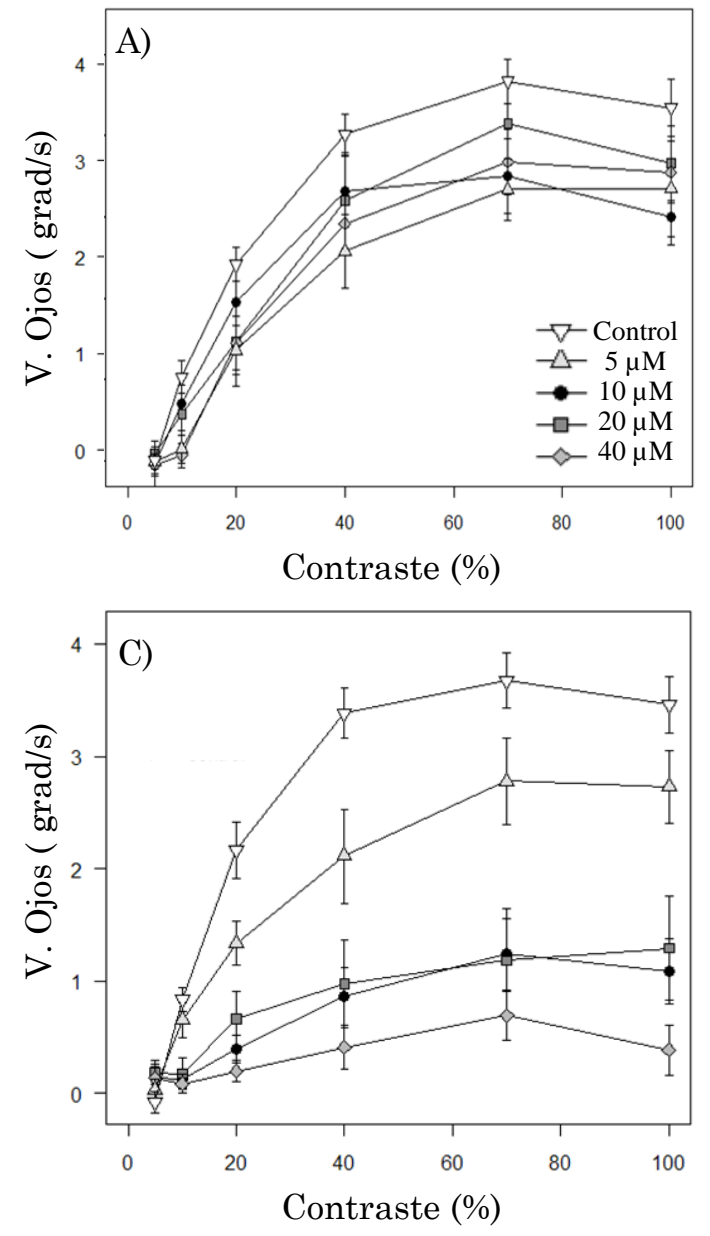

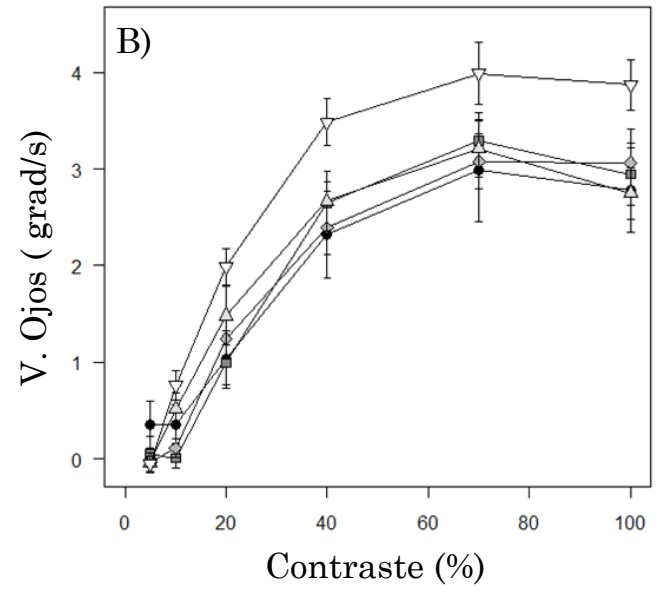

Fig. 70: Mediciones del comportamiento del contraste de la ROC a los 4,5 y 6 dpf. Media de la velocidad de los ojos en dirección temporal a nasal y viceversa. A) A los 4 dpf, B) A los 5 dpf, C) A los 6 dpf. En todos los grupos hay una disminución de la velocidad de los ojos Los grupos con mayor concentración de nicotina presentan una disminución más drástica en el movimiento ocular. Barras de errores \pm 1 en el error estándar 
También se realizó un ensayo de la respuesta optocinética en el que se pudo registrar los movimientos espontáneos del ojo en larvas de pez cebra para evaluar un potencial problema sensorial subyacente a la ausencia de la respuesta optocinética. El ROC presenta movimientos oculares que se dividen en dos componentes: un seguimiento lento del estímulo visual, seguido de un movimiento sacádico rápido para restablecer los ojos una vez que el estímulo ha salido de campo visual.

En animales de 5 dpf (Fig. 71), se analiza el parámetro contraste en la ROC. En los ejemplares control, aumentando la intensidad de la luz, aumenta el número de movimientos sacádicos; en intensidad máxima de luz se encuentran entre 10 y 11 movimientos sacádicos (Fig. 71). En los animales tratados con nicotina se observó una disminución suave en el número de movimientos sacádicos. Los animales tratados con la mayor dosis de nicotina son los que presentan una mayor disminución de movimientos sacádicos. En los animales tratados con las concentraciones más bajas (5 y $10 \mu \mathrm{M})$ de nicotina, disminuye el número de los movimientos sácadicos, en comparación con los controles, con cada una de las intensidades de luz (Fig. 71). La diminución más significativa se encuentra en el grupo tratado con $40 \mu \mathrm{M}$, ya que hasta la u log 3 no presenta movimientos sacádicos (Fig. 71). Y en valores de intensidad máxima (u log 0) solo cuentan 1 u 2 movimientos.

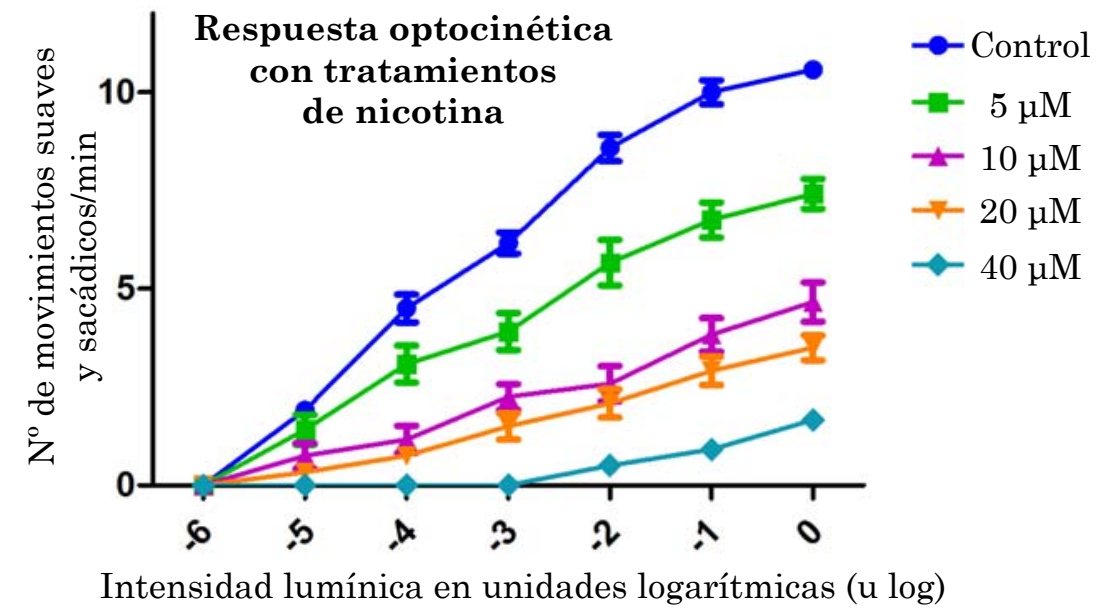

Fig. 71: ROC en larvas de 5 dpf después de la adaptación a la oscuridad. La gráfica indica el número de movimientos suaves y sacádicos por minuto con diferentes concentraciones de nicotina $y$ en las distintas intensidades de luz. Barra de errores SEM. 
En cuanto a la variación del parámetro de la frecuencia espacial en la ROC a los 4 dpf (Fig. 72A) en los animales control, observamos que a velocidades de estimulo muy altas ocurre un descenso de la velocidad de rotación del ojo: a partir de 0,05 ciclos por grado el animal no es capaz de seguir el movimiento. Al igual que ocurre con el grupo control, los animales tratados disminuyen el seguimiento del estímulo a medida que aumenta la velocidad del estímulo visual. A esta edad no se detecta grandes diferencias entre los distintos grupos de tratamiento nicotínico y el grupo control.

A la edad de los 5 dpf (Fig. 72B), los animales control siguen presentando la máxima velocidad de rotación de los ojos a una frecuencia espacial de 0,04 ciclos por grado; la velocidad del movimiento ocular disminuye paulatinamente a medida que se aumenta la velocidad del estímulo. Las larvas tratadas con diferentes concentraciones de nicotina presentan una disminución en la velocidad de rotación ocular con respecto al grupo control, sin apenas diferencia entre las diferentes concentraciones de nicotina administrada.

En el estadio de 6 dpf (Fig. 72C), los animales control se comportan igual que en los estadios anteriores para las distintas frecuencias espaciales. Los animales tratados han disminuido drásticamente la velocidad de movimiento en los ojos para las distintas frecuencias espaciales. Los animales tratados con $5 \mu \mathrm{M}$ de nicotina disminuye la velocidad de movimiento ocular, alcanzando los 0,04 ciclos por grado de frecuencia espacial, a una velocidad de rotación media de 3,2 grados por segundo. Las grupos de estudios de concentraciones de nicotina de 10, 20 y $40 \mu \mathrm{M}$ sufren una disminución mayor de la velocidad de sus ojos, con valores máximos que no superan los 1,2 grados por segundo. 


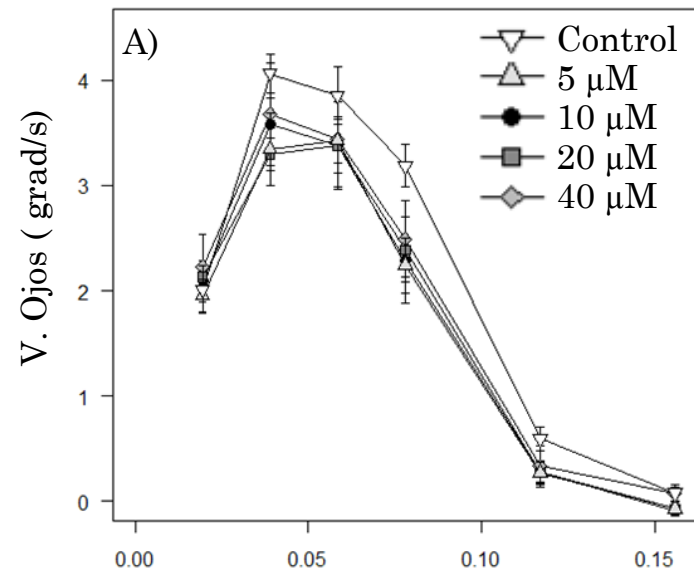

Frec. espacial (ciclos/grad)

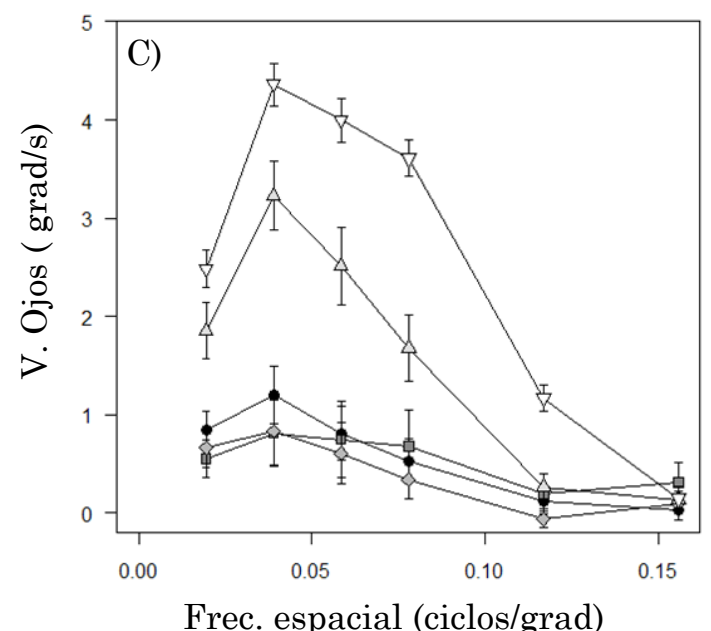

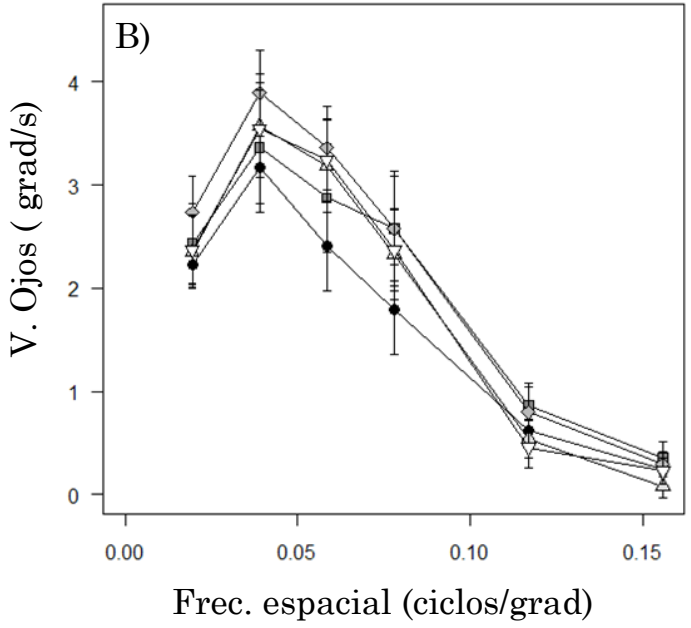

Fig. 72: Mediciones del comportamiento de la ROC a los 4, 5 y 6 dpf. Media de la velocidad de los ojos en dirección temporal a nasal y viceversa. A) A los 4 dpf, B) A los 5 dpf, C) A los 6 dpf. En todos los grupos disminuye la velocidad del movimiento ocular. Los grupos con mayor concentración de nicotina presentan una disminución que es más drástica en el movimiento ocular. Barras de errores \pm 1 en el error estándar

Al estudiar el parámetro de la frecuencia temporal en la ROC a los 4 dpf (Fig. 73A), en los animales control se aprecia un aumento de la velocidad del movimiento de los ojos al incrementar la velocidad de giro del estímulo visual con la máxima velocidad angular del estímulo a 25 grados por segundo. En los animales tratados con nicotina disminuye el movimiento ocular. En este estadio no se aprecian diferencias entre las diferentes concentraciones de nicotina, si bien hay con una alta variabilidad.

En el estadio de 5 dpf (Fig. 73B) los animales control continúan aumentando la velocidad en los movimientos de los ojos a medida que aumenta la frecuencia temporal del estímulo. Por otro lado, en los animales tratados con nicotina decrece la velocidad de movimiento de los ojos con respecto a al grupo control, con diferencias entre las distintas concentraciones de nicotina. Los animales tratados con las concentraciones mayores de nicotina, 20 y $40 \mu \mathrm{M}$, son 
las que presentan mayor decremento de la velocidad de los ojos en la frecuencia temporal.

A la edad de 6 dpf (Fig. 73C), las larvas control presentan un incremento de la velocidad de los movimientos de los ojos con respecto a los dos estadios anteriores con valor máximo de 7 grados por segundo en la velocidad ocular, en frecuencia temporales altas en la ROC. En cambio, las larvas tratadas con nicotina muestran disminuyen la velocidad del movimiento ocular. Los animales tratados con $5 \mu \mathrm{M}$ de nicotina presentan valores máximos de 4,5 grados por segundo. En los animales tratados con las otras concentraciones (10, 20 y $40 \mu \mathrm{M}$ ) la velocidad de movimiento de los ojos apenas llega a 2 grados por segundo en la frecuencia temporal.
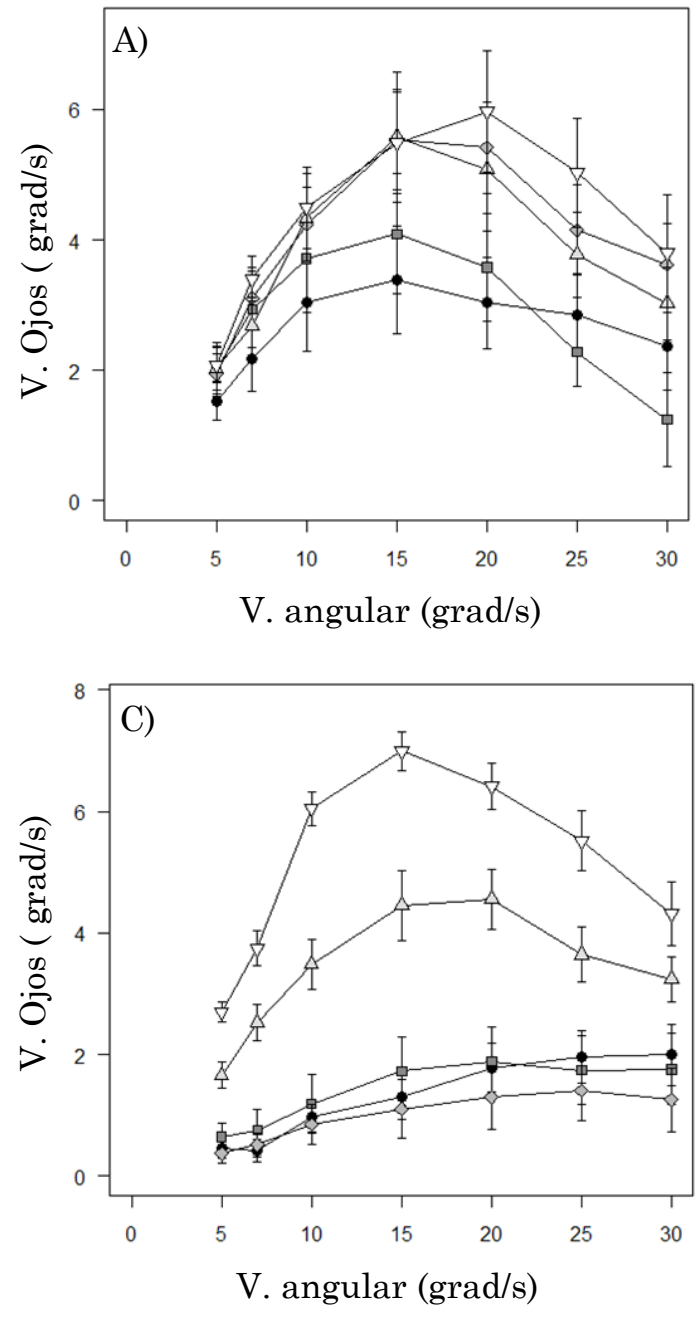

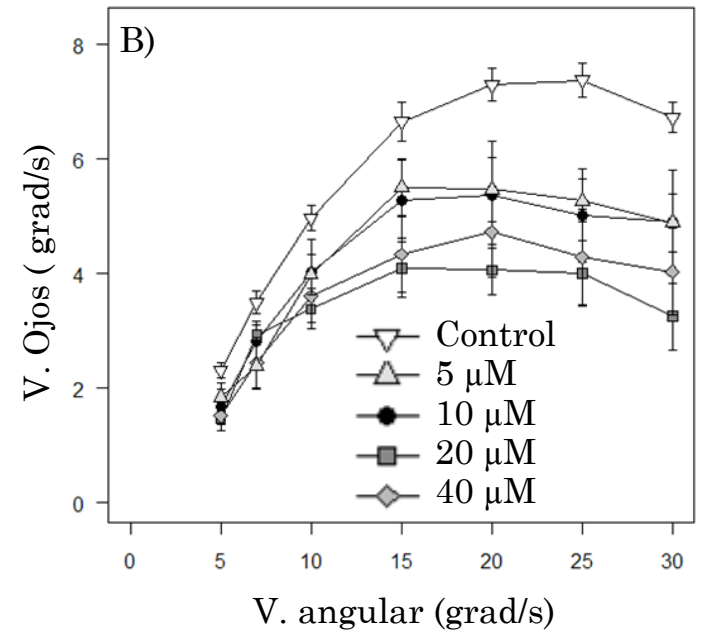

Fig. 73: Mediciones del comportamiento de la frecuencia temporal en la ROC a los 4, 5 y 6 dpf. Media de la velocidad de los ojos en dirección temporal a nasal y viceversa. A) A los $4 \mathrm{dpf}$, B) A los $5 \mathrm{dpf}$, C) A los 6 dpf. En todos los grupos disminuye la velocidad de los movimientos de los ojos. Los grupos con mayor concentración de nicotina muestra una disminución más drástica en el movimientos oculares. Barras de errores \pm 1 en el error estándar 


\section{Respuesta visual motora}

Para la respuesta visual motora (RVM) se analiza la actividad, como la velocidad de nado de la larva a cambios de luz y oscuridad y viceversa. En esta respuesta hemos analizado larvas de 4, 5 y $6 \mathrm{dpf}$.

A los 4 dpf (Fig. 74), el grupo control presenta una RVM en respuesta a cambios de luz a oscuridad y viceversa. En los animales tratados, la velocidad y la actividad de natación es menor que en los controles. La actividad y velocidad media de natación de emergencia (sobresalto) es un poco menor que en el grupo control. La mayoría de cambios de luz a oscuridad están asociados a la concentración de nicotina a la que se exponen las larvas. La actividad y la velocidad de natación en respuesta a cambio de oscuridad a luz es menor en los animales tratados con nicotina que en la respuesta al cambio de luz a oscuridad, si bien las diferencias son mínimas.
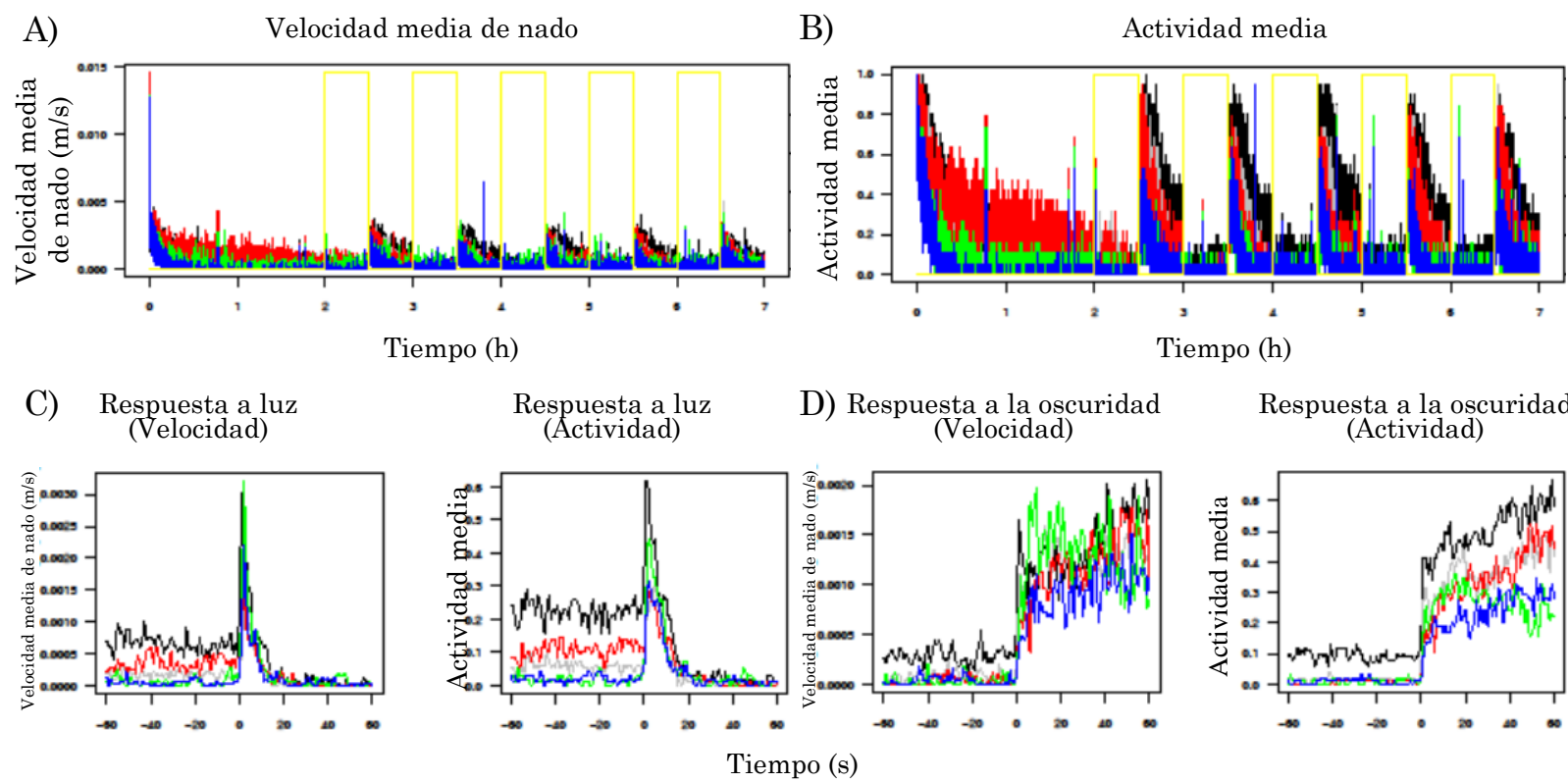

Fig 74: RVM a los $4 \mathrm{dpf}$, analizamos, media de la actividad y velocidad en los cambios de luz a oscuridad y viceversa. A) Velocidad media de nado. B) Actividad media de las larvas. C) Respuesta de las larvas a cambios de oscuridad a luz. D) Respuesta de las larvas a cambio de luz a oscuridad. En los animales tratados con nicotina decrece tanto la actividad y la velocidad de nado, esta diminución esta asociada a la concentración de nicotina.

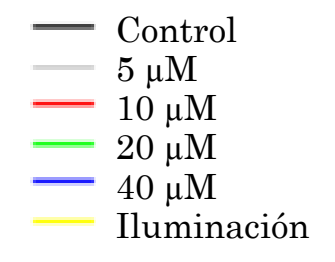


En el estadio de 5 dpf durante la RVM (Fig. 75) en los animales control se mantiene la misma actividad y velocidad, con máximo en los pasos de luz a oscuridad. En los animales tratados la velocidad de natación de las larvas es menor que en el grupo control, y la disminución es máxima con el tratamiento de $40 \mu \mathrm{M}$. La actividad de natación de emergencia es un poco mayor que los controles. La actividad y la velocidad de la respuesta al paso de oscuridad a luz es mayor en aquellos animales tratados con una menor concentración de nicotina, mientras que la actividad y la velocidad en el cambio de luz a oscuridad es menor en los tratados con nicotina en comparación con el grupo control.

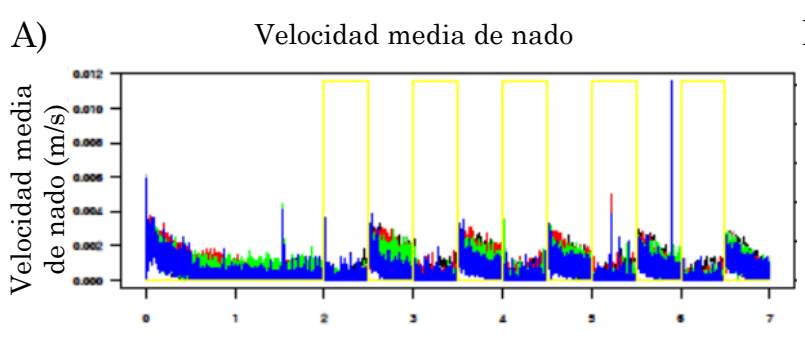

Tiempo (h)

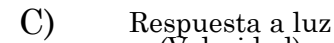
(Velocidad)

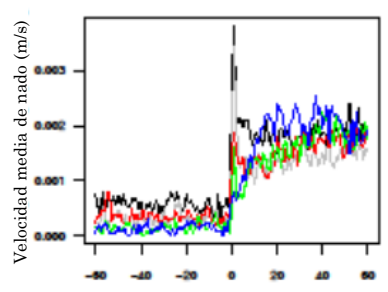
Respuesta a luz

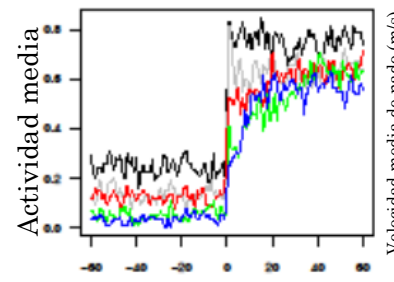

B)

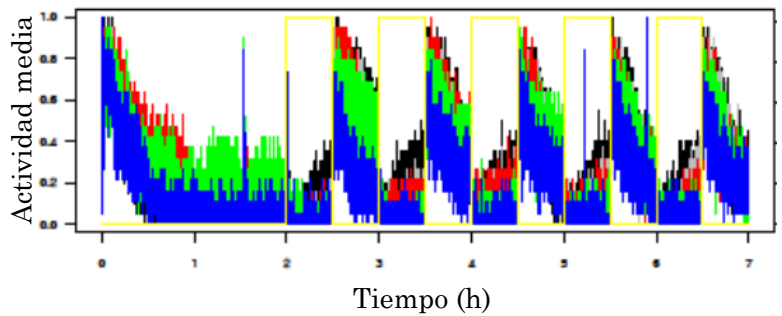

D) Respuesta a la oscuridad (Velocidad)

Respuesta a la oscuridad
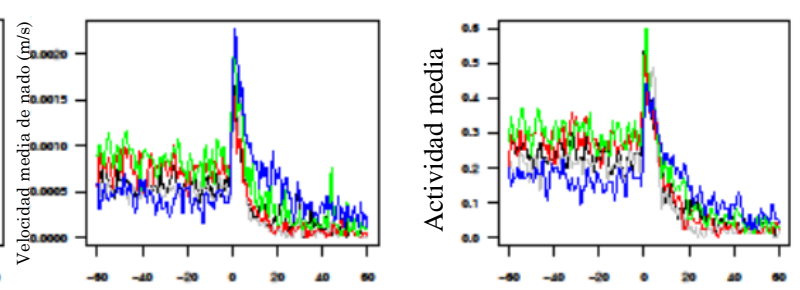

Tiempo (s)

Fig. 75: RVM a los $5 \mathrm{dpf}$, analizamos, media de la actividad y velocidad en los cambios de luz a oscuridad y viceversa. A) Velocidad media de nado. B) Actividad media de las larvas. C) Respuesta de las larvas a cambios de oscuridad a luz. D) Respuesta de las larvas a cambio de luz a oscuridad. En los animales tratados con nicotina decrece tanto la actividad y la velocidad de nado, la disminución más drástica es en el grupo de $40 \mu \mathrm{M}$ de nicotina.

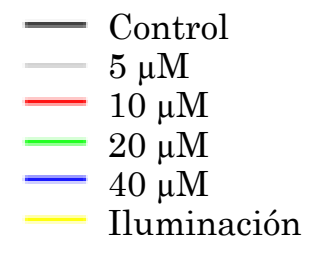

En el periodo larvario de 6 dpf (Fig. 76), se mantiene lo indicado en el estadio de 5 dpf. Durante el proceso de RVM, en general, la velocidad de natación de las larvas es menor en los tratados que en los controles, en la que hay una actividad de natación de emergencia (sobresalto) menor que en los animales control. La actividad y la velocidad en la respuesta a cambio de oscuridad a luz son mayores en aquellos tratados con una menor concentración de nicotina, mientras que la actividad y la velocidad de respuesta a cambios de 


\section{Resultados}

luz a oscuridad es menor en los tratados con nicotina.

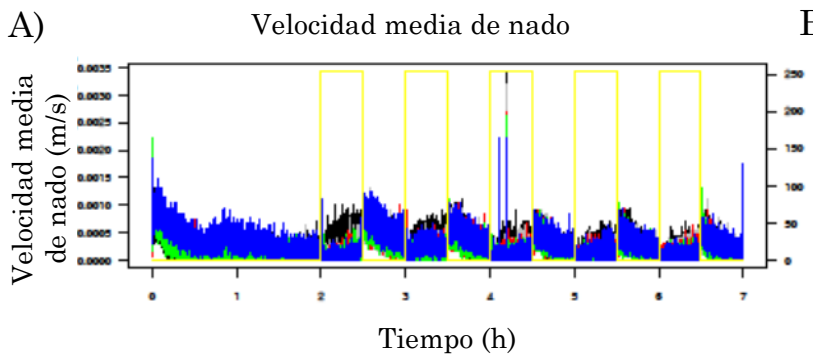

B) Actividad media

C) Respuesta a luz

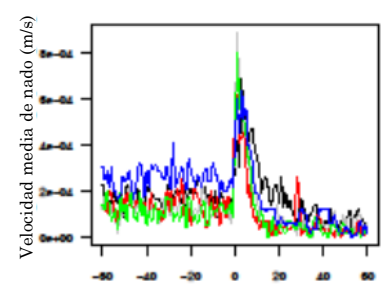
$\underset{\text { (Actividad) }}{\text { Respuesta a luz }}$

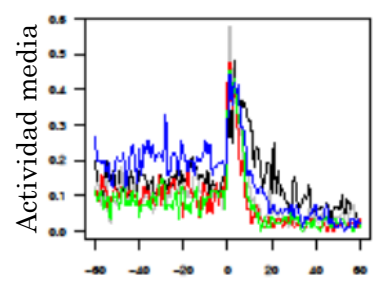

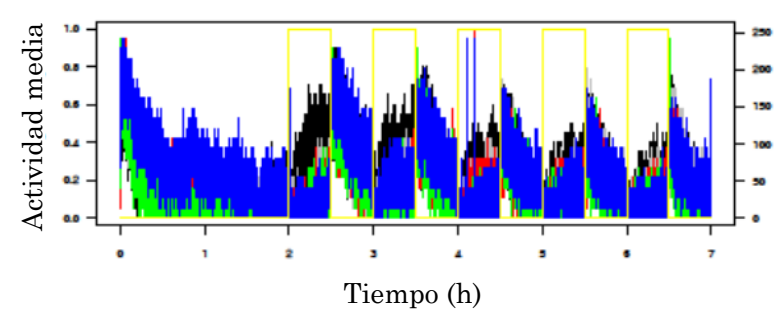

D) Respuesta a la oscuridad (Velocidad)

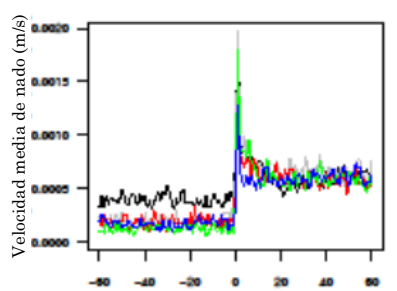

Tiempo (s) Respuesta a la oscuridad (Actividad)

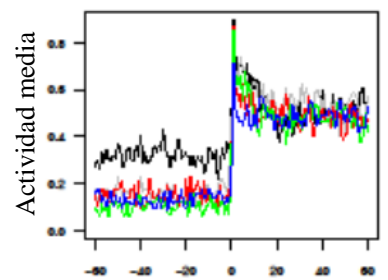

Fig. 76: RVM a los 6dpf, analizamos, media de la actividad y velocidad en los cambios de luz a oscuridad y viceversa. A) Velocidad media de nado. B) Actividad media de las larvas. C) Respuesta de las larvas a cambios de oscuridad a luz. D) Respuesta de las larvas a cambio de luz a oscuridad. En los animales tratados con nicotina en este estadio decrece de manera más drástica tanto la actividad y la velocidad de nado, esta disminución esta asociada a la concentración de nicotina. 
Discusiôn 



\section{EFECTOS DE LA NICOTINA EN EL DESARROLLO DEL PEZ CEBRA}

En la actualidad los conocimientos sobre el desarrollo del pez cebra hacen que sea un excelente modelo para estudiar los efectos de la nicotina en el desarrollo embrionario, así como el papel de las subunidades del receptor nicotínico para acetilcolina (nAChR) específicamente implicadas en provocarlos. Sin embargo, en comparación con la amplia información publicada sobre el uso de nicotina en modelos in vivo en otras especies, el pez cebra se ha empleado sólo muy recientemente en el campo de la investigación sobre nicotina en el desarrollo.

Los primeros estudios de tratamiento con nicotina datan de mediados del siglo XIX (Haughton, 1872), mientras que los primeros que utilizan el pez cebra como modelo para el estudio de los efectos de la nicotina en el desarrollo datan de principios del siglo XXI (Sovoboda et al., 2002). Se han realizado estudios cognitivos tras tratamiento con nicotina (Levin y Chen, 2004), así como estudios genéticos (Petzold et al., 2009).

La nicotina afecta a diversos procesos durante el desarrollo del embrión, incluyendo expresión génica, distribución de proteínas, apoptosis, proliferación celular y comportamiento (Svoboda et al., 2002; Boyd et al., 2003; Edwards, 2007; Parker y Connaughton, 2007; Menelaou y Svoboda, 2009; Thomas et al., 2009; Welsh et al., 2009).

La ruta de metabolización de la nicotina en el pez cebra es aún desconocida; la vida media de la nicotina en el organismo del pez cebra no ha sido determinada $\mathrm{y}$, como la nicotina se suministra de forma constante $\mathrm{y}$ exógena durante todo el período de exposición, la tasa de eliminación también está sin determinar (Matta et al., 2007). La exposición a la nicotina puede realizarse inmediatamente después de la fecundación, en el periodo de una a 


\section{Discusión}

cuatro células (Boyd et al., 2003), una ventaja que no presentan los modelos de rata o ratón donde la exposición comúnmente comienza en el día embrionario 4 (Seidler et al., 1992). También se ha realizado la administración de nicotina en otras etapas del desarrollo embrionario, por ejemplo entre las 16 y $22 \mathrm{hpf}$ (Svoboda et al., 2002; Parker y Connaughton, 2007; Menelaou y Svoboda, 2009; Thomas et al., 2009; Welsh et al., 2009), y en pez cebra adulto (Levin y Chen, 2004; Levin et al., 2006; Levin et al., 2007; Bencan y Levin, 2008; Kily et al., 2008; Eddins, 2009; Levin et al., 2011).

El pez cebra no requiere alimentación hasta 5-7 días después de la fecundación porque tiene vitelo (Kimmel et al., 1995) pero puede administrarse nicotina incorporándola en el medio en el que están los animales. La duración de la exposición y la concentración de nicotina pueden ser controladas a través de la renovación del medio en que se desarrollan los animales, con o sin nicotina, o con otros agonistas/antagonistas. Como la estabilidad de la nicotina en el medio no se ha determinado, éste debe renovarse diariamente. Por otra parte, las concentraciones de nicotina son muy variadas en los diferentes estudios realizados con el pez cebra en desarrollo; oscilan desde 0 a $40 \mu \mathrm{M}$ (Svoboda et al., 2002; Parker y Connaughton, 2007; Menelaou y Svoboda, 2009; Thomas et al., 2009; Welsh et al., 2009) y $50 \mu \mathrm{M}$ (Boyd et al., 2003).

Cada estudio sobre exposición de pez cebra a nicotina suele utilizar rangos de concentración muy estrechos (Goolish et al., 1999, Svoboda et al., 2002; Boyd et al., 2003) con tiempos de exposición que van desde minutos (Levin et al., 2006) a 5 días (Svoboda et al., 2002; Boyd et al., 2003; Parker y Connaughton, 2007). A partir del estadio embrionario 16-22 hpf se han analizado varios periodos que comprenden hasta cuatro días de exposición (Svoboda et al., 2002; Parker y Connaughton, 2007). En esta Tesis Doctoral hemos realizado un estudio preciso en el mismo rango de concentraciones analizado por la mayoría de los autores y en periodos de exposición entre los 21 somitos (19,5 hpf) hasta 48 hpf, 3 y 5 dpf. Mediante el uso de la técnica de HPLC hemos cuantificado la concentración de nicotina real incorporada por los 
ejemplares de pez cebra y demostramos que, tanto en la etapa embrionaria de 48 hpf en la que presentan corion, como en los estadios larvarios de 3 y 5 dpf, la concentración de nicotina presente en el cuerpo de los animales es prácticamente idéntica a la suministrada.

Se han realizado estudios de exposición crónica a nicotina en embriones de pez cebra (Svoboda et al., 2002; Parker y Connaughton, 2007; Menelaou y Svoboda, 2009; Thomas et al., 2009; Welsh et al., 2009). La exposición crónica probablemente es más parecida a la concentración de nicotina constante en el plasma (Rowell y Li, 1997; Ghosheh et al., 2001) encontrada en los fumadores o en las personas que utilizan parches terapéuticos de nicotina (Slotkin, 1998; Matta et al., 2006). En estudios crónicos con diferentes especies animales se administra nicotina a través de mini-bombas o inyecciones diarias, a través de agua que contiene nicotina (ratas y ratones) o alimentos (mosca de la fruta) (Ghosheh et al., 2001). En nuestro diseño experimental, para asegurar niveles constantes de nicotina en el medio, lo renovamos diariamente, al igual que se ha realizado en estudios previos (Evereklioglu et al., 2003; Evereklioglu et al., 2004; Sekhon et al., 2004; Wielgus et al., 2004; Slotkin et al., 2005; Parker y Connaughton, 2007). El análisis de los animales mediante HPLC demuestra que los embriones asimilaban la concentración administrada, que se mantenía constante a lo largo del tiempo.

En el estudio de Svoboda et al. (2002) mediante tratamiento crónico, en el que los embriones eran tratados a las $22 \mathrm{hpf}$, no aparecían anormalidades morfológicas inmediatas, pero a las $66 \mathrm{hpf}$ los embriones son un 5\% más pequeños que los controles. Los embriones a $42 \mathrm{hpf}$ mantienen capacidad de movimiento tras la exposición a una concentración de $33 \mu \mathrm{M}$ de nicotina, ya que todavía se curvan en respuesta a la estimulación táctil. Los animales a las 120 hpf pierden la capacidad de movimiento tras dicho tratamiento, muy probablemente por la desensibilización de los nAChRs musculares. El número de prolongaciones de las motoneuronas secundarias se reduce drásticamente en la etapa de 66 hpf en los embriones expuestos de manera continua desde las 22 


\section{Discusión}

hpf. Estos fallos en las motoneuronas y déficits de comportamiento pueden ser atribuibles a un retraso en la diferenciación de las neuronas motoras secundarias y/o a la alteración de su ruta axonal. Los déficits motores son también observados cuando los embriones se exponen a la concentración de 15 $\mu \mathrm{M}$ de nicotina, aunque no se observaba ningún efecto con tratamientos a una concentración de $5 \mu \mathrm{M}$ (Svoboda et al., 2002).

En una comparación directa entre diferentes estirpes de pez cebra $(\mathrm{AB}$, WIK, y Tübingen), la concentración de $33 \mu \mathrm{M}$ de nicotina provoca comportamientos y alteraciones anatómicas muy similares, sugiriendo que no existe expresividad genética subyacente respecto a los efectos que produce la nicotina (Svoboda et al., 2002).

En el pez cebra adulto se han identificado mediante inmunohistoquímica las células que expresan colina acetiltransferasa y acetilcolinesterasa. Hay células colinérgicas en médula espinal, núcleos motores craneales, bulbo olfatorio, retina, telencéfalo dorsal, tegmentum, y cerebelo, en distribuciones similares a las descritas en otros vertebrados (Clemente et al., 2004). Además, las células que contienen acetilcolinesterasa en los embriones de pez cebra son necesarias para un patrón conjunto de desarrollo correcto (Hanneman y Westerfield, 1989; Behra et al., 2002) En el músculo, el gen de la subunidad nAChR a fue clonada tras haber sido identificado como el gen defectuoso en el pez cebra mutante paralizado nic1 (Sepich et al., 1994; 1998). La amplia extensión de todos los elementos del sistema colinérgico sugiere un efecto amplio y difuso de la nicotina sobre el SNC del pez cebra. 


\section{EFECTOS DE LA NICOTINA SOBRE EL SISTEMA}

\section{VISUAL}

El pez cebra constituye un buen modelo para describir el desarrollo del sistema visual y analizar cómo se ve afectado por la exposición a distintas sustancias (Parng, 2005; Tierney, 2011). En este sentido se ha analizado ampliamente la plasticidad neural en el sistema visual como resultado de la actividad sináptica en la organización estructural de los terminales aferentes (Ruthazer y Cline, 2004; Bence y Levelt, 2005; Taha y Stryker, 2005). El resultado final es una segregación de los terminales aferentes procedentes del ojo sobre sus dianas específicas en el encéfalo. Se conoce en mamíferos que los receptores nicotínicos desempeñan un importante papel en esta segregación, como indica el hecho de que una mutación nula de la subunidad 82 de nAChR evite una correcta segregación de las aferencias visuales encefálicas (Rossi et al., 2001). Además de estar presente en la retina, esta subunidad se encuentra también en regiones visuales específicas del encéfalo (Marks et al., 2006), siendo también un componente de otros receptores nicotínicos heteroméricos presentes en el nervio óptico, que van a ser transportados a los sitios presinápticos encefálicos (DeAngelis, 2000).

Junto a la segregación encefálica de los terminales que llevan información de un ojo, las proyecciones aferentes de la retina también se proyectan sobre su zona específica en el encéfalo, dirigiéndose estas proyecciones de regiones del espacio visual a regiones de destino visual (Debski y Cline, 2002; Ruthazer y Cline, 2004). Los mapas topográficos son esenciales para funciones tales como la percepción de profundidad, reconocimiento de objetos, reconstrucción de la escena visual y comportamientos de orientación visual (Bednar et al., 2004; DeAngelis, 2000; Kaas, 1997; Navalpakkam y Itti, 2005; Weber et al., 2006). El proceso de asignación se ha estudiado ampliamente en el techo óptico (Ruthazer y Cline, 2004). El mapa que reconoce una zona en la CCG de la retina, en su correspondiente zona en el TO está mediado por la actividad de receptores 


\section{Discusión}

NMDA (Cline y Constantine-Paton, 1989). En estudios con antagonistas de los receptores nicotínicos se observa, un refinamiento de la retinotopía del mapa topográfico entre una zona de la CCG de la retina con su correspondiente zona en el TO, indicando una dependencia del proceso respecto a la actividad de los receptores nicotínicos (Tu et al., 2000).

Todo ello sugiere una influencia directa de la nicotina sobre el desarrollo y maduración visual.

\section{$\underline{2.1 \text { Efectos de la nicotina en la morfometría y citoarquitectura del }}$} sistema visual

Hemos analizado el efecto de la exposición a nicotina sobre el tamaño del ojo, parámetro que se estima midiendo el área proyectada del ojo de los ejemplares en crecimiento (Kashyap et al., 2011). Las medidas obtenidas del área ocular fueron consistentes y disminuyeron significativamente en los estados larvarios de 3 y 5 dpf en relación con los controles, especialmente en los tratamientos con concentraciones de nicotina más altas, 20 y $40 \mu \mathrm{M}$.

Tras cuantificar el área retiniana, se detecta una disminución del tamaño de la retina y en paralelo una disminución significativa de las dimensiones cefálicas en el mismo sentido que el tamaño del ojo. En estudios previos realizados en ratas, la exposición crónica a nicotina provoca retraso del desarrollo del cristalino y formación de cataratas (Evereklioglu et al., 2004), reduciéndose en general el espesor de la retina debido a la pérdida de células ganglionares y al adelgazamiento de la capa plexiforme interna (Evereklioglu et al., 2003). En ratones, la exposición a nicotina forma vasos sanguíneos coroideos anormales sobre el epitelio pigmentario (Suñer et al., 2004). La formación de los ojos del pez cebra es sensible a otros compuestos, tales como el etanol, en forma comparable a la detectada en este trabajo tras el tratamiento con nicotina: reduce el diámetro del ojo, altera los registros de electrorretinograma y disminuye la agudeza visual (Bilotta et al., 2002; Bilotta et al., 2004). 
También analizamos el efecto de la nicotina sobre el crecimiento general del animal midiendo la distancia desde el ojo al otolito (una estructura bien diferenciada en la cabeza del animal en todos los estadios analizados; Kimmel et $a l .$, 1995), así como la distancia que separa los ojos como indicador del tamaño del animal, y el peso seco. En consonancia con la literatura, el crecimiento en longitud de las larvas de pez cebra disminuye con el tratamiento con nicotina (Svoboda et al., 2002; Parker y Connaughton, 2007). De nuestro estudio se concluye que las anomalías en los parámetros morfométricas se acrecientan a medida que tratamos a los animales con concentraciones más altas de nicotina y aumenta el tiempo de exposición. En las concentraciones de nicotina más altas probadas los animales muestran las disminuciones de tamaño más acusadas, y también reducen los valores del peso seco. En estudios en los que ratas prenatales se expusieron a ciclos de humo de tabaco se observa bajo peso al nacer frente al de controles (Bassi et al., 1984; Roy y Sabherwal, 1994; Leichter, 1995; Cutler et al., 1996), así como disminución en el peso corporal y parámetros de medidas cerebrales en ratones a cuya madre gestante se le suministró nicotina (Santiago y Huffman, 2012). Se ha sugerido que la nicotina prenatal activa el sistema colinérgico placentario y al tiempo que se suprime el transporte de aminoácidos y la difusión de nutrientes en la circulación placentaria; todo esto resulta en un retraso del crecimiento intrauterino (Naeye, 1981; Sastry, 1991).

En conjunto, estos hallazgos sugieren que la nicotina altera significativamente el crecimiento. Los efectos de la nicotina se relacionan directamente con la dosis y con el tiempo de administración, por lo que se requiere cierta exposición antes de que los cambios se aprecien. Una vez que se manifiesta el efecto de reducción de parámetros del animal, si continua la exposición de nicotina, éste efecto va progresando de manera gradual.

En relación con la citoarquitectura de las estructuras visuales nerviosas durante su maduración, observamos que están bastante conservadas en los animales tratados con nicotina, sin diferencias apreciables con respecto a la 


\section{Discusión}

morfología laminar ni de sus tipos celulares. Esta ausencia de alteraciones no depende ni de la concentración, ni el tiempo de exposición a la nicotina. En concreto el desarrollo histogenético de la retina de animales tratados con nicotina no presenta grandes alteraciones en ninguno de los estadios de desarrollo analizados: en el estadio de $48 \mathrm{hpf}$ solamente se observa una capa y tras la eclosión ( 3 dpf) observamos las seis capas que constituyen la retina en condiciones normales. Por lo que respecta al epitelio pigmentario, el tratamiento con nicotina no produce grandes variaciones en su estructura. En el pez cebra, el esbozo de las estructuras visuales no se aprecia hasta el estadio de 21 somitos (19,5 hpf) (Kimmel et al., 1995) momento en que en nuestro estudio comenzamos la administración de nicotina. Con las concentraciones de nicotina y a los tiempos de administración utilizados en nuestro trabajo, aunque las tallas del ojo, de la retina y el tamaño de la cabeza se reducen, no se aprecian alteraciones en el grosor o distribución de las capas en la retina. Por lo que respecta al TO de los ejemplares tratados con nicotina, ni su aspecto, ni su laminación están alteradas.

Nuestros resultados sugieren que la administración de nicotina no provoca alteraciones graves en el sistema visual en etapas tempranas del desarrollo. Sin embargo en etapas tardías, en procesos de diferenciación de la retina neural (36 hpf-3 dpf), se producen alteraciones que provocan retrasos en el patrón de distribución celular.

En los mamíferos, la exposición a la nicotina provoca diversos efectos que pueden conducir a un crecimiento reducido, tales como alterar el DNA en las células, induciendo la apoptosis (Slotkin, 1998). Estos efectos son selectivos sobre las células que expresan los nAChR (Rowell y Li, 1997; Slotkin, 1998; Ernst et al., 2001; Slotkin et al., 2005). En particular, cuando se administra la nicotina durante el desarrollo embrionario, ésta regula y activa prematuramente estos receptores, alterando el calendario de acontecimientos del desarrollo, dando lugar a efectos perjudiciales sobre los procesos fisiológicos (Slotkin, 1998; Ernst et al., 2001). En estudios previos con ratas se ha observado 
una disminución en el grosor de la CCG y de la CPI de la retina (Evereklioglu et $a l ., 2003)$. Se considera que la pérdida de tamaño en las estructuras puede deberse a una disminución en la proliferación, un aumento de la muerte celular o una disminución en el número o volumen de las prolongaciones de las células. En nuestro trabajo no hemos observado variaciones significativas en el número de células apóptóticas, por lo que, en consonancia con estudios realizados anteriormente (Yan et al., 2006), creemos que la nicotina afecta el patrón definitivo de organización de las neuronas tanto en la retina como en el TO.

En este sentido, el tratamiento del TO con antagonistas de los receptores nicotínicos provoca un refinamiento del mapa retinotectal que demuestra una dependencia del proceso respecto a la actividad de los receptores nicotínicos ( $\mathrm{Tu}$ et al., 2000). Así el tratamiento crónico con nicotina en ranas altera el mapa topográfico del TO reduciendo el área que proyecta desde la retina a las correspondientes dianas tectales específicas (Yan et al., 2006). Esta reducción se produce en ausencia de muerte celular aparente. En nuestro estudio hemos observado con marcadores asociados a proyecciones de la vía visual, como son CR y Zn-8, que la administración de nicotina provoca en algunos casos (Figs. 37 y 40) una disminución de las proyecciones retinotectales hacia el TO que perdura a lo largo del tratamiento.

Las observaciones experimentales antes citadas reafirman la importancia de la activación de los receptores nicotínicos en la actividad neuronal para el mantenimiento del mapa topográfico de los sistemas visuales de vertebrados. La alta densidad de receptores nicotínicos en el colículo superior y en el núcleo geniculado lateral talámico sugieren que estos receptores también juegan un papel importante en los sistemas visuales de mamíferos (Clarke et al., 1984). En ratas, la administración subcutánea de nicotina produce un aumento de la actividad en estas áreas, así como en la corteza visual (London et al., 1988; Marenco et al., 2000). Los estudios en humanos que examinan los efectos de la administración de nicotina exógena sobre el funcionamiento del sistema visual son todavía escasos (Sedwick, 1991; Hakim y Tielsch, 1992; Rizzo, 1993). Sin 


\section{Discusión}

embargo, es posible encontrar en ellos algunos datos relacionados con defectos visuales provocados por consumo de tabaco que muestran analogías con los trabajos experimentales anteriormente citados y podrían tener como base una alteración en los mapas de conexión retinoencefálica.

\section{$\underline{2.2}$ Efectos de la nicotina en la proliferación y muerte celular}

El marcaje de la histona H3-fosforilada es característico de las fases G2 tardía y M (Hendzel et al., 1997). La fosforilación de esta histona está asociada a la condensación de los cromosomas. Sólo en un estudio previo se utiliza la histona H3-fosforilada como marcador de mitosis en la retina de peces, pero no se describe su distribución en detalle (Hitchcock y Kakuk-Atkins, 2004). Además son escasos los estudios de análisis de proliferación celular con este marcador en el pez cebra, sin que conozcamos ningún análisis exhaustivo en las áreas visuales (Murphey et al., 2006; Kizil et al., 2009). En el presente estudio hemos observado células marcadas para histona H3-fosforilada distribuidas por toda la retina en el estadio de $48 \mathrm{hpf}$, mientras que en los estadios larvarios este marcaje queda restringido al margen ciliar de las retinas. Esta localización del marcador de células en división refleja el patrón previamente documentado de división celular durante la retinogénesis en estos estadios en el pez cebra (Ochocinska y Hitchcock, 2007).

El efecto de la nicotina sobre la proliferación celular analizada mediante la inmunodetección de la histona H3-fosforilada en la retina es variable dependiendo del estadio de desarrollo y de la dosis de nicotina suministrada. Se produce una disminución paulatina de la densidad de células proliferativas y se reducen las regiones con alta actividad proliferativa. No hemos encontrado diferencias significativas en la densidad de células en proliferación en el estadio de $48 \mathrm{hpf}$, para ninguna de las concentraciones de nicotina suministradas en comparación con los controles. En cambio, en los estadios embrionarios de 3 dpf y 5 dpf hemos encontrado una disminución en el número de células proliferativas. Esta disminución es mayor en las concentraciones más altas de 
nicotina; esto coincide con que la administración aguda de nicotina en ratas neonatales provoca la inhibición de la síntesis de DNA, promoviendo el cese prematuro de la proliferación y la aparición temprana de la diferenciación (McFarland et al., 1991). Además, se conoce que la administración de nicotina inhibe la proliferación en células de carcinoma embrionario P19 (Resende et al., 2008), aunque se ha demostrado que la nicotina induce la proliferación en cultivo de células de pulmón humano (Petros et al., 2012; Wu et al., 2013) y que la nicotina promueve la progresión del cáncer de páncreas (Treviño et al., 2012).

Mediante la técnica de TUNEL hemos analizado la evolución de la apoptosis en las retinas de animales tratados con nicotina. No hemos encontrado diferencias significativas en la densidad de células apoptóticas en los distintos grupos experimentales, si bien se ha documentado que la tasa de apoptosis puede variar dependiendo de la edad inicio de la exposición del embrión, de la duración del tratamiento y de la concentración de nicotina administrada. En rana se ha demostrado que la administración de nicotina provoca reducción de áreas topografícas visuales, sin que haya una muerte celular aparente ni en el TO, ni en la retina (Yan et al., 2006). Además, en cultivos celulares de carcinoma de pulmón humano, la nicotina inhibe la apoptosis (Petros et al., 2012). Por otro lado, se ha demostrado en pez cebra que una concentración muy alta de nicotina administrada en el estadio de 4 células y con un tratamiento crónico, aumenta las células apoptóticas (Boyd et al., 2003). También se conoce en roedores que la exposición prenatal a la nicotina da como resultados la disminución de la actividad colinérgica después del nacimiento, sobre todo en la segunda semana postnatal (Navarro et al., 1989), y disminuye la transcripción y los niveles de proteína por célula en los casos de exposición prenatal con nicotina, lo que sugiere algún nivel de hipertrofia celular (Slotkin et al., 1987).

\subsection{Efectos de la nicotina en la neuroquímica del sistema visual}

La organización y diferenciación de la retina de los ejemplares tratados con nicotina se encuentra alterada en todos los estadios analizados. La 


\section{Discusión}

exposición embrionaria a nicotina altera, en diversos grados, los patrones de distribución y expresión de todos los marcadores moleculares analizados. El efecto de la nicotina conduce a dos tipos de modificaciones en la organización neuroquímica del sistema visual. Por un lado, algunos marcadores (Islet-1, Zn-8, $\mathrm{CR}$ ) presentan una alteración en su expresión o distribución, que en cierto grado restablecen, con el tiempo, su patrón normal. Por otro lado, el tratamiento con nicotina provoca que otros marcadores (Pax6a, TH, Zpr1, Zpr3) modifiquen su patrón a lo largo del tiempo. Estas modificaciones en tipos celulares y/o regiones de la retina y del TO, frente a lo observado en los animales control, son dependientes de la dosis de nicotina administrada. Estos datos sugieren que el efecto de la nicotina es específico para cada tipo celular.

\section{Calretinina}

La inmunorreactividad para CR ha sido observada en células localizadas a lo largo de todo el sistema visual: retina, área preóptica, tálamo, pretectum, tegmentum y TO. En la retina del pez cebra hemos identificado a las células positivas a CR como células ganglionares y amacrinas desplazadas en la CCG y células amacrinas en la CNI. Además, aparece neuropilo teñido en la CFNO y en la CPI. Estos resultados coinciden con los descritos anteriormente en la retina de pez cebra en desarrollo (Yazulla y Studholme, 2001; García-Crespo y Vecino, 2004; Arenzana, 2006).

La exposición embrionaria a nicotina induce un retraso en el inmunomarcaje para $\mathrm{CR}$ en todas las áreas visuales positivas a $\mathrm{CR}$, sobre todo con las concentraciones más altas de nicotina, aunque al final del periodo larvario el patrón de distribución de esta proteína ligante de calcio es similar al observado en el grupo control. Se ha sugerido que durante el desarrollo de la retina es necesario un mínimo grado de diferenciación tisular y celular para que se detecte la expresión de CR (Ellis et al., 1991; Doldan et al., 1999). El retraso en la distribución de la inmunotinción para CR observada en los animales tratados con nicotina estaría en concordancia con el retraso en la diferenciación 
celular de la retina neural de dichos animales. En la vía visual, se ha sugerido que la CR podría intervenir directamente en la transmisión de la información visual desde la retina hasta el TO, así como desempeñar algún efecto adicional por su presencia en células del circuito tectal (Arévalo et al., 1995).

En estudios sobre cultivos celulares tratados con diferentes concentraciones de nicotina aumenta el calcio intracelular en las células, de manera dependiente a las dosis. Es decir, que a mayor dosis de nicotina, más calcio intracelular (Sabban y Gueorquiev, 2002). Esto apoya los resultados obtenidos en nuestro trabajo, donde al disminuir la distribución de una proteína ligante de calcio, como es la $\mathrm{CR}$, la concentración de $\mathrm{Ca}^{++}$intracelular no ligado puede ser mayor. Otros estudios han observado que la alteración del patrón de las células encefálicas CR positivas depende de la edad perinatal a la que se expone a nicotina. En roedores tratados con nicotina de manera crónica, después del nacimiento o en edades adolescentes aumenta la densidad de células CR positivas en regiones encefálicas (Liu et al., 2005).

\section{$\underline{\mathrm{Zn}-8}$}

El marcaje para Zn-8 en la vía visual del pez cebra se localiza en las células ganglionares de la CCG (Trevarrow et al., 1990). Zn-8 también aparece en células del hipotálamo, pretectum, tálamo, tegmentum y TO al final del periodo larvario (Arenzana, 2006).

El antígeno reconocido por el anticuerpo $\mathrm{Zn}-8$ es una proteína transmembrana de superficie denominada Neurolina (Laessing et al., 1994), que se localiza en axones en crecimiento, especialmente en los axones de las células ganglionares de la retina, tanto durante el desarrollo normal (Paschke et al., 1992; Arenzana, 2006), como durante la regeneración (Paschke et al., 1992; Sherpa et al., 2008; Parrilla et al., 2013). Por tanto, el anticuerpo Zn-8 permite inmunodetectar las células ganglionares de la retina, ya que la Neurolina se encuentra en toda la superficie celular (Trevarrow et al., 1990; Arenzana, 2006). 


\section{Discusión}

En el pez cebra se han encontrado dos genes codificantes para sendas isoformas de Neurolina: Neurolina-a y Neurolina-b (Diekmann y Stuermer; 2009) y ambos genes se expresan en las células ganglionares de la retina. La Neurolina-a interviene en la diferenciación de las células ganglionares de la retina, mientras que la Neurolina-b es de aparición más tardía e interviene en el crecimiento y guía de los axones de dichas células (Diekmann y Stuermer; 2009). Ambas proteínas son detectadas por el anticuerpo $\mathrm{Zn}-8$ que hemos utilizado en nuestro estudio inmunocitoquímico. El patrón de marcaje observado en los animales control de 48 hpf y 3 dpf coincide con el descrito anteriormente en pez cebra (Arenzana, 2006).

No hemos encontrado en la literatura estudios en los cuales se haya utilizado Zn-8 para analizar las posibles alteraciones de la vía visual producidas por la administración exógena de nicotina. En esta Tesis, los ejemplares tratados con nicotina presentan una reducción en la extensión del patrón de distribución de Zn-8 en la retina. La exposición embrionaria a nicotina altera la expresión de Zn-8 tanto en la retina como en el TO. En el estadio embrionario de 48 hpf observamos marcaje para Zn-8 en células ganglionares de la CCG, al igual que en el grupo control, pero con una distribución menos extensa. Esta alteración es más acusada de manera inversa a la dosis de nicotina suministrada, es decir, que en las dosis más bajas la disminución de esta proteína es mayor. Por lo que respecta al TO de los ejemplares tratados con nicotina, se reduce la densidad de neuropilo inmunorreactivo a Zn-8.

La alteración del patrón de distribución de la Neurolina tras el tratamiento con nicotina puede modificar la adhesión celular y el crecimiento y fasciculación de axones (Pourquie et al., 1992), así como la sinaptogénesis (Chédotal et al., 1996). Dicha respuesta puede interpretarse como un tipo de plasticidad neuronal encaminada a promover la guía, el crecimiento y la fasciculación de los primeros axones ópticos hasta el disco óptico, como paso previo en su camino hacía el TO. La reducción de neuropilo inmunorreactivo a Zn-8 en el TO sería consecuencia de la disminución de inervación retinotectal 
paralela al menor número de células ganglionares.

\section{Tirosina-hidroxilasa}

Todas las regiones encefálicas implicadas en el procesamiento de la información visual presentan elementos marcados para TH. En la vía visual del pez cebra se ha estudiado el patrón de distribución de TH en la retina (Guo et al., 1999; Holzschuh et al., 2001) y en las regiones diencéfalicas con aferencias retinianas (Rink y Wullimann 2002; Wullimann y Rink 2002). En la retina de pez cebra las células inmunorreactivas para TH han sido descritas por algunos autores como células amacrinas (Holzschuh et al., 2001) y por otros como células interplexiformes (Guo et al., 1999; Arenzana, 2006). La inmunorreactividad para TH en las regiones prosencefálicas con aferencias retinianas aparece durante el periodo embrionario (hipotálamo, área preóptica, tálamo ventral) o tras la eclosión (pretectum) (Rink y Wullimann, 2001; Wullimann y Rink, 2002).

El tratamiento con nicotina altera el patrón de distribución de TH en la retina y el TO del pez cebra. En la retina de animales tratados con nicotina se detecta por primera vez marcaje para TH tras la eclosión, al igual que en el grupo control. Además, al final del periodo larvario no observamos neuropilo teñido para TH en ninguna de las capas plexiformes, que aparece en los animales control. Estas alteraciones del patrón de distribución de TH pueden conducir a modificaciones del correcto desarrollo del circuito neuronal de la retina, ya que se ha demostrado que la dopamina sintetizada en las células retinianas interviene en funciones tales como movimientos retinomotores durante adaptación a situaciones de iluminación, regulación del tamaño del campo receptivo de las células horizontales, síntesis y liberación de melatonina, así como en regulación del balance de sinapsis de conos y bastones sobre las células horizontales (Manglapus et al., 1999). Por lo que respecta al patrón de distribución de TH en el TO de ejemplares tratados con nicotina, desaparece la inervación catecolaminérgica extrínseca procedente del pretectum y del locus coeruleus (Ma, 1994). Sin embargo, se observan células inmunorreactivas para 


\section{Discusión}

TH como consecuencia de la exposición embrionaria a nicotina. Esto puede deberse a un error en la migración de las células catecolaminérgicas pretectales, ya que el estadio en el que se detecta por primera vez la inmunorreactividad para TH en ambas regiones coincide (5 dpf) en animales control. Además, las células marcadas del TO están muy próximas a las células marcadas del pretectum y ambas poblaciones comparten la misma morfología (fusiforme) y la presencia de una prolongación marcada.

En animales tratados con nicotina las células positivas a TH disminuyen a lo largo del tiempo y el descenso es mayor con las dosis de nicotina más altas. Estos resultados coinciden con trabajos previos que indican que la nicotina disminuye la expresión de TH (Naha et al., 2009). Además, la administración crónica de nicotina da lugar a la disminución, dependiente de las dosis administradas, en la expresión del receptor de dopamina D2 y TH a nivel proteico y trasncripcional. (Naha et al., 2009).

\section{$\underline{\text { Islet-1 }}$}

Las células marcadas para Islet-1 se localizan en todas las regiones que componen la vía visual del pez cebra: retina, área preóptica, hipotálamo, pretectum, tálamo, tegmentum y TO. En la retina, por su morfología y localización, hemos identificado las células positivas a Islet-1 como células ganglionares en la CCG, así como células amacrinas y horizontales en la CNI. En la retina de todos los grupos de vertebrados estudiados hasta el momento, Islet-1 ha sido detectado en células ganglionares y amacrinas (peces: Arenzana, 2006; aves: Fischer et al., 2002; Sakagami et al., 2003; mamíferos: Galli-Resta et $a l .$, 1997). Además, en algunos grupos de vertebrados, Islet-1 se detecta en otros tipos celulares como células horizontales en peces (Arenzana, 2006) y bipolares en aves (Fischer et al., 2002; Sakagami et al., 2003).

La exposición embrionaria a nicotina disminuye el marcaje para Islet-1 en todas las estructuras visuales en el estadio de $48 \mathrm{hpf}$ y $3 \mathrm{dpf}$, mientras que a los 
5 dpf se recupera parcialmente el marcaje. Esta reducción, al igual que ocurre con el marcaje para Zn-8, se produce de tal modo que a menor dosis de nicotina, mayor disminución en la expresión de este factor de transcripción. La modificación del patrón de expresión de Islet-1 tras exposición embrionaria a nicotina confirma estudios previos donde se documenta una reducción del número de motoneuronas que pueden diferenciarse a secundarias tras el tratamiento con nicotina (Svoboda et al., 2002). Por otro lado, Islet-1 es un marcador específico de células ganglionares (Austin et al., 1995) y su expresión comienza una vez que éstas han finalizado su migración hasta la superficie vitreal y se diferencian (Sakagami et al., 2003). Estas alteraciones del patrón de expresión de Islet-1 apoyan las observaciones de que la nicotina parece afectar más a etapas tardías de la retinogenesis (diferenciación celular de las estructuras visuales) que a etapas tempranas (especificación de epitelio pigmentario y retina neural) (Schmitt y Dowling, 1994).

\section{$\underline{\operatorname{Pax} 6 a}$}

Por lo que respecta a la inmunorreactividad para Pax6a, ésta se localiza en células de la retina, área preóptica, pretectum, tálamo, tegmentum, así como en la región rostral del TO. En base a criterios morfológicos y topográficos, hemos identificado las células positivas a Pax6a de la retina como células ganglionares en la CCG y células amacrinas en la CNI. Estos resultados coinciden con los ya publicados en el pez cebra (Wullimann y Rink, 2001).

El patrón de distribución de Pax6a sufre modificaciones tras el tratamiento con nicotina respecto al grupo control. Se demuestra una disminución de la densidad de marcaje en todos los estadios analizados. Esta disminución de expresión sigue conservándose en el estadio larvario de 5 dpf, siendo la alteración dependiente de las dosis de nicotina. Pax6 es uno de los factores de transcripción necesarios para el correcto desarrollo de las vesículas

ópticas (Zuber et al., 2003) y una alteración del mismo puede provocar anomalías en la correcta formación de los ojos. Ello puede estar relacionado con 


\section{Discusión}

la disminución del tamaño de los ojos, ya que existen estudios previos con ratones mutantes nulisómicos para Pax6 que presentan un tamaño reducido de los ojos y otras estructuras encefálicas (Theiler et al., 1978, Hogan et al., 1988, Glaser et al., 1990, Fujiwara et al., 1994, Hanson et al., 1994, Dellovade et al., 1998). En concreto en ratones homocigóticos SeyDey, ya en el día E7 se observa un retraso en el desarrollo respecto a los animales $+/+$, que se mantiene a lo largo de toda la vida del animal y que se traduce en una reducción del tamaño corporal del 10\% respecto a los animales control (Theiler et al., 1978).

La nicotina inhibe sensiblemente la metilación de $\mathrm{CpG}$, que es el sitio de unión de Pax6 en el promotor StAR, lo que impide la unión de Pax6 y regula a la baja la expresión del gen StAR (Wang et al., 2011). Se ha demostrado en cultivo celular que la nicotina inhibe las expresiones de StAR/P450scc, media la tasa de limitación de paso en la síntesis de hormonas esteroides, que es esencial para el desarrollo fetal. Además, también se inhibe la producción de cortisol de manera dependiente de la dosis de nicotina y el tiempo de exposición, ejerciendo efecto sobre la proliferación de células en las glándulas suprarrenales fetales (Wang et al., 2011). En mamíferos, esta supresión permanece durante el tratamiento intrauterino con nicotina, proporcionando un mecanismo epigenético heredable e inducido por nicotina que puede provocar la aparición de enfermedades en adultos (Wang et al., 2011).

\section{Zpr1 y Zpr3}

Los marcadores de detección de los fotorreceptores (Zpr1 para conos y Zpr3 para bastones) se comportan de manera diferente tras el tratamiento de nicotina. Zpr1 no presenta apenas diferencias (para ninguna de las dosis de nicotina utilizada) en su densidad de marcaje en la retina con respecto a los ejemplares control, ni a los 3 dpf, ni a los 5 dpf. Sin embargo, Zpr3 aumenta significativamente su densidad de marcaje en todas las dosis de nicotina utilizadas. Sin embargo, a los 5 dpf se recupera parcialmente el marcaje en las más bajas; por el contrario, con las dosis más altas de nicotina se mantiene la 
densidad de bastones. Por lo tanto, la nicotina altera la diferenciación de los fotorreceptores al aumentar la densidad de los bastones con respecto a la densidad de los conos. Algunas de las alteraciones documentadas con los registros de los electrorretinogramas apoyan esta alteración de la función de los fotorreceptores, que a su vez puede afectar significativamente a la función visual.

Es conocido que el segmento externo de los fotorreceptores no muestra inmunorreactividad para nAChRs, aunque tienen acetilcolina (Brandon, 1987) y enzimas que procesan la acetilcolina (Matsumoto et al., 2012). Estudios recientes han confirmado que en el EP se expresan nAChRs (Maneu et al., 2010; Pons y Marin-Castaño, 2011) en las microvellosidades que cubren el extremo de los segmentos externos de los fotorreceptores. Estos trabajos también apoyan la existencia de comunicación de célula a célula entre los segmentos externos de los fotorreceptores a las células del EP. Además, las disfunciones entre estos dos tipo celulares producen enfermedades como la retinitis pigmentosa, la degeneración macular asociada a la edad. Por lo tanto, creemos que la nicotina puede alterar la señalización en el mantenimiento de la función de los fotorreceptores, si no directamente, de manera indirecta debido a la comunicación intercelular. 


\section{EFECTOS DE LA NICOTINA SOBRE LOS RECEPTORES NICOTÍNICOS DE LA VÍA VISUAL}

Los receptores nicotínicos desempeñan importantes funciones pre- y postsinápticas en la modulación de la actividad neuronal. Son componentes importantes de los mecanismos dependientes de actividad para fortalecer y organizar las sinapsis en diferentes regiones del encéfalo ( $\mathrm{Gu}$ et al., 2003; Origlia et al., 2006). La variación de su actividad por la nicotina exógena puede producir alteraciones sinápticas a largo plazo que alteren el rendimiento del sistema nervioso. Tales alteraciones dependen de la exposición a nicotina, así como de la localización y densidad de los receptores nicotínicos en la región del sistema nervioso afectada.

En el presente trabajo hemos analizado los efectos de diferentes dosis de nicotina sobre los receptores nicotínicos de acetilcolina durante el desarrollo embrionario del pez cebra. Hemos clonado y secuenciado los genes de las subunidades a6, B3a, B3b y cuantificado con qPCR sus niveles de expresión en animales control y en animales tratados con diferentes dosis de nicotina. Mediante hibridación in situ hemos establecido su distribución espaciotemporal, tanto en condiciones normales como tras la administración de nicotina durante el desarrollo.

\section{$\underline{3.1 \mathrm{nAChR} a 6}$}

Los nAChRs a6 se han estudiado ampliamente en las vías dopaminérgicas del SNC, y se expresan intensamente en áreas relacionadas con el sistema visual, como el colículo superior, tracto óptico, núcleos geniculados y retina (Whiteaker et al., 2000; Moretti et al., 2004; Cox et al., 2008; Liu et al., 2009). Además, en ratas se expresa $\mathrm{nAChR}$ a6 en regiones no visuales relacionadas con ciclos luz-oscuridad como la glándula pineal o el hipotálamo; y en regiones visuales como la CCG de la retina y el TO (Gotti y Clementi, 2004). En pez cebra también se ha demostrado que esta subunidad se expresa en estructuras no 
visuales como la glándula pineal y los ganglios trigéminos; y también en estructurales visuales como la CCG y la CNI de la retina, y el TO (Ackerman et al., 2009). Las células de la CNI de la retina, por su localización, y en consonancia con estudios anteriores (Ackerman et al., 2009), se identifican como células amacrinas. El nAChR a6 también aparece en el pez cebra en las células ganglionares de la CCG de la retina. También se ha observado la expresión de nAChR a6 en la retina de pollo en estadios embrionarios (Gotti y Clementi, 2004). Sin embargo, aunque hemos detectado nAChR a6 en el TO en desarrollo del pez cebra, no aparece en el TO del pollo (Gotti y Clementi, 2004).

La amplia expresión de $\mathrm{nAChR}$ a6 en el sistema visual y la retina de mamíferos sugiere que esta subunidad es muy importante en la visión (Moretti et al., 2004; Millar y Gotti, 2009). Los experimentos realizados para evaluar el efecto de la privación visual en los nAChRs mostró que no hay cambios en la expresión de nAChR a6 en las ratas criadas en la oscuridad (Moretti et al., 2004). También se ha visto que la enucleación ocular produce la reducción de los nAChRs a6 en colículo superior y núcleo geniculado lateral (Gotti et al., 2005). Sin embargo, la función concreta de los $\mathrm{nAChRs} \mathrm{a6}$ en la visión es actualmente desconocida. La acetilcolina que actúa sobre los nAChRs modula la excitabilidad neuronal en la corteza visual (Xiang et al., 1998), mientras que los estudios con bloqueantes de nAChRs sugieren que puede tener un papel permisivo para la inervación colinérgica en la función visual (Morishita et al., 2010).

La exposición de los embriones de pez cebra a nicotina produce un incremento significativo en la expresión de nAChR a6 en los estadios larvarios de 3 y 5 dpf con las dosis más altas (20 y $40 \mu \mathrm{M}$ ), lo que sugiere implicaciones de la nicotina en los procesos de laminación, y en los procesos de proliferación. En ratones, tras una inyección con nicotina aumenta la expresión de la subunidad a6 de los nAChRs en neuronas dopaminérgicas en el área tegmental ventral posterior, concluyéndose que en dosis altas, la nicotina activa selectivamente las neuronas dopaminérgicas (Zhao-Shea et al., 2011). Otros estudios sugieren que la sobrexpresión funcional de $\mathrm{nAChR}$ a6 en áreas del sistema 


\section{Discusión}

mesocorticolímbico, tales como el área tegmental ventral y el núcleo acumbens, produce un aumento de la liberación de dopamina (Shytle et al., 2002).

\section{2 nAChR $\beta 3$}

En el caso del receptor nAchR B3, el pez cebra presenta un gen duplicado para este receptor, el nAchR 63 a y el nAchR $63 b$. Nuestro estudio muestra que la nicotina produce modificaciones diferentes en cada uno estos genes.

No conocemos estudios previos de qPCR, ni de hibridación in situ, que analicen su expresión en el pez cebra. Existen estudios de la expresión del nAChR 83 en pez cebra (Zirger et al., 2003) donde se ha observado marcaje en la CCG de la retina y en el TO, aunque sin datos concluyentes.

El nAChR B3a se expresa en la glándula pineal y en los ganglios trigéminos, además de en la CCG de la retina y en el TO. La exposición de los embriones de pez cebra a nicotina produjo un incremento significativo en la expresión del nAChR B3a en las dosis más altas (20 y $40 \mu \mathrm{M})$. Por otro lado el nAChR $63 \mathrm{~b}$ se detecta en los ganglios trigéminos y en la CCG de la retina. La administración de nicotina provoca en todas las dosis una diminución de la expresión a las 48 hpf, mientras que aumenta la expresión en los estadios de 3 y 5 dpf. Ambos alteraciones pueden provocar fallos en la diferenciación celular y en la organogénesis primaria.

Se ha estudiado el patrón de expresión del nAChR $B 3$ en la rata y el pollo. El nAChR B3a se detectó en el estadio embrionario 15 en la retina de la rata, específicamente en la CCG (Hoover y Goldman, 1992), también se ha identificado en la CCG y en la CNI de la retina del embrión de pollo (Hernández et al., 1995; Matter et al., 1995).

Mediante en el uso de transgénicos EGFP en nAChR 83 de pez cebra se ha estudiado el desarrollo de proyecciones axonales de la CCG hacía el TO, observándose que las proyecciones no son uniformes en el TO (Tokuoka et al., 
2002). Utilizando ratones nulisómicos para el nAChR $B 3$ (Booker et al., 2007) se demuestra un aumento de actividad en el sistema de iluminación en campo abierto, incluyendo un componente de ansiedad y un componente de actividad motora (Montgomery y Monkman, 1955; Rodgers et al., 1997).

En el curso de la neurogénesis, las células ganglionares son las primeras neuronas que se generan durante la morfogénesis de la retina y pueden contribuir a la formación de ambientes concretos que pueden influir en la diferenciación de las otras neuronas. Los estudios ultraestructurales de Hinds y Hinds (1983) revelaron que, durante el desarrollo de la retina, un subconjunto de neuronas amacrinas se genera mediante transformaciones morfológicas de células ganglionares que incluyen la pérdida de axones y la migración a la mitad interior de la CNI. Por su parte, Matter et al. (1995) demuestran que la expresión de nAChR $B 3$ en las células ganglionares induce la determinación del destino celular en el desarrollo de la retina. En etapas muy tempranas de la neurogénesis de la retina, algunas células ya tienen un linaje preestablecido en la población de células progenitoras (Matter et al., 1995). La retina neural contiene un grupo de células, aproximadamente una décima parte de las células progenitoras, que expresan el nAChR $B 3$ antes de los últimos ciclos de división, lo que sugiere que este rasgo fenotípico determina cuando las células precursoras están todavía proliferando.

\subsection{La relación entre receptores}

Una serie de estudios relacionan de manera muy estrecha la subunidades a6 y 83 de nAChR y muestran la influencia directa entre ellas. Los estudios de Gotti et al. (2005) demuestran que la supresión de nAChR 83 reduce en gran medida la expresión de nAChR a6 en diferentes regiones encefálicas. En tratamientos crónicos con nicotina se altera la expresión de los nAChRs (Marks et al., 1992). Esta alteración se produce a nivel postraduccional. No obstante, en otros estudios la eliminación de nAChR 83 no tiene efecto sobre la expresión de la subunidad a6 (Cui et al., 2003). Esto, es en gran medida, debido a que un gran 


\section{Discusión}

porcentaje de subunidades 83 se ensamblan con las a6 (Champtiaux et al., 2003; Cui et al., 2003; Perry et al., 2007).

Esta estrecha regulación entre estas dos subunidades se da también en áreas visuales. $\mathrm{Al}$ menos hay siete subtipos de $\mathrm{nAChRs}$ diferentes en la retina de rata (Moretti et al., 2004; Marritt et al., 2005), y muchos de estos mismos receptores se encuentran en el nervio óptico. El transporte de los nAChRs en el sistema visual también esta documentado en carpín dorado (Henley et al., 1986) y en pollo (Swanson et al., 1987). Estudios de inmunoprecipitación secuencial demuestran que muchos de los nAChRs del nervio óptico contienen subunidades a6 y 83. De hecho, el nervio óptico tiene el mayor número y concentración de nAChRs a6 y 83 encontrados en el SNC (Cox et al., 2008). La gran población de nAChRs a6 del nervio óptico también se aprecia en la retina, colículo superior, cuerpo geniculado lateral, tractos ópticos y núcleos pretectales (Le Novere et al., 1996; Whiteaker et al., 2000; Champtiaux et al. 2002). Curiosamente, el porcentaje de receptores que contienen subunidades a 6 excede al porcentaje de B3, lo que indica que las dos subunidades no siempre se asocian. Las subunidades a6 y 83 son expresadas en niveles más altos en el nervio óptico que en la retina, lo que indica que los nAChRs que contiene estos subunidades se transportan por el nervio óptico.

En nuestro estudio hemos analizado cómo se comportar las subunidades a6, B3a y 63b de los nAChRs en el pez cebra tras la administración de diferentes dosis de nicotina. El nivel de expresión de las subunidades a6 y 63 a presenta patrones similares. Estas subunidades muestran unos valores parecidos tras los tratamientos con nicotina de 10, 20 y $40 \mu \mathrm{M}$; con respecto al comportamiento en el tiempo de tratamiento, se aprecia que a las $48 \mathrm{hpf}$ se produce una disminución de su expresión o unos valores similares a los controles, mientras

que a los 3 y 5 dpf aumenta su expresión. Además, las subunidades a 6 y B3a se expresan conjuntamente en más regiones tanto visuales como no visuales que a6 y $63 b$. 
Por otro lado, la relación entre $a 6$ y $63 b$ no es tan clara. Estas subunidades muestran unos valores parecidos solo tras el tratamiento de nicotina de $20 \mu \mathrm{M}$; con respecto al comportamiento en el tiempo de tratamiento, se aprecia que a las $48 \mathrm{hpf}$ la disminución de la expresión de $83 \mathrm{~b}$ es mucho más drástica y se mantiene en todos los grupos de tratamiento, pero a los $3 \mathrm{dpf}$ sigue disminuyendo la expresión en algunos grupos, mientras que a los 5 dpf, al igual que la subunidad a6, aumentan los niveles de expresión. Por lo que respecta a las regiones que comparten localización de a6 y $83 b$, se limitan a la CCG de la retina y a estructuras no visuales, como los ganglios trigéminos. 


\section{EFECTOS DE LA NICOTINA EN LA ELECTROFISIO- LOGÍA DE LA RETINA}

Nuestros resultados muestran que la nicotina aumenta en gran medida las amplitudes de las ondas-b de conos en larvas de pez cebra, pero deprime significativamente las amplitudes de las ondas-b de bastones. Estos resultados aclaran y amplían los resultados obtenidos en conejos (Jurklies et al., 1996) y humanos (Varghese et al., 2011), que sugieren que la nicotina puede aumentar la onda-b en condiciones fotópicas y disminuir en condiciones escotópicas. Aunque la nicotina altera enormemente las amplitudes de las ondas-b impulsadas de conos y bastones, no afecta a la sensibilidad de la respuesta. Es decir, en las intensidades de log -5 las ondas-b, tanto de conos como de bastones, se mantienen en la misma posición en el eje de intensidad. Así, la nicotina altera la amplitud de las respuestas de la onda-b, pero no la sensibilidad de las respuestas, independientemente de la dosis de nicotina. La sensibilidad de la onda-b viene determinada en gran parte por los fotorreceptores (Renninger et al., 2011).

No está claro cómo la nicotina puede afectar las amplitudes de las ondasb. Suponiendo que la onda-b en el pez cebra se manifiesta directamente en las respuestas de las células bipolares, nuestros datos sugieren que la nicotina aumenta la respuesta a la luz en las células bipolares ON de conos, pero disminuye la respuesta a la luz en células bipolares ON de bastones. La repuesta a la luz de las células bipolares se genera en la capa plexiforme externa (CPE), como resultado de la entrada sináptica a las células bipolares desde los fotorreceptores (Dowling, 2012). En las larvas de pez cebra, Arenzana et al., (2005) han observado prolongaciones celulares que contienen colina acetiltransferasa (ChAT) en la $\mathrm{CPE}$, y puede ser que estas prolongaciones sean la fuente de acetilcolina que afecta a las células bipolares. Las prolongaciones que contienen ChAT desaparecen poco a poco cuando las larvas maduran, y en pez cebra adultos solamente se encuentra ChAT en la CPI. Como se señaló anteriormente, la nicotina aumenta las respuestas de células ganglionares a la luz, y nuestros resultados pueden su- 
gerir que parte de este aumento se debe a una mayor respuesta de las células bipolares $\mathrm{ON}$ de los conos bajo la luz en condiciones fotópicas.

En los mamíferos, las células bipolares de cono y las células bipolares de los bastones están generalmente segregadas (Pang et al., 2010) y la nicotina puede provocar efectos opuestos sobre estas dos clases de células bipolares ON. En el pez cebra, sin embargo, mientras que hay células bipolares que reciben información sólo a partir de conos, todas las células bipolares que reciben entrada de bastones también tienen entradas de conos (Li et al., 2012). Sin embargo, de las cuatro categorías de conexión de conos y bastones con las células bipolares en el pez cebra, una es mayoritaria (6 veces más), concretamente la constituida por células que reciben información en su mayoría de bastones, y la siguiente en porcentaje corresponde a las que tienen más aportaciones de conos que de bastones. Puede ser que las células bipolares que reciben información mixta sean dominadas por los bastones, que es el principal contribuyente a la onda-b escotópica en el pez cebra, y serían estas células las que tendrían una actividad disminuida por la nicotina, mientras que las otras células bipolares $\mathrm{ON}$ ven aumentada su actividad por la nicotina. En los mutantes nof las células bipolares mixtas de conos y bastones no reciben ninguna entrada de los conos, tal vez por ello hay mayor supresión de la onda-b de las células bipolares ON de los bastones por parte de la nicotina.

La función de la acetilcolina en la retina aún se encuentra en discusión. Aunque se conoce que el pez cebra parece tener grupos específicos de células ganglionares, así como células amacrinas starburst (Taylor y Smith, 2012), los detalles de la anatomía y fisiología del sistema colinérgico en CPI no son bien conocidos. El patrón de inervación colinérgica en el pez cebra sugiere una mayor complejidad en términos de estratos en la CPI (Yazulla y Studholme, 2001). En la mayoría de las especies examinadas se han observado prolongaciones colinérgicas sólo en los estratos 2 y 4 de la CPI (Dowling, 2012), pero en el pez cebra también se observan en los estratos 1 y 5 (Dowling, 2012). 
La acetilcolina no parece desempeñar un papel importante en la mediación de dirección-selectividad en células ganglionares, aunque está presente en ellas y es también liberada por las células amacrinas starburst (Dowling, 2012). Se postula que papel de la acetilcolina en la retina consiste en mediar en la propagación de las oleadas espontáneas de la actividad de las células ganglionares a través de la retina antes de que esta sea sensible a la luz (Dowling, 2012). Durante el desarrollo, las sinapsis convencionales, típicas de las sinapsis de células amacrinas, se observan en la capa plexiforme interna antes de que haya respuestas de luz evocadas (McArdle et al., 1977), y es probable que estas sinapsis se produzcan entre células amacrinas y entre células amacrinas y ganglionares. Inicialmente están mediadas exclusivamente por acetilcolina y glutamato, pero más tarde también contribuyen otros neurotransmisores. Se cree que estas oleadas son críticas para el desarrollo y el refinamiento de las proyecciones de las células ganglionares en los centros superiores visuales. Así, por ejemplo, si la actividad de la retina se altera en un ojo por manipulación farmacológica, la segregación de la entrada específica de proyecciones al núcleo geniculado lateral se interrumpe (Shatz y Stryker, 1988) y se postula que ello se relaciona con la ausencia de las oleadas. Con respecto a la generación de oleadas, se cree que la actividad espontánea no correlacionada converge desde células amacrinas sobre células ganglionares, produciendo actividad correlacionada en grupos de células ganglionares (Feller et al., 1997).

Con el tiempo las oleadas desaparecen inducidas por la respuesta a la luz. Solo aparecen durante el desarrollo, por lo que estas oleadas no se observan en la retina adulta. La acetilcolina tiene niveles de actividad sesgada en las células ganglionares, lo que podría ser su papel principal (Dowling, 2012). Nuestros resultados sugieren que no solo es mediada por las células de empuje starburst mediante sinapsis sobre las células ganglionares y otras células amacrinas, sino también, tal vez, sobre las células bipolares. 


\section{EFECTOS DE LA NICOTINA EN EL COMPORTA- MIENTO UNDUCIDO POR LA FUNCIÓN VISUAL}

El uso de ensayos experimentales que dependen de comportamientos reflejos para el análisis de la función visual produjo inicialmente cierta confusión. En 1914 von Hess llegó a la conclusión de que los insectos y vertebrados anamniotas son completamente ciegos al color, una conclusión refutada en el mismo año por von Frisch (1914). Actualmente, conocemos que muchos animales con capacidad para la visión en color pueden comportarse como daltónicos en algunos contextos, especialmente en las pruebas experimentales con visión de movimiento; así se ha demostrado en las abejas (Lehrer, 1994), el carpín dorado (Schaerer y Neumeyer, 1996) y también en el pez cebra (Krauss y Neumeyer, 2003). No obstante, los ensayos de comportamientos reflejos pueden proporcionarnos valiosos indicios acerca de las capacidades visuales de los animales de experimentación. De hecho, este tipo de ensayos son el método de elección en los cribados genéticos o farmacológicos.

\section{$\underline{5.1 \text { Respuesta optomotora }}$}

El ensayo de la respuesta optomotora (ROM) evalúa el efecto de los compuestos sobre la visión de pez cebra con un rendimiento más alto que la respuesta optocinética (ROC). Sin embargo, los compuestos que afectan a la capacidad locomotora del pez cebra podrían generar respuesta positiva en el ensayo ROM. Por lo tanto, el ensayo ROM puede ser utilizado como una criba importante para compuestos que evalúan defectos en la función visual con un cribado secundario en ROC y para una hipomotilidad en un ensayo locomotor (Richards et al., 2008). Todavía no está claro qué campos topográficos de conexión de las células ganglionares están involucrados en la elaboración superior de estos estímulos, aunque Roeser y Baier (2003) demostraron que la ROM persiste después de provocar ablaciones bilaterales del neuropilo tectal y del campo de arborización pretectal (AF-7), lo que sugiere que estas zonas no están implicadas en este compor- 


\section{Discusión}

tamiento.

Tras el tratamiento con nicotina, la respuesta optomotora frente al contraste disminuye, mientras que si aumentamos el contraste mejora la capacidad visual de respuesta al estímulo y aumenta el número de larvas que responden correctamente, pero sin llegar a los niveles del grupo control. Ocurre lo mismo en el caso de la frecuencia espacial, que presenta un déficit con las dosis de nicotina más bajas, si bien se recupera esta función con las dosis más altas, pero sin alcanzar los niveles de los controles. Tanto en el contraste como en la frecuencia espacial, la disminución de la respuesta de las larvas está asociada a la dosis de nicotina con que se las ha tratado. En el caso de la frecuencia temporal ocurre lo mismo que con los parámetros anteriores, aunque las diferencias solo son patentes en los animales tratados con las mayores dosis de nicotina. Por tanto, el grupo tratado con $5 \mu \mathrm{M}$ de nicotina presenta unos correctos niveles de actividad motora, y las alteraciones detectadas han de deberse a un defecto visual, que no recuperan. El grupo tratado con la dosis de $10 \mu \mathrm{M}$ de nicotina presenta una actividad motora normal, con defectos visuales incrementados. Y los grupos tratados con dosis de 20 y $40 \mu \mathrm{M}$ de nicotina, presentan problemas motores, pero además también tienen problemas visuales aún mayores.

Los resultados que hemos obtenido en el análisis de la respuesta optomotora indican un problema de seguimiento del estímulo visual, que puede estar enmascarado por un problema de hipomotilidad de los animales tratados con nicotina (Svoboda et al., 2002). Cierto componente de la modificación de la respuesta se debe a un problema visual, puesto que al aumentar el contraste, la frecuencia espacial o la frecuencia temporal, mejora la respuesta optomotora. Con las dosis de nicotina más altas administradas no se recuperan los valores de respuesta en comparación con los controles, aunque mejora la respuesta; si se tratase de un problema motor, dichos incrementos en la respuesta no se producirían al mejorar el estímulo visual. 


\subsection{Respuesta optocinética}

El uso de mediciones del movimiento ocular ha sido de gran utilidad para la comprensión de disfunciones neurofisiológicas y neuroquímicas tras la administración de diferentes drogas o en trastornos clínicos (Maurer et al., 2011). Los estudios de comportamiento en modelos animales y humanos expuestos a diferentes drogas indican que las medidas oculomotoras pueden proporcionar un índice farmacodinámico altamente sensible del efecto de drogas en los sistemas cerebrales (Reilly et al., 2008).

La respuesta optocinética (ROC) se altera tras la administración de nicotina. En los ejemplares tratados se produce una diminución de la velocidad del ojo en el seguimiento del estímulo visual asociada a la dosis de nicotina. Además disminuyen los movimientos sacádicos de los animales tratados con nicotina, lo que concuerda con lo descrito en humanos (Clarke et al., 1985; Domino et al., 1997; Larrison et al., 2004; Rycroft et al., 2006; Zingler et al., 2007). Dichos estudios han demostrado que la nicotina reduce el número de movimientos sacádicos principales durante tareas de búsqueda en fumadores, y en pacientes no fumadores con esquizofrenia (Avila et al., 2003; Olincy et al., 2003; Tanabe et al., 2006).

\section{$\underline{5.3 \text { Respuesta visual motora }}$}

Los factores circadianos, como el ciclo luz-oscuridad, tienen efectos sobre el desarrollo del sistema visual (Abramov y Hainline, 1991; Organisciak y Winkler, 1994; Guido et al., 2010). Así, las condiciones adversas de iluminación afectarían en la anatomía retiniana. En este sentido, hay estudios que sugieren que una intensidad moderada de luz produce un daño sustancial (Abramov y Hainline, 1991), mientras que otros estudios indican que estas condiciones, incluso durante períodos de tiempo prolongados (hasta 8 meses), tienen pocos efectos sobre la anatomía retiniana (Bilotta, 2000). Es un hecho que las unidades de cuidados intensivos neonatales son muy estrictas en el control de iluminación para la pre- 
vención de la ictericia y el trastorno afectivo estacional, e incluso una exposición continua de luz puede provocar alteraciones en el sistema nervioso (Harwerth y Sperling, 1975; Powers et al., 1988; Bilotta, 2000).

Nuestros resultados de la RVM, muestran que los peces cebra tratados con bajas dosis de nicotina responden de manera similar al estímulo lumínico que los animales control, mientras que al incrementarse la dosis de nicotina disminuye la respuesta al estímulo lumínico. Esto indica el posible desarrollo de un déficit de acomodación visual con respecto al paso de luz a oscuridad y viceversa. En estudios complejos con ratas, en los que se han empleado estímulos visuales de encendido y apagado de la luz en sus habitáculos, se ha comprobado que la nicotina aumenta la respuesta mantenida por ambos tipos de cambios estímulo (Raiff y Dallery, 2009), aún considerando que la asociación del estímulo con alimento pueden haber interferido en los resultados. 
Conclusiones 

De acuerdo con los objetivos planteados en este Trabajo de Tesis Doctoral, y como consecuencia de los resultados obtenidos, concluimos:

I. La exposición de embriones de pez cebra a nicotina reduce el área ocular y el tamaño del animal en relación con la dosis administrada, sin que se produzca modificación de la laminación de la retina o el techo óptico.

II. La exposición de embriones a nicotina provoca efectos menos acusados durante la segregación entre la retina neural y el epitelio pigmentario, que en la diferenciación celular de la retina neural, asociado a un retraso en la maduración neuroquímica de las diferentes poblaciones de la retina neural.

III. El tratamiento con nicotina durante el desarrollo altera los patrones de expresión de los nAChRs. Las subunidades a6 y B3a aumentan al incrementar la dosis de nicotina. Las subunidades a6 y $83 b$ difieren en sus niveles de expresión en los distintos grupos de tratamientos con nicotina y en diferentes estadios de desarrollo analizados.

IV. La nicotina altera el electrorretinograma del pez cebra, estimulándose las células bipolares $\mathrm{ON}$ de conos e inhibiéndose a las células bipolares ON de bastones.

V. Los animales expuestos a bajas dosis de nicotina tienen una actividad motora correcta y cierto déficit visual, mientras que al aumentar la dosis de nicotina administrada aparecen, en las más altas, los problemas en la actividad motora, agravándose además el déficit visual. 

Summary 



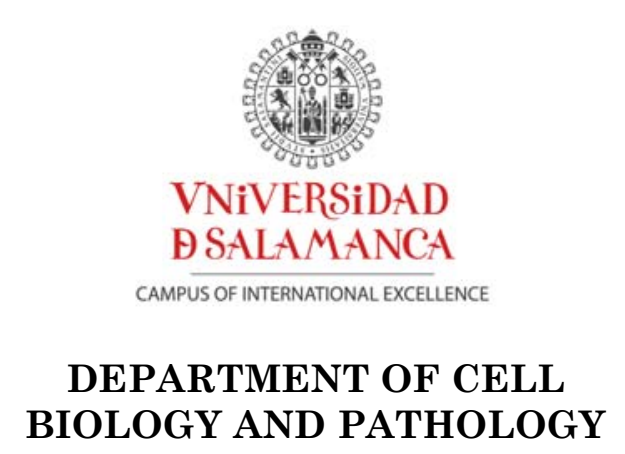

BIOLOGY AND PATHOLOGY

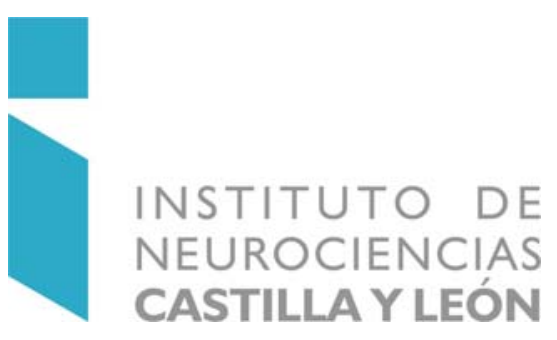

COMPARATIVE NEUROBIOLOGY LAB.

DOCTORAL THESIS

Nicotine-induced alterations during

the development of the visual system of the zebrafish

Miguel Moyano Téllez

2013 



\section{INTRODUCTION}

The zebrafish provides a good model for studying the development of the visual system of vertebrates. At early embryonic development, the primary visual field is located in the anterior neural plate $(6 \mathrm{hpf})$. Once that the visual field has divided, optical primordia forms (10 $1 / 3 \mathrm{hpf})$. Then these visual regions transformed into bistratified optical cups (retinal pigment epithelium and neural retina) (Schmitt and Dowling, 1994). Already in early stages of morphogenesis of the retina, the cells that compose the optical vesicles are morphologically and molecularly equivalent components that can generate the entire neural retina, the retinal pigmented epithelium and the optical peduncle. Simultaneously, the lens forms (at the stage of 21 somites, $19.5 \mathrm{hpf}$ ). At the stage of 48 hours post-fertilization, the eye is almost completely formed, but the choroidal fissure is not fully closed until hatching, approximately at 3 days postfertilization. At 3 days post-fertilization all cell types and all layers of the retina are formed (Kimmel et al., 2005).

The retina is a laminated structures that is formed by alternating layers of cells (inner nuclear layer, outer nuclear layer and ganglion cell layer) and neuropil (inner plexiform layer, outer plexiform layer and optic never fibre) with highly conserved cytoarchitecture in all vertebrates (Ramón y Cajal, 1892). The light crosses the vitreal face and, after passing through all retinal layers, incide on the photoreceptors, which transform the signal into electrical impulses that are transmitted to bipolar cells, and finally to ganglion cells (Dowling, 2012). The axons of these neurons form the optic nerve that exits the retina and project to the optic tectum that during the early stages of development have two layers: the white surface zone and the periventricular gray zone Vanegas et al., 1984; Meek y Nieuwenhuys, 1998).

During the development of the visual system different molecular markers are expressed. This helps us analyze the different areas of the visual 
pathway during ontogeny. We used in this study a marker for proliferation as phosphorylated histone $\mathrm{H} 3$, starting in the late G2 phase and extends around the nucleus during the M phase transition (Hendzel et al., 1997). Also we used differentiation markers: Calretinin is abundantly expressed in the central and peripheral neural system, particularly in the retina, but also in other sensory pathways (Bertschy et al., 1998). Zn-8 allows inmunolabeling ganglion cells and their growing axons (Westerfield, 1995). Islet-1 label ganglion cells when begin their differentiation (Sakagami et al., 2003). Pax6a involved in the early development of the eye (MacDonald et al., 1995, Wilson and MacDonald, 1996). and final distribution of specific cell populations as Tyrosine-hydroxylase for cells catecholaminergic, Zpr1 for cones and Zpr3 for rods.

The valuation of an innate response behavior should be as solid as possible, quantifiable and automated. Assays have been developed to conduct zebrafish larvae that have been used for mutation detection and characterization of the visual system of wild larvae vision and/or mutants. The tests used are optomotor was studied for Lyon (1904), optokinetic this test is a tool for detection of mutations that affecting the visual system of zebrafish larvae (Brockerhoff et al., 1995, 1997; Neuhauss et al., 1999, Gross et al., 2005; Muto et al., 2005). and visual-motor responses recordin the locomotor activity of the larvae in response to changes from light (McPhail et al., 2009; Kokel et al., 2010).

The electroretinogram (ERG) is a recording of the electrical activity of the whole retina. When a flash ERG is performed on a dark-adapted eye, the response derives primarily from the rod system. Sufficiently bright flashes will elicit ERGs containing mainly an a-wave (from photoreceptors) (Witkovsky et al., 1975) and a b-wave (from bipolar, amacrine, and Müller cells) (Miller and Dowling, 1970; Newman and Odette,1984).

Tobacco addiction is one of the socio-economic and health major problems in developed countries and the prevalence of this disease is increasing 
significantly in developing countries. According to the World Health Organization (WHO), more than one billion people smoke tobacco worldwide and its consumption produces more than 5 million deaths per year. Furthermore, tobacco consumption constitutes a risk factor for 6 of the 8 major causes of mortality worldwide (WHO, 2012). Nicotine is the main psychoactive component of tobacco and responsible for smoke addiction.

The effects of nicotine are a result of its action on the nicotinic acetylcholine receptor (nAChR) (Le Novere and Changeux, 1995), whose main function is the modulation of synaptic transmission. Recent findings indicate that acetylcholine can play an important role in nervous system development (Zoli et al., 1995; Role and Berg, 1996). It has been determined from animal studies that the nicotinic acetylcholine receptor $(\mathrm{nAChR})$ is functional from the early fetal development, when the neural tube is forming (Alturi et al., 2001). Through the stimulation of nAChRs, acetylcholine can trigger neural development (Navarro et al., 1989; Eriksson et al., 2000). It has also been demonstrated that acetylcholine has a very active role in the development of the brain and is responsible for the proliferation, maturation and differentiation of many cell types (Kolb, 1989; Pugh and Margiota, 2000).

Studies of the effects of nicotine on neural development have demonstrated that failure occurs in early growth axonal (Svoboda et al., 2002). It has also been shown that nicotine delayed differentiation of spinal motoneurons with involvement of nicotine-specific receptors (Higashijima et al., 2000).

There is studies about alterations in the startle response in adult zebrafish exposed to nicotine during embryonic development (Eddins et al., 2009). Persistent alterations in neuronal differentiation and axon growth have also been evaluated in adult zebrafish (Menelaou et al., 2008), that had been previously described in embryos (Svoboda et al., 2002). These findings on chronic effects in zebrafish complement those described it in rodents after prenatal 
exposure to nicotine (Shacka et al., 1997; Slotkin et al., 2006). Exposure to nicotine during fetal development causes abnormalities in growth rates (Wang et al., 2009) and alterations during nervous system development (Mao et al., 2008).

Specific nicotinic receptors ( $a 6$ y B3) contribute to the organization and normal functioning of the visual system (Cui et al., 2003; Gotti et al. 2005). The administration of nicotine can give rise to changes in the organization of this system, refining the visual topographic map (Yan et al., 2006). Histopathological studies have shown that maternal intake of nicotine causes damage in newborn rat retina (Evereklioglu et al., 2003). In animals treated with high doses of nicotine, the retinal ganglion cell layer and the overall thickness of the retina are reduced compared with control retinas. Selective degenerative changes were also observed in the inner plexiform layer, which is a characteristic shared with retinal ischemic atrophy (Evereklioglu et al., 2003).

In this work, we have analyzed the morphogenesis of the zebrafish visual system in normal conditions and after exposure to nicotine in the 21-somite stage (19.5 hpf), when cellular differentiation events are initiated (Blader et al., 2003; Quillien et al., 2011). The analysis has been carried out under anatomical, neurochemical, electrophysiological and behavioral approaches. 


\section{OBJECTIVES}

As hypothesis for this work we propose that nicotine affects the neurochemical expression pattern during development in different cell populations of the visual system, altering visual electrophysiological properties, which will result in changes on visually directed behavior. The specific objectives of the study are:

I. Analysis of changes in the cytoarchitecture of the main components of the visual pathway after exposure to different concentrations of nicotine and at different stages of development.

II. Study of alterations in the neurochemical development of the visual pathway after exposure to nicotine, through the analysis of variations in expression patterns of different markers.

III. Analysis of changes in the expression of nAChRs that to specific to the visual pathway after exposure to nicotine at different stages of development.

IV. Study of the variations in the retinal electrophysiological response in animals exposed to nicotine.

V. Analysis of the potential impact induced on the visual behavior after exposure to different concentrations of nicotine. 


\section{MATERIALS AND METHODS}

The experiments were carried out in $\mathrm{AB}$ strain zebrafish embryos. They were staged and reared according to standard procedures (Westerfield, 1995). We have also used nof zebrafish mutants supplied by Prof. John E. Dowling, Harvard University (Cambridge, USA). Nof mutants exhibit a transition mutation in the gene for the a transducin (Tca) of the cones, making it nonfunctional.

All procedures and experimental protocols were in accordance with the guidelines of the European Communities Directive (86/609/EEC, 2003/65/EC and 2010/63EU) and the current Spanish legislation for the use and care of animals in research (RD 1201/2005, BOE 252/34367-91, 2005).

Embryos were treated in the stage of 21 somites (19.5 hpf). Embryos were exposed to different concentrations of nicotine (5, 10, 20 y $40 \mu \mathrm{M})$ during different periods of time (until 48 hpf, 3 y 5 dpf). Untreated embryos were used as control specimens.

To assess the different objectives we used diverse experimental procedures including:

1. Morphometric measurements.

2. Quantification by HPLC.

3. Semithin sections stained with toloudine blue.

4. Whole-mount in situ hybridization using riboprobes (HIS).

5. In toto immunohistochemistry.

6. Immunohistochemistry in cryo-sections.

7. TUNEL technique. 
8. Quantitative PCR.

9. Electroretinogram recording.

10. Behavioral analysis (optomotor, optokinetic and visual-motor responses).

11. Quantitative measurements were carried out by using ImageJ software, and Prism 4.0 (GrapPad) software was used for the statiscal analysis.

\begin{tabular}{|c|c|c|c|}
\hline Riboprobes & Origin & $\begin{array}{c}\text { Restriction } \\
\text { enzymes }\end{array}$ & Polimerase \\
\hline Islet-1 & $\begin{array}{c}\text { S. Wilson (Univeristy } \\
\text { College London) }\end{array}$ & XbaI & $\mathrm{T} 7$ \\
\hline Pax6a & $\begin{array}{c}\text { S. Wilson (Univeristy } \\
\text { College London) }\end{array}$ & SmaI & $\mathrm{T} 7$ \\
\hline a6 nAChR & Own & HindIII & $\mathrm{T} 7$ \\
\hline B3a nAChR & Own & HindIII & $\mathrm{T} 7$ \\
\hline B3b nAChR & Own & XbaI & $\mathrm{Sp} 6$ \\
\hline
\end{tabular}

Table 1: Riboprobes used in the study.

\begin{tabular}{|c|c|c|c|}
\hline Antigen & Primary antibody & Dilution use & Source \\
\hline $\begin{array}{c}\text { Phosphorylated histone H3 } \\
\text { (PH3) }\end{array}$ & Mouse monoclonal IgG & $1: 500$ & Abcam \\
\hline $\begin{array}{c}\text { Calretinin (CR) } \\
\text { Digoxigenin }\end{array}$ & Rabbit policlonal IgG & $1: 10000$ & Swant \\
\hline Neuroline (Zn-8) & Mouse monoclonal IgG & $1: 500$ & Jackson \\
\hline Tyrosine hydroxylase (TH) & Mouse monoclonal IgG & $1: 800$ & Chemicon \\
\hline Zpr1 & Rat monoclonal IgG & $1: 200$ & ZIRC \\
\hline Zpr3 & Rat monoclonal IgG & $1: 200$ & ZIRC \\
\hline
\end{tabular}

Table 2: Primary antibodies used in the study. 


\section{RESULTS}

\section{Morphological analysis}

We have analyzed the changes in animal size and ocular parameters after nicotine treatment. In our study, we have not observed significant differences in the ocular size at $48 \mathrm{hpf}$, at any concentration of nicotine analyzed. At $3 \mathrm{dpf}$ (Fig. 1) and $5 \mathrm{dpf}$, exposure to nicotine produces significant differences between treated animals and controls. The ventral and lateral ocular areas are significantly reduced. The treatment with nicotine reduces the ventral and lateral ocular projection area, the distance interocular and the eye and otolith. The reduction is higher in the groups of animals treated with nicotine concentrations of 20 and $40 \mu \mathrm{M}$.

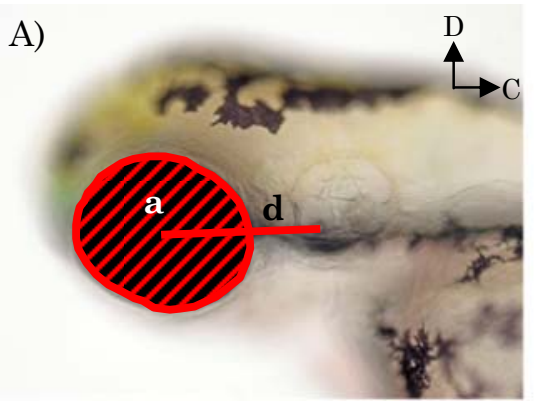

C)
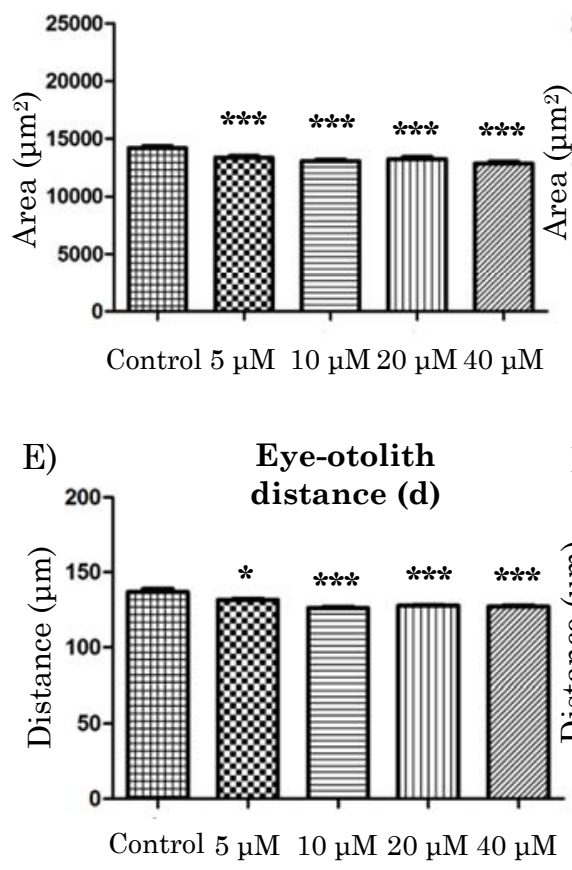

B)

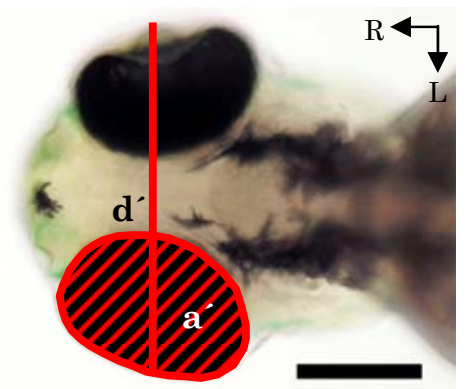

D) ocular ventral area (á)
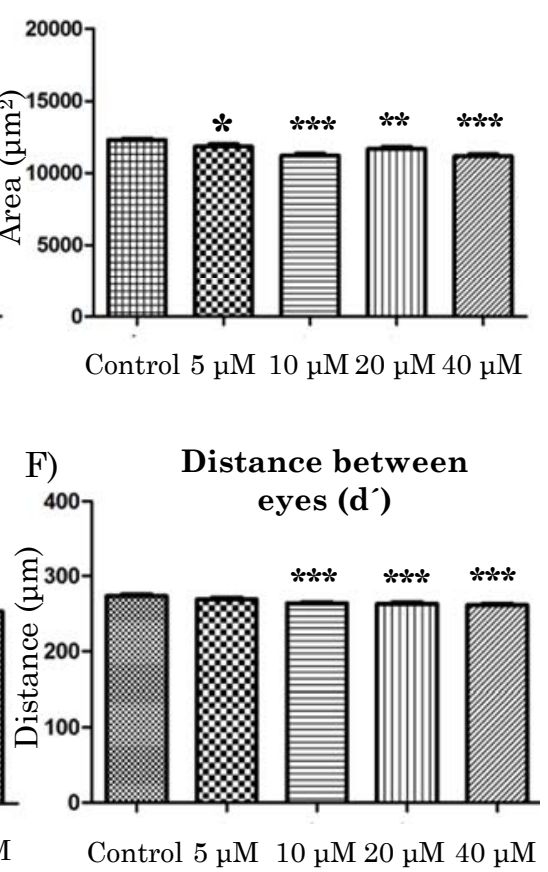

Fig. 1: A) Lateral view of a 3 dpf zebrafish embryo. a: projection area of left eye. d: distance between eyes and otolith. B) Ventral view from of a $3 \mathrm{dpf}$ zebrafish embryo. a': projection area of left eye. $d$ ': distance between eyes. C), D), E) and F) Histograms of the ocular area and head morphometric distances of embryos in the different groups of study. C) Lateral ocular area. D) Ventral ocular area. E) Distance from the center of the eye to the otolith. F) Distance from the central end of one eye to the other eye. C: Caudal. D: Dorsal. L: Lateral. R: Rostral.

$*=\mathrm{P}<0.05$.

$* *=0.05>p>0.001$ $* * *=\mathrm{P}<0.001$.

Scale bar: $100 \mu \mathrm{m}$. 
We quantified the changes in the average size of the retina in the specimens treated with nicotine. In all cases, comparable anatomical regions were selected among all groups. At the stage of $48 \mathrm{hpf}$ (Fig. 2) there is a small decrease in the retinal area in animals treated with nicotine compared to controls. The average size of the retinal area is $13,390 \pm 684.1 \mu^{2}$. At the stages of $3 \mathrm{dpf}$ (Fig. 2) the average size of the area of the retina $(16,490 \pm 616.2$ $\mu \mathrm{m}^{2}$ ) was significantly lower in the $40 \mu \mathrm{M}$ treated animals with respect to the control group. At $5 \mathrm{dpf}$ (Fig. 2) the decrease of the retinal area is larger than the previous stage, and the values are highly significant relative to those in control specimens, with an average area of the retina of $17,830 \pm 291.2 \mu \mathrm{m}^{2}$.
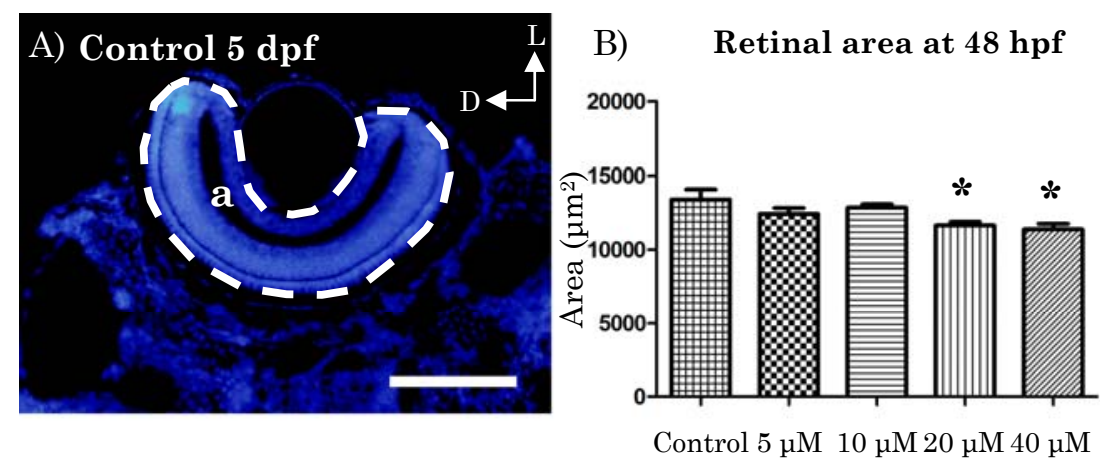

C) Retinal area at $3 \mathbf{d p f}$

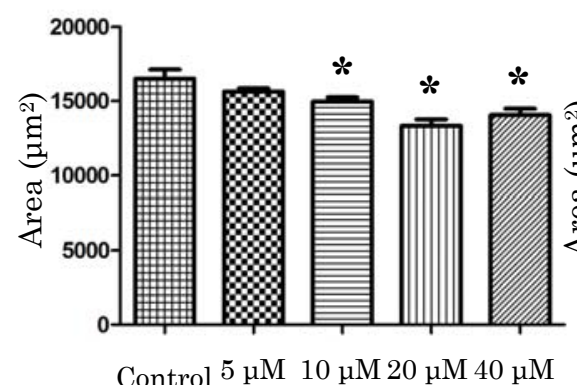

D)

Retinal area at $5 \mathbf{d p f}$

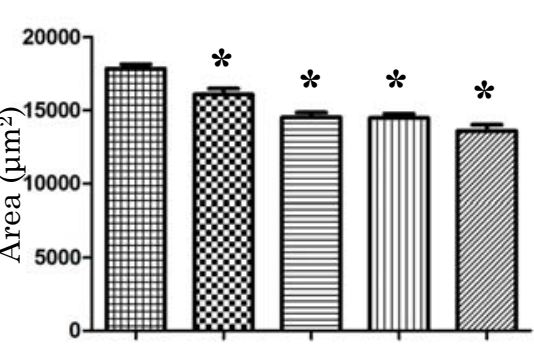

Control $5 \mu \mathrm{M} 10 \mu \mathrm{M} 20 \mu \mathrm{M} 40 \mu \mathrm{M}$
Fig. 2: A) Coronal section of an eye at $5 \mathrm{dpf}$. B), C) and D) Histograms of the area of the retina at different stages and treatments. B) Retinal area of 48 hpf embryos. C) Retinal area of $3 \mathrm{dpf}$ larvae. D) Retinal area of $5 \mathrm{dpf}$ larvae. a: area of a coronal section of a retina of $5 \mathrm{dpf}$. D: Dorsal. L: Lateral.

$*=\mathrm{P}<0.05$.

$* *=0.05>\mathrm{p}>0.001$.

$* * *=\mathrm{P}<0.001$.

Scale bar: $50 \mu \mathrm{m}$.

\section{Neurochemical analysis}

We have analyzed the effect primary nicotine the on cell proliferation, cell differentiation and cell death in the visual areas of zebrafish. The study in an embryonic stage (48 hpf) and two larval stages (3 and $5 \mathrm{dpf}$ ).

We have analyzed the changes in cell proliferation by immunohistochemistry against phosphorylated histone H3. At the stage of 48 
hpf, in animals treated with nicotine, the staining was observed in both lateral margins and in the central retinal area, with no significant differences with respect to the control group. At $3 \mathrm{dpf}$ (Fig. 3) and $5 \mathrm{dpf}$, proliferating cells were observed in the ciliary margin, and in a lesser amount in the central area of the retina. The reduction in the number of proliferating cells with respect to controls maintains. The reduction is significant and the variations are associated to the concentrations of nicotine used.
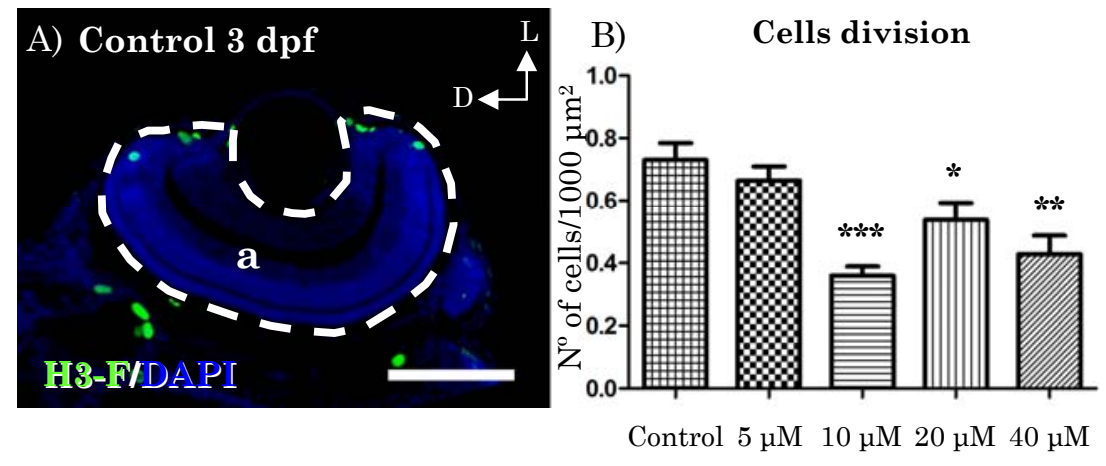

Fig. 3: A) Image of a coronal section of an eye at 3 dpf. B) Histogram showing the number of cells labeled for phosphorylated histone H3 at 3 dpf. a: coronal secction of a retina. D: Dorsal. L: lateral. $*=\mathrm{P}$ $<0.05 . * *=0.05>\mathrm{p}>0.001$. $* * *=\mathrm{P}<0.001$. Scale bar: $50 \mu \mathrm{m}$.

After TUNEL technique, apoptotic cells in the retina are a in both control and treated animals, with no significant differences between groups in any of the stages analyzed, or for the different concentrations tested.

The distribution of Calretinin positive elements in animals treated with nicotine was reduced after the nicotine treatment at $48 \mathrm{hpf}$ and $3 \mathrm{dpf}$ (Fig. 4), and it recovers with respect to the control group at the $5 \mathrm{dpf}$ stage.

The number of immunoreactive elements for $\mathrm{Zn}-8$ at 48 hpf (Fig. 5) decrease after nicotine treatment, in a inversely related manner to the concentration of nicotine administered. After hatching the number recovers, and is also maintained at the 5 dpf stage. 


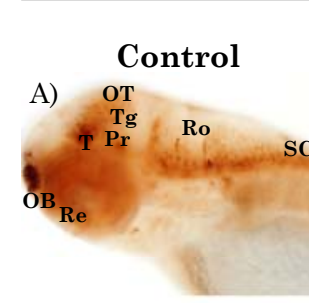

Nicotine $5 \mu \mathrm{M}$
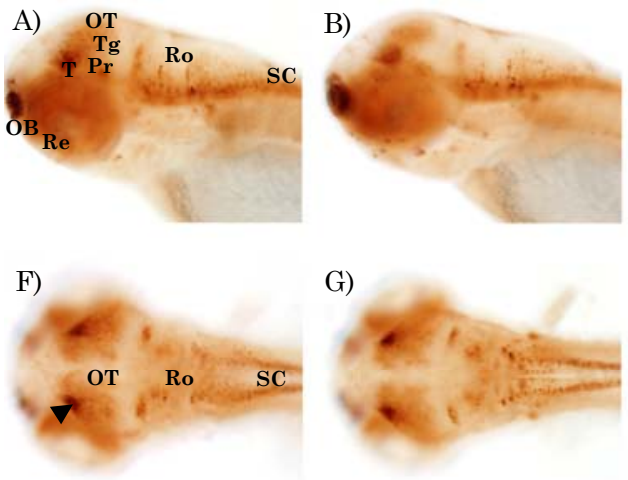

G)

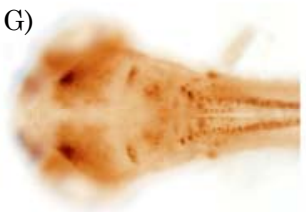

L)

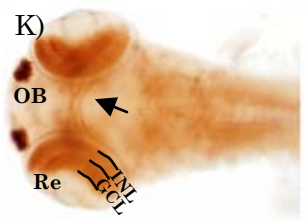

Nicotine $10 \mu \mathrm{M}$
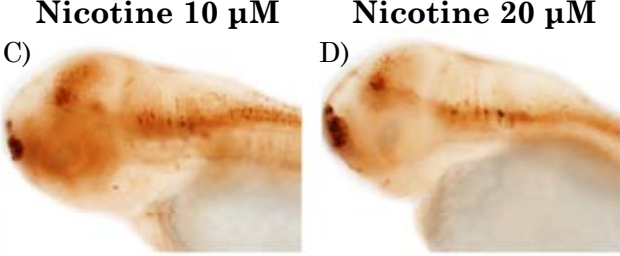

H)

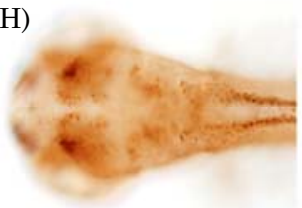

I)
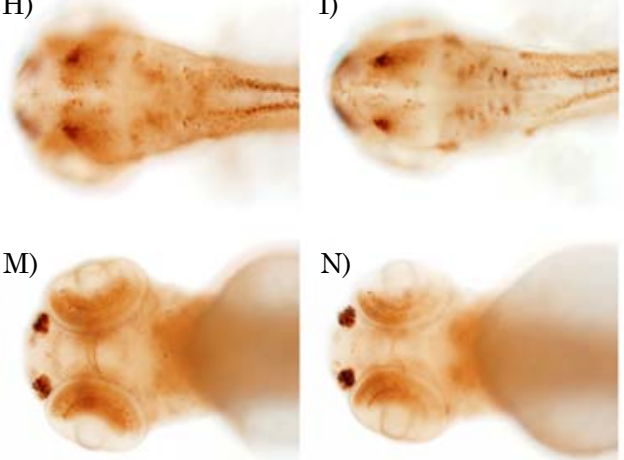

Nicotine $40 \mu \mathrm{M}$
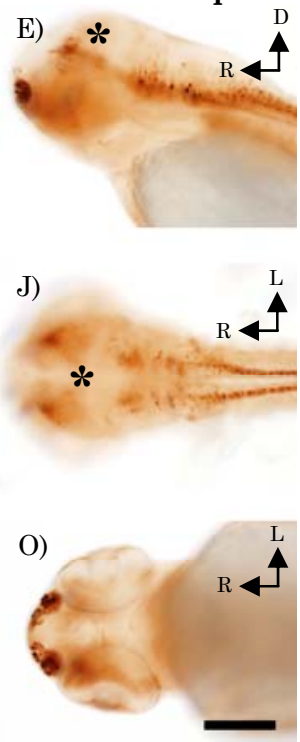

Fig. 4: In toto immunohistochemistry for calretinin (CR) in 3 dpf larvae. A)-E) Lateral view. F)-J) Dorsal view. $\mathrm{K})$-O) Ventral view. A), F) and K) Control animals, CR labeling is located in the olfactory bulbs, diencephalic structures as pretectum, and thalamus and in the rhombencephalon. At this stage there is also labeling in the OT (arrowhead), and in the retina in the GCL (arrow) and in the INL. In animals treated with nicotine the labeling for CR is reduced in the areas mentioned above. The nicotine $40 \mathrm{uM}$ group shows a large decrease in OT labeling (asterisk), as occurs in the GCL of the retina. D: Dorsal. GCL: Ganglion cell layer. INL: Inner nuclear layer. L: Lateral. OB: Olfactory bulb. OT: Optic Tectum. Pr: Pretectum. R: Rostral. Ro: Rhombencephalon. T: Thalamus. Tg: Tegmentum. SC: Spinal cordal. Scale bar: $100 \mu \mathrm{m}$.

A)

\section{Control}

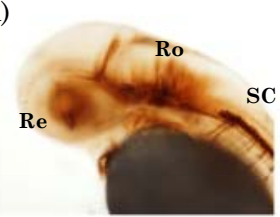

F)

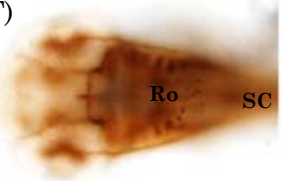

K)

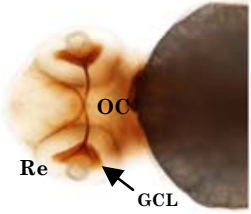

B)

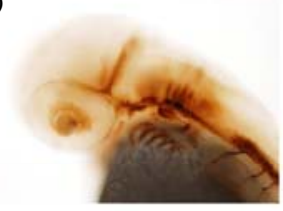

G)

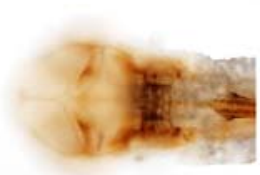

L)

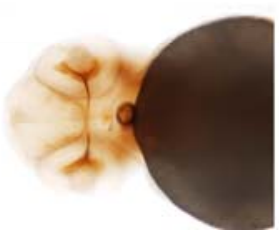

Nicotine $10 \mu \mathrm{M}$

C)

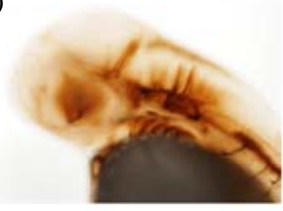

H)

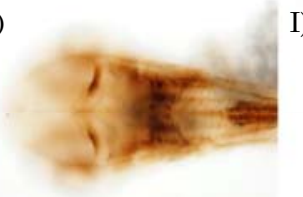

M)

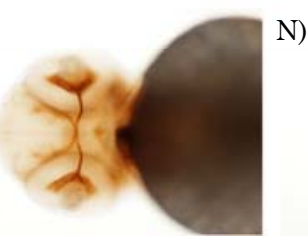

D)

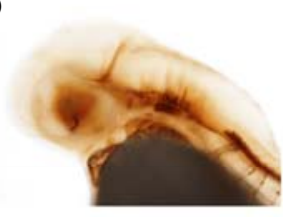

I)

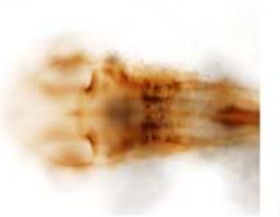

$\mathrm{N})$

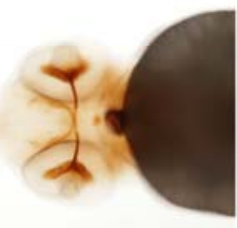

Nicotine $40 \mu \mathrm{M}$

E)

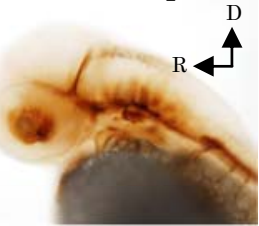

J)

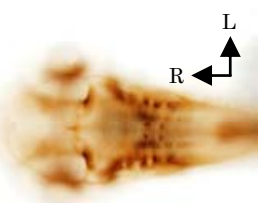

O)

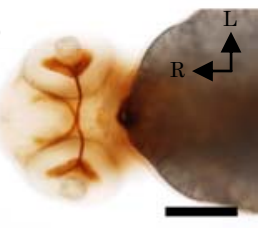

Fig. 5: In toto immunohistochemistry for Zn-8 in 48-hpf embryos. A)-E) Lateral view. F)-J) Dorsal view. K)-O) Ventral view. A), F) and K) Control embryo labeling for Zn-8 at the GCL of the retina (arrow) and optic nerves, which decussate in the optic chiasm and reach the TO. The animals treated with nicotine show a decreased staining for Zn-8 which is higher at lower concentration of nicotine administered. The concentration of $5 \mu \mathrm{M}$ produces the highest marking reduction in optic nerves (asterisk). D: Dorsal. GCL: Ganglion cell layer. OC: Optic chiasm. R: Rostral. Re: Retina. Ro: Rhombencephalon. SC: Spinal cord. Scale bar: $100 \mu \mathrm{m}$.

The distribution pattern of Tyrosine-hydroxylase in animals treated with different concentrations of nicotine is less extensive labeling in visual areas, decreasing the projections that guide to different centers. These changes are more evident at higher doses and longer treatments (5 dpf) (Fig. 6). 

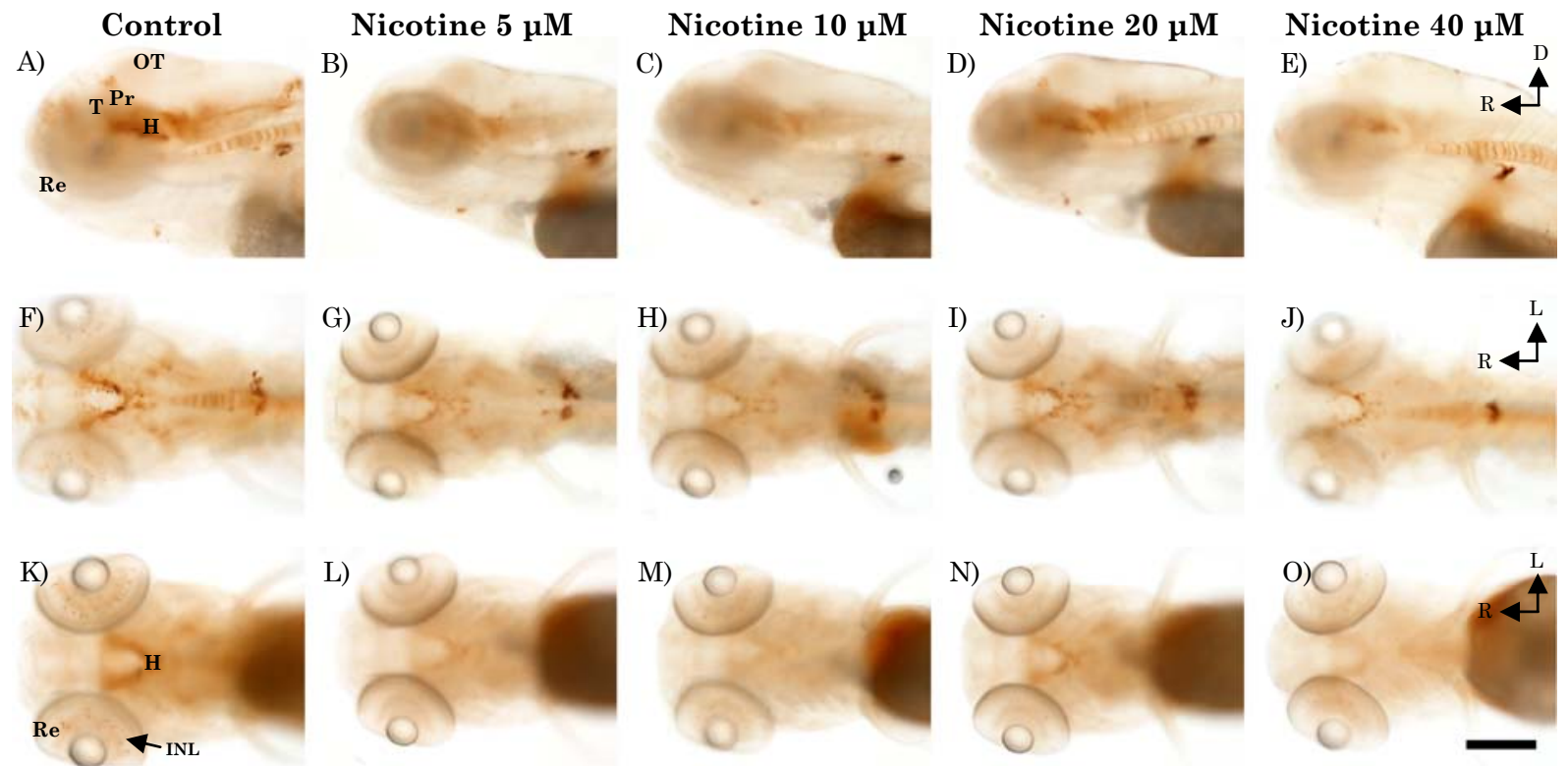

Fig. 6: In toto immunohistochemistry for TH in 5 dpf larvae. A)-E) Lateral view. F)-J) Dorsal view. K)-O) Ventral view. A), F) and K) The control animals show staining in the hypothalamus, thalamus and pretecum. Note also the labeling in the OT (arrowhead). At this stage the rounded cells of the INL are marked (arrow). The nicotine-treated specimens show a remarkable reduction of staining for TH in the aforementioned regions. We did not observe any labeling for TH in nicotine treatment groups in the OT. D: Dorsal. H: Hypothalamus. INL: Inner nuclear layer. L: Lateral. OT: Optic tectum. Pr: Pretectum. R: Rostral. Re: Retina. T: Thalamus. Scale bar: $100 \mu \mathrm{m}$.

The expression of Islet-1 analyzed by HIS in nicotine treated animals show a reduction remarkable inversely to the concentration administered in all three stages of development analyzed (Fig. 7). The decrease was more evident at lower concentrations of nicotine.

A)

\section{Control}

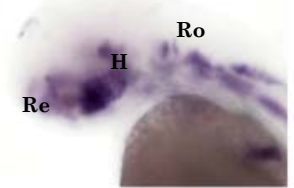

F)

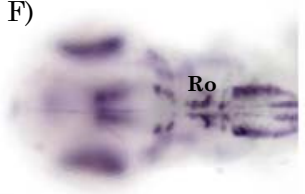

$\mathrm{K})$

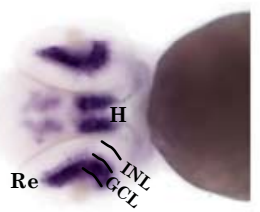

Nicotine $5 \mu \mathrm{M}$

B)

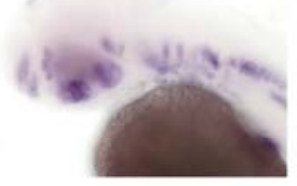

G)

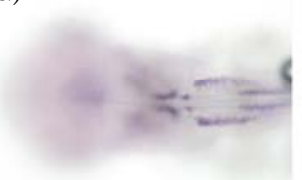

L)

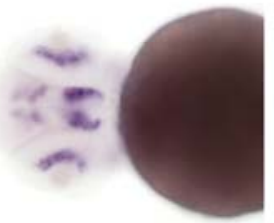

Nicotine $10 \mu \mathrm{M}$

C)

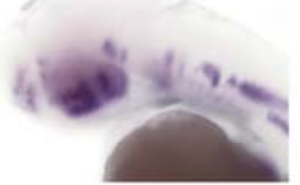

H)

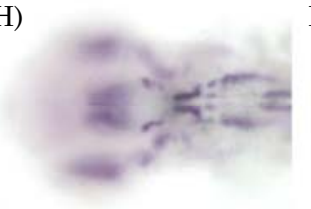

M)

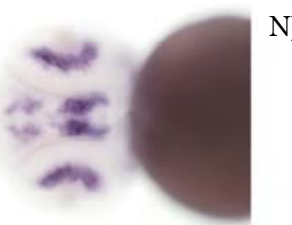

Nicotine $20 \mu \mathrm{M}$

D)

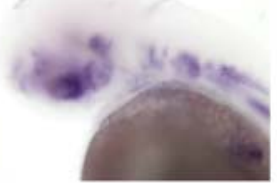

I)

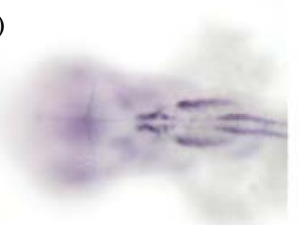

N)

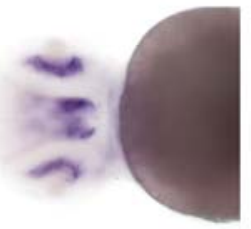

Nicotine $40 \mu \mathrm{M}$

E)

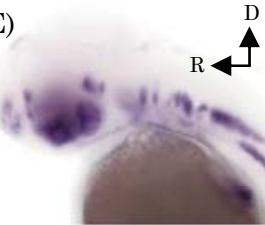

J)

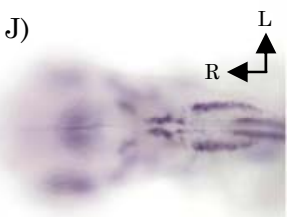

O)

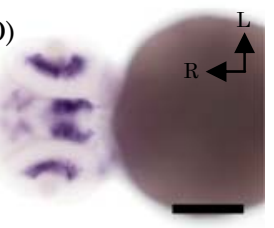

Fig. 7: In toto in situ hybridization for Islet-1 in 48-hpf embryos. A)-E) Lateral view. F)-J) Dorsal view. K)-O) Ventral view. A), F) and K) In the control group we observed labeling in the hypothalamus and in the GCL of the retina. The nicotine-treated specimens show a marked decrease of Islet-1 expression in visual structures that were also labeled in the control group. The modification was greater at lower concentrations of nicotine administered. Animals being treated with $5 \mu \mathrm{M}$ present the higher alteration. D: Dorsal. GCL: Ganglion cell layer. H: Hypothalamus. INL: inner nuclear layer. L: Lateral. R: Rostral. Re: Retina. Ro: Rhombencephalon. Scale bar: 100 Hm. 
After Pax6a immunohistochemistry in animals treated with different concentrations of nicotine the expression pattern shows a decrease which is maintained at the three stages of development analyzed (Fig. 8). This reduction is higher for the highest concentration of nicotine used.

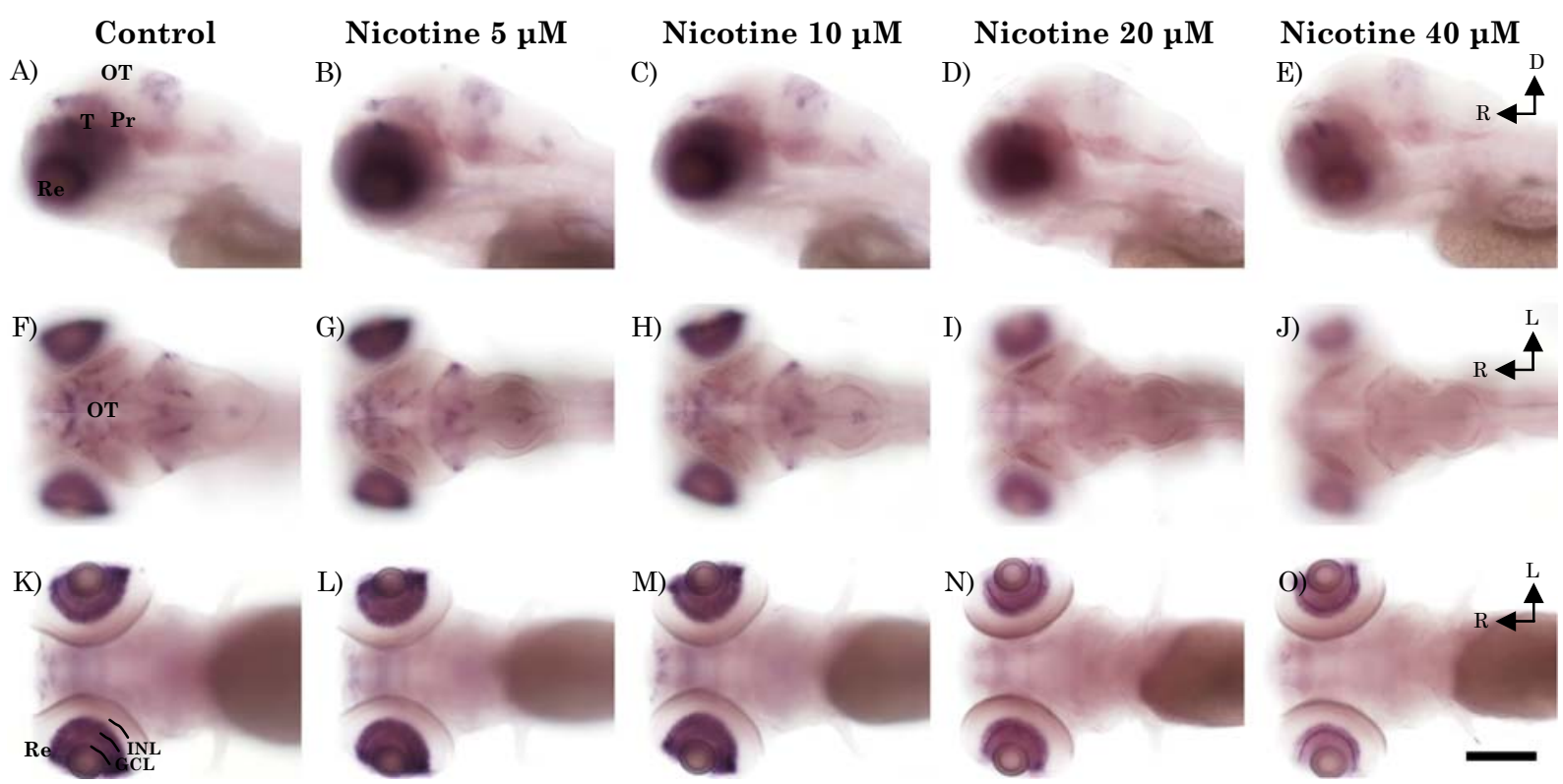

Fig. 8: In toto in situ hybridization for Pax6a in 5 dpf larvae. A)-E) Lateral view. F)-J) Dorsal view. K)-O) Ventral view. A), F) and K) Control group shows labeling in the thalamus and pretectum. At this stage of development there is expression in the OT in its rostralmost region. No expression was observed in the GCL and INL of the retina . The nicotine treated animals show a reduction in the expression of Pax6a in the visual structures mentioned in the control group. D: Dorsal. GCL: Ganglion cell layer. INL: Inner nuclear layer. L: Lateral. Pr: Pretectum. R: Rostral. Re: Retina. T: Thalamus. OT: Optic tectum. Scale bar: $100 \mu \mathrm{m}$.

We observed labeling for Zpr1, a marker specific for cone photoreceptors, in both larval stages analyzed, and there are no significant differences in the number of cones in the retina after the nicotine treatment with respect to the control groups.

We have analyzed at $3 \mathrm{dpf}$ and $5 \mathrm{dpf}$ the density of Zpr3, a marker specific for rod photoreceptors in animals treated with different concentrations of nicotine (Fig. 9) and we found a significant increase in the average number of rods per retina in both larval stages, more pronounced at $3 \mathrm{dpf}$. 


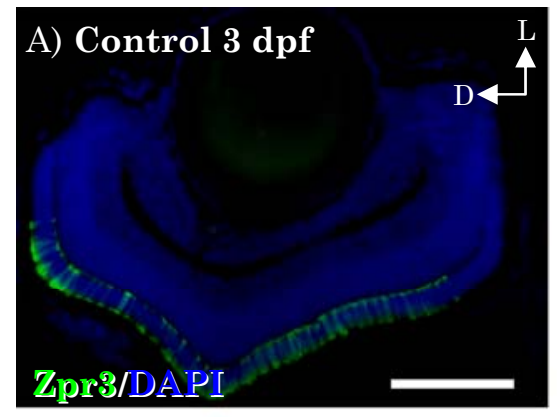

C) Zpr3 + cells at $3 \mathbf{d p f}$

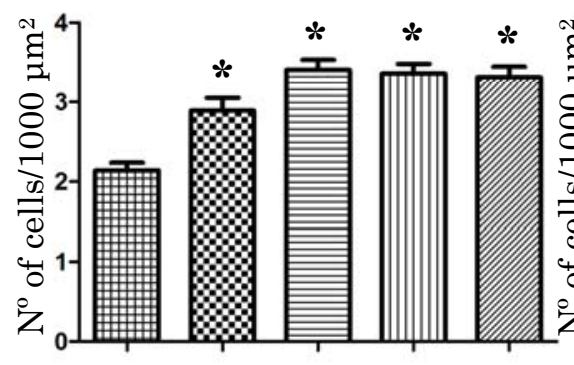

Control $5 \mu \mathrm{M} \quad 10 \mu \mathrm{M} 20 \mu \mathrm{M} 40 \mu \mathrm{M}$

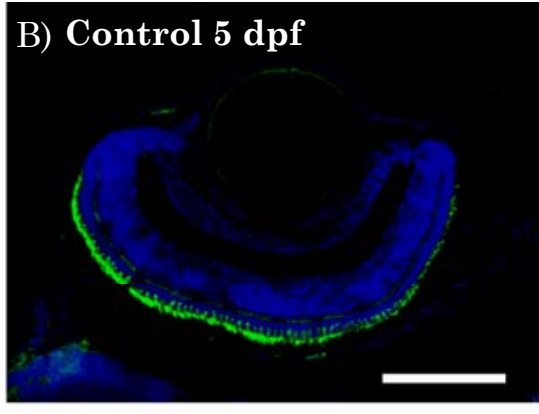

D) Zpr3 + cells at 5 dpf

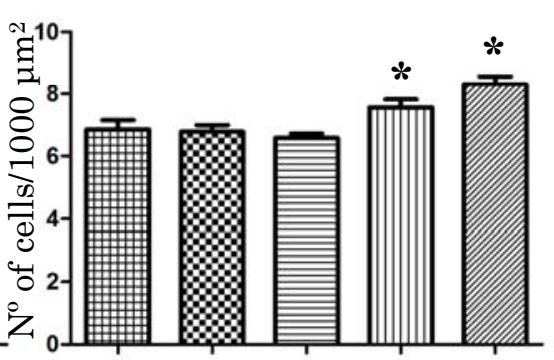

Control $5 \mu \mathrm{M} 10 \mu \mathrm{M} 20 \mu \mathrm{M} 40 \mu \mathrm{M}$
Fig. 9: A) Image of a coronal section of an eye at 3 dpf. B) Image of a coronal section of an eye at $5 \mathrm{dpf}$ C) and D) Histograms for Zpr1 labeled cells in the retina. C) 3 dpf larvae. D) 5 dpf larvae. In animals treated with nicotine, we observed at the stage of 3 $\mathrm{dpf}$ that there is a significant increase in the number of rods in all concentrations of nicotine administred. At 5 dpf the significant increase in rods is only maintained at the higher dose of nicotine. D: Dorsal. L: lateral. $*=\mathrm{P}$ $<0.05$. Scale bar: A) $50 \mu \mathrm{m}$. B) $100 \mu \mathrm{m}$.

\section{Analysis of the expresion of nAChRs in the visual pathway}

We quantified the expression of the a6, B3a and $83 \mathrm{~b} \mathrm{nAChR}$ subunits that are present in the zebrafish visual pathway. We analyzed by quantitative PCR and HIS the pattern of expression of these receptors, comparing the results after treatment with different concentrations of nicotine with those from control animales.

The qPCR experiments showed an increase in a6 nAChR expression (Fig. 10A) over time of exposure to nicotine, which is more significant at higher concentrations. At low nicotine concentrations, the expression of this receptor increases slightly at the different stages analyzed. The values are very close to 1 , similarly to the values obtained in the control group. In animals exposed to higher concentrations of nicotine, no differences in the expression with the control group were observed at $48 \mathrm{hpf}$. At $3 \mathrm{dpf}$ and $5 \mathrm{dpf}$ we observed a significant increase in the expression of this receptors with respect the control group. 

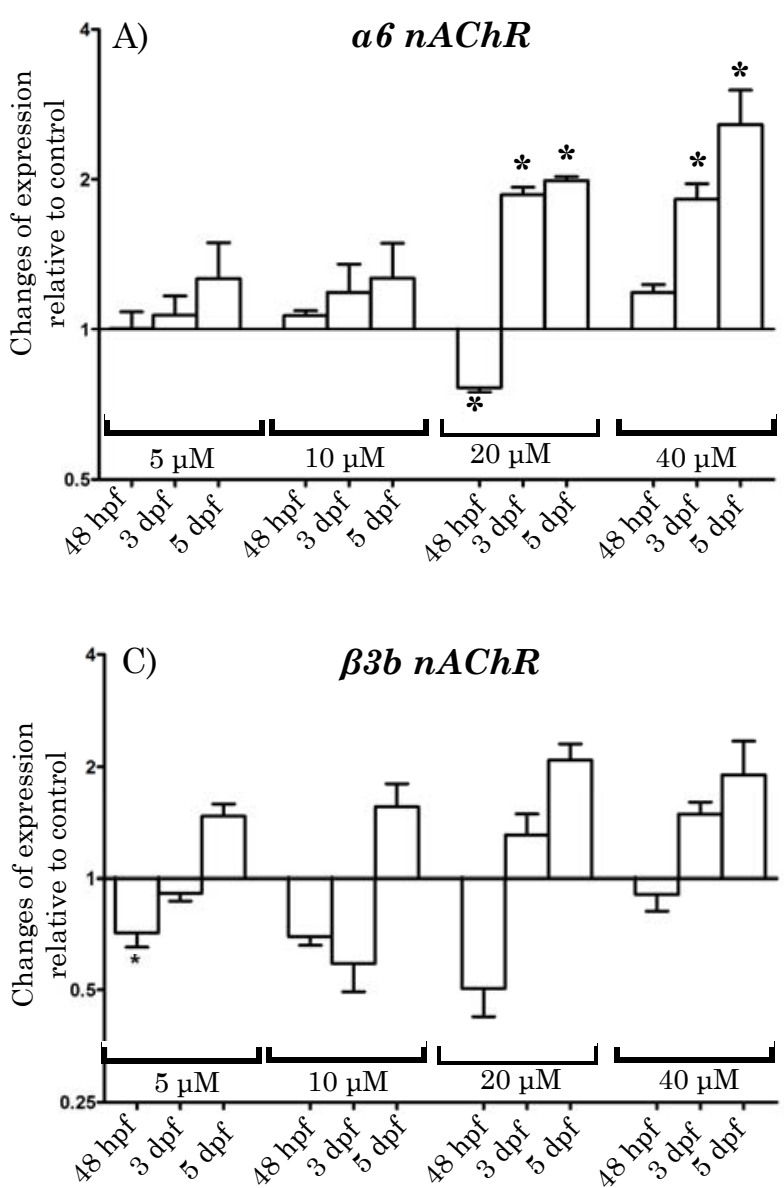

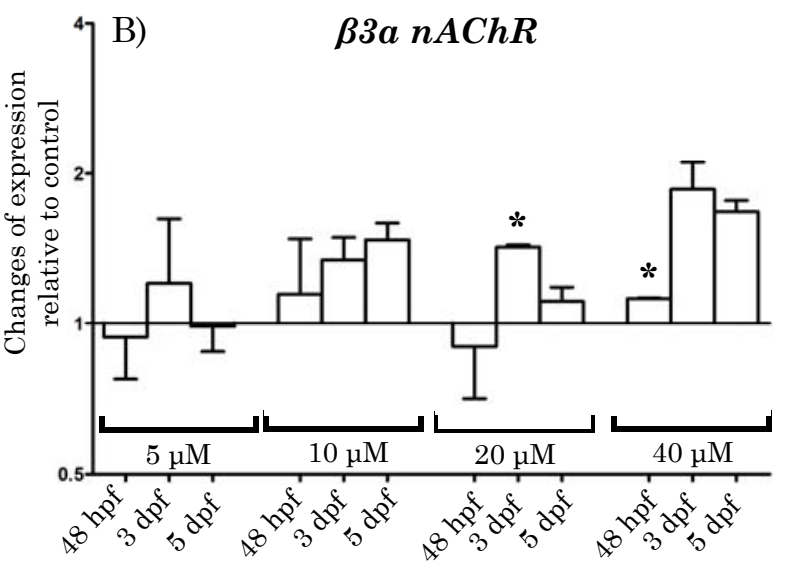

Fig. 10: Levels of $\mathrm{nAChR}$ expression determined by qPCR in experimental groups at stages of $48 \mathrm{hpf}, 3$ and $5 \mathrm{dpf}$. All values are normalized to the reference gene Ef1a. The horizontal line indicates the value of the control group. A) Small changes were observed in $a 6 n A C h R$ at $48 \mathrm{hpf}$. We observed an increase in expression with time, particularly at high nicotine concentrations. B) There are significant variations at high nicotine concentracions in $\beta 3 a n A C h R$ expression. C) Expression of $\beta 3 b n A C h R$ decreases at $48 \mathrm{hpf}$ at all concentrations of nicotine administered. ${ }^{*}=\mathrm{P}<0.05$.

After HIS. the labeling for the a6 subunit of the nAChR is localized the GCL of the retina. This receptor subunit is also expressed in the OT and in nonvisual structures, as the pineal gland and the trigeminal ganglion. At the larval stages of $3 \mathrm{dpf}$ (Fig.11) and $5 \mathrm{dpf}$, the labeling was observed in the GCL and in the INL of the retina, and in the OT.

After quantifying the expression of $83 \mathrm{a}$ nAChR (Fig. 10B) we observed that the differences were dependent on the concentration of nicotine administered. In animals treated with $5 \mu \mathrm{M}$, no major changes in expression were observed at the different stages analyzed, with values close to 1 . The specimens treated with $10 \mu \mathrm{M}$ show slight increase of the expression over time of exposure, but without significant differences. At $3 \mathrm{dpf}$, with a concentration of $20 \mu \mathrm{M}$ of nicotine, there is a significant increase in $83 \mathrm{a}$ nAChR expression; this expression decreases at $5 \mathrm{dpf}$. In the specimens treated with the highest concentration $(40 \mu \mathrm{M})$, a significant increase is detected over time. 


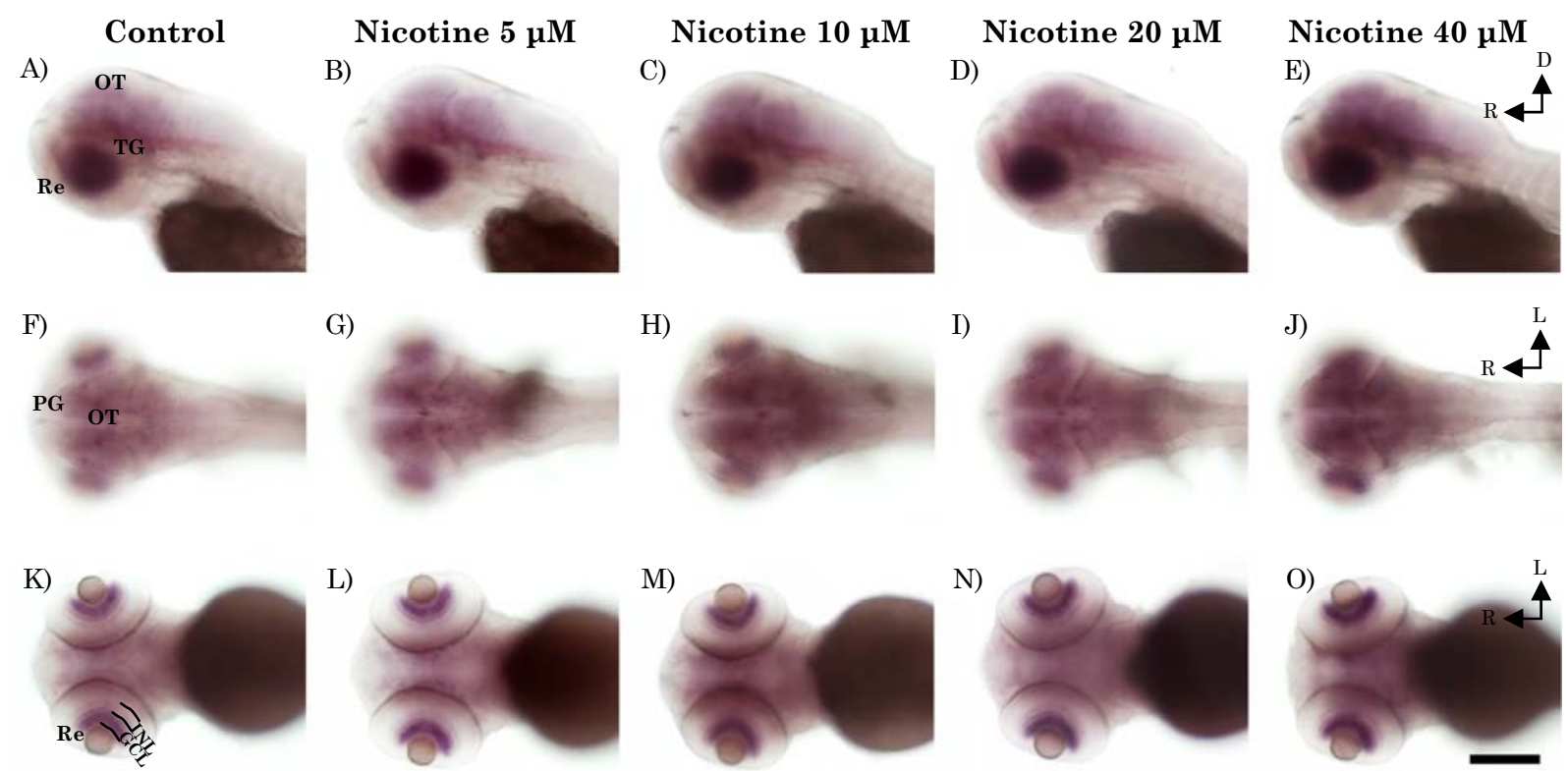

Fig. 11: In toto in situ hybridization for a6 nAChR in 3 dpf larvae. A)-E) Lateral view. F)-J) Dorsal view. K)-O) Ventral view. A), F) and K) Control animals are labeled in the OT. Expression is observed in the GCL of the retina and in isolated cells of the INL of the retina. Labeling is also observed in the pineal gland and trigeminal ganglion. The specimens treated with the higher concentrations of nicotine showed a greater intensity of staining in the visual and nonvisual structures mentioned in the control group. D: Dorsal. GCL: Ganglion cell layer. INL: Inner nuclear layer. L: Lateral. OT: Optic tectum. PG: Pineal gland. R: Rostral. Re: Retina. TG: Trigeminal ganglion. Scale bar: $100 \mu \mathrm{m}$.

At the stage $48 \mathrm{hpf}$, B3a nAChR is expressed in the GCL in the most central area of the retina. There was also labeling in the pineal gland in the trigeminal ganglion, and small groups of cells scattered throughout the brain. After hatching, at $3 \mathrm{dpf}$ (Fig. 12) and $5 \mathrm{dpf}$, $83 \mathrm{a} \mathrm{nAChR}$ expression is maintained in the same structures as in the control group: GCL of the retina, pineal gland and trigeminal ganglion.

The $33 \mathrm{~b}$ nAChR analysis by qPCR technique provides expression values (Fig. 10C) showing, a decrease at the stage of $48 \mathrm{hpf}$, which is significant at the concentration of $5 \mathrm{\mu M}$. However, there is no significant increase in the expression of the receptor at 3 and $5 \mathrm{dpf}$.

Expression of $B 3 \mathrm{~b}$ nAChR was not detected by HIS technique at the stage of 48 hpf. Labeling appears after hatching, at 3 dpf (Fig. 13) and 5dpf. B3b $\mathrm{nAChR}$ is expressed in the GCL of the central retina and in the trigeminal ganglion. At $5 \mathrm{dpf}$, the expression is observed in these same regions. 


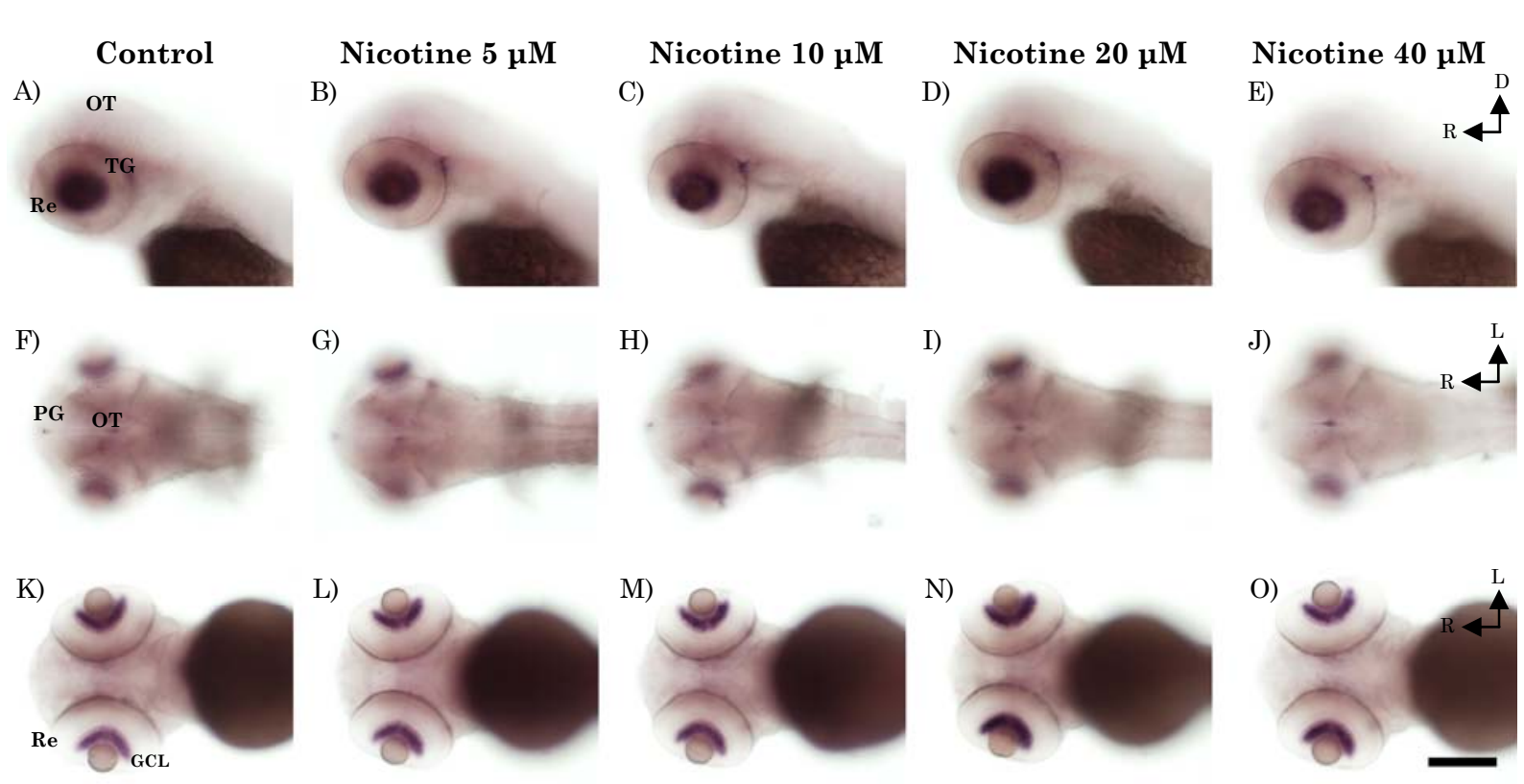

Fig. 12: In toto in situ hybridization for $\beta 3 a \mathrm{nAChR}$ in 3 dpf larvae. A)-E) Lateral view. F)-J) Dorsal view. K)-O) Ventral view. A), F) and K) Control animals present labeling in the GCL of the retina, and also in nonvisual structures as the pineal gland and the trigeminal ganglion. The animals treated with nicotine slightly increase the expression of this receptor in all treatment groups. This increase is observed in the same visual and non-visual structures mentioned in the control group. D: Dorsal. GCL: Ganglion cell layer. L: Lateral. OT: Optic tectum. PG: Pineal gland. R: Rostral. Re: Retina. TG: Trigeminal ganglion. Scale bar: $100 \mu \mathrm{m}$.
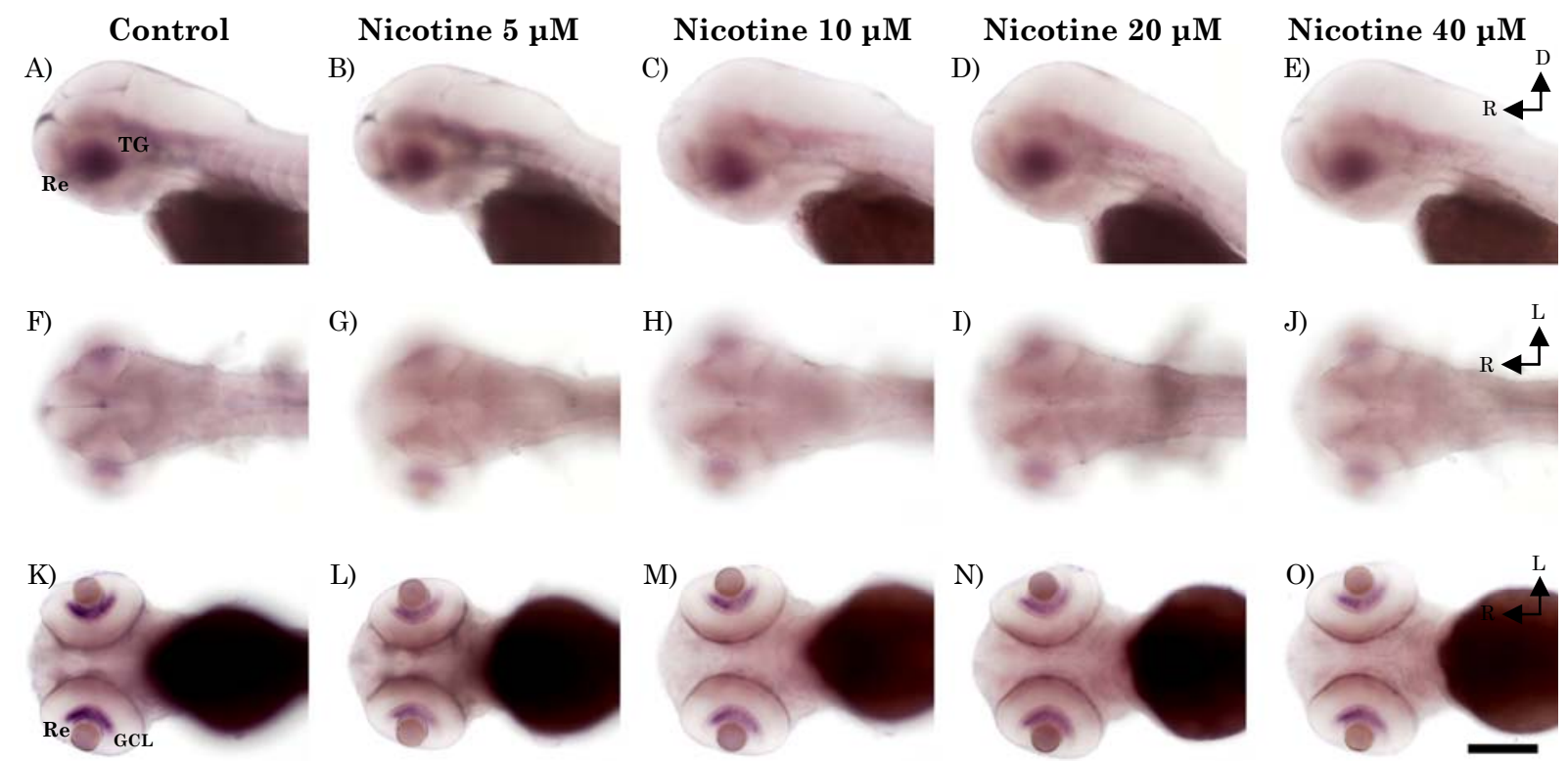

Fig. 13: In toto in situ hybridization for $\beta 3 b$ nAChR in 3 dpf larvae. A)-E) Lateral view. F)-J) Dorsal view. K)-O) Ventral view. A), F) and K) Control animals present labeling in the retina, only in the central region of the GCL and in nonvisual structures as the trigeminal ganglion. At this stage, nicotine treated animals showed a decrease in the expression of this receptor in all treatment groups, being more pronounced in the group treated with $5 \mathrm{uM}$ of nicotine. This decrease is observed in the same visual and non-visual structures mentioned in the control group. D: Dorsal. CCG: Ganglion cell layer. GT: Trigeminal ganglion. L: Lateral. R: Rostral. Re: Retina. Scale bar: $100 \mu \mathrm{m}$.

\section{Electrophysiological analysis of the retina}

The electroretinogram (ERG) records the summed electric field potential of the retina in response to light flashes and is a sensitive physiological tool to 
assess radial retinal cell function (i.e., photoreceptor and bipolar cells). In zebrafish larvae, the ERG is dominated by a prominent b-wave which reflects mainly the responses of ON-bipolar cells (Wong et al., 2004). The b-wave largely masks the response of the photoreceptors, the a-wave, which is not generally seen unless bright flashes are used. We elicited ERG responses over an intensity range of 5-6 log units. In control animals (Fig. 14), we observed a clear b-wave response at $\log \mathrm{I}=-4$, and with increasing flash intensities the b-wave grew larger reaching a peak amplitude with the brightest light tested (Log $\mathrm{I}=0)$.

In response to all concentrations of nicotine applied (Figs 14), two consistent changes in the ERG were noted. First, with a dim flash (Log I= -4), there was a decrease or loss of the b-wave. With brighter flashes (Log I= -2 and greater), the b-wave amplitude was increased, and at the highest doses (20 and $40 \mu \mathrm{M})$ of nicotine the increase was striking. Although b-wave amplitudes were

A)
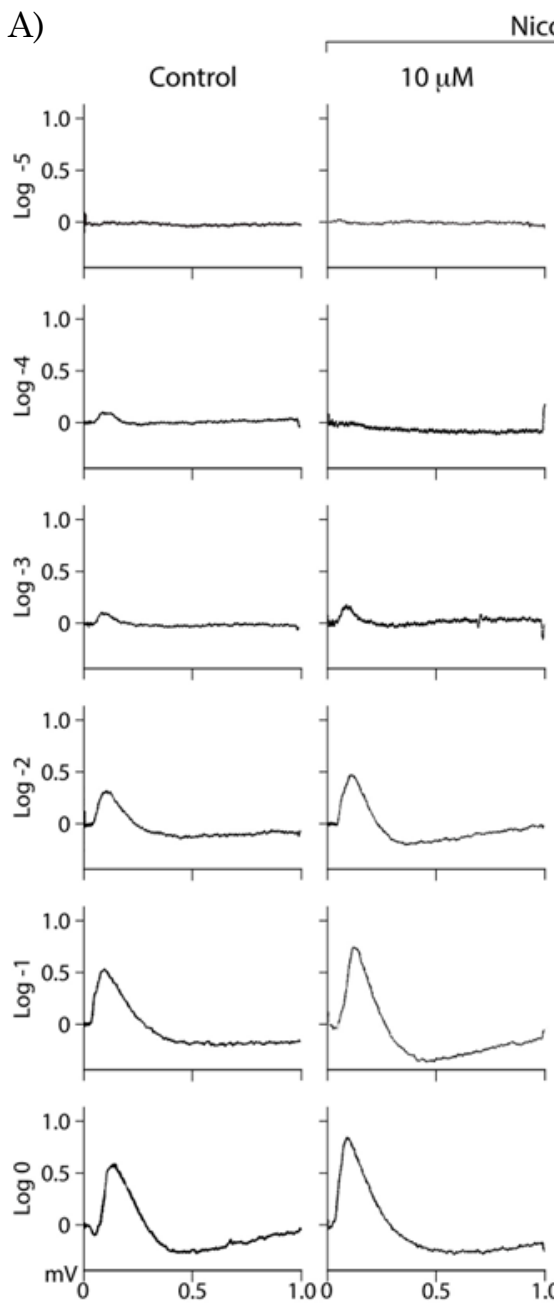
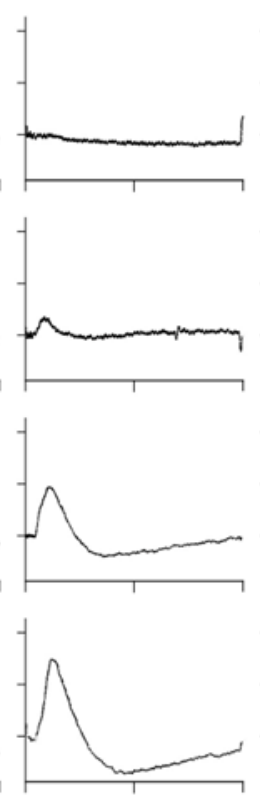

cotine
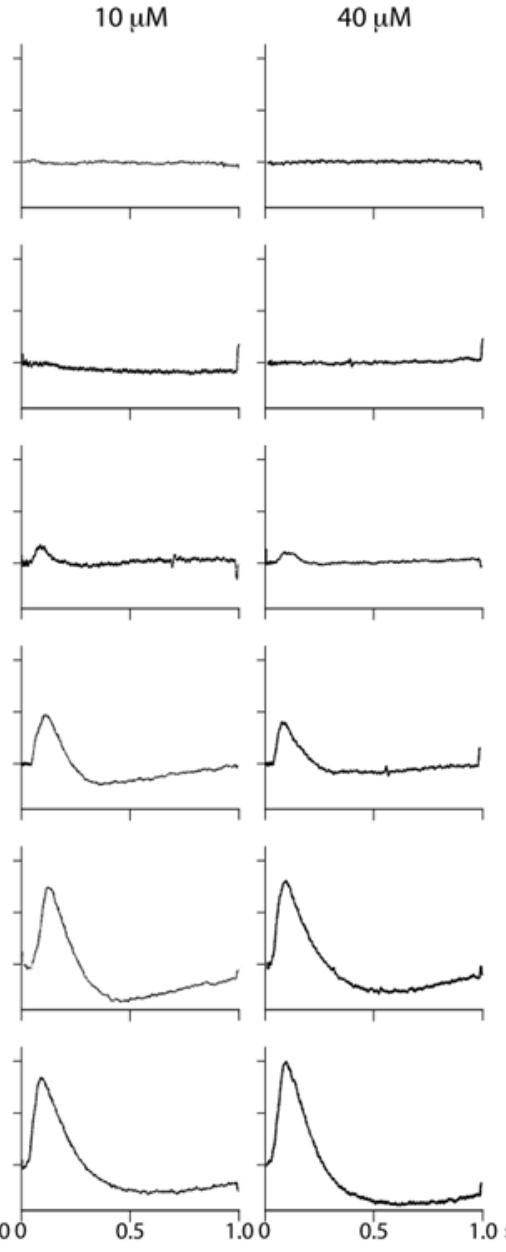

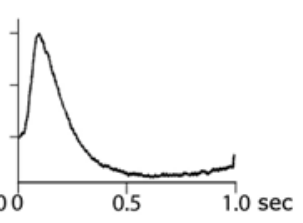

B)

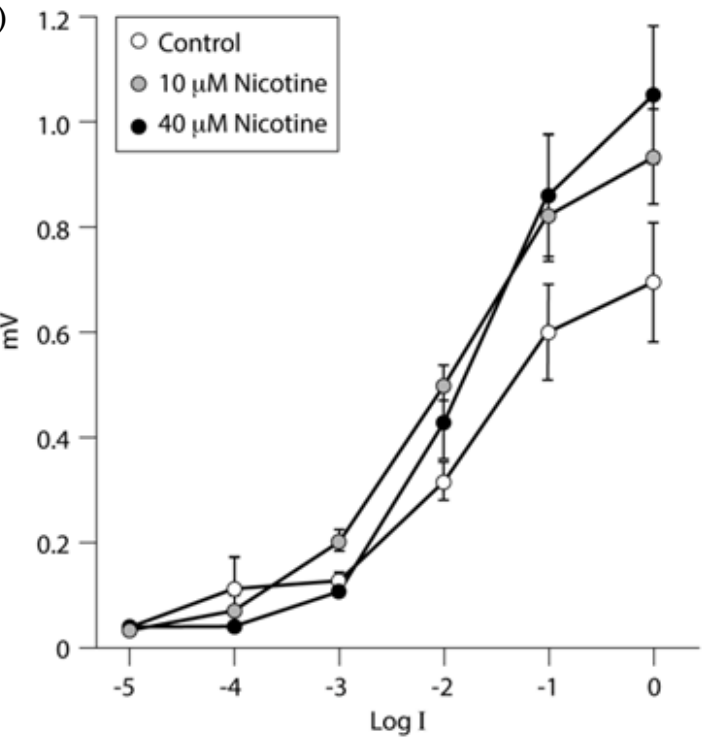

Fig. 14: A) Representative ERG traces from a control eye and eyes from animals exposed to nicotine at concentrations of 10 and $40 \mu \mathrm{M}$ (all the animals were $5 \mathrm{dpf}$ ). The ERGs were elicited over a range of light intensities (Log $\mathrm{I}=-5$ to 0 ), and the scale to the left of each set of traces is in millivolts $(\mathrm{mV})$. Note that at $\log \mathrm{I}=-4$, only the control eye gave a substantial response. B) Voltage intensity curves for the ERG b-wave recorded from eyes of control animals and those exposed to nicotine. Error bars of SEM. 
enhanced at all light-intensities (except for the dimmest intensities), there was no significant change in the b-wave sensitivity to light.

The largest increase in amplitude was observed following the $20 \mu \mathrm{M}$ dose of nicotine, and was an increase of $66 \%$. At a concentration of $40 \mu \mathrm{M}$ nicotine, the maximum amplitude decreased somewhat, suggesting that $20 \mu \mathrm{M}$ nicotine may be the saturating concentration. However; the stimulus interval may have been too short $(8 \mathrm{sec})$ at $\log \mathrm{I}=0$ to allow complete recover from the previous flash.

The nof mutant has a point mutation the a subunit of the cone transducin (Tca) gene, rendering it non-functional. All four types of cones in nof have undetectable levels of the Tca protein. Not surprisingly, nof cones do not respond to photopic light stimulation (Brokerhoff et al., 2003), but this enables recordings from the relatively few rods that exist at this point in zebrafish development. In nof mutants (Fig. 15), it is possible to record small b-wave responses over a range of $4 \log$ units (Log $\mathrm{I}=-5$ to -2 ). The maximum amplitude is about $40 \mu \mathrm{V}$, and that is observed at a light intensity of $\log \mathrm{I}=-4$. At light intensities brighter than $\log \mathrm{I}=-3$, the $\mathrm{b}$-wave response declines in amplitude and at $\log \mathrm{I}=-1$ or 0 , no b-wave at all is recorded, probably due to rod saturation. With a nicotine concentration of 5 and $10 \mu \mathrm{M}$, a decrease in b-wave amplitude is observed at all light intensities, but because of the small rod response amplitudes in nof animals, the data are not significant $(\mathrm{P}=0.61$ and 0.46 respectively). However, at a concentration of both 20 and $40 \mu \mathrm{M}$ nicotine, the decrease in $\mathrm{b}$-wave amplitude is significant ( $\mathrm{P}=0.05$ and 0.04 respectively). 


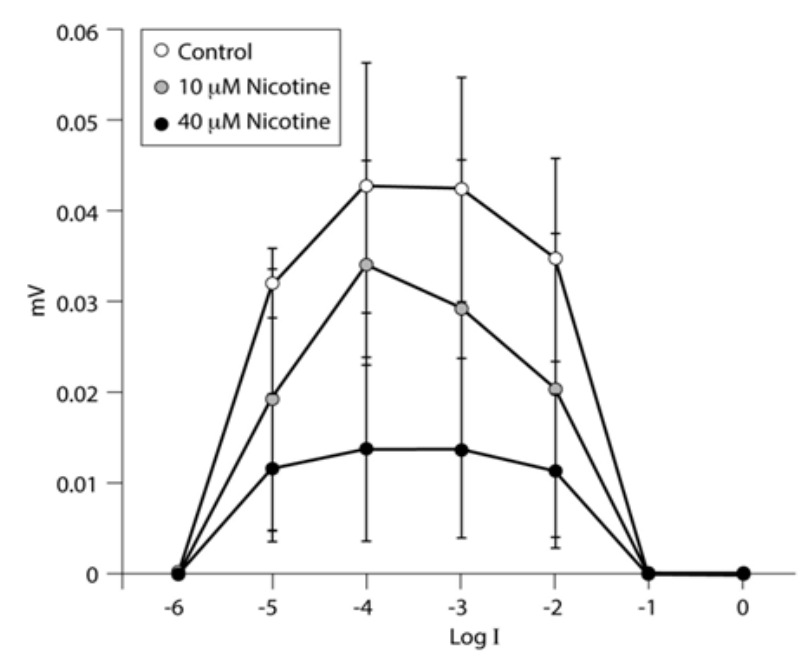

Fig. 15: ERG b-wave intensity curves recorded from the eyes of nof mutant fish that have no cone function. All animals were $5 \mathrm{dpf}$, and $\mathrm{n}=10$. When fully dark-adapted small responses could be recorded at Log $\mathrm{I}=-5$ to -2 (up to $\sim 40 \mu \mathrm{M})$. At $\log \mathrm{I}=-1$ and above, no responses could be elicited, presumably due to rod saturation. After nicotine treatment, all responses were smaller in amplitude. Error bars of SEM.

\section{Behavioral analysis}

Behavioral responses include visual-motor movements to escape, and simple swimming movements guided to catch food. A key visual response in zebrafish larvae is the optomotor response (OMR), in which there is a motor coordination to follow the movement. The optokinetic response (OKR) stabilizes the image on the retina during the free swimming. The visual-motor response (VMR) in zebrafish larvae is the startle response to changes in light intensity.

We have studied these different behavioral responses in larvae of 4, 5 and $6 \mathrm{dpf}$, to detect the neural alterations induced by nicotine in the visual context in relatively basic behaviors. In all responses, $4 \mathrm{dpf}$ is the first stage in which this response appears, and we evaluated the answer later stage to assess the evolution of the response more time. We have analyzed various visual parameters such as contrast, spatial frequency and temporal frequency in control animals and in the groups treated with different concentrations of nicotine.

\section{Optomotor response}

Animals treated with different concentrations of nicotine have a significant decrease in the OMR (Fig. 16). Optomotor index decreases with 
higher concentrations of nicotine. In animals treated with a nicotine concentration of $40 \mu \mathrm{M}$, the optomotor index is significantly reduced with respect to controls. Larvae treated with nicotine recovered activity levels with increasing contrast, but without reaching control levels.

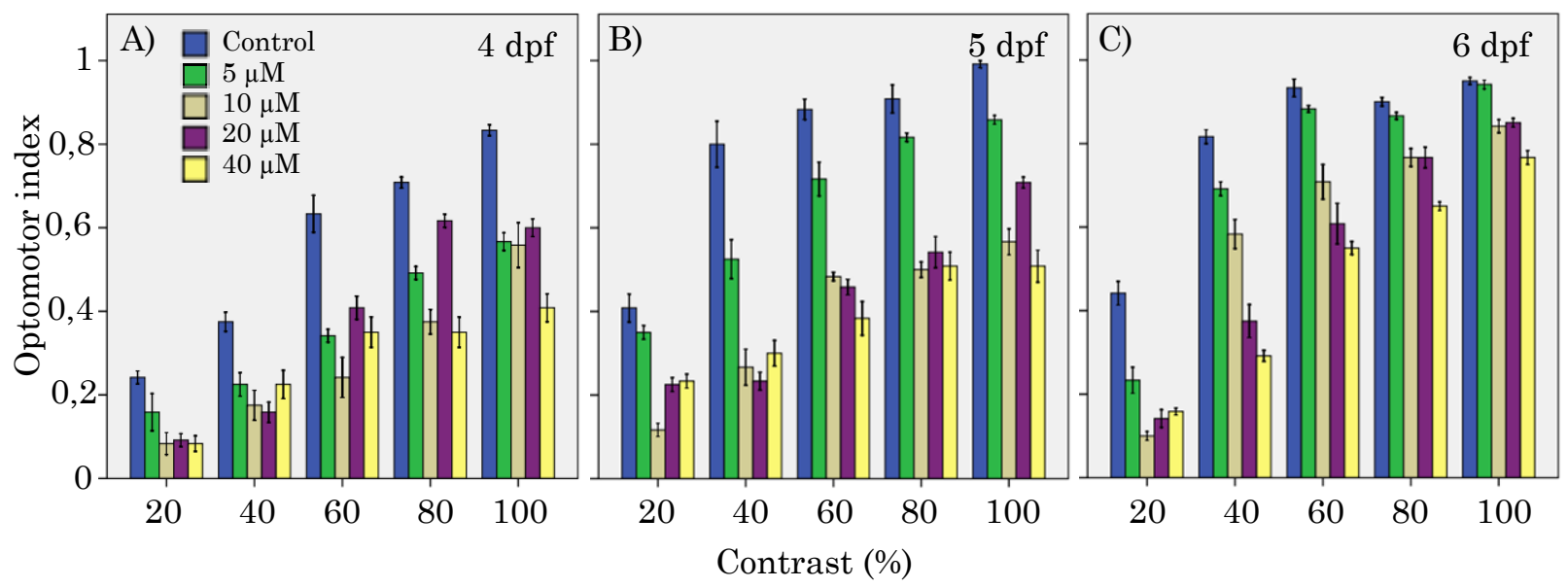

Fig 16: Behavioral measurements of contrast in the OMR at 4, 5 and 6 dpf. Average values of the optomor index, number of larvae that reach the end of the tank, by contrast values. Error bars indicate \pm 1 standard error.

\section{Optokinetic response}

The animals treated with nicotine exhibit a speed difference in ocular movements with respect to the control group. This decrease varies depending on the concentration of nicotine administered (Fig. 17). Animals treated with $5 \mu \mathrm{M}$ of nicotine showed the lower reduction. Other treatment groups show a less pronounced decrease. After increasing the contrast between black and white stripes, the decrease in eye movement speed persists. Animals treated with 40 $\mu \mathrm{M}$ of nicotine present the lowest speed of movement of the eyes. 

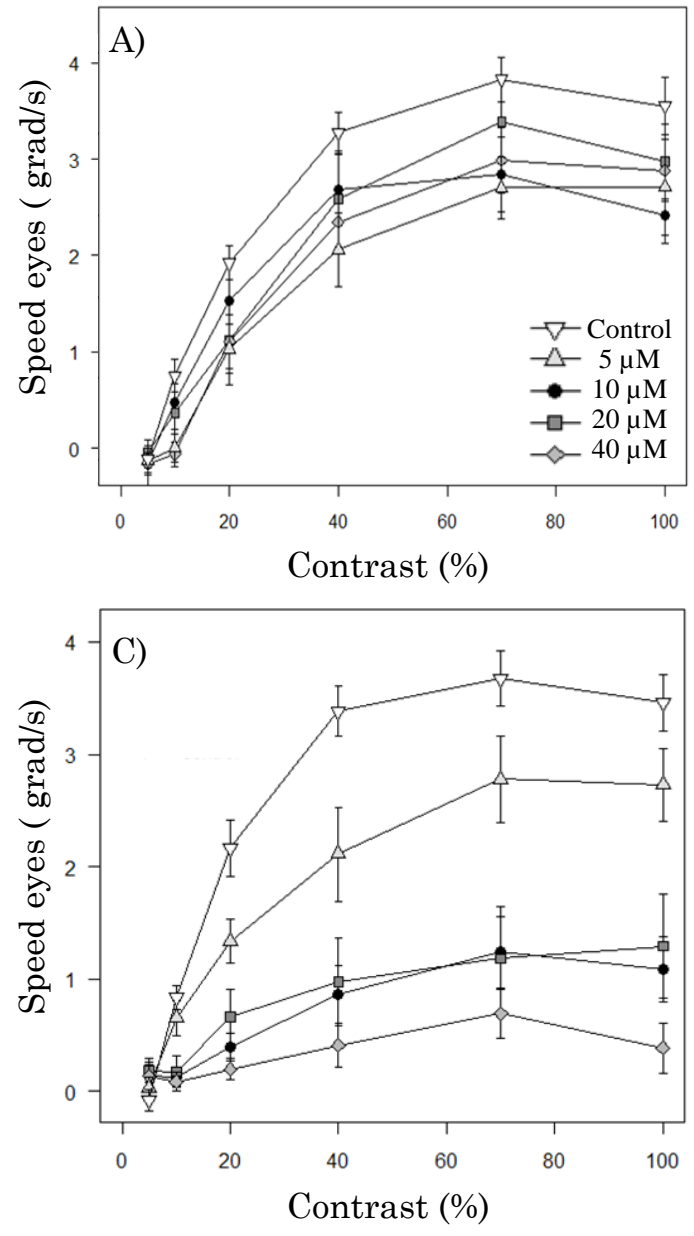

\section{Visual-motor response}

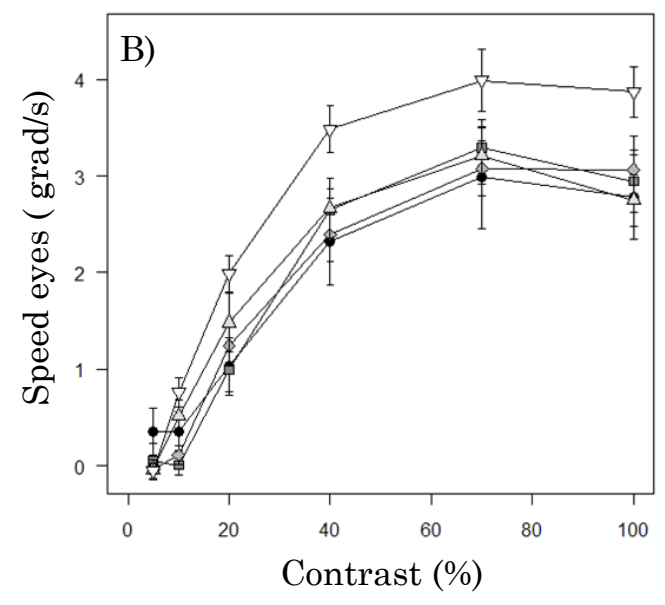

Fig. 17: Measurements of speed in OKR at 4, 5 and 6 dpf. Average speed in the eyes in nasal-temporary direction. A) At $4 \mathrm{dpf}, \mathrm{B})$ At $5 \mathrm{dpf}$, C) In all groups there is a decrease in speed at 6 dpf.. Higher concentrations of nicotine produce a greater reduction in eye movement. Error bars indicate \pm 1 standard error.

The VMR of control animals present the same activity and speed, with maximum when crossing from light to dark. At 5 dpf in treated animals (Fig. 18) swimming speed is lower than in the control group, and the reduction is greater in animals treated with $40 \mu \mathrm{M}$ nicotine. The started swimming activity is higher than in controls. The activity and the speed of response to movement from light to dark is higher in those animals treated with a lower concentration of nicotine, while the activity and the change in the speed of movement from light to dark is lower in animals treated with higher doses of nicotine. 
A)

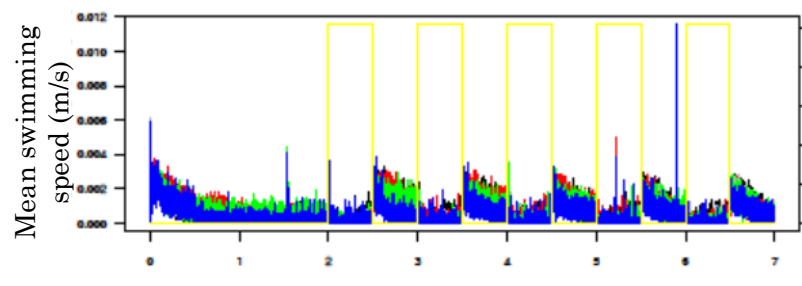

Time (h)

C) Response to light (Speed)

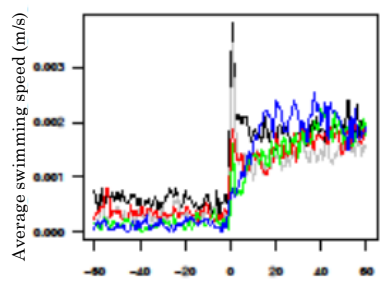

B)

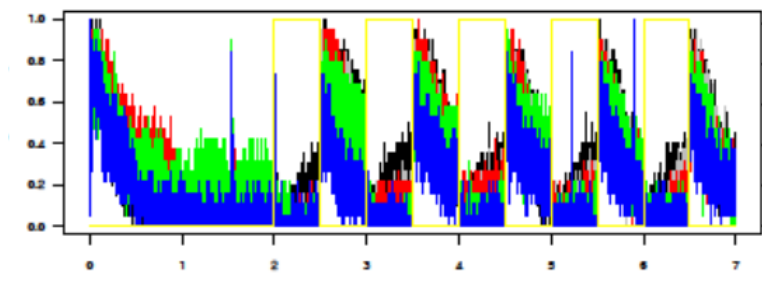

Time (h)

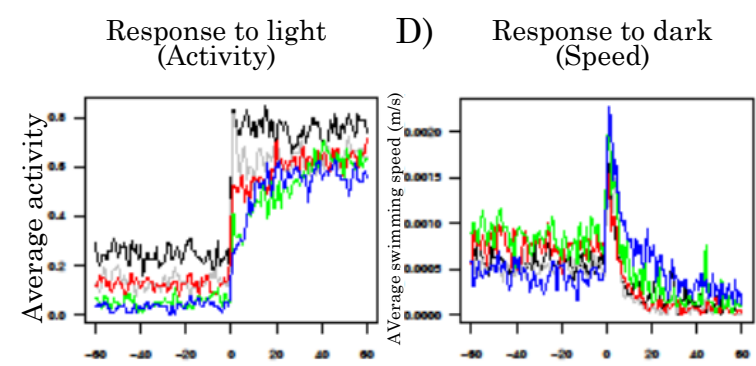

Time (s)

Fig. 75: Analysis of VMR at 5 dpf, showing the activity and average speed changes from light to dark and vice versa. A) Average swimming speed. B) Average activity of the larvae. C) Response of larvae to movement from dark to light. D) Response of larvae to movement from light to dark. In animals treated with nicotine both activity and swimming speed decrease. The greater decrease is observed in the group treated with $40 \mu \mathrm{M}$ nicotine.
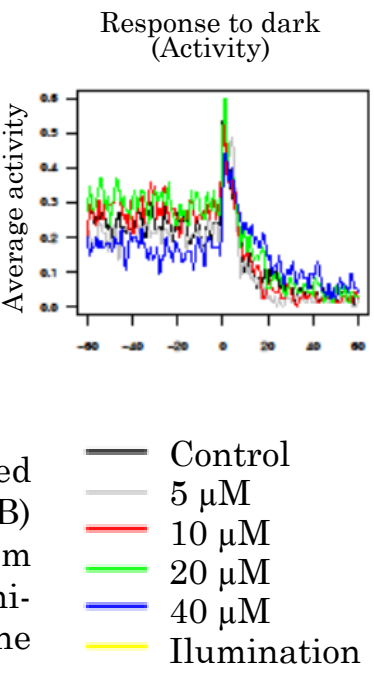


\section{DISCUSSION}

\section{Effects of nicotine during zebrafish development}

Early studies about the effects of nicotine date from the mid-nineteenth century (Haughton, 1872), whereas the use of zebrafish as a model to study the effects of nicotine on the development dates from the early XXI century (Sovoboda et al., 2002). Nicotine produce different events processes during embryonic development, including gene expression, protein distribution, apoptosis, cellular proliferation and behavior (Svoboda et al., 2002, Boyd et al., 2003, Edwards, 2007; Parker and Connaughton, 2007, Welsh et al., 2009; Menelan and Svoboda, 2009; Thomas et al., 2009).

Previous studies of chronic exposure to nicotine in zebrafish embryos indicate (Svoboda et al., 2002, Parker and Connaughton, 2007; Menelaou and Svoboda, 2009; Thomas et al., 2009, Welsh et al., 2009). Our experimental design assure consistent levels of nicotine during the treatment. Analysis the different stages by HPLC demonstrated a constant assimilation of nicotine over time by the animals.

\section{Effects of nicotine on the visual system}

The zebrafish is a good model to study the development of the visual system and analyze how it is affected by exposure to different substances (Parng, 2005, Tierney, 2011). We have analyzed the effect of nicotine exposure on eye size, parameter that was estimated by measuring the projected area of the eye of the specimens in growth (Kashyap et al., 2011). The measurements obtained were consistent, and the ocular area decreased significantly at the larval stages of 3 and $5 \mathrm{dpf}$ in relation to the controls, especially in the treatments with nicotine concentrations, 20 and $40 \mu \mathrm{M}$. 
Our results suggest that nicotine does not cause evident disturbances in the visual system at early stages of development. However, at later stages, when differentiation processes of the neural retina (36 hpf-3 dpf) occur, nicotine causes a delay in the pattern of cellular distribution. Previous studies in rats have shown a decrease in the thickness of the GCL and the INL of the retina (Evereklioglu et al., 2003). Besides, chronic exposure to nicotine causes development delay in the lens and cataract formation (Evereklioglu et al., 2004). It is considered that the loss of size in the structures may be due to a decrease in proliferation, increased cell death or a decrease in the number or volume of the of the cells. In our study, significant changes were not observed in the number of apoptotic cell process, in agreement with previous studies (Yan et al., 2006). Markers associated with projections of the visual pathway, such as CR and Zn-8, showed that nicotine administration caused a decreased retinotectal projection to the OT that persists during the treatment.

We also observed a gradual decrease in the density of proliferative cells and a reduced extension of proliferative regions. This decrease is greater at higher concentrations of nicotine, which is in agreement with data obtained after administration of nicotine in neonatal rats, that causes inhibition of DNA synthesis, promoting premature termination of the proliferation and differentiation of cells (McFarland et al., 1991).

Embryonic exposure to nicotine alters heterogeneously the expression of all molecular markers analyzed. The changes in cell types and/or regions of expression in the retina and the OT, vary with the dose of nicotine administered. Exposure to nicotine induces decrease in cell labeling CR positive cells in all visual areas, especially with higher concentrations of nicotine, but at the end of the larval period the distribution pattern of this calcium binding protein is similar to that observed in the control group. It has been suggested that during the development of the retina the expression of $\mathrm{CR}$ requires a minimum degree of tissue and cellular differentiation (Ellis et al., 1991; Doldan et al., 1999). The delay in CR immunostaining pattern observed in animals 
treated with nicotine would be consistent with a delay in cellular differentiation of the neural retina.

The nicotine-treated specimens show a reduction in the distribution pattern of Zn-8 (a marker for Neuroline), in the retina, that can affect cell adhesion, growth and fasciculation of axons (Pourquie et al., 1992), and synaptogenesis (Chedotal et al., 1996). This might be interpreted as a neural plasticity response aimed to promote the growth and fasciculation of the first optic axons on their way towards the OT.

All brain regions involved in processing of visual information presented elements marked for TH. It has been studied in the zebrafish visual pathway the distribution pattern of TH in the retina (Guo et al., 1999; Holzschuh et al., 2001) and in diencephalic regions with retinal afferents (Rink and Wullimann, 2002; Wullimann and Rink, 2002). This may be due to an error in pretectal catecholaminergic cell migration, as the onset for $\mathrm{TH}$ immunoreactivity coincides in both regions (5 dpf) in control animals. In animals treated with nicotine, the density of $\mathrm{TH}$ positive cells decreases in all regions over time and the decrease is greater with higher doses of nicotine. These results are consistent with previous studies indicating that nicotine affects the expression of TH (Naha et al., 2009). Furthermore, chronic administration of nicotine results in a decrease in the expression of the D2 dopamine receptor and $\mathrm{TH}$ protein transcriptional level, depending on the dose administered (Naha et al., 2009).

Islet-1 is a specific marker of ganglion cells (Austin et al., 1995) and its expression starts once they have completed their migration to the vitreal surface (Sakagami et al., 2003). The alterations of the expression pattern of Islet-1 suggest that nicotine appears to affect more the later stages of retinogenesis (cellular differentiation of the visual structures) than early stages of retinal development (specification of neural and retinal pigment epithelium) (Schmitt and Dowling, 1994). 
Pax6 is a transcription factor required for proper development of the optic vesicles (Zuber et al., 2003), and its alteration can cause abnormalities in eye formation. Pax6 mutant mice exhibit a reduced size of the eyes and other encephalic structures (Theiler et al., 1978, Hogan et al., 1988, Glaser et al., 1990, Fujiwara et al., 1994, Hanson et al., 1994, Dellovade et al., 1998). Nicotine inhibits methylation of $\mathrm{CpG}$ noticeably, which is the binding site in the promoter StAR Pax6, which prevents binding of Pax6 and downregulates StAR gene expression (Wang et al., 2011).

\section{Effects of nicotine on nAChRs of the visual pathway}

A series of studies relate very closely the $a 6$ and $B 3$ nAChR subunits, showing a direct influence between them. Gotti et al. (2005) demonstrated that the $B 3 \mathrm{nAChR}$ gene suppression greatly reduces the a $\mathrm{nAChR}$ gene expression in different brain regions.

The tight regulation between these two subunits is also found in visual areas. At least seven subtypes of $\mathrm{nAChRs}$ are present in the rat retina (Moretti et al., 2004; Marritt et al., 2005) and many of these receptors are also found in the optic nerve. Sequential immunoprecipitation studies demonstrate that the optic nerve contains many of the $\mathrm{nAChR} \alpha 6$ and $B 3$ subunits. In fact, the optic nerve has the largest number of $a 6$ and $B 3 \mathrm{nAChRs}$ concentration found in the CNS (Cox et al., 2008).

Chronic treatment with nicotine seems to alter the expression of the nAChRs (Marks et al., 1992). In our study we have analyzed the expression levels by $\mathrm{qPCR}$ of $a 6,63 \mathrm{a}$ and $63 \mathrm{~b}$ subunits of $\mathrm{nAChRs}$ in zebrafish after administration of different doses of nicotine. The a6a nd 63a subunits show similar values after treatment with nicotine in concentrations of 10, 20 and 40 $\mu \mathrm{M}$. Acording to the temporal evolution, at $48 \mathrm{hpf}$ there is a decrease in the expression while at 3 and 5 dpf there is an increase in expression. In addition, 
the a6 subunit is expressed together with B3a subunit in visual and non-visual anatomical regions both, that $a 6$ and $B 3 b$ altogether do.

The $a 6$ and $B 3 b$ subunits show similar expression values after treatment with a concentration of $20 \mu \mathrm{M}$ nicotine of treatment. With respect to temporal evolution at $48 \mathrm{hpf}$ the expression decreased more drastic in $83 \mathrm{~b}$ than a6, but at $3 \mathrm{dpf}$ expression of $B 3 \mathrm{~b}$ continues to decrease in some treatments while than $a 6$ to increase. At $5 \mathrm{dpf}$, both subunits, increases levels of expression. With respect to locating regions sharing $a 6$ and B3b limited to the visual structures in CCG of the retina and non-visual, such as trigeminal ganglion.

The expression of a6 nAChR in the visual system and the mammalian retina suggests that this subunit is important in vision (Moretti et al., 2004, Millar and Gotti, 2009). In mice, after injection of nicotine the expression of the $\mathrm{nAChR}$ a6 subunit increases dopaminergic neurons of the ventral tegmental area, concluding that high doses of nicotine selectively activates dopaminergic neurons (Zhao-Shea et al., 2011).

Zebrafish has a duplicate gene for nAchR 83 subunit, the nAChR B3a and nAchR B3b. Our study shows that nicotine produces different effects in each of these receptors. Mattes et al. (1995) indicate that expression of $83 \mathrm{nAChR}$ affects the fate of ganglion cells in the developing retina.

\section{Effects of nicotine in electrophysiology of the retina}

Our results show that nicotine enhances greatly cone-driven b-wave amplitudes in larval zebrafish, but significantly depresses rod-driven b-wave amplitudes. These results clarify and extend the earlier results in rabbits (Jurklies et al., 1996) and humans (Varghese et al., 2011) that suggested nicotine may enhance the $b$-wave under photopic conditions and decrease the $b$ wave under scotopic conditions. Whereas nicotine greatly altered both cone and rod driven b-wave amplitudes, it did not affect the sensitivity of the responses. 
It is unclear how nicotine might affect b-wave amplitudes. Assuming that the b-wave in zebrafish directly reflects ON-bipolar cell responses, our data suggest that nicotine increases the light response in cone ON-bipolar cells, but decreases the light response in rod ON-bipolar cells, but how this is mediated is unclear. Bipolar cell light responses are believed to be generated in the outer plexiform layer (OPL), as a result of synaptic input onto the bipolar cells from the photoreceptors. In larval zebrafish, Arenzana et al., (2005) have observed processes containing choline acetyltransferase (ChAT) in the OPL, and it may be that these processes are the source of the acetylcholine that affects the bipolar cells. The processes containing ChAT gradually disappear as the larvae mature, and in the adult zebrafish processes containing ChAT are found only in the IPL.

In zebrafish, however, whereas there are bipolar cells that receive input only from cones, all of the bipolar cells that receive rod input also have cone input ( $\mathrm{Li}$ et al., 2012). However, of the four mixed rod-cone bipolar cells in zebrafish, one has the great majority ( 6 times) of its input from rods; the others have more input from cones than rods. Also, all of the rod-dominated bipolar cells are ON-cells, whereas most of the bipolar cells receiving mixed rod-cone input are OFF-cells or ON-OFF cells. It may be that the rod dominant mixed bipolar cell is the main contributor to the scotopic b-wave in zebrafish, and it is this cell whose activity is strongly depressed by nicotine, whereas the other ONbipolar cells give a mixed or no response to nicotine. In nof mutants the mixed rod-cone bipolar cells receive no cone input, perhaps enhancing the rod suppression of the b-wave.

Interestingly, whereas an a-wave is usually readily observed with bright stimuli in control fish. We interpret our data to mean that nicotine substantially enhances cone b-wave activity and quickens it, but may depress rod b-wave responses. However, as noted earlier, zebrafish larvae are highly cone dominant, and rod responses are difficult to isolate because of the very large cone responses. Therefore, we turned to a mutant (nof) fish that has no cone function to better evaluate the effects of nicotine on the rod-driven $b$-wave. 


\section{Effects of nicotine in the behaviour induced by visual function}

The optomotor response (OMR) test evaluates the effect of compounds on zebrafish vision with higher performance optokinetic response (OKR). However, compounds that affect the locomotive capacity of zebrafish could generate positive response in the OMR test. Therefore, the OMR test can be used as a screen for compounds which cause defects in the visual function and a secondary screening with OKR and hypomotility in a locomotor test (Richards et al., 2008).

The results we observed in optomotor response analysis indicate a deficit in tracking visual stimulus, which may be influenced by hypomotility problems in nicotine treated animals (Svoboda et al., 2002). Certain component of the change in the response is due to a vision problem, since the increasing in contrast, spatial frequency or temporal frequency, improves OMR.

The use of eye movement measurements has been very useful for understanding neurophysiological and neurochemical dysfunction after administration of different drugs or clinical conditions (Maurer et al., 2011). Behavioral studies in animal models and humans exposed to different drugs indicate that oculomotor measures can provide a highly sensitive index of pharmacodynamic drug effect on brain systems (Reilly et al., 2008). OKR is altered after administration of nicotine. With a speed diminution in eye tracking associated to a visual stimulus. Furthermore, saccades decrease in nicotine treated animals, which is consistent with data from humans (Clarke et al. 1985; Domino et al., 1997; Larrison et al., 2004; Rycroft et al.; 2006 Zingler et al., 2007). These studies have shown that nicotine reduces the number of primary saccades during search tasks in smokers, non-smokers and in patients with schizophrenia (Avila et al., 2003; Olincy et al., 2003, Tanabe et al. 2006).

Circadian factors, such as the light-dark cycle, have effects on the development of the visual system (Hainline and Abramov, 1991; Organisciak and Winkler, 1994; Guido et al., 2010). Thus, adverse lighting conditions affect 
the retinal anatomy. In this sense, studies suggest that alterations in ilumination can produce substantial damage (Hainline and Abramov, 1991), while other studies indicate that this cirscunstance, even during long periods of time (up to 8 months) have little effects on the retinal anatomy (Bilotta, 2000). In our results of VMR show that zebrafish treated with low doses of nicotine respond similarly to the light stimulus than control animals, whereas the increase in the dose of nicotine decreases the response to light stimulation. This indicates the possible development of a deficit in visual accommodation with respect to the movement from light to dark. In studies with rats in which visual stimuli have been employed on and off of the light in dwellings, it has been found that nicotine increases the sustained response rates for both stimulus changes (Raiff and Dallery, 2009), althought the association of the stimulus with food may have interfered with the results. 


\section{CONCLUSIONS}

According to the objectives of this Doctoral Thesis, and as a consequence of the results and discussion, we have concluded that:

I. Exposure of zebrafish embryos to nicotine reduces the ocular area and the size of the animal in relation to the dose administered, without affecting the lamination of either the retina or the optic tectum.

II. Exposure of zebrafish embryos to nicotine causes less pronounced effects during the segregation between the neural retina and the retinal pigment epithelium, than during cell differentiation of the neural retina, which is associated with a delay in the neurochemical maturation of different populations of the neural retina.

III. The treatment with nicotine during development alters the expression patterns of nAChRs. B3a and a6 subunits increase after treatment with increasing doses of nicotine. $63 \mathrm{~b}$ and $a 6$ subunits differ in their expression levels in different nicotine treatment groups and at different stages of development analyzed.

IV. Nicotine alters the electroretinogram in zebrafish, stimulating ON bipolar cells that receive cone input and inhibiting ON bipolar cells with rod input.

V. Animals exposed to low concentrations of nicotine present a correct motor activity but an impairment in visual skills, whereas animals exposed to higher concentrations of nicotine have increased visual deficits and problems in motor activity appear. 


\section{Bibliografía}



A

bramov, I.; Hainline, L. (1991). Light

and the developing visual system. In: Marshall J, editor. The Susceptible Visual Apparatus, vol. 16. London, UK: Macmillan. 104-33.

Ackerman, K.M.; Nakkula, R.; Zirger, J.M.; Beattie, C.E.; Boyd, R.T. (2009). Cloning and spatiotemporal expression of zebrafish neuronal nicotinic acetylcholine receptor alpha 6 and alpha 4 subunit RNAs. Dev Dyn. 238(4):980-92.

Ali, M.A.; Anctil, M. (1976). Retina of fishes: an atlas. Berlin: Springer-Verlag.

Atluri, P.; Fleck, M.W.; Shen, Q.; Mah, S.J.; Stadfelt, D.; Barnes, W.; Goderie, S.K.; Temple, S.; Schneider, A.S. (2001). Functional nicotinic acetylcholine receptor expression in stem and progenitor cells of the early embryonic mouse cerebral cortex. Dev Biol. 240(1):143-56.

Anderson, M.E.; Johnson, D.C.; Batal, H.A. (2005). Sudden Infant Death Syndrome and prenatal maternal smoking: rising attributed risk in the Back to Sleep era. BMC Medicine. 3:4.

Andressen, C.; Blumcke, I.; Celio, M.R. (1993). Calcium-binding proteins: selective markers of nerve cells. Cell Tissue Res. 271, 181-208.

Arenzana, F.J.; Clemente, D.; SánchezGonzález, R.; Porteros, A.; Aijón, J.; Arévalo, R. (2005). Development of the cholinergic system in the brain and retina of the zebrafish. Brain Res Bull. 66(46):421-5.

Arenzana, F.J. (2006). Caracterización neuroquímica de las áreas visuales primarias del pez cebra en condiciones normales y en ciclopia inducida por etanol. Tesis Doctoral. Universidad de Salamanca.

Arenzana, F.J.; Arévalo, R.; SánchezGonzález, R.; Clemente, D.; Aijón, J.; Porteros, A. (2006). Tyrosine hydroxylase immunoreactivity in the developing visual pathway of the zebrafish. Anat Embryol. 211, 323-334.
Arévalo, R.; Alonso, J.R.; Porteros, A.; Briñón, J.G.; Crespo, C.; Lara, J.; Aijón, J. (1995). Calretinin-like immunoreactivity in the optic tectum of the tench (Tinca tinca L.). Brain Res. 671, 112118.

Armington, J.C. (1974). The electroretinogram. New York: Academic Press.

Austin, C.P.; Feldman, D.E.; Ida, J.A.; Cepko, C.L. (1995). Vertebrate retinal ganglion cells are selected from competent progenitors by the action of Notch. Development. 121: 3637-50.

Avila, M.T.; Sherr, J.D.; Hong, E.; Myers, C.S.; Thaker, G.K. (2003). Effects of nicotine on leading saccades during smooth pursuit eye movements in smokers and nonsmokers with schizophrenia. Neuropsychopharmacology. 28(12):2184-91.

B achman, E.S., Berger-Sweeney, J.; Coyle, J.T.; Hohmann, C.F. (1994). Developmental regulation of adult cortical morphology and behavior: an animal model for mental retardation. Int $J$ Dev Neurosci. 12: $239-253$.

Bando, T. (1993). Discrimination of random dot texture patterns in bluegill sunfish, Lepomis macrochirus. J Comp Physiol A. 172: 663-669.

Bassi, J.A.; Rosso. P.; Moessinger, A.C.; Blanc, W.A.; James, L.S. (1984). Fetal growth retardation due to maternal tobacco smoke exposure in the rat. Pediatr Res. 18(2):127-30.

Bäumer, N.; Marquardt, T.; Stoykova, A.; Ashery-Padan, R.; Chowdhury, K.; Gruss, P. (2002). Pax6 is required for establishing naso-temporal and dorsal characteristics of the optic vesicle. Development. 129(19):4535-45.

Bear, M.F.; Connors, B.W.; Paradiso, M.A. (1996). Neurociencia. Explorando el cerebro. Baltimore: Williams \& Wilkins.

Becerra, M.; Manso, M.J.; Rodríguez- 
Moldes, M.I.; Anadón, R. (1994). The structure and development of dopaminergic interplexiform cells in the retina of the brown trout, Salmo trutta fario: a tyrosine hydroxylase immunocytochemical study. J Anat. 185 (Pt 2), 377-385.

Bednar, J.A.; Kelkar, A.; Miikkulainen, R. (2004). Scaling self-organizing maps to model large cortical networks. Neuroinformatics. 2004;2(3):275-302.

Behra, M., Cousin, X.; Bertrand, C.; Vonesch, J.L.; Biellmann, D.; Chatonnet, A.; Strähle, U. (2002). Acetylcholinesterase is required for neuronal and muscular development in the zebrafish embryo. Nat Neurosci. 5(2):111-8.

Bencan, Z., Levin, E.D. (2008). The role of alpha7 and alpha4beta2 nicotinic receptors in the nicotine-induced anxiolytic effect in zebrafish. Physiol Behav. 95(3):408-12.

Bence M, Levelt CN. (2005). Structural plasticity in the developing visual system. Prog Brain Res. 147:125-39.

Benowitz, N.L. (1996). Pharmacology of nicotine: addiction and therapeutics. Annu. Rev. Pharmacol Toxicol. 36: 597-613.

Berger, F.; Gage, F.H.; Vijayaraghavan, S. (1998). Nicotinic receptor-induced apoptotic cell death of hippocampal progenitor cells. $J$ Neurosci. 18: 6871 6881.

Bertschy, S.; Genton, C.Y.; Gotzos V. (1998). Selective immunocytochemical localisation of calretinin in the human ovary. Histochem Cell Biol. 109, 59-66.

Betchaku, T.; Trinkaus, J.P. (1978). Contact relations, surface activity, and cortical microfilaments of marginal cells of the enveloping layer and of the yolk syncytial and yolk cytoplasmic layers of fundulus before and during epiboly. $J$ Exp Zool. 206, 381-426.

Bilotta, J. (2000). Effects of abnormal lighting on the development of zebrafish visual behavior. Behav Brain Res. 116 (1):81-7.
Bilotta, J.; Saszik, S.; Givin, C.M.; Hardesty, H.R., Sutherland, S.E. (2002). Effects of embryonic exposure to ethanol on zebrafish visual function. Neurotoxicol Teratol. 24:759-766.

Bilotta, J.; Barnett, J.A.; Hancock, L.; Saszik, S. (2004). Ethanol exposure alters zebrafish development: a novel model of fetal alcohol syndrome. Neurotoxicol Teratol. 26:737-743.

Blader ,P.; Plessy, C.; Strähle, U. (2003). Multiple regulatory elements with spatially and temporally distinct activities control neurogenin 1 expression in primary neurons of the zebrafish embryo. Mech Dev. 120(2):211-8.

Blanco, M.J.; Barrallo-Gimeno, A.; Acloque, H.; Reyes, A.E.; Tada, M.; Allende, M.L.; Mayor, R.; Nieto, M.A. (2007). Snail1a and Snail1b cooperate in the anterior migration of the axial mesendoderm in the zebrafish embryo. Development. 134, 4073-4081.

Blümcke, I.; Hof, P.R.; Morrison, J.H.; Celio M.R. (1990). Distribution of parvalbumin immunoreactivity in the visual cortex of Old World monkeys and humans. J Comp Neurol. 301, 417-432.

Booker, T.K.; Butt, C.M.; Wehner, J.M.; Heinemann, S.F.; Collins, A.C. (2007). Decreased anxiety-like behavior in beta3 nicotinic receptor subunit knockout mice. Pharmacol Biochem Behav. 87(1):146-57.

Boyd, R.T.; Beattie, C.E.; Zirger, J.M. (2003). Nicotine-induced apoptosis in developing zebrafish embryos. Program no. 249.9, abstract viewer/itinerary planner. Society for Neuroscience. Washington, D.C.

Brandon, C. (1987). Cholinergic neurons in the rabbit retina: immunocytochemical localization, and relationship to GABAergic and cholinesterase-containing neurons. Brain Res. 401: 385-391.

Brockerhoff, S.E.; Hurley, J.B.; JanssenBienhold, U.; Neuhauss, S.C.; Driever, W.; Dowling, J.E. (1995). A behavioral screen for isolating zebrafish mutants with visual system defects. Proc Natl Acad Sci U S A. 92: 10545-10549 
Brockerhoff, S.E.; Hurley, J.B.; Niemi, G.A.; Dowling, J.E. (1997). A new form of inherited red-blindness identified in zebrafish. J Neurosci. 17: 4236-4242.

Brockerhoff, S.E.; Rieke, F.; Matthews, H.R.; Taylor, M.R.; Kennedy, B.; Ankoudinova, I.; Niemi, G.A.; Tucker, C.L., Xiao, M.; Cilluffo, M.C.; Fain, G.L.; Hurley, J.B. (2003). Light stimulates a transducin-independent increase of cytoplasmic $\mathrm{Ca} 2+$ and suppression of current in cones from the zebrafish mutant nof. J Neurosci. 23(2):470-80.

Broide, R.S., O'Connor, L.T., Smith, M.A.; Smith, J.A.; Leslie, F.M. (1995). Developmental expression of alpha 7 neuronal nicotinic receptor messenger RNA in rat sensory cortex and thalamus. Neuroscience. 67: 83-94.

Brown, K.T., Wiesel, T.N. (1961). Localization of origins of electroretinogram components by intra retinal recording in the intact cat eye. J Physiol. 158:257-280.

Brown, K.T. (1968). The electroretinogram: its components and their origin. Vision Res. 8:633-677.

Brunner, G. (1935). Über die Sehschärfe der Elritze (Phoxinus laevis) bei verschiedenen Helligkeiten. J Comp Physiol A. 21: 296-316

Buttler, A.B.; Hodos, W. (1996). Comparitive vertebrate neuroanatomy. Evolution and adaptation. Nueva york: Wiley-Liss, Inc.

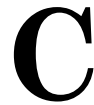

allaerts, P.; Halder, G.; Gehring W.J.

(1997). PAX-6 in development and evolution. Annu Rev Neurosci. 20 , 483-532.

Castles, A.; Adams, E.K.; Melvin, C.L.; Kelsch C.; Boulton, M.L. (1999). Effects of smoking during pregnancy. Five metaanalyses. Am J Prev Med. 16:208-215.

Castro, A.; Becerra, M.; Manso, M.J.; Anadón, R. (2006a). Calretinin immunoreactivity in the brain of the zebrafish, Danio rerio: distribution and comparison with some neuropeptides and neurotransmitter-synthesizing enzymes. I.
Olfactory organ and forebrain. $J$ Comp Neurol. 494, 435-459.

Castro, A.; Becerra, M.; Manso, M.J.; Anadón R. (2006b). Calretinin immunoreactivity in the brain of the zebrafish, Danio rerio: distribution and comparison with some neuropeptides and neurotransmitter-synthesizing enzymes. II. Midbrain, hindbrain, and rostral spinal cord. J Comp Neurol. 494, 792-814.

Castro, N.G.; Albuquerque, E.X. (1995). Alpha- Bungarotoxin-sensitive hippocampal nicotinic receptor channel has a high calcium permeability. Biophys J. 68: 516-24.

Cavodeassi, F., Kapsimali, M., Wilson, S.W.; Young, R. (2009). Forebrain: early development in L. R. Squire (editor) Elsevier. Oxford: Academic Press. Encyclopedia of Neuroscience. 4:321-325.

Celio, M.R.; Gray, E.G.; Yasargil, G.M. (1979). Ultrastructure of the Mauthner axon collateral and its synapses in the goldfish spinal cord. J Neurocytol. 8, 19-29.

Cerveny, K.L.; Cavodeassi, F.; Turner, K.J.; de Jong-Curtain, T.A.; Heath, J.K.; Wilson, S.W. (2010). The zebrafish flotte lotte mutant reveals that the local retinal environment promotes the differentiation of proliferating precursors emerging from their stem cell niche. Development. 137, 2107-2115.

Chalepakis, G., Fritsch, R., Fickenscher, H.; Deutsch, U.; Goulding, M.; Gruss P. (1991). The molecular basis of the undulated/Pax-1 mutation. Cell. 66, 873884.

Champtiaux, N.; Han, Z. Y.; Bessis, A.; Rossi, F. M.; Zoli, M.; Marubio, L.; McIntosh, J. M.; Changeux J. P. (2002). Distribution and pharmacology of a6containing nicotinic acetylcholine receptors analyzed with mutant mice. J. Neurosci. $22,1208-1217$.

Champtiaux, N.; Gotti, C.; CorderoErausquin, M.; David, D.J.; Przybylski, C.; Léna, C.; Clementi, F.; Moretti, M.; Rossi, F.M.; Le Novère, N.; McIntosh, J.M.; Gardier, A.M.; Changeux, J.P. (2003). Subunit composition of functional 
nicotinic receptors in dopaminergic neurons investigated with knock-out mice. J Neurosci. 23(21):7820-9.

Changeux, J.P.; Edelstein, S.J. (1998). Allosteric receptors after 30 years. Neuron. 21: 959-980.

Chédotal, A.; Pourquie, O.; Ezan, F.; San Clemente, H.; Sotelo, C. (1996). BEN as a presumptive target recognition molecule during the development of the olivocerebellar system. $J$ Neurosci. 16, 3296-310.

Cid, E.; Santos-Ledo, A.; Parrilla-Monge, M., Lillo, C.; Arévalo, R.; Lara, J.M.; Aijón, J.; Velasco, A. (2010). Prox1 expression in rod precursors and Müller cells. Exp Eye Res. 90, 267-276.

Cimino, M.; Marini, P.; Colombo, S.; Andena, M., Cattabeni, F.; Fornasari, D.; Clementi, F. (1995). Expression of neuronal acetylcholine nicotinic receptor alpha 4 and beta 2 subunits during postnatal development of the rat brain. $J$ Neural Transm Gen Sect. 100(2):77-92.

Clark, D. T. (1981). Visual responses in developing zebrafish (Brachydanio rerio). Ph.D. Dissertation. University of Oregon.

Clarke, P.B.; Pert, C.B.; Pert, A. (1984). Autoradiographic distribution of nicotine receptors in rat brain. Brain Res. 323(2):390 -5 .

Clarke, P.B.; Hommer, D.W.; Pert, A.; Skirboll, L.R. (1985). Electrophysiological actions of nicotine on substantia nigra single units. British J. Pharmacology. 85, 827-835.

Clemente, D.; Porteros, A.; Weruaga, E.; Alonso, J.R.; Arenzana, F.J.; Aijón, J.; Arévalo, R. (2004). Cholinergic elements in the zebrafish central nervous system: Histochemical and immunohistochemical analysis. J Comp Neurol. 474(1):75-107.

Cline, H.T.; Constantine-Paton, M. (1989). NMDA receptor antagonists disrupt the retinotectal topographic map. Neuron. 3, $413-426$.

Connor, R.J.; Menzel, P.; Pasquale, E.B.
(1998). Expression and tyrosine phosphorylation of Eph receptors suggest multiple mechanisms in patterning of the visual system. Dev Biol. 193, 21-35.

Conroy, W.G.; Berg, D.K. (1998). Nicotinic receptor subtypes in the developing chick brain: appearance of a species containing the alpha4, beta2, and alpha5 gene products. Mol Pharmacol. 53: 392-401.

Cox, B.C.; Marritt, A.M.; Perry, D.C.; Kellar, K.J. (2008). Transport of multiple nicotinic acetylcholine receptors in the rat optic nerve: high densities of receptors containing alpha6 and beta3 subunits. $J$ Neurochem. 105:1924-38.

Cui, C.; Booker, T.K.; Allen, R.S.; Grady, S.R.; Whiteaker, P.; Marks, M.J.; Salminen, O.; Tritto, T.; Butt, C.M.; Allen, W.R.; Stitzel, J.A.; McIntosh, J.M.; Boulter, J.; Collins, A,C,; Heinemann, S,F. (2003). The beta 3 nicotinic receptor subunit: a component of alpha-conotoxin MII-binding nicotinic acetylcholine receptors that modulate dopamine release and related behaviors. $J$ Neurosci. 23 (35):11045-53.

Culverwell, J.; Karlstrom, R.O. (2002). Making the connection: retinal axon guidance in the zebrafish. Semin Cell Dev Biol. 13, 497-506.

Cutler, A.R.; Wilkerson, A.E.; Gingras, J.L.; Levin, E.D. (1996). Prenatal cocaine and/or nicotine exposure in rats: preliminary findings on long-term cognitive outcome and genital development at birth. Neurotoxicol Teratol. 18(6):635-43.

Czerny, T., Schaffner, G.; Busslinger, M. (1993). DNA sequence recognition by $\mathrm{Pax}$ proteins: bipartite structure of the paired domain and its binding site. Genes Dev. 7, 2048-2061.

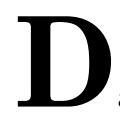

akubo, G.D.; Wang, Y.P.; Mazerolle, C.; Campsall, K.; McMahon, A.P.; Wallace, V.A. (2003). Retinal ganglion cell -derived sonic hedgehog signaling is required for optic disc and stalk neuroepithelial cell development. 
Development. 130, 2967-2980.

Dani, J.A.; Mayer, M.L. (1995). Structure and function of glutamate and nicotinic acetylcholine receptors. Curr Opin Neurobiol. 5: 310-7.

Dani, J.A.; Heinemann, S. (1996). Molecular and cellular aspects of nicotine abuse. Neuron. 16: 905-908.

David, C. T. (1979). Optomotor control of speed and height by free-flying drosophyla. J Exper Biology. 82, 389- 392.

Dayhaw-Barker, P. (2002). Retinal pigment epithelium melanin and ocular toxicity. Int J Toxicol, 21, 451-454.

DeAngelis, G.C. (2000). Seeing in three dimensions: the neurophysiology of stereopsis. Trends Cogn. Sci. 4, 80-90.

Debski, E.A.; Cline, H.T. (2002). Activitydependent mapping in the retinotectal projection. Curr Opin Neurobiol. 12(1):939.

Decker, E.R.; Dani, J.A. (1990). Calcium permeability of the nicotinic acetylcholine receptor: the singlechannel calcium influx is significant. J Neurosci. 10: 3413-20.

Dellovade, T.L.; Pfaff, D.W.; SchwanzelFukuda, M. (1998). Olfactory bulb development is altered in small-eye (Sey) mice. J Comp Neurol. 402:402-18.

De Robertis, E.M.; Sasai, Y. (1996). A common plan for dorsoventral patterning in Bilateria. Nature. 380:37-40.

DeVries, S. H.; Schwartz, E. A. (1999). Kainate receptors mediate synaptic transmissionbetween cones and 'Off bipolar cells in a mammalian retina. Nature. 397, 157-160.

Díaz-Regueira S.M.; Anadón R. (2000). Calretinin expression in specific neuronal systems in the brain of an advanced teleost, the grey mullet (Chelon labrosus). J Comp Neurol. 426, 81-105.

Díaz-Regueira S.M.; Lamas I.; Anadón R. (2005). Calretinin immunoreactivity in taste buds and afferent fibers of the grey mullet Chelon labrosus. Brain Res. 1031, 297-301.

Diekmann, H.; Stuermer, C.A. (2009). Zebrafish neurolin-a and -b, orthologs of ALCAM, are involved in retinal ganglion cell differentiation and retinal axon pathfinding. J Comp Neurol. 513, 38-50.

DiFranza, J.R.; Aligne, C.A.; Weitzman, M. (2004). Prenatal and postnatal environmental tobacco smoke exposure and children's health. Pediatrics. 113:10071015.

Doldan, M.J.; Prego B.; de Miguel Villegas E. (1999). Immunochemical localization of calretinin in the retina of the turbot (Psetta maxima) during development. J Comp Neurol. 406, 425432 .

Domino, E.F.; Ni, L.S.; Zhang, H. (1997). Effects of tobacco smoking on human ocular smooth pursuit. Clinical Pharmacology and Therapeutics. 61, 349359.

Dörr, S.; Neumeyer, C. (1997). Simultaneous color contrast in goldfish a quantitative study. Vision Res. 37: 15811593

Dörr, S.; Neumeyer, C. (2000). Color constancy in goldfish: the limits. $J$ Comp Physiol A. 186: 885-896.

Dowling, J.E. (2012). "The Retina: An Approachable Part of the Brain- Revised Edition.” the Belknap Press of Harvard University Press. Cambridge, MA.

$\mathbf{E}$ aster, S.S.Jr.; Stuermer, C.A. (1984). An evaluation of the hypothesis of shifting terminals in goldfish optic tectum. $J$ Neurosci. 4, 1052-1063.

Easter, S.S.Jr.; Ross, L.S.; Frankfurter, A. (1993). Initial tract formation in the mouse brain. J Neurosci. 13, 285-299.

Easter, S.S.Jr.; Nicola, G.N. (1997). The development of eye movements in the zebrafish (Danio rerio). Dev Psychobiol. 31: 
267-276.

Echteler, S.M.; Saidel, W.M. (1981). Forebrain connections in the goldfish support telencephalic homologies with land vertebrates. Science. 212, 683-685.

Eddins, D.; Petro, A.; Williams, P., Cerutti, D.T.; Levin, E.D. (2009). Nicotine effects on learning in zebrafish: the role of dopaminergic systems. Psychopharmacology (Berl). 202(1-3):103-9.

Edwards, J.G.; Greig, A.; Sakata, Y.; Elkin, D.; Michel, W.C. (2007). Cholinergic innervation of the zebrafish olfactory bulb. $J$ Comp Neurol. 504(6):631-45.

Ellis, J.H.; Richards, D.E.; Rogers, J.H. (1991). Calretinin and calbindin in the retina of the developing chick. Cell Tissue Res. 264(2):197-208.

Emran, F.; Rihel, J.; Dowling, J.E. (2008). A behavioral assay to measure responsiveness of zebrafish to changes in light intensities. J Vis Exp. (20). pii: 923.

Emran, F.; Rihel, J.; Adolph, A.R.; Dowling, J.E. (2010). Zebrafish larvae lose vision at night. Proc Natl Acad Sci U S A. 107(13):6034-9.

England, S.J.; Blanchard, G.B.; Mahadevan, L.; Adams, R.J. (2006). A dynamic fate map of the forebrain shows how vertebrate eyes form and explains two causes of cyclopia. Development. 133, 46134617.

Ericson, J.; Thor, S.; Edlund, T.; Jessell, T.M.; Yamada, T. (1992). Early stages of motor neuron differentiation revealed by expression of homeobox gene islet1. Science. 256: 1555-60.

Eriksson, P., Ankarberg, E.; Fredriksson, A. (2000). Exposure to nicotine during a defined period in neonatal life induces permanent changes in brain nicotinic receptors and in behavior of adult mice. Brain Res. 853:41-48.

Ernst, M.; Moolchan, E.T.; Robinson, M.L. (2001). Behavioral and neural consequences of prenatal exposure to nicotine. J Am Acad Child Adolesc Psychiatry. 40(6):630-41
Euler, T.; Schneider, H.; Wassle, H. (1996). Glutamate responses of bipolar cells in a slice preparation of the rat retina. $J$ Neurosci. 16, 2934-2944.

Evereklioglu, C., Ozkiriş, A.; Alaşehirli, B.; Sari, I.; Güldür, E.; Cengiz, B.; Kontaş, O. (2003). Effect of gestational nicotine treatment on newborn rat retina: a histopathological and morphometric analysis. Ophthalmic Physiol Opt. 23(6):527 -33 .

Evereklioglu, C.; Alaşehirli, B.; Sari, I.; Cengiz, B.; Bagci, C. (2004). Effect of nicotine exposure during gestation on neonatal rat crystalline lenses. Eye (Lond). 18(1):67-73.

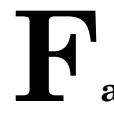
adool, J.M., Dowling, J.E. (2008).

Zebrafish: a model system for the study of eye genetics. Prog Retin Eye Res. 27(1):89110.

Fashena, D.; Westerfield, M. (1999). Secondary motoneuron axons localize DMGRASP on their fasciculated segments. $J$ Comp Neurol. 406, 415-24.

Feller, M.B.; Wellis, D.P.; Stellwagen, D.; Werblin, F.S.; Shatz C.J. (1996). Requirement for cholinergic synaptic transmission in the propagation of spontaneous retinal waves. Science. 272, 1182-1187.

Fischer, A.J.; Dierks, B.D.; Reh, T.A. (2002). Exogenous growth factors induce the productionof ganglion cells at the retinal margin. Development. 129: 2283-91.

Fratzer, C.; Dörr, S.; Neumeyer, C. (1994). Wavelength discrimination of the goldfish in the ultraviolet spectral range. Vision Res. 34: $1515-1520$.

Freedman, R.; Coon, H.; Myles-Worsley, M.; Orr-Urtreger, A.; Olincy, A.; Davis, A., Polymeropoulos, M., Holik, J.; Hopkins, J.; Hoff, M., Rosenthal, J.; Waldo, M.C.; Reimherr, F., Wender, P.; Yaw, J.; Young, D.A.; Breese, C.R.; Adams, C.; Patterson, D.; Adler, L.E.; Kruglyak, L.; Leonard, S.; Byerley, W. 
(1997). Linkage of a neurophysiological deficit in schizophrenia to a chromosome 15 locus. Proc Natl Acad Sci U S A. 94: 587592.

Freyd, G.; Kim, S.K.; Horvitz, H.R. (1990). Novel cysteine rich motif and homeodomain in the product of the Caenorhabditis elegans cell lineage gene lin-11. Nature. 344: 876-9.

Fujiwara, M.; Uchida, T.; OsumiYamashita, N.; Eto, K.; (1994). Uchida rat (rSey): a new mutant rat with craniofacial abnormalities resembling those of the mouse Sey mutant. Differentiation. 57:31-8.

G

alli-Resta, L., Resta, G.; Tan, S.S.;

Reese, B.E. (1997). Mosaics of islet1expressing amacrine cells assembled by short-range cellular interactions. $J$ Neurosci. 17: 7831-8.

García-Crespo D.; Vecino, E. (2004). Differential expression of calretinin in the developing and regenerating zebrafish visual system. Histol Histopathol. 19 (4):1193-9.

Gèrmana, A.; Paruta, S.; Germana, G.P.; Ochoa-Erena F.J., Montalbano G., Cobo J.; Vega, J.A. (2007). Differential distribution of S100 protein and calretinin in mechanosensory and chemosensory cells of adult zebrafish (Danio rerio). Brain Res. 1162, 48-55.

Ghosheh, O.A.; Dwoskin, L.P.; Miller, D.K.; Crooks, P.A. (2001). Accumulation of nicotine and its metabolites in rat brain after intermittent or continuous peripheral administration of [2'-14C]nicotine. Drug Metab Dispos. 29: 645-651.

Gilbert, S.F. (2010). Development of biology. Sinauer Associates, Inc. Publishers. Suderland, MA.

Glaser, T.; Lane, J.; Housman, D. (1990). A mouse model of the aniridia-Wilms tumor deletion syndrome. Science. 250:823-7.

Goolish, E.M., Okutake, K.; Lesre, S. (1999) Growth and survivorship of larval zebrafish Danio rerio on processed diets.
North Am J Aquacult. 61:189-198.

Gotti, C.; Moretti, M.; Longhi, R.; Briscini, L.; Balestra, B.; Clementi, F. (1994). Expression of alphabungarotoxin receptor subtypes in chick central nervous system during development. J Recept Res. 14: 33546.

Gotti, C.; Clementi, F. (2004). Neuronal nicotinic receptors: from structure to pathology. Prog Neurobiol. 74: 363-396.

Gotti, C.; Moretti, M.; Zanardi, A.; Gaimarri, A.; Champtiaux, N.; Changeux, J.P.; Whiteaker, P.; Marks, M.J.; Clementi, F.; Zoli, M. (2005). Heterogeneity and selective targeting of neuronal nicotinic acetylcholine receptor (nAChR) subtypes expressed on retinal afferents of the superior colliculus and lateral geniculate nucleus: identification of a new native nAChR subtype alpha3beta 2 (alpha5 or beta3) enriched in retinocollicular afferents. Mol Pharmacol. 68(4):1162-71.

Gotti, C.; Zoli, M.; Clementi, F. (2006). Brain nicotinic acetylcholine receptors: native subtypes and their relevance. Trends Pharmacol Sci. 27: 482-491.

Guillery, R.W.; Mason, C.A.; Taylor J.S. (1995). Developmental determinants at the mammalian optic chiasm. J Neurosci. 15, 4727-4737.

Gottlob, I.; Wundsch, L.; Tuppy, F. K. (1988). The rabbit electroretinogram: effect of GABA and its antagonists. Vision Res. 28, 203-210.

Granit, R. (1933). The components of the retinal action potential in mammals and their relation to the discharge in the optic nerve. J Physiol. 77:207-239.

Granit, R. (1947). Sensory Mechanisms of the Retina. London: Oxford University Press.

Granit, R. (1962). Neurophysiology of the retina. In: The Eye, Vol. 2 (New York, Academic).

Graw, J. (2010). Eye development. Curr Top 
Dev Biol. 90, 343-386.

Greenberg, M.E.; Ziff, E.B.; Greene, L.A. (1986). Stimulation of neuronal acetylcholine receptors induces rapid gene transcription. Science. 234: 80-83.

Grindley, J.C., Davidson, D.R.; Hill R.E. (1995). The role of Pax-6 in eye and nasal development. Development. 121, 1433-1442.

Gross, J.M.; Perkins, B.D.; Amsterdam, A.; Egaña, A.; Darland, T.; Matsui, J.I.; Sciascia, S.; Hopkins, N.; Dowling J.E. (2005). Identification of zebrafish insertional mutants with defects in visual system development and function. Genetics. 170: 245-261.

Grover, B.G.; Sharma S.C. (1981). Organization of extrinsic tectal connections in Goldfish (Carassius auratus). J Comp Neurol. 196, 471-488.

Grundfest, H. (1931). The Relative Effectiveness of Spectral Radiation for the Vision of the Sun-Fish, Lepomis. Proc Natl Acad Sci U S A. 17: 359-66.

Gu, Q. (2003). Contribution of acetylcholine to visual cortex plasticity. Neurobiol Learn Mem. 80(3):291-301.

Guglielmone, R.; Corvetti, G. (2000). First appearance and distribution of calretininimmunoreactive neurons in the early development of the chick central nervous system. Cell Tissue Res. 300, 21- 28.

Guido, M.E.; Garbarino-Pico, E.; Contin, M.A.; Valdez, D.J.; Nieto, P.S.; Verra, D.M.; Acosta-Rodriguez, V.A.; de Zavalía, N.; Rosenstein, R.E. (2010). Inner retinal circadian clocks and nonvisual photoreceptors: novel players in the circadian system. Prog Neurobiol. 92(4):484504

Guo, S.; Wilson, S.W.; Cooke, S.; Chitnis, A.B.; Driever, W.; Rosenthal, A. (1999). Mutations in the zebrafish unmask shared regulatory pathways controlling the development of catecholaminergic neurons. Dev Biol. 208: 473-87.

Guthrie, D.M.; Banks J.R. (1990). A correlative study of the physiology and morphology of the retinotectal pathway of the perch. Vis Neurosci. 4, 367-377.

$\mathbf{H}$ akim, R.B.; Tielsch, J.M. (1992). Maternal cigarette smoking during pregnancy. A risk factor for childhood strabismus. Arch Ophthalmol. 110(10):145962 .

Halilagic, A.; Ribes, V.; Ghyselinck, N.B.; Zile, M.H.; Dolle, P.; Studer, M. (2007). Retinoids control anterior and dorsal properties in the developing forebrain. Dev Bio. 303, 362-375.

Hanneman, E., Westerfield, M. (1989). Early expression of acetylcholinesterase activity in functionally distinct neurons of the zebrafish. J Comp Neurol. 284(3):35061.

Hanson, I.M.; Fletcher, J.M.; Jordan, T.; Brown, A.; Taylor, D.; Adams, R.J.; Punnett, H.H.; van Heyningen, V. (1994). Mutations at the PAX6 locus are found in heterogeneous anterior segment malformations including Peters' anomaly. Nat Genet. 6:168-73.

Harwerth, R.S.; Sperling, H.G. (1975). Effects of intense visible radiation on the increment-threshold spectral sensitivity of the rhesus monkey eye. Vis Res. 15:1193204.

Haughton, S. (1872). Case of Strychnia Poisoning, Successfully Treated by Nicotine. Br Med J. 1(599):660-1.

Hecht, S.; Wolf, E. (1929a). The visual acuity of the bee and its relation to illumination. Proc Natl Acad Sci U S A. 15: 178-85.

Hecht, S.; Wolf, E. (1929b). The visual acuity of the honey bee. J Gen Physiol. 12: 727-760.

Hendzel, M.J.; Wei, Y.; Mancini, M.A.; Van Hooser, A.; Ranalli, T.; Brinkley, B.R.; Bazett-Jones, D.P.; Allis, C.D. (1997). Mitosis-specific phosphorylation of histones H3 initiates primarily within pericentromeric heterochromatin during 
G2 and spreads in an ordered fashion coincident with mitotic chromosome condensation. Chromosoma. 106:348-360.

Henley, J. M.; Lindstrom, J. M.; Oswald, L. E. (1986). Acetylcholine receptor synthesis in the retina and transport to the optic tectum of the goldfish. Science. 232, $1627-1629$.

Hensley, S. H.; Yang, X. L.; Wu, S. M. (1993). Identification of glutamate receptor subtypes mediating inputs to bipolar cells and ganglion cells in the tiger salamander retina. J Neurophysiol. 69, 2099-2107.

Hernández, M.C.; Erkman, L.; MatterSadzinski, L.; Roztocil, T.; Ballivet, M.; Matter, J.M. (1995). Characterization of the nicotinic acetylcholine receptor beta 3 gene. Its regulation within the avian nervous system is effected by a promoter 143 base pairs in length. $J$ Biol Chem. 270 (7):3224-33.

Higashijima, S.; Hotta, Y.; Okamoto, H. (2000). Visualization of cranial motor neurons in live transgenic zebrafish expressing green fluorescent protein under the control of the islet-1 promoter/ enhancer. J Neurosci. 20:206-218.

Hinds, J.W.; Hinds, P.L. (1983). Development of retina1 amacrine cells in the mouse embryo: evidence for two modes of formation. J Comp Neurol. 213:1-23.

Hirose, G.; Jacobson, M. (1979). Clonal organization of the central nervous system of the frog. I. Clones stemming from individual blastomeres of the 16-cell and earlier stages. Dev Biol. 71, 191-202 .

Hisaoka, K.K.; Battle, H.I. (1958). The normal developmental stages of the zebrafish, Bachydanio rerio. (HamiltonBuchanan). J Morphol. 102:311-328.

Hitchcock, P.; Kakuk-Atkins, L. (2004). The basic helix-loop-helix transcription factor neuroD is expressed in the rod lineage of the teleost retina. J Comp Neurol. 477(1):108-17.

Hogan, B.L.; Hirst, E.M.; Horsburgh, G.; Hetherington, C.M. (1988) Small eye (Sey): a mouse model for the genetic analysis of craniofacial abnormalities. Development. 103 Suppl:115-9.

Hohmann, C.F.; Brooks, A.R.; Coyle, J.T. (1988). Neonatal lesions of the basal forebrain cholinergic neurons result in abnormal cortical development. Brain Res. 470: 253-264.

Hohmann, C.F.; Wilson, L.; Coyle, J.T. (1991). Efferent and afferent connections of mouse sensory-motor cortex following cholinergic differentiation at birth. Cerebral Cortex. 1: 158-172.

Holmgren, F. (1865). Method att objectivera effecten af ljusintryck på retina. Uppsala Läk. För. Förh. 1: 184-98.

Holt, C.E.; Harris, W.A. (1993). Position, guidance, and mapping in the developing visual system. J Neurobiol. 24: 1400-22.

Holzschuh, J.; Ryu, S.; Aberger, F.; Driever, W. (2001). Dopamine transporter expression distinguishes dopaminergic neurons from other catecholaminergic neurons in the developing zebrafish embryo. Mech Dev. 101, 237-243.

Hoover, F.; Goldman, D. (1992). Temporally correlated expression of $\mathrm{nAChR}$ genes during development of the mammalian retina. Exp Eye Res. 54(4):56171.

Hurst, P.M. (1953). Color discrimination in the bluegill sunfish. J Comp Physiol Psychol. 46: 442-445.

Hyatt, G.A.; Schmitt, E.A.; Fadool, J.M.; Dowling, J.E. (1996). Retinoic acid alters photoreceptor development in vivo. Proc Natl Acad Sc U S A. 93, 13298-13303.

le, K.E.; Kassen, S.; Cao, C.; Vihtehlic, T.; Shah, S.D.; Mousley, C.J.; Alb, J.G.Jr.; Huijbregts, R.P., Stearns, G.W.; Brockerhoff, S.E.; Hyde, D.R.; Bankaitis, V.A. (2010). Zebrafish class 1 phosphatidylinositol transfer proteins: PITPbeta and double cone cell outer segment integrity in retina. Traffic. 11 (9):1151-1167. 
Ingle, D.J. (1985). The goldfish as a retinex animal. Science. 227: 651-654.

Ishii, K. (1967). Adhesiveness and histogenesis of various tissues of ectodermal origin from chick embryos in culture. Embryologia. (Nagoya) 10, 1-10.

Ito, Y.; Tanaka, H.; Okamoto, H.; Ohshima, T. (2010). Characterization of neural stem cells and their progeny in the adult zebrafish optic tectum. Dev Biol. 342, 26-38.

J ohns, P.R. (1977). Growth of the adult goldfish eye. III. Source of the new retinal cells. J Comp Neurol. 176, 343-357.

Jurklies, B.; Kaelin-Lang, A.; Niemeyer, G. (1996). Cholinergic effects on cat retina In vitro: changes in rod- and cone-driven $b$ wave and optic nerve response. Vision Res. 36(6):797-816.

$\mathbf{K}$

aas, J.H. (1997). Topographic maps are fundamental to sensory processing. Brain Res. Bull. 44 (1997) 107-112.

Kashyap, B.; Frey, R.A.; Stenkamp, D.L. (2011). Ethanol-induced microphthalmia is not mediated by changes in retinoic acid or sonic hedgehog signaling during retinal neurogenesis. Alcohol Clin Exp Res. 35 (9):1644-61.

Kay, J.N.; Finger-Baier, K.C.; Roeser, T.; Staub, W.; Baier, H. (2001). Retinal ganglion cell genesis requires lakritz, a Zebrafish atonal Homolog. Neuron. 30, 725736.

Kanki, J.P.; Chang, S.; Kuwada, J.Y. (1994). The molecular cloning and characterization of potential chick DMGRASP homologs in zebrafish and mouse. $J$ Neurobiol. 25: 831-45.

Karlsson, O.; Thor, S.; Norberg, T.; Ohlsson, H.; Edlund, T. (1990). Insulin gene enhancer binding protein Isl-1 is a member of a novel class of proteins containing both a homeo- and a Cys- His domain. Nature. 344: 879-82.

Kenyon, K.L.; Zaghloul, N.; Moody, S.A. (2001). Transcription factors of the anterior neural plate alter cell movements of epidermal progenitors to specify a retinal fate. Dev Biol. 240, 77-91.

Kern, R.; Lutterklas, M.; Petereit, C.; Lindemann, J. P.; Engelhaaf, M. (2001). Neuronal processing of behaviourally generatedoptic flow: experiments and mod el stimulations. Network. 12, 351-369.

Kily, L. J. M.; Cowe, Y. C. M.; Hussain, O.; Patel, S.; McElwaine, S.; Cotter, F. E.; Brennan, CH. (2008). Gene expression changes in a zebrafish model of drug dependency suggest conservation of neuroadaptation pathways. Journal of Experimental Biology. 211(Pt 10), 16231634.

Kimmel, C.B.; Warga, R.M.; Schilling, T.F. (1990). Origin and organization of the zebrafish fate map. Development. 108, 581594.

Kimmel, C.B., Hatta, K.; Eisen, J.S. (1991). Genetic control of primary neuronal development in zebrafish. Development Suppl. 2, 47-57.

Kimmel, C.B.; Ballard, W.W.; Kimmel, S.R.; Ullmann, B.; Schilling, T.F. (1995). Stages of embryonic development of the zebrafish. Dev Dyn. 203, 253-310.

Kizil, C.; Otto, G.W.; Geisler, R., NüssleinVolhard, C.; Antos, C.L. (2009). Simplet controls cell proliferation and gene transcription during zebrafish caudal fin regeneration. Dev Biol. 325(2):329-40.

Klein, C.; Fisher, B.; Hartnegg, K.; Heiss, W. H.; Roth, M. (2000). Optomotor andneurop sychological performance in oldage. Exp Brain Res. 135, 141-154.

Kokel, D.; Bryan, J.; Laggner, C.; White, R.; Cheung, C.Y.J.; Mateus, R.; Healey, D.; Kim, S.; Werdich, A.A.; Haggarty, S.J.; Macrae, C.A.; Shoichet, B.; Peterson, R.T. (2010). Rapid behaviorbased identification of neuroactive small molecules in the zebrafish. Nat Chem Biol. 6: 231-237. 
Kolb, B. (1989). Brain-development, plasticity, and behavior. Am Psychol. 44:1203-1212.

Koob, G.F.; Le Moal, M. (2006). Neurobiologic of addiction. Academic Press Hardbound, San Diego, CA.

Krauss, A.; Neumeyer, C. (2003). Wavelength dependence of the optomotor response in zebrafish (Danio rerio). Vision Res. 43: 1273-1282.

Kuhlenbeck, H. (1973). The Central Nervous System of Vertebrates. Basilea: S. Karger.

\section{L}

aessing, U.; Giordano, S.; Stecher, B.;

Lottspeich, F.; Stuermer, C.A.O. (1994). Molecular characterization of fish neurolin, a growth associated cell surface protein and member of the immunoglobulin superfamily in the fish retinotectal system with similarities to chick protein DM-GRASP/SC1/BEN. Differentiation. 56: 21-9.

Lagutin, O.V., Zhu, C.C.; Kobayashi, D.; Topczewski, J.; Shimamura, K.; Puelles, L.; Russell, H.R.; McKinnon, P.J.; Solnica-Krezel, L.; Oliver, G. (2003). Six3 repression of Wnt signaling in the anterior neuroectoderm is essential for vertebrate forebrain development. Genes Dev. 17, 368379.

Lambers, D.S.; Clark, K.E. (1996). The maternal and fetal physiologic effects of nicotine. Semin Perinatol. 20:115-126.

Lara, J.M.; Velasco, A.; Alonso, J.R.; Aijón, J. (1995). The neuroglia in the CNS of teleost. En: Vernadakis A, Roots BI (eds.): "Neuron-glia interelations during phylogeny. I. Phylogeny and ontogeny of glial cells". Totowa, Nueva Jersey: Humana Press Inc. pp. 131-156.

Larison, K.D.; Bremiller, R. (1990). Early onset of phenotype and cell patterning in the embryonic zebrafish retina. Development. 109(3):567-576.

Larrison, A.L.; Briand, K.A.; Sereno, A. B. (2004). Nicotine improves antisaccade task performance without affecting prosaccades.
Human Psychopharmacology. 19, 409-419.

Laufer, M.; Vanegas, H. (1974). The optic tectum of a perciform teleost. II. Fine structure. J Comp Neurol. 154: 61-96.

Lehrer, M. (1994). Spatial vision in the honeybee: the use of different cues in different tasks. Vision Res. 34: 2363-2385.

Leichter, J. (1995). Decreased birth weight and attainment of postnatal catch-up growth in offspring of rats exposed to cigarette smoke during gestation. Growth Dev Aging. 59(1-2):63-6.

Le Novere, N., Changeux, J.P. (1995). Molecular evolution of the nicotinic acetylcholine receptor: an example of multigene family in excitable cells. $J \mathrm{Mol}$ Evol. 40: 155-172.

Le Novere, N.; Zoli, M.; Changeux J. P. (1996). Neuronal nicotinic receptor a6 subunit mRNA is selectively concentrated in catecholaminergic nuclei of the rat brain. Eur. J. Neurosci. 8, 2428-2439.

Leppert, C.A.; Diekmann, H.; Paul, C.; Laessing, U.; Marx, M.; Bastmeyer, M.; Stuermer, C.A.O. (1999). Neurolin Ig domain 2 participates in retinal axon guidance and $\mathrm{Ig}$ domains 1 and 3 in fasciculation. J Cell Biol. 144: 339-49.

Levin, E.D.; Chen, E. (2004). Nicotinic involvement in memory function in zebrafish. Neurotoxicol Teratol. 26(6):7315 .

Levin, E.D.; Limpuangthip, J.; Rachakonda, T.; Peterson, M. (2006). Timing of nicotine effects on learning in zebrafish. Psychopharmacology (Berl). 184 (3-4):547-52.

Levin, E.D.; Bencan, Z.; Cerutti, D.T. (2007). Anxiolytic effects of nicotine in zebrafish. Physiol Behav. 90(1):54-8.

Levin, E.D.; Tanguay, R.L. (2011). Introduction to zebrafish: current discoveries and emerging technologies for neurobehavioral toxicology and teratology. Neurotoxicol Teratol. 33(6):607. 
Li, H.; Tierney, C.; Wen, L.; Wu, J.Y.; Rao, Y. (1997). A single morphogenetic field gives rise to two retina primordia under the influence of the prechordal plate. Development. 124, 603-615.

Li, Y.N.; Tsujimura, T.; Kawamura, S.; Dowling, J.E. (2012). Bipolar cellphotoreceptor connectivity in the zebrafish (Danio rerio) retina. J Comp Neurol. 520 (16):3786-802.

Lindsey, A. E.; Chawla, R. K.; TownesAnderson, E. (2002). Spatial sensitivity decreases with age in the adult tiger salamander. Association for Research in Vis Opht A M. Abstract, 729.

Linnet, K.M.; Dalsgaard, S.; Obel, C.; Wisborg, K.; Henriksen, T.B.; Rodriguez, A.; Kotimaa, A.; Moilanen, I.; Thomsen, P.H.; Olsen, J.; Jarvelin, M.R. (2003). Maternal lifestyle factors in pregnancy risk of attention deficit hyperactivity disorder and associated behaviors: review of the current evidence. Am J Psychiatry. 160:1028-1040.

Liu, J.; McGlinn, A.M.; Fernandes, A.; Milam, A.H.; Strang, C.E.; Andison, M.E.; Lindstrom, J.M.; Keyser, K.T.; Stone, R.A. (2009). Nicotinic acetylcholine receptor subunits in rhesus monkey retina. Invest Ophthalmol Vis Sci. 50:1408-15.

Liu, J.J.; Mohila, C.A.; Gong, Y.; Govindarajan, N.; Onn, S.P. (2005). Chronic nicotine exposure during adolescence differentially influences calcium-binding proteins in rat anterior cingulate cortex. Eur $J$ Neurosci. 22 (10):2462-74.

Logan, C.Y.; Nusse, R. (2004). The Wnt signaling pathway in development and disease. Annu Rev Cell Dev Biol. 20:781810.

London, E.D.; Dam, M.; Fanelli, R.J. (1988). Nicotine enhances cerebral glucose utilization in central components of the rat visual system. Brain Res Bull. 20(3):381-5.

Lowery, L.A.; Sive, H. (2004). Strategies of vertebrate neurulation and a re-evaluation of teleost neural tube formation. Mech Dev.
121, 1189-1197.

Luger, K.; Mader, A.W.; Richmond, R.K.; Sargent, D.F.; Richmond, T.J. (1997). Crystal structure of the nucleosome core particle at 2.8 A resolution. Nature. 389:231 -233 .

Lukas, W.; Jones, K.A. (1994). Cortical neurons containing calretinin are selectively resistant to calcium overload and excitotoxicity in vitro. Neuroscience. 61, 307316.

Lupo, G.; Liu, Y.; Qiu, R.; Chandraratna, R.A.; Barsacchi, G.; He, R.Q.; Harris, W.A. (2005). Dorsoventral patterning of the Xenopus eye: a collaboration of Retinoid, Hedgehog and FGF receptor signaling. Development. 132, 1737-1748.

Lyon, E.P. (1904). On rheotropism. I. Rheotropism in fishes. Am Jour Physiol. 12: 149-161.

$\mathbf{M}_{\text {a }}$

P.M. (1994). Catecholaminergic systems in the zebrafish. II. Projection pathways and pattern of termination of the locus coeruleus. J Comp Neurol. 344: 25669.

MacDonald, R.; Barth, K.A.; Xu, Q.; Holder, N.; Mikkola, I.; Wilson, S.W. (1995). Midline signalling is required for Pax gene regulation and patterning of the eyes. Development. 121, 3267-3278.

MacDonald, R.; Wilson, S.W. (1996). Pax proteins and eye development. Curr Opin Neurobiol. 6, 49- 56.

MacDonald, R.; Xu, Q.; Barth, K.A.; Mikkola, I.; Holder, N.; Fjose, A.; Krauss, S.; Wilson S.W. (1994). Regulatory gene expression boundaries demarcate sites of neuronal differentiation in the embryonic zebrafish forebrain. Neuron. 13, 1039-1053.

MacPhail, R.C., Brooks, J.; Hunter, D.L.; Padnos, B.; Irons, T.D.; Padilla, S. (2009). Locomotion in larval zebrafish: influence of time of day, lighting and ethanol Neurotoxicology. 30, pp. 52-58. 
Maneu, V.; Gerona, G.; Fernandez, L.; Cuenca, N.; Lax, P. (2010). Evidence of alpha 7 nicotinic acetylcholine receptor expression in retinal pigment epithelial cells. Vis Neurosci. 27: 139-147.

Manglapus, M.K.; Iuvone, P.M.; Underwood, H.; Pierce, M.E.; Barlow, R.B. (1999). Dopamine mediates circadian rhythms of rod-cone dominance in the Japanese quail retina. J Neurosci. 19: 413241.

Mann, C.J.; Hinits, Y.; Hughes, S.M. (2006). Comparison of neurolin (ALCAM) and neurolin-like cell adhesion molecule (NLCAM) expression in zebrafish. Gene Expr Patterns. 6, 952-63.

Mao, C.; Yuan, X.; Cui, Y.; Li, H.; Lv, J.; Feng, X.; Liu, Y.; Chen, L.; Xu, Z. (2008). Prenatal exposure to nicotine with associated in utero hypoxia decreased fetal brain muscarinic mRNA in the rat. Brain Res. 1189:43-50.

Marcus, R.C.; Blazeski, R.; Godement, P.; Mason C.A. (1995). Retinal axon divergence in the optic chiasm: uncrossed axons diverge from crossed axons within a midline glial specialization. J Neurosci. 15, 3716-3729.

Marenco, T.; Bernstein, S.; Cumming, P.; Clarke, P.B. (2000). Effects of nicotine and chlorisondamine on cerebral glucose utilization in immobilized and freelymoving rats. $\mathrm{Br} J$ Pharmacol. 129(1):14755.

Marks, M.J.; Pauly, J.R.; Gross, S.D.; Deneris, E.S.; Hermans-Borgmeyer, I.; Heinemann, S.F.; Collins, A.C. (1992). Nicotine binding and nicotinic receptor subunit RNA after chronic nicotine treatment. $J$ Neurosci. 12(7):2765-84.

Marks, M.J.; Whiteaker, P.; Collins, A.C. (2006). Deletion of the alpha7, beta2, or beta4 nicotinic receptor subunit genes identifies highly expressed subtypes with relatively low affinity for $[3 \mathrm{H}]$ epibatidine. Mol Pharmacol. 70(3):947-59.

Marlow, F.; Zwartkruis, F.; Malicki, J.; Neuhauss, S.C.; Abbas, L.; Weaver, M.;
Driever, W.; Solnica-Krezel, L. (1998). Functional interactions of genes mediating convergent extension, knypek and trilobite, during the partitioning of the eye primordium in zebrafish. Dev Biol. 203, 382-399.

Marquardt, T.; Ashery-Padan, R.; Andrejewski, N.; Scardigli, R.; Guillemot, F.; Gruss P. (2001). Pax6 is required for the multipotent state of retinal progenitor cells. Cell. 105, 43-55.

Marritt, A.M.; Cox, B.C.; Yasuda, R.P.; McIntosh, J.M.; Xiao, Y.; Wolfe, B.B.; Kellar, K.J. (2005). Nicotinic cholinergic receptors in the rat retina: simple and mixed heteromeric subtypes. Mol Pharmacol. 68:1656-1668.

Martínez-Morales, J.R.; Rembold, M.; Greger, K.; Simpson, J.C.; Brown, K.E.; Quiring, R.; Pepperkok, R.; MartinBermudo, M.D.; Himmelbauer, H.; Wittbrodt, J. (2009). Ojoplano-mediated basal constriction is essential for optic cup morphogenesis. Development. 136, 21652175.

Masai, I.; Stemple, D.L.; Okamoto, H.; Wilson, S.W. (2000). Midline signals regulate retinal neurogenesis in zebrafish. Neuron. 27, 251-263.

Matsumoto, H.; Shibasaki, K.; Uchigashima, M.; Koizumi, A.; Kurachi, M.; Moriwaki, Y.; Misawa, H.; Kawashima, K.; Watanabe, M.; Kishi, S.; Ishizaki, Y. (2012). Localization of acetylcholine-related molecules in the retina: implication of the communication from photoreceptor to retinal pigment epithelium. PLoS One. 7(8):e42841

Matta, S.G.; Balfour, D.J.; Benowitz, N.L.; Boyd, R.T.; Buccafusco, J.J.; Caggiula, A.R.; Craig, C.R.; Collins, A.C.; Damaj, M.I.; Donny, E.C.; Gardiner, P.S.; Grady, S.R.; Heberlein, U.; Leonard, S.S.; Levin, E.D.; Lukas, R.J.; Markou, A.; Marks, M.J.; McCallum, S.E.; Parameswaran, N.; Perkins, K.A.; Picciotto, M.R.; Quik, M.; Rose, J.E.; Rothenfluh, A.; Schafer, W.R.; Stolerman, I.P.; Tyndale, R.F.; Wehner, J.M.; Zirger, J.M. (2007). Guidelines on 
nicotine dose selection for in vivo research. Psychopharmacology (Berl). 190(3):269-319.

Matter, J.M.; Matter-Sadzinski, L.; Ballivet, M. (1995). Activity of the beta 3 nicotinic receptor promoter is a marker of neuron fate determination during retina development. J Neurosci. 15(9):5919-28.

Maurer, C.M.; Huang, Y.Y.; Neuhauss, S.C. (2011). Application of zebrafish oculomotor behavior to model human disorders. Rev Neurosci. 22(1):5-16.

McArdle, C.B.; Dowling, J.E.; Masland. R.H. (1977). Development of outer segments and synapses in the rabbit retina. J Comp Neurol. 175(3):253-74.

McFarland, B.J., Seidler, F.J.; Slotkin, T.A. (1991). Inhibition of DNA synthesis in neonatal rat brain regions caused by acute nicotine administration. Brain Res Dev Brain Res. 58(2):223-9.

Meek, J.; Nieuwenhuys, R. (1998). Holosteans and teleosts. En: Nieuwenhuys, R., Donkelaar, H.J., Nicholson, C. (eds): "The Central Nervous System of Vertebrates“. Berlin: Springer Verlag, 759937.

Menelaou, E.; Husbands, E.E.; Pollet, R.G.; Coutts, C.A.; Ali, D.W.; Svoboda, K.R. (2008). Embryonic motor activity and implications for regulating motoneuron axonal pathfinding in zebrafish. Eur $J$ Neurosci. 28(6):1080-96.

Menelaou, E.; Svoboda, K.R. (2009). Secondary motoneurons in juvenile and adult zebrafish: axonal pathfinding errors caused by embryonic nicotine exposure. $J$ Comp Neurol. 512(3):305-22.

Messi, M.L.; Renganathan, M.; Grigorenko, E. ; Delbono, Q. (1997). Activation of alpha 7 nicotinic acetylcholine receptor promotes survival of spinal cord motoneurons. FEBS Lett. 411: 32-38.

Millar, N.S.; Gotti, C. (2009). Diversity of vertebrate nicotinic acetylcholine receptors. Neuropharmacology. 56(1):237-46.

Miller, R.F.; Dowling, J.E. (1970). Intracellular responses of the Müller (glial) cells of the mudpuppy retina: their relation to the b-wave of the electroretinogram. $J$ Neurophysiol. 33:323-341

Miyayama, Y.; Fujimoto, T. (1977). Fine morphological study of neural tube formation in the teleost, Oryzias latipes. Okajimas Folia Anat Jpn. 54, 97-120.

Moens, C.B.; Prince, V.E. (2002). Constructing the hindbrain: insights from the zebrafish. Dev Dyn. 224, 1-17.

Montgomery, K..C.; Monkman, J..A. (1995). The relation between fear and exploratory behavior $J$ Comp Physiol Psychol. 48, pp. 132-136.

Moore, K.B.; Mood, K.; Daar, I.O.; Moody, S.A. (2004). Morphogenetic movements underlying eye field formation require interactions between the FGF and ephrinB1 signaling pathways. Dev Cell. 6, 55-67.

Moreau, M.; Leclerc, C. (2004). The choice between epidermal and neural fate: a matter of calcium. Int $J$ Dev Biol. 48, 7584.

Moretti, M.; Vailati, S.; Zoli, M.; Lippi, G.; Riganti, L.; Longhi, R.; Viegi, A.; Clementi, F.; Gotti, C. (2004). Nicotinic acetylcholine receptor subtypes expression during rat retina development and their regulation by visual experience. $\mathrm{Mol}$ Pharmacol. 66:85-96.

Morishita, H.; Miwa, J.M.; Heintz, N.; Hensch, T.K. (2010). Lynx1, a cholinergic brake, limits plasticity in adult visual cortex. Science. 330(6008):1238-40.

Morley, B.J. (1997). The embryonic and post -natal expression of the nicotinic receptor alpha3-subunit in rat lower brainstem. Brain Res Mol Brain Res. 48: 407-12.

Morris, A.C.; Fadool, J.M. (2005). Studying rod photoreceptor development in zebrafish. Physiol Behav. 86, 306-313.

Moser, N.; Wevers, A.; Lorke, D.E.; Reinhardt, S.; Maelicke, A.; Schroder. (1996). Alpha4-1 subunit mRNA of the nicotinic acetylcholine receptor in the rat olfactory bulb: cellular expression in adult, 
pre- and postnatal stages. Cell Tissue Res. 285: 17-25.

Murphey, R.D.; Stern, H.M.; Straub, C.T.; Zon. L.I. (2006). A chemical genetic screen for cell cycle inhibitors in zebrafish embryos. Chem Biol Drug Des. 68(4):213-9.

Muto, A.; Orger, M.B.; Wehman, A.M.; Smear, M.C.; Kay, J.N.; Page-McCaw, P.S.; Gahtan, E.; Xiao, T.; Nevin, L.M.; Gosse, N.J.; Staub, W.; Finger-Baier K.; Baier, H. (2005). Forward genetic analysis of visual behavior in zebrafish. PLoS Genet 1: e66.

\section{$\mathbf{N}$} aarendorp, F.; Sieving, P. A. (1991).

The scotopic threshold response of the cat ERG is suppressed selectively by GABA and glycine. Vision Res. 31, 1-15.

Naeye, R.L. (1981). Influence of maternal cigarette smoking during pregnancy on fetal and childhood growth. Obstet Gynecol. 57(1):18-21.

Naha, N.; Lee, H.Y.; Hwang, J.S.; Bahk, J.Y.; Park, M.S.; Lee, S.Y.; Kim, S.H.; Kim, M.O. (2009). Nicotine tolerance to PC12 cell line: acute and chronic exposures modulate dopamine D2 receptor and tyrosine hydroxylase expression. Neurol Res. 31(3):289-99.

Nakajima, Y.; Iwakabe, H.; Akazawa, C.; Nawa, H.; Shigemoto, R.; Mizuno, N.; Nakanishi, S. (1993). Molecular characterization of a novel retinal metabotropic glutamate receptor mGluR6 with a high agonist selectivity for L-2amino-4-phosphonobutyrate. J Biol Chem. 268, 11868-11873.

Nakao, T., Ishizawa, A. (1984). Light- and electron-microscopic observations of the tail bud of the larval lamprey (Lampetra japonica), with special reference to neural tube formation. Am J Anat. 170, 55-71.

Navalpakkam, V.; Itti, L. (2005). Modeling the influence of task on attention, Vision Res. 45 205-231.

Navarro, H.A., Seidler, F.J.; Schwartz,
R.D.; Baker, F.E.; Dobbins, S.S.; Slotkin, T.A. (1989). Prenatal exposure to nicotine impairs nervous-system development at a dose which does not affect viability or growth. Brain Res Bull. 23:187-192.

Neuhauss, S.C.; Biehlmaier, O.; Seeliger, M.W.; Das, T.; Kohler, K.; Harris, W.A.; Baier, H. (1999). Genetic disorders of vision revealed by a behavioral screen of 400 essential loci in zebrafish. J Neurosci. 19: 8603-8615.

Neuhauss, S.C. (2010). Zebrafish vision: Structure and function of the zebrafish visual system. In SF Perry, M Ekker, AP Farrell and CJ Brauner (Eds.) Zebrafish. Academic Press Inc. Elsevier Science, Amsterdam.

Neumeyer, C. (1984). On spectral sensitivity in the goldfish. Evidence for neural interactions between different 'cone mechanisms'. Vision Res. 24: 1223-1231.

Neumeyer, C.; Arnold, K. (1989). Tetrachromatic color vision in the goldfish becomes trichromatic under white adaptation light of moderate intensity. Vision Res. 29: 1719-1727.

Neumeyer, C.; Dörr, S.; Fritsch, J.; Kardelky, C. (2002). Colour constancy in goldfish and man: influence of surround size and lightness. Perception. 31: 171-187.

Neumeyer, C. (2003). Wavelength dependence of visual acuity in goldfish. $J$ Comp Physiol A. 189: 811-821.

Newman, E.A. (1979). B-wave currents in the frog retina. Vision Res. 19, 227-234.

Newman, E.A. (1980). Current source-density analysis of the b-wave of frog retina. $J$ Neurophysiol. 43, 1355-1366.

Newman, E.A.; Odette, L.L. (1984). Model of electroretinogram b-wave generation: a test of the K+ hypothesis. $J$ Neurophysiol. 51:164-182.

Nieuwenhuys, R. (1964). Further studies on the general structure of the actinopterygian forebrain. Acta Morphol Neerl Scand. 6, 65- 
79.

Noell, W. K. (1954). The origin of the electroretinogram. A J Ophta.38, 78-90.

Northcutt, R.G.; Wullimann, M.F. (1988). The visual system in teleost fishes: morphological patterns and trends. En: Atema J., Fay R.R., Popper A.N., Tavolga W.N. (eds.): "Sensory biology of aquatic animals". Nueva York: Springer Verlag. pp. 515-552.

Northcutt, R.G.; Butler A.B. (1993). The diencephalon of the Pacific herring, Clupea harengus: retinofugal projections to the diencephalon and optic tectum. J Comp Neurol. 328, 547-561.

Northmore, D.P.M.; Oh, D.J.; Celenza, M.A. (2007). Acuity and contrast sensitivity of the bluegill sunfish and how they change during optic nerve regeneration. Vis Neurosci. 24: 319-331.

akley, B.; Green, D. G. (1976).

Correlation of light-induced changes in retinal extracellular potassium concentration with c-wave of the electroretinogram. J Neurophysiol. 59,11171133.

Oba, S.; Koji, T. (2000). In situ nick endlabeling: light microscopial. En: Molecular histochemical techniques. Koji T. (ed.). Tokio. 19-30.

Ochocinska, M.J.; Hitchcock, P.F. (2007). Dynamic expression of the basic helix-loophelix transcription factor neuroD in the rod and cone photoreceptor lineages in the retina of the embryonic and larval zebrafish. J Comp Neurol. 501(1):1-12.

Olincy, A.; Johnson, L.L.; Ross, R.G. (2003). Differential effects of cigarette smoking on performance of a smooth pursuit and a saccadic eye movement task in schizophrenia. Psychiatry Res. 117(3):22336 .

Origlia, N.; Kuczewski, N.; Aztiria, E.; Gautam, D.; Wess, J.; Domenici, L. (2006). Muscarinic acetylcholine receptor knockout mice show distinct synaptic plasticity impairments in the visual cortex. 577(Pt 3):829-40.

Organisciak, D.T.; Winkler, B.S. (1994). Retinal light damage: Practical and theoretical considerations. Prog Retin Eye Res. 13:1-29.

Orr, H. (1887). Contribution to the embryology of the lizard. $J$ Morphol. 1:311372.

Orger, M,B,; Baier, H. (2005). Channeling of red and green cone inputs to the zebrafish optomotor response. Vis Neurosci. 22: 275281.

Ott, H.; Bastmeyer, M.; Stuermer, C.A.O. (1998). Neurolin, the goldfish homolog of DM-GRASP, is involved in retinal axon pathfinding to the optic disk. $J$ Neurosci. 18: 3363-72.

Ott, H.; Diekmann, H.; Stuermer, C.A.; Bastmeyer, M. (2001). Function of Neurolin (DMGRASP/ SC-1) in guidance of motor axons during zebrafish development. Dev Biol. 235, 86-97.

Ozawa, S.; Kamiya, H.; Tsuzuki, K. (1998). Glutamate receptors in the mammalian central nervous system. Prog Neurobiol. 54, 581-618.

\section{$\mathbf{P}$} ang, J.J.; Gao, F.; Lem, J.; Bramblett,

D.E.; Paul, D.L.; Wu, S.M. (2010). Direct rod input to cone $\mathrm{BCs}$ and direct cone input to rod $\mathrm{BCs}$ challenge the traditional view of mammalian BC circuitry. Proc Natl Acad Sci U S A. 107(1):395-400.

Parker, B.; Connaughton, V.P. (2007). Effects of nicotine on growth and development in larval zebrafish. Zebrafish. 4(1):59-68.

Parrilla, M.; Lillo, C.; Herrero-Turrión, M.J.; Arévalo, R.; Lara, J.M.; Aijón, J.; Velasco, A. (2009). Pax2 in the optic nerve of the goldfish, a model of continuous growth. Brain Res. 1255, 75-88.

Parrilla, M.; Lillo, C.; Herrero-Turrión, 
M.J.; Arévalo, R.; Aijón, J.; Lara, J.M.; Velasco, A. (2012). Characterization of Pax2 expression in the goldfish optic nerve head during retina regeneration. PLoS One. 7(2):e32348.

Parrilla, M.; Lillo, C.; Herrero-Turrión, M.J.; Arévalo, R.; Aijón, J.; Lara, J.M.; Velasco, A. (2013). Pax2+ astrocytes in the fish optic nerve head after optic nerve crush. Brain Res. 1492:18-32.

Parng C. (2005). In vivo zebrafish assays for toxicity testing. Curr Opin Drug Discov Devel. 8(1):100-6.

Paschke, K.A.; Lottspeich, F.; Stuermer, C.A. (1992). Neurolin, a cell surface glycoprotein on growing retinal axons in the goldfish visual system, is reexpressed during retinal axonal regeneration. $J$ Cell Biol. 117: 863-75.

Peitch, M.C.; Müller, C.; Tschopp, J. (1993). DNA fragmentation during apoptosis is caused by frequent singlestrand cuts. Nucleic Acids Res. 21: 42064209.

Pepperberg, D.R.; Brown, P. K.; Lurie, M.; Dowling, J. E. (1978). Visual pigment and photoreceptor sensitivity in the isolated skate retina. J Gen Physiol. 71, 369-396.

Pepperberg, D.R.; Masland, R. H. (1978). Retinal-induced sensitization of lightadapted rabbit photoreceptors. Brain Res. 151, 194-200.

Perry, D.C.; Mao, D.; Gold, A.B.; McIntosh, J.M.; Pezzullo, J.C.; Kellar, K.J. (2007). Chronic nicotine differentially regulates alpha6- and beta3-containing nicotinic cholinergic receptors in rat brain. J Pharmacol Exp Ther. 322(1):306-15.

Petros, W.P.; Younis, I.R.; Ford, J.N.; Weed, S.A. (2012). Effects of tobacco smoking and nicotine on cancer treatment. Pharmacotherapy. 32(10):920-31

Petzold, A.M.; Balciunas, D.; Sivasubbu, S.; Clark, K.J.; Bedell, V.M.; Westcot, S.E.; Myers, S.R.; Moulder, G.L.; Thomas, M.J.; Ekker, S.C. (2009). Nicotine response genetics in the zebrafish.
Proc Natl Acad Sci U S A. 106(44):18662-7.

Pfaff, S.L.; Mendelsohn, M.; Stewart, C.L.; Edlund, T.; Jessell, T.M. (1996). Requirement for LIM homeobox gene isl1 in motor neuron generation reveals a motor neuron-dependent step in interneuron differentiation. Cell, 84: 30920.

Picciotto, M.R.; Caldarone, B.J.; Brunzell, D.H.; Zachariou, V.; Stevens, T.R.; King, S.L. (2001). Neuronal nicotinic acetylcholine receptor subunit knockout mice: physiological and behavioral phenotypes and possible clinical implications. Pharmacol Ther. 92: 89-108.

Piccolo, S.; Sasai ,Y.; Lu, B.; DeRobertis, E.M. (1996). Dorsoventral patterning in Xenopus: inhibition of ventral signals by direct binding of chordin to BMP-4. Cell. $86,589-598$.

Pichini, S.; Garcia-Algar, O. (2006). In utero exposure to smoking and newborn neurobehavior: how to assess neonatal withdrawal syndrome? Ther Drug Monit. 28(3):288-90.

Pombal, M.A.; de Arriba, M.C.; Sampedro, C.; Alvarez, R.; Megias M. (2002). Immunocytochemical localization of calretinin in the olfactory system of the adult lamprey, Lampetra fluviatilis. Brain Res Bull. 57, 281-283.

Pons, M.; Marin-Castano, M.E. (2011). Nicotine increases VEGF/PEDF ratio in retinal pigment epithelium: a possible mechanism for $\mathrm{CNV}$ in passive smokers with AMD. Invest Ophthalmol Vis Sci. 52: 3842-3853.

Porteros, A.; Arévalo, R.; Weruaga, E.; Crespo, C.; Briñón, J.G.; Alonso, J.R.; Aijón J. (1997). Calretinin immunoreactivity in the developing olfactory system of the rainbow trout. Brain Res Dev Brain Res. 100, 101-109.

Pourquie, O.; Hallonet, M.E.; Le Douarin, N.M. (1992). Association of BEN glycoprotein expression with climbing fiber axonogenesis in the avian cerebellum. $J$ Neurosci. 12, 1548-57. 
Powers, M.K.; Bassi, C.J.; Raymond, P.A. (1988). Lighting conditions and retinal development in goldfish: absolute visual sensitivity. Invest Ophthalmol Vis Sci. 29:37-43.

Prada, C.; Puga, J.; Pérez-Méndez, L.; López, R.; Ramírez, G. (1991). Spatial and temporal patterns of neurogenesis in the chick retina. Eur J Neurosci. 3: 559-69.

Prigent, C.; Dimitrov, S. (2003). Phosphorylation of serine 10 in histone H3, what for? Journal of Cell Science 116:36773685 .

Prusky, G.T.; West, P.W.; Douglas, R.M. (2000). Behavioral assessment of visual acuity in mice and rats. Vision Res. 40: 2201-2209.

Puelles, L.; Rubenstein, J.L. (1993). Expression patterns of homeobox and other putative regulatory genes in the embryonic mouse forebrain suggest a neuromeric organization. Trends Neurosci. 16, 472-479.

Pugh, P.C.; Margiotta, J.F. (2000). Nicotinic acetylcholine receptor agonists promote survival and reduce apoptosis of chick ciliary ganglion neurons. Mol Cell Neurosci. 15:113-122.

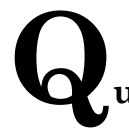

uik, M.; Chan, J.; Patrick, J. (1994).

a-bungarotoxin blocks the nicotinic receptor mediated increase in cell number in a neuroendocrine cell line. Brain Res. 655: 161-167.

Quillien, A.; Blanco-Sanchez, B.; Halluin, C.; Moore, J.C.; Lawson, N.D.; Blader, P.; Cau, E. (2011). BMP signaling orchestrates photoreceptor specification in the zebrafish pineal gland in collaboration with Notch. Development. 138(11):2293302.

\section{$\mathbf{R}_{\text {aif, }}$}

B.R.; Dallery,

J. (2009)

Responding maintained by primary reinforcing visual stimuli is increased by nicotine administration in rats. Behav
Processes. 82(1):95-9.

Ramón y Cajal, S. (1889). Sistema visual, órgano receptor de la excitación visual o retina. En: "Textura del sistema nervioso del hombre y los vertebrados". Madrid, Imp. Nicolás Moya.

Ramón y Cajal, S. (1892). La rétine des vertébrés. Cellule 9, 121-225.

Reese, B.E.; Maynard, T.M.; Hocking D.R. (1994). Glial domains and axonal reordering in the chiasmatic region of the developing ferret. J Comp Neurol. 349, 303-324.

Reilly, J.L.; Lencer, R.; Bishop, J.R.; Keedy, S.; Sweeney, J.A. (2008). Pharmacological treatment effects on eye movement control. Brain Cogn. 68(3):41535 .

Rembold, M.; Loosli, F.; Adams, R.J.; Wittbrodt, J. (2006). Individual cell migration serves as the driving force for optic vesicle evagination. Science. 313, 11301134.

Renninger, S.L.; Gesemann, M.; Neuhauss, S.C. (2011). Cone arrestin confers cone vision of high temporal resolution in zebrafish larvae. Eur J Neurosci. 33(4):65867.

Resende, R.R.; Alves, A.S., Britto, L.R.; Ulrich, H. (2008). Role of acetylcholine receptors in proliferation and differentiation of P19 embryonal carcinoma cells. Exp Cell Res. 314(7):1429-43.

Rèsibois, A.; Rogers, J.H. (1992). Calretinin in rat brain: an immunohistochemical study. Neuroscience. 46, 101-134.

Richards, F.M.; Alderton, W.K.; Kimber, G.M.; Liu, Z.; Strang, I.; Redfern, W.S.; Valentin, J.P.; Winter, M.J.; Hutchinson, T.H. (2008). Validation of the use of zebrafish larvae in visual safety assessment. J Pharmacol Toxicol Methods. 58(1):50-8.

Ridgway, P.; Almouzni, G. (2001). Chromatin assembly and organization. $J$ Cell Science. 114:2711-2712.

Rink, E.; Wullimann, M.F. (2001). The 
teleostean (zebrafish) dopaminergic system ascending to the subpallium (striatum) is located in the basal diencephalon (posterior tuberculum). Brain Res. 889: 316-30.

Rink, E.; Wullimann, M.F. (2002). Development of the catecholaminergic system in the early zebrafish brain: an immunohistochemical study. Brain Res Dev Brain Res. 137: 89-100.

Rinner, O.; Rick, J.M.; Neuhauss S.C. (2005). Contrast sensitivity, spatial and temporal tuning of the larval zebrafish optokinetic response. Invest Ophthalmol Vis Sci. 46: 137-142.

Rizzo, J.F.3rd. Lessell, S. (1993). Tobacco amblyopia. Am. J. Ophthalmol. 116 (1993) 84-87.

Rodgers, R.J.; Cao, B.J.; Dalvi, A.; Holmes, A. (1997). Animal models of anxiety: an ethological perspective. Braz J Med Biol Res. 30 (3), pp. 289-304.

Roeser, T.; Baier, H. (2003). Visuomotor behaviors in larval zebrafish after GFPguided laser ablation of the optic tectum. $J$ Neurosci. 23: 3726-34.

Role, L.; Berg, D.K. (1996). Nicotinic receptors in the development and modulation of CNS synapses. Neuron. 16: 1077-1085.

Ross, L.S.; Parrett, T.; Easter, S.S. (1992). Axonogenesis and morphogenesis in the embryonic zebrafish brain. J Neurosci. 12: 467- 82 .

Rossi, F.M.; Pizzorusso, T.; Porciatti, V.; Marubio, L.M.; Maffei, L.; Changeux, J.P. (2001). Requirement of the nicotinic acetylcholine receptor beta 2 subunit for the anatomical and functional development of the visual system. Proc Natl Acad Sci $U$ $S$ A. 98(11):6453-8.

Rowell, P.P.; Li, M. (1997). Dose-response relationship for nicotine-induced upregulation of rat brain nicotinic receptors. J Neurochem. 68: 1982-1989.

Roy, T.S.; Sabherwal, U. (1994). Effects of prenatal nicotine exposure on the morphogenesis of somatosensory cortex.
Neurotoxicol Teratol. 16(4):411-21.

Roy, T.S.; Andrews, J.E.; Seidler, F.J.; Slotkin, T.A. (1998). Nicotine evokes cell death in embryonic rat brain during neurulation. J Pharmacol Exp Ther. 287: 1136-1144.

Ruthazer, E.S.; Cline, H.T. (2004). Insights into activity-dependent map formation from the retinotectal system: a middle-ofthe-brain perspective. $J$ Neurobiol. 59 (1):134-46.

Rycroft, N.; Hutton, S.B.; Rusted, J.M. (2006). The antisaccade task as an index of sustained goal activation in working memory: Modulation by nicotine. Psychopharmacology (Berl). 188, 521-529.

\section{abban, E.L.; Gueorguiev, V.D. (2002).}

Effects of short- and long-term nicotine treatment on intracellular calcium and tyrosine hydroxylase gene expression. Ann N Y Acad Sci. 971:39-44.

Sakagami, K., Ishii, A.; Shimada, N.; Yasuda, K. (2003). RaxL regulates chick ganglion cell development. Mech Dev. 120: 881-95.

Sanes, D.H.; Reh, T.A.; Harris, W.A. (2000). Academic Press. A Harcount Science and Technology.

Sanders, T.A.; Lumsden, A.; Ragsdale C.W. (2002). Arcuate plan of chick midbrain development. J Neurosci. 22, 10742-10750.

Santiago, S.E.; Huffman, K.J. (2012). Postnatal effects of prenatal nicotine exposure on body weight, brain size and cortical connectivity in mice. Neurosci Res. 73(4):282-91.

Sasaki, T.; Kaneko, A. (1996). L-Glutamateinduced responses in OFF-type bipolar cells of the cat retina. Vision Res. 36, 787795 .

Sastry, B.V. (1991). Placental toxicology: tobacco smoke, abused drugs, multiple chemical interactions, and placental 
function. Reprod Fertil Dev. 3(4):355-72.

Schaerer, S.; Neumeyer, C. (1996). Motion detection in goldfish investigated with the optomotor response is "color blind". Vision Res. 36: 4025-4034.

Schellart, N.A.M. (1990). The visual partway and central non-tectal processing. En: Douglas,R.H., Djamgoz, M.B.A (eds.) "The visual system of fish". Londres: Chapman \& Hall. pp. 345-372.

Schmitt, E.A.; Dowling, J.E. (1994). Early eye morphogenesis in the zebrafish, Brachydanio rerio. J Comp Neurol. 344, 532-542.

Schmitz, B.; Papan, C.; Campos-Ortega, J. A. (1993). Neurulation in the anterior trunk región of the zebrafish Bachydanio rerio. Roux's Arch Dev Biol. 202:250-259.

Schoenwolf, G.C.; Smith, J.L. (1990). Mechanisms of neurulation: traditional viewpoint and recent advances. Development. 109, 243-270.

Schoenwolf, G.C. (1991). Cell movements driving neurulation in avian embryos. Development Suppl. 2, 157-168.

Schoepp, D.; Johnson, B. (1988). Excitatory amino acid agonist-antagonist interactions at 2-amino-4phosphonobutyric acid-sensitive quisqualate receptors coupled to phosphoinositide hydrolysis in slices od rat hippocampus. J Neurochemistry. 50, 16051613.

Schültze, M. (1866). Ueber den gelben Fleck der Retina, seinen Einfluss auf normales Sehen und auf Farbenblindheit. Bonn: Von Max Cohen and Sohn.

Schwarz, M.; Cecconi, F.; Bernier, G.; Andrejewski, N.; Kammandel, B.; Wagner, M.; Gruss P. (2000). Spatial specification of mammalian eye territories by reciprocal transcriptional repression of Pax2 and Pax6. Development. 127, 43254334.

Schweitzer, J.; Driever W. (2009). Development of the dopamine systems in zebrafish. Adv Exp Med Biol. 651, 1-14.
Sedwick, L.A. (1991). The perils of Pauline: visual loss in a tippler. Surv. Ophthalmol. $35,454-462$.

Seguela, P.; Wadiche, J.; Dineley-Miller, K.; Dani, J.A.; Patrick, J. (1993). Molecular cloning, functional properties, and distribution of rat brain a7: a nicotinic cation channel highly permeable to calcium. J Neurosci. 13: 596-604.

Seidler, F.J.; Levin, E.D.; Lappi, S.E.; Slotkin, T.A. (1992). Fetal nicotine exposure ablates the ability of postnatal nicotine challenge to release norepinephrine from rat brain regions. Brain Res Dev Brain Res. 69(2):288-91.

Sekhon, H.S.; Proskocil, B.J.; Clark, J.A.; Spindel, E.R. (2004). Prenatal nicotine exposure increases connective tissue expression in fetal monkey pulmonary vessels. Eur Respir J. 23:906-915.

Sepich, D.S.; Ho, R.K.; Westerfield, M. (1994). Autonomous expression of the nic1 acetylcholine receptor mutation in zebrafish muscle cells. Dev Biol. 161(1):8490 .

Sepich, D.S.; Wegner, J.; O'Shea, S.; Westerfield, M. (1998). An altered intron inhibits synthesis of the acetylcholine receptor alpha-subunit in the paralyzed zebrafish mutant nic1. Genetics. 148(1):361 -72 .

Shacka, J.J.; Fennell, O.B.; Robinson, S.E. (1997). Prenatal nicotine sexdependently alters agonist-induced locomotion and stereotypy. Neurotoxicol Teratol. 19(6):467-76.

Shatz, C.J.; Stryker, M.P. (1988). Prenatal tetrodotoxin infusion blocks segregation of retinogeniculate afferents. Science. 24:8789.

Sher, E.; Chen, Y.; Sharples, T.J.; Broad, L.M.; Benedetti, G.; Zwart, R.; McPhie, G.I.; Pearson, K.H.; Baldwinson, T.; De F.G. (2004). Physiological roles of neuronal nicotinic receptor subtypes: new insights on the nicotinic modulation of neurotransmitter release, synaptic transmission and plasticity. Curr Top Med Chem. 4: 283-297. 
Sherpa, T.; Fimbel, S.M.; Mallory, D.E.; Maaswinkel, H.; Spritzer, S.D.; Sand, J.A.; Li, L.; Hyde, D.R.; Stenkamp, D.L. (2008). Ganglion cell regeneration following whole-retina destruction in zebrafish. Dev Neurobiol. 68(2):166-81.

Shkumatava, A.; Fischer, S.; Muller, F.; Strahle, U.; Neumann, C.J. (2004). Sonic hedgehog, secreted by amacrine cells, acts as a short-range signal to direct differentiation and lamination in the zebrafish retina. Development. 131, 38493858 .

Shytle, R.D.; Silver, A.A.; Lukas, R.J.; Newman, M.B.; Sheehan, D.V.; Sanberg, P.R. (2002). Nicotinic acetylcholine receptors as targets for antidepressants. Mol Psychiatry. 7(6):525-35.

Sieving, P. A.; Murayama, K.; Naarendorp, F. (1994). Push-pull model of the primate photopic electroretinogram: a role for hyperpolarizing neurons in shaping the bwave. Vis Neurosci. 11, 519-532.

Sine, S.M.; Kreienkamp, H.J.; Bren, N.; Maeda, R.; Taylor, P. (1995). Molecular dissection of subunit interfaces in the acetylcholine receptor: identification of determinants of alpha-conotoxin M1 selectivity. Neuron. 15: 205-211.

Sine, S.M. (1997). Identification of equivalent residues in the gamma, delta, and epsilon subunits of the nicotinic receptor that contribute to alpha-bungarotoxin binding. $J$ Biol. Chem. 272: 23521-23527.

Slaughter, M.M.; Miller, R.F. (1981). 2Amino-4-phosphonobutyric acid: a new pharmachological tool for retinal research. Science. 211:182-185.

Slotkin, T.A., Cho, H.; Whitmore, W.L. (1987). Effects of prenatal nicotine exposure on neuronal development: selective actions on central and peripheral catecholaminergic pathways. Brain Res Bull. 18(5):601-11.

Slotkin, TA. (1998). Fetal nicotine or cocaine exposure: which one is worse? J Pharmacol Exp Ther. 285(3):931-45.

Slotkin, T.A. (1999). Developmental

cholinotoxicants: nicotine and chlorpyrifos. Stenkamp, D.L., Frey, R.A.; Prabhudesai,
Environ Health Perspect. 107 Suppl. 1: 7180 .

Slotkin, T.A.; Seidler, F.J.; Qiao, D.; Aldridge, J.E.; Tate, C.A.; Cousins, M.M.; Proskocil, B.J.; Sekhon, H.S.; Clark, J.A.; Lupo, S.L.; Spindel, E.R. (2005). Effects of prenatal nicotine exposure on primate brain development and attempted amelioration with supplemental choline or vitamin $\mathrm{C}$ : neurotransmitter receptors, cell signaling and cell development biomarkers in fetal brain regions of Rhesus monkeys. Neuropsychopharmacology. 30:129-144.

Slotkin, T.A.; Tate, C.A.; Cousins, M.M.; Seidler, F.J. (2006). Prenatal nicotine exposure alters the responses to subsequent nicotine administration and withdrawal in adolescence: Serotonin receptors and cell signaling. Neuropsychopharmacology. 31 (11):2462-75.

Spemann, H. (1938). Embryonic Development and Induction. New York, Yale University Press.

Springer A.D.; Gaffney J.S. (1981). Retinal projections in the goldfish: a study using cobaltous-lysine. J Comp Neurol. 203, 401424.

Sretavan, D.W.; Feng, L.; Pure, E.; Reichardt L.F. (1994). Embryonic neurons of the developing optic chiasm express L1 and CD44, cell surface molecules with opposing effects on retinal axon growth. Neuron. 12, 957-975.

Srinivasan, M. V.: Poteser, M.: Kral, K. (1999). Motion detection in insect orientation andnavigation. Vision Research. $39,2749-2766$.

Starr, M. S. (1975). The effects of various amino acids, dopamine and some convulsants on the electroretinogram of the rabbit. Exp Eye Res. 21, 79-87.

Steinberg, R. H.; Schmidt, R.; Brown, K. T. (1970). Intracellular responses to light from cat pigment epithelium: origin of the electroretinogram c-wave. Nature. 227, 728 730 . 
S.N.; Raymond, P.A. (2000). Function for Hedgehog genes in zebrafish retinal development. Dev Biol. 220, 238-252.

Stuart E.T.; Kioussi C.; Gruss P. (1994). Mammalian Pax genes. Annu Rev Genet. 28, 219-23.

Stuermer, C.A.O.; Bastmeyer, M. (2000). The retinal axon's pathfinding to the optic disk. Progr Neurobiol. 62: 197-214.

Suñer, I.J.; Espinosa-Heidmann, D.G.; Marin-Castano, M.E.; Hernandez, E.P.; Pereira-Simon, S.; Cousins, S.W. (2004). Nicotine increases size and severity of experimental choroidal neovascularization. Invest Ophthalmol Vis Sci. 45(1):311-7.

Svoboda, K.R.; Vijayaraghavan, S.; Tanguay, R.L. (2002). Nicotinic receptors mediate changes in spinal motoneuron development and axonal pathfinding in embryonic zebrafish exposed to nicotine. $J$ Neurosci. 22(24):10731-41.

Swanson, L. W.; Simmons, D. M.; Whiting, P. J.; Lindstrom J. (1987). Immunohistochemical localization of neuronal nicotinic receptors in the rodent central nervous system. J. Neurosci. 7, 3334-3342.

$\mathbf{T}$ aha, S.A.; Stryker, M.P. (2005).

Molecular substrates of plasticity in the developing visual cortex. Prog Brain Res. $147: 103-14$

Tanabe, J.; Tregellas, J.R.; Martin, L.F.; Freedman, R. (2006). Effects of nicotine on hippocampal and cingulate activity during smooth pursuit eye movement in schizophrenia. Biol Psychiatry. 59(8):75461.

Taylor, W.R.; Smith, R.G. (2012). The role of starburst amacrine cells in visual signal processing. Vis Neurosci. 29(1):73-81.

Tierney, K,B. (2011). Behavioural assessments of neurotoxic effects and neurodegeneration in zebrafish. Biochim Biophys Acta. 1812(3):381-9.
Theiler, K.; Varnum, D.S.; Stevens, L.C. (1978). Development of Dickie's small eye, a mutation in the house mouse. Anat Embryol. 155:81-6.

Thomas, L.T.; Welsh, L.; Galvez, F.; Svoboda, K.R. (2009). Acute nicotine exposure and modulation of a spinal motor circuit in embryonic zebrafish. Toxicol Appl Pharmacol. 239(1):1-12.

Thompson, I.; Holt, C. (1989). Effects of intraocular tetrodotoxin on the development of the retinocollicular pathway in the Syrian hamster. J Comp Neurol. 282, 371-388.

Thor, S.; Ericson, J.; Brannstrom, T.; Edlund, T. (1991). The homeodomain LIM protein Isl-1 is expressed in subsets of neurons and endocrine cells in the adult rat. Neuron. 7: 881-9.

Tokuoka, H.; Yoshida, T.; Matsuda, N.; Mishina, M. (2002). Regulation by glycogen synthase kinase-3beta of the arborization field and maturation of retinotectal projection in zebrafish. $J$ Neurosci. 22(23):10324-32.

Treinin, M.; Chalfie, M. (1995). A mutated acetylcholine receptor subunit causes neuronal degeneration in $C$. elegans. Neuron. 14: 871-7.

Trevarrow, B.; Marks, D.L.; Kimmel, C.B. (1990). Organization of hindbrain segments in the zebrafish embryo. Neuron. 4(5):669-79.

Treviño, J.G.; Pillai, S.; Kunigal, S.; Singh, S.; Fulp, W.J.; Centeno, B.A.; Chellappan, S.P. (2012). Nicotine induces inhibitor of differentiation- 1 in a Src-dependent pathway promoting metastasis and chemoresistance in pancreatic adenocarcinoma. Neoplasia. 14 (12):1102-14.

Tu, S.; Butt, C.M.; Pauly, J.R.; Debski, E.A. (2000). Activity-dependent regulation of substance $\mathrm{P}$ expression and topographic map maintenance by a cholinergic pathway. J. Neurosci. 20, 5346-5357.

Tucker, P.; Laemle, L.; Munson, A.; Kanekar, S.; Oliver, E.R.; Brown, N.; 
Schlecht, H.; Vetter, M.; Glaser, T. (2001). The eyeless mouse mutation (ey1) removes an alternative start codon from the Rx/rax homeobox gene. Genesis. 31, 4353.

rbach, R.; Technau, G.M. (2003).

Segment polarity and DV patterning gene expression reveals segmental organization of the Drosophila brain. Development. 130, 3607-3620.

V

anegas, H.; Ebbeson, S.O.E.; Laufer,

M. (1984). Morphological aspects of the teleostean optic tectum. En: Vaengas,H. (eds.): "Comparative neurology of the optic tectum”. Nueva York: Plenum Press, 93-120.

Varga, Z.M.; Wegner, J.; Westerfield, M. (1999). Anterior movement of ventral diencephalicprecursors separates the primordial eye field inthe neural plate and requires cyclops. Development. 126: 5533-46.

Varghese, S.B.; Reid, J.C.; Hartmann, E.E.; Keyser, K.T. (2011). The effects of nicotine on the human electroretinogram. Invest Ophthalmol Vis Sci. 52(13):9445-51.

Vernino, S.; Amador, M.; Luetje, C.W.; Patrick, J.; Dani, J.A. (1992). Calcium modulation and high calcium permeability of neuronal nicotinic acetylcholine receptors. Neuron. 8: 127-34.

Verninio, S.; Rogers, M.; Radcliffe, K.A.; Dani, J.A. (1994). Quantitative measurement of calcium flux through muscle and neuronal nicotinic acetylcholine receptors. J Neurosci. 14: 5514-24.

von Frisch, K. (1913). Weitere Untersuchungen über den Farbensinn der Fische. Zoologische Jahrbücher Abteilung für allgemeine Zoologie und Physiologie der Tiere 34.

von Frisch, K. (1914). Der Farben- und Formensinn der Bienen. Zoologische Jahrbücher Abteilung für allgemeine Zoologie und Physiologie der Tiere 35: 1-
188.

von Hess, C. (1914). Die Entwicklung von Lichtsinn und Farbensinn in der Tierreihe. Bergmann, Wiesbaden.

\section{W}

all, T.L.; Schoedel, K.; Ring, H.Z.;

Luczak, S.E.; Katsuyoshi, D.M.; Tyndale, R.F. (2007). Differences in pharmacogenetics of nicotine and alcohol metabolism: Review and recommendations for future research. Nicotine Tob Res. 9: S459-S474.

Wang, J.; Kim, J.M.; Donovan, D.M.; Becker, K.G.; Li MD. (2009). Significant modulation of mitochondrial electron transport system by nicotine in various rat brain regions. Mitochondrion. 9(3):186-95.

Wang, T.; Chen, M.; Liu, L.; Cheng, H.; Yan, Y.E.; Feng, Y.H.; Wang, H. (2011). Nicotine induced CpG methylation of Pax6 binding motif in StAR promoter reduces the gene expression and cortisol production.Toxicol Appl Pharmacol. 257 (3):328-37.

Weber, C.; Wermter, S.; Elshaw, M.(2006). A hybrid generative and predictive model ofthe motor cortex. Neural. Netw. 19 339353.

Welsh, L.; Tanguay, R.L.; Svoboda, K.R. (2009). Uncoupling nicotine mediated motoneuron axonal pathfinding errors and muscle degeneration in zebrafish. Toxicol Appl Pharmacol. 237(1):29-40.

Weruaga, E.; Velasco, A.; Briñón, J.G.; Arévalo, R.; Aijón, J.; Alonso J.R. (2000). Distribution of the calcium-binding proteins parvalbumin, calbindin D-28k and calretinin in the retina of two teleosts. $J$ Chem Neuroanat. 19, 1-15.

Wessely, O.; DeRobertis, E.M. (2002). Neural plate patterning by secreted signals. Neuron. 33, 489-491.

Westerfield, M. (1995). The Zebrafish Book. A guide for the laboratory use of zebrafish (Danio rerio). Eugene: University of Oregon Press. 
Whiteaker, P.; McIntosh, J.M.; Luo, S.; Collins, A.C.; Marks, M.J. (2000). 125Ialpha-conotoxin MII identifies a novel nicotinic acetylcholine receptor population in mouse brain. Mol Pharmacol. 57:913-25.

Wielgus, J.J.; Downey, L.C.; Weald, K.W.; Hatley, M.E.; Wilson, K.C.; Yeilding, R.H. (2004). Exposure to low concentrations of nicotine during cranial nerve development inhibits apoptosis and causes cellular hypertrophy in the ventral oculomotor nuclei of the chick embryo. Brain Res.1000:123-133.

Wilkinson, D.G. (1989). Homeobox genes and development of the vertebrate CNS. Bioessays. 10, 82-85.

Wilson, S.W.; Houart, C. (2004). Early steps in the development of the forebrain. Dev Cell. 6, 167-181.

Witkovsky, P.; Dudek, E.F.; Ripps, H. (1975). Slow P-III component of the carp electroretinogram. J Gen Physiol. 65:119134.

Wong, K. Y.; Adolph, A. R.; Dowling, J. E. (2005a). Retinal bipolar cell input mechanisms in giant danio. I. Electroretinographic analysis. $J$ Neurophysiol. 93, 84-93.

Wong, K. Y.; Cohen, E. D.; Dowling, J. E. (2005b). Retinal bipolar cell input mechanisms in giant danio. II. Patchclamp analysis of on bipolar cells. $J$ Neurophysiol. 93, 94-107.

Wong, K. Y.; Dowling, J. E. (2005). Retinal Bipolar Cell Input Mechanisms in Giant Danio: III. ON-OFF Bipolar Cells and Their Color-Opponent Mechanisms. $J$ Neurophysiol. 94(1):265-72.

Wu, S.Q.; Lv, Y.E.; Lin, B.H.; Luo, L.M.; Lv, S.L.; Bi, A.H.; Jia, Y.S. (2013). Silencing of periostin inhibits nicotinemediated tumor cell growth and epithelialmesenchymal transition in lung cancer cells. Mol Med Rep. 7(3):875-80

Wullimann, M.F.; Meyer, D.L.; Northcutt, R.G. (1991). The visually related posterior pretectal nucleus in the non-percomorph teleost Osteoglossum bicirrhosum projects to the hypothalamus: a DiI study. J Comp Neurol. 312, 415-435.

Wullimann, M.F.; Rupp, B.; Reichert H. (1996). Neuroanatomy of the zebrafish brain. A topological atlas. Basilea: Birkhäuser Verlag.

Wullimann, M.F.; Puelles, L. (1999). Postembryonic neural proliferation in the zebrafish forebrain and its relationship to prosomeric domains. Anat Embryol (Berl). 199, 329-348.

Wullimann M.F. y Knipp S. (2000). Proliferation pattern changes in the zebrafish brain from embryonic through early postembryonic stages. Anat Embryol (Berl). 202, 385-400.

Wullimann, M.F.; Rink, E. (2001). Detailed immunohistology of Pax6 protein and tyrosine hydroxylase in the early zebrafish brain suggests role of Pax6 gene in development of dopaminergic diencephalic neurons. Brain Res Dev Brain Res. 131: 173-91.

Wullimann, M.F.; Rink, E. (2002). The teleostean forebrain: a comparative and developmental view based on early proliferation, $\operatorname{Pax} 6$ activity and catecholaminergic organization. Brain Res Bull. 57: 363-70.

Wolf, E.; Zerrahn-Wolf, G. (1936). Threshold intensity of illumination and flicker frequency for the eye of the sun-fish. JGen Physiol. 19: 495-502.

\section{$\mathbf{X}_{\text {ings, }, Z_{\text {; }} \text { Hegsenand, J.R.; Prince. }}$}

D.A. (1998). Cholinergic switching within neocortical inhibitory networks. Science. 281 (5379):985-8.

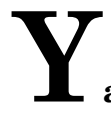
an, X.; Zhao, B.; Butt, C.M.; Debski, E.A. (2006). Nicotine exposure refines visual map topography through an NMDA receptor-mediated pathway. Eur J Neurosci. 24(11):3026-42. 
Yazulla, S., Studholme, K.M. (2001). Neurochemical anatomy of the zebrafish retina as determined by immunocytochemistry. $J$ Neurocytol. 30 (7):551-92.

Yoshida, M.; Usui, T.; Tsujimura, K.; Inagaki, M.; Beppu, T.; Horinouchi, S. (1997). Biochemical differences between staurosporine-induced apoptosis and premature mitosis. Experimental Cell Research. 232:225-239.

$\mathbf{Z}$ hao-Shea, R.; Liu, L.; Soll, L.G.;

Improgo, M.R.; Meyers, E.E.; McIntosh, J.M.; Grady, S.R.; Marks, M.J.; Gardner, P.D.; Tapper, A.R. (2011). Nicotinemediated activation of dopaminergic neurons in distinct regions of the ventral tegmental area. Neuropsychopharmacology. 36(5):1021-32.

Zingler, V.C.; Denecke, K.; Jahn, K.; von Meyer, L.; Krafczyk, S.; Krams, M.; Elfont, R.; Brandt, T.; Strupp, M.; Glasauer, S. (2007). The effect of nicotine on perceptual, ocular motor, postural, and vegetative functions at rest and in motion. $J$ Neurol. 254(12):1689-97.

Zirger, J.M.; Beattie, C.E.; McKay, D.B.; Boyd, R,T. (2003). Cloning and expression of zebrafish neuronal nicotinic acetylcholine receptors. Gene Expr Patterns. 3(6):747-54.

Zoli, M.; LeNovere, N.; Hill, J.A.Jr.; Changeux, J-P. (1995). Developmental regulation of nicotinic acetylcholine receptor subunit mRNAs in the rat central and peripheral nervous systems. J Neurosci. 15: 1912-1939.

Zuber, M.E.; Gestri, G.; Viczian, A.S.; Barsacchi, G.; Harris, W.A. (2003). Specification of the vertebrate eye by a network of eye field transcription factors. Development. 130, 5155-5167.

Zupanc, G.K.; Hinsch, K.; Gage, F.H. (2005). Proliferation, migration, neuronal differentiation, and long-term survival of new cells in the adult zebrafish brain. $J$ Comp Neurol. 488, 290-319.

\section{Páginas web:}

Ministerio de Sanidad, Servicios Sociales e Igualdad: http://www.msc.es/

\author{
Webvision. The Organization of the \\ Retina and Visual System: http:// \\ www.webvision.med.utah.edu \\ World Health Organization \\ (Organización Mundial de la Salud): \\ http://www.who.int/en/
}



Utilizamos el pez cebra como modelo experimental para analizar los efectos sobre la morfología, la neuroquímica, la electrofisiología y en el comportamiento, de la administración de diferentes concentraciones de nicotina durante el desarrollo del sistema visual.

La exposición a nicotina en el desarrollo reduce el tamaño de estructuras visuales y produce un retraso en la maduración neuroquímica de diferentes poblaciones celulares. El tratamiento con nicotina durante el desarrollo también afecta a los patrones de expresión de los receptores nicotínicos y altera el registro electrofisiológico de la retina del pez cebra. Además, los animales expuestos a nicotina en concentraciones bajas tienen una actividad motora correcta y cierto déficit visual, mientras que a medida que aumenta la concentración de nicotina administrada, aparecen y se incrementan los problemas en la actividad motora, agravándose además el déficit visual.

Los datos obtenidos se orientan al diseño de estrategias terapéuticas o de prevención frente a los efectos de la nicotina durante el desarrollo.
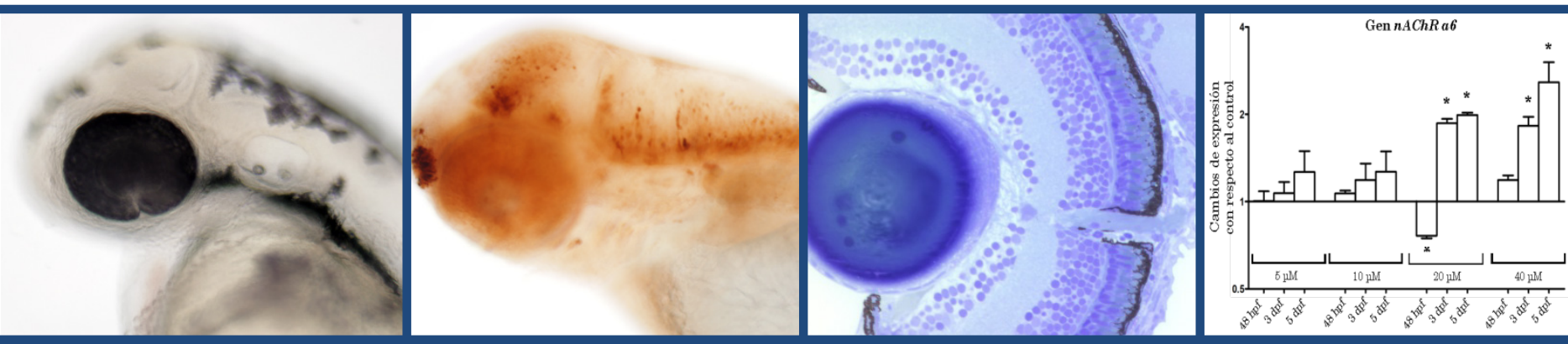